
$\ell \mid=$

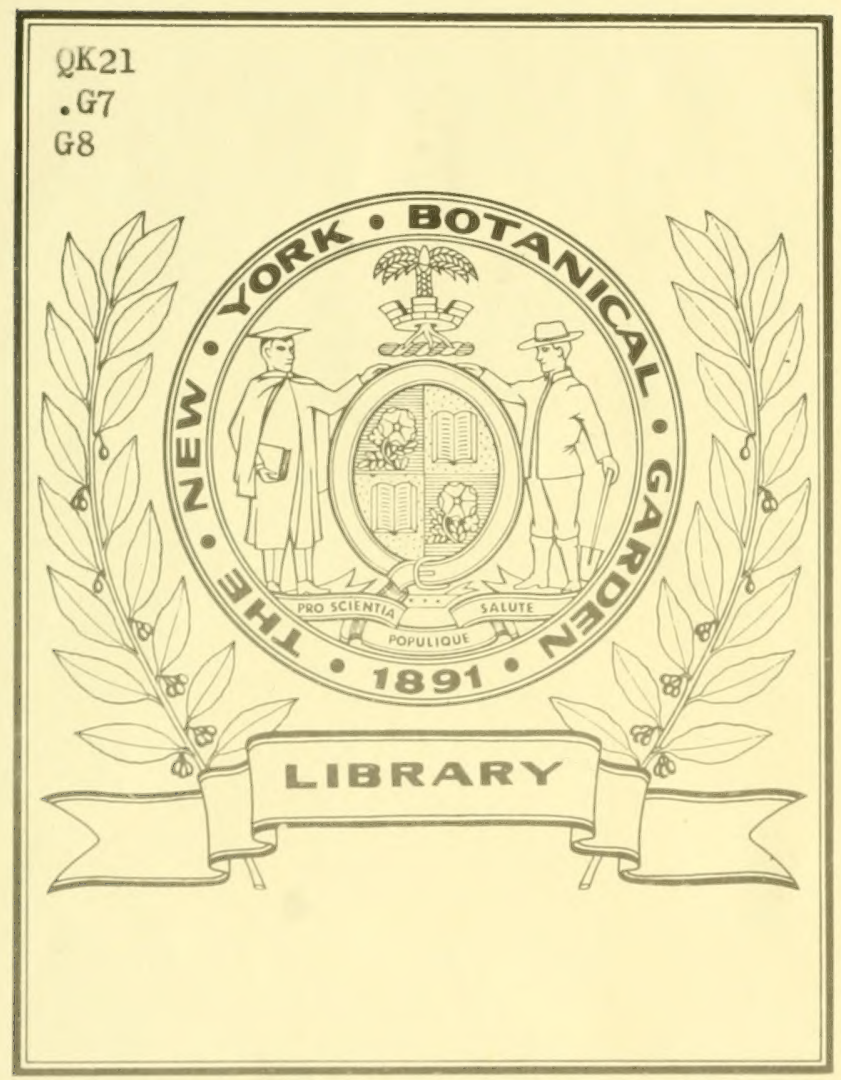





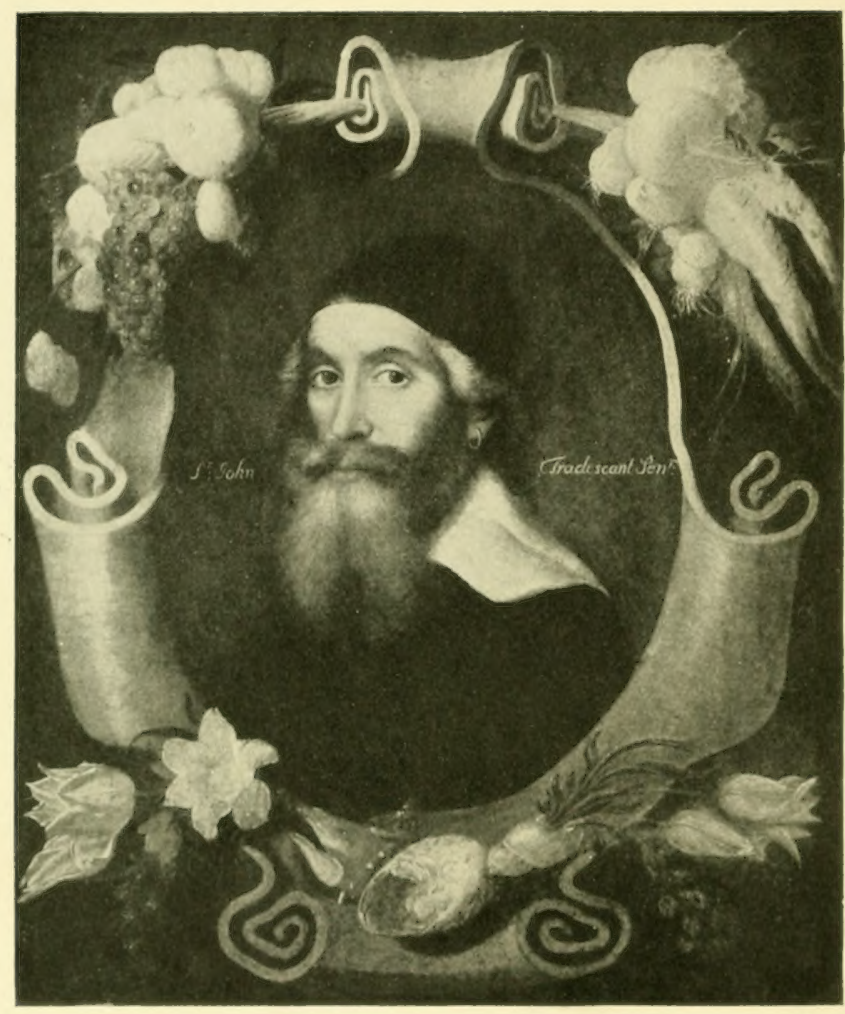

JOHN TRADESCANT THE ELDER 


\section{EARLY}

\section{BRITISH BOTANISTS}

\section{AND THEIR GARDENS}

BASED ON UNPUBLISHED WRITINGS OF

GOODYER, TRADESCANT, AND OTHERS

BY

R. T. GUNTHER, M.A., F.L.S.

LIBRARIAN AND RESEARCH FELLOW OF MAGDALEN COLLEGE

With Nine Plates and Trenty-one other Illustrations

O X F O R D

PRINTED BY FREDERICK HALL FOR THE AUTHOR AT THE UNIVERSITY PRESS

I 922 


$$
\begin{array}{r}
G 7 \\
68
\end{array}
$$




\section{PREFACE}

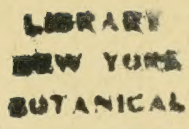

(4) 2 . 2 eqpat

THE following accounts of some Botanists of the Elizabethan and Jacobean age have gathered around the literary remains of one who, but twelve years ago, was introduced to us as 'A forgotten Botanist of the seventeenth Century'. By a strange hazard we can now come closer to John Goodyer through his own writings than to any of the contemporaries whose names have been writ larger on the roll of the history of botany: and through him, other botanists of distinction have been made known, who otherwise would have remained in almost total oblivion; for as a modern authority has recently discovered, 'Every writer of the period owned help from Goodyer in one way or another'.'

The Goodyer papers serve to illustrate missing chapters in the histories of Botany and Horticulture in that most interesting period of British Science, the hundred years which preceded the foundation of the Royal Society. Authors of standard histories of British Botany, largely based on German authority, have been apt to skim rapidly over this period, in which several of our countrymen were in some respects well abreast of Linnaeus. And these manuscripts with all the annotated books, which Goodyer bequeathed to Magdalen College in 1664, are probably the completest and most useful collection, for a study of English Botany that was not merely pre-Linnean, but was న్pre-Morisonian and pre-Raian as well.

I- In his scientific attitude of mind Goodyer was superior - to several of the first members of the Royal Society.

1 White, Bristol Flora, p. 57. 
He had no use for the superstitions of Ashmole or Aubrey, nor would he, like Sir Kenelm Digby, have fed his wife on capons fattened with the flesh of vipers in order to preserve her beauty. Nor would he, like the credulous Sir R. Moray, have seen tiny geese, perfectly shaped, in little shells adhering to trees among the western islands of Scotland.

His notes begin in 1616 , show the period of his greatest activity to have been in 1621 , and become fewer after 1633. The material came into my hands in the form of thousands of scraps of paper in disorder and in various handwritings. These had first to be sorted and bound; and then, although Goodyer could, and did generally write a remarkably clear hand, his jotted notes are scribbles, and exceedingly difficult to read. In some cases weeks elapsed before the meaning of the more difficult passages dawned upon me, and even with expert help, there are still unread words in our text. Our readers will kindly remember that many notes, that we have printed as indications of occupations and interests, were solely intended for the eye of the writer.

Further biographical details have been gleaned from visits to various parts of the country, from ledgers relating to College estates, from the parish registers of several Hampshire towns, from the account books of the Weston Charity at Petersfield, from wills at Somerset House.

As the work progressed new facts relating to Goodyer's botanical contemporaries emerged, which were scarcely less interesting than those relating to himself. Except in the papers which we now describe, there is no other surviving record of their work for Botany or Horticulture. This is due in some measure to the disturbances of the Civil War, partly too to the death of such workers as 
How, Dale, and Johnson at an early age, and before the complete publication of their work, and partly to the absence at that early period of any School of English Botany or of any botanical journal.

Thanks to Goodyer we are now able to print much new matter relating to the plant-records of Sir John Salusbury, William Mount, Richard Shanne, Walter Stonehouse, William How, Dr. John Dale, and others, to publish many 'first evidences' of the plants of Kent, Hampshire, and other counties, and to list the garden plants grown by John Coys, John Parkinson, the elder Tradescant, and Morison; and in some instances from their original writings. To many, our lists of pre-Linnean plant-names may appear uninteresting, but we believe that such publication is a necessary preliminary to the preparation of any comprehensive monograph on the subject of the introduction of plants into English Gardens, whence a few, e.g. the Italian Ivy-leaved Toadflax, have run wild all over the country.

If in this compilation I have disentangled a few of the knots in that ancient skein of names and dates, I rest satisfied. I know that the fabric is left with plenty of 'ends' for other workers, and, like the Irishman's net, is full of holes.

It remains for me to acknowledge my obligations to my College, not only for having given me the opportunity of finding and arranging the Goodyerian manuscripts, but also for having made a most substantial contribution towards the heavy cost of the printing. St. John's and Jesus Colleges have likewise assisted with grants in aid of the publication of the plant records of How and Salusbury, distinguished members of their respective Societies, and the Delegates of the Clarendon Press have assisted financially at a very difficult time and by the loan 
of their block of the Tradescant portrait. Mr. J. Murray has lent blocks of Lobel and Parkinson. Miss Lacell permitted me to look over Goodyer's house in Petersfield and Mr. C. Branfill Russell pointed out the vestiges of Coys's house and garden. The design of a partridge with a good ear of wheat in its bill, which is impressed on the binding of this volume, is the crest of Mr. Edward Goodyear, who has kindly lent the stamps with which all the books bequeathed to Magdalen College by his kinsman have been marked.

I have derived much advantage from the printed works of my predecessors, Canon Vaughan the 'discoverer', Miss Wotton the 'pioneer', and Mr. Druce the 'producer' of the forgotten Hampshire botanist of the Seventeenth Century. On certain doubtful points I have had the advantage of the experience of Dr. Church, and in the reading of difficult passages, of Messrs. Salter, Driver, Craster, and Gambier-Parry.

My grateful acknowledgements are due to my friends Sir David Prain, Professor Keeble, the officers of the Botanical Department of the British Museum, Dr. Rendel and Mr. James Britten; Dr. Stapf of the Kew Herbarium, and especially Dr. Daydon Jackson, the biographer of Gerard and Turner. To all I must express my thanks for much valuable assistance. I have also to thank my wife for sacrificing much time in the labour of revising both manuscript and proofs.

R. T. GUNTHER.

Magdalen College.

February 1922. 


\section{CONTEN'TS}

Life of John Goodyer $\cdot \stackrel{\text { I }}{\text { II }} \cdot \underbrace{\text { PAGE }}$

Descriptions of Plants by Goodver . . . ioo

III

The Goodyer's Botanical Library . . . 197

IV

Notes on Contemporary Botanists . . . 233

\section{V}

Lists of Plants grown in English Gardens . 303

\section{I}

Lists of Exotic Plants .

- 358

VII

Goodyer's Miscellaneous Papers . . . . 372

\section{INDEXES}

Goodyer's List of Plants (Index I) • . $\quad 387$

II. Index of Plants . . . . . . 402

III. Index of Persons, Places, and Things • 409 


\section{LIST OF ILLUSTRATIONS}

PAGE

John Tradescant

Frontispiece

Map of South-east Hampshire. . . . . . 4

Mapledurham House. . . . . . . . 7

The Garden at Stubbers . . . . . facing I6

Mill-mountain . . . . . . . . 22

Jerusalem Artichoke . . . . . . . . 23

Sheet Mill . . . . . . facing 28

Goodyer's four Elms . . . . . . 39-42

Goodyer's signature . . . . . . . . 55

Plan of Petersfield . . . . . . . . 64

Goodyer's House in the Spain . . . . facing 64

Goodyer's House in the Spain . . . . . . 66

Interlinear Translation of Dioscorides . . facing 84

Drawings by Goodyer . . . . . . . 99

Potamogeton . . . . . . . 124-125

Description of $\mathrm{Ycw}$. . . . . . . . . . . . . . . .

The Heath at Petersfield . . . . facing 188

Notes in Ray's Catalogus . . . . . . . . 223

Lobel . . . . . . . . 246

fOld Testimonial to Lobel. . . . facing 248

Sonnet dedicated to Lobel . . . . " 249

Signatures to Lobel's sccond Testimonial . . . 250

John Parkinson . . . . . . . . . 266

\} Lctter. . facing 276

First Draft of a British Flora by How . facing 276

Yucca . . . . . . . . . 313

Tradescant's 'Title-l'age . . . . . . . 334 


\section{THE LIFE OF JOHN GOODYER}

JoHn Goodyer was born at Alton in Hampshire in $1592 .{ }^{1}$ Possibly he first saw the light in a house belonging to Magdalen College, Oxford, the College which both through its landed property in the Petersfield district, through Goodyer's relationship to its tenants and bailiffs, and through the scientific members of its foundation, was so fully to win his confidence and affection, that in his last will and testament he bequeathed to it his most cherished possession, his botanical library and manuscripts. These materials are now available for the reconstruction of his life and work.

His father, Reginald Goodyer, appears several times in the College books. ${ }^{2}$ There is a copy of the terms on which the then President, William Langton, and the Fellows of the College leased to 'Reginald Goodyeare', a yeoman of the parish of St. Laurence in Alton, the farm called Beeches Place and the wood called Priors Reade now or late in the tenure of Henry Mervyn, Esq., at an annual rent of $£ 43 s .4 d$. together with two quarters of 'good, sweete, \& marchantable wheate, and furthermore 3 quarters of good siveete malte to be delivered within the said College', or their value in money according to the prices of the Oxford market.

${ }^{1}$ I have no knowledge of an entry in any Baptismal Register. The year has probably been calculated from his Marriage Licence which states his age as forty in 1632 .

2 The entry in Ledger $\mathrm{K}$ is dated 27 July $\mathrm{I} 6 \mathrm{I} 4$, and on f. $\mathrm{I} 88$ there is a further entry made in 1619, when the name is spelt Reginald Goodier. According to information from Miss Wotton, Reginald Goodyer had previously paid taxes direct from Alton in 1600 , and was described in a Star Chamber Case as a yeoman of Alton in 1605. Then (Star Chamber Proc. James 1, 204-13) he gave evidence for Sir Richard Pawlett, showing intimate acquaintance with the manor of Herriard, where his father was living in 1572, and with the hamlet of Southropp. It is possible that he was a sub-tenant of Beeches Place under Henry Mervyn, before he held it under a direct lease from the College. 
Concerning Reginald's family history we have no knowledgre. His wife Ann, who predeceased him, bore him two sons and two daughters: Lewis, b. I579, d. I655, Rose, Ann, and John, b. I592. L.ewis had at least eight children and left numerous descendants; Rose married William Yalclen; Ann married Richard Pratt and had three sons; and John, the subject of this memoir, had an only daughter Elizabeth.

The Yaldens were still more closely connected with Magdalen Collegre. In 1593 William Yalden, perhaps the father of John's brother-in-law, leased from Magdalen farm-lands in Sheet, near Petersfield, known as Brookeland, Skindre, Shirk leyes, and Pulyns. As early as I 587 (30 Elizabeth) with 'Dorothie his wyffe' he rented Sheet mills, and in 1596 acting as the College bailiff, collected the College rents, $£ I 7 I$ 5s. $3 d$. from Selborne and $£ 18$ 9s. 6d. from Petersfelde. In I597, he was appointed steward for the holding of courts and leets within the borough of Petersfield, by Th. Hanbury of Buriton, who had recently purchased the property. The lease for the Sheet mills mentions 'water mills, a wheat mill and a malt mill, together with all the waters, watercourses, ponds, fishinge, banckes, baies, and fludgares thereunto belonging, with free libertie to digg turfe in the great moore'. Even the legal document is redolent of the natural amenities, for which the rent was $£ 56 s, 8 d$. and half a crown in I6I8. William Yalden, described as of the diocese of Chichester, was the College Clerk of the Account from 16I6 to I643; and among the other College tenants were Crusophilus Yalden at Roplie Farm (1618) and Henrie Yalden in the Spaine in Petersfield.

John Goodyer's nephew and heir, the Rev. Edmund Yalden, son of William Yalden of Sheet, gin., became a Demy and Fellow of Magdalen, 1630 to 1642 , when he resigned his fellowship on being presented to the Rectory of Compton in Surrey. Sheet was a botanical locality often mentioned by Goodyer. 
The Goodyer country is perhaps better known to, though less visited by the English reader, than any other inland area in England. Its natural features and attractions have been made widely known by the premier work on nature study in our language, the classic Natural History of Selborne, by Gilbert White.

This country in which John Goodyer lived extends among the chalk hills at the junction of the North and South Downs, on and around one of the principal watersheds of south Britain. Born in the valley of the Wey, whose waters flow into the Thames, he passed his young manhood at Droxford on the Meon, which runs straight down to the Solent six miles west of Portsmouth; while at Petersfield he lived by the sources of the Rother, whose waters, mingling with those of the Arun, enter the English Channel at Arundel. A cyclist could visit all his homes in an afternoon.

As Gilbert White said a century and a half later, in this district 'so diversified with such a variety of hill and dale, aspects and soils, it is no wonder that great choice of plants should be found. Chalks, clays, sands, sheep-walks and downs, bogs, heaths, woodlands, and champaign fields cannot but furnish an ample Flora. The deep rocky lanes abound with flices, and the pastures and moist woods with fungi. If in any branch of botany we may seem to be wanting, it must be in the large aquatic plants, which are not to be expected on a spot far removed from rivers, and lying up amidst the hill country at the spring heads'. And yet perhaps it was just this upland character of his native country that caused Goodyer to pay especial attention to water plants whenever he came across them, an attention of which the reward was several most remarkable discoveries. He added at least a dozen aquatics to the British flora.

Nor are the literary associations of this favoured spot confined to the name of Gilbert White. Droxford is remembered as the village where Izaak Walton passed 
the last years of his life, Steventon was the cradle and Chawton the inspiration of the genius of Jane Austen, for if Pride and Prejudice and Scnse and Sensibility were composed at the former, Emma, Mansfield Park, and Persuasion were produced at the latter; while Buriton was the home of the childhood of Edward Gibbon, who always

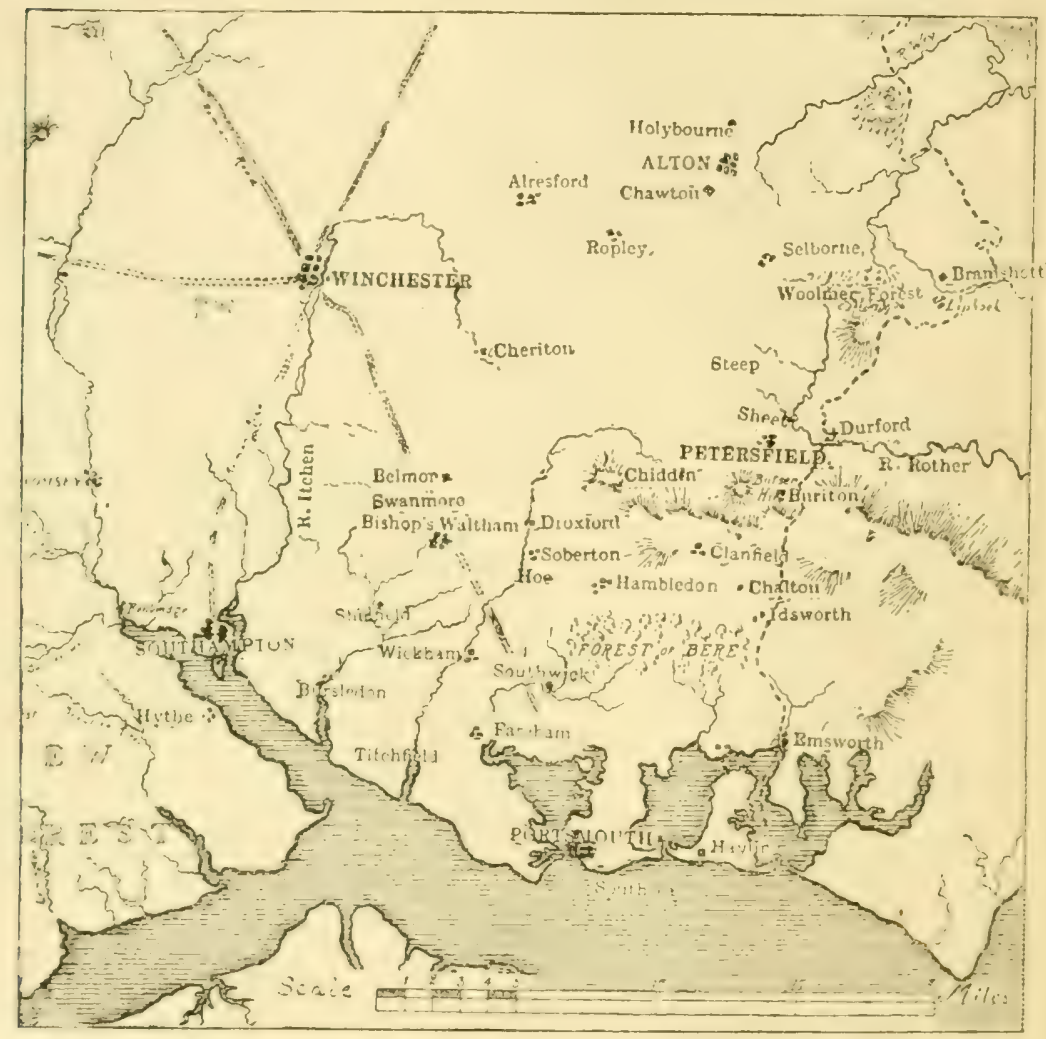

SKETCh-MaP of SoUth-EAST Hampshire.

cherished fond recollections of its natural beanties. 'The aspect of the adjacent grounds was various and checrful: the Downs commanded the prospect of the sea, and the long hanging woods in sight of the house could not perhaps have been improved by art or expense.' Such is the appreciation of the place in the Autobiosmouphy of the great historian. 
The localities most frequently mentioned in the Goodyer papers are Alton on the high road from London to Winchester and about half-way between Farnham and Alresford, three miles east of which is Ropley. To the north-east and south-west of Alton are Holybourne and Chawton respectively. Bramshott and Liphook lie to the east, Selborne to the west of Woolmer Forest.

The Petersfield localities lie in a ring of about two miles radius from the town: Steep due north; Sheet to northeast on the London-Portsmouth road, Durford Abbey due east, Buriton due south, overhung by Butser Hill on the west. The Forest of Bere is about eight miles south of Petersfield; while in the south-west quarter lie Hambledon, seven miles, and Droxford and Soberton about eight miles distant. Petersfield is about twenty miles from Southampton and about sixteen miles from Winchester: Idsworth is about six miles south. Bursledon Ferry over the Hamble is about four miles from Southampton.

In Goodyer's day, according to a survey of the manor of East Meon taken on 3I July I647, "The "bacon" (beacon-fire) on Butser Hill was usually supplied out of the coppices of Hyden woods both with timber and fuel. Stroud Common was overgrown with bushes which the tenants claim a right unto for making and mending their fences, but the great wood belonging to the lord was of late destroyed except some very little and young oaks all at present not worth above 3os.' In the defining of the boundaries of the manor, several large trees are mentioned which must have been well-known landmarks to Goodyer. They included the yew-tree at Wheatham Green, 'a great oak standing in the midst of Chescombe, and so abutting upon the manor of Berriton and Mapledurham upon the south-east', and a great ash standing on the side of Butser Hill.1

We have no information as to Goodyer's schooling. We know that he was not educated either at Winchester

1 Vict. County Hist. Hants, iii, p. 67. 
or at Oxford: it may be that he went to the local Grammar School at Alton.

His translations of Theophrastus and Dioscorides show that, like many men of science, he appreciated the classics, and that he was a considerable Greek scholar for his time. His library included Latin, Greek, French, Italian, Dutch, and German books : his notes show that he was well able to find his way about them, even though he was not very familiar with 'Duch and the Teutonick'.

As regards his walk in life we have evidence from many scraps of paper, often torn, upon which he scribbled botanical notes, drafted letters, kept accounts, wrote prescriptions, \&c. The original writings upon these papers generally relate to legal proceedings, village affairs, the collection of tithe and taxes, while two or three documents definitely associate Goodyer with Sir Thomas Bilson, Knight, of West Mapledurham, as his steward or agent.

Goodyer's service with the Bilsons is of some importance, because all who have hitherto written of him have followed Johnson in describing him as John Goodyer of Mapledurham, thereby suggesting that he was a landed proprietor in that place. Moreover, the name by confusion with the well-known Mapledurham on the Thames, has led to the concealment of John's identity, as, for instance, when the editor of the Flora of Hampshire remarks in $188_{3}$ that as Maple Durham is in Oxfordshire, Goodycr's Maple Durham was a possible misprint for Maple Durwell, near Basingstoke!

A clear account of the exact relations of the Hampshire Mapledurhams is given in the Victoria County History of Hampshive. They are situate in the parish of Buriton in the hundred of Finchdean. From an original manor of Mapledurham, dating from before the conquest, were divided a chief manor of Mapledurham, formerly held by the Gibbons, and now by the Bonham-Carter family, and the manor of West Mapledurham which Bishop Bilson purchased: it is now held by a member of the Legge family. Then there is Weston, a tithing in the parish of 
Buriton, which is believed to have been roughly co-extensive with the manor of West Mapledurham, and likewise belongs to Mr. Legge. The old manor-house of West Mapledurham was pulled down in I 829, and there is no tradition of any other old house in the district. The present Farm House of Weston was built in $1776 .^{1}$

Sir Thomas Bilson's father, Thomas, Bishop of Winchester I 597-I6I6, purchased the manor of West Mapledurham in

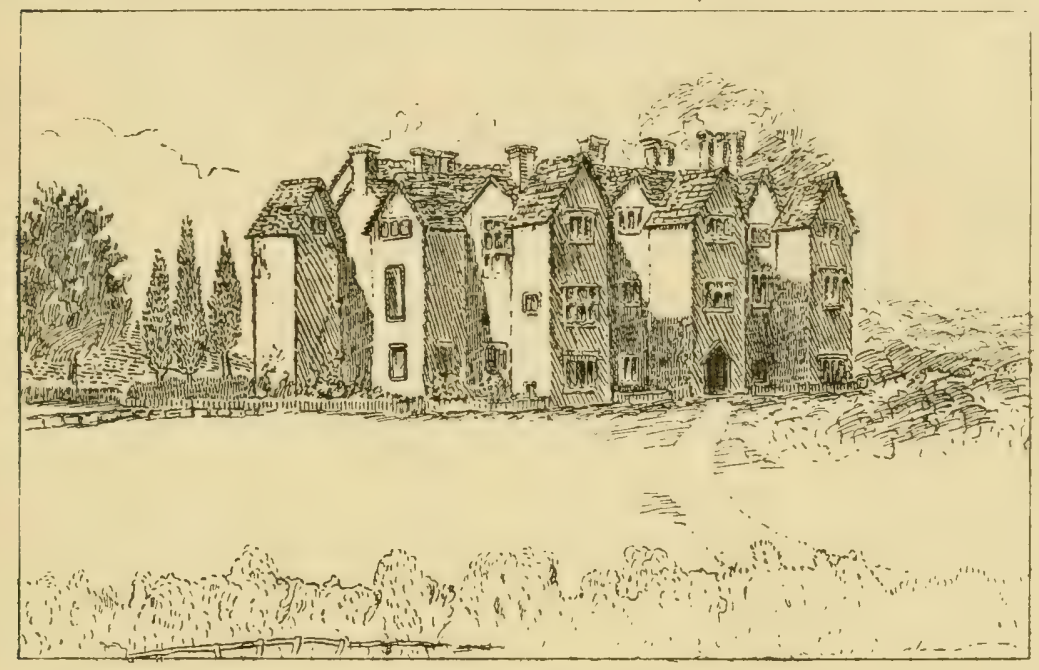

Mapledurham House.

I 605 from the widow and sons of the recusant Henry Shelley. On the death of the Bishop in 1616 , the manor descended to the eldest son Thomas 'aged twenty-four and more' and on the latter's death in 1649 to the second son Leonard.

The manor-house was a house with a history. During the occupation of the Shelleys it had been a centre where Papists foregathered during the latter part of the sixteenth century. There in 1586 the recusant Edward Jones used daily to 'consociate withal and heard mass every day'. There were 'priest's holes' which must have been a great joy to the Bilson boys: "there is a hollow place in the parlour by the livery cupboard where two men may well

1 Information from Capt. P. Seward. 
lie together, which has many times deceived the searchers'; and elsewhere "under a little table is a vault, with a grate of iron for a light into the garden, as it were the window of a cellar, and against the grate groweth rosemarye'. It is said that sometimes as many as six or seven priests were in hiding at the same time.

Goodyer may have entered the service of Sir Thomas in 1616 or 1617; he was certainly working for him for the next seven or eight years, and he may actually have been dwelling in Mapledurham House at the time that he was corresponding with Johnson in $1632-3$. Thus he would have been correctly designated as 'of Mapledurham', though not as a landed proprietor there.

Sir Thomas Bilson of Mapledurham, Knight, had married at Wickham, 6 August I 6 I 2, Susanna the youngest daughter of Sir William Uvedale of Wickham, Kt. (a surname which occurs among Goodyer's notes), having issue Thomas Bilson of Buriton, born I614, who married Edith Betisworth of Roegatt in $1640,{ }^{1}$ and Leonard, baptized 5 December I6 6 , who was named by Goodyer as one of the executors of his will, and whose monument may be seen at the west end of Buriton Church.

How long Goodyer remained with Sir Thomas we do not know. We deem it certain that he had periodically to visit the neighbouring towns and outlying farms, and even to ride up to London on his master's business. But botany was his hobby, and he probably endeavoured to combine so far as possible business with pleasure and visits to his friends' gardens with sittings in courts.

It would be easy to interweave writings of contemporary local interest into the life of our hero. The lists of the villagrers assessed for tithes and taxes, the picturesque roll-call of Armour-bearers and Spearmen and 'Peionors of Beritun' (= Pioneers of Buriton), were probably all part of his daily life, but we feel bound to keep within limits, and have relegated most of the contemporary documents

1 Bishop of London Marr. Lic. For other children, see p. 96 note. 
to the Appendix. At the same time these documents probably illustrate his varied avocations more definitely than anything else that has come down to us, and his biography would be incomplete without a mention of them.

Of special interest are:

I. A Deposition of Arthur Hyde of Weston in the parish of Buriton concerning Weston Farm in the possession of Sir Thomas Bilson, Knight (p. 375).

2. A Petition from Fra. Waller 'most humbly intreating yo ${ }^{x}$ good worship $\mathrm{S}^{\mathrm{r}}$ Thomas Bilson and to you and $\mathrm{yo}^{\mathrm{r}}$ man $\mathrm{Ma}^{\mathrm{r}}$. Goodyer greeting . . ' (p. 375). Written before I9 July I62I.

3. Notes of acres held by $\mathrm{S}^{\mathrm{r}}$ Tho. (Bilson) and ten other persons in an unmentioned parish (p. 379).

4. Receipt for $£ 250$ received by W. Inkferbie and Richard Bell from Sir Tho. Bilson, Knight, at his Mansion House called West Mapledurham in the county of Southampton (p. 374). Dated I5 November, but unfortunately the year, possibly I 620 or 1622 , is not mentioned.

All these and other papers are endorsed with notes in Goodyer's hand; and even more convincing evidence as to his occupation is supplied by the draft of a letter, which we provisionally assign to the year 1618 .

Sep. $\begin{aligned} 3-4 & \\ 5-6 & \text { hervest }\end{aligned}$

Oct. II-I 2 moving cocks

12-I4 lay by Coppels

15-16 mow gard. \&

No. I4 cover hartichokes at my being $w^{\text {th }}$ you I spak of Canary Wine $w^{\mathrm{ch}}$ my masters mother $M^{\text {ris }}$ Bilson was used to ... for to you, you told Mr. Hall had not made payment for all that had fetch in her

name, now he protesteth he hath. You then faithfully promised me if my master $\mathrm{S}^{\mathrm{r}}$ Thomas Bilson did send for any, you would send him of your best, which you affirmed to be as good as any was in England. For my lord Bishoppe Bilson was wont to comend your tast. Nowe my master entreates you to send him by this bearer Robt Palmer who you comend for his honesty, 4 or 5 gallons of such Canary Sack as you promised me to send in a sweet vessel. And the next weeke after we know what quantum you have sent you shall receave your money by the same bearer.

And so I rest

Your loving freind, JOHN GOODIER.

[MS. f. 6. 
It is likely that Goodyer found a distraction from thoughts on the grievous troubles of the times in his botanical studies. During his early years the bitter strife between Papists and Protestants reached an extreme intensity, as first one and then the other of the conflicting parties gained the ascendancy, but in all his multifarious writings there is no note as to the side to which he belonged. It may be assumed that he shared the general tendency of scientific men to take a 'philosophic' view of life, showing some disregard of the petty, transient events which chiefly absorb the attention of mean minds. $\mathrm{He}$ appears to have been a man who felt most at peace when his thoughts were reposing on the larger and more enduring aspects of the moral and material world. Yet all round him was turmoil. In his own county he would have known many who could have told lurid tales of the heavy blows of the 'Hammer of Heretics'. As a young man he might have seen one of the greatest Englishmen, the immortal Raleigh, undergo trial, imprisonment, and execution, and the Pilgrim Fathers driven abroad to seek that most elemental of all liberties, the liberty of worship: they sailed from Southampton in 1620 . In the prime of life the Civil Wars robbed him both of his best years for scientific work, and of his great friend, Dr. T. Johnson, killed at Basing House, to the great loss of natural science.

There is always a danger in reading into fragmentary documents more than was really meant, and yet there is a great temptation to a Magdalen man to recall an inciclent relating to a Magdalen College choir boy who became a Bishop of Winchester and Visitor of the College. The story gives one a vivid idea of the troubled state of Hampshire in the boyhood of John Goodyer, and greatly enhances the human interest attaching to his papers about 'pioneers' 1 and about Vachell ${ }^{2}$ and Uvedale." Thomas Cooper, translated from Lincoln to Winchester in 1594. was sorely troubled by the number of Romish recusants
1 p. 380.
2 p. 376.
s p. 161. 
in Hampshire, and made it a matter of conscience in 1586 to petition 'for certaine Orders to represse the bouldness and waiewardnes of the recusants in the Countie of Southampton', and also that 'an hundred or two of obstinate recusants, lustie men well hable to labour, maie by some convenient Commission be taken up and sent into Flaunders as Pioners and labourers, whereby the Country shall be disburdened of a companie of dangerous persons, and the residue $y^{t}$ remaine be put in some feare $\mathrm{y}^{\mathrm{t}}$ theie maie not so safe revolte as now they doe'.

The council turned a favourable ear to the bishop's appeal, and wrote to the sheriff and certain of the justices authorizing the suggested sudden searches and ordering them to follow the bishop's directions. ${ }^{1}$ That is why the occurrence among the Goodyer papers of a list of pioneers of Buriton carries with it ominous suggestions.

Bishop Cooper died in I594, when John Goodyer was two years old, and was succeeded by Thomas Bilson, with whose son, Sir Thomas Bilson, Goodyer was most closely associated. Recusancy was still being punished by imprisonment in Winchester gaol, but the prisoners benefited by the general sympathy of the public and were frequently released. Indeed, Bishop Bilson found that the manor of Woodcot, Hants, given for the safe keeping of the gaol, had actually been inherited by a recusant, one Anthony Uvedale, lately deceased, and had passed to his sevenyear old grandson, Anthony Brewning, whose parents were recusants. The penalty for the wealthier recusants, that was enforced about I590, was the seizure of two-thirds of their land; and among those whose names appear in the Recusant Rolls at the Record Office are Anthony Uvedale (the hereditary keeper of Winchester gaol) of Woodcote, near Alresford, and Stephen Vachell of Heath House, Buriton, both of whom are mentioned in the Goodyer papers.

A few years later an evil system prevailed of farming

1 Acts of Privy Council, 1586-7, p. 125; Vict. County Hist. Hants, ii, p. 82. 
out the recusancy fines for a fixed sum, and the payments by Henry Shelley of Petersfield, among others, were allotted to certain servants of James I. ${ }^{1}$

Goodyer was in the habit of jotting down lists of plants and odd notes on the backs and covers of letters, on petitions, or on any stray scrap of paper that came handy. In a way this is fortunate, for often the date of the document helps us to date the notes which he put upon it. Intermingled are the figures of calculations, shopping lists, series of days of the month with the Sundays ticked, names or plants and books, notes for excursions, medical prescriptions, names of litigants, taxpayers, and the like.

The sums done on the papers show that his arithmetical practice did not include the 12 times table, but that he first multiplied by 2 and then by 10 , and added the results as in long multiplication.

It is through these papers that we infer Goodyer to have had a training corresponding to that obtained in a solicitor's office at the present day.

The oldest document in the collection, a fragment, bearing the name Edward Cole, is dated when Goodyer was only sixteen years of age, but it would probably have come into his hands at a later date as part of an account with which Sir Thomas Bilson was concerned. Edward Cole may have been the Mayor of Winchester who in the year before the Armada contributed $£ 50$ to the war fund, and who is still remembered in Winchester as the founder of Christ's Hospital. On the back of this paper Goodyer jotted down a botanical note dated 1624 .

Then there is an Order from one of H.M. Justices of the Peace resicling at New Alresford, but holding court at Bishops Waltham, to John Rowland of Ropley, requiring him to take his 'Corporall oth for the dewe Execution and performance of the office of Tithingman-shippe for the Tithinge of Roplie'. Dated 23 September I614. This document is written in a clerkly hand: whether John Goodyer's or

\footnotetext{
'Dom. State Papers, James I, xlix, pp. 54-80.
} 
not does not much matter. And there are several similar papers. The deduction we would make is that the training which he received at this period left its mark on all his botanical work. He acquired an exceptionally neat handwriting, and learnt the value of methodical habits and the importance of dating every note and recorded circumstance relating to his observations. His descriptions of plants are most conscientiously dated. Many of his books are clearly marked with the day and year of purchase, the cost of binding, and the cost of carriage from London, even though this came, as in one case, to $£ \circ$ os. od.

Sometimes the exact hour of the day at which a piece of work was begun or finished is recorded with the precision that might have been expected of his astrologer contemporaries. But there is no evidence that Goodyer himself believed in horoscopes: his writings are severely scientific records of actual observation.

\section{I6I6}

From his practice of dating his books, we know for certain that Goodyer was contemplating the scientific study of botany in I6I6. During the winter of this year he added some very important works to his library. In each case the date and price are neatly written inside the cover of the book.

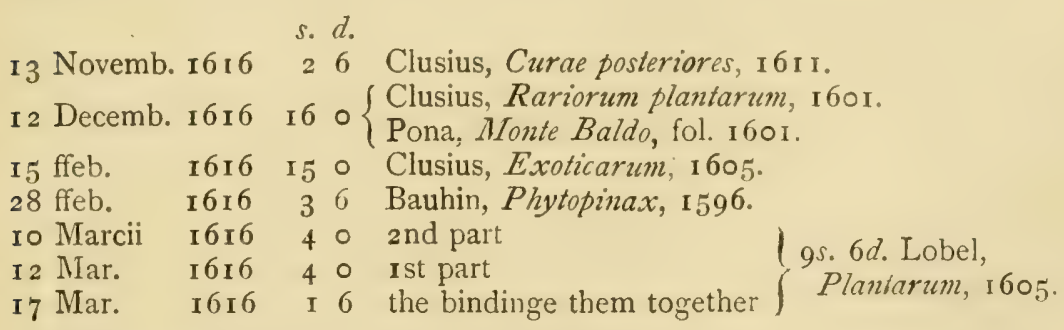

The conclusion is irresistible. Such books were not to be bought in Hampshire: Goodyer must have spent the winter in London, and have begun to make a serious study of the literature of botany. He was twenty-four years of age; and if, as we surmise, he were already in the service of 
Sir Thomas Bilson, whose father, the bishop, had recently been buried in Westminster Abbey, he might well have gone up to London on his master's business. A paper that throws much light on this visit to London is one on which he wrote out a list, dated the 24th and $25^{\text {th }}$ of March, of the more remarkable plants in the garden of Mr. Coys of Stubbers, a place a few miles east of London in Essex. On the same sheet of paper are a list of drugs and two London addresses, 'de Laune in ye black friers', and 'Mr. Cole $y^{t}$ married Mr. Lobel's daughter in Lyne Street'. This last is a most interesting note, because it gives the correct spelling of a name which from the time of Pulteney onwards has generally appeared in literature as 'Coel'. James Cole was a London merchant, mentioned by Johnson as exceedingly well experienced in the knowledge of simples.

The fact of Goodyer's visiting James Cole at this time would have a special significance. The eminent botanist Mathias de L'Obel, Cole's distinguished father-in-law, who had been living with him, had just died, leaving his botanical writings to his son-in-law. Lobel, as he wrote his name in this country, was the youngest of the triumvirate of great Flemish botanists, Dodoens, Clusius, L'Obel. He had brought to this country the learning of his master Rondelet of Montpelier and the botanical illustrations of that prince of printers, patron of botanists. Christof Plantin of Antwerp; he had made a special study of English plants and during his last years had been engaged on a new botanical work, the Illustrationes Stirpium. To Goodyer the name of Lobel, like that of Gerard, was probably a household word: he was known as the only botanist in Britain on whose scientific accuracy a student could rely. There is nothing more probable than that Goodyer, learning of his death on 3rd March, would lose no time in visiting Cole, and so get to hear of the manuscripts, which later, after the death of their editor How, did eventually come into his charge and were bequeathed 
by him to Magdalen College. In addition to the copy of the Plantarum Historia mentioned above, and purchased within a week of the death of Lobel, Goodyer owned five other editions by the same author: one of these, the edition of 1576 , was a presentation copy from Lobel to Dr. Martin Ramerus or Rhamneirus, a Licentiate of the Royal College of Physicians. A copy of the Icones Stirpium with notes by William Mount, and with some figures coloured, may have been among Goodyer's first botany books as a boy. We know that he could draw and that he painted in water-colour.

Goodyer's miscellaneous papers show that even while he was occupied with the business of estate management, or of the Courts, or in dealings with tithing officers, his mind would always be turning to the plants which he had seen in the gardens of his friends or had found on his excursions.

The earlier notes are scrappy, but of great historical importance, for they place our knowledge of early English gardening on a far surer basis than heretofore. The notes become progressively more methodical until in I62I their number and finish show that descriptive botany had become the principal object of the author's life. Whether Goodyer ever had any thoughts of publishing these descriptions under his own name we do not know, but of many he made both rough and fair copies: some of the latter he handed over to his friend Dr. Thomas Johnson for inclusion in the new edition of Gerard's Herbal to be mentioned in 1633 .

His first gardening friends included Parkinson, Coys, and Franqueville, who have often been mentioned in histories of early gardening, but now for the first time have we anything in the nature of lists of the plants actually growing in their gardens. Last year when editing the long list of plants grown by Walter Stonehouse in 1640 at Darfield in Yorkshire, it was pointed out that only three earlier garden lists were then known, those of the Holborn 
garden of Gerard ( 1596 ), of George Gibbes' yarden at Bath ( 1634 ), and of the Lambeth garden of the elder Tradescant (I634). We are now able to add several other lists of intermediate date which comprised the more novel plants then being grown by horticulturists.

The earliest of Goodyer's garden notes go back to the year 1616, when he first gathered seeds of Astragalus lusitanicus 'in the garden of my good friend Mr. John Parkinson an Apothecarie of London Anno 1616' (f. 107), and about the same time he noticed in the same garden in Long Acre, Pisum arvense, which he called 'P. maculatum Boelii' and 'Ervilia silvestris Dodonaei' (Lathyms Ochrus). The two former were no doubt two of the many new plants introduced into English gardens by Guilhaume Boel from Portugal and Spain in I608. Parkinson has put it on record that Boel 'gathered there about two hundred sorts of seeds . . . of all which seeds I had my part, and by sowing them saw the faces of a great many excellent plants but many of them came not to maturitie with me, and most of the other whereof I gathered ripe seed one yeare, by unkindly yeares that fell afterwards, have perished likewise'. ${ }^{1}$

Goodyer grew all three plants from seed in his own garden at Droxford and described them in I62I.

The next garden of which we have his notes was that of Wm. Coys ${ }^{2}$ at Stubbers, North Okington, in Essex. It was already old-established, and well known to Gerard in 1597 for its exotic plants, and was visited by Lobel during the early years of the seventeenth century. The latter botanist was moreover greatly impressed by Coys' methods of brewing beer and ales.

We are glad to think that this garden is not only still in existence but is in the possession of the family which succeeded the Coyses at the end of the seventeenth century. Through the curtesy of the present owner, Mr. Champion Branfill Russell, I was privilesed to make a pilgrimage

\footnotetext{
1 Parkinson, Thatrum, p. 1108.

${ }^{2}$ Sec p. 312.
} 


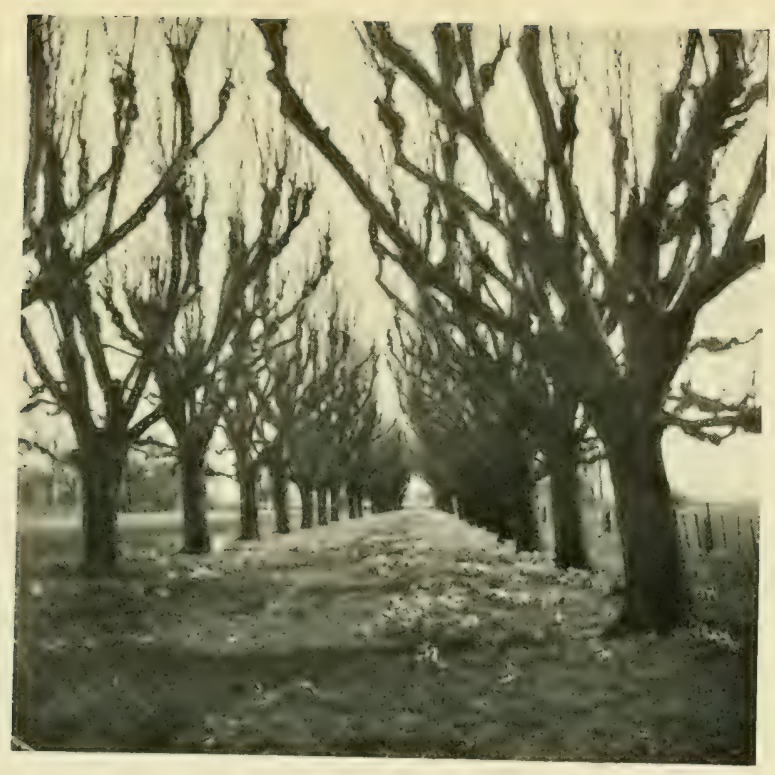

The Lime Avenue

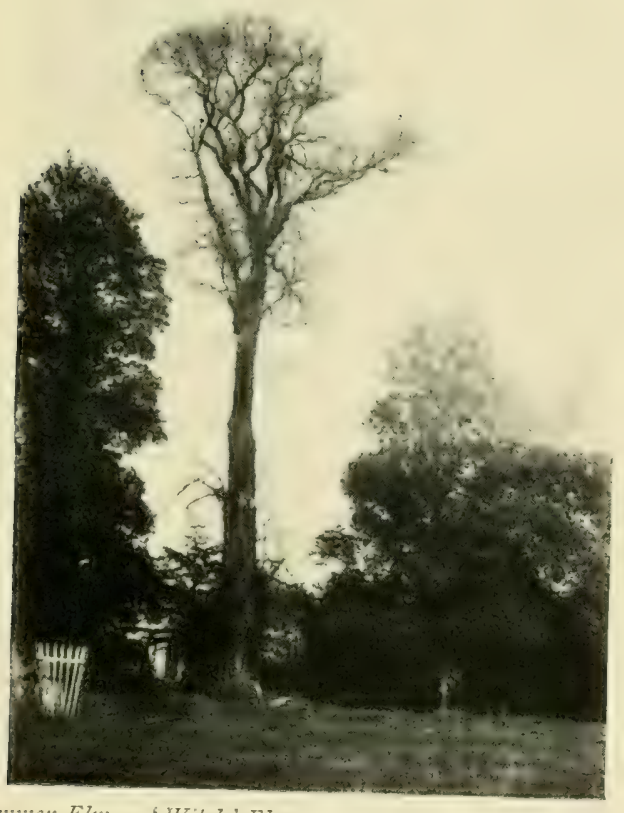

Elms in Spring

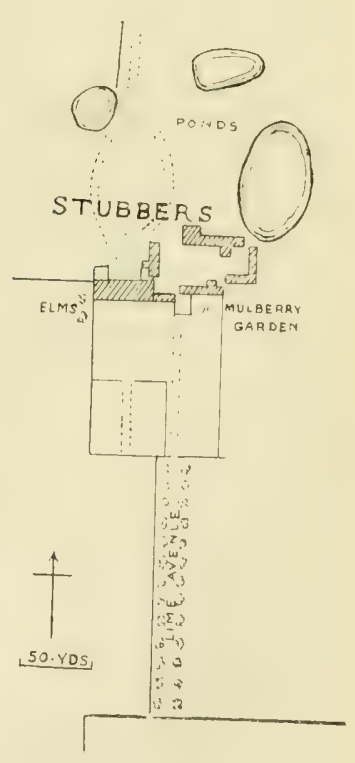

Plan

THE GARDEN AT STUBBERS 

to Stubbers this spring, and there on the day of the eclipse of the sun to celebrate the tercentenary of Goodyer's visit. The gardens were much altered by Repton at the end of the eighteenth century, and the house has been practically rebuilt, but sufficient remains to indicate the general arrangement of the old sites.

The flower garden of William Coys almost certainly coincided with what is now known as the Mulberry garden at the south-east corner of the house. The middle line of an old enclosed garden is indicated by a fine avenue of small but ancient limes, whose great age is hardly apparent at first sight. The trees were pollarded early, and their trunks being bark-bound have ceased to grow for many years. A very old-fashioned pink rose, a plant of which has been sent to Shakespeare's garden at Stratford-on-Avon, may also date from Coys' time. And to my great joy I found a more certain link with him in the pretty little Ivy-leaved Toadflax that is still growing on the older walls around this classic spot, where it was first grown as a garden plant in England and before it had become the common wall-weed that it now is. Another plant that may be directly descended from Coys' garden is the Yellow Fig-wort (Scrophularia vernalis L.), which comes up sporadically in the borders.

But of even greater botanical interest are the elms on the west side of the garden. At the time of my visit, one differed in the most conspicuous manner from its neighbours by being later and quite leafless while they were almost in full leaf. Had Goodyer seen the elms between Romford and Stubbers under the same circumstances, he could hardly have failed to remark on the matter to Coys, who would then have informed him of the local name 'Witch Elm', and would have expounded the special qualities of its wood, which was more 'desired for naves of carts' than common elm.

The garden of William Coys has always been famous in the annals of horticulture because it was there in 1604 
that the Yucca first flowered in England. Now, thanks to Goodyer, we are able to print a list of 126 names of plants that were growing at Stubbers in March $1616-17$, two lists including plants given by Coys to Goodyer in I62 I or I622, and a longer list in which 324 plants are marked with the letter C (= Coys). ${ }^{1} \quad$ This last list was made by Goodyer between I6I 8 and I625.

The earlier of these lists of Coys' garden is the oldest known MS. list of an English garden, in which the plants are properly distinguished by their scientific names. I have no doubt but that the names, which are in Goodyer's handwriting, were supplied by Coys, who may have determined many of them himself. In the history of English horticulture it therefore comes between the printed Catalogue of the Trees, Fruits, and Plants grown by John Gerard in his garden at Holborn ${ }^{2}$ and the lists of George Gibbes and John Tradescant, both of which are printed below. It is entitled

Mr. Coys his garden 24 and 25 of March $1616,161 \%$

Then follow ten names of plants distinguished with $g$ (= Gerard), and then twenty-four others which may or may not have formed part of the same collection. The latter include the American novelties:

Battata Virginiana.

Prunus Virginianus. Pishimon.

Cerastus Virginianus.

Vitis Virginiana.

Anonymos Sumas Virginianum.

Solanum Virginianum.

In after years Goodyer received many plants and seeds from Mr. Coys, which he grew in his Hampshire garden at I)roxford, and described in cletail when they flowered.

${ }^{1}$ See p. 387.

${ }^{2}$ Gerard's printed Catalogus arborum, \&c., of 1596 is only represented by a single copy, which has been admirably edited by Dr. B. D. Jackson in 1876 . 


\section{I6I7}

It was inevitable at the outset that the medicinal interest of herbs should be much to the fore. Botanical lore was practically confined to physicians, apothecaries, and herbalists; and perhaps this strong human interest supplied the motive power for the beginnings of the science of botany. All English botany books of early days were practically treatises on Materia Medica, and even Parkinson found a medicinal use for nearly every plant.

Goodyer's development took the same course. The notes made during his early period show that a medicinal interest in herbs was certainly present to his mind, though it may not have provided the principal incentive to his studies. In I6I7 he abstracted the names of forty-six exotic medicinal plants and products from Lobel's writings, and added the following list of drugs :

$\begin{array}{ll}\text { Terra sigillata } & \text { Tartar } \\ \text { Gum Elemni } & \text { Ladanum } \\ \text { Aurmi vulgar } & \text { Castor } \\ \text { Virga aurea } & \text { Paeina ppi } \\ \text { Mirrh } & \text { Bac mirti } \\ \text { Bolus armenic } & \text { Acacia } \\ \text { Caious } & \text { Spodium } \\ \text { Borax } & \text { Bdellium }\end{array}$

Litharg. auri

And on 28 April I6I 7 he added:

2. Corall dissolved \& swetned with Juyce of Granates Syrup of Rheubarbe made of ye extracte

The Extracte of Rhubarbe

Pearle dissolved

Liquor solutionis Scamonii 1610 23 Marcij

Balsamum

Scamonium corrected I6I0 23 Marcij

Hirae simpl. jiiij pro quat. viribus

Manna $2 \mathrm{oz}$.

Santali Citrini incisi 3iij

Olibanum

Epithimum 3ij

Oximel simpl.

Dia Codion simp.

Dia moron.

de Laune in ye black friers. 
The study of drugs was evidently going strong about this time, for in this very year, I6I 7 , the Society of Apothecaries of London, the Socictas Pharmaceutica Londinensis, severed its connexion with the Grocers' Company, and received a new charter from James I. Goodyer appears to have obtained his list of drugs from one of the early masters of the Society, Mr. de Laune, ${ }^{1}$ an apothecary in Blackfriars, whose name and address he noted on the back of the paper, and who is known as having sent from Burgundy to Gerard plants of Gentiana maior, the Great Felwoort or Bald money, now known as Gentiana lutea L.

The two Scammony preparations are dated I6ro, when he would have been eighteen years of age. And in the first list the figure 16 before five drugs may show that he became possessed of them in that year. The five are Hermodactyli non venenati offic. Lo. I46; Rha Ponticum antiquonum Lo. 289; Aloe Lo. 374; Glans unguentaria Lo. o. IоI ; Araba lacca.

Towards the close of his life he again revived his interest in medical matters. He bought medical books, he wrote out prescriptions, and he copied notes from medical

${ }^{1}$ By finding the will of William Delaune (P. C. C. Wood 23) at Somerset House I have obtained evidence that the de Laune visited by Goodyer is likely to have been the son, Paul de Laune. Wr. Delaune, Preacher of the word of God and Physician, willed that he should be buried near his late wife. To Gedeon his eldest son he left his lands in Blackfryars near Ludgate which he had purchased of Sir Wm. More ; to poor of French church in London $£ 4$; to poor of Blackfriars and of Church of Norwich and Deepe 20s.; to kindred beyond the sea $£ 6$ (to be administered by s. Nathaniel); to s.-in-law Mary Desloges, widow of Cornellis Tance, $£ 3$; to s. Paul the newe house, greate Court $\&$ house of office, and the Apothecary stuffe and furniture.

The relations mentioned include sons, Gideon, Peter, Nathaniel, and Paul; grandsons Abraham s. of Gideon, and Henry s. and h. to Isaack Delaune dec.; das. Sara, Ester, and Elizabeth; sons-in-law Chambleyn and Nathaniel Mary. The will is dated 20 November 1610 ; proved 12 March 1610 . Both William and Paul were on the Roll of the College of Physicians. Gideon de Laune made money as Apothecary to Mary, the Queen Mother, and died worth $£ 80,000$. Shakespeare's friend, Sir IV. Davenant, was his great acquaintance (Aubrey, Lives). Paul is believed to have died in Jamaica, c. 1654 : he was a relative of Dr. John Argent see p. 250. 
authors into the margins of his herbals; all of which goes to show that he was turning his knowledge to practical use by attending to the medicinal needs of his neighbours.

But John Goodyer, though mindful of the medicinal and economic value of plants, clearly saw that the science of botany could not be advanced without detailed morphological descriptions from living plants. His ideals were those of his great predecessors Fuchs and Brunfels: but whereas they put their observations into their drawings, Goodyer put his into descriptions.

One of his local discoveries of I6I 7 was the Woolly Thistle, 'Corona fratrum quorundam' (Carduus eriophorus L.), which he found 'wilde neare London highwaie on the East part of Haliborne in Hampshire'.

Another was the Purging or Cathartic Flax, or Millmountaine, a plant of known medicinal virtue which used to grow plentifully in localities where 'Carduus acaulis septentrionalium L'obelii' was also found, namely, 'in the unmanured inclosures of Hampshire on chalky downes and on Purfleet hils in Essex, and in many other places'. He owed his information concerning the properties of this plant to one of his apothecary acquaintances.

'I came to know this herbe by the name of Mil-mountaine, and his vertue by this meanes. On the second of October I6I7 going by $\mathrm{M}^{\mathrm{r}}$. Colsons shop an Apothecary of Winchester in Hampshire, I saw this herbe lying on his stall, which I had seene growing long before: I desired of him to know the name of it, he told me that it was called Mill-mountain, and he also told me that beeing at Doctour Lake his house at Saint Crosse a mile from Winchester, seeing a man of his have this hearbe in his hand, he desired the name; hee told him as before, and also the use of it, which is this.

Take a handfull of Mill-mountaine, the whole plant, leaves, seedes, flowers and all, bruise it and put it in a small tunne or pipkin of a pinte filled with white Wine, and set in on the embers to infuse all night, and drinke that wine in the morning fasting, and hee said it would give eight or tenne stooles. This Doctour Lake 
was afterward made Bishop of Bath and Wells, who alwaies used this hearbe for his purge, after the said manner, as his man affirmed.' 1

But the outstanding event of this year was the introduction of the Jerusalem Artichoke to English gardens

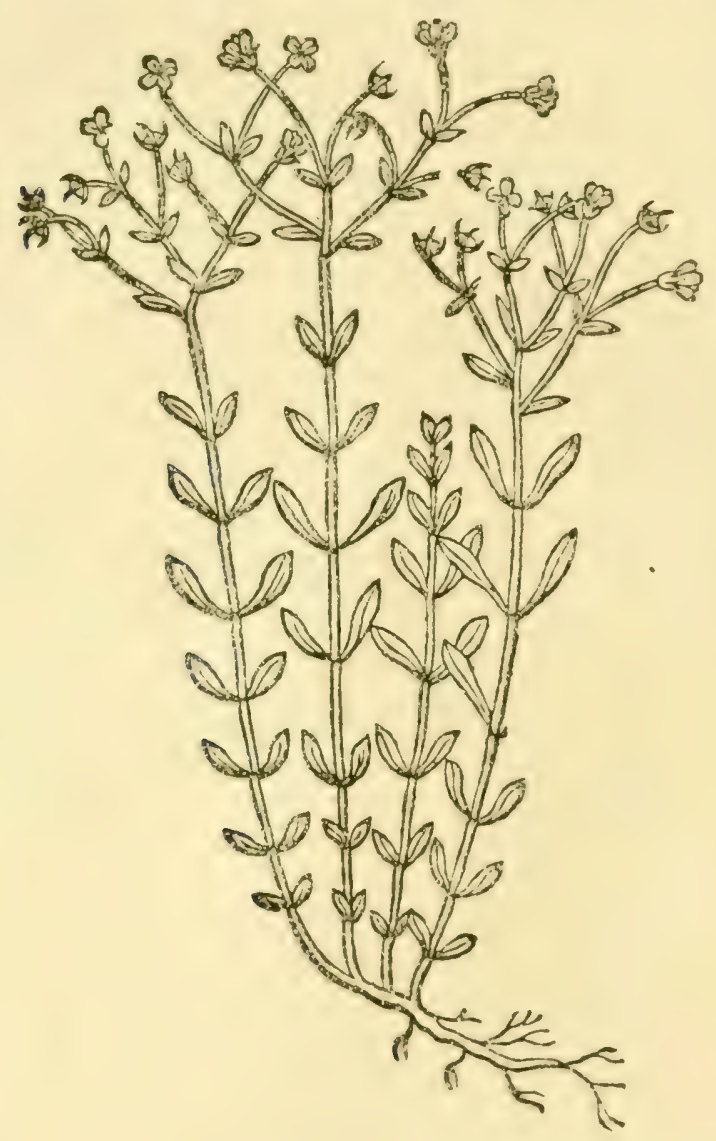

Mili-Mountain.

and cookery, undoubtedly the result of a visit to the London garden of John Franqueville. Of this garden we are also able to give a list, but as Goodyer was there at

"Ger. emac. 560. For Goodyer's description of the plant, see p. 112. The use of Honewort, as Corn Parsley was locally called in Hampshire, steeped in beer to cure swellings of the cheek, was also duly recorded by him, and will be again referred to under 1625 . 
the end of the year, when it would be looking its worst, the list is short (p. 326).

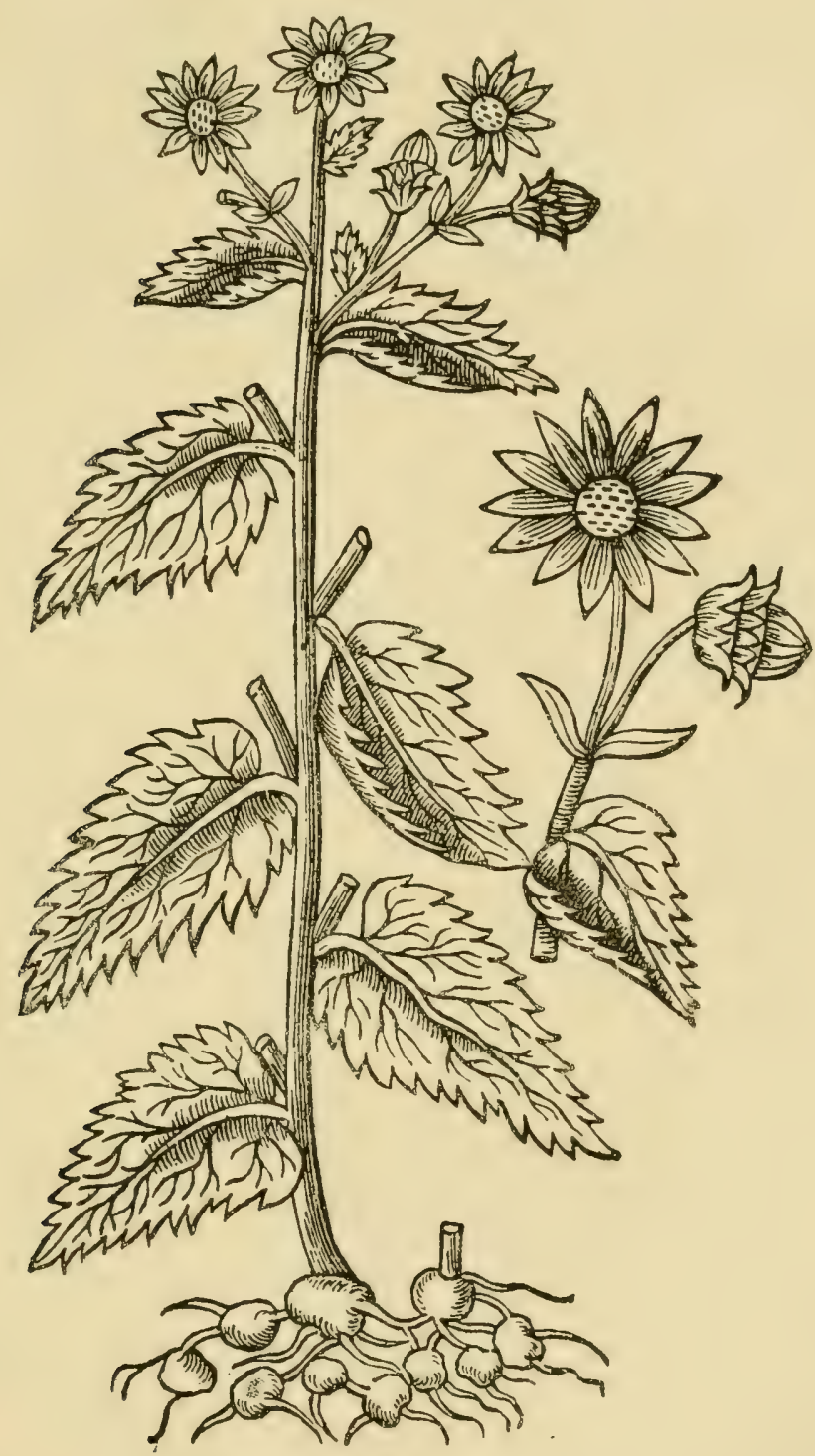

The Jerusalem ARtichoke.

We here quote his description of the circumstances of his success with the new ' wonderfull increasinge 'vegetable, leaving the account of the plant for a later chapter. 
'Where this plant groweth naturallie I knowe not. In Anno I6I 7 I receaved two small rootes thereof from Master Franquevill of London, no bigger then hens eggs, the one I planted, the other I gave to a frend, mine brought me a peck of rootes, wherewith I stored Hampsheire.'-MS. I I, f. I I7; Ger. emac. 754.

The friend is almost certainly William Coys, for whom he afterwards wrote out a very long list of plants (I 7 pages), with notes and references to the works of Lobel and Gerard, and to their occurrence in the gardens of Coys, Parkinson, and Franqueville. In this list after the entry relating to the Artichoke 'Heliotropium indicum vel virginianum', he added the note, 'you had lately planted it when I was at your house 25 Martii i6I7’.

Goodyer's quaint description of The Vertues of the Artichoke have often been quoted: but it is a story that does not lose in the repetition.

'Theis rootes are dressed divers waies; some boile them in water, and after stewe them with sack and butter, addinge a little Ginger : others bake them in pies, puttinge Marrow, Dates, Ginger, Reasons of the Sunne, Sack, \&c. Others some other way, as they are led by their skill in Cookerie. But in my iudgement, which way soever they be drest and eaten they stirre and cause a filthie loathsome stinking winde within the bodie, thereby causing the belly to bee pained and tormented, and are a meat more fit for swine, than men: yet some say they have usually eaten them, and have found no such windie qualitie in them.'-MS. II, f. I17; Gcr. emac. 754 .

But before making any attempt to account for the tastes of past generations, it is necessary to know precisely both how they prepared their food and how they arranged their dietary. The transition from the age of beer to that of tea and coffee must have profoundly modified the national palate. And this is well illustrated by a very striking instance of an acquired taste, quoted by Goodyer's contemporary Parkinson. Chocolate, he described as a drink 'well pleasing and accepted with the greatest among the Indians, who account nothing of more esteeme; but to the Christians it seemeth a wash fitter for hogs, yet by use even accepted by them also in the want of better'. 
The cultivation of the other, the Globe Artichoke, appears to have spread through the southern counties of England some half a century earlier, and the vegetable that figured in legal documents in Goodyer's lifetime is more likely to have been the Globe than the Jerusalem Artichoke. For in one of the Bodleian charters relating to Kent there is a stipulation that the tenant of a garden in Wateringbury is not to have "the benefit of the Sparrow Grass beds and Hartichoaks in the Garden'. An Hartichoke Garden, 44 perches in extent, was one of the features of Henrietta Maria's garden at Wimbledon, and at the time of the survey of 1649 contained plants and roots to the value of \& I IOs. ${ }^{1}$ Her gardener probably grew both sorts.

Every one who has hitherto written about Goodyer appears to have tacitly assumed that he spent his early manhood at Mapledurham, and that there his first experiments in horticulture were made. This, however, was not the case, for although he was no doubt often at Mapledurham, his home and, what interests us more particularly at present, his garden were at Droxford. It was Droxford, therefore, that must have the honour of having been the first village in England to produce the new Artichokes in quantity. How completely all recollection of this important horticultural event has disappeared, is proved by the fact that even the modern 'discoverer' of John Goodyer, Canon Vaughan, did not know that his botanical predecessor had ever dwelt in Droxford. Yet Canon Vaughan, while Rector of that parish, when engaged in researches into the forgotten details of Izaak Walton's life there, passed the history of Droxford through a hair sieve. But then Hampshire is a forgetful county. Do not the lives of Walton, of Goodyer, of Gibbon, and above all, of Jane Austen show it?

The papers that have been reposing for the last two and a half centuries in the manuscript room of Magdalen are evidence that Goodyer lived and gardened at Droxford,

${ }^{1}$ Archaeologia, vol. x. 
but unfortunately their information goes no further. There is no hint as to where his house may have stood, or where the first Artichokes increased so amazingly. The village, writes Canon Vaughan, is but little changed since the time when Izaak Walton spent the last days of his life resting in 'the cool shade of the honeysuckle hedge' and watching the moorhens 'on the gliding stream'. The old mill is still standing, on the bridge of which 'the aged angler must often have lingered, as he watched the rush of water making pleasant music beneath his feet' and thought of his fishings in swift streams 'full of great stores of trout'. Nor would it have been very different in Goodyer's early manhood. Then, as now, the church was flanked on either side by the Manor House and the Rectory, with their gardens, orchards, and pastures sloping down to the clear running Meon. The underground tunnel from the Manor House below the Rectory garden to the house beyond, may or may not have existed: at present it is only a reality in local tradition. Of greater permanence are those details of uncultured nature, of the birds and flowers, which the Canon has described so well: his sketch of the wild life of 'Longmead' bordering the Meon is for all time: that is Droxford as Goodyer knew it. He would have recognized the spot where the green Alkanet (Anchusa semporvircus) puts forth its rich blue flowers and he would have revelled in the rare beauty of the Yellow Meadow Rue in its season, but it is cloubtful whether Coral Root would have escaped him, had it been growing near Church Mead, where Canon Vaughan tells us it grew within recent years. Certainly there is no evidence that Goodyer knew it in Droxford before he found it at Mayfield. Botanists tell us that Coral Root is only found in this one locality in the whole of Hampshire, and we may not unreasonably deduce that Goodyer will have followed his usual practice of lifting roots found away from home and planting them in his garden. The Hampshire colony may be descended from a garden-cscape. Is it a clue to the site of his garden? 
In after years Goodyer cultivated many other new fruits and vegetables, including the Virginian water-melon or Pompion, 'no bigger nor larger than a great apple', but none are now so well known as the Artichoke, his first horticultural triumph, and one with which his name will always be connected. Indeed, it may be that this early success inspired those assiduous searchings for new and rare plants that characterized the whole of his active career.

\section{8}

Several papers dated I6I 8 show Goodyer's connexion with the Bilson household, probably, as we have said, in the capacity of steward or agent. In the corner of a roughly scribbled letter, printed on page 9 , is a fragment of a diary, with a reference to the fact that his 'hartichokes' required protection in cold weather.

At the same time his interest in field botany was steadily increasing. He made several journeys on horseback in his own and neighbouring counties and up to London, perhaps on his master's business, but certainly to his own profit and advancement as a botanist.

On one of these visits he would almost certainly have again visited the well-known garden in Long Acre belonging to John Parkinson who, like Coys, had received many rare plants collected by William Boel in Spain in 1607 , an acquisition all the more desirable since many of his own fine plants had perished during the 'most violent frosty winter' that preceded. In 16 18 Parkinson was gloating over his various horticultural triumphs, including the Great Double Yellow Spanish Daffodil which he claimed to have been the first to grow. ${ }^{1}$

On the 9th of April Goodyer noted 'Cowslipps 2-in-a-hose' and 'Primrose 2-in-a-hose' at Sheet, probably in the garden of William Yalden, who almost certainly lived in a new house by the mill on the upper waters of the Rother. The

1 Parkinson, Paradise, p. 103: 
house is still standing, and even though more than three hundred years old, is a comfortable home. A stone in the wall records the year 1606 , when it was built, and the year I867, when it was repaired. The timber-framed walls of the upper story are partly filled in with wattle and dab, and partly with a warm red brick. The old kitchen chimney is so wide that it can only be swept by climbing inside; and there is, it is said, but one man now living who is willing to strip to his trousers and bring down the soot. This was the home of Rose Yalden, Goodyer's sister: plants in the garden at Sheet are oft-times mentioned in his papers, the last being some Sweet Potatoes in 1637.

To plants found near his own home at Droxford, he frequently refers. In a wood by Strugnells in the Thetcher, near Droxford, he found Lunaria minor on 2 Ist May, and again on I June. These are the first notices of Moonwort in Hampshire. He records plants collected (and incidentally his own movements) at Chawton ${ }^{1}$ (Io June), Sheet ${ }^{2}$ (7 July), Chawlton "(i 8 July), Tichfield ${ }^{4}$ (20 July), Hounslow Heath ${ }^{5}$ ( 30 July). In August he was travelling in Wiltshire, visiting Warminster ${ }^{\circ}$ (2 I August), and Venny Sutton, ${ }^{7}$ now Sutton-Veny (27 August). And nearer home he visited Winchester, Southampton, and Emsworth.

At Winchester he noted that 'Willowe' was the popular name for 'Chamaenerion Gesneri', which is therefore the first evidence of the Willow herb (Epilobium angustifolium L.) in Hampshire. It is a plant which has since been

1 'Herba Paris, some with five and six leaves.' The first notice for Hants of Paris quadrifolia: Gilbert White noted it again in 1778 .

2 'Scabiosa minima hirsuta.' Probably the first record of Jasione montana L.

3 'Jacea flore albo.' Perhaps a white variety of the Greater Knapweed (Centanera Scabiosa L.).

' 'Eryngium marinum.' First evidence of the Sea Holly (Eryngium maritimum L) in Hants. Eryngo roots candied were a favourite delicacy in the days of James I, but they were then obtained from the East coast. Sir John Salusbury, c. 1580, knew their medicinal value.

s 'Plantago aquatica stellata.' First record of Damasonium Alisma Mill., the rarest of our Water Plantains.

6 'Colchicum flo. albo et purpureo.'

7 'Ebulus', 'called Scots Blood'. Sambucus Ebulus L. or' Danewort. 


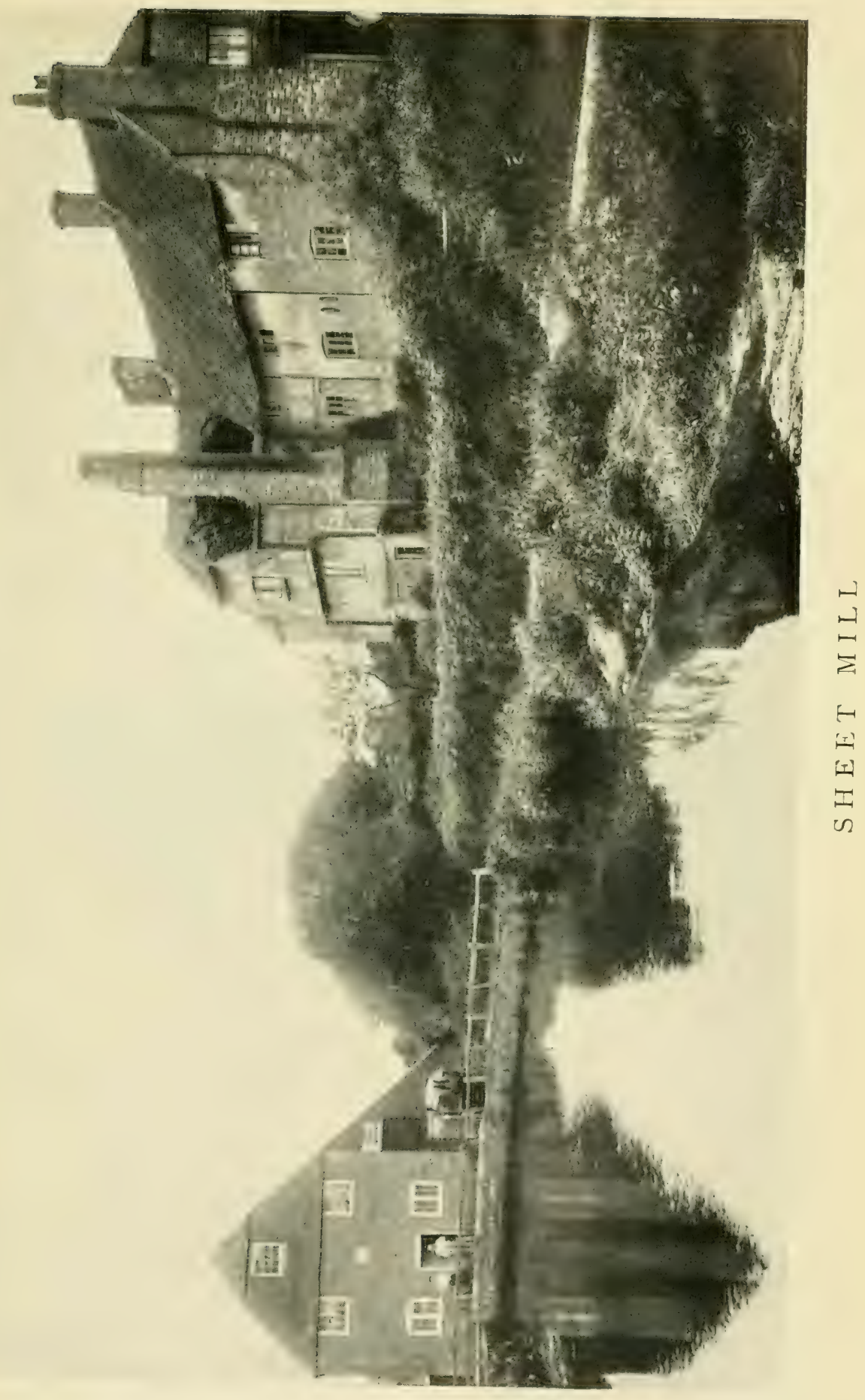



reported as abundant in the valley from Beech Farm, where he lived as a boy, to Meadstead. He may, therefore, have known the plant near home, but may not have been familiar with its Winchester name. The Willow herb remained unrecorded in Hampshire until Gilbert White mentioned it again in his Garden Kalendar for September 1765 .

A more striking discovery was that of 'Lactuca sylvestris vera ingrato odore'. 'This wilde stinkinge lettice I found wild on the walls and dry bancks of earth at Southampton. Anno 16I8.' This is the first county record of Lactuca virosa L. He sent seeds to Parkinson, in whose garden Johnson saw it growing about 1630 . A detailed description was written on 13 September 1621 .

By a mill at Emsworth he found 'Anagallis aquatica tercia', the Brookweed or Water Pimpernel (Samolus Valerandi L.), thus making his first contribution to the paludal flora of his county. It was not recorded in Hampshire again for more than two hundred years.

During the last two weeks in August he was travelling in south Wiltshire and passed through Salisbury. The finds on this trip are mentioned in a draft letter dated 7 November and written in London. The name of the person to whom it was written does not appear, but from the fact that the names of the plants mentioned are included in a long list which Goodyer sent to his friend Coys, I strongly suspect that it was addressed to him.

$\mathrm{S}^{\mathrm{r}}$ after my service remembered ... I wrote unto you a letter from Droxford $y^{\mathrm{e}} 8$ of Sept. last, and therein enclosed certaine stalks \& seeds of an herbe which I found in Wiltshere somethinge like to Lysimachia, [I found it in Wiltshere (erased)] also I sent you some of the leaves \& stalks of Plantago aquatica stellata which I found in Hounslowe Heath. I therein wrote unto you that I found Colchicum $f$. albo \& purpureo in Wiltshere, in flower in August last, $I$ have of this roots of them at Droxford, if you want I can furnish you with some of them. I doubt you receaved not that letter, for that our foot-post died by the waie going towards London, since whose death we wanted a foot-post for 
a year, but now we have another who did lye at $y^{\mathrm{e}}$ King's armes in Shoe Lane, the place where the old foot-post lay, but nowe he is removed to another place which yet I doe not know. I have left at MIris Capells (for Mr. Capell ${ }^{1}$ they tell me is dedd since my last being with you) a small plant of our Wich Hasell which I take to be Vlmuns latifolic lobelii: it came from seed this last year. I have seen $y^{e}$ leaves of them this somer twise as brode as I saw any of $y^{e}$ leaves of our Common Elm. This desiring that God do bless you with health and happiness to your great Comfort, I comitt you to Gods protection and rest

to you my bounden

[Unsigned]

From my Lodging at the Red Lyon

in Fleet Street, London, the 7 of November 16I8.

Yf at any tyme you wright to me you may direct your letters to be left at Mr. Tho. Johnsons [a Tayler (crased)] at the signe of the Raynedeare without Temple Barre neare St. Clements Church, where our foot-post shall endever to have them.

[MS. f. 2

This letter is of great interest because it is the earliest evidence for the Willow herb, 'something like to Lysimachia' (he found it on 27 August), and for the Autumn Crocus in Wiltshire. It settles the question of the priority of the discovery of the Water Plantain, Damasonizm Alisma, as a British plant, in favour of our author rather than of Johnson. It also dates his first recognition of the Wych Elm (Ulmus montana Stokes) as a distinct species of English timber tree. Apparently it was growing at Droxford and was known to Goodyer by its south-country name of Witch Hazel. Now this name has been generally: superseded by the northern name of Wych Elm. I have no doubt that by this observation at an early period of his carcer, his eye became trained and apt to distinguish the two other elms which he was the first to describe. His

\footnotetext{
1 At a later period CAPEL was quite one of the best-known names in connexion with English gardens. Sir Henry Capel began horticulture at Kew, his brother Lord Capel made one of the most beautiful gardens of the seventeenth century at Cassiobury, and Mary Somerset (née Capel) had a botanic garden at Badmington, but there is of course no evidence that Goodyer's friend was 'born in the Purple'.
} 
descriptions of the four species are reprinted on page 38 , but the first draft of his description of the Broad-leaved Elm may appropriately appear here. It is written on the back of a document dated I6I4.

The broad-leaved Elme or Witch Hasell groweth to be a very greate tree, and very high, especially when he groweth in woods amongst other trees, the tymber in $\mathrm{y}^{\mathrm{e}}$ yonge trees is very white, his branches or boughes are grosse \& bigge and doe spread themselves broader [and hang more downewards than those of the first]. The leaves are rougher and much broader and longer than those of $y^{\text {e }}$ Comon Elme, stript or cutt about $y^{e}$ edges, of a dark greene colour, nearer resemblinge $y^{e}$ leaves of $y^{e}$ Hasell, which is $y^{e}$ cause of $y^{e}$ name.

The one side of $y^{e}$ leaves are allwaies longer and doe come nearer to $y^{e}$ boughes whereon they were then the other, like unto $y^{e}$ leaves of all $y^{e}$ rest of $y^{e}$ kind of elmes, as Lobell's figure of the Common Elm well expresseth; the leaves of the older trees are very much narrower than those of $y^{e}$ younge ones, also on $y^{e}$ leaves of this Elme doe growe blisters or bladders in which at $y^{\mathrm{e}}$ springe are little creatures about $y^{e}$ bignes of Bed-fleas, which in $y^{e}$ somer (as I take it) turn into flies growinge wings like those of the Comon Elme. The barke on $y^{e}$ out side is blacker than that of $y^{\mathrm{e}}$ Comon Elme \& is very tough. So that when $y^{\mathrm{e}}$ sappe is uppe, it will strippe \& peele from the lower end of $y^{e}$ boughes to $y^{e}$ toppe, without breakinge, whereof are made cords \& ropes.

The roots spread far abroad in $y^{\mathrm{e}}$ earth \& are very tough, which makes the tree with much difficultie to be grubbed uppe.

Whereon doe growe $y^{\mathrm{e}}$ flowers nearly compacted together \& like unto $y^{\mathrm{e}}$ pointells or chives growinge in midle of flowers, which afterwards turn into flatt seed, more long than broade, not much unlike to Arach seed; and doe for the most parte fall away before or shortly after, the leaves springe forth, and some hang on a greate parte of the somer. They flower at the latter end of ffebr or beg of March.

[MS. f. 4 ; Ger.emac. p. I 48I (much alterèd)

The following lines are written on the cover of a letter addressed to 'Nicholas Everender at his brother's house in Sedlescombe in Sussex. This to $\mathrm{M}^{\mathrm{r}}$ Samuell Shute at Mr. Thomas Caltherste at ye albus Lion in Dea(?)side'. On the other side is written the draft of the letter already 
quoted, dated by Goodyer from his lodging at the Red Lyon in Fleet Street, on the 7 of November 1618.

'Even such is tyme, that takes in trust Our youth, our ioyes and all we have And paies us but with age and dust Who in the darke and silent grave When we have wanderd all our waies Shutts uppe the storie of our daies And from which earth and grave and dust The Lord shall raise me uppe I trust.'

[MS. f. 2

Being, regrettably, unfamiliar with the poem I consulted my friend Sir Walter Raleigh, our Professor of English Literature, in the confident expectation that he would identify it for me. The strange coincidence could hardly have been anticipated that the lines should be known as the 'Last Poem of Sir Walter Raleigh' of Elizabethan fame. There is a tradition that they were written in the Tower, shortly before the execution, but whether this be so or not, it is surely remarkable that Goodyer should have had a copy on the back of a letter written within a few days of the execution on 28 October I 6 I 8.

As a twelve-year old boy Goodyer must have heard of the infamous trial at Winchester, when the people first pelted Raleigh with tobacco pipes and later were won over by the eloquence of his defence and the dauntlessness of his bearing. He would assuredly have taken a sympathetic interest in his great contemporary not only for his heroic career, but as a pioneer familiar with the splendours of the tropical vegetation of the New World. Goodyer's Artichoke culture was perhaps modelled on that of the Potato. Whether he was a smoker, we do not know, but about 16I8 he paid 4d. for 'tabaco', apparently at Alresford. It was only a few years before, that James I had stigmatized smoking as 'a custom loathsome to the eye, hateful to the nose, harmful to the brain, dangerous to the lungs, and in the black stinking fume thereof nearest resembling the horrible Stygian smoke of the pit that is bottomless'. 
In I6 I9 Goodyer took to growing two kinds of tobacco at Droxford.

There are several lists of garden plants among the Goodyer papers, but unfortunately they have no localities or dates attached to them, with the exception of a short list of plants, without date, and not in Goodyer's hand (see p. 347). It is headed To have from Mr. Gibbes. Of the plants enumerated only six are noted by Johnson as occurring in the garden of Mr. George Gibbes of Bath in I634.

Another list in his own autograph may refer to plants growing at Droxford (p. 327).

\section{I619}

Of the year 16 I9 there is but little to record except the discovery and description of two plants, one of which was new to the British flora. He also wrote the description of the Limm catharticum, part of which has already been quoted.

On the 3rd of August he found the Small Woodruff or Squinancy-wort (Asperula Cynanchica L.), and thus he independently discovered one of the denizens of the chalk hills which had been previously, though probably unknown to him, noticed by Lobel in the Isle of Wight: 'cretaceis gaudet montosis prope Drayton e regione Vectis Insulae'. Goodyer's observation of I6 I 9 was printed by his friend Johnson in 1633 , and Lobel's earlier note was printed by his admirer, Dr. How, in 1655. The Procumbent Marshwort (Apinm nodiflorum) is recorded on the authority of Goodyer ${ }^{1}$ by How: we are now able to print the original description (p. I 14 ).

A further success was the addition of a new HedgeParsley to our flora (Caucalis nodosa Scop. ${ }^{2}$ ). Later on Goodyer discovered the Field Hedge-Parsley 'amongst wheat plentifully near Petersfield'. 3

His well-known description of the Dewberry (Rubus cacsizs L.), distinguishing it from other Brambles under

${ }^{1}$ How, Phytologia.

2 Druce, Goodyer, p. I.

3 Merret, Pinax, 24. 
the name of 'Rubus repens fructu caesio', was written in September of this year, but the original MS., from which Johnson's account was printed, is not now extant. It was almost certainly taken from a Hampshire plant, but since Goodyer omitted to mention the locality, he is not quoted as a first recorder in Townsend's local Flora, in which seventy species of brambles are now distinguished: truly a thorny subject! Hampshire, perhaps with one exception, is stated to be richest in brambles of all the counties in England.

In his garden he raised some specimens of the forbidden plant, tobacco. 'In anno i6 I 9 I receaved the seedes hereof from Mr. Anthony Uvedale ${ }^{1}$ who that yere intended to plante greate store thereof, and was hindered of his purpose by a proclamation sett forth by Authoritie.'

\section{0}

The next two years were perhaps the most eventful in his career as a botanist. His excursions were rewarded by the discovery of several other plants new to the British flora, and many new plants imported from the south of Europe throve so well at Droxford, that he was able to give the first English description of them.

On the 28th of April we find him making observations on the Oak, Walnut, and Chestnut, being especially in-

1 Anthony Uvedale, the Governor of Winchester Gaol, has already been mentioned. The Uvedales were a Hampshire family who lived at Wickhan, and intermarried with the May family, living at Mayfield in Sussex.

The name of Uvedale is well known in the annals of early horticulture. Robert Uvedale (1642-1722) became master of the grammar school at Enfield, Middlesex, about the year of Goodyer's death. He was 'a great lover of plants, and, having an extraordinary art in managing them, is become master of the greatest and choicest collection of exotic greens that is perhaps anywhere in this land. His greens take up six or seven houses or roomsteads. His orange trees and largest myrtles fill up his biggest house, and . . those more nice and curious plants that need closer keeping are in warmer rooms, and some of them stoved when he thinks fit' (Gibson, Acconnt of sevcral Gardens near London, 1691, Archaeologia, 1794, xii. 188). He was thus one of the earliest possessors of hothouses in England. One of his former pupils is said to have brought him from Mount Lebanon a cedar which was recently flourishing at Enfield.

The copy of Turner's Herball, I568, in the Oxford Physic Garden, which belonged to $W$. Clowes in $157 \mathrm{I}$, bears the signature of 'Roh. Udall.' 
terested in their flowers, buds, and galls. He added to these notes and wrote them out afresh on 9 May 1622 : they are printed under that date in Johnson's Gerard.

Business at this time brought him into touch with the lands and villagers of Soberton, a hamlet about a mile and a half south of Droxford. It was there that he gathered the 'Oenanthe Angustifolia'. This has been identified by Druce as the first record of the Marsh Parsley Oenanthe in Britain, but Townsend (Flor a) considers that it was the Sulphur-wort Dropwort (Oenanthe silaifolia Bieb.) that was found.

'This I9 of May I620 I found this wild in East Hoo in ye parish of Subberton about 7 miles from Petersfield in Hampshire in a hedgerowe about a flightshott from ye then dwelling-house of Mr. William Browne on ye south part of ye said house and ye I 8 of June 1620 I saw it there in flower.' ${ }^{1}$

Merrett ${ }^{2}$ gives the locality as East How. William Browne of Hoe had purchased the manor of Soberton in $1619 .^{3}$

A few days later an excursion to the New Forest yielded another new plant, the Narrow-leaved Lungwort (Pulmonaria angustifolia), whose fine blue flowers attracted his attention on 25 May 'in a Wood by Holbury House'. It is a rarity in Britain; Hampshire and the Isle of Wight being the only stations where it grows wild. The Forest children call it 'Joseph and Mary'. 4

In the summer he described the following plants:

20 June Antirrhinum minus.

2 July Pastinaca aquatica minor.

5 , Rapunculum silvestre Tragi.

5 , Eufrasia altera Dod.

5 " Anthyllis montana.

8 " Carduus acaulis septentrionalium L'Ob.

22 , Melampium luteum.

26 „ Herba Doria altera.

Io Aug. Panicum.

12 " Acinos.

I8, (Aster conyzoides).

Sium siffoliis.
Linaria minor Desf.

Sizm erectum Huds.

Phyteuma orbiculare L.

Bartsia Odontites L.

Thesium humifusum DC.

Carduus acaulis $\mathrm{L}$.

Melampyrum sylvaticum L.

Senecio sarracenicus L.

Echinochloa Crus-galli L.

Ocimum Basilicum L.

Jasonia tuberosa DC.

Carum segetum, Benth.

${ }^{1}$ Goodyer quoted by How. MS. note to Phytologia; p. 8r.

${ }^{2}$ Pinax, p. 84. ${ }^{3}$ Vict. County Hist. Hants, iii. $263 . \quad{ }^{4} \mathrm{~J}$. Vaughan. 
He found both the Water Parsnip (Simm crectum Huds.) and the Bastard Toadflax (Thesium humifusum DC.), near Droxford, the former growing in the River Meon, the latter "wild on the side of a chalkie hill in an inclosure on the right hand by the way, as you goe from Droxford to Poppie Hill'. Both these references are the earliest we have to these plants in Britain, as also is his excellent description of the Honewort or Corn Parsley (Camm segetum), which he again wrote out for the new Herbal in I $6: 2$.

Further detailed descriptions were written of plants as they flowered in his own garden or in those of his friends, for instance Acinos odoratissimn : 'I first found growing in the garden of Mr. William Yalden in Sheete near Petersfield in Hampshire, Anno I620, amongst sweet Marjerom, and which by chance they bought with the seedes thereof. It is to be considered whether the seedes of sweete Marjerom degenerate and send forth this herbe or not, I I th October I62I, John Goodyer' (Ger. emac. 677).

But the outstanding event of the year was a visit to the garden of his 'worthy friend and excellent Herbarist of happy memorie Mr. William Coys of Stubbers in the parish of North Okington in Essex'. Goodyer came away with the seeds of many rare and little known plants, including several that had been collected by Boelius in Spain and had been brought over by him to England. Among other novelties which were thus introduced into the Droxford garden in 1620 were:

Acarna flore rubro.

Aracus maior Baeticus Boelii.

Cattaria tuberosa radice Bactica Boelii.

Ervilia silvestris Dodonaei.

Faba veterum serratis foliis Boelii.

Geranium Baeticum Boelii.

Gramen cristatum Baeticum Boelii.

Gramen tremulum maximum.

Herba Doria altera 26 July I620.

Hieracium stellatum Boelii. medio nigrum ff. maior $\mathrm{B}$.
Carlina lanata L.

Vicia sativa B linearis Lange.?

Nepeta tuberosa L.

Lathyrus Ochrus L.

Vicia Faba L. var.

Erodium gruinum IVilld.?

Cynosurus echinatus L.

Briza maxima I.

Senecio sarracenicus L.

Rhagadiolus edulis Gaertn.

Tolpis barbata Gaertn. 
Hieracium medio nigrum fl. minore $B$. lanosum.

Horminum silvestre tertium Clusii.

Jacea capitulis hirsutis Boelii.

Lagopus trifolius maior Baeticus.

Legumen pallidum Vlissiponense.

Malva flore amplo Baetica aestiva.

Petum indicum folio pene obtuso.

Scabiosa flore rubro. Scabiosa sexta Indica Clusii.

Silibum minus fl. nutante Boelii.

Valeriana mexicana.
Tolpis umbellata $\beta$ minor Lange.

Hieracium andryatoides Vill.

Salvia verticillata $\mathrm{L}$. ?

Trifolium ligusticum Balb.?

Vicia lutea $\beta$ laevigata Boiss.

Malva moschata L.

Nicotiana Tabacum v. brasiliensis.

Scabiosa atropurpurea'L.

Notobasis syriaca Cass.

Valeriana cormucopiae L.

Most of the plants raised from Coys' seed did so well with him that he was able to describe them as they flowered in the following summer.

It has been suggested ${ }^{1}$ that on his way home Goodyer passed Rickmansworth, and there 'in the ponds about Moore Park' found 'Sium alterum Olusatii facie'. There is, however, no ground for this supposition; Goodyer himself wrote that he visited Moore Park in 1625.

We owe our first description of a new kind of English Elm to this same journey into Essex.

When we consider that many of our contemporaries are so deficient in powers of observation as to be unable to tell one tree from another, it is remarkable that Goodyer should have been so quick in distinguishing the various species of Elm. Two of these had already been recognized by Gerard in I 597, and were redescribed by Goodyer for the second edition in 1633 : to these he now added a third, on his way to visit Mr. Coys :

'I observed it growing very plentifully as I rode betweene Rumford and ... Stubbers in the year 1620 , intermixed with the first kinde (the Common Elm), but easily to be discerned apart, and is in those parts usually called Witch Elme.'

The name of this Elm has caused considerable confusion in the minds of those who have not attentively read the words 'in those parts'. The Elm is certainly not the Wych Elm ordinarily so called, which Goodyer knew as the Witch Hasell or Broadest-leaved Elm; but, as 
Mr. Russell told me on my recent visit to Stubbers, it is the tree which is still locally known in that part of Essex as the 'Witch Elm', a name which is thus proved to have survived locally since Elizabethan times. Goodyer named it 'VImus folio glabro' or Smooth-leaved Elm, a name that has been adopted by Miller in the form of Ulmus slabra, the name by which it is still widely known, although Elwes prefers the name $U$. nitens Moench. for it.

Systematists of the eighteenth and nineteenth centuries have brought the species of Elms into such a state of confusion that it is a relief once more to get back to the simpler system of Goodyer, whose accounts of the four species of Elms were doubtless redrafted in ${ }^{6} 6_{32}$, but the original observations were much earlier. Johnson prefaces the descriptions with a short introduction:

'Our Author [Gerard] only described two Elms, and those not so accurately but that I thinke I shall give the Reader content, in exchanging them for better received from $\mathrm{M}^{\mathrm{r}}$. Goodyer; which are these.'-T. Johnson.

\section{Ulmus campestris $\mathrm{Sm}$.}

Vlmus vulgatissima folio lato scabro. The common Elme.

This Elme is a very great high tree, the barke of the young trecs, and boughes of the Elder, which are usually lopped or shred, is smooth and very tough, and wil strip or pil from the wood a great length without breaking: the bark of the body of the old trees as the trees grow in bignesse, tearcs or rents, which makes it very rough. The innermost wood of the tree is of reddish yellow or brownish colour, and curled, and after it is drie, very tough, hard to cleave or rent, whereof naves of Carts are most commonly made: the wood next the barke, which is called the sap, is white. Before the leaves come forth the flowers appeare, about the end of March, which grow on the twigs or branches, closely compacted or thrust together, and are like to the chives growing in the middle of most flowers, of a reddish colour: after which come flat seed, more long than broad, not much unlike the garden Arach seed in forme and bignesse, and doc for the most part fall away before or shortly after the leaves spring forth, and some hang on a great part of the Sommer : the leaves grow on the twigges, of a darke greene colour; the middle size whereof are two inches broad, and three inches 
long, some are longer and broader, some narrower and shorter, rough or harsh in handling on both sides, nickt or indented about the edges, and many times crumpled, having a nerve in the middle, and many smaller nerves growing from him : the leafe on one side of the nerve is alwaies longer than on the other. On these leaves oftentimes grow blisters or small bladders, in which at the spring

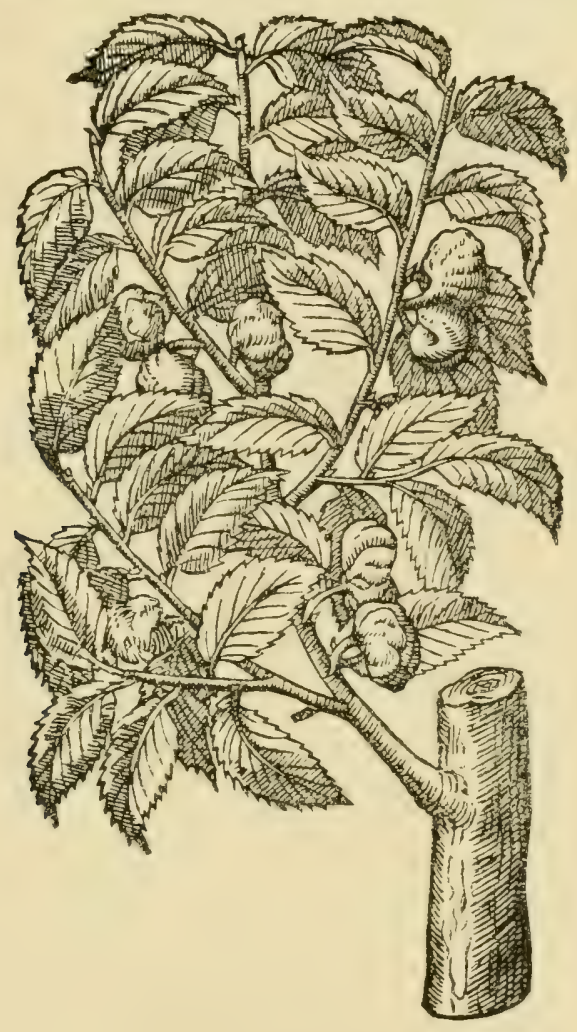

The COMMON ELM. ${ }^{+}$

are little wormes, about the bignesse of Bed-fleas. This Elme is common in all parts of England, where I have travelled.

\section{Ulmus minor Miller.}

Vlmus minor folio angusto scabro. The Narrow leaved Elme.

This tree is like the other, but much lesser and lower, the leaves are usually about two inches and a halfe long, and an inch or an

1 This figure originally appeared in Mathiolus, I44; was copied in Lobel, Obs. 607. I ; reproduced in Ger. emac. I480. I, and reappeared in Parkinson, I404. I. 6. It shows blisters on the leaves. 
inch and a quarter broad, nickt or indented about the edges, and hath one side longer than the other, as the first hath, and are also harsh or rough on both sides, the barke or rinde will also strip as the first doth: hitherto I have not observed either the flowers or seed, or blisters on the leaves, nor have I had any sight of the timber, or heard of any use thereof. This kinde I have seene growing but once, and that in the hedges by the high way as I rode.

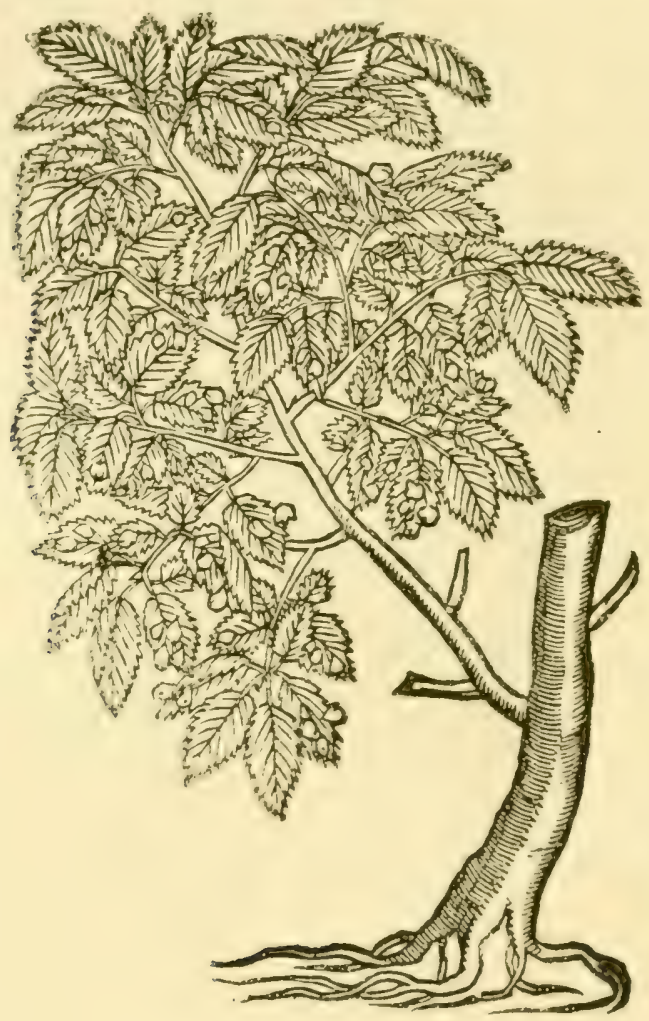

THE NARRON-LEAVED ELM.?

betweene Christ Church and Limmington in the New Forrest in Hampshire, about the middle of September $\mathrm{I}_{2} \mathrm{z}_{4}$, from whence I brought some small plants of it, not a foot in length, which now, 1633, are risen up ten or twelve foot high, and grow with me by the first kinde, but are easily to be discerned apart, by any that will looke on both.

1 Dodoens, 837; reproduced in Ger. cmac. I 480.2 ; copied in Parkinson, 1404. 4. The leaves have been attacked by insects. 
Wych Elm. Ulmus montana Stokes.

Vlmus folio latissimo scabro. Witch Hasell, or the broadest leaved Elme.

This groweth to be a very great tree, and also very high, especially when he groweth in woods amongst other trees: the barke on the outside is blacker than that of the first, and is also very rough, so that when there is plenty of sap it will strip or

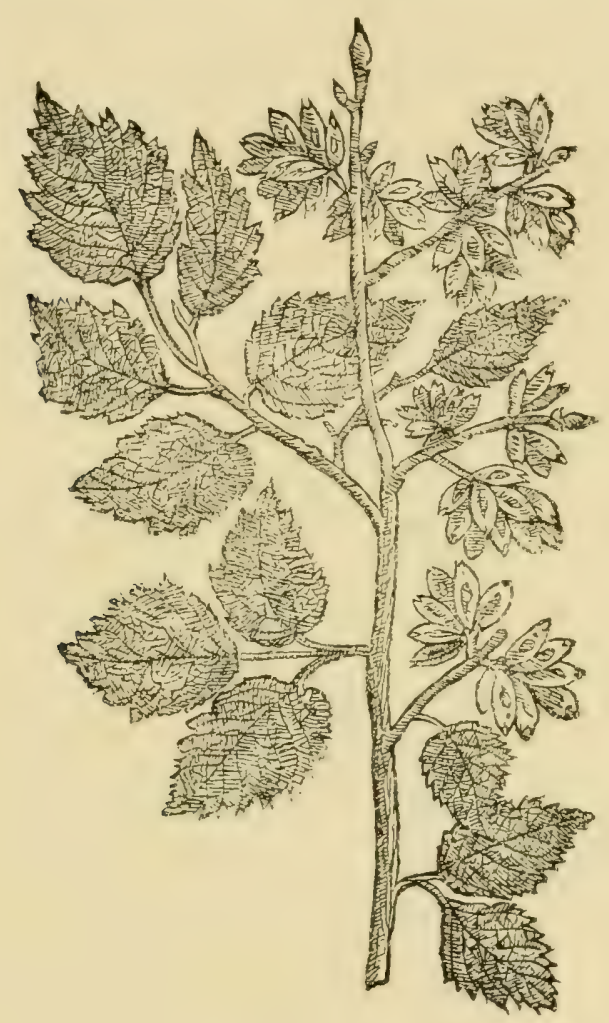

THE Wych ELM.

peele from the wood of the boughes from the one end to the other, a dozen foot in length or more, without breaking, whereof are often made cords or ropes: the timber hereof is in colour neere like the first; it is nothing so firme or strong for naves of Carts as the first is, but will more easily cleave; this timber is also covered with a white sappe next the barke: the branches or young

1 Ger. emac. I481. 3 ; copied in Parkinson, I404.2. (Stokes' edit. of Withering, 1787.) 
boughes are grosser and bigger, and do spread themselves broader and hang more downewards than those of the first; the flowers are nothing but chives, very like those of the first kind: the seed is also like, but something bigger: the leaves are much broader and longer than any of the kindes of Elme, usually three or foure inches broad, and five or six inches long, also rough or harsh in handling on both sides, snipt or indented about the edges, neere

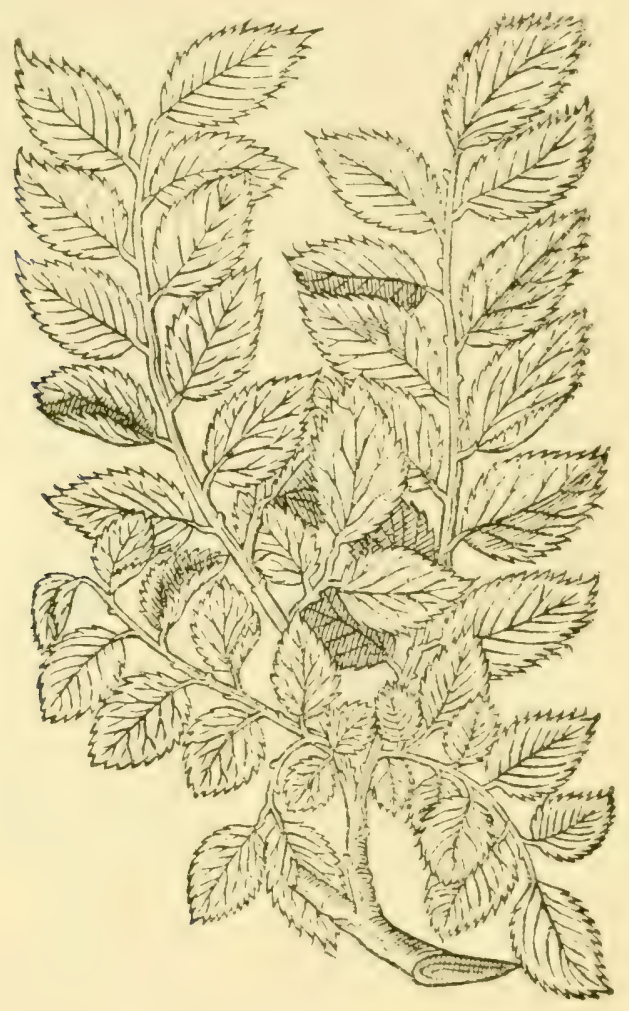

The Smooth-Leaven Elmo ${ }^{1}$

resembling the leaves of the Hasell: the one side of the leaves are also most commonly longer than the other, also on the leaves of this Elme are sometimes blisters or bladders like those on the first kinde. This prospereth and naturally groweth in any soile moist or dry, on high hills, and in low vallies in good plenty in most places in Hampshire, wher it is commonly called Witch Hasell.

1 Gerard, 1297. 2; copied in Ger. e'mac. 1481. 4; recopied in Parkinson, 1403. 3. Stokes considered this figure as 'rather a variety of $U$. campestris'. 
Old men affirme, that when long boughes were in great use, there were very many made of the wood of this tree, for which purpose it is mentioned in the statutes of England by the name of Witch Hasell, as 8. El. I0. This hath little affinitie with Carpinus, which in Essex is called Witch Hasell.

\section{Smooth Leaved Elm. Ulmus glabra Miller.}

Vlmus folio glabro. Witch Elme, or smooth leaven Elme.

This kinde is in bignesse and height like the first, the boughes grow as those of the Witch Hasell doe, that is hanged more downewards than those of the common Elme, the barke is blacker than that of the first kinde, it will also peele from the boughes: the flowers are like the first, and so are the seeds: the leaves in forme are like those of the first kinde; but are smooth in handling on both sides. My worthy friend and excellent Herbarist of happy memorie $\mathrm{M}^{\mathrm{r}}$. William Coys of Stubbers in the parish of Northokington in Essex told me, that the wood of this kinde was more desired for naves of Carts than the wood of the first. I observed it growing very plentifully as I rode between Rumford and the said Stubbers, in the yeere 1620 intermixed with the first kinde, but easily to be discerned apart, and is in those parts usually called Witch Elme.-Ger. emac. I479-82.

A copy of a Memorandum, dated I 5 November, in Goodyer's handwriting is printed on p. 374 .

Part of the winter was spent in working through Gerard's Herbal and in extracting lists of plants, one of which (MS. f. 83) was dated I6 Januarii I620.

\section{I62I}

Goodyer signalized his twenty-ninth year by turning out more descriptions of new or rare plants in the three months of July, August, and September than in all the rest of his life. There must have been some special reason for this great output. It is reasonable to think that he found an incentive in the large number of novelties he had seen in the gardens of Coys and Parkinson. There was also the added interest of possession, of the triumph of the horticulturist: seeds given to him by Coys in the preceding year were coming up well. What would they become? 
What new benefits to mankind might they not be made to yield? Many of them growing at Droxford uncler his own eye were either not described or were imperfectly described in Gerard's Herbal; there was room for a new edition, or at any rate for a Supplement. The new plants might not be hardy enough to survive the next winter, and Boel might never be able to procure the same seed again. Whatever the reasons may have been, Goodyer's enthusiasm certainly reached a red-heat this summer.

It was the enthusiasm that every true naturalist feels when he is conscious of being the first to obtain an insight into unknown processes and phenomena. What plans for publication he may have had we know not, nor clo we know what hindrances arose, but there followed a hiatus and these notes of Goodyer's were laid aside for twelve years, and then a selection of them were freely placed at the disposal of Dr. Johnson for the new edition of Gerard.

The descriptions conform rigidly to the style in vogue at the period. The habit of the plant, its stalks, branches, leaves, flowers, seed, root, duration are all considered in order, and in many cases notes are added on the season, hardiness, and locality. The technical words such as 'footstalk' in the sense of petiole, 'knee' = node, 'bosome' = axil (of a leaf), 'pointell' = pistil, 'cheives' = stamens, and umbell in the modern sense are in the language of Gerard. Occasionally the descriptions are brightened by refreshing comparisons. The flower of Monotropa 'resembleth ye suck-bottle which children use to suck their drinke out of'; 'seed no bigger than a flea'; 'clammie as Bird-lime'; 'woollie like Spiders webbs'; a colour is 'orange tawnie velvett'; a herb 'heateth and burneth the mouth'; the distribution of the pollen of the Yew is thus described, 'if you shall beate on them stones into this tree about the end of February, there will proceed and fly from the flowers an aboundance of dustie smoke'.

Moreover, at this period of his scientific life he might have written as Ray did in June 1667 that he had been 
at work 'in gathering up into a catalogue all such plants as I had found at any time growing wild in England, not in order to the present publishing of them, but for my own use, possibly one day they may see the light'.

It must be remembered that at this period there was no English botany book worthy of the name in existence. The standard works used in this country were the Herbal of Dr. William Turner, printed in I 568 at Cologne, and illustrated, not with drawings of British plants, but with reduced copies of some 400 figures drawn from continental plants and previously used at Basel to illustrate the I545 edition of Fuchs' great work. That Fuchs' original drawings were of considerable beauty, and that nothing to equal them could have been engraved in England, is admitted; but as illustrations to an English Flora they were misleading.

In 1574 a further impetus was given to the study of English botany by the publication of Henry Lyte's edition of Dodoens' Herbal, which, as the preface shows, has considerable claims to originality rather than to being a mere translation, but for this again the small, inferior copies of Fuchs' figures were requisitioned.

The next and best known of English Herbals, that of Gerard, appeared in I597, but again it was a compilation from foreign works, so imperfectly 'accomodated unto our English nation' that Lobel was requested by the printer to correct the blunders, and still Goodyer was able to discover many others.

Consequently, like many other botanists, Goodyer must have been eternally plagued with the attempt to make English plants fit the descriptions and figures of continental writers-a labour that has been aptly compared with the endeavour to fit square pegs in round holes. He was, however, sufficiently gifted to perceive the futility of the attempt, and to recognize at an early period the need for accurate descriptions made from the living, flowering plant beside him. 
Among foreign authors he would have relied largely on Matthiolus, Bauhin, and on Lobel. One of the most important works that appeared during his working life was the Pinax of Kaspar Bauhin, the result of forty years of toil, published in 1623 , and acquired by Goodyer in the same year. This work carried still further Lobel's idea that natural affinity must be the foundation of a truly natural system : it went far to clear up the confusion in the nomenclature of the clay, which had resulted from the fact that different names had often been griven to the same plant by different authors. The Pinax, as Reynolds Green has well put it, "not only got rid of much confusion by setting forth the different synonyms in use, but it introduced greater terseness of description, and helped to restrict the inordinate length of names'. Green did not think that Bauhin's work had exerted any great influence in England: ${ }^{1}$ but we have noted a profound influence upon Goodyer's work, who prepared and, had times been favourable, would assuredly have published a Pinax of the British flora on the lines of Bauhin, whose works he had read, marked, and inwardly digested from cover to cover.

Goodyer's excursions in search of plants were rewarded by the finding on 2 June of two species of Pondweeds new to the British aquatic flora. Both were growing quite near home, the one actually in Droxford, the other just over the Sussex border at Durford on the upper waters of the Rother. A paper, MS. f. 6, suggrests that either Goodyer, or more probably Sir T. Bilson, was interested in land that once belonged to the old Priory at Durford.

On 29 June, about a mile from his native town of Alton, he found a plant which he described as 'Nidus avis flore et caule violaceo purpureo colore'. This he 'found wilde in the border of a field called Marborne, neere Habridge in Haliborne . . being the land of one

1 On this point Dr. Church notes that in Oxford 'Bauhin's Pinax prompted Sherard's Pinax of Dillenius, and hence was responsible in England for the Sherardian Professor of Botany'. 
William Balden. ${ }^{1}$ In this place also groweth wild the thistle called Corona fratrum'. The identity of the species has been the subject of speculation. The most recent review of the position is that of Mr. Druce, who follows Sir J. E. Smith in considering that the plant was probably the Purple Broomrape (Orobanche purpurea) growing parasitically upon the roots of the common Yarrow which is now abundant in a locality, which Mr. Druce believes that he has correctly identified with the 'field called Marborne'. Townsend, on the other hand, suggests that the plant was the rare Violet Helleborine, Epipactis violacea Dur., which he found near Alton; a view with which Dr. Stapf agrees. In his annotated copy of Tabernaemontanus' Icones, Goodyer has added a note and a reference to the picture of Orobanche I to the effect that it is Nidus Avis Lob. 0.356 or ' 86 (b. 2)', which is evidently a reference to Orihis abortiva violacea in Bauhin's Pinax. ${ }^{2}$

Although closely tied to his work and his garden during the early part of the summer, Goodyer appears to have paid short visits to the coast, at Haylinge on 20 August, where he found Sea Heath (Frankenia laevis L.), and Diotis maritima, which was formerly much more widely distributed than it is now ; to Southsea on the 3 oth; and to Bursledon Ferry on 3 September. Here he saw the Sea Heath in flower and described it a second time. At Bellmere Pond he found a white-flowered Eyebright in flower on 24 August, and at Southsea Castle he saw Climbing Fumitory in flower on 30 August.

Altogether he described at least ninety species of plants during the summer, and when October brought him a respite from his labours it was but natural that he should

\footnotetext{
1 Parish Records might possibly show whether 'Balden' is an old error for Yalden, the name of Goodyer's kinsfolk.

${ }^{2}$ Yet another view is printed by the editors of the catalogue of the Morisonian Herbarium. The entry is 'Orobanche radice compacta major flore violaceo, nobis. No specimen. In agro Hantoniensi prope Alton oppidum invenit D. Goodyer. This is usually referred to Limodonem abortivum Sw., but Goodyer's plant (of which no specimen is known to exist) was probably Helleborine purpurata Druce'. Vines and Druce, p. 173.
} 
wish to compare notes with his friend Coys. His description of 'Jacea capitulis hirsutis Boelii' certainly implies that it was taken on Io October I62 I in Coys' own garden. And a letter from his friend, Laurence Davis, about gold weights addressed to him at Droxford on 9 November, implies that he was home again then.

To my very loving freind $\mathrm{Mr}$. John Goodier at Droxford give this.

Mr. Goodyer I have sent you by Maye $y 0^{\mathrm{r}}$ gould waights $w^{\text {th }}$ those other that you desired extraordinary, only the Elz. Angell serves both for the Edward \& Elzabeth waight, theye cost 6 ${ }^{8}$. And $y 0^{r}$ peice I could gett but $8^{9}{ }^{d} 0^{d}$ for ; the Remaynder I have returnd by Maye. And I am gladd to have this occasion to expresse my desire to bee esteemed.

$\mathrm{Yo}^{\mathrm{r}}$ ever loving freind

I praye remind mee kindly to $\mathrm{yo}^{\mathrm{r}}$ fellows

Laurence Davis.

Patience, Mr. Parker, and Henry Henly.

[MS. f. 9

This letter was endorsed by Goodyer ' Rec. 9 November I62I' and annotated 'rec. $3^{\mathrm{g}}$ againe'.

6

His last work this winter was to distinguish between 'the Yew bearing Acorns and berryes' and 'the Iew with only flowers'.

A number of the papers in which Sir Thomas Bilson's affairs are mentioned belong to 1621 and 1622. Shopping notes occur on MS. f. 46. 'Morgan is to doe the fan of a pinke color'. 'The fans handell is to be doble gilt'. Among the things to be purchased are ' 20 yards of galom lace', buttons, fustian, cambic, oyle skins, 50 needles, and other such feminine gear, p. $3 S_{2}$. The addresses 'Little Minories' and 'Barbican' on the same paper indicate that business had again taken him to London.

\section{I622}

The principal journey of 1622 was to Oxford. It is not difficult to find good reasons for the visit. The relations that existed between Magdalen Colleye and Goodyer's 
own county, with William Yalden the College Clerk of the Account, his brother-in-law, and in addition his scientific interests may rather make us wonder that he should not have visited Oxford more frequently. It was but the year before, that Magdalen had granted to the University five acres of land, then in process of being laid out as a Botanic Garden, and Goodyer may have contributed some of the first plants. Among the then fellows of the College was Walter Stonehouse whose garden-lists subsequently came into Goodyer's possession, and among the new Demies was Sampson Johnson, the friend of Thomas Johnson and an early authority on the purgative action of various kinds of rhubarb. ${ }^{1}$

In May Goodyer completed his notes on the flowers and galls of the oak, and on the cachryes ${ }^{2}$ of the walnut, chestnut, alder, and birch. Oak-galls had long had a peculiar interest, because a gardener by 'looking whether there be in them eyther Flyes, Wormes, or Spiders' could presage battle, dearth, and scarcity or plague. ${ }^{3}$

On 2 July 'in the high waie neare Abington leadinge towards Oxford' he saw the fine Woolly Thistle (Cnicus criophorus), which he had already found by a Hampshire roadside in I6I 7 (f. 107). On the $5^{\text {th }}$ while exploring 'by the Rivers side and in the water diches about Oxford' he saw the Great Water Parsnip (Simm latifolium L.) before the flowers were fully formed, and continuing his walk on the west part of Gloster Hall, now Worcester College, he there noted for the first time the Wood Club Rush (Scirpus syluaticus L.) (f. 7 vo).

${ }^{1}$ Thomas Johnson wrote ${ }^{6}$ My friend Mr. Sampson Johnson, Fellow of Magdalen College in Oxford, assures me, that the Physitions of Vienna in Austria use scarce any other [medicine] at this day than the Rubarb of the Antients which grows in Hungary not far from thence: and they prefer it before the dried Rubarb brought out of Persia and the East Indies, because it hath not so strong a binding facultie as it, neither doth it heate so much; onely it must be used in somewhat a larger quantitie' (Ger. emac. 396). S. Johnson had no doubt opportunity of testing this statement during his year's leave of absence from College, beginning on 14 March $1630-1$.

2 See p. I74.

3 Thomas Hill, The profitable Arte of Gardening, I 574. 
In the autumn he paid his customary visit to Coys, ${ }^{1}$ who on 29 September was able to show him 'Scabiosa flore rubro' in flower (cf. 8 October $162 \mathrm{I}$ ).

During the winter months he was evidently occupied with a literary labour that will be referred to in the following year when it was finished.

In February a stray note on the Curled Parsley (Apizm crispum) growing at Idsworth suggests an excursion down the steep wooded hills beyond the South Downs in the midst of very beautiful country, then part of the Forest of Bere. And in March he received seeds of twenty-two garden plants from Coys, including two kinds of 'aples of love' or tomatoes, p. 325.

\section{3}

His botanical descriptions now cease for a while. We have only one note, on a species of Acorus dated July I623. It may be that he was unable to pursue his hobby with the same activity as heretofore: perhaps he had to leave Droxford-for we find no mention of his garden there after this date. But the advancement of botanical learning still remained the prevailing occupation of his leisure, only from henceforth we find it taking another form, a desire to make the plant lore of antiquity available for English readers, and to this he devoted the winter months.

By this time he had collected a considerable number of botanical works both of his contemporaries and of the great Masters of the past. A beautifully bound copy in Italian binding of the Alcline folio edition of Theophrastus (1497) was among them. The margins of this book he inscribed with the numbers of the chapters, and translated the whole into English. The ten books De Plantis fill 2.38 pages of his neat small script, and the six books $D e$ Causis Plantarum take 256 more. We do not know when

1 This is proved by a marginal note on p. 130 of his copy of Parkinson's Theatrum. There he renames Parkinson's No. 8, Aster Virgineus, as 'Helianthemum radice repente Virginianum. Mr. William Coys of Stubbers in Essex was wont to call it so. 26 Sept. 1622 I sawe it in his garden. John Goodyer'. 
he began the translation, but he noted the dates on which he completed the chapters De Causis Plantarum.

$\begin{array}{cccrl}\text { Chap. } & 2 & \text { finis } & 25 & \text { Febr. } 1622 \\ " & 3 & , & 8 \text { Marcii } 1622 \\ " & 4 & " & \text { I } 8 \text { Marcii } 1622 \\ " & 5 & " & 28 \text { Jan. } 1623\end{array}$

At the end is written

'Finis $6^{\text {to }}$ die Februarij I623.

This booke was sent from bindinge the six and twentieth day of September $166 \mathrm{I}$.

The bindinge-the cleane paper-the claspes $4^{8}$.'

This, so far as we know, was the only English translation of the De Plantis until 19I9, when Sir Arthur Hort published his translation; but Goodyer's still remains the only version of the De Causis in the English language.

\section{4}

We find him resuming his botanical excursions in 1624 . He made a second trip into Wiltshire, and noted the occurrence of Sanfoin (Onobrychis sativa Lam.) at Langford and Stapleford on 24 July. A carefully prepared itinerary for a tour in the New Forest in September of the same year shows his route:

From hyve to Lymington from Lymington to Christchurch from Christchurch to Poole 8 myle from Poole to Wareham 7 myles
to Wimborne 6
to Brainford 10 to lichett
3

from Wareham to Wooll \& Briden + myle frō woll to Waymouth 9 myle

to Dorchester 9 myle

to Woodbury hill 4 myle

to Winfruite 2 to Osmunton 4 to bean 3

fro Waymouth to Woobury I 4 to Wimborne 8 fro

Wimborne to Christchurch from Christchurch to Lemington 9 frō Lemington to Bewly 4 fro Bewly to Hyve 2
Fr. hampto to Redbridg 4 fro Redbridge to Ringw $\quad$ I 6 fro Ringwood to Langham 6 fr Langham to Poole 4

$\begin{array}{lll}\text { Ringewood } & 2 & 4 \\ \text { Poole } & \text { I } & 2 \\ \text { Wooll } & 2 & 4 \\ \text { horse hire } & \text { I } & 0 \\ \text { passag } & 0 & 4 \\ \text { Waymouth } & 3 & 0 \\ \text { Christchurch } & 3 & 0 \\ \text { Lymington pass } & 0 & 2 \\ \text { Hyve pass } & 0 & 4 \\ \text { hampton } & 2 & 0 \\ \text { ichen pass } & 0 & 2 \\ \text {.. ct Church } & 0 & 6\end{array}$

Mr. laden of Wimborne. $\overline{16 \quad 4}$

[IIS. f. I 3 
In preparation for this journey he made copies of Lobel's descriptions of four species of plants which were already recorded as living at Portland. Anthyllis prior lentifolia peplios effiric maritima, ${ }^{1}$ Sedum Portlandicum, ${ }^{2}$ Hederatium thlaspi," and Papaver cormutum flore phoeniceo." We do not know whether he found them all, but we do know that he noticed as a new species a fourth kind of English Elm, the Narrow-leaved Elm, already described on p. 40.

Eight years later he wrote, "This kinde I have seene growing but once, and that in the hedges by the high way as I rode betweene Christ Church and Limmington in the New Forest, about the middle of September I624, from whence I brought some small plants of it, not a foot in length, which now, 1633, are risen up ten or twelve foot high, and grow with me by the first kinde [the common Elme], but are easily to be discerned apart, by any that will looke on both.'

It has been suggested, by Druce, that Goodyer's Narrowleaved Elm was the Cornish Elm, but Elwes and Henry both refer it to Ulmus minor Miller, which they call Goodyer's Elm, and with which they merge Druce's $U$. Plotii. Elwes states that Goodyer's Elm has been lately found near Christchurch by Dr. Moss.

On ro September he wrote a description of the Shrubby Suaeda (Suacda fruticosa Forsk.) under the name of 'Chamaepytis vermiculata'.

Johnson quotes him on the subject of the great abundance of the Common Spleenwort in Woolmer Forest. 'Mr. Goodyer saith that in January I624 he saw enough to lade an horse growing on the bancks in a lane, as he rode betweene Rake and Headly in Hampshire, neere Wollmer Forrest' (Ger. emac. I I 46).

1 Arenaria peploides L.

2 Euphorbia portlandica L.

${ }^{3}$ Cochlearia danica L. 'Glaucium phocniceum Crantz. The 'Sedum' is usually quoted as 'Tithymalus', and the following plant as 'Thlaspi hederaceum'. These records are about a century earlier than those given by Mansell-Pleydell, Flora of Dorset. 


\section{5}

It was about this time that he learnt the local name (Honewort) and vertues of Corn Parsley, a plant with which he had been long familiar, and to which he had already given the name 'Selinum Siifoliis' : but he had no English name for it, until one day he saw Miss Ursula Leigh, servant to Mistress Bilson of Mapledurham, gathering it in the 'wheate ershes' about Mapledurham (where it still grew in $1_{32}$, especially in clay grounds). She told him that it was called Honewort, and that her mother ' Jate of Brading in the Isle of Wight deceased, taught her to use it after the manner heere expressed, for a swelling which she had in her left cheeke, which for many yeeres would once a yere at the least arise there, and swell with great heat, rednesse, and itching, until by the use of this herbe it was perfectly cured, and rose no more nor swelled, being now (5 Martij 1632) about twenty yeeres since, only the scar remaineth to this day. This swelling her mother called by the name of a Hone, but asking whether such tumors were in the said Isle usually called Hones she could not tell, by reason shee was brought from Brading aforesaid young, and not being above twelve yeeres old when shee used this medicine'.

\section{The Vertues.}

' Take one handfull of the greene leaves of this Honewort, and stampe them, put to it about halfe a pinte or more of beere, straine it, and drinke it, and so continue to drinke the like quantity every morning fasting till the swelling doth abate, which with or in her was performed in the space of two weekes at the most.' ${ }^{1}$

Next we have the discovery of the compact little Knotted Pearlwort (Sagina nodosa), described as 'Alsine palustris foliis tenuissimis: sive Saxifraga palustris alsinefolia ', on the boggy ground below the Red Well of Wellingborough in Northamptonshire. "This hath not been described that I finde. I observed it at the place aforesaid I I August 1625.'

And in the following month he was the first to record the poisonous Cowbane or Water Hemlock (Cicuta virosa),

1 Ger. emac. I017-18. See p. I21. 
which he named 'Sium alterum olusatri facie', on I6 September i625. The locality was 'by Moreparke, and at Denham in Hertfordsheire in standinge water sine caule' (f. 58).

It has been suggested that Goodyer, as a staunch Royalist, visited the Red Well because King Charles and Henrietta were residing there. But surely the evidence is of the flimsiest. The legend repeated by Morton, and supported by a misquotation from Laud's Diary, ${ }^{1}$ of the King and Queen living for wecks in a tent beside the habitat of Sagina nodosa, supplies but a sorry explanation for Goodyer's visit to a popular watering-place.

The Northamptonshire flora owes the first notice of the Grass of Parnassus to the same visit.

\section{$1627-8$}

Of his proceedings during the next few years there are but few notes. On 9 February 1627 he 'Rec. of Christopher Potecary of Stockton, 5 myles from Venny Sutton Clother'. It is not clear what he did receive, for after this note follows, though written another way up, a list of fruit trees and plants, days of Assizes, and (upside down) the recipe for an ointment. ${ }^{2}$

Two entries, dated 23 June 1628 , show that he visited the garden of one 'Millaine' in London, and saw there 'Sophia latifolia in horto millaine prope le pest house' and 'Triticum spica multiplici, in horto Millaine'.

The former may have been Sisymbrium Soplia (?) and Millen's grass may have been a varicty of Triticum turgidum L.

The owner of the garden was the 'Master John Millen, dwelling in Old Street, in whose nursery are to be found

1 The statement in a well-known County History that Laud visited the sovereigns at Wellingborough, is based on a misreading of his own entry that the King appointed him Bishop of J3ath and Wells, 'Rex Carolus me nominavit in Episcopum Bathon. et Wellen.'

2 MS. f. $129 \mathrm{v}$, see p. 384. 
the choisest fruits this kingdom yields' 1 and 'who from John Tradescant and all others that have good fruit hath stored himself with the best only, and he can sufficiently furnish any'. ${ }^{1}$ Parkinson mentions the 'Great bearing cherry of Master Millen in I629'. His name and address also occur on the back of a letter of $163 \mathrm{I}^{2}$

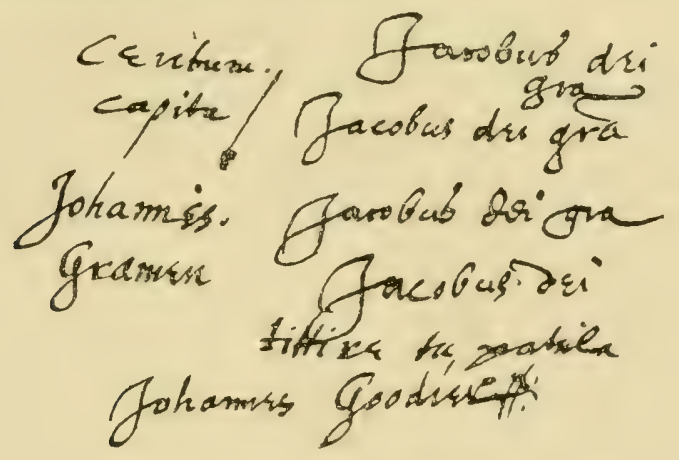

GOODYER'S HANDWRITING

\section{I63I}

In $6_{3}$ I Goodyer was living at Mapledurham. When he moved, we do not know, but both his letters and notes show that his thoughts were in the planting of a new garden. He journeyed to London and possibly to Oxford, and on 27 May appears to have been at 'Godlemen in Surrey' (Godalming). He would have had a good reason for visiting Oxford, for his favourite nephew Edmund Yalden had gone up to Magdalen College as a Demy in 1630. A note of a botanical station near Oxford was supplied him by Leonard Buckner, ${ }^{3}$ a London apothecary, and one

1 Johnson, I633, and Parkinson, I629, p. 575.

${ }^{2}$ MS. f. 133.

${ }^{3}$ Leonard Buckner's discoveries are printed by Johnson. 'In a field joyning Witney Parke' in 1632 he found Stachys germanica L., and 'in a bog upon a common by the Beacon hill neere Cumner-wood in the end of August 1632', three miles beyond Oxford, a little on this side of Eynsham ferry, he found the Horse-taile Coralline. Ger. emac. 1115. This last plant has been variously regarded as Equisetum sylvaticum L., Druce, Flora Oxford, p. 356, and as Chara hispida L., Druce, Flora Berks. xcix. In the case of the Stachys, Goodyer's note antedates the date printed, and generally quoted from Johnson, by a year and a month.

Leonard's excursions near Oxford suggest kinship with Dr. Thomas Buckner, Fellow of Magdalen, I6I8-3I. 
of the 'loving friends and Fellow travellers' who accompanied Johnson in searching for plants over a great part of Kent.

'Stachys: by windy parke wall on ye west of it, 8 myles from Oxford-July I6 3 I. Leo. Buckner.'

[MS. f. 133

Another correspondent, Griffith Hinton, who shows as much familiarity with the movement of Bishops as with the stock-in-trade of nurserymen, addressed two letters to Goodyer in this year.

To his very loving frend

$\mathrm{M}^{\mathrm{r}}$ John Goodyear at Maple Derham neare Peeterfyeld in I Iampshier geeve theis.

Mr. Goodyer I rec, the Acquittances, and as sone as I have the Rents togeather you shall heer from mee. My Lo. Byshop of Wynchester ${ }^{1}$ is this day com out of the town for Farnham and how long he wyll stay ther I know not, but as I heard by on of my Lords men hee wyll stay at Farnham ro dayes. Thus wyth my duety and kynd Remembrance this $13^{\text {th }}$ of July 163 I I rest,

Yors ever loving

GRIFFITH Hinton.

[MS. f. 14

In November $1_{3}$ I Goodyer was again in London. The nutes of this visit are not very easy to read, but there is sufficient to show that he paid I 3 's. $8 d$. for 'Diett at Gilford' and that supper at the King's Head cost Ios. The paper is undated, but the year is settled by the days of the month on which he purchased certain books, Dioscorides and Thevett among others, which are still in existence, and are clearly inscribed with a date and price exactly corresponding with the note on the paper and the year I63I. The further entry 'Nov. 8 wyne $w^{\text {th }}$ Johnson $6^{d '}$ 'has a special significance, for about this time the two friends would have been discussing their great scheme of producing a second cdition of Gerard's Herbal. In spite of its great popularity, this Herbal had been an unsatisfactory book from the start. Indeed, when we remember its history, it would have been strange had it

' In 1631 Walter Curle succeeded Richd Neile as Bishop of Winchester. 
been otherwise. The printer, John Norton, had commissioned Dr. Priest to translate Dodoens' Pemptades ( 1583 ) into English. Priest died, and Gerard continued the work. But to mask the fact of his Herbal being little else than a mere translation, he altered the arrangement from that of Dodoens to that of Lobel; and flippantly remarking that he had heard of Dr. Priest's labours, but the man being dead his work had perished with him, he had the effrontery to declare that his own researches had produced the work. Wood-blocks used by Tabernaemontanus in his Eicones (1590), with some others, were procured from Frankfort by Norton, but Gerard soon showed his slender knowledge, by misapplying many of the figures, and caused so much confusion in the early chapters of the Herbal, that the attention of the printer was directed to it by James Garret, the London apothecary. Lobel was therefore invited to correct the work, and by his own account he actually corrected it in a thousand places, but further emendation was stopped by the author, who contended that the Herbal was already sufficiently accurate, and that his censor had forgotten the English language. ${ }^{1}$

Gerard's book gave a very real impetus to the study of our English flora, but it was avowedly a popular work, 'being principally. intended for gentlewomen' '; and in this connexion Mrs. Gerard, who assisted her barber-surgeon husband in his practice, would have been most helpful; for her professional assistance was similar to that which Mrs. Gamp was in the habit of rendering at

${ }^{2}$ An excellent account of the Herbal is contained in B. J. Jackson, Gerard's Catalogue of Plants, 1876.

${ }^{2}$ Americans of 'royal descent' may be interested to learn that the copy of Gerard's Herbal now in the library of the Botanic Garden at Oxford, originally belonged to a gentlewoman, Dorathie Redmayne (1565-1645) whom I believe to have been identical with the mother of John Rolfe of Heacham, ancestress of all who trace their descent to the Indian Princess Pocahontas. Dorothy Rolfe's second husband was Robert Redmayne, Chancellor of Norwich. She was buried 'at the feet of her two husbands' in.Heacham Church. Rolfe Family Records, p. II. 
certain periods to her lady clients. The scientific botanist, however, judges a book from another standpoint. Even the genuineness of the Catalogue of plants in Gerard's own garclen has been denied by the 'attestor' Lobel himself. In one copy of the work in the British Museum the certificate has been crossed out, and the words, in Lobei's handwriting, 'haec esse falsissima, Matthias de Lobel', are written at the end of it.

Goodyer made the fullest use of the Herbal, and in 1620-I he may have been contemplating a new and improved edition. When or how the same thought came to Dr. Johnson we do not know, but in the next year Goodyer was sending Johnson twenty-seven sheets of manuscript.

The name of the inn, where he put up, is given in a second letter from his loving friend Hinton, addressed:

To his very Loving frend

Mr. John Goodyear at the sygne of the

Angell neere Denma ${ }^{\mathrm{r} k}$ Hous in Strand.

I63I

Mr. Goodyer I wrote unto my frend for the trees and this day I spake with him and hee telleth mee that ther is no sure trees growying about Barn Elmes ${ }^{1}$ wher hee dwelleth, but hee hath enquired and found that ther is Malacaton trees at Twycknam in Mydd. and they wyll not be sold under $3^{\mathrm{s}} 6^{\mathrm{d}}$ a tree, but hee may have an apricok tree for $\mathrm{I}^{\mathrm{s}}{ }^{2}$ I shall speake with him agayn eyther

1 The Earl of Essex had a garden at Barne Elmes, Ger. ennuc. I396, and so had Sir Francis Walsingham (d. 1590), Ger. 501.

2 The Twickenham fruit garden must have been that of Mr. VINCENT POINTER, who had the greatest variety of plums in England (Gerard), and is quoted by Sir Hugh Platt, Floraes Paradise, 1608, pp. I17-18, as an authority on grafting. His nurseries are mentioned by Ben Jonson, who states that he was better known 'by Poynter's name than by his owne'. His real name was CORBET, and he was the father of Dr. Richard Corbet (b. 1582), Dean of Christ Church (Aubrey, Lives), and was also connected with a garden at Ewell in Surrey.

An Epitaph on Master Vincent Corbet.

Deare Vincent Corbet who so long Had wrestled with Disenses strong That though they did possesse each limbe, Yet he broke them, e're they could him,

With the just Canon of his life,

A life that knew nor noise nor strife:
His Mind was pure, and neatly kept, As were his Nourceries; and swept So of uncleannesse, or offence, 'That never came ill odour thence: And adde his Actions unto these They were as specious as his Trees. Ben Jonson, Underrioods, 1640. 
tomorrow or Thursday that I may geve him an answer, therfore I pray you send mee word by this bearer or yf you Gooe to have them about this town bethink yo ${ }^{r}$ self. I spake with on Crawley who was my Lord Byshopp Androse ${ }^{1}$ his gardner after I had written to Barn elmes and Crawley promysed me to help mee to som but at what pryce I know not yf you please to speake with him send mee word and appoynt the tyme and I will speak with him tomorrow or yf you wyll have them out of the contry send me word that they may bee reddy to bee sent down by the carrier tomorrow. serving this with my duety this I 5 of november I rest

$\mathrm{Yo}^{\mathrm{r3}}$ ever

Griffith Hinton.

[MS. f. I 33

On the same letter is written in Goodyer's hand:

\begin{tabular}{|c|c|c|c|}
\hline James & II & 10 & 4 \\
\hline D. & I6 & 7 & 4 \\
\hline Roberts & - & 10 & 0 \\
\hline \multirow{4}{*}{$\begin{array}{l}\text { Pashley } \\
\text { (sic) }\end{array}$} & - & 12 & 6 \\
\hline & 28 & 0 & 2 \\
\hline & II & IO & 4 \\
\hline & 16 & 7 & 4 \\
\hline \multirow[t]{2}{*}{ Buckett } & 4 & 10 & 0 \\
\hline & 32 & 7 & \\
\hline
\end{tabular}

$$
\begin{array}{lll}
\text { Violett } & \text { I } & 0 \\
\text { May cherry } & \text { I } & 8 \\
\text { Duke cherry } & 2 & 0 \\
\text { Bon crittian } & \text { I } & 8 \\
\cline { 2 - 3 } & 6 & 4
\end{array}
$$
cent pts of Shepey.

Mr. Withowbie Hamshere Audit

Draba ger.

Gramen alopecuroides spica aspera is Gramen cristatum Baeticum by $\mathrm{y}^{\ominus}$ adia-

Stachys. by windy parke wall on ye west of it 8 myles from Oxford in July 1631 .

Leo. Buckner.

at Mr. John Harrison in pater noster Rowe at the Golden Unicorne-a stationer.

[MS. f. 133

Both the letter and Goodyer's notes written upon it show that he was stocking his garden. 'Millain of old Street ' is again mentioned, as is 'Hugobert at Ratcliffe'.2 The prices paid for some fruit trees are noted on the back of this letter.

In January he was trying to get into touch with foreign herborists with a view to obtaining the seeds of foreign plants in exchange for English seeds. Drafts of two letters are extant.

Sir,

I have made a short Catalogue of some plants which growe for the most $\mathrm{P}[\mathrm{ar}] \mathrm{te}$ wild in Fraunce; you may acquaint anie herborists there that you please yf they will [be pleased] helpe me to seeds of them, or any other, I will by your directions furnish

1 Lancelot Andrewes, Bishop of Winchester, 1618-26.

2 The name Hugobert recalls an apothecary, Abraham Hugobert, who was fined by the Apothecaries Company for not presenting an apprentice in 1650. 
them with such as they shall desire which growe wild with us in England or in our gardens; those in my Catalogue are all contayned in Pena his Adicrsaria. I have quoted the page that there may be no mistakinge. And I entreate you to desire so much of those that send me any seeds to name the Author and the page of his booke that wrightes of them for every seed-all sort he sends, if not written of, to say so. This way is the triall of an herborist, and will save me a greate deale of paines; by gods helpe I will doe the like to them for those seeds I shall send. Thus making bold to trouble you uppon your kind promise, wishing you a prosperous journey,-I rest

Yours to my power-

[MS. f. I 32

[The catalogue contains the names of fifty-one plants with references to Lobel and Pena, Adversaria.]

I6 January I6.3I.

Mr. Wray, I have made bold to send this inclosed letter to you, I entreate you to convey him to Mr. Langrish if he be yet in England, if gone over to send him after him if it may be done with convenience, if not pray send him back to me againe. It was his desire when he was with us in the contrey that I should send this letter to you for him. Thus remayning ready to doe as much and more for you as it be in my power, I rest

\section{Your loving friend}

[MS. f. I 32

Both of these letters are in Goodyer's handwriting. The identity of Mr. Wray is a matter of doubt. In the D. N.B. are mentioned two members of a Yorkshire family of the name, of whom Sir J. Wray (1586-1655) is known to have spent $1603-6$ in foreign travel, which is rather early for our present purpose, and the Captain IVray, who with John Evelyn in I 646 found rare simples growing on the Euganean Hills, is rather too late.

\section{2}

The doctrine of the fixity of species so tenaciously held in after years by Linnaeus and his school formed no part of the science of Goodyer and his contemporaries, or of the ancients. The artificial production of new varieties was 
already known to Shakespeare before i6io, at any rate as far as gillyflowers are concerned. Perdita, having been told the cause of their streakiness, cared not to get slips of them for her rustic garden: they had the reputation of being 'nature's bastards', and she was also aware that it was possible to produce similar piedness by art (inoculation). Polixenes tried to argue with her that as all arts that add to nature are made by nature, the crossing of different races is but natural after all, and that she should therefore make her garden ' rich in gilliflowers'.'

In Shakespeare's day people were familiar with the idea of two sexes among plants, although the function of pollen was still unrecognized. But it was a remarkable prevision of genius, which we can only describe as Shakespearean, to explain the production of varieties among plants as the result of cross-breeding, at a time when botanists knew nothing about the function of the flower. ${ }^{2}$ The Art to which Perdita refers must be the art of Inoculation, of inserting the buds of one plant into or upon another. ${ }^{3}$ And Shakespeare's alter ego, Bacon, reflects the same thought. 'It is a Curiosity to make Flowers Double. ... Enquire also, whether Inoculating of Flowers (as Stock

1 Winter's Tale, iv. 3.

${ }^{2}$ Dr. Church points out that at the time of which we are speaking, the idea of crossing by grafting was accepted, and the methods of grafting fruit trees were fully set forth in many books. As far as the 'Secretes' of the ordering and care of Gillyflowers are concerned, Th. Hill, Arte of Gardening, I574, divulged the following: "you may make one stalke to bring forth floures of many colours, if you take the seeds of every colour of the Gilifloure, and put them altogether into a thinne small rede or Terdill of a sheepe or goate, or else tied up in a thinne worne linnen cloth, setting the same in the earth well mixed with dung: which after the watering will cause a plant to come uppe, bearing the like number of colours in one stalke, as there were seedes sowen.

And there be some which write, that if you myxe the Basill seedes with the Gilifloure seedes, and use them (as above sayde) that they will spring togither on one stalke'.

It must also be remembered that Hill had many contemporaries, who, had they been acquainted with the method of the production of new varieties by hybridization, would not have imparted their secret to others, so long as they thought that there might be money in it.

3 Fleming's Virgil, Georgics, ii. 21 . 1589. 
Gilly-flowers, Roses, Musk-Roses, \&c.), doth not make them Double'. ${ }^{1}$

The idea of the sudden appearance of a new species as a Mutation would have been quite familiar to Goodyer. We have already quoted a passage ${ }^{2}$ (under I 620) in which he put forward a theory, as worthy of consideration, that the seed of Sweet Marjoram might degenerate and send forth Acinos odoratissimum.

Francis Bacon, seven years later, accepted the possibility of such a change, and suggested an experiment for the Transmutation of Flowers. "The second rule shall be to bury some few seeds of the herb you would change, amongst other Seeds; And then you shall see whether the juyce of those other seeds doe not so qualify the Earth, as it will alter the seed, whereupon you worke. As for Example ... put Basill-seed amongst Thyme-seed, and see the change of taste, or otherwise.' ${ }^{3}$ The effect of a change of environment was illustrated by the classical instance of Lobel, ${ }^{4}$ who sowed 'Papaver nigrum' in Somersetshire and found it to come up changed 'by the sport of Nature and metamorphosis' into 'Papaver album'. ${ }^{5}$ And in 1632 Goodyer found what was believed to be an instance of the partial change of an ear of wheat into oats. Our modern knowledge of the possibilities of plant-breeding will of course not permit us to believe in his explanation of the phenomenon: he was probably misled by some monstrosity in the ear, but the record is of value as showing the frame of mind in which these early botanists tried to describe honestly what they saw. A later generation would have cast the thing aside as being 'against nature' and not worth a serious thought. Johnson records it as 'a rare

'Bacon, Nit. Hist. \$513. 1627. Here the word 'flower' is used in different senses, first as a bloom, secondly as a plant. Bacon's science was occasionally muddled,

2 Ger. emac. 65.

${ }^{3}$ Bacon, $l . c . \S 527$.

- Lobel, Officina Pharmaceutices Rondellet, 1605, p. 37.

5 A change of colour from blue or yellow to white in the case of Wild Succory and Moth Mullein was attributed by Merrett to a change to a poor soil. Pincax, Epistle to reader, 16th page. 1667. 
observation, of the transmutation of one species into another, in plants; which though it have beene observed of ancient times, as by Theophrastus, de caus. plant. lib. 3. cap. 6, whereas amongst others hee mentioneth the change

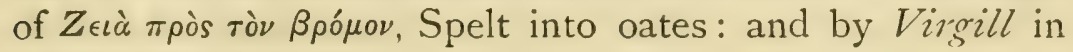
these verses ;

Grandia saepe quibus mandavimus Hordea sulcis, Infoelix Lolinm, \& steriles dominantur avenae.

\section{That is ;}

In furrowes where great Barley we did sow,

Nothing but Darnel and poore Oats do grow ; yet none that I have read have observed, that two severall graines, perfect in each respect, did grow at any time in one eare: the which I saw this yeare 1632 , in an eare of white Wheat, which was found by my very good Friend Master Iolu Goodyer, a man second to none in his inclustrie and searching of plants, nor in his iudgement or knowledge of them. This eare of wheat was as large and faire as most are, and about the middle thereof grew three or foure perfect Oats in all respects: which being hard to be found, I held very worthy of setting downe, for some reasons not to be insisted upon in this place'. ${ }^{1}$

The Goodyer crest, a partridge with a good car of wheat in its beak, is said to have been suggested by this exceptional find.

Various lists of exotic plants and of foreign floras which passed between correspondents abroad and their agents in this country, show how eager botanists were at this period to obtain accounts of the floras of foreign countries. Few of these documents are dated, but one, a list of Russian plants, was written in June of this year. At the end of the list the writer adds: 'and many other which I know not and are not to be found in my herball. I will have their effigies drawne, and will hereafter send them you with their leaves and Russe names and vertues.

Mosco, I 2 Junij I 632

'Robert Tewe.'

\footnotetext{
1 Ger. emac. 65.
} 
The note which follows may or may not refer to Tewe's expenses.

$$
\text { 'I } 50^{\text {l }} \text { p. ann. I } 2^{1 \mathrm{li}} 10^{\mathrm{s}} \text { a moneth.' }
$$

It is clear that Tewe must have been a member of, or have been helped by, the Muscovia Company, then engaged in active trade with Russia.

The important domestic event of his marriage occurred in this year. The Licence issued by the Faculty Office of the Archbishop of Canterbury bears date I 5 November I6 32 .

'John Goodyer of Beryton co. Southampton, gentleman, bachelor, 40, and Patience Crumpe, spinster, about 30 , daughter of Walter Crumpe, late of St. Giles in the Fields, Middlesex, tailor at St. Giles in the Fields or St. Gregory's London.'

There is evidence that John and Miss Crump were friends of long standing. In a letter dated 9 November I62 I Laurence Davis ends with a postcript: 'I praye remind me kindly to yor fellows Patience, Mr. Parker, and Henry Henly'. At that time Goodyer and presumably

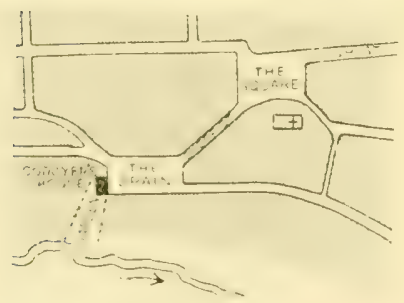

PETERSFIELD,

Patience also, were living at or near Droxford. Soon after the wedding he moved from Mapledurham to a house in the Spain in Petersfield. The Spain is a picturesque open place or square which is said to have received its name from the Spanish merchants who resorted there for wool-clealing. ${ }^{1}$ The street of approach from the marketplace is still named Sheep Street. In the eighteenth century a horse-market was held there.

John Goodyer's house 'is still standing to-day, and is one of the most interesting in the whole of Hampshire. The half of it which I had the privilegre of inspecting has been burdened with the ridiculous name of St. Aubyns, but until 1907 it bore legally the title which it bore in 


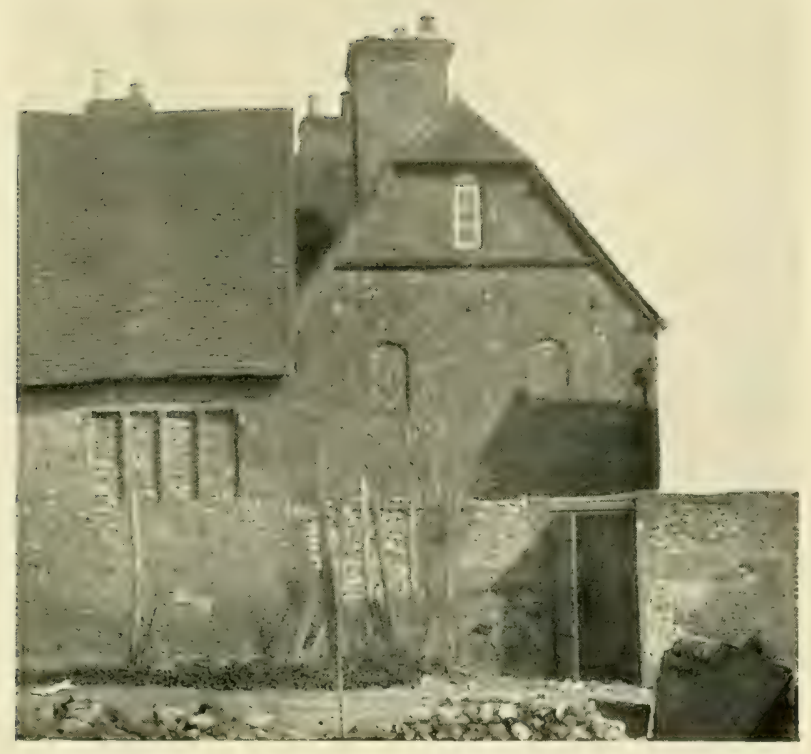

It'st side shoreing the blocked zinduri's

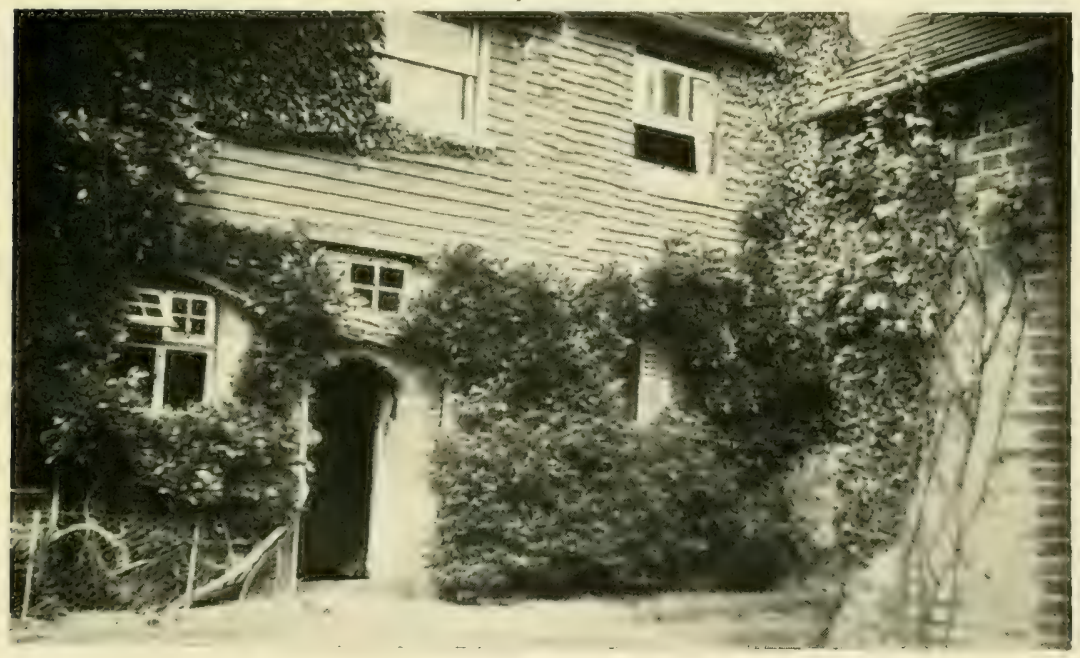

South side

GOODYER'S HOUSE, IN THE SPAIN, PETERSFIELD 

John Goodyer's time, "The Great House". The word "great" was not synonymous with "big"; it simply meant of chief importance'. ${ }^{1}$ In April I9I7 a tablet was imbedded in the brickwork of the front of the house :

JOHN' GOODYER

Botanist and Royalist

(1592-I664)

lived here.

In August last I made a pilgrimage to Petersfield to see the house. The two-gabelled front facing the Spain was a disappointment: it has been altered out of recognition by the substitution of sash windows for the old casements : Goodyer would not know it. To south and west there are still a few of the original features. On the south an old doorway, with stone jambs and flat-pointed arch-stone dated ' $1755^{\prime}$, leading out into the garden, is almost certainly the original front door to the house. The old mullioned windows, with splayed jambs of red brick, have mostly been covered with wall-tiling, though several, now walled up, are an architectural feature in the small yard at the back of the house. Perhaps the window-tax may have been the cause of the blocking of the windows, and the utility of their embrasures inside, when fitted as cupboards, may have led to some hesitation in reopening them.

Within the house there is much to delight the antiquary. The heavy oak beams crossing the ceilings, the uneven floors of thick and broad oak planks, the broad slanting corbels close under the ceilings, which support the hearthstones above, and many other details, all help him to reopen in his mind the old windows whose splays and mullions he sees in the walls, and to think away the thin partitions that now subdivide the rooms in which Goodyer had his library, and where he worked and wrote.

Of unusual interest is the old stairway, a square brick and stone built structure at the back of the house, formerly lit on two sides by small windows, now blocked up, placed

${ }^{1}$ M. E. Wotton, Fohn Goodyer in Hants and Sussex Neres, I I April 1917. 
in a spiral to follow the stairs. The window-openings can be seen from the inside, but on the outside they have been concealed by more modern buildings raised against them. The conjectural arrangement of the original windows is shown in the sketch.

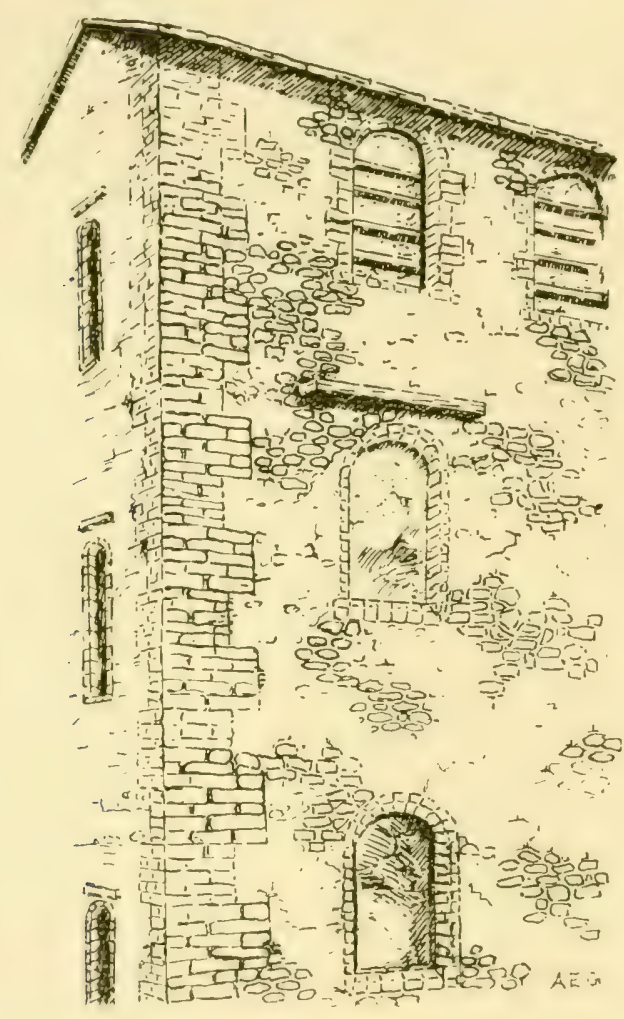

Goodyer's House in the Spain.

(The blocked windows of the Slairzeay have been reconstructed by Mr. A. E. Gunther from photographs taken for the purpose by Mr. Llewelly'n Bradley.)

And then there is a long four-light mullioned window up in the wall of the present kitchen, so high above the floor that to one architect it has suggrested a chapel, but perhaps the original builder knew the advantage of a top light to his kitchen, as well as of a window through which the neighbours could not peep. Many constructional details, 
including an upstairs fire-place in a massive pier, facing a window, and within four feet of it, still need explanation: the well in the cellar and a possible underground passage need exploration. It is greatly to be desired that the house may find an owner who will undertake the intelligent and sympathetic restoration of what is perhaps the most interesting house in Petersfield.

The papers of the next two years bear evidence of his change of abode and change of state. Memoranda and accounts show that he was occasionally commissioned to do shopping for his wife. Notes of one and a half yards of white cotton, of hooks and eyes, of silk and buttons, tell a story as clear as it is brief, while on the other hand we read of the employment of certain labourers on 24 June I 634 for 'digging my grounds'. ${ }^{1}$ This evidently refers to a new garden in Petersfield.

On 5 March $6_{32}$ he noted the beneficial result of the application of Honewort (Carum segetum Benth.) to a swelling or 'Hone' in the cheek of Mrs. Mooring, when a young girl.

\section{I633}

The summer after his marriage he found on 2 July the local Starry-headed Small Water Plantain (Damasonium stellatum Pers.) between Sandie Chappell and Kingston, having previously found it on Hounslow Heath. Johnson found it a little beyond Ilford in the way to Rumford. ${ }^{2}$ But Goodyer had observed it in 16 18.

On 4 July he was busy with the Ferns of the neighbourhood of Petersfield. 'I have observed' he wrote 'fower sorts of Ferne, by most wrighters esteemed to be the male Fern of Dioscorides: by Anguillara, Gesner, Caesalpinus, and Clusius accounted to be the Female, and so indeed doe I thinke them to be, though I call them the Male with

1 Theophilus Hasted)

Tho. Crowcher
Andrew Ansell $\quad$ 24 Junij

Andrew Ansell

2 Ger. emac. 418. $\left.\begin{array}{l}\text { Tho. Bowyier } \\ \text { Tho. Sylvester }\end{array}\right\}$ digging my grounds.

[MS. f. I4 
the multitude. If you looke on these Fernes accordinge to their seuerall growthes and ages, you may make many more sorts of them than I have done; which I am afraid hath beene the occasion of describinge more sorts than indeed there are in nature. These descriptions I made by them when they were in their perfect growthes' (cf. p. I 8 I).

His No. I 'Filix mas ramosa pinnulis dentatis' is the earliest reference to the Broad Shield-fern (Aspidium dilatatumi).

'This groweth plentifully in the boggie shadowic moores neare Durford Abbey in Sussex, and also on the moist shadowic rocks by Niapledurham in Hampsheire . . and I have found it often on the dead putrificd bodies and stemms of old rotten okes, in the said moores, neare the old plants I have observed verie manie small yonge plants growinge, which came by the fallinge of the seed from those dusty scales: for I believe all herbes have seeds in themselves to produce their kindes, Gen. i. II and I2.'

His second species was the Male Shield-fern (Aspidium Filix mas). 'This grows plentifully in most places in shadowie woods and copses.' It had not been previously recorded for Hampshire. The variety Aspidium Filix mas a'ar. affinis, was noted 'in many places in the shade'. The Prickly Shickd-fern (Polystichum lobatum) or the allied Angular Shield-fern ( $P$. ançulare) was also abundant 'on the shadowie moist rockes by Mapledurham neare Petersfeld in Hampsheire'.

The Marsh Shield-fern (Aspidium Thelyptcris Sw:) is probably the species described under the name "Dryopteris Penae et Lobelii' on 6 July; if so, Goodyer's is the earliest British record of it.

'Manie yeres past $I$ found this ferne in a verie wett more or bogge beinge the land of Richard Austen called Whitrowe moore, where I'eate is now digged, a mile from I'ctersfeld in I Iampsheire, and this sixt of July I633 I digged there manic plants, and by them made this description. I never found it growinge in anie other place.'

The descriptions of these Ferns were almost certainly 
prepared for his friend Johnson's new edition of Gerard's Herbal, which appeared in the winter of 1633 , and has hitherto been the principal source of information about Goodyer's plants, many of which are acknowledged in the most exemplary manner. On the other hand many species are just referred to him without further notice of the date or place of discovery, and doubtless other species of Goodyer's, having come to Johnson's knowledge independently, are not acknowledged as his at all. Among the Goodyer MSS. there is a list of descriptions of I 3 plants sent by him on 5 March 1632, of five more sent on I 2 March, and of two more sent on 19 March, to Johnson for incorporation in the book, and with the exception of seven, ${ }^{1}$ all these descriptions are extant.

In the preface to the edition, dated from his house on Snow-hill 22 October 1633 , Johnson acquaints the reader with what he has performed, "either by mending what was amisse or by adding such as formerly were wanting', or by putting out descriptions and words that were not very necessary. Moreover, he conscientiously marked all new figures and text with signs ł, by which the new work can be readily distinguished from the old. In all this Johnson's work shows much careful thought; and it is here that we would desire to quote from his concluding sentences.

'I must not in silence passe over those from whom I have received any favour or incouragement, whereby I might be the better enabled to performe this Taske. In the first place let me remember the onely Assistant I had in this Worke, which was $\mathrm{M}^{\mathrm{r}}$. Iohn Goodyer of Maple-Durham in Hampshire, from whom I received many accurate descriptions, and some other observations concerning plants; the which (desirous to give every man his due) I have caused to be so printed, as they may be distinguished from the rest: and thus you shall know them; in the beginning is the

1 The seven descriptions which we have not been able to trace are: Sonchus Africanus Boelii, Alsine major repens Clusio, A. palustris foliis tenuissimis, Ranunculus flammeus aquatilis angustifolius hirsutus flore magno, Anagallis erecta floribus albis, Radix cava minima viridi flore; Draba lutea siliquis longissimis, v. strictissimis C. Bau.

[MS. f. 134 . 
name of the plant in Latine in a line by it selfe, and at the end his name is inserted; so that the Reader may easily finde those things that I had from him, and I hope together with me will be thankfull to him, that he would so readily impart them for the further increase of this knowledge.'

Dr. Reynolds Green has estimated that the new book contained about 2,850 descriptions of plants, so far the largest number included in any herbal. This made the work the most important and influential of its time, but we cannot agree with Dr. Green in attributing the name by which it is widely quoted, 'Gerard Emaculatus', to Ray, for How in 1650 , and John Goodyer still earlier, had already made a practice of referring to it by that name. Nor can we agree that Johnson was the first to depart from the practice of the older botanists in relying on their gardens for the plants they described. Goodyer had long paid special attention to wild plants.

Green remarks, as have some others, on the 'rapidity with which Johnson worked' and that 'he had but little assistance'. But this is a wrong view. He had the assistance of the best English botanist of the day.

The work of the two men was essentially on different lines. Johnson was an M.D., he had translated the surgical works of Ambrose Parey; he discussed the medicinal properties or vertues of plants with greater gusto than he displayed for their morphology. Goodyer was a scientific botanist, 'second to none in his industrie and searching of plants, nor in his judgement or knowledge of them'.

Johnson freely availed himself of the archaeological knowledge of Goodyer, as in the case of the figure that was supposed to be the oldest drawing of Saxifraga, taken from an illustrated manuscript of Apuleius Platonicus.

In the case of the confusion between Solidago sarracenica and Arabis quorundam, Johnson notes "My very good friend Mr. Iohn Goodyer was the first, I thinke, that observed this mistake in our Author; for which his observation, together with some others formerly and hereafter to be remembered, I acknowledge myself beholden 
to him' (Ger. emac. 275). Nor did Goodyer's criticisms cease when the 'emaculated' Gerard appeared. Among his notes are four pages of suggested emendations to the first twenty-two chapters of the book, which are characteristic of the accuracy and carefulness of his work.

\section{Goodyer's Corrections to Folnson's Gerard's Herbal.}

The first booke. Ca. I.

Description of Comon Meadowe Grasse.

p. I, 1. 2 from bottom. For light read smooth.

p. 2. Tyme. I have seene it flowringe in the beginninge of March A ${ }^{\circ}$. I6Ig. Names. After äypwirs read, And this particular meaclowe grasse is called of Theophrastus $\pi$ óa, as Bauhinus hath it in his Phytopinax, pag. 4 .

Nature. Number that which is spoken for the nature amongest the vertues for indeed Pena affirmeth that the seed of hay beinge beaten forth, many Physicians doe use for the stopping of the inward parts, beinge druncke: and applied to the dissolvinge of hard tumors and wind.

p. 3. Vertues. Theis vertues doe properlie and trewlie belonge to Gramen caninum pag. 22.

D. It is apparent that Fernelius, li. 4 , ca. 4 de methodo medendi, meaneth the roots of Gramen caninum to have theis vertues.

Ca. 2. Names. L'obell calls the first of theis grasses, Gramen minimum Xerampelinum, and Xerampelinus color is a color somewhat ruddie, and therefore this name cannott belonge to White dwarfe grasse.

Ca. 3. Names. He mistaketh, for that which L'obell calleth Agrorum venti spica, and Gramen agromm, is this 2 kind called here called Gramen harundinaceum.

He mistaketh the 2 grasse also for it is not L'obell but Tabernaemontanus that calleth it Gramen harundinaceum.

The titles over the figures I would amend thus:

I. Gramen pratense vulgatius. Common Meddow Grasse.

2. Gramen minus vulgatius. Small Common grasse. For the description sheweth it not to grow in Meddowes.

The figures are better in L'obell's Icones, p. I, which are the same with Dodoneus in Latyne of the laste edition, to which you may refer them.

Description. Dodoneus describeth not the particular Meddow grasses but in generall only, therfore you shall doo well to examyn the descripcon both of the first and second, by the $A d v s$. \& the Observ. unlesse you cann add any notorious difference in them from other grasses, out of your own observation.

Ca. 4. Both their descriptions are in Dutch \& in no Author that I have, and quere for what grasse the figure under the title of Gramen maius aquaticum must serve.

Ca. 5. The description of Gramen Sorghinum is also in Duch. Somethinge may be added to the description of the root of Calamogrostis, if the worth of the grasse deserve it, \& you thinke it pertinent. 
Ca. 6. The grasse under the title of Gramen Panniculatum, p. 8, seemes to be Gramen amourettes Clusii, p. ccxviii. If it be so? howe came it to be Gramen tomentosum \& acerosum Lobell: in Icon. pag. 6 . I have two editions of Lobell's Icons printed at severall tymes, the first MDLXXXI, printed at Anwerpe, and hath but one table, viz. the lattin, french, duch all together; the other was printed at Anwerpe $A^{\circ}$. MDXCI and hath severall tables, everie language by itself. The first it seems was one Willm. Mounts, a Physician dwellinge at Mallinge (in what Sheere I knowe not) who hath added to some herbes certaine noates, and thus he hath noted of Gramen paniculosum' phalarioides Lobel, Icon. p. 7, 'Grasse called in Surrey braunched grasse, in Corne: and in orchards, or shadowie places usuallie mowen. They seeth it in water with Purslaine and small Reysons for wormes, in the somer tyme, and geve it comonly to very younge children'. I must leave this Grasse (which Gerard hath confusedlie written of) to be sett dulie, and in his true place by you.

Gramen sylvaticum, I knowe not where it is written of, in Tabermont I thinke.

Ca. 7. Their descriptions are all in dutch.

Ca. 8. The I is described I knowe not where, the 2 you shall find in the Obs. p. 10, the eares are not described.

Ca. 9. The $I$ is in the Obs.p. Io the 2 I knowe not where, belike in Tabermont. Ca. 10-16, 18, 19. Their descriptions are in the Teutonick or Duch.

Ca. 16. The 2), the description saith the knobs or buttons growe on both sides of the stalk, the figure hath them but on one side, query whether this be not Gramen montanum spicatum Clusii, p. ccxix.

Ca. I7. The I) I can observe no such cuttinge qualitie in the edges of the leaves of this grasse.-Vertues. Many more vertues are spoken of in Advers. p. 468, and if you please you may add the best of them.

Ca. 2I. I see nothing that $\mathrm{I}$ can amend.

Ca. 22. Cyperus Typhinus I know not where to find the descriptions.

'Venarum spiracula laxat Cyperus.' Only Turner hath taken notice of theis words which I have added. I take it the meaninge of it is that it openeth the small branches of vena porta, called mesentericae venae. If it be so ?, it is a speciall vertue not to be omitted.

[MS. ff. 149-52

Goodyer also made several corrections in the text of his copy of the 1633 edition of the Herbal, e. g. on p. 567 he notes that the figure given for Saxifraga anglicana alsinefolia is really the picture of Synanchica, and should be placed on p. I120. Also that the adjoining figure named $S$. palustris is really an Arenaria. This mistake explains Johnson's confused account of Saxifruga anglicana on p. 568 .

His other additions consist of a few medical notes on the virtues of certain herbs, e.g. Tithymalus cupressinus, p. 499, Elaterium, p. 913, and Vicia maior sylvestris, p. 1229.

\section{4}

After Johnson had sent his Gerard emaculatus to the printers, we are left with next to no published news of Goodyer's doings for the next twenty years. Fortunately 
many papers among his manuscripts help to bridge the gap. He still does shopping for his wife (p. $38 \mathrm{I})$; there is a letter of 24 June showing that he was interested in the date of the Surrey Assizes.

'Mr. Worlidge you were intreated to wright me word, when Surrey Assizes were kept, at what place and what Judge was to sitt on the Nisi prius; which hetherto you have not done. If you can be at Surrey:Assizes \& our triall goe forward I must goe to the $\mathrm{Bp}$. of Wint ${ }^{1}$ \& expound his letter to that Judge, which will aske some time to doe, \& I must also goe before hand to London to prepare our witnesses. In regard whereof I pray you this weeke wright me word all those things I have spoken of, \& if any other things you knowe to be therein necessarie, And so I rest

\section{Your assuredly}

24 June 1634 .

[MS. f. I4

In August he was away in Sussex on one of the summer excursions, which he generally performed on horseback, having previously, as was his way, made careful notes for the intended journey.

From London to Lewsam

to Brumley

to Farnborowe

to Rethered

to Sen oak [Sevenoaks]

to Tunbridge

to Ffant [Frant]

to Mayfield

to Black boyes

to Ringmer

to Lewis

3 fro London to Croydon 7

4 to Godstone 7

3 to Lingfield $6 \mathrm{wch}$ is

54 miles from East Grinstead.

I-at Riverhill

5

$6-34$

4

2

Mayfield Carrier John Manser lyeth at the White Hart in Southwark: comes in Thursday out Friday.

Lewis Abell Tabrett lodgeth at the Tabott, comes in Wed., out Thurs. Wm Barham of Mallinge halfe a mile from Lewis but goes to Borne Io myles from Lewis. Mountaine Neppe.

Mr White of West Tarringe.

Mr Ric Relf of Tenterden 4 miles from Rumney mersh.

Putt in the L.T. 8 li. $8 s$. 1od. 4 Aug.

[MS. f. 62

Goodyer visited Mayfield at the time of the greatest

1 Walter Curle. 
prosperity of the iron industry in Sussex, and although the connexion between iron smelting or forging and the county flora may not appear very intimate, yet it is far closer than might be supposed. In 1607 there were, or had lately been, nearly 140 hammers and furnaces for iron in Sussex alone, and each of them spent 'in every twenty-four hours two, three, or foure loades of charcoal, which in a yeare amounteth to an infinit quantitie'. ${ }^{1}$ About the year I6 40 some 1,300 cords of wood were being used at one works alone, and the woodlands were in danger of being lost.

Jove's oak, the warlike ash, vein'd elm, the softer beech,

Short hazel, maple plain, light asp, the bending wych,

Tough holly, and smooth birch, must altogether burn,

What should the builder serve, supplies the forger's turn.

Drayton, Polyolbion (1612).

The botanical results of the journey are noted on the same page.

Dentaria baccifera.

[Coral-root. Dentaria bulbifera L.]

At Mayfield in a wood of Mr. Stephen Penckhurst, called Highwood, and in another wood of his called Foxholes.

Oxyacantha in Rumney Mersh neare the house of Mr. John Snave the place called Whey street, flours at about Xmas I605 in November.

[MS. f. 62

Elsewhere he noted 'Dentaria bulbifera Lo. 687, G. $8_{33}$, in Foxholes wood in Mayfeilde parish 6 Aug. I634', which fixes the date of his tour."

On 9 August at Buttersworth Hill he collected 'Ferrum equinum Germanicum siliquis in summitate' with ripe seed. (Hippocrepis comosa L.) For the year 16,36 we have only. a List of 'Virginia seeds recl. from Mr. Morrice is March' (p. 370), but in the case of this document, which is in the handwriting of John Parkinson, we cannot be sure that it came into Goodyer's possession at so early a date.

1 Norden, Surveyor's Dialogue, Suss. Arch. Coll. ii. 192.

${ }^{2}$ I have suggested elsewhere that the little colony of Coral-root near the Church Meadow at Droxford may have sprung from roots of his planting. 


\section{I637-40}

On 2 I August 1637, when visiting his brother-in-law William Yalden at Sheet, he saw 'Batata Hispanorum, or Common Potatoes'. They were the Sweet Potatoes, Ipomaca Batatas, such as could be purchased at the Exchange in London, and were liable to be killed by the first frosts. The tubers 'howsoever they' be dressed, they comfort, nourish, and strengthen the body, procuring bodily lust, and that with greedinesse'.

Goodyer was acquainted with 'Potatoes of Virginia', but we do not know that he cultivated them himself.

There is no evidence that he ever accompanied Johnson and his 'socii itinerantes' upon their herborizing excursions, but he certainly took the greatest interest in their discoveries and helped them with their reports. He possessed the accounts of their Kentish tours in 1629 and 1632 , and added to the list of plants in the former from his own knowledge. His presentation copy of the Mercurius botanicus inscribed ' 28 Octob. I634-Ex dono Thomae Johnson', containing the account of the tour in Wales in which Stonehouse of Magdalen College also took part, is similarly annotated, and has many plant names picked out by yellow paint marks-a favourite method of his. The Appendix to this work, a treatise on the Waters of Bath (1634), as well as the lure of new plants, may have determined him to visit Bath in 1638 .

Johnson (Mercurizs, pars altera I64I) is our authority for believing that Goodyer found a new Speedwell on St. Vincent's Rocks near Bristol, and as the statement is left unaltered in Goodyer's own copy of the book we may take it that he did botanize there.

And nothing is more natural, for the grand and precipitous cliffs of St. Vincent's Rocks have always been classic ground to the botanist. Their vegetation is luxuriant: their ledges, crowded with an abundance of good plants in a small area, are comparable only to the similar floral 
wealth of Cheddar Gorge. This towering limestone mass and the adjoining Downs, rising to a height of over 300 feet, overlook the tidal Avon in so picturesque a fashion that Clifton's river scenery will ever be famous. ${ }^{1}$

And if they are a Nature reserve now, what a paradise these rocks must have been in the days of Lobel and Goodyer when they were clothed with 'millions' of ferns.

The father of English botany, William Turner, discovered Trinia or Honewort here. It is one of the choicest indigenous plants in England and of great local interest. In 1562 . he recorded 'Peucedanum... I found a root of it at Saynt Vincentis rock a little from Bristow'.

The next visitor, L'Obel, found the 'Mules Fern' about I 569. Gerard 'spent two daies upon the Rocks to seeke for Meum', which had been reported to him as growing there, probably in mistake for Trinia. In I634 Johnson and his 'socii itinerantes' guided by John Price, a jovial apothecary of Bristol, directed their steps to the famous Rocks and the precipitous cliffs commanding the banks of the Avon. It is no wonder that Goodyer was drawn thither also.

And he was rewarded by finding a species new to the British flora, the ll'elsh Spiked Speedwell (Veronica hybrida L.), which he called 'Veronica recta mas, Lob. Ger., vulgaris recta Clus.' It is the same as the 'Great Speed-well or Fluellin. Found at Saint Vincents Rocke by Master Goodyer':" White" states that it is still abundant on the more inaccessible ledges of the rocks, and occasionally strays on to the riverside masonry below. It is the most beautiful of our native Veronicas, and in the Avon gorge often grows twice as large as on the Great Orme's Head in North Wales.

He verified the occurrence of the Tutsan (Hypericum Androsacmum L.), already recorded by Lobel (1 570), Lyte (1578), and Johnson (1634), Dropwort, and Trinia, and

1 White, Flora, 1912.

${ }^{2}$ Johnson, Mercuriues, pars altera, I641.

3 Flora, p. 463 (1912). 
added the Horseshoe Vetch to the County flora. ${ }^{1}$ His records were :

Androsaemum magnum, the Great Saint John's-wort in a wood over the ... St. Vincents rocks nigh Bristow.

Filipendula vulgaris, Oenanthe Fuch. Lob. Dropwort. 'On St. Vincents rock $3 \circ$ Aug.' (= Spiraea filipendula L., previously noted by Lobel.)

Ferrum equinum siliquis in summitate. 'On St. Vincent's Rock

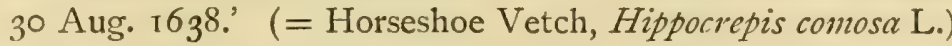
Peucedanie facie pusilla planta Lob. = Selinum montanum pumilum Clus. $=$ Peucedanum pumilum, Petroselinum $=$ Dwarfe Rock Parsley, s638. (= Trinia or Apinella glanca O. Kuntze.)

Rock Stonecrop (Scdum Rupestre L.), 'Sedum Divi Vincentii Non Descriptum', is also said to have been first recorded by him. ${ }^{2}$

The manuscript notes in Goodyer's hand in the Johnson's Mercurius, I634, have unfortunately been cut off by some wretched bookbinder, but one about 'Saxifraga palustris alsinefolia ${ }^{3}$ Ger. emac.' confirms ${ }^{6} 638$ as the year of his visit to the west of England. He found it 'In the springs about Smocombe wood neare Bath, on the northeast parts of the wood, j. Sept. I638'. In modern language it is the White Sandwort (Sagina nodosa) that he had been the first to add to science in 1626 .

Probably at the same time he became acquainted with the Wood Vetch (Vicia sylvatica L.), which he called 'Vicia Bathoniensia vel maxima sylvatica' and found 'In Smoakhall Wood by the Bathe, and at the Devizes in Wiltshire'."

A list of the names of useful Willows bears date I640.

Salix aquatica lo. o. I $37 \mathrm{~g}$. I 203 . I have seene 8 kinds of osyars thus called by the baskett makers
I. gelderlander
5. redd willowe
2. goldstone or hornead
6. privett
3. white withe
4. yealowe osier
7. black $\}$ yelster

1 Not noted by White, Flora Bristol, 1912, p. 256.

2 Merrett, p. III (1666).

3 Sagina nodosa Meyer.

1. Merrett, Pinax, 1666, p. 125. The same plant is mentioned in How, Phytologia, p. 129. 
A similar list, on a small scrap of paper, is dated " 18 Marcii I 640 of Eclw. Greene (? Gawne)'. And two rather longer and later lists enumerate thirteen varieties.

I. White gorerod

2. Black gore rod

3. Gelderlander

4. Yealowest yelster

5. Hard yelster-the best

6. Erlie leavinge redd osier

7. Backward Leavinge redd osier-skragged.
8. Gilford redd osier

9. Erlie ta rod [lesser browne rod

Io. Backward ta rod, or Privett, or

II. White osier

I2. Horneyead or golston.

I3. Oxford or Dutch golston

[MS. f. I6 v.

\section{I643-9}

The disturbed state of the country during the next few years made peaceful pursuits impossible. Hampshire men were soon in the thick of the Civil War. Lucky were those who were not driven from their homes when the 'wrong' side obtained the ascendancy.

During one of the many phases of the struggle Petersfield was garrisoned for King Charles under the then General in Command, Ralph, Lord Hopton. Goodyer, like all his family, was a strong 'King's man', and his loyalty was acknowledged by a 'Protection Order' which was granted him by Hopton. This document of great interest was accidentally found in 1907 , concealed under a floor-board in a dwelling-room of Goodyer's house in the Spain in Petersfield. It runs as follows :

To all Colonells \& Lewetennt-Colonells, Serjant-Maijors, (SEAL)

Captains \& Commanders, Officers \& Soldyers of his $\mathrm{Ma}^{\text {ts }}$ army both of horse \& foot And to all other his $\mathrm{Ma}^{\text {ts }}$ officers and loving Subjects whom these may concerne.

These are in his $\mathrm{Ma}^{\text {ts }}$ name to will \& command you \& every and either of you not to fayle upon all occasions to defend and protect John Goodyer of Petersfield in the County of Southton Gent : his house horses servants family groods chattcls and cstates of all sortes from all damages disturbances \& oppressions whatsoevere to the uttermost of $\mathrm{yo}^{\mathrm{r}}$ abillitys And that you and every of you forbeare to grieve or molest him the sayd John Goodyer or any of his as 
aforesayd requiring hereunto $\mathrm{yo}^{\mathrm{r}}$ due obedience as you will answere the contrary at $\mathrm{yo}^{\mathrm{r}}$ uttermost perill Given under my hand \& seale the 9 th December, 1643

\section{RALPH HOPTON. ${ }^{1}$}

Of Goodyer's movements we know nothing for certain, but it is quite likely that a State Paper in the Record Office may refer to him. About 1649 one Daniel Cusick stated that John Goodyer was a malignant and recusant, and was constantly resident in Oxford during the war. Having adventured his own life in the service of the State, and being now in the Lord General's regiment, the informer begged his arrears out of Goodyer's estate. ${ }^{2}$

If it be true that Goodyer was 'constantly resident' in Oxford during this troubled period, he would have found many botanical friends with tastes congenial to his own.

Walter Stonehouse, now no longer a Fellow of Magdalen, would not have been in residence, but he may have joined his Oxford friends in 1648 when ejected from his Darfield living. And there were other botanists at Magdalen to whom the botanical uncle of Edmund Yalden, Fellow until I 642, would have needed no further introduction.

The senior of them, William Hooper, the arboriculturist, became a Fellow in I643. He had been 'outed' from his Fellowship, but was allowed a pension of $£ 30$ per annum and lived in one of the College houses in the Gravel Walk. 'After he had left the College he went without a gown, and wore constantly a very long coat, like your frocks worn by wagoners; and applied himself to gardening with wonderful success, digging himself with a man that he constantly hired. He would carry his spade upon his shoulders, and work hard every working day. He would likewise prune, engraft, and do other things of that kind himself. He raised several nurseries, and planted many orchards; but he did all for nothing, for he would never

1 Mabel E. Wotton, Hants and Sussex News, II April 1917.

${ }^{2}$ Calendar of Commission fo: Advancement of Money, p. II78, State Papers Domestic, 1649 . 
take anything of anybody soever. It was his constant practice to give away trees, \&c.; but then he took care it should only be to the poor and such as were in want, not to others. He was near fourscore years of age, a comely, neat, proper, upright man, and beloved and respected by all sorts of people.' He planted (c. I660) elms in the Gravel Walk by Magdalen College; ${ }^{1}$ and elms on this site are well known all over the world as an essential feature in what was formerly one of the most popular views in Oxford.

In his old age he was one of the characters of Oxford, but when Goodyer might have known him he had just been recommended by Charles I for election to a Fellowship on the ground that he had 'given ample proof of his sober carriage, conformableness, and commendable abilities in the way of his studies'.

Among the younger men then up at Magdalen College were the three contemporaries Browne, Stonehouse, and Drope. William Browne, Demy 1644, was a native of Oxford, who became 'one of the best botanists of his time, and had a chief hand in the composure of a book entitled, Catalogus Horti Botanici Oxoniensis', 8vo. Oxon. I658; Walter Stonehouse, Demy I645, was the son of Goodyer's friend the Rev. Walter Stonehouse of Darfield, whose garclen lists are preserved among the Goodyer papers: and Francis Drope, Demy 1645, was a most enthusiastic lover of trees and author of $A$ short and sure Guide in the practice of raising and ordering Frait-trees. 8vo. Oxford, 1672. And, in any account of the botanists of Magdalen of this early period, should also be mentioned the unknown writer of marginal notes in the Bodleian copy of Lyte's Herbal. This book was successively in the possession of

'Hearne, Diary. According to one account Hooper's Elms were replaced by others in 1680 , but, be that as it may, the Gravel Walk elms, after forming for more than two hundred years an incomparably beatiful setting to the grey stone architecture of the Great Tower of Magdalen, were wantonly felled before their time in 1916 , when many who would have advocated their retention were away at the War. 
a Thomas Gill and of a John Herbert, I6rg. The writer of the notes was almost certainly a Magdalen man who had studied at Padua.

At this time Goodyer may have made the acquaintance of Dr. Philip Stephens, Principal of Magdalen Hall and collaborator with Browne, and of William How who came up as a Commoner to St. John's College in I637, and took his Master's degree in 1645 .

Goodyer's other friend Dr. Merrett, the author of the Pinax rerum Naturalium Britannicum, had been a student both of Gloucester Hall (I63I) and of Oriel College (1633-4). He was created a Doctor of Physic in I642, and afterwards became one of the original Fellows of the Royal Society. At New College was William Cole, the future author of Adam in Eden; and Jacob Bobart was gradually forming the first University collection of plants in the new Physic Garden, the catalogue of which he published in 1648 .

And yet Oxford was in the very midst of troubles. At the end of 1642 the Royalists gathered round the King at Oxford, students and citizens alike worked together on the fortifications and barricades: the College plate was being surrendered to the minters : fighting in the neighbourhood was incessant. Goodyer's friend, Thomas Johnson, appears to have been in Oxford on 9 May I 643 to receive the $\mathrm{D}$.Ph. degree, but he must have left soon afterwards, for he is heard of as a Colonel of Horse and one of the defenders of Basing House, which was being strongly fortified by the Marquis of Winchester. And it was there that he met his death in September 1644, fighting for the King. The Royalists were defeated at Alton and Cheriton. Winchester was taken by Cromwell in October 1645, and the King became a fugitive. What followed is matter of history. On Midsummer Day, 24 June I646, the Royalist garrison of Oxford, 3,000 strong, ' marched out of the town through a guard of the enemy extending from St. Clement's to Shotover Hill'. 
In $1648-9$ the Parliamentarian Visitors, after many delays, expelled all from the University who did not submit to their visitation, including young Stonehouse and Drope. The latter answered 'I cannot submit for fear of perjury'.

\section{1}

After the Civil War Goodyer was unquestionably the best botanist in England. Parkinson had died in 1650 ; and, until Morison returned in I 660 and Ray had reached his full development, there was no one to approach him in knowledge of our native plants or of the whole range of botanical literature.

The high reputation that he had acquired naturally brought him visitors and correspondence. Elias Ashmole, the antiquary, had not long 'entred upon the Study of Plants'. A note in his diary is to the effect that 6 June I648 'about three of the clock was the first time I went a Simpling. Dr. Canter of Reading and Mr. Watlington ${ }^{1}$ an apothecary there, accompanying me'. And on 'I 9 Oct. I65 I my Father, Backhouse, ${ }^{2}$ and I went to see Mr. Goodier, the great botanist, at Petersfield'. Unfortunately we have no further account of the visit, but possibly Ashmole's recent experiences of the virtues of Bryony may have formed part of the conversation. He had fallen ill of a surfeit occasioned by drinking water after venison at the Astrologer's Feast in Lonclon. 'I was', he wrote, 'greatly oppressed in my stomach; and next day Mr. Saunders the astrologian, sent me a piece of bryony root to hold in my hand, and within a quarter of an hour my stomach was freed of that great oppression, which nothing which I took from Dr. Wharton could do before.' It is characteristic of the writings of Goodyer that no hint of this kind of quackery appears. He was evidently able to put Ashmole

\section{John Watlington, buried a October 1659.}

:Mr. William Backhouse, astrologer of Swallowfield in Berkshire, had communicated so many secrets to Ashmole that he caused his pupil to call him 'Father' (Ashmole, Di(t)y, 3 April 1651). 
on sounder lines of thought; for after this visit Ashmole 'took a journey into the Peake, in search of plants and other curiosities '; and as there is no entry between the $15^{\text {th }}$ and the 29 th of October of this year in the notebook, ${ }^{1}$ in which he usually cast his horoscopes, we may assume that he was not encouraged to foretell Goodyer's future by the stars.

\section{$1652-6$}

The books printed in Oxford during the next few years bear witness to the pleasure and profit that many were deriving from their gardens. And in illustration we may cite the works of Ralph Austen on Fruit Trees, various editions of which were published in Oxford in 1653,1657 , I658, and 1665 , of John Beale whose Treatise on Fruit Trees shewing their manner of Grafting, Pruning, and Ordering, of Cyder and Perry, of Vineyards in England, \&c., appeared in Oxford in 1653, and of Robert Sharrock, Fellow of New College, ${ }^{2}$ whose History of the Propagation and Improvement of Vegetables, by the Concurvence of Art and Nature, 8vo. Oxford, 1660. These works show the natural tendency of the time, a utilitarian tendency that our recent experiences towards the end of the Great War will teach us to connect with the troubles of the forties of the seventeenth century.

During the last ten years of his life Goodyer's occupations appear to become more and more sedentary. When a man is over sixty years of age, he must perforce leave the searching for new plants to the young and active. John Goodyer now devoted himself to his books. The dated entries in the covers of his volumes show that he kept in the closest touch with the London booksellers; indeed, in some cases he appears to have secured a work in advance of the day of publication. Some of his books he pro-

${ }^{1}$ MS. Ashmole, 374, which contains the horoscope of John Tradescant, the younger.

${ }^{2}$ Sharrock gave several medical books, with his autograph, to New College Library. They are still, we are glad to think, on the shelves: among others a copy of Lower, de Corde. 
cured through Dr. How, some through Dr. Dale, and they came down to Petersfield by carrier, or in the trunk of Mrs. Heath, presumably the wife of his friend and neighbour the Rev. John Heath.

He was now closely associated with a botanist in the work of preparing a list and a synonymy of all known British plants, incorporating and extending the lists drawn on by How. The greater part of the labour of this work fell on a collaborator who had access to Goodyer's books and made notes in them: his name is not known to us for certain, but we have his manuscript. The evidence all tends to identify him with the Dr. Dale just mentioned, but the matter will be again discussed below, p. 295 .

This last period of his life is also marked by a literary labour that remains a record which to this day has never been broken. It was the writing out of the Greek text of the Materia Medica of Dioscorides, and the rendering it into English. Goodyer therefore accomplished in the case of Dioscorides a work which not one of the tens of thousands of Greek scholars who have lived before or during the past three centuries have been known to have attempted, a worthy sequel to his translation of Theophrastus.

And neither Theophrastus nor Dioscorides can be considered as of no import. Of Matthiolus' Commentaries on Dioscorides alone thirty-two thousand copies were sold before I56I, and it passed through seventeen editions. His works have been translated into almost every civilized language, except English, and there is no separate article on Dioscorides in our national Encyclopaedia.

The interlinear translation of Dioscorides fills six quarto volumes of 4,540 pages in all. It is most clearly written, the Greek text being easier to read in Goodyer's manuscript than in the 1499 edition, printed at the $A$ ldine Press at Venice, Goodyer's copy of which has now been restored to its proper place among his books in the Magdalen Library. 
3 Martin $6: 3$

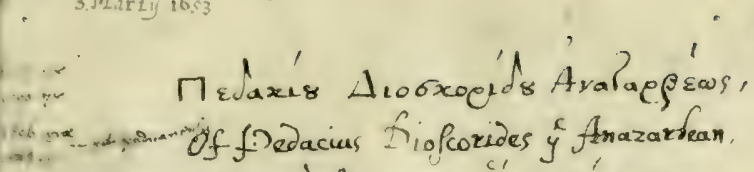
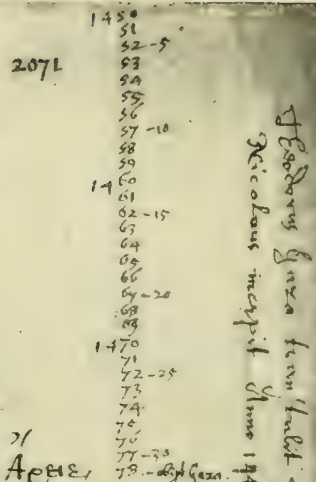

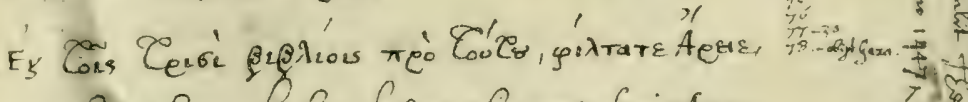

In the three boares before this, most doungy freus,

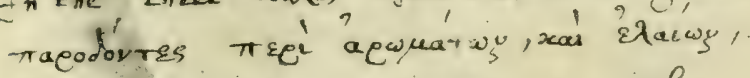
nicuma paken, of fromatical matrexs, \& oyles,

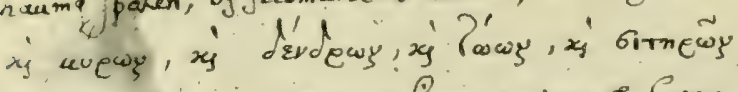
\& ontmants, trees, \& Puing creatuos, \& Corre,

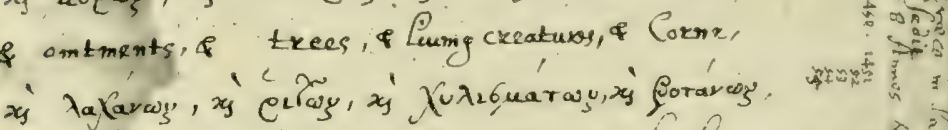
\& potherbs, oroots, \& inices, \& herbs.

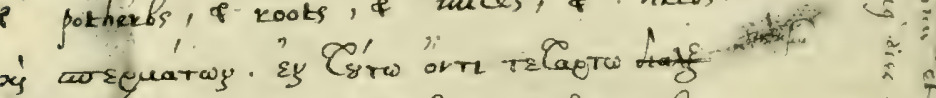
4. of fears. In this boing $y$ foworth.

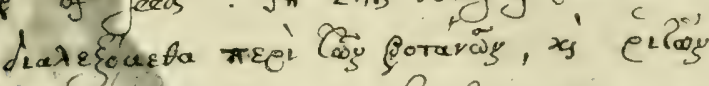
weeroill difcourf of $y^{e}$ hexbs, and xootos

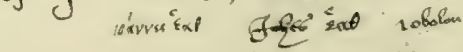
$\lambda$ ELTTOMEN Left unposen of :3318 6 $6 \cot ^{2}$
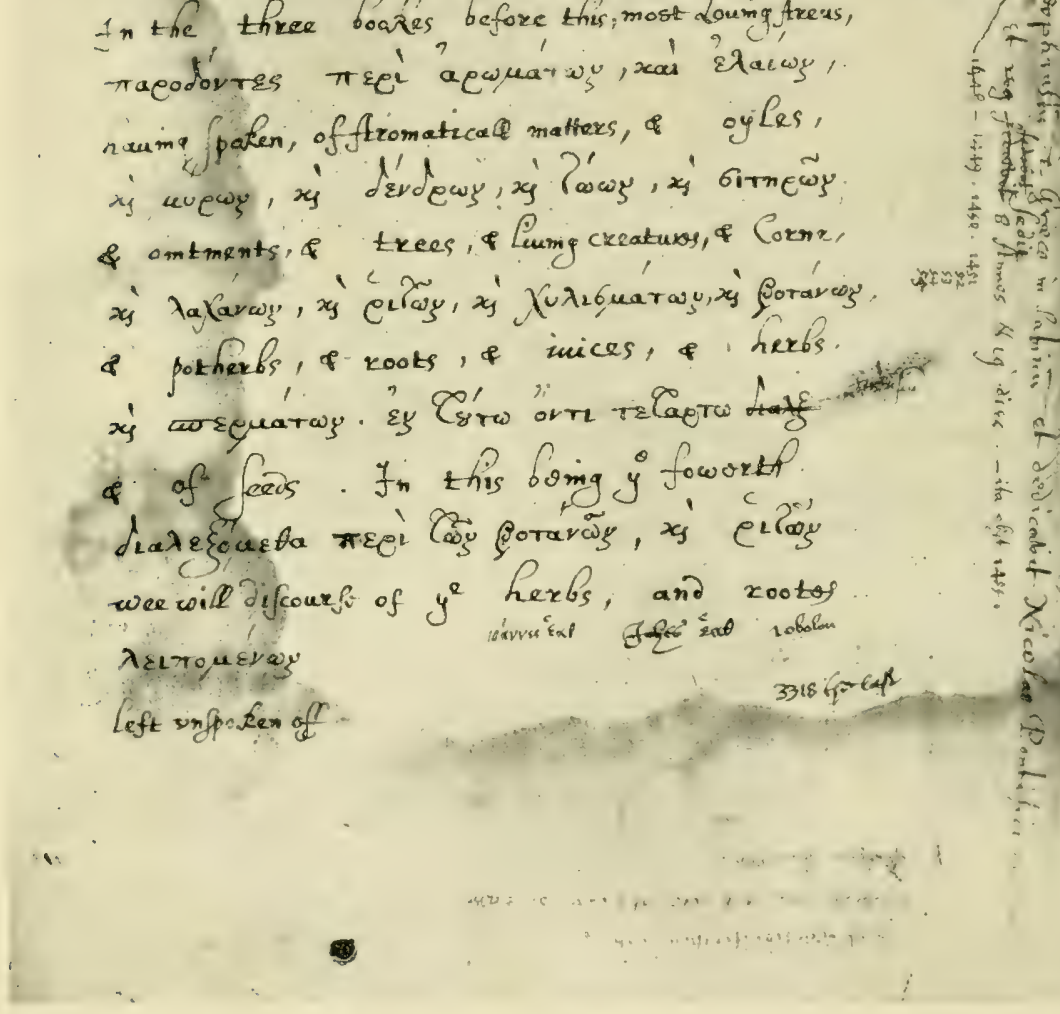

pistiog.

15. 

Every page bears evidence to his neat and methodical habits. At the beginning and end of every volume he wrote the dates of the beginning and end of his labours, and also of the time that was spent on reading over and revision. The entries are of interest because they show the speed with which the work was accomplished.

Pages. English. Greek.

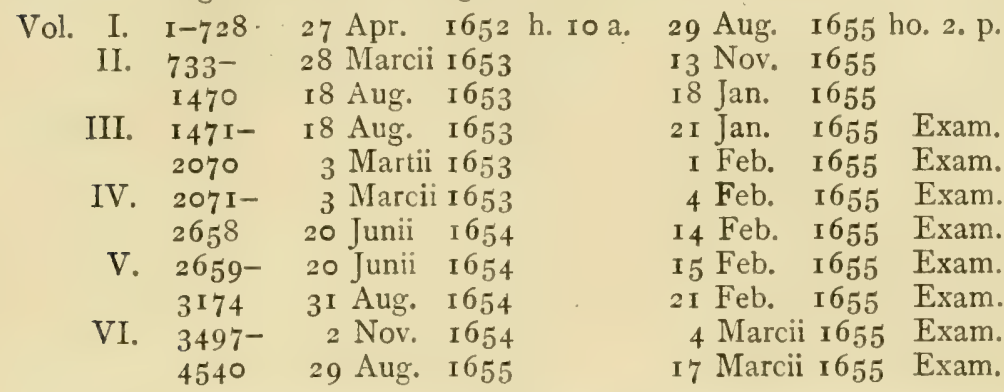

Other entries show that he paid an assistant, probably as a reader:

Vol. II. 'Receaved of Mr. John Goodyeere, upon this 28 of March 1653 And 18 of Januarie 1655

IV

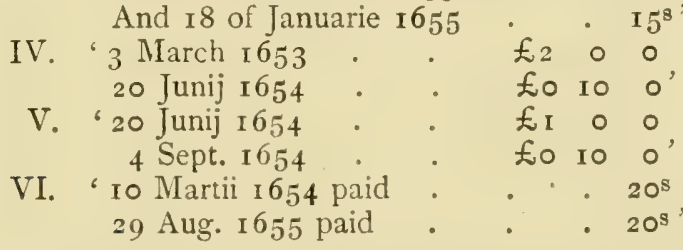

In Vol. $\mathrm{V}$ there is an entry for ' $3^{\mathrm{s}}$ binedinge' on I 4 September 1654 , and in the last volume is written:

' 22 Sept. 1655 cariage upp and doone the bindinge'

A few notes on a duplicate page (p. 207 I, MS. f. I 7) of the fourth volume, written on 3 March 1653 , show that he was acquainted with at least eighteen editions of Dioscorides dated ' I 499 gr., I 500 gr., I 506 gr., I 5 I 2 paduanensis, I 5 I 8 gr., I 529 gr., I 529 Herm. Barb., I 549 Gualt. Riffe, I 549 gr.-lat., I 552 Ruellius, I 552 Lacuna, I 554 lat. Mat., I 557 Jan Cornarius, I $55^{8}$ Amatus Lusitanus, I 566 french, 1581 Alphabeticum Empyricum, I59I Antonini Pasini, I 598 gr.-lat. Saracen.' There is also a note that 
Theodorus Gaza translated Theophrastus from Greek into Latin and dedicated it to Pope Nicolas: a calculation shows that Nicolas was pope from I 447 to I 455 and that Gaza died in 1478 . But of still greater interest are the words:

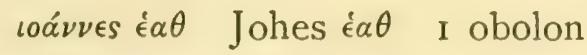

which evidently refer to Goodyer's coadjutor John Heath, who will be mentioned again presently, and to whom we believe that the payments just recorded were made.

Had Goodyer wished for a Preface to his translation he might well have used the words of his senior, Henry Lyte :

'If perchaunce any list to picke a quarrell to my translation, as not being either proper or not ful, if I may obteine of him to beare with me til he himselfe shall have set foorthe a better ... and in the meane while (considering that it is easier to reprehend a mans doing than to amend it) use me as a whetstone to further himselfe withal, I will not much strive: for I seeke not after vayne glorie, but rather how to benefite and profite my countrie.'

In March he continued his studies in the botany of the ancients by translating, doubtless with the help of John Heath, the work of one of the principal commentators on Dioscorides, the Scholia or Animaducrsions upon the 5 Bookes of Dioscorides of Physisall matter and upon his two Bookes of Poisons, of Antonius Saracenus of Lyons, 'In which $y^{\mathrm{e}}$ severall readings of divers Bookes are examined, $y^{\mathrm{e}}$ different opinions of $\mathrm{y}^{\mathrm{e}}$ old or new propounded, and some tymes reconciled, and $\mathrm{y}^{\mathrm{e}}$ most corrupt, obscure, and difficult places of $y^{e}$ Author himself, restored, illustrated, and unfolded'.

Goodyer, with his usual punctiliousness, noted that the translation was begun on 20 March I655 at II a.m.

Saracen's dedication is 'To Henry $y^{\mathrm{e}}$ 4th $\mathrm{y}^{\mathrm{e}}$ most Christian King of France and Navarre' and is dated ' $y^{e}$ Calends of March 1598'. This is followed by the Introduction, which is worth quoting as an example of the literary style of the time. 


\section{To the Gentle Reader}

\section{Salutation.}

Thou willt wonder, it may be (Gentle Reader) how it should come into my minde, $\mathrm{y}^{\mathrm{t}} \mathrm{I}$ should sett about a new interpretation of Dioscorides, especially since $y^{t}$ soe many famous men, renowned for Eloquence, learning and iudgement, as Hermol. Barbarus, Marc. Virgilius, Janus Cornarius, \& Jo. Ruellius, have long since with great contention \& aemulation taken abundant if not overabundant paines in translating him, \& have donne well herein to their great commendations. But you will then leave off to wonder, when you shall have understood by what reasons I was induced, or drawen heereunto. Dr. Jo. Sambucus of godly memorie the Emperours Physition \& Historiographer had formerly often importuned by letters Henry Steevens, Printer, a man most skillful of $y^{\mathrm{e}}$ twoe tongues both Greek and Latin, to sett out in print $y^{\mathrm{e}}$ Greek \& Latin text of Dioscorides with $y^{\mathrm{e}}$ most elegant letters of $\mathrm{y}^{\mathrm{e}}$ King's stampe, \& $y^{t}$ hee should add to $y^{e}$ Margent thereof his notes, sent over a little before, or rather $y^{\mathrm{e}}$ divers readings upon $\mathrm{y}^{\mathrm{t}}$ Author, gathered by him with great labour, by a faithfull \& diligent comparing of divers antient bookes found in $y^{\mathrm{e}}$ severall Libraries of Princes. But while Steevens did prepare himself to goe about this worck, hee was minded to place Ruellius his Translation (which hee did, and not without cause, prefur before the rest) right over against the Greek text, but hee found it to be, as indeed it is, a little too free in many places, that $y^{e}$ Latin did not sufficiently aunsere to the Greeke: therefore for $y^{e}$ acquaintance sake $y^{t}$ did passe between him \& mee, hee did intreat you \& overintreate mee, $y^{t}$ I would take a diligent review of it, \& sett downe in the margent $y^{e}$ correction of all $y^{e}$ places in which Ruellius, either following some corrupted copie, or else by his beeing too much addicted to Plinie, as for $y^{\mathrm{e}}$ most part hee is, did not sufficiently expresse $y^{\mathrm{e}}$ sence of Dioscorides, nor $y^{\mathrm{e}}$ force of his wordes. But I had scarce compared a few of the first leaves, when being as it were deterred with $y^{e}$ difficultie of soe most grievous a burthen, I was compelled to decline from my first resolution, \& to change my minde. For I mett forther (under favour be it spoken) with soe many places worthy of censure, \& animadversion, $\mathrm{y}^{\mathrm{t}}$ partly to avoide $\mathrm{y}^{\mathrm{e}}$ hatefull labour, \& partly to avoide $y^{\mathrm{e}}$ envie, \& offence of them, which might have suspected mee to be too injurious against Ruellius his ghost, I thought it better to sett out a new translation, then to correct an others. In which I may truely say, $y^{t}$ I have performed $y^{e}$ part, 
not of a Paraphrast, but an Interpreter, as whoe, as much as lay in mee, have not departed a nailes breadth from Dioscorides his meaning, and yet withall have stuck close to $y^{\mathrm{e}}$ puritie of Plinie's style. But I had rather they should judge of this, which shall faithfully compare mine with their translations. Howsocver it be, I had allmost made an end of $y^{e}$ worch, when behold Sambucus an earnest prosecutor hecreof was taken away from us by untimely death. Then Steevens began to be, as it were, faint hearted in $y^{e}$ businesse, yea \& although $y^{t}$ many others were urgent upon $y^{\mathrm{e}}$ worck, to knit many delaies, and to put it off from day to day, either by his due employments, whereby he was some tymes diversly distracted or for $y^{\mathrm{e}}$ travellings, which befell him often in $y^{e}$ meane space, \& were allmost continuall soe $y^{t}$ he could not performe his promise nor be as good as his word. And soe it came to passe that these my Elucubrations upon Dioscorides lay concealed in my desk for many yeares. This then, when $y^{e}$ heyres of Andrew Wecher did understand, being most studious of helping on learning \& did withall desire to satisfie $\mathrm{y}^{\mathrm{e}}$ wishes \& expectations of some good men, at last they obtained this of mee $y^{t} I$ should suffer them to be brought out into $y^{e}$ sight \& view of men. These are $\left(y^{t} I\right.$ may once say it) $y^{\mathrm{e}}$ causes of this worcke intended, \& also of the suppressing of it soe long unto this tyme.

As concerning $y^{e}$ Greek text, wee have laboured, $y^{t}$ as farre as might be, it should be restored to its old splendor. For although wee have relligiously followed $y^{\mathrm{e}}$ Parisian edition of $y^{\mathrm{e}}$ most learned Goupylus, as $y^{\mathrm{e}}$ most sound, \& best amended of any that are extant, yet wee have, as much as might be, taken away $y^{e}$ faults of $\mathrm{y}^{\mathrm{e}}$ print, which were yet remaining. But what passages, both $y^{\mathrm{e}}$ matter it self, \& $y^{\mathrm{e}}$ certaine faith \& authoritie of $\mathrm{y}^{\mathrm{e}}$ Copies, whether printed, or manuscript. did persuade to be changed, those wee have boldly changed. Yet wee have noe where yielded soe much to our owne or others conjectures, that wee have dared to doc anything without $y^{e}$ Creditt of $y^{e}$ better bookes, being contented only to note them with an interlineary Asterisck, which should direct thee $y^{e}$ Reader to our Notes. But if, which yet falls out but seldome, wee found some places, soe corrupted \& depraved, $y^{t}$ there could noe sence be made of them, and yet there was no place for any Remedie either out of conjecture, or out of $y^{\mathrm{t}}$ footsteps of antient readings, there wee have marcked $y^{*}$ margent with an Asterisck. But $y^{\text {e }}$ divers readings, both of the most renowned man Dr. Sambucus, as also of others drawne out here \& there upon Dioscorides. For both $y^{e}$ same Ir. Steevens communicated some 
unto us, \& D. Opsopous some by comparing of $y^{e}$ Palatine copies, these, I say, and $y^{t}$ without choice, I have thought fitt to set upon $y^{\mathrm{e}}$ margent, $y^{\mathrm{t}}$ it might be free for every man to judge of them, and withall some Animadversions \& Corrections of Interpretors, adding still $y^{e}$ names of everie one out of whom wee tooke them, $y^{t}$ wee might not seem to defraud any one of his desert. But wee have placed our own notes at $\mathrm{y}^{\mathrm{e}}$ end of $\mathrm{y}^{\mathrm{e}}$ worck, in which for the most part, there is a reason given of our different interpretation from others, as also there are sett downe our divers conjectures upon Dioscorides. And also you may finde many thinges incidently, \&, as it were by $\mathrm{y}^{\mathrm{e}}$ way, noted upon divers Authors, but especially upon Theophrastus \& Plinie, as they came under mine hand.

Finally wee doe propose, velut, $\dot{\epsilon} \xi \dot{\xi} \pi \mu \mu \dot{\epsilon} \tau \rho y, i$. by way of Additament, the severall, \& discrepant opinions, whether of $y^{\mathrm{e}}$ old or new writers concerning Medicinall Matter, \& some tymes wee reconcile them, \& besides, wee endeavour to resolve \& cleare many doubts which wee met with everie where. But yet I would have you to understand, $y^{t}$ I did chiefly cavell heereat with all my labour, $y^{t} I$ might restore, illustrate, \& explaine $y^{\mathrm{e}}$ most corrupted, obscure, \& difficult places of Dioscorides himself. And soe you have been given to understand (Gentle Reader) what thinges have been performed by us in this Edition, out of which if I shall percieve, $\mathrm{y}^{\mathrm{t}}$ you have got any fruit, it will encourage mee pcradventure to divulge other more great \& more profitable matters.

In the meane space, Farewell.

[Goodyer MS. 6*, ff. 5-8

The text of the work is written out on pp. I $3-292$ of the MS., which ends abruptly with Book 4, chap. $6 \mathrm{r}$, the last line being dated ' 2 Octob. 1656 ', and then follows an ominous note, which evidently refers to his collaborator.

'Johannes Heath Clericus obijt $25^{\text {to }}$ die Novembris 1656 .'

This must have been Goodyer's neighbour, the Rev. John Heath, who was presented by the Earl of Worcester to the rectory of Clanfield, ${ }^{1}$ in or soon after 1617 . He may have been the John Heath who came up to Christ Church as a Westminster Student in 1607 , and who matriculated in 1610 aged $19 .{ }^{2}$

${ }^{1}$ Clanfield is about three miles south-west of Buriton, and six from Petersfield.

${ }^{2}$ Foster, Alumni Oxon. 
In 1654 we have evidence of the return of Goodyer to his old love, field botany. There is the short note

'Behen album ... Rotherwort 5 Maij 16.54'.

And there is an interesting description of a station where 'Dryopteris Tragi' used to be found. ${ }^{1}$

'It growes on a bottome called Rogers Deane in $y^{\mathrm{e}}$ parish of Faringdon in Hampshire, about a mile and halfe from $y^{e}$ church, a furlong from one John Trybes dwelling-house on $y^{\mathrm{e}}$ north-east part of $y^{e}$ house about 2 miles from Alton above a mile north-east from Dogford Wood. Great antient beeches kept $y^{\mathrm{e}}$ sunne from shining on $y^{e}$ Plants. Anno 1654 many of those trees were cut downe. The Plants $y^{\mathrm{e}}$ sunne shoane on $\mathrm{y}^{\mathrm{e}}$ summer 54 were short $y^{e}$ leaves growing on short stemms neere $y^{e}$ earth, as Tabernaemont pictureth it, pag. jOI, tom. 2, under $y^{e}$ title of Filicula petraca fem. 3. Those $y^{t}$ grew under $y^{e}$ trees were much higher agreable to 'Tragus' figure pag. 538.'

In the beginning of August 1654 he recorded a new Crane's bill (Geranium columbinum) in his native county." The Rubia sylvestris described by him on I 2 August 1655, if it be the Wild Madder ( $R$. peresrina L.), is of historical interest because of its having been one of the first Hampshire plants to be recorded by our first botanist. William Turner, more than a century previously, wrote of it, "The most that ever I saw is in the Isle of Wight, but the fairest and greatest that ever I saw groweth in the lane besyde Wynchester, in the way to Southampton'. It is now very rare on the mainland, but that is where Goodyer may have found it.

His botanical labours in the field were almost done. IVe only note two occasions in the last ten years of his life on which he may possibly have left home and herborized.

Again, the summer of 1656 he found the Marsh Isnardia (Ludwigia apetala Walter), 'Holosteum perpusillum', which he had previously observed near Holburie

\footnotetext{
I In Goodyer MS. 9, under Pin. 358, there is a note 'Dryopteris Tragi, 17 Aug. 1650, J. G. first saw it'.

2 Morison, in ignorance of Goodyer's discovery, attributed this species to Jacob Bobart in 1680. The plant should be called Goodyer's long cut Crane's bill rather than ' Bobarts long cut Crane's bill'.
} 
in the New Forest, growing in a little lake in the east part of a heath near Petersfield, "The water of this lake this 2 of June 1656 about 4 of $y^{\mathrm{e}}$ clocke in $y^{\mathrm{e}}$ afternoone was well neere as warme as $\mathrm{y}^{\mathrm{e}}$ Bath-water at Bath in Summersetshire although $y^{\mathrm{e}}$ day was cloudy'. 'In a hott summer some parts of $y^{\mathrm{e}}$ lake are drie in August, sometimes before, and then the plant, which had been green, all the winter under water, flowered'. Immediately recognizing the novelty of the plant, he described it as 'Anonymos aquatica rubida, foliis Anagallidis flore luteo'.

\section{$1657-9$}

In June 1657 he described what appears to be our Smooth Tare (Vicia tetrasporma), but as no locality is stated, we cannot claim his note as being the first evidence for the occurrence of this plant in Hampshire.

The following information on a scrap of paper was sent him by an acquaintance:

$5^{\circ}$ March 1657

At Judge Rumseys 3 miles from Abergevenny croweth the Sweet Willowe, as I remember the plant I saw, was called

Robert Baskett.

To this a note is added in Goodyer's hand:

$9^{\circ}$ Apr. 1658 - Judge Rumsey lives in Glamorganshire by the relation of Gryffin Morgan of Malmesbury, a glasse carrier. [MS. f. I 47

But though able to move about in his own county, where he found the alien Xanthium Strumarium in 1659 (his last recorded find), we imagine that he now felt himself too old to herborize in Wales.

But the record would have been valued by him as an addition to the last work on which he is known to have been engaged, the compilation of a new British Flora. How's Phytologia Britannica, published in 1650 , was very imperfect, as any first attempt at so comprehensive a work is bound to be, and no one would have been in a better position to recognize its many errors and deficiencies than 
Goodyer, nor more ready to remedy them. Our information comes through Edward Moryan, the 'very skilful botanist' of Westminster, who was in close touch with what was going on in the botanical world. He told John Ward in 1662 that Dr. Dale, Dr. Merrett, and Mr. Goodyer, ' next Dr. Modesy, the best botanists of their age in London, were about a new phytologia 3 or 4 years agoe:, but that 'Dr. Nodeseye's coming to towne, itt's thought, hindered itt'. Elsewhere Ward ${ }^{1}$ also noted that 'Dr. Dale and another had a designe to amend $\mathrm{y}^{\mathrm{e}}$ phytologia Brittanica to adde somewhat and take out somewhat'. This contemporary account is of the greatest interest to us, because it explains the presence of certain excellent catalogues of British plants among the Goodyer manuscripts (Goodyer NIS. 8, 9, see p. 296), and it also explains why they were never printed. I have not as yet found any clue to the handwriting, but I strongly suspect it to be that of Doctor John Dale, and the 'another' to have been Goodyer himself. The case will be again considered in our note on Dr. Dale, and in the light of his Will which I have recently discovered at Somerset House.

The 30 April 1659 must have been a red-letter day, for he then received the interleaved and annotated copy of the Phytologia to which reference has so often been made, and possibly with it the Lobel manuscripts which are described in a later chapter. Their late owner and part editor, Dr. How, died 30 August 1656.

The greater number of manuscript notes in the Phytologia are in How's handwriting: they include information received from William Browne of Magdalen College and from John Goodyer, obviously between I650 and I656. Goodyer after acquiring the volume wrote in it the notes on seven plants, printed on p. 194, including his last dated record of a plant, the Common Ragwort (Seneico Facobaea L.) from Ladle Hill (I659).

${ }^{1}$ Ward also noted that 'Mr. Goodyer is good at Insects as well as plants.' 


\section{$1662-4$}

The last specimen of his handwriting, which we have, was written when he was seventy years of age. His hand was evidently very shaky. It is a receipt for a Resin ointment similar to that in use until recently in the British Pharmacopoeia.

20 Mar. I662

Rosen that is blackish

Fresh lard a wallnutt

Crowne sope a wallnutt

Boil till it sets clere (?) $\mathrm{H}$.. and keepe stirringe.

[MS. f. I6

Then follows, in a steadier hand, "Mar. 22. John Neale in Lippock, the howse is called Gurmes, hadd a third Ague, and hath lost him about a moneth, and now hath a great cough'.

Another note on the same paper is ominous:

$$
\text { 'The Line of Selborne }\left\{\begin{array}{l}
\text { Goute } \\
\text { Scurvie } \\
\text { Dropsie.' }
\end{array}\right.
$$

These notes supply the clue to the occupation of his declining years. He was evidently applying his great knowledge of simples to the good of ailing neighbours. The latest medical works were sent him, as soon as they were printed, by his London bookseller, who evidently had a standing order to secure the sheets direct from the press. Thus he acquired Culpeper's English Physician, Pemel on Simples and on the Diseases of Children, Cole's Art of Simpling, Cooke's two works on Chirurgery (containing the 'Marrow of many good authors on the art of Chyrurgery'), Coghan's Haven of Health, and Muffet's Health's Improvement; or rules comprizing and discovering the nature, method and manner of preparing all sorts of food used in this nation. But the most striking confirmation of his practising I found in the single word 'phisicke', with a blank space in front of it, which occurs after his name in the opening sentence, written within a few months 
of his death, in the Book of Accounts kept by the Trustees of the Weston Charity in Petersfield.

Obviously he was well known as a physician, but the writer left a blank as if in doubt whether to style him 'Doctor of Physic'-probably because he held no such degree, qualification, or licence at all. Moreover, his charitable disposition would have led to doctoring without fees.

His great friend and neighbour, Dr. John Dale, died in May 1662, having appointed Goodyer one of the overseers of his will, but we do not know whether he was able to act.

The exact day of John Goodyer's death is uncertain, but his will is dated 22 April I664, and was proved 9 May I 664 by the executor, the Rev. Edmond Yalden. ${ }^{1}$ He is now described as of Weston, in the parish of Buriton, co. Southampton.

IN THE NAME OF GOD AMEN I John Goodyer of Weston in the Parish of Buriton in the County of Southampton Gentleman being sick and weak in body but of good and perfect mind and memory thanks be given to God therefor revoking all former Wills by me made do this two and twentieth day of April in the sixtcenth year " of the reign of our Sovereign Lord Charles the Second by the grace of God of England Scotland France and Ireland King Defender of the Faith \&c and in the year of our Lord $166+$ make and ordain this my last Will and Testament in manner and form following (that is to say)

First I bequeath my soul into the hands of Almighty God Jesus Christ my only Saviour and Redeemer hoping assuredly by his mercies and merits to receive pardon and remission of all my sins and to enjoy life everlasting And my body to the earth from whence it was taken decently to be buried by my Executor hereafter named in the Church yard of Buriton aforesaid near my late wife and as for such worldly goods and estate as it hath pleased God of his goodness to bestow on me I give and dispose thereof as followeth Item I give to the poor people of the Tything of Weston aforesaid twenty shillings to be clistributed with-in a month after my decease at the discretion of my Executor hereafter named

\footnotetext{
2 Archdeaconry Court of Winchester Register, 1660-6, fol. 564 .

2 That the beginning of the reign is reckoned not from the Restoration in 1660 , but from the execution of Charles I in 1649 , is a further indication that John Goodyer belonged to the Royalist party.
} 
I give and devise unto my honoured friend Leonard Bilson Esq and my Nephew Edmund Yalden in the County of Surrey Clerk and to their heirs and assigns for ever all my messuage dwellinghouse together with all the barns stables outhouses and buildings and all the gardens and orchards thereunto belonging situate in Weston aforesaid wherein I now live and in my possession and likewise all those lands in Weston aforesaid called Halfpenny Land now in the possession of Thomas Jacques together with free liberty to water and overflow the said lands as it now and heretofore hath been used for the best improvement thereof to the intent and purpose that they the said Leonard Bilson and Edmund Yalden and the Survivor of them their heirs and assigns shall grant and convey all the said messuage lands and premises with the appurtenances unto six able honest and sufficient persons their heirs and assigns as they or the Survivor of them shall think fit Upon trust and confidence and to the intent and purpose that all the yearly rents issues and profits of the said messuage lands and premises shall be employed and disposed of for ever hereafter for the putting forth and placing abroad of all such poor children of the Tything of Weston aforesaid and the overplus thereof shall be distributed unto the poorest inhabitants of the said Tything of Weston aforesaid as my said Trustees and their assigns shall think fit and if any or either of my said Trustees shall die then the Survivors of them shall convey the premises aforesaid unto the use intents and purposes and upon the trust aforesaid all the rest of my messuages lands tenements meadows and hereditaments whatsoever in Weston aforesaid I give and devise unto my said Nephew Edmund Yalden his heirs and assigns for ever Item I give and bequeath unto the said Leonard Bilson, Osmund Bilson Gentleman, William Bilson Gentleman five pounds a piece to buy each of them a piece of plate Item I give and bequeath unto all the children that shall live unto the age of one and twenty years of Anne Worlidge Widow the sum of Forty pounds of lawful money of England equally to be divided betwixt them at their several and respective ages of one and twenty years and to such of them as shall be of the age of one and twenty years at my decease to be paid unto them within three months after my decease. Item I give unto my servant Mary Blackman the sum of twenty shillings all the rest of my goods chattels household stuff and personal estate whatsoever my debts legacies and funeral expenses being first satisfied paid and discharged except all my books de plantis which I do give and bequeath to Magdalen College in Oxon to be kept 
entircly in the library of the said College for the use of the said College unto my said Nephew Edmund Yalden whom I make sole Executor of this my last Will and Testament. IN IVITNESS whereof to this my last Will and Testament contained in three sheets of paper together with this being fixed together I have set my seal subscribed my name the day and year above written JOHN GOODYER. Signed sealed and published as the last Will and Testament of the above named John Goodyer in the presence of Arch. Bold, Osmund Bilson, ${ }^{3}$ John Westbrook, Richard Goddin, John Winter, William Gammon.

MEMORANDUM that immediately after the signing and sealing and before the publication hereof the above named John Goodyer did declare that his Will was that Susan the daughter of Thomas James should have and enjoy the lease of the houses he holdeth of the Dean and Chapter of Winton during all his term therein and likewise did give unto John Westbrook Gentleman his book of Chirurgery called Ambrose Barry ${ }^{2}$ in the presence of Arch. Bold, Osmund Bilson, William Gammon.

The books came to Magdalen College soon after his death, but some of the manuscripts may have been a year or two later in coming, for Edmund Yalden lent his uncle's descriptions of plants to Dr. Christopher Merret to be used in his 'Pinax' in I666. The loan is duly acknowledged by Merret in his preface, but by a mistake he refers to Edmund Yalden as Mr. Yalden Goodyer, evidently believing him to have taken the family name on succeeding to his uncle's property. This was certainly not the case.

He was buried, as he directed in his will, in 'the Churchyard of Buriton near his late wife'. No stone marks the spot, and when Canon Vaughan wrote his charming account of him in $1909,{ }^{3}$ no memorial commemorated his benefactions to the parish. Through the devotion of Miss Mabel Wotton a sum of money, towards which Magdalen Collegre contributed five pounds, was col-

${ }^{1}$ Sir Thomas Bilson had four sons and two daughters: I. Thomas Bilson m. Edith da. of Peter Bettesworth of Finning, co. Sussex; 2. Leonard B. m. Eleanor da. of Sir W. Lewis, Kt. ; 3. Osmund B.; 4. William B. ; 5. Anna ; 6. Susanna. (Information from Charles Billson, Esq.)
${ }^{2}$ Parey.
J. Vaughan, Cornhill, 1909. 
lected and an armorial window to his memory was put up in Buriton Church. Under the Goodyer arms is the inscription 'To the Glory of God and in Memory of John Goodyer of Alton, Mapledurham, Petersfield, I 592-1664, Royalist, Botanist, Founder of Goodyer Charity, Weston . A water-colour drawing of the window by Mrs. Davis has been hung near his books in the Magdalen Library.

The property which he left for the benefit of the poor of Weston, has already been described in his will. The way in which his Trustees set out to administer the Trust is shown in their first Account Book which we had the pleasure of consulting through the kindness of Mr. Burley, the solicitor to the Trust. The first entries of receipts and payments give some idea of the initial value of the legacy.

A Booke of Reccipt and Disbursements of the issues and profitts of the house and lands in Weston late Mr. John Goodyers, [a blank space] phisicke, And by his last Will and Testament settled upon two Trustees viz. Leonard Bilson Esq and Edmund Yalden, Clarke, to the end that they should nominate six able persons and Convey the said house and lands to them or ffeoffees in trust for the prolating and puttinge forth apprentices of $y^{\mathrm{e}}$ Children of the poorer sort of Inhabitants within the said Tithinge of Weston accordinge to the true intent and purport of the said last Will and Testament. In pursuance whereof they, the said Leonard Bilson and Edmund Yalden have nominated, and by their deed bearinge date the $\mathrm{II}^{\text {th }}$ day of June in the sixteenth yeare of the Raigne of King Charles the second, have Conveyed the said house \& lands unto these six persons followinge viz. :

William Bilson, gent.

Henry Voake, yeoman. John James, gent. John Bold, gent. Jacob Voake, yeoman. Robert Cox, yeoman.

The first Receipts.

1664

I2 Julii Recd of John Girdler for a bushell and an halfe of apples . . . . . 00023 Rec $^{\mathrm{d}}$ of Will ${ }^{\mathrm{m}}$ Budde for a parcell of faggotts 00 OI 8

I2 Aug. Rec. of John Girdler for 3 halfe bushell one gallon of apples \& one gallon of peares $\& 3$ halfe bushells . . . . . $\infty \circ 63$ 23 Sept. ditto ditto for apples 004 \% 
I 5 Oct. Rec. of Mr. Jaques for halfe a yeares rent of halpenney lands ending at Michaelmas last past

7 I0 0

1665

I4 Apr. Rec. of Mr. Bettesworth for his halfe yeares rent ending att Lady day last past (abatinge nine shillings for Chimney money before hee came to the house

4 II 0

The first Payments.

1664

24 June Imprimis to Will. Cox and Robert Tribe for mending the garden hedge . . $0000 \quad 9$

13 Julii To Will. Cox and Robert Tribe for scouringe the river . $\cdot{ }^{*}$.

I5 Oct. Paid att the Trustees first meeting to lett the lands the expenses of the house in fire, beare, \& tobacco . . .

30 Dec. Paid John Gamons Bill for repairinge the glasse windowes of the house

00024

00050

00100 I666

30 March Paid Doctor Gunter for losse of time in cominge over for a witnesse. . . 00 10 0

His 'large house' was afterwards sold for over $£ \mathrm{I}, 0 \circ 0$, the proceeds of which, invested in Consols, together with the rent of the land, bring in an annual income of some $£ 75$, which is a source of considerable benefit to the parish. Part of this sum is yearly expended in gifts of money and clothing, part in making allowances by way of encouragement to servant girls, and part in apprenticing the young lads of the tithing. The people of Buriton have, indeed, much cause for gratitude towards the good botanist of Petersfield, whose very name is now forgotten in the village.

His memorial in modern scientific botany is the customary one of a genus named in his honour. But unfortunately his name has been somewhat inappropriately connected with a rare Orchid, Goodycre refins, that is found in certain firwoods in Cumberland and Scotland, but which could never have lived, where it was thought that he might have found it, in the 'moist meadow named Wood-mead, neere the path leading from l'ctersficlel towards Beryton'. There Goodyer was accpuainted with an orchid which he knew by 
the name of 'Palma Christi radice repente' or 'Creeping Satyrion', and which we should now call the Marsh Helleborine or Epipactis palustris. Robert Brown, who gave the name Goodyera to the northern genus in honour of our Hampshire botanist, was misled by Johnson, who in error had attached a figure of Goodyera repens to the text relating to the Marsh Helleborine. It is somewhat unfortunate that by a triple error his name should have been attached to a plant which in all probability he could never have seen, but that is only one of the many chance circumstances which have led to the passing from memory. of the services of ' an incomparable botanist, of sound judgement, and of immense industry'.

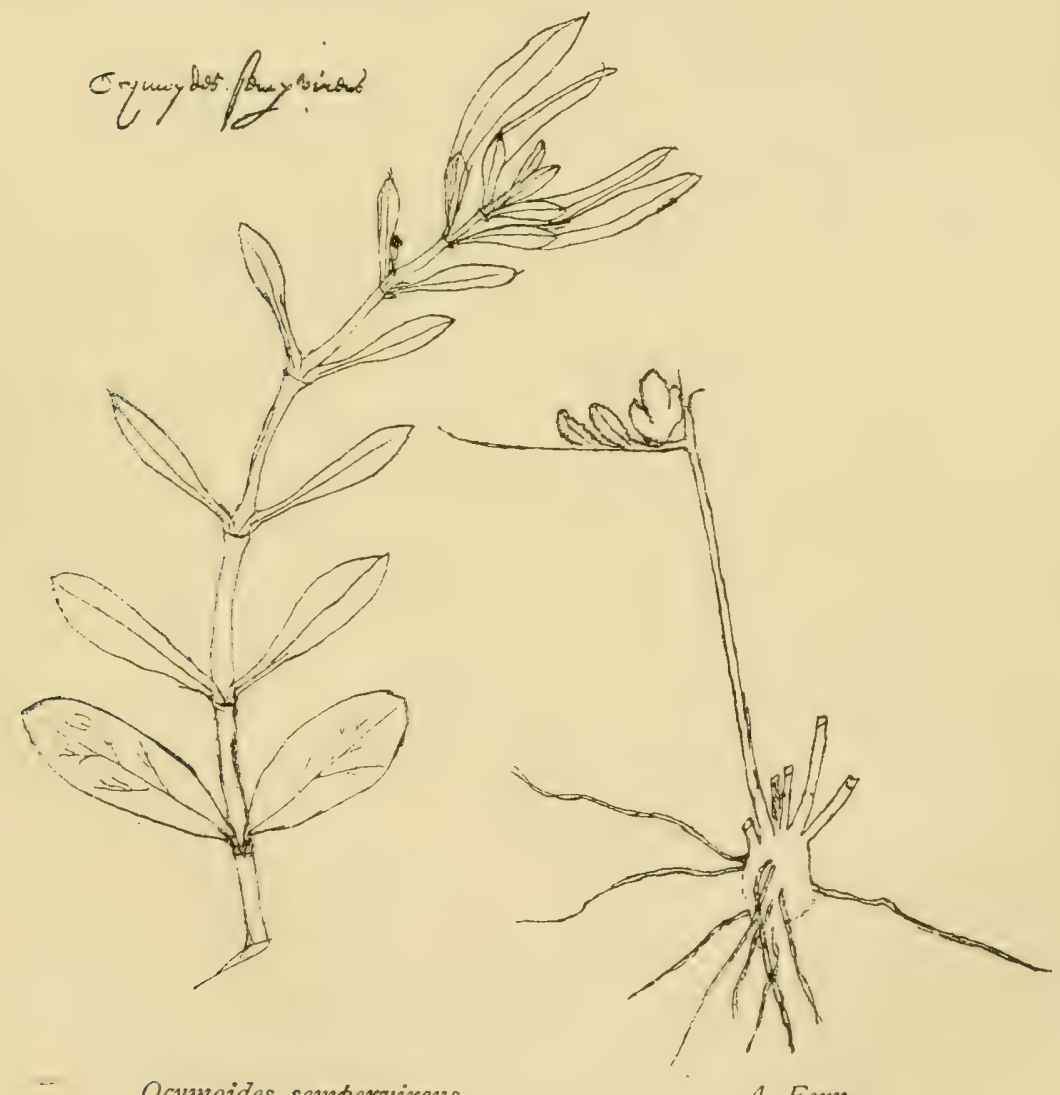

Ocymoides sempervirens

A Fern

DRAWINGS BY GOODYER 


\section{DESCRIPTIONS OF PLANTS BY JOHN GOODYER}

Tuese descriptions of plants are for the most part the earliest that are extant in the English language. They are now printed for the first time from Goodyer's original manuscripts, with others reprinted from passages contributed to the second or emaculate edition of Gerard's Herbal, printed in 1633 .

In the following Table the extent of Goodyer's botanical labours is indicated by differences in the type.

\section{Table of Names with Modern Equivalents, grouped in NATURAL ORDERS.}

Capital letters indicate plants of which descriptions are extant.

Small letters indicate plants of which no descriptions are extant.

Roman type indicates English plants.

Italic type indicates Foreign and Garden plants.

B, H, S, w, \&c., denote Record or First Mention for Britain or for the Counties of Hants, Sussex, or Wilts., \&.c.

Gardens are denoted by the names of their owners.

Goodyer frequently quotes more than one name of at plant: in such cases we hate only printed one for reasons of economy of space. Determinations for which I have had the advantage of the experience of Dr. Daydon Jackson, Mr. Britten, and Dr. Stapf are marked with J., B., and S. respectively.

Modem Name. $\quad$ Locality. Goodyer's Name. PAGE

Ranunculaceae.

Ranunculus Ficaria L.

" Flammula L.

Adonis autumnalis $\mathrm{L}$.

NIGELLA DAMASCENA L.

$" \quad H I S P A N I C A$ L. (prob.). Spain

Papaveraceae.

Pafiver hybridum L. (possibly).

Papaver Argemone, L.

Rhoeas, $\beta$ setigernm Boenn. (J.) Spain HŸPECOUM PROCUMBENS L. Coys

Fumariaceae.

Corydalis claviculata DC.
Chelidonium minus.

Ranunculus flammeus aquatilis angustifolius.

Adonis.

Nigella multiplex.

" elegans.

115

69

136

152

153

Argemone Pavio. 155

S Argemone capitulo longiore. $17 S$

Papaver Rhoeas Baeticum. $\quad 155$

Hypecoon Clusii.

129

Southsea If Fumaria claviculis donata. $\quad 47$ 
Cruciferae.

Modern Name.

Sisymbrium Alliaria Scop.

Irio L.

Nasturfium sylvestre R. Br.

Cardamine impatiens $\mathrm{L}$.

Dentaria bulbifera L.

SINAPIS ALBA L.?

Brassica Sinapistrum Boiss.

Draba sp.

IBERIS UMBELLATA L. (J.)

Bunias orientale L.

Violaceae.

Viola tricolor L.

Viola odorata L. fl. pl.

Frankeniaceae.

FRANKENIA LAEVIS L. " $"$

Caryophyllaceae.

Silene fruticosa L. (J.)

Lychnis dioica L.

" Githago Scop.

SAG̈INA NODOSA Meyer.

" APETALA L.

Stellaria aquatica Scop.

Portulaceae.

Montia fontana $\mathrm{L}$.

Hypericineae.

Hypericum Androsaemum L. St.Vincent's Rocks

Malvaceae.

Malva moschata L.

„ stipulacea Cav.? (J.)

Mapledurham

Linaceae.

LINUM CATHARTICUM L. Hants, Purfleet

Geraniaceae.

Geranium columbinum L. Hants, Whitechapel

" lucidum $\mathrm{L}$.

ERÖDIUM GRUINUM

Willd.? ( $\mathrm{J}$.)

Leguminosae.

ULEX EUROPAEUS L

" NANU'S Forst. (S.) (whitish fl. var.) (S.)

" parviflorus. (S.)

MEDICAGO MINIMA L.? (J.)

MEDICAGO POLYMORPHA L. Spain

Goodyer's Name.

PAGE Coys. Spain

Guildford

Provence

Whitechapel

Bath

Droxford

[Crete]

Whitechapel

Haylinge

Petersfield

Chichester

Bath

Hants

\section{H 'Alsine flosculis conniventibus'} Merrett. 'Blinks' Goodyer. 195

Androsaemum magnum. 77

H Alcea vulgaris albo flore.

Malva flore amplo Baetica aestiva.

II I

I 34

E Linum silvestre catharticum

$\mathrm{H}$ Milmountaine. I09, I 12

B 'Geranium columbinum' How. I9I

B 'Geranium saxatile' Park.708. I85 Geranium Baeticum sp. Boelii. 146

Ye great furze. $\quad 189$

Genista spinosa flore albo. $\quad 189$

Ye least furze (not Gen. sp. minor Park. 1003).

Genista spinosa major brevibus aculeis B.P. 394. $\quad 190$

Genista spinosa minor. $\quad$ I 89

Medica anglica minor. I4I

Medica major Baetica sp. I. spinulis intortis.
91

186

62

69

30 $\begin{array}{ll}\text { Eruca palustris minor. } & 192 \\ \text { Cardamine impatiens. } & \end{array}$

Rapistrum aliud non bulbosum. I9I John.' II I

Draba lutea sil. long.

Viola tricolor sylv.parva. How. I94 109

99 195 12 77 69 
Modern Nane.

MEDICAGO INTERTEXTA L. $M A R I N A$ L.

PISUM SATIVUM L.

MELILOTUS INDICA L.?

ASTRAGALUS HAMOSUS L.

Trifolium ligusticum Balb. ? (J.)

$$
\text { , Lagopus L. ? (J.) }
$$

HEDYSARUM HUMILE L.

Onobrychis sativa Lam.

Hippocrepis comosa L.

Langford, Wilts. w

Buttersworth Hill

St. Vincent's Rocks

ASTRAGALUS LUSITANI- Park. Spain

CUS Lam. (J.)

VICIA FABA L. var. (J.)

Coys. Spain

Vicia tetrasperma Moench.

Vicia sylvatica $L$.

VICIA SATIVA L. var.

LEUCOSPERMA Moench. ( $J_{\text {. }}$

VICIA SATIVA $\beta$ LINEARIS Coys. Spain Lange? (J.)

Vicia luter $\beta$ laevigata Boiss. (J.) Coys. [Portu-

Ervum Lens L.

PISU.M ARVENSE L.

LATHYRUS OCHRUS DC.

L. O'CHRUS DC.? (J.)

Park. Coys

gal]

Droxford

Park. Spain

LATHYRUS CLYMENUM L.?(J.)

LATHYRUS SPHAERICUS Retz? (J.)

LATHYRUS TUBEROSUS L.

Spain

$$
\text { " PALUSTRIS L. }
$$

Lathyrus sylvestris $L$.

LENS ESCULENTA Moench. ? (J.)

ORNITHOPUS SCORPIOIDES L.

SCORPIURUS SUBVILLOSA L. (J.)

SCORPIURUS VERMICULATA L.

laevigata L. (J.)

Cucurbitaceae.

CUCURBITA PEPO L. var.

CITRULLUS VULGARIS Schrad. (J.)

Rosaceae.

POTENTILLA COMARUM Nutt.

Potentilla Anserina $L$.

ALCHEMILLA ALPINA L. ?(J.)

Spiraea Filipendula L.

RUBUS CAESIUS L.

" Chamaemorus L.

Riosa cinnamomea L.

Rosa Eglanteria L.

St. Vincent's Jocks

? Ingleborough Droxford
Bath

Spain

Spain Bath

Goodyer's Name. PAGE

Medica major Baetica altera. 142 " marina spinosa sp. $\quad 142$

Pisum quadratum. $\quad 139$

Melilotus Indiae orientalis. $\quad 126$

Securidaca minor. I30

Lagopus trifolius maior Baeticus.

Lagopus trifolius flore ruberrimo.

Hedysarum clypeatum. 147

Caput Gallinaceum Belgarum 178

Ferrum equinum Germanicum. 187 cus Boelii. I 40

Faba veterum serratis foliis Boelii.

140

H Vicia sive Cracca minima. I93

'Vicia maxima sylvatica spicata 77 Bathoniensis Goodyeri.' I90, 196

Vicia indica fructu albo. $\quad 139$

Aracus maior Baeticus Boelii. I 38

Legumen pallidum Vlissiponense Nonii Brandonii. $\quad 139$

Lens minor. III

Pisum maculatum Boelii. $\quad 141$

Ervilia silvestris Dodonaei. I4I

Lathyrus aestivus flore luteo. $\quad$ 136

Lathyrus aestivus Bacticus ff. coeruleo Boelii.

Lathyrus aestivus flore miniato. 137

Lathyrus aestivus dumetorum Baet. Boelii.

Lathyrus palustris Lusitanicus Boelii.

Hants $H$ 'Lathyrus maior angustifol. $f$. pall. rubro ' Merrett.

Lathyrus aestivus Baeticus $f$. albo Boelii.

Scorpioides mathioli. $\quad$ I $3 \mathbf{I}$

Scorpioides multiflorus Boelii. 15I

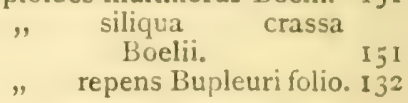

Macocks Virginiani. $\quad 165$

Melones Aquatici. $\quad 165$

Quinquefolium palustre. $\quad 170$

Heptaphyllon maius Phyto.65I 155

Filipendula vulgaris. $\quad 77$

Rubus repens fructu caesio. $\quad 114$

If Cloudberry. 195

Rosa cinamomea simpl. fl. $\quad$ II 2

'Rosa sylvestris oclora Eglanteria' How MS. 
Modern Name.

Locality.

Goodyer's Name.

PAGE

Rosa gallica L. ${ }^{1}$

Pyrus Aria L.

Rosa holoserica.

I 10

Onagrarieae.

Epilobium angustifolium L.

OENOOTHERÄ BIENNIS L.

LUDWIGIA PALUSTRIS

Elliot.

'Sandrish in Kent' $\mathrm{K}$ 'Aria Theophrasti' Merrett. 195

Crassulaceae.

Sedum rupestre L. var. minus.

"sp.

Winchester
New Forest
St. Vincent's
Rocks

Saxifrageae.

Chrysosplenium oppositifolium L. Mapledurham H Saxifraga aurea.

Parnassia palustris L.

Umbelliferae.

Eryngium maritimum L.

Trinia glauca O.K.

Cícuta virosa $L$.

w Lysimachia forte. II I

APIUM NODIFLORUM Reich.

Wellingborough N Gramen parnassi.

Chamaenerion Gesneri. · III

Lysimachia virginiana. $\quad 159$

Herba aquatica rubescens facie 187

Anagall. Holosteum. 193, 195

'Sedum Divi Vincentii nondescr.' Merrett.

77,195

Aizoon.

Tichfield Bay H Eryngium marinum.

Peucedanum pumilum.

110

Denham, Herts.

Petersfield

APIUM INUNDATUM Reich. b. f. (J.)

Apium crispum L.

Idsworth

Aegopodium Podagraria L.

Sison Amomum L.

B Sium alterum olusatri facie. $\quad 179$

B (Sium repens.

$\{$ 'Sium umbellis ad caulium

nodos' Merrett. 195

Sium pusillum foliis variis. $\quad 192$

Apium crispum. $\quad 172$

? $\mathrm{H}$ Podagria germanica. I IO

Sium odoratum Tragi. I2I

CARUM SEGETUM Benth.

SIUM LATIFOLIUM L.

SIUM ERECTUM Huds.

Bupleurum rotundifolium L.

OENANTHE LACHENALII Gmel. Soberton

," $\quad$ pilimpinelloides L.

Crithmum maritimum L.

Peucedanum sativum B. and $H$.

Caucalis arvensis Huds.

, nodosa Scop.

$$
\text { " LATIFOLIA L. (S.) }
$$

Daucus Carota L.

Smyrnium Olusatrum L.

Hurst Castle

B Sium siifoliis. Honewort. 53, I2 I

Oxford B Pastinaca aquatica latifolia. ${ }^{53}, 176$

Droxford B ," " minor. 116

Thorow-wax.

B Oenanthe angustifolia Lob. $\quad 115$

" apii folio. $\quad 35$

H Crithmum chrysanthemum G. 193

Petersfield B Caucalis pumila segetum Merrett.

B Caucalis nodosa echinato semini Bauhini.

Caucalis major Baetica.

Droxford H Siser erraticum Plinii.

Alexanders.

Radix cava minima viridi flore. 69

Adoxa Moschatellina L. Bunny-

kens Holworte.

Sambucus Ebulus L.

Rubiaceae.

RUBIA PEREGRINA L.

CRUCIANELLA sp.

Sherardia arvensis $\mathrm{L}$.

ASPERULA CYNANCHICA L.

Valerianeae.

VALERIANA CORNUCOPIAE L. " Locusta L.
Veny Sutton 126

Veny Sutton w Ebulus. III

Rubia sylvestris. I9I

,y spicata Cretica Clusii. $\quad 132$

Rubia minor flore rubro. 148

Hants B Synanchica. II3

Valeriana mexicana. $\quad \mathbf{I 3 3}$

Lactuca agnina. $\quad$ I 33

1 Probably. J. notes that the Moss Rose R. muscosi Ait. seems not to be catalogued before 1720 by Boerhave. 

Modern Name.
Locality.
Goodyer's Name.
PAGE

Dipsaceae.

Jasione montana L.

SCABIOSA ATROPURPUREA L.

, columbaria L.

Compositae.

Tussilago Farfara L.

ERIGERON ACRE L.

Jasonia tuberosa DC.

ANTHEMIS TINCTORIA L.

Anthemis Cotula L.

nobilis $\mathrm{L}$.

CHRYSANTHEMUM CORONA RIUM L.

CHRYSANTHEMUM CORONA. RIUM L.

CHRYSANTHEMUM CORONARIUM L.

Chrysanthemum segetum $\mathrm{L}$.

HELIANTHUS TUBEROSUS L.

Senecio Doria L.

SENECIO SARRACENICUS L. (S. J.) Coys. Senecio paludosus L. , Jacobaea L.

Downham Fen Ladle Hill $\mathrm{H}$

XERANTHEMUM ANNUUM L. (S.)

ACHILLEA NOBILIS L.

Achillea Millefolium L.

DIOTIS MARITIMA Cass.

Gnapialium margaritaceum L.

[Filago minima Pers. ${ }^{1}$

Xanthium Strumarium L. Southwick Petersfield

Arctium minus Bernh.?

, Lappa L.

Mangerfield, Glos.

NOTOBASIS SYRIACA Cass. Coys. Spain

\section{CNICUS PRATENSIS Will.}

CNICUS ERIOPHORUS Roth. CARDUUS ACAULIS L.

Carduus crispus L.

, nutans L.

Carlina vulgaris $\mathrm{L}$.

CARLIN.I LANATA L.

CENTAUREA SALMAN. $T I C A \mathrm{~L}$.

Centaurea Scabiosa L.

sonchus tingitanus L.?

LACTUCA VIROSA L. Hants: B Carduus acaulis septentrionaPurfleet lium L'Obelii. II8, I45

[Hants] H' Carduus viarum fl. purp. et alb. 112 Hants: Purfleet HE Carlina sylvestris. II Coys. [Naples] Acarna flore rubro.

Montp. Spain Stoebe Salmantica i Clusii foliis Cichorei. $\quad$ I54 Jacea albo fiore. " major. 165 Sonchus Africanus Boelii. $\quad 69$

Southampton H Lactuca silvestris vera ingrato odore. $\quad 111,158$

${ }^{1}$ Fillago minor is included in How's list, p. 280 . He may have obtained the locality, Petersfield, from Goodyer. 
Modern Name.

LACTUCA AGRESTIS L.

RHAGADIOLUS EDULIS

Gaertn. (J.)

TOLPIS BARBATA Gaertn. (J.)

Lange (J.)

UMBELLATA $\beta$ MINOR Spain

HIERACIUM INTYBACEUM L.? [Italy] LOID̈ES Vill. (J.) $A N D R Y A-\quad$ Coys. Spain

Hieracium murorum L.

Godalming

Pilosella L.

Taraxacum officinale Willd.

Cichorium Intybus L.

Lapsana communis $\mathrm{L}$.

LAPSANA ZACINTHA L.? [Italy: Florence] CENTAUREA NEVADENSIS Bois. Coys \& Reut.? (J).

Primulaceae.

ANDROSACE MAXIMA L. (J.)

Primula veris $\mathrm{L}$.

, vulgaris Huds.

Samolus Valerandi L.

Lysimachia nemorum $\mathrm{L}$.

Campanulaceae.

PHYTEUMA ORBICULARE L. (S.) Mapledurham

Campanula patula $\mathrm{L}$.

Droxford

CAMPANULA PUMILA L. var.?

RESEDA PHYTEUMA L. (J.)

Reseda Luteola L.

Ericaceae.

MONOTROPA HYPOPITYS L.

GENTIANA PNEUMONANTHE L.

Convolvulaceae.

Convolvulus Soldanella L.

CONVOLVULUS PURPUREUS L.

or some var. of it $(\mathrm{J}$.).

Emsworth

Sheet 
Modern Name.

Solanaceae.

Hyoscyamus niger $\mathrm{L}$.

NICOTIANA TABACUM L. var. BRASILIENSIS Comes. (S.)

NICOTIANA TABACUM L.

var. FRUTICOSA Hook, f. (S.)

Orobanchaceae.

\section{LATHRAEA SQUAMARIA L. .}

Orobanche Purpurea Jacq.?

Scrophulariaceae.

Verbascum nigrum L.

LINARIA MINOR Desf.

LINARIA THYMIFOLIA DC. ?(J.) Coys

\section{LINARIA CYMBALARIA Mill.}

\section{LINARIA SERPYLLIFOLIA}

Lange ? (J.)

Linaria Elatine Desf.

Scrophularia vernalis $L$.

Scrophularia nodosa $L$.

DIGITALIS FERRUGINEA L.

Veronica hybrida L.

St. Vincent's Rocks

BARTSIA ODONTITES Huds.

MELAMPYRUM "SYLVATICUM

Pedicularis sylvatica $\mathrm{L}$.

? CERINTHE MAJOR L.

CERINTHE MINOR L.

Warwickshire
[Prob. Spain]

Spain

" major L. var. flazio flore.

Labiatae.

SALVIA VERTICILLATA L.

Nepeta muda L

Origanum Majorana L.

OCIMUM BASILICUM L.

Nepeta Cataria L. var.? (J.)

NEPETA TUBEROSA L.

Lavandula officinalis $\mathrm{L}$.

STACHYS GERMANICA L.

\section{" Betonica Benth.}

Lamium Orvala L.

Coys. Droxford $\mathrm{H}$

Coys

Coys

Antirrhinum minus.

Antirrhinum minus flore Linariae luteo inscriptum.

Cymbalaria Italica.

Linaria minor aestiva.

I7. 163

Anblatum Dod.

Dentaria maior sive $a \phi v \lambda \lambda$ os Clus.

Orobanche.

Fluellin. Elatine

Common Scrophularia. $\quad 156$

Digitalis ferruginea. I86

B 'Veronica mas recta' Merrett. 76

Eufrasia altera Dodo. $\quad$ I 7

$\mathrm{H}$ Euphrasia 2 Dod. flo. albo. I 50

B Melampirum luteum latefolium. I 8

V ' Pedicularis fl.albo' How MS.

Cerinthe flore rubro. $\quad 128$ " minor flore albo veris luteis.

Yeallow flowered Cerinthe. $\quad 128$

Thymus Serpyllum L.

Galeopsis Tetrahit L. var, bifida.

Plantagineae.

Littorella lacustris L.

Plantago Psyllium L.

Plantago Coronopus L.
Coys

Droxford Yalden, Sheet Parkinson
Coys

Witney

Horminum silvestre iii Clusii. I56

Menthastrum montanum. II

Sweete Marjoram. $\quad \mathbf{I 6 6}$

Acinos [odoratissimum]. I66

Nepeta media. $\quad$ I62

Cattaria tuberosa radice Baetica Boelii non script. I6I

Lavender. 157

B Stachys (Buckner). 59

Stachys Wild Horehound. $\quad 177$

Betony. $\quad 120$

Lamium Pannonicum $2^{\text {ut }}$ exoticum Clusii. dum Goodyeri" How MS. Merrett.

If 'Cannabis spuria altera 195 purp.' How.

B 'Holosteum Junciifolium repens Goodyeri" How MS.

Psyllium.

Cornu cervinum Lobelii. 130,155
Coys 
Modern Name.

Locality.

Goodyer's Name.

PAGE

Illecebraceae.

Scleranthus annuus L. Knawel. (B.) Tichfield Bay H Polygonum germanis.

Chenopodiaceae.

SUAEDA FRUTICOSA Forsk. SALICORNIA HERBACEA L. EMEX SPINOSA Campd. (J.)

Rumex Acetosa L.

179

? Portland H Kali album, p. 8I, Dodo.

Blitum spinosum Creticum.

Acetosa maxima.

152

136

194

Santalaceae.

THESIUM HUMIFUSUM DC.

Urticaceae.

Urtica dioica $\mathrm{L}$.

Humulus Lupulus L.

Ulmaceae.

ULMUS CAMPESTRIS Sm.

, MONTANA Stokes.

" GLABRA Miller.

" MINOR Miller.

Amentaceae.

ALNUS GLUTINOSA Gaertn.

BETULA ALBA L.

Fagus sylvatica $L$.

"̈

Droxford B Anthyllis montana, Linaria adulterina.

Nettle.

Hop.

I 56

II 4

Ulmus vulg. folio lato scabro. 38 " folio latissimo scabro. 4I

Stubbers B " folio glabro. 43

New Forest B " minor f. angusto scabro. 39

Alder.

Unnamed.

175

Faringdon $H$ "Great antient Beeches. $\quad 189$

Fagus. $\quad 188$

Quercus. Cachryes and Galls. I72 " agg. Bramshaw, Wilts. w 'Quercus serotina, procerior.

Dor-Oak' Merrett.

Longwood

Nux Juglans.

195

Salix aquatica.

CASTANEA SATIVA Mill

Monocotyledons.

ACORUS CALAMUS L.

POTAMOGETON CRISPUS L.

Durford B Tribulus aquaticus minor floribus uvae.

Droxford B Tribulus aquaticus minor muscatellae floribus.

,

DENSUS L.

Butomus.

Alisma Plantago L.

Damasonium stellatum Pers. Hounslowe Heath Between Sandie Chappell

B Plantago aquatica stellata, IIO Plantago aquatica stellata. $\quad 180$

Neottia Nidus-avis Rich.

Epipactis palustris Crantz.

EPIPACTIS VIOLACEA Bor.

TAMUS COMMUNIS L.

Allium ursinum $\mathrm{L}$.

Colchicum autumnale $\mathrm{L}$.

Juncus bufonius L.

Paris quadrifolia.

SCIRPUS SYLVATICUS L.

Carex vulpina $L$. or C. Pseudo Cyperus ? (J.).

Carex pulicaris L.

Hordeum sylvaticum Huds.

Panicum sanguinale $\mathrm{L}$. and Kingston

Petersfield

Holiborne

Nidus avis.

127, 195

B Palma Christi, radice repente. 184

B Nidus avis flore et caule violaceo.

47,126

Hants $\mathrm{H}$ Bryonia nigra. $\quad$ I27, 153

Ramsons.

Warminster w Colchicum flo. albo et purpur. I10

Gramen holosteum Alp. min. 190

Chawton H Herba Paris. Ilo

Oxford B Cyperus gramineus Lobelii. $\quad 175$

'Gramen palustre Cyperoides Lob. Ger. Great Cyperus Grasse' How.

194

?o Flea-grass. Ray, Synopsis. 196

Petersfield B 'Gramen secalinum maximum' Merrett.

Petersfield 'Gramen paniceum procum196 bens' Merrett. 
Modern Name.

Locality.

CALAIIAGROSTIS EPIGEJOS Roth.

?(not Festuca Myurus L.) (S.)

Winchester

B Calamagrostis.

Goodyer's Name.

PAGE

ECHINOCHLOA CRUS-GALLI Petersfield L. (S.)

$\begin{array}{ccc}\text { PHALARIS CANARIËNSIS L. (S.) } & \begin{array}{l}\text { Sheet } \\ \text { Spain }\end{array} \\ \text { MINOR L. (S.) } & \text { Spain } \\ \text { BULBOSA L. (S.) } & \text { Spain }\end{array}$

Gramen murorum spica longis-

sima. 171,190

'Gramen Paniceum' Merrett. 195

Panicum sylvestre. 120

Phalaris minor Baetica Boelii, sem. nigro. 133

Phalaris minor Baetica Boelii, sem. albo. $\quad 133$

Phalaris bulbosa Boelii. I $\quad 133$

CYNOSURUSECHINATUS L. Coys. Sheppey
Nardus stricta L.

BRIZA MAXINA L.

Phragmites communis Trim.

Coniferae.

JUNIPERUS COMMUNIS L. $\sigma^{7}$

TAXUS BACCATA L.

"

Filices, etc.

Ophioglossum vulgatum L.

Botrychium Lunaria Sw.

POLYPODIUM DRYOPTERIS L.

ASPIDIUM ACULEATUM

Siv. var. $\beta$ LOBATUM.

DRYOPTERIS THELY-

PTERIS Sw.

ASPIDIUM FILIX-MAS Sw.

$" \quad$ var. AFFINIS

" DILATATUM Sm.

Asplenium Trichomanes L. Ruta-muraria L.

Scolopendrium vulgare L. var. multifida

Ceterach officinarum Willd.

Lycopodium clavatum $\mathrm{L}$.

Pilularia globulifera L.

Clathrus cancellatus L. (J.)
Coys. Spain

Spartum or Matweed. I7 I

Gramen tremulum maximum. I58

Arundo vallatoria. $\quad 176$

Surrey $\mathrm{S}$ Juniperus sterilis. I23, I95

Taxus glandifera baccifera. $\quad 168$ ,$\quad$ tantum florens. 169,196

Droxford H Lunaria minor.

Mapledurham H Filix mas non ramosa pinnulis latis auriculis spinosis. $\quad 183$

nr. Petersfield B) Dryopteris Penae et Lobelii. I 83

I 10 189 3.

,

Hants H Filix mas non ramosa pinnulis latis. I 82

Filix mas non ramosa pinnulis angustis.

Durford; B Filix ramosa pinnulis dentatis. I I I Mapledurham Wolmer Forest

? H Ruta muraria

Swaneling $\mathrm{H}$ Phyllitis multifida.

Petersfield $\begin{aligned} & \text { ? } \mathrm{H} \\ & \mathrm{H}\end{aligned}$ polyspermos' Nerrett. 196

Petersfield H Gramen piperinum' Merrett. I96 Petersfield H Fungus corallinus' Merrett. Ig6

The manuscript descriptions are wholly in Goodyer's handwriting: the colour of the ink show's that in several cases the whole of a paragraph was not written at the same time. The conclucling sentences, usually mentioning locility and date, were sometimes added later in a browner ink. Such sentences are indicated by the use of the mark $\|$.

These additions must have been made before 16,32 , when many of the descriptions were handed to Iohnson for his revision of the Herbal. The methodical Goodyer kept a list of descriptions thus lent to Johnson (MS. I I, 
f. I 34). In all more than two hundred and fifty plants are specially noticed in addition to some hundred which are casually mentioned in his descriptive writings. About a hundred and fifty of Goodyer's descriptions of plants are still extant: sixty were printed by Johnson, ninety are in manuscript. Johnson did not print all the descriptions sent him.

In cases in which both printed and manuscript versions are available, we have followed Goodyer's own manuscript in essential particulars, but have retained the spelling of the printed version, except of the word 'flower', in which case we have adopted Goodyer's spelling.

It may be noted that Goodyer's spelling of English words, though perhaps more uniform than that of many of his contemporaries, was apt to vary. On the whole he favoured such forms as color, devide, flower, yealowe, coople, apece, fower, toppe, ioynt, bignes, ymediatlie, ynch, and a final $e$ at the ends of present participles and other words.

The manuscript referred to is Goodyer MS. I I.

Woolly-headed Thistle. Cnicus eriophorus L. Carduus eriocephalus. Corona fratrum quorundam.

[See 29 June 1621 and 13 Aug. 162I.]

Linum silvestre catharticum. Mil-mountaine.

Oct. 1617

[See 2 July 1619.]

Jerusalem Artichoke. Helianthus tuberosus L. Heliotropium Indicum vel Virginianum.

25 March 1617

You had lately planted it when I was at your howse. 25 Martii I6I 7. - MS. ff. 48 v., 54 .

[Refers to a visit to Coys. See p. 24 and under I7 Oct. 1621.]

Cowslipps 2-in-a-hose.

Double violet. Viola odorata L., fl. plen. Viola martia purpurea multiplex.

9 Apr. I6I8

At Sheet.-MS. f. $5^{8} \mathrm{v}$.

Primula veris $\mathrm{L}$. var. and $P$. vulgaris Huds, var.

Primula veris flore gemino.

9 Apr. 1618

Cowslipps 2 in a hose at Sheet.

Primrose 2 in a hose at Sheet. $-M S$. f. $5^{6} \mathrm{v}$. 
A shweed. Agopodium Podagraria L.

Podagria germanica. Lo. 700 ; Herba Gerardi, 848 . I 1 Apr. 1618 Lungwort, good wife hewes.-MS. f. $5^{6} \mathrm{v}$.

Moonwort. Botrychium Lumaria Sw.

Lunaria minor.

2I Maij \& I Junii I618

I found it in Droxford in a wood by Strugnells in the Thetcher.-MS. f. 5.5.

Velvet Rose. Rosa gallica L.

Rosa holoserica. G. 1085 ; Lo. 0. 207.

$3^{\circ}$ Junii I 618

Ch: Edwards.-MS. f. 57 .

$\mathrm{Herb} \mathrm{Par}$ is. Paris quadrifolia $\mathrm{L}$.

Herba Paris. Lo. 267 ; G. 328 .

I0 Junii 1618

I save some with 5 leaves and some with 6 leaves at Chawton.HS. f. jt.

[This is the first notice for Hants, but the discovery of 5- and 6-leaved forms had been already made by Sir John Salusbury in North Wales in 1606.]

Sheep's bit Scabious. Fasione montana L.

Scabiosa minima hirsuta. G. 585 .

7 Julii I6I 8

At Sheete-MS. f. 57 v.

Greater Knapweed. Centanrea Scabiosa L.

Jacea albo flore. G. 589 .

I 8 Julii I6 8

At Chawlton.-MS. f. 54 v.

Sea Holly. Eryngium maritimum L.

Eryngium marinum. G. 999.

One plant at Tichfield Bay.-MS. f. 53 v.

20 Julii I6I 8

Knaw el. Scleranthus anmus L.

Polygonum germanis. Trag. p. 393 .

20 Julii 1618

In a barren ryc feild belowe Tichficld Bay \& is $y^{e}$ Parsley pert of Ger. p. $453 .-M S$. f. 56 v.

Water Plantain. Damasonium stellatum Pers.

Plantago aquatica stellata. Phitopinax 35.j; Lo. 301 ; Deles. I058. 30 Julii 1618

In Hounslowe Heath. $-M S$. f. 56 v.

[First record for Britain (see 2 July i633). In 1723 the Duke of Argyle took in a large part of the Heath and planted it with a large collection of trees and shrubs from the Northern Colonies.]

Autumn Crocus. Colchicum antummale L.

Colchicum flo. albo et purpureo.

21 Aug. I6IS

At Warminster in flo: 21 August I6 18.-MS. f. 59. 
? Willow - herb.

Lysimachia forte.

27 Augusti 1618

Wiltshere.-MS. f. 55 .

D a new ort. Sambucus Ebulus L.

Ebulus. Lo. o. I64; G. 1238 .

27 Augusti 16 I 8

At Venny Sutton in Wiltes : it is called Scotts blood.-MS. f. 53 .

['They call it Danes weede in Suffolk,' Bullein 1562.]

Brookweed. Samolus Valerandi L.

Anagallis aquatica tercia. Lo. $4^{6} 7$.

1618

By a mill at Emsworth.-MS. f. $5^{\mathrm{I}}$.

Willow-herb. Epilobium angustifolium L.

Chamaenerion Gesneri. Lo. 343 ; G. 386.

I618

It is called Willowe at Winchester.-MS. f. $5^{2} \mathrm{v}$.

White Mustard. Sinapis alba L.

Sinapi alterum sativum. Lo. ps. 2 : pag. 277.

1618

White pepper: Drox.-MS. f. 54 v.

Lactuca virosa $\mathrm{L}$.

Lactuca silvestris vera ingrato odore.

I61 8

[See 13 Sept. 1621.]

Musk Mallow. Malva moschata L.

Alcea vulgaris albo flore.

At Mapledurham.-MS. f. 5 I.

Malva verbenacea.

'Mr. Goodyer found the Vervain Mallow with white flowers growing plentifully in a close neere Maple-Durham in Hampshire, called Aldercrofts.'-Ger. emac. 93I.

[The first record for Hants.]

J ack-by-the-H edge. Sisymbrimm Alliaria Scop.

Alliaria recentiorum. Lo. 530 ; G. 560.

At Droxford. herbe John.-MS. f. 5 I.

[I6I 8$]$

Lentil. Ervum Lens L.

Lens minor. Lo. o. 74 ; G. 1049.

$[1618]$

Droxford-MS. f. 55 .

Nepeta mida L.

Menthastrum montanum.

Droxford in $y^{\theta}$ stone wall.-MS. f. $55 \mathrm{v}$.

Phyteuma orbiculare $\mathrm{L}$.

Rapunculum silvestre. Tragi, p. 726.

[16I8]

Droxford.-MS. f. 57 . 
Cinnamon Rose: Rosa cinnamomea L.

Rosa cinamonea simplici flore. G. Io86.

Droxford.-MS. f. 57 .

Wild Carrot. Dancus Carota L.

Siser erraticum Plinii.

Droxford.-MS. f. $57 \mathrm{v}$.

Black Mullein. Verbascum nigm L.

Blattaria flo. luteo. G. 633 ; Lo. 565 .

I found this wild.-MS. f. $47 \mathrm{v}$.

Musk Thistle. Cardunsmins L.

Carduus viarum flo. purpureo. G. 10II.) viarum flo. albo. G. IOII. ,

We have a kind here that smells like muske.-MS. f. $47 \mathrm{v}$.

Carlina vulgaris L.

Carlina sylvestris. Lo. I4; G. 997 ; Math. 497.

Clusius, p. clvi, hath ye figure of Carduns vulgatiss. viamum, Lo. o. 20, for Carlina sylvestris. || It growes on our Chalke Downes \& also at Purflet.-MS. ff. 47 v., 52.

[See 8 July 1620.$]$

Dodder. Cuscuta Epithymum L.

Cuscuta. Lo. 427 ; G. 462 .

I have seene it on furse, heath, nettles.--MS. f. 48 .

$[1617-18]$

$" \quad " \quad$ on furse, heath, nettles, fatches.-MS. f. 53 .

Wa $1 \mathrm{nut}$. Fuglans regia $\mathrm{L}$.

Nux Juglans. Lo. o. 108 ; G. I252.

Forked at $y^{e}$ toppe: at Longwood. Ex relat. Daniel Waite.MS. f. 55 v.

[Longwood, in the parish of Owslebury, was in the possession of Richard Garth, who died seised of it in I 597.]

Corn Cockle. Lychnis Githago Scop.

Pseudomelanthium. G. 926 ; Lo. 38 .

Crappe. In Sussex about Cheichester.-MS. f. $5^{6}$ v.

[The name Crap was formerly given to various weeds growing among corn. Withering applied it to Rye Grass and Buckwheat.]

Purging Flax. Limm catharticum L.

Linum silvestre catharticum. Mil-mountaine.

2 July I6I 9

It riseth up from a small white threddy crooked root, sometime with one, but most commonly with five or six or more round stalks, about a foot or nine inches high, of a browne or reddish color, 
every stalk dividing it selfe neere the top, or from the middle upward into many parts or branches of a greener colour than the lower part of the stalke: the leaves are small, smooth, of colour green, of the bignes of Lentill leaves, and have in the middle one rib or sinew, and no more that may bee perceived, \& grow alongst the stalke in very good order by couples, one opposite against the other: at the tops of the small branches grow the flowers, of a white colour, consisting of five small leaves apiece, the nailes whereof are yellow: in the inside are placed small short chives also of a ycllow colour, after which come up little knobs or buttons, the top whereof when the seede is ripe divideth it selfe into five parts; wherein is contained small, smooth, flat, slippery, yellow seed: when the seed is ripe the herbe perisheth: the whole herbe is of a bitter taste, and herby smell. It groweth plentifully in the unmanured inclosures of Hampshire, on chalkie downs, \& on Purfleet hils in Essex, and in many other places. It riseth forth of the ground at the beginning of the Spring, and flowereth all the sommer.-Ger. emac. 559 .

[For the rest of Goodyer's description see p. 21.]

Squinancy wort. Asperula Cynanchica L. Synanchica.

3 Aug. 1619

This herbe groweth in $y^{\theta}$ inclosures of Hampshire in drie Chalkie grounds. The root is crooked, blackish without, yellow underneath the skinne, white within that and wooddie; about five or six inches long, with many hairy strings: from the root arise many foure-square branches trailing upon the ground, sometimes reddish towards the root: the leaves are small and sharpe pointed, like [those of] Gallium, and grow along the stalke, on certaine knees or ioints, foure or 5 together, sometimes fewer: from those knees the stalk divideth it selfe towards the toppe into many parts, whereon grow many flowers, each flower having foure leaves, sometimes white, sometimes of a flesh colour, and every leafe of these flesh coloured leaves is artificially straked in the middle, and neere the sides with three lines of a deeper red, of no pleasant smell: after which commeth the seed something round, growing two together like stones. It flowereth all the sommer.-MS. f. 81 ; Ger. emac. II 20.

[In the printed version the date is given as 13 August, and either Goodyer or his editor has added an account of the Vertue. 'It dries without biting, and it is excellent against squinancies, either taken inwardly or applied outwardly, for which cause they have called it Synanchica, Hist. Lugd.'] 
Water Parsnip. Apium nodiflorum Reichb. f. and Caucalis nodosa Scop.

Sium repens.

27 Aug. I6I9

Hath longe plaine and smoothe leaves, made and fashioned like the leaves of the Ash havinge comonlie 4 or 5 small leaves growinge on ech side of the midle ribbe directlie one against another, snipt about the edges, amongst which come forth a round chamfered or furrowed hollowe stalk, of the bignes of a thumbe, browne or reddish neare the root, 4 or 5 foot longe, devided at the ioyntes or knees into many $\mathrm{p}[\mathrm{ar}] \mathrm{tes}$ or braunches ymediatlie from the root even to the toppe whereon growe the leaves without order like the former but shorter, nowe and then of a browne colour both above and underneath, of a stronge smell as is the whole plant, the flowers are white and many in number consisting of 5 sharpe pointed leaves apeece, growinge at the ioynts or devidinge of the stalkes, on short stems umbell fashion, after the manner of Caucalis nodosa cchinato semine Bauhini. The stalks creape or run on the water, river or diches bankes, and hamper or matt them selves fast together, (contraric to both those before mentioned, which growe upright and beare their flowers and seed at the topps of their stalks and branches). The flowers past, there appeareth the seed, two ioyned together at the first greene when it is ripe of a browne colour like to parsley seed, of a stronge tast but not plesant. The root is compacted of white threddic stringes infinite in number for the most parte as small as haires growinge or crecpinge at the bottome of the water within the mire or marish ground, wherby it infinitely increaseth. The leaves of this plant growe greene in or above the water all the yere winter and somer. This groweth plentifullic by the lakes and rivers sides at Droxford in Hampshire.-MS. f. 82 .

Dewberry. Rubus caesius L.

Rubus repens fructu cacsio.

6 Sept. 1619

This hath a round stalke set full of small crooked and very sharpe pricking thornes, and creepeth on hedres and low bushes of a great length, on the upper side of a light red colour, and underncath grecne, and taketh root with the tops of the trailing branches. whereby it doth mightily encrease: the leaves grow without order, composed of three leaves, and sometimes of five, or else the two lower leaves are divided into two parts, as Hop leaves are now and then, of a light greene colour both above and underneath. The flowers grow on the tops of the branches, raccmatim, many together, sometimes white, sometimes of a very light purple colour. 
every flower containing five leaves, which are crompled or wrinkled, and do not grow plaine: the fruit followes, first green, and afterwards blew, everie berry composed of one or two graines, seldome obove foure or five growing together, about the bignesse of corans; wherein is contained a stony hard kernell or seed, and a iuyce of the colour of Claret wine, contrarie to the common Rubus or Bramble, whose leaves are white underneath: the berries being ripe are of a shining blacke colour, and every berry containes usually above forty graines closely compacted and thrust together. The root is wooddy and lasting. This growes common enough in most places, and too common in ploughed fields.-Ger. emac. I 27 I-2.

Lesser Celandine. Ramunculus Ficaria L. Chelidonium minus, Lo. 593, Ger. 669.

Io March 1620

Inc. fl. [flowers open] to Marcii I620.-MS. f. $5^{2} \mathrm{v}$.

Dandelion. Taraxacum officinale Willd.

Dens leonis vulgi, Lo. 232, Ger. 228. Io March 1620

Inc. fl. [flowers open] to Marcii I620.-MS. f. 53 .

Marsh Parsley Dropwort. Oenanthe Lachenalii Gmel.

Oenanthe angustifolia Lob. Obs. p. 420.

[Identified by Druce as the first British Record.]

I9 May 1620

This I9 of May 1620 I found this wild in East Hoo in ye parish of Subberton about 7 miles from Petersfield in Hampshire in a hedgerowe about a flightshott from ye then dwelling house of Mr. William Browne on ye south part of ye said house and ye I 8 of June I620 I saw it there in flower.-G. quoted by How in MS. note to Phytologia, p. 81.

[Merrett, Pinax, p. 84, gives the locality as East How. Druce gives the date as 28 June, but the figure is more like I8.]

L ung wort. Pulmonaria angustifolia L. Pulmonaria foliis Echii.

Found, May 25 Anno 1620 flowering in a Wood by Holbury House in the New Forest in Hampshire.-Ger. emac. 809.

Linaria minor Desf.

Antirrhinum minus.

20 Junii 1620

The stalks are small, round, hairy \& branched, about 4 or 5 ynches high, ye leaves are small, smooth, blunt topped \& like to Hissope leaves, $y^{0}$ flowers are small fashioned like ye greate Antirrhinum, ye upper leaves whereof are of an ill favored purple color, \& ye under leaves somewhat whitish, havinge a very little 
taile like to larkes spur, ye seed followeth contayned in a husk which is somethinge longe. The root is small whitish \& threddy.MS. f. 83 .

Sinm evectum Huds.

Pastinaca aquatica minor. Sium odoratum Tragi. 2 Julij 1620 figura in hist. lug: p. 7or. A pium palustre Fuchsii.

The leaves and footstalkes that growe in the water by them selves distant from the stalk are about 2 foot longe, reddish, spongie, smooth, on the upper parte whereof on ech side of the midle ribbe groweth nine or ten broad short smooth sharpe pointed leaves and opposite against another, fast to the midle ribbe without any footstalk notched about the edges, and one alone at the toppe of the footstalk, which leaves are of a browne colour; amongest which cometh uppe a small round hollowe ioynted stalk about 3 foot high, no bigger then a parsley stalk, reddish towards the root, finely straked, not deeply champfered, devided into many partes towards the toppe, on ech ioynt groweth one leafe more notched and devided then the former, and those towards the toppe of the stalk have fewer leaves growinge on the sides of the midle ribbe then the lower, and of a lighter greene. The flowers growe on the topps of the braunches in umbells, of colour white, everie flower havinge five very small leaves devided into two pts at the toppe, the flowers past the seed followeth, $\mathrm{w}^{\text {ch }}$ is small very like to parsley seed. The root is verie full of white hairy threddes, and putteth forth by the sides newe springes or shootes whereby it encreaseth. The whole herbe doth yeld a stronge savor, like to Petrolium. This groweth plentifullie in the River by Droxford in Hampshire.-MS. f. 82 v.

Phyteuna orbiculare L.

Rapunculum silvestre Trago. p. 726. Phyto. I37 (4).

$5^{\text {to }}$ Julij \& 27 Augusti 1620

This hath 6 or 7 leaves with footstalks square abroad uppon the ground, in forme like those of ye wild March violett, but much smaller, fincly indented about ye edges, amongst which riseth uppe a small, round straked stalk, not so bigg as a strawe, sometimes of a browne color, seldome a foot high whereon growe very small, narrowe, sharpe pointed leaves, without fontstalks at ye toppe of ye stalk groweth one blewe flower tendinge to purple, almost round and sometimes somewhat longe, like those of ye comon Trefoile, composed of abundance of small crooked flowers, ech crooked flower beinge devided into two parts at ye toppe. After which follow 
[ ] seeds contayned in small husks. Ye root is white growinge deepe into ye ground, nine or ten ynches longe whereof 2 or 3 ynches of ye upp part is very small, and sometimes devided into more hedds than one. Ye midle part is Rampion-like, as bigge as a goose quill, the whole herbe \& root beinge broken or cut doth yeld a white iuyce like milke.-MS. f. 84 .

[Dr. Stapf points out that $P$. spicatum with which this plant has been identified has white flowers.]

Bartsia odontites Huds.

Eufrasia altera Dodo.

$5^{\text {to }}$ Julij \& 22 Augusti 1620

This sendeth forth from a small threddie, hard, crooked root, one 4 square, upright hard rough stalk, about 9 ynches or a foot high, devided into many branches, which are sett one opposite against another, ye leaves are small, rough, sharpe pointed, indented about ye edges, comonly hanginge or bowinge downewards, growinge by cooples, also one opposite against another, ye flowers are many hooded and growe but one side of ye branches and stalks, of a reddish color, with yealowish cheives in ye midle, after which cometh a small round seed vessell, neare as bigge as a wheate corne, wherein is contayned [ends abruptly]. $-M S$. f. 84 .

\section{Bastard Toadflax. Thesium humifusum DC.}

Anthyllis montana. hist. lug. p. II 50. Phyto: 403. I5. an Anonymos Clus: p. 324. $\quad 5$ Julij I620 et citius et 27 Augusti I620

[First record for Britain of the only species of the Sandalwood family known in Britain.]

This hath many very small round, cornered branches sometimes I 7 or 18 from one root, which are devided into branches, growinge close uppon ye ground, sometimes 7 or 8 ynches longe, whereon growe very small narrowe, thick leaves out of order, one after, not one against another, of $\mathrm{a}^{1}$ or yealowish greene color, as are also ye branches, of a salt tast, neare ye topps of ye branches on short footstalks growe leaves smaller then ye other, 3 allwaies together whereof one is longer then ye other two, in ye midst of these 3 leaves groweth one small white flower, havinge 5 sharpe pointed leaves, spreadinge wide open starr fashion, in ye midle whereof groweth 7 small short cheives, with pale yealowe topps, after cometh one small long round harde husk, contayninge a seed which is white within. The root is small white, crooked, short, devided into branches \& threddie and is perennis. $-M S$. f. $8_{4}$.

\footnotetext{
${ }^{1}$ The word 'pale' is struck out here, and the ivord substituted looks like
} 'nervie'. 
Linaria adulterina.

n. d.

Johnson states that 'Mr. Goodyer found it growing wilde on the side of a chalkie hill in an inclosure on the right hand of the way, as you goe from Droxford to Poppic Hill in Hampshire'.-Ger. emac. 555 .

\section{Dwa $\mathrm{rf}$ Thist lc. Carduns acaulis $\mathrm{L}$.}

Carduus acaulis septentrionalium L'obelii. $\quad 8^{\circ} \mathrm{Julij} \& 5$ Sept. 1620 Ger. non habet.

It hath many greene short narrowe leaves, somewhat hairie, spread abroad uppon the ground, seldome above six ynches longe, parted or gashed even to the midle ribbe, sett with sharpe prickles: amongst which groweth onc (sometimes more) scaly head without prickles, with a thrum of purple flowers which are nothinge but small cheives, and after turne into downe, contayninge gray seed within : theis hedds growe close to the ground comonly without any stalk, yet sometimes havinge a small smooth footstalk 3 or 4 ynches longe. The root is small crooked scragged, with many out growinge branches, reddish in the midle, and of longe continewance. $\|$ It groweth wild on the Chalkie downes of Hampsheire plentifullie; and also at Purflett in Essex.-MS. f. 105.

[See I6r8.]

Common Cow weat. Melampyrum sylvaticum L. Melampirum luteum latifolium. Phyto. 444 (3). Pin. 234 (a. 4). Crategonon, Lob. icon. p. $3^{6}$. Parietaria silvestris, 2 Clus. p. xliiij. Ger. p. 84 (2).

22 Julij \& 22 Augusti 1620

It hath a stalk about a cubit high, round close by ye root 4 square above, spreading it selfe abroad, often of a browne redd color on ye upper side, ioynted, devided ymediatly from ye root into branches, alwaies one branch growinge right against another, under which branches growe ye leaves, also onc opposite against another, ye brodest and lowest are about 3 ynches longe, \& one ynch broad, smooth nothinge at all notched by the sides, of a darke grecne color, of an unpleasant an harsh tast, yc flowers growe neare ye toppes of ye branches, amongst smaller iagged leaves, and opposite against another, yet ye topps hang downwards \& ioyne neare together of a yealowe color, which when they begin to wither are whitish, ye mouth not withstanding remayninge yealowe, after which followeth broad, flatt, sharpe pointed seed ressells, wherein is contayned 2 or 3 seeds like wheate cornes.

The root is small, whitish and threedic, and dieth at winter.$M S$. f. $83 \mathrm{v}$. 
Xeranthemum annum L.

Ptarmica imperati.

Ptarmica Austriaca species Clusii.

26 Julii 1620

This riseth uppe with a small hard tough cornered whitish woolly stalk, devided into many branches, and those againe devided into other branches like those of Cyamus about two foot high, whereon grow long narrow whitish cottonie leaves out of order, of a bitter taste, whiter below than above, of the colour of the leaves of Wormwood, having but one rib or sinew \& that in the midle of the leafe, and commonly turne downewards: on the top of each slender branch groweth one small scalie head or knap, like that of Cyanus, which bringeth forth a pale purple flower without smell, containing sixe, seven, eight, or more, small hard drie sharp pointed leaves: in the midle whereof groweth many stiffe chives, their tops being of the colour of the flowers; these flowers fall not away till the whole hearbe perisheth, but change into a rustie colour: amongst those chives grow long flat blackish seed, with a little beard at the toppe. The root is small, whitish, hard and threddie, and perisheth when the seed is ripe, and soone springeth up by the fallinge of the seed, and remaineth greene all the Winter, and at the Spring sendeth foorth a stalke as aforesaid. The herbe touched or rubbed sendeth forth a pleasant aromaticall smell.MS. f. 92 ; Ger. emac. 606-7.

\section{Senecio sarracenicus L.}

Herba Doria altera.

26 July 1620

This herbe groweth uppe with a greene round brittle stalke, very much champhered, sinewed, or furrowed; about 4 or 5 foot high, full of white pith like that of Elder, and sendeth for th small branches: the leaves growe on the stalk out of order, \& are smooth, sharpe pointed, in shape resembling those of Herba Doria, but much shorter and narrower, the broadest and longest seldome being above Io or II inches long, and scarce 2 inches broad, and are more finely and smally nickt or indented about the edges; their smell being nothing pleasant, but rather when together with the stalke they are broken and rubbed yeeld forth a smell having a small touch of the smell of Hemlocke. Out of the bosomes of these leaves spring other smaller leaves or branches. The flowers are many, and grow on small branches at the tops of the stalkes like those of Herba Doria, but more like those of Iacobcea, of a yealow colour, as well the middle button, as the small leaves that stand round about, every flower having commonly 8 of those small leaves. Which being past the button turneth into downe and 
containeth a very small long seed which flieth away with the winde. The root is nothing else but an infinite of small strings which most hurtfullic spread in the ground, and by their infinite increasinge destroyeth and starveth other herbes that grow neare it. Its naturall place of growing. I know not, $\|$ for I had it from $\mathrm{M}^{\mathrm{r}}$. Iolm Coys, and yet kecp it growing in my garden.-MTS. ff. 83, 92 ; Ger. emac. 43 r.

[The sentence after the $\|$ is written in a hand that I believe to be that of the editor, Thomas Johnson.]

Fasonia tuberosa DC.

Aster conyzoides Gesneri.

[Goodyer's note in Latin on this plant (MS. f. $83 \mathrm{v}$.) is copied from Lobel, Observationes, (I 576) p. I8g.]

Echinochloa Crus-galli Beauv.

Panicum sylvestre. Sheet.

Io Augusti 1620

Hath very many ioynted stalks, 2 foot high or higher, whereot some growe upright, and some growe sidelonge \& leane towards ye earth, the leaves are longe \& smooth not hairie. On ye toppe of ye stalks growe spikes or eares, sometimes single but comonly devided into many parts, lesser shorter \& thinner than those of Panick, everie one whereof is composed of small short sharpe pointed husks, of a browne redd color sometimes of a greenish color, not [words illegible] ye stem on rib whereon they growe, but growinge on ye outer side thereof; wherein is a whitish seed, somewhat hard, lesse then those of Panick. The root is nothinge els but white strings.-MS. f. $83 \mathrm{v}$.

\section{Basil. Ocimum Basilicum L.}

Acinos [odoratissimum]. I2 Augusti I620 \& longe before. Phyto: 427 (4). Ger. 548.2. Math. 595 (i).

It hath manie fower square hairie stalks proceedinge from the root, sometimes two foot longe or longer, parted into a fewe branches, the leaves growe on the ioynts, in wide distances by cooples one opposite against another, in forme like those of wild Margerom but smaller and are hairie, rough, lightlic snipt or indented about the edges: the flowers are purple \& resemble those of Betonic, but of a lighter purple colour and growe forth of rough round whorles or crownetts close above the leaves, and one allwaies at the toppe of the stalk and branches, in forme like those of Horchound. The flowers past the secd followeth inclosed in those whorles. The root is small threedic \& lastinge.-MS. ff. 83 v., 84 .

[This description differs essentially from that printed in Gerard. Sec II Oct. 1621.] 
Corn Parsley. Carum segetum, Benth. Sium siifoliis. Hone-wort.

I 8 August 1620

\section{The Description.}

This herbe commeth up at the first from seed like Parsley, with two small long narrow leaves, the next that spring are two small round smooth leaves nickt about the edges, and so for two or three couples of leaves of the next growth there are such round leaves growing on a middle rib by couples, and one round one, also at the top; after as more leaves spring up, so the fashion of them also change, that is to say, every leafe hath about eight or nine small smooth greene leaves, growing on each side of a middle rib one opposite against another, and one growing by it selfe at the top, and are finely snipt or indented about the edges, in forme resembling those of Sium odoratum Tragi, but not so bigge, long, or at all brownish; amongst which rise up many small round straked stalkes or branches, about two foot long, now and then above twenty from one root, sometimes growing upright, sometimes creeping not farre from the ground, joynted or kneed, and dividing themselves into very many branches, at every joynt groweth one leafe smaller than the former, which together with the lowermost perish, so that there is seldome one greene leafe to be seen on this herbe when the seed is ripe; the flowers are white, and grow most commonly at the tops of the branches, sometimes at most of the joynts even from the earth, in uneven or unorderly umbells, every flower having five exzeeding small leaves, flat, and broad at the toppe, and in the middle very small cheives with purple tops, the whole flower not much exceeding the bignesse of a small pins head, which being past there commeth up in the place of every flower two small gray crooked straked seeds, like Parsley seeds, but bigger, in taste hot and aromaticall. The root is small and whitish, with many threds not so big as Parsley roots. It beginneth to flower about the beginning of Iuly, \& so continues flowering a long time; part of the seed is ripe in August, and some scarce in the beginning of October, mean while some falleth wherby it renueth it selfe, and groweth with flourishing greene leaves all the winter.

I tooke the description of this herbe the yeere 1620 , but observed it long before, not knowing any name for it: first I refered it to Sium, calling it, Sium terrestre, and Sium segetum \& agromum; afterwards upon sight of Selimum peregrinum primun Clusii, which in some respects resembleth this herbe, I named it 
Sclinum Sij folijs; yet wanting an English name, at length about the yeere I625 I saw Mistris Visula Leigh (then servant to Mistris Bilson of Mapledurham in Hampshire, and now (5 Marcij I6 32 wife to Master IVilliam Mooring Schoolemaster of Petersfield, a Towne neerc the said Mapledurham) gather it in the wheate ershes about Mapledurham aforesaid (where in such like grounds it still groweth, especially in clay grounds) who told me it was called Honewort.-Ger. emac. 1017-18.

[The remainder of the description has been printed on p. 53.]

Yell ow Bird's-nest. Monotropa Hypopithys L. Orobanche verbasculi odore, MS. Good:

22 August I620

This riseth up with a soft round very brittle stalk, seldome 8 ynches high, sett with thinn small short scaly leaves likc skynns growing close to the stalk, at or very near ye top of ye stalk groweth one sometimes 4 or 5 small flowers in fashion like ye flowers of Hyosciamus huteus or of ye Cowslip every flower consisting of 4 , but most commonly of 5 leaves, growing all of one height, evenly \& of one proportion, \& nothing like those of Orobanche. In ye middle of every flower groweth a small round umbo, no further out but just even with ye leaves, broad at ye top, with a small hoale in the middle, and ye lower end of which groweth at ye bottome of ye flower round, as bigge as a pease, so that it rescmbleth $y^{\ominus}$ suckbottle which children use to suck their drinke out of, having small chcives growing round about it with purplish tops. The root is obtuse, not usually so bigge as ye stalk, with very few threeds growing to it, \& groweth at ye very upper face of ye earth. The whole herbe, flowers stalks \& leaves are at thcir first flowring of a whitish yealowe, or strawe colour, and being broken or brused smelleth like to ye roote of a Primrose. This I found in a hedgerowe in a ground belonging to Droxford farme, neare ye foot path that leadeth from Droxford to Waltham, and took this Description ye 22 of August 1620.

[This copy of a lost note of G.'s is written on the back of f. 249 of Bannister's Herbarium Siccum, (Herb. Sloane) in the Botanical Department of the British Museum, to which my attention was drawn by Mr. J. Britten.

A similar description evidently derived from this same description and an engraving of the plant are given by Plot, Nat. Hist. of Oxfordshire, 1677 , p. 146, who was the first to find this plant in Oxfordshire. Plot gives the number of flowers as 'eight or ten': he adds that 'It grows at the bottoms of Trees in the woods near Stoken-Church, and we find it mention'd in some MS, notes of the famous Mr. Goodyer'.] 
Toothwort. Lathraea squamaria $\mathrm{L}$.

Anblatum Dod. in fol. p. 553 ; Math. 689 (9).

I5 Apr. I62 I

Dentaria maior sine $\alpha \dot{\phi} v \lambda \lambda$ os Clus: p. cxx.

From the root riseth uppe 2 or 3 sometimes more slender brickle stalks, hairy \& full of iuyce, like those of Orobanche, 6 or 7 ynches longe, garnished with many flowers thick sett together not much unlike those of Satyrion or Orobanche, which doe all bend or looke that way which the stalk bendeth or leaneth. On ye back side growe 2 rowes of leaves, or rather small whitish skinne-like scales, and also amongst ye flowers there growe the like leaves: the flowers past there come small hedds wherein is contayned very small seed the stalk soone perisheth, and leaveth the root in $y^{\mathrm{e}}$ ground which is composed of whitish scales like teeth. The stalks and flowers when they growe in darke shadowic woods, are of a purplish color, but when they growe where the sunne cometh on them, they have no purple at all.

The scales on the root are not sharpe pointed as Clusius, Lobel \& Dodo: pictureth them, but round topped, as Math: hath best of all by his figure expressed them.-MS. f. 87 .

[This note is written on the back of an uncompleted order to the Overseers of the Poor, dated Southwick 1621.] Cachryes.

[See under 9 May 1622.]

28 Apr. I62I

J uniper. Funiperus communis L.o7

Iuniperus sterilis.

I5 Maii 162 I

This shrub is in the manner of growing altogether like the Iuniper tree that beareth berries, only the upper part of the leaves of the youngest and tenderest bowes and branches are of a more reddish greene colour: the flowers grow forth of the bosoms of the leaves, of a yellowish colour, which never exceed three in one row, the number also of each row of leaves: each flower is like to a small bud, more long than round, never growing to the length of a quarter of an inch, being nothing else but very small short crudely chives, very thicke and close thrust together, fastened to a very small middle stem, in the end turning into small dust, which flieth away with the winde, not much unlike that of Taxus sterilis: on this shrub is never found any fruit.-Ger. emac. I629.

\section{Curly Pondweed. Potamogeton crispus L.} Tribulus aquaticus minor, quercus floribus [uvae]. 2. Junii I 62 I

This water herbe bringeth forth from the root, thin, flat, knottie stalkes, of a reddish colour, two or three cubits long, or longer, according to the depth of the water (which when they are drie, are 
pliant and bowing) devided towards the top into many parts or branches, bearing but one leafe at every ioynt, sometimes two ynches long, and halfe an ynch broad, thin, and as it were shining, so wrinckled and crompled by the sides that it seemeth to be

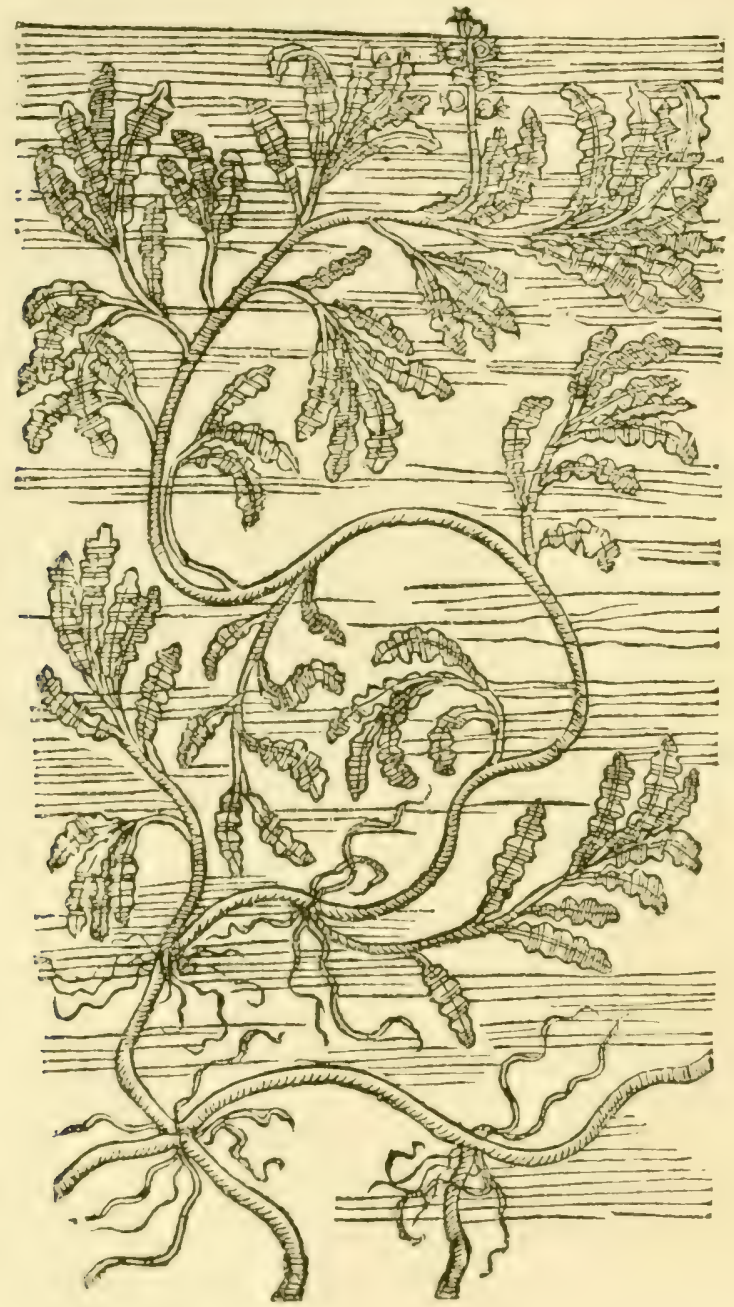

POTAMOGETON CRISPUS.

torne, of a reddish greene colour: the foot-stalkes are something long and thicke, and rise up from amongst those leaves, which alwaies grow two one opposite against another, in a contrarie manner to those that grow below on the stalk: neare the top of which foot-stalke groweth small grape-like huskes, out of which spring 
very small reddish flowers, like those of the Oke, every flower having foure very small round topped leaves. After every flower commeth commonly foure sharpe pointed graines growing together, containing within them a little white kernell. The lower part of the stalke hath at every ioint small white threddie roots, somewhat

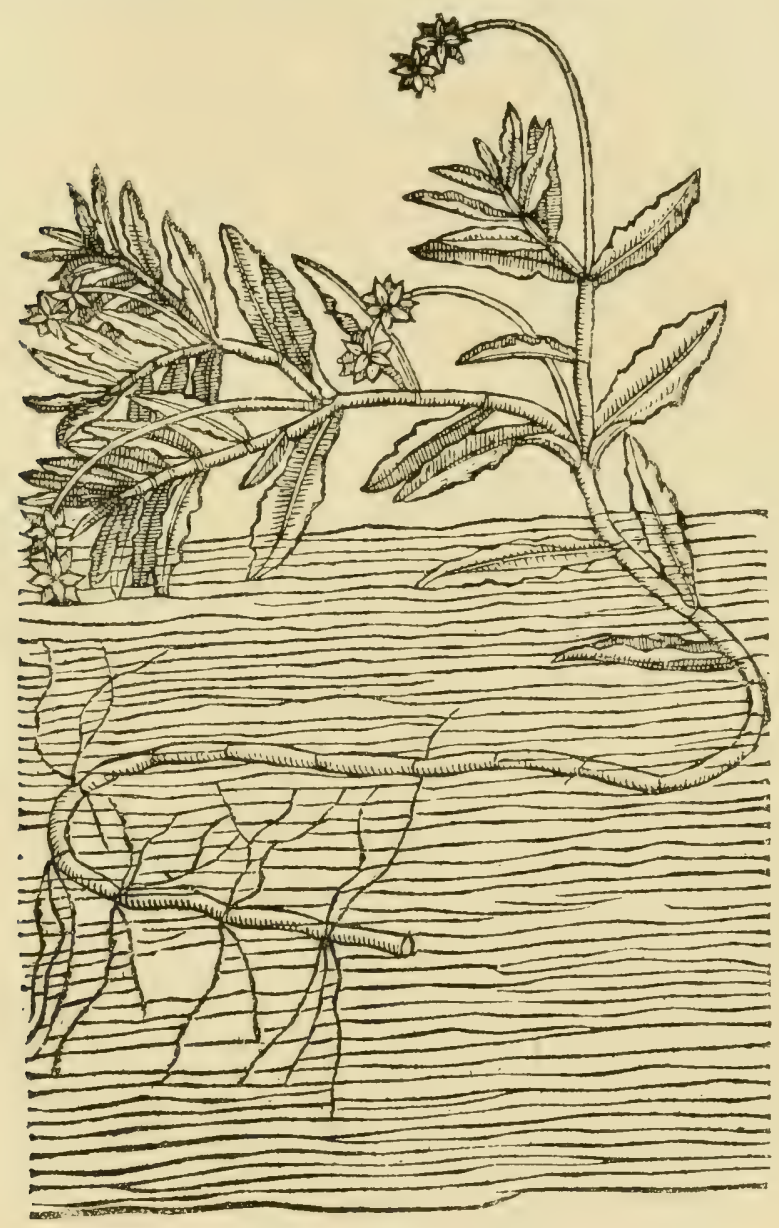

POTAMOGETON DENSUS.

long, whereby it taketh hold in the mudde, and draweth nourishment unto it. The whole plant is comonlie covered over with water. It flowereth in June and the beginning of July. I found it in the standing pooles or fish-ponds adioyning to a dissolved Abbey called Durford, which ponds devide Hampshire and Sussex, and in other standing waters elswhere. This description was made] upon 
sight of the plant the 2 of Iune, 1622.-MS. ff. I 20 a, $122 ; G \mathrm{cr}$. .823 .

[In the fair copy (f. 122) Goodyer altered the name 'floribus uvae' to 'quercus floribus'. The rough copy (MS. f. I20 a) has the notes 'about ye beg. of July, or fortnight before Lamas' and 'both begunn to flower 2 Junij $162 I^{\prime}$ 'written in the margin. If the year 1622 given in the text be correct, Goodyer would appear to have been at Durford two years running on the and of June.]

Pondwe ed. Potamogeton densus L.

Tribulus aquaticus minor, muscatellae floribus.

2 Junii 1621

This hath not flatt stalkes like the other, but round, kneed, and alwaies bearing two leaves at every ioint, one opposite against another, grecner, shorter and lesser then the other, sharpe pointed, not much wrinckled and crumpled by the edges. Clusius saith, that they are not at all crompled. I never observed any without crumples and wrinckles. The flowers grow on short small footstalkes, of a whitish green colour, like those of Muscatclla Cordi, called by Gerard, Radix cava minima viridi flore: viz. two flowers at the top of every foot-stalke, one opposite against another, every flower containing foure small leaves: which two flowers beeing past there come up eight small husks making six several waies a square of flowers. The roots are like the former. This groweth abundantly in the river by Droxford in Hampshire. It flowereth in June and July when the other doth, and continueth covered over with water, greene, both winter and somer.-MS. ff. I20 a, I22 ; Ger. emac. $823-4$.

[The rough copy (MS. f. I20 a) has the note 'in running brooks' and a reference to Clusius cclij after the name.]

\section{? Melilotus indica L.}

Melilotus Indiae orientalis.

II Junij I62I

This is in stalks, branches, leaves flowers and smell altogether like Mclilotus Italica Camerarii, but smaller more branched \& delicate, not growinge so high, \& the stalks are greenc and have no redd at all. $\|$ The seed is also like, but smaller. The root groweth downe right, and is small white, with a very fewe thredds, and perisheth when the seed is ripe the same yere it is sowen. II This hath not beene writen of by any that I find. I receaved seeds thereof from Mr. William Coys often remembred.-MS. f. 97.

Epipactis violacea Dur.

Nidus avis flore et caule violaceo purpureo colore. an Pseudoleimodoron Clus. Hist. Rar. Pl. p. 270.

29 June 1621

This riseth up with a stalke about nine inches high, with a few 
smal narrow sharpe pointed short skinny leaves, set without order, very little or nothing at all wrapping or inclosing the stalke; having a spike of flowers like those of Orobanche, without tailes or leaves growing amongst them: which fallen, there succeed small seed-vessels. The lower part of the stalke within the ground is not round like Orobanche, but slender or long, and of a yellowish white colour, with many small brittle roots growing underneath confusedly, wrapt or folded together like those of the common Nidus avis. The whole plant as it appeareth above ground, both stalkes, leaves, and flowers, is of a violet or deepe purple colour. This I found wilde in the border of a field called Marborne, neere Habridge in Haliborne, a mile from a towne called Alton in Hampshire, being the land of one William Balden. In this place also groweth wilde the thistle called Corona fratmum.-Ger. emac. 228 ; Druce, pp. 6-7.

[In Dillenius' interleaved copy of Ray's Synopsis, 1724, 'cum notis MSS. Lightfoot, Yalden, etc.', at the Botanic Garden at Oxford is a note, 'Limodorum Austriacum found in the border of a field called Marborne near Habridge in Haliborne a mile from Alton. Mr. Goodyer. See Camden's Britannia. I have searched for it in vain several years'.

The identity of this plant is very doubtful. See p. 47.]

Woolly $\mathrm{T}$ hist 1 e. Cnicus eriophoms $\mathrm{L}$.

Corona fratrum herbar. Caput monachorum.

29 June 1621

I found this wild in Hampshire in greate plentie by Haliborne in a feild called Marborne, nere a bridge called Habridge, beinge the land of Wm. Balden, \& also in the next feild to it 29 Junii I62I.MS. f. 53 .

[See under 1617 and 13 Aug. I621 for the description.]

$\mathrm{Black} \mathrm{Bryony.} \mathrm{Tamus} \mathrm{commmis} \mathrm{L}$. Bryonia nigra florens et fructum ferens.

Summer I62I florens non fructum ferens.

This is altogether like the first described in roots, branches, and leaves; onely the foot-stalks whereon the flowers grow are about eight or nine inches long: the flowers are something greater, having neither before or after their flowering any berries or shew thereof; but the flowers and footstalks do soone wither and fall away: this I have heretofore, and now this Sommer, I62I, diligently observed, because it hath not beene mentioned or observed by any that I know.-Ger. emac. 87 I.

[The first record for Hants : probably of a male plant.] 


\section{Cerinthe major L.}

Cerinthe flore rubro.

9 Julij I 62 I

The stalks or braunches for the most parte growe uppe of 2 or 3 foot high devided into branches even from the root, about which growe leaves out of order, not one against another like the yealowe flowred Cerinthe, but somethinge lesser, of a greene and blewe color as it were mixed together, also spotted with white spots on the upper side, the topps of the stalks bend downewards, and send forth amonge the leaves, out of cupps whose footstalks (not cupps as Clusius was informed) are of a deepe purple color, longe hollowe flowers like those of the said yealowe flowred Cerinthe growinge but one in a place, of a redd purple color, which seeme to be sprinckled with a certaine whiteness, which fallen there followeth blackish seed contayned in small seed vessells two usually ioyned together in forme like to the seed of Borage or redd Ciches, but as bigge as a pease. The root is white and short with a fewe small branches or thredds, and perisheth when the seed is ripe.MS. f. I 20 .

\section{Cancalis latifolia L.}

Caucalis maior Baetica.

9 Julii 1621

An Caucalis pumila, Clusio Cur. post. p. 37 .

The stalks are rough round straked, a cubite high or higher, kneed or ioynted devided into branches, sett with rough iagged leaves, of an herbie smell, on the topps of the stalks and branches growe umbells of flowers, reddish before they open, after of a perfecte white color, the leaves that growe on the out side of ech particular flower are greater and broader then those within; close under ech umbell groweth a rowe of greene leaves cutt and devided into very small sharpe pointed leaves. After the flowers cometh greate prickley burrs half as bigge as those of Xanthium sett with rowes of large prickles everie burr when it is ripe partinge into 2 parts contayninge one secd a peece. The root is small white threddie in smell like to a carrott and perisheth when the seed is ripe. The whole plant in stalks, leaves and flowers is verie like to the wild carrott. $\|$ The seeds hereof I receaved from $\mathrm{M}^{\mathrm{r}}$ William Coys often remembred, and he from Boclius a Lowe Contry man.MS. f. 95 .

\section{Xanthium Strumarium L.}

Bardana minor. The lesser Burre Docke.

It groweth plentifullie in Southwicke street in Hampshire, as I have been informed by Mr. Goodyer.-Ger. cmac. 810.

[Not included in Hants Flor by Townsend.] 
Horned wild Cumin. Hypecoon procumbens L. Hypecoon Clusii.

I I Julij I62 I

The leaves of this plant are devided into many partes, verie like in figure and color to the leaves of Rewe but softer or tenderer, and sometimes longer, spread uppon the ground; amongest which rise uppe many small stalks, growinge slopewise, about 6 ynches longe, without leaves, but onlie neare the toppe where it devideth itself into 3,4 or more small branches and those againe sometimes devided into other little short branches, with little tender footstalks at their topps, ech foot stalk bearinge one small yealowe flower, somewhat sweet, contayninge 6 leaves, but of a strange fashion, and unlike other flowers, for it hath 2 leaves bigger then the rest, with a greene strake or line on the out side, (which is blunt and as it were bowed or folded in) the other fower leaves are very small, round topped and scarce to be seene, unlesse the flower be open, which past there succeed uppon everie of the said footstalks or branches, one longe crooked blunt topped codd, with ioynts knotts or devisions contayning in the space betwene everie bunch or knott, one blackish seed in a manner round, which is hard to be pulled forth. The root is single sometimes parted, somewhat yealowe, añuall, not livinge over yere, the whole plant with us is of little smell or none at all. || It groweth not wild in England. I have seene it growinge plentifullie in $\mathrm{Mr}$. $\mathrm{W}^{\mathrm{m}}$ Coyses garden in Essex, who kindlie imparted seeds thereof unto me, Anno I620.MS. f. 97 .

\section{Convolvulus purpureus L.}

Convolvulus coeruleus minor Baeticus.

II Julij I62I

This herbe hath many tender, small round weake hairie branches a foot or a Cubite longe or longer, devidinge it self presently from the root, some leaninge some traylinge on the ground none standinge upright, or windinge them selves about anie thinge, whereon growe rough leaves without footstalks, out of order, like those of Alsine myosotis, L'obelij, narrowe neare the stalk, broad towards the toppe, out of the bosomes of those leaves growe the flowers on long footstalks, made of one leafe, like in forme and bignes to those of the common Convolvulus minor, folded or plated when it is shut uppe, into five folds of a bright blewe color, with raies of yealowe in the bottom within, which fallen there succeedeth round buttons or knapps, as bigge or little bigger then a pease, wherein in ech button is contayned 2, 3 or 4 three cornered seeds almost as bigge as Radish seed. The root is small white single, and groweth 
downeright with a fewe threddie strings or side branches. Both herbe and root do perish at winter. "

The seeds hereof were gathered in Spaine by Boelius and communicated by him to my good friend Mr. William Coys who yerlie doth carefullie sowe the same and infinite other seeds of strange herbes, and hath imparted thereof unto me. It hath not beene hetherto written of that I knowe.-MS. f. 97.

Astragalus hamosus L.

Securidaca minor. Ob. p. 523. Adversar. p. 40I. I3 Julij I62I

This plant is like to the greater Securidaca in stalks and leaves, but altogether smaller, and of a clarker greene color, ech little leafe havinge a small nick at the toppe; the flowers are very small and white, (and not purple with us, as Pena hath it) growinge in small ıufts: after which followe round, crooked, sharpe pointed codds, so sharpe that they will perce into the flesh, first bowinge downewards to the footstalk, and then turninge uppe againe, like crooked hornes, wherein is contayned two rowes of small seed, in fashion of a kidncy almost round, in tast like drie pease or beanes, not bitter; of a darke color drawinge neare an ash color. The root is small white with some threddes, and perisheth when the seed is ripe. II Seeds hereof were sent me from Mr. Milliam Coys a man veric skillfull in the knowledge of symples, my singuler good frend.MS. f. 97.

\section{Iberis umbellate L.}

Thlaspi umbellosum marinum flore albo. An Thlaspi quartum parvum odorato flore Clusii, p. cxxxij.

This plant riseth uppe with one small stalk and divideth it self ymediatelie from the root into many branches which are about a foot high, greene, round, rough brittle straked as is the stalk and everie branch devidinge it self into more branches, whercon growe longe narrowe rough leaves, devided neare the toppe like to Cormu Cervimm L'obelij, of a bitter tast, which leaves sometimes turne downewards: on the toppe of the stalks \& branches growe umbells of pleasant flowers, of a stronge but no pleasant smell, appearinge purple before they be open, (the midle of the umbell alwaies flowringe last) but beinge fullic blowen. they are of a perfect white color, ech flower beinge made of fower blunt topped laves, sometimes nicked at the toppe, and the two leaves that growe on the out side, are neare fower times as bigge, as those two that growe within, havinge short yealowe cheives in the midle, which fallen there succeedeth || broad flatt powches, secd vessels or huskis, forked 
or devided into two parts at the toppe, ech huske contayninge two flatt yealowish seeds, of a very bitter tast. The root is white and short, with a fewe side branches. The whole herbe perisheth when the seed is ripe. $-M S$. f. 98 .

[A rough copy of the last five lines is written on MS. f. II.]

Asclepias purpurascens L.

Periploca recta Virginiana.

An Apocynum Syriacum Clusii, p. Ixxxvij.

I4 Julij I62I

The stalk is bluntlie fower squared, upright, strait, not branched fower or 5 foot high, straked, of the bignes of a finger, black spotted, full of spungious white pith within, whereon growe by cooples, one opposite against another, uppon thick short footstalks, large, broad blunt topped leaves, with a whitish softe cotton underneath, of a light greene above, plaine and smooth not notched by the sides, neare the toppe of ech stalk, exactlie against the leaves (not out of the bosomes of the leaves) groweth forth about two short rough footstalks, but one in a place, ech bearinge 4 or more knapps like small buttons, which by nature turne downe, open and appeare like a greenish flower, with five leaves; above which groweth the flower of a purple or reddish color, composed of 5 round small hollowe leaves sharpe pointed on the outside, ech leafe havinge a short sharpe pointed pointell of the color of the flower, turninge into the umbo or midle of the flower.-MS. f. y8.

Anchusa angustifolia $\mathrm{L}$.

Buglossum Scorpioides.

I4 Julij I62I

An Echij facie Buglossum minimum flore rubente. Ob. p. 310.

This is like the common Buglosse in stalks and leaves, but altogether smaller \& lower, the topps of the branches whereon the flowers growe, are more crooked, turninge and bowinge inwards, the occasion (as I take it) of the name. The flowers are smaller, the leaves thereof narrower at the toppe, at their first openinge more reddish, and when they are fullie blowne, of a perfecte purple, or black violet color, but in tast, savor, operation and all things else alike. $-M S$. f. 98 .

\section{Ornithopus scorpioides L.}

Scorpioides Mathioli.

I6 Julij 162 I

Math. p. 895. Phyto. 568 (5). Ger. hath it not.

This hath many small round firme branches proceedinge from one root, and those againe devided into other branches, whereon growe leaves almost round, comonly 3 sometimes 4 together; whereof the midlemost is 4 times as bigge as anie of the other, both 
stalks and leaves, are of a mealie white color, and are some what like the leaves of Portulaca: the flowers are small, yealowe, like those of Scorpioides repens Bupleuri folio L'Obelij, but smaller, growinge forth of the bosomes of the leaves, on long footstalks, sometimes three, most comonly 4 together. After which cometh on ech footstalk as many longe, small, jointed, slender, sharpe pointed codds, bowinge like the taile of a scorpion or like to birds clawes, wherein is contayned betweene everie ioynt one longe slender yealowish seed like Galega. The root is small, white, with a fewe thredds, and perisheth when the seed is ripe.-MS. f. 88 .

\section{Crucianella sp.}

Rubia spicata Cretica Clusii, p. clxxvii.

I9 July I62 I

This hath proceeding from the root many knottie foure square rough little stalks, a foot high, devided immediately from the root into many branches, having but one side branch growing forth of one ioint: about which ioints grow spread abroade 4, 5, sometimes 6 narrow, short, sharpe pointed leaves, somewhat rough: the toppes of the stalkes and branches are nothing but long small foure square spikes or eares, made of three leafed greene huskes: out of the top of each huske groweth a very small greenish yellow flower, having foure exceeding smal leaves scarce to be seene: after which followeth in each huske one smal blackish seed, somewhat long, round on the one side, with a dent or hollownesse on the other. The root is small, hard, woodie, crooked or scragged, with many little branches or threds, red without, and white within, and perisheth when the seed is ripe.-MS. f. 88; Ger. emac. II I9.

Campanula pumila hort. C. pulla e.

Lesser Bellflower.

[I9 July I62I]?

Ye lesser Bellflower hath small, rough, round, straked stalks, seldom braunched, or above a foot or a cubit high. The leaves are rough, of a light greene colour, very lightly indented about $y^{\circ}$ edges in form like sloe leaves, or those of ye wild violett, those that grow below have footstalks, \& those above are smaller, \& grow close to ye stalk without any footstalk at all; the flowers are like small bells, \& devided in the toppe into 5 sharpe pointed leaves, which are pointed in $y^{\mathrm{c}}$ middle devided in ye toppe in 3 pts. Some whereof growe alongest ye stalk, and some times I 2 together in a bunch or Cluster at very toppe of ye stalk, after which cometh ye sced cod in small rough(?) husks. The root is white, small, strayght, with many threads \& perennis.-MS. f. $8 \mathrm{v}$.

[Note on the back of a letter from F. Waller to Sir T. Bilson, bearing date 19 July 1621 .] 


\section{Phalaris canariensis L.}

Phalaris minor Baetica Boëlij, semine nigro.

20 Julij I 62 I

Is in stalks, height, leaves and scalie eares, like the greate Phalaris, but twise as small, of a darker greene color, and the seed is much smaller and of a blackish color.-MS. f. 88.

\section{Phalaris minor $\mathrm{L}$.}

Phalaris minor Baetica semine albo Boëlij.

[20 July I62I]

The stalks growe not above a foot high, the leaves are whighter then the other, the eares are also whighter, and scarce growe forth of the greate hose or uppermost leafe, the seed is whitish in all things else like the former.-MS. f. 88 .

\section{Phalaris bulbosa L.}

Phalaris bulbosa Boëlij.

[20 July I62I]

Is altogether like the Phalaris with blackish seed in stalks, leaves and spikes, but the roots are bulbus, like those of Catts taile grasse, growinge most comonlie on the upper crust of the earth, with a fewe small threddie roots hanginge thereat fastened within the earth, the seed is of an Ash color or darke white, the bulbus roots most comonlie live manie yeres.-MS. f. 88 .

\section{Valeriana Cormucopiae L.}

Valeriana mexicana.

20 Julij I62I

non est Valeriana Indica Clusii.

The stalke is round, tender, brittle, verie much straked, hollowe, greene, yet reddish in some places, \& ioynted, devided into branches, about 2 foot high; at everie ioynt groweth two leaves, those on the lower parte of the stalk are crompled, not notched by the sides, round topped, of a light greene color, verie like the leaves of garden lettice (nothinge at all like the leaves of Lactuca agnina) about 4 ynches longe, and 3 ynches brode, with broad leafed footstalks; those on the upper parte of the stalke, are narrower, shorter, somewhat notched by the sides, without footstalks; on the topps of the branches growe the flowers as it were in umbells, and are longe, of a bright purple color, everie flower contayninge 5 small round topped leaves, whereof 2 are greater then the rest. The seed followeth (sem. I. Sept.) growinge in chaffie scales or hedds, as bigge or bigger then a wheate corne, blackish, seminge to be nothinge but light husks and no seed.

The root is very small for the bignes of the plant, white and threddie, and perisheth when the seed is ripe; the whole plant is without any manifest tast or smell. \|| Clusius, Gerard \& Bauhinus 
have written of Valeriana mexicana sive indica, but this herbe agreeth with neither of their descriptions. I receaved seeds whereof grewe this described herbe from $\mathrm{Mr}$. William Coys often remembred. $-M S$. f. 89 .

\section{Reseda Phyteuma L.}

Phyteuma monspeliensium. Ger. p. gr8.

2 I Julij I62I

The stalks are small, greene, round, straked, rough, creepinge or leaninge neare the ground, a foot long, devided into many branches imediatlic from the root; the leaves are small like those of Lutcola, round topped, rough on the midle ribbe on the under side, sometimes crompled by the sides; the flowers growe from the midle pte of the stalk upwards spike fashion, not close together, on short rough foot stalks; beinge nothinge but thrumie whitish cheives, like those of Rheseda ; ech flower havinge growinge close adioyninge under it comonlie 6 small leaves star fashion, the flowers past.MS. f. 89 .

\section{? Malva stipulacea Cav.}

Malva flore amplo Baetica aestiva.

2I Julij I62I

This mallowe hath stalks and leaves altogether like the greate comon high wild mallowe; but the flowers are as bigge againe, composed likewise of five leaves a peece, of a lighter purple color and makinge a braver showe, the seed is blackish like a half moone, not rough !but finely straked on the upper side, twise as bigge as the seed of the comon mallowe, growinge in a round circle closely compact together within or at the bottome of a duble huske, and covered over with a flatt spongious cake, blackish on the upper side, so this seed in manner of growinge is contrarie to the comon mallowe, this havinge two husks and a little cake anci seed underncath, and that having by one huske a little cake but half so bigge, made only of the seed. The root is very small, white, brittle, with a fewe small threddes hanginge thereat and perisheth at winter. $\|$

I cannot find that this mallowe hath been written of heretofore. The seeds were sent to my worthy frend Mr. William Coys by Boelius who gathered them in Spaine, who with many other imparted them unto me Anno I620.-MS. f. 89.

Chrysanthomum coronarium $\mathrm{L}$.

Chrysanthemum Creticum primum Clusii.

28 Julii 1621

The stalkes are round, straked, branched, hard, of a whitish greene, with a very little pith within; neere three foot high: the 
leaves grow out of order, devided into many parts, and those again snipt or devided, of the color of the stalkes : at the topps of the stalkes and branches grow great flowers, bigger than any of the rest of the Corne-flowers, forth of scaly heads, consisting of twelve or more broad leaves apeece, notched at the top, of a shining golden colour at the first, which after turne to a pale, whitish, or very light yellow, and grow round about a large yellow ball, of smell somewhat sweet. The flowers past, there commeth abundance of seed closely compact or thrust together, and it is short, blunt at both ends, straked, of a sand color, somwhat flat, \& of a reasonable bignes. The root is whitish, neere a fingers bignesse, short, with many threds hanging thereat, and perisheth when the seede is ripe; and at the Spring groweth uppe againe by the falling of the seed.-MS. f. 90 ; Ger. emac. 744-5.

\section{Chrysanthemum coronarium L.}

Chrysanthemum Baeticum Boëlij inscriptum.

28 Julij I62I

The stalks are round, straked, reddish brown, devided into branches, containing a spungious white pith within, a cubite high: the leaves growe out of order, without footstalkes, about 3 inches long, and an inch broad, notched about the edges, not at all devided, of a darke greene colour : the flowers growe at the tops of the stalkes and branches, forth of great scalie heads, containinge twentie leaves a piece or more, notched at the top, of a shining yellow color, growinge about a round yellow ball, of a reasonable good smell, verie like those of the common Chrysanthemum scgetum: the seede groweth like the other, and is very small, long, round, crooked and whitish: the root is small, whitish, threddie, and perisheth also when the seed is ripe-MS. f. 90 ; Ger. emac. 745 .

\section{Chrysanthemum coronarium L.}

Chrysanthemum tenuifolium Baeticum Boelij.

28 Julij 1621

The stalks are round, small, straked, reddish, somewhat hairie, branched, a cubit high, or higher: the leaves are small, much devided, iagged, and verie like the leaves of Cotula fotida: the flowers are yellow, shining like gold, composed of thirteene or fourteene leaves a pece, notched at the top, set about a yealowe ball, also like the common Chrysanthemum segetum: the seed groweth amongst white flattish scales, which are closelie compacted in a round head together, and are small, flat, greyish, and broad at the top: the root is small, whitish, with a few threds, and dyeth when the seed is ripe.-MS. f. 90 ; Ger. emac. 745 . 
Prickly Beet of Candy. Emex spinosa Campd. Blitum spinosum Creticum.

28 Julij I62I est Beta Cretica semine aculeata Bauhini. Joynt Flower-topp.

This sendeth forth from one root many round greene straked, trayling, ioynted, small branches, about a foot longe: the leaves are of a light greene colour, and srow at every ioint one, somewhat like the leaves of great Sorrell, but they are round topped without barbes or eares below, or any manifest tast or smell, very like the leaves of Beetes. but much smaller: the flowers grow clustering together about the ioynts, and at the tops of the branches small and greenish, each flower containing .5 or 6 very small blunt topped leaves, and a few dustie cheives in the middle: which past, there cometh greate prickley shrivelled seed, growing even close to the root, and upwards on the ioints, each seed having three sharpe prickes at the top growing sidewaics, which indeed may be more properly called the huske; which huske in the inside is of a darke reddish color, and containeth one seed in forme like the seed of $A$ donis, round at the lower end, 3 comered towards the toppe, and sharp pointed, covered over with a darke yealowish skyn; which skyn pulled away, the kernell appeareth yealow on the outside, and exceeding white within, and will with a light touch fall into very small powder like meale.-MS. f. $90 ;$ Ger. emac. I626.

\section{Lathyms Ochmus DC. or L. anmuns L.}

Lathyrus aestivus flore luteo.

28 Julii I62I

This is like Lathyris latiore folio Lobclij, in stalks, leaves, and branches, but smaller: the stalks are two or three foot long, made flatt with two skyns, with 2 exceedinge small leaves growinge on the stalks, one opposite against another: betweene which spring up flat footstalks, an inch long, bearing two exceeding narrow sharpe pointed leaves, three inches long: betweene which grow the tendrels, devided into many parts at the top, and taking hold therwith: the flowers are smal, and grow forth of the bosomes of the leaves, on each footstalk one flower, wholly yealow. with purple strakes. After each flower followeth a smooth cod, almost round, two inches long, wherein is contained scven round Peason, somewhat rough, but after a curious manner, of the bignesse and taste of field Peason, and of a darke sand color-MS. f. $108 ; G \mathrm{cr}$. emac. 1628 .

\section{? Lathyrus Clymenum L.}

Lathyrus aestivus Baeticus flore cocruleo Boëlii. [28 Julii 162I] This is also like Lathyris latiore folio Lobelij, but smaller, yet 
greater than that with yellow flowers, having also adioining to the flat stalkes, two eared sharpe pointed leaves, and also two other slender sharpe pointed leaves, about foure inches long, growing on a flat foot-stalke betweene them, an inch and a halfe long, and one tendrel between them devided into two or three parts: the flowers are large, and grow on long slender foure-square footstalkes, from the bosomes of the leaves, on each footstalk one: the upper great covering leafe being of a light blew, \& the lower smaller leaves of a deeper blew : which past there come up short flat cods, with two filmes, edges, or skins on the upper side, like those of Eruilia Lobelij, containing within foure or five great flat cornered Peason, bigger than field Peason, of a darke sand color.MS. f. I08; Ger. emac. 1628.

\section{? Lens esculenta Moench.}

Lathyrus aestivus edulis Baeticus flore albo Boelii. [28 Julii 162I]

This is in flat skinny stalks, leaves, foot-stalks, and cods, with two skins on the upper side, and in all things else like the said Lathyrus with blew flowers; only the flowers of this are milk white: the fruit is also like.-MS. f. 108 ; Ger.emac. I6:88.

\section{? Lathyms sphaericus Retz.}

Lathyrus aestivus flore miniato.

[28 Julii I66 I ]

This is also in skinnie flat stalks and leaves like the said Lathyris latiore folio, but far smaller, not three foot high: it hath also small sharp pointed leaves growing by couples on the stalke, between which grow two leaves, about three inches long, on a flat foot-stalk half an inch long: also between those leaves grow the tendrels : the flowers are of the color of red ledd, but not so bright, growing on smooth short foot-stalks, one on a foot-stalke: after which follow cods very like those of the common field peason, but lesser, an inch and a halfe long, containing foure, five, or sixe cornered Peason, of a sand color, or darke obscure yealowe, as big as common field peason, and of the same taste-MS. f. Io8; Ger. emac. I628-9.

\section{Lathyrus palustris $\mathrm{L}$.}

Lathyrus palustris Lusitanicus Boelii.

Hath also flat skinnie stalks like the said Lathym latiore folio, but the paire of leaves which grow on the stalke are exceeding small as are those of Lathyrus flore luteo, and are indeed scarce worthie to be called leaves: the other paire of leaves are about two inches long, above halfe an inch broad, and grow from betweene those small leaves, on flat foot-stalks, an inch long: betweene which 
leaves also grow the tendrels: the flowers grow on footstalks which are five inches long, commonly two on a foot-stalke, the great upper covering leaves being of a bright red colour, and the under leaves are somewhat paler: after commeth flat cods, containing seven or eight small round peason, no bigger than a Pepper corne, gray and blacke, spotted before they are ripe, and when they are fully ripe of a blacke colour, in taste like common Peason: the stalks, leaves, foot-stalkes and coddes'are somwhat hairy and rough.-MS. f. Io9; Ger. emac. I629.

\section{Lathyrus tuberosus L.}

Lathyrus aestivus dumetorum Baeticus Boelii. [28 Julii I62I] Hath also flat skinnie stalks like the said Lathy'mes latione folio, but smaller, and in the manner of the growing of the leaves altogether contrarie. This hath also two small sharp pointed leaves, adioyning to the stalke: betweene which groweth forth a flat middle rib with tendrels at the top, having on each side (not one against another) commonly three blunt topped leaves, sometimes three on the one side, and two on the other, and sometimes but foure in all, about an inch and a halfe long: the flowers grow on foot-stalks, about two or three inches long, each foot-stalk usually bearing two flowers, the great covering leafe being of a bright red colour; and the two under leaves of a blewish purple colour: after which follow smooth cods, above two inches long, containing, five, sixe, or seven smooth Peason, of a browne Chestnut colour, not round, but somewhat flat, more long than broad, especially those next both the cnds of the cod, of the bignesse and taste of common field peason.-MS. f. I09; Ger. emac. 1629.

\section{cia sativa $\beta$ linearis Lange.}

Aracus maior Baeticus Boelii.

30 Julii 162 I

It hath small wcake foure square straked trayling branches, two foot high, lesser, but like those of Fetches; whereon grow manie leaves without order, and every severall leafe is composed of six, seven, or more small sharpe pointed leaves, like those of Lentils, set on each side of a middle rib, which middle rib endeth with clasping tendrels: the flowers grow forth of the bosomes of the leaves, but one in a place, almost without any foot-stalkes at all, like those of Vetches, but of a whitish colour, with purple strakes, and of a deep colour tendinge to purple towards the nailes of the upper covering leaves: after which follow the cods, which are little above an inch long, not fully so big as those of the wilde beane, almost round, and very hairy: wherein is contained about + peason, 
seldom round, most commonly somewhat flat, and sometimes cornered, of a blackish colour, neere as big as field peason, and of the taste of Fetches. The whole herbe perisheth when the seed is ripe. $\|$ This plant Boelius sent to $\mathrm{M}^{\mathrm{r}}$. William Coys, who hath care fully preserved the same kind ever since, and friendly imparted seeds thereof to me in Amno 1620.-MS. f. 91 ; Ger. emac. 1627.

Vicia lutea $\beta$ laevigata Boiss.

Legumen pallidum Vlissiponense Nonii Brandonii. $\quad 30$ Julii I62 I

This plant is very like, both in stalks, leaves, and cods, to Aracus maior Beticus, but the flowers of this are of a pale yellow or primrose colour, and the whole herbe smaller, and nothing so hairy. It perisheth also when the seed is ripe. $\| I$ received the seeds likewise from Mr ${ }^{r}$. Coys.-MS. f. 9 I ; Ger. emac. 1627.

Vicia sativa var. leucosperma Moench.

Vicia indica fructu albo. Pisum indicum Gerardo. 30 Julii I62 I

This Vetch differeth not in any thinge at all, eyther in stalkes, leaves, codds, fashion of the flowers, or colour thereof, from our common manured Vetch, but that it groweth higher, and the fruit is bigger and rounder, and of a very cleare white colour, more like to peason than Vetches. $\| \mathrm{M}^{\mathrm{r}}$. Gerard was wont to call this Vetch by the name of Pisum Indicum, or Indian Pease, gotten by him after the publishing of his Herball, as $\mathrm{M}^{\mathrm{r}}$. Coys reported to me. But the said $\mathrm{M}^{\mathrm{r}}$. Coys hath (in my iudgment) more properly named it Vicia fructu albo: which name I thought most fit to call it by, only addinge Indica to it, from whence it is reported to have been gotten.-MS. f. 9I ; Ger. emac. 1627.

\section{Pisum sativum L.}

Pisum quadratum.

30 Julij 162 I

Lotus siliquosus rubello flore. Clus: p. ccxliiij. Phyto. 668 (60).

This hath many round, hairie, branches, proceedinge imediatelie from the root, longe spreadinge for the most pte uppon the ground; yet the topps or ends of the branches liste themselves somewhat upright, whereon growe broad rough hairie blunt-topped leaves at certaine distances 3 allwaies on one foot stalk, out of whose bosomes growe round hairy footstalks, bearinge three other leaves like the former but smaller, and one or two flowers like those of Vetches, of a beautifull color like deepe redd or orenge tawnie velvett, after which cometh uppe the codds, about 3 ynches longe, havinge 4 wrinckled filmes or skyns growinge alongst them viz. two on the upper side and 2 on the lower side, which make the codds (?) appeare fower square when they be drie, wherein in ech 
codd is contayned about 10 or I I round seeds, browne when they are ripe, neare of the bignes of feild peason, and of the same tast. The root is white and small, with abundance of thredie small side branches, and perisheth at winter.

It begineth to flower in June, and so contineweth flowringe and bearinge fruite till the extreame froste.-MS. f. 91.

[Goodyer sent a description of Pisum quadratum to Johnson on 5 March 1632, but the text printed in the Herbal differs markedly from this one: cf. Ger. emac. IIg8.]

Astragalus lusitanicus Lam.

Astragalus marinus lusitanicus Boelii.

3I Julii I62I

This hath five, six, or more round straked reddish hairy stalks or branches, of a reasonabic bignesse: proceeding from one root, sometimes creeping or lcaning necre the sround, and sometimes standing upright, a cubit high, with many greene leaves, set by certaine distances, out of order like those of Glaux vulgaris, but lesser, every leafe being composed of fourteen or more round topped leaves, a little hairy by the edges, set on each side of a long middle rib, which is about nine or ten inches in length, without tendrels: the flowers grow forth of the bosomes of the leaves, neere the tops of the stalkes, on long round streaked hairy footstalkes, of a very pale yellow colour, like those of Securidaca minor, but bigger, growing close together in short spikes, which turne into spikes of the length of two or three inches, containing many small three cornered cods about an inch long, srowing close together like those of Glaux vulgaris, each cod containing two rowes of small flat foure cornered seeds, three or foure in each row, of a darke yellowish or leadish colour, like to those of Securidaca minor, but three or foure times as big, of little taste: the root is small, slender, white, with a few threds, and groweth downe right, and perisheth when the seed is ripe. II I first gathered seeds of this plant in the garden of my good friend $\mathrm{M}^{\mathrm{r}}$. Iolun Parkinson an Apothecary of London, Anno 1616.-MS. f. 107; Ger. emac. 1627-8.

Vicia Faba L. var.

Faba veterum serratis foliis Boclii.

3 I Julii I62I

This is like the other wilde Beane in stalls, flowers, cods, fruit, and clasping tendrels, but it differeth from it in that the leaves hereof (especially those that grow neere the tops of the stalks) are notched or indented about the edges like the teeth of a saw. The root also perisheth when the seed is ripe. "The seeds of this wilde Beane were gathered by Boclius a Low-country man, in Batica a part of Spaine, and by him sent to $\mathrm{M}^{\mathrm{r}}$. William Coys, and by 
him carefully preserved, who also imparted seeds thereof to me, in Anno 1620.-MS. f. 107; Ger. emac. 1628.

\section{Lathyrus Ochrus DC.}

Ervilia silvestris Dodonaei, p. 522 .

3I Julij I62I

Ervilia sendeth forth 3 or 4 stalks or branches from one root, somewhat like Lathyrus, but broader weaker and lyeinge flatt uppon the ground: the leaves are about two ynches longe and an ynch broad, with claspinge tendrells at the ends, without footstalks, making the stalks flatt with their two edges, whole bendath on the lower parte of the stalk onlie devided into 2 parts at the ends, but neare the topps of the branches everie leafe is devided at the toppe into 2,3 or 4 small leaves. The flowers are small of a pale yealowe or primrose color growinge but one in a place on a short footstalk. The codds are short somewhatt flatt havinge 2 edges or filmes on the upper side wherein is contayned 4 or 5 or 6 round ash colord fruite, verie like feild peason of the same bignes, and verie neare of tast. The root is verie small and threddie and perisheth when the seed is ripe.

|| I first observed this pulse in the garden of Mr. John Parkinson in London Anno I6I6, and after I620 I receaved seeds hereof from my trewe frend Mr. William Coys, often remembred, with many other.-MS. f. 10\%.

[Cf. L. Ochrus DC., 28 July I62I.]

\section{Pisum arvense $\mathrm{L}$.}

Pisum maculatum Boelii.

3I Julii I 62 I

They are like to the small common field Peason in stalkes, leaves, and cods; the difference is, the flowers are commonly smaller, and of a whitish greene colour: the Peason are of a darke gray colour, spotted with blacke spots in shew like to blacke velvet; in taste they are also like, but somewhat harsher. \|These peason I gathered in the garden of $\mathrm{M}^{\mathrm{r}}$. Iohn Parkinson, a skilfull Apothecarie of London; and they were first brought out of Spaine by Boelins a low-countrey man.-MS. f. 107; Ger. emac. 1628.

\section{Medicago minima L.}

Medica Anglica minor

2 Augusti i62I

an Trifolium cochleatum alterum. Dod. p. 579.

Hath many fower square hairy straked reddish branches, growinge from one root, two or three foot longe, and those also devided againe into other branches, whereon growe smooth leaves three on a footstalk, somewhat indented, very broad at the toppe, and narrowe belowe, of the fashion of a hart, with a crooked black 
spott in the middest of ech leafe. The flowers are very small and yealowe, growinge on short footstalls, alongest the branches, forth of the bosomes of the leaves, 3,4 or 5 on a footstalk; after cometh small round fruits, writhen or wound together, flatt at the toppe, prickley, no bigger then a small pease, whercin lyeth small yealowe seed, in fashion of a kidncy, but no bigger then a flea. The root is small, whitish, groweth downeright with a fewe side branches and small thredds, and perisheth at winter after the seed is ripe.-MTS. f, IO4.

\section{Medicago polymorpha L.}

Medicae maioris Baeticae species prima, spinulis intortis.

2 Aug. I62I

Hath also foure square reddish streaked hairy trailing branches, like the small English MIcdica, but greater and longer, foure or 5 foot long: the leaves are also smooth, growing thrce together, neither sharpe pointed, nor yet so broad at the top as the said English Medica, but blunt topped, with a small blacke spot in the midst, not crooked: the flowers are also yellow, three, foure, or five on a foot-stalke: after commeth a round writhed fruit fully as big as a hasell nut, with small prickles not standing foreright, but lying flat on the fruit, finely wrapped, plaited, folded, or interlaced together, whercin lieth wrapped the seed in fashion of a kidney, very like a kidney beane, but foure times smaller, and flatter, of a shining blacke colour without, like polished Icat; containing a white kernell within: the root is like the former, and perisheth also at Winter.-MS. f. I04; Ger. emac. I200.

[' Ieate' in MS., probably $=$ jet.]

Hedgehog Medick. Medicago intertexta L.

Medicae maioris Baeticae spinosae species altera. 2 Aug. I62I

The branches also creepe on the ground, and are straked smooth foure square, reddish here and there, three or foure foot long: the leaves are smooth, fincly notched about the edges, sharp pointed, without blacke spots, very like Midica pericarpio plano: the flowers are small and yellow like the other: the fruit is round, writhed or turned in, also fully as big as a hasell nut, somewhat cottonie or woolly, with short sharpe prickles: wherein lyeth also wrapped a shining blacke kidney-like seed, so like the last described, that they are not to be discerned apart: the root is also alike, and perisheth at Winter.-MS. f. 104; Ger. cmac. 1200.

\section{Medicago marina $\mathrm{L}$.}

Medicae marinae spinosae species.

2 Aug. 1621

The branches of this are the least and shortest of all the rest, 
little exceeding a foot or two in length, and are foure square, greene, somewhat hairie, and trailing on the ground: the leaves are like to those of Medica pericarpio plano, not fully so sharpe pointed, without blacke spots, soft, hairy, three on a foot-stalke: the flowers grow alongst the branches, on very small foot-stalkes, forth of the bosomes of the leaves, (not altogether on or neere the tops of the branches) and are very small and yellow, but one on a foot-stalke: after commeth small round writhed fruit, no bigger than a pease, with very short sharpe prickles, wherein is contained yellowish seed of the fashion of a kidney like the former, and is the hardest to be plucked forth of any of the rest: the root is also whitish like the roots of the other, and also perisheth at Winter.-MS. f. I04; Ger. emac. 1200.

\section{Linaria thymifolia $\mathrm{DC}$.?}

Antirrhinum minus flore Linariae luteum inscriptum. 3 Augusti I 62 I

This hath at the first many very small, round, smooth branches from one root, trayling on the ground, about foure or five inches long, set with many small greene short sharp pointed leaves, like those of Serpillinn, but that these are longer, smooth, and three or foure growing opposite one against another: amongst which rise up five or six, sometimes ten or twelve upright round smooth little stalks a cubit high, divided into branches bearing small long smooth greene leaves, growing without order, as narrow as the upper leaves of Oenanthe Angustifolia: at the toppes of the stalks and branches grow clustering together five six or more small yellow flowers, flowering upwards, leaving a long spike of very small huskes, each huske having a small line or chinke as though two huskes were ioined together, the one side of the huske being a little longer than the other, wherein is contained exceeding small blackish seed. The root is very short, small, and white, with a few threds, and perisheth at winter.

\| This plant is not written of that I can finde. I received seed thereof from $\mathrm{M}^{\mathrm{r}}$. William Coys often remembred.-MS. f. I03; Ger. emac. 1626.

\section{Linaria serpyllifolia Lange?}

Linaria minor aestiva.

3 Augusti I021

The stalkes are round, smooth, of a whitish greene colour, a foot high, weake, not able to stand upright: whereon grow long narrow sharpe pointed leaves, most commonly bending or turning downewards. The flowers grow in spikes at the toppes of the branches, yet not very neere together, and are verie small and yellow, with 
a small tayle : the seed of this plant is small, flat, and of a blackish gray colour, inclosed in small round huskes, and you shall commonly have at one time flowers and ripe seed all on a stalke. The whole plant is like to the common Linaria, but that it is a great deale lesser, and the flowers are six times as small, and perish at Winter. $\| \mathrm{I}$ also received seeds thereof from $\mathrm{M}^{\mathrm{r}}$. William Coys. MS. f. 103; Ger. emac. 1626.

\section{? Trifolium Lagopus L.}

Lagopus trifolius flore ruberrimo.

4 Augusti I62I

This Lagopus sendeth forth many leaves presentlic from the root three growinge together uppon a longe footstalk almost round softe hairie of a light greene amongest which groweth uppe a round hairy reddish stalk of a foot or a cubite high devided into certaine branches under which growe the like leaves not so round but a little longer. At the topps of the stalks and branches growe longe heads or spikes about two ynches longe of a finger bignes made of rough husks ech huske devided into five small narrowe parts at the toppe out of which growe small flowers of a delicate bright redd color, which fallen there succedeth in ech of those husks a round thick yealowe seed. II The root is very small, white, short, and perisheth when the seed is ripe.-MS. f. Io6.

Trifolium ligusticum Balb.

Lagopus trifolius maior Baeticus.

[4 Augusti 1621]

Hath many small round weake hairy branches about nine ynches longe proceedinge from one root traylinge on the ground and those againe devided into other branches whereon growe small greene round topped hairie leaves three together on a round hairy footstalk like those of Trifolinu flore albo but longer. On the topps of the branches growe round hairie woollie heads amongest which come forth small white flowers like those of Trifolium flore albo but smaller, and have allwaies close adioyninge underneath each flower three broad hairy scales and three leaves growinge thereon like the former on a veric short footstalk.

\|The Seeds of this Hares foot were gathered in Baetica by Boëlius, and by him sent to Mr. William Coys, who hath ever since carefullie preserved the plant, and imparted seeds to me in Anno I620.-MS. f. 106.

\section{Cnicus pratensis Willd.}

Carduus buibosus Monspelliensium. n. d.

Hath at the first manic leaves spread abroad uppon or neare the ground greene above \& somewhat white underneath and cottonie 
about two foot longe, sometimes parted or devided into manie parts, sometimes into verie fewe, sett with many small weake prickles in fashion like the leaves of Carduns viamum, amongest which riseth uppe one stalke somewhat wollie champhered or straked and devided into branches, whereon growe leaves like the former but much shorter and smaller, on the topps of the branches growe round buttons or hedds, not so bigge as an olive sett full of small scales with verie short innocent pricks, forth of which growe abundance of small purple cheives, and no borderinge flowers like those of Carduns acaulis Septentrionalinm but lesser, which past the seed followeth inclosed in downe like other thistles. The rootes are bulbus after the manner of Asphodelus, the old ones yerelie dieinge, and yonge succeedinge, as doe the roots of Oenanthe apii folio.-MS. f. I 24 .

[It is a great pity that no locality is given for this plant. If Goodyer found it growing wild this would be the earliest record for Britain. The plant is now confined to the county of Wiltshire, whence it was recorded for the first time in 1813 . Smith.]

\section{Carlina lanata L.}

Acarna flore rubro.

II Augusti I62I

The stalk is round upright, straked full of white pith within, about 5 foot high devided into many branches espetiallie neare the root; under which growe longe broad leaves deepely notched by the sides, and sett with very sharpe pricks, very full of milk white strakes, smooth above somewhat hairie on the vaines or sinewes underneath: on the topps of the stalks and branches growe 3,4 or 5 small hedds not farr apart, not fullie an ynch thick full of gentle short crooked pricks by the sides, with purple cheives at the toppe closely compact together, ech havinge growinge close underneath him 3,4 or more prickly leaves with reddish vaynes, the seed is greate, broad at the toppe, blackish without, with a white kernell within wrapped or inclosed in white downe, of a bitter tast, and is more then twise as bigge, as the seed of Carduns marie.

This plant at the first sight is in stalks leaves and purple flowers, verie like to our ladies thistle \& is hard to be distinguished from it but by the number of the flowers growinge neare together, and the prickley leaves growinge close underneath them. \|Mr. William Coys receaved the seeds hereof from L'obell by the foresaid name. Mr. Coys imparted of his seeds unto me, Anno 1620.-MS. f. 105.

Notobasis syriaca Cass.

Silibum minus flore nutante Boelii.

II Augusti I62 I

This Thistle is in stalkes and leaves much smaller than our Ladies 
Thistle, that is to say, the stalkes are round, straked, somewhat woolly, with narrow skinny prickly edges three or foure foot high, divided into many branches, whereon grow long leaves, deeply divided, full of white milke-like strakes and sharpe prickles by the edges: the flowers grow on the tops of the stalks and branches, forth of small heads, commonly turning downwards, of the bignesse of an Olive, set with very small slender sharpe pricks, containing nothing but small purple chives, spreading abroad like those of Iacca, with some blewish chives in the middle: the seed followeth, inclosed in downe, and is small and grayish like the seed of other Thistles, but it is as clammy as Bird-lime. \|The whole plant perisheth at Winter, and reneweth it selfe by the falling of his seed. I finde not that this is written of. It was first gathered by Boclizes in Spaine, and imparted unto M $\mathrm{I}^{\mathrm{r}}$. William Coy's, who friendly gave me seeds thereof.-MS. f. 105 ; Ger. cmac. I627.

\section{Woolly Thistle. Cnicus eviophomus L.}

Carduus Eriocephalus, Corona fratrum quorundam. I3 Augusti I62 I It is the $6^{\text {th }}$ in Ger. p. 900.

This thistle hath many leaves at the beginninge spread on the ground bigge longe very much devided very pricklie white underneath but greene above and somewhat rough ech leafe havinge as it were fower rowes of small leaves betwene which groweth uppe a stalk 3 or 4 foot high somewhat woollie thick straked devided into many branches sett with leaves like to those which spread uppon the ground but lesser uppon the topps of the branches growe greate hedds with many thornie prickles and so cumpassed about or fraught with woollines like Spiders webbs that the prickles doe only a little appeare, the hedds openinge themselves comes out the flowers consisting of many purple cheives, whereunto succeedeth the seed inclosed with downe, shininge somethinge longe as in many other thistles. The roote is longe with many little thredds, above an ynch thick Russett without. It seedeth not till two or three yeres after the sowinge, and most comonly perisheth after it hath borne seed.

|| I found this wild neare London highwaie on the east parte of Haliborne in Hampsheire. 1617 . And also in the highwaie neare A bington leadinge towards Oxford the 2 of July I $622 .-$ IIS. f. 105 .

[See also under 29 June 162 J.]

Erodium gruinum Willd.

Geranii Boeticae, species Boelii.

I4 Aug. 1621

This hath at the beginning many broad leaves, indented about 
the edges, somwhat divided, like those of Goranium Crcticum, but of a lighter greene colour, and smaller: amongst which grow up many round hairy kneed trailing branches, divided into many.other branches, bearing leaves like the former, but smaller, and no more divided. The flowers are smal like those of Geranium Moschatum, but of a deeper reddish colour, each flower having five small round topped leaves: after followeth small long hairie seed, growing at the lower end of a sharpe pointed beak like that of Geranium Moschatum: the whole plant perisheth when the seed is ripe.

|| Boelizes a Low-countrey man gathered the seeds hereof in Bœtica a part of Spaine, and imparted them to Mr. William Coys, a man very skilfull in the knowledge of Simples, who hath gotten plants thereof, and of infinite other strange herbes, and friendly gave me seeds hereof, and of many other, Anno 1620.-MS. f. I06; Ger. emac. 1626 .

[This species is probably the Geranium Alceae vesicariae folitis or Venice Mallow-leafed Cranesbill concerning which Parkinson wrote, 'This and the third among a number of other seeds were brought me by Guillaume Boel which he gathered in Spaine upon my charge; however Mr. Goodier getting the seeds from Mr. Coys, caused it and divers other things to be published in his name: notwithstanding I told him the charge was mine that procured it and many other'. Theatrum, p. 707.]

\section{Hedysarum humile L.}

Hedysarum clypeatum.

14 Aug. I62I.

Hath at the first many smooth large leaves, lyeinge on or neare the ground, ech leafe beinge made comonly of 7 or more leaves, usuallie growinge on a cornered straked midle ribbe three one against another, and the biggest at the toppe, sometimes one or 2 growinge by them selves, ech leafe beinge about an ynch broad and 2 ynches longe, and are proportionablie round both at the toppe \& towards the midle ribbe or footstalk; amonge which from one root growe uppe 4,5 or more round greene pliant straked stalks, leaninge towards the ground, of a reasonable bignes about three foot high bearinge by longe distances leaves like the former; the flowers growe at the topps of $y^{\mathrm{e}}$ stalks on very longe footstalks in greate spikes, of a delicate redd color, in fashion like those of broome, after followeth rough round flatt burrs, growinge likewise in spikes 4,5 or more fastened or growinge forthright one uppon another, or one at the toppe of another after a strange fashion, ech burr beinge verie like in fashion and biggnes to the burrs of Cynoglossum or Hounds tongue, everie burr inclosinge one small seed. The root [MS. ends abruptly].-MS. f, 106. 
Diotis maritima Cass.

Gnaphalium marinum.

Gerard pag: 515. The I \& 2 are both one.

The root is longe slender yealowish woodic and groweth deepe in the sande or gravell, and sendeth forth many small round branches and those againe devided into other branches about half a foot longe, besett with small short blunt topped leaves growinge all alongest the stalk very thick together, without footstalks. The whole herbe both branches \& leaves are covered over with a thick white delicate softe cotten like Guaphalium Americamum, called in English 'live ever' 'much whiter softer and more cottonic then anic of the other Cotton-weeds. Of a bitter tast and pleasant smell, somethinge like to sea wormewood. \| The flowers I obscrved not.

I found one plant hereof growinge on the seashoare on the south parte of the Iland of Haylinge in Hampsheire, the $20^{\text {th }}$ of August 1621. And brought it into my garden where the winter followinge it pcrished.-MS. f. 103 .

Sea $\mathrm{Heath}$. Frankenia laevis L.

An Polygoni marini species.

20 Augusti I62I

This hath one verie longe whitish root of the bignes of a wheate strawe, sett here and there with small threeds, creapinge farr into the sand or sea baich, which a little within the soile sendeth forth manie weake smooth greene branches sometimes devided into other branches three or fower ynches longe above the grounde, bearinge many smooth grasse greene short small leaves; somewhat round yet sharpe at the toppe, a little resemblinge Rubia minor flore rubro. There groweth at the topps of the branches very small whitish flowers ${ }^{1}$ contayninge 5 little round topped leaves a peece, no bigger then a pinns head, which perished without bearinge any seed at all.

\| This I found on the sea shoare in the west parte of the Iland of Haylinge in Hampsheire and in other places by sea likewise. I brought it into my garden where it flowred as aforesaid about the midle of May.-MS. f. 103 .

\section{Rhagadiolus cdulis Gaertn.}

Hieratium Narbonense falcitia siliqua L'obelij.

22 Augusti 1621

Ger. p. $285 \cdot(7)$.

The stalks are round hairy straked a cubite high or higher, devided into many branches: whereon growe broad rough greene leaves, very bluntly indented about the edges; the flowers are small and

1 Flo: in horto 21 Maij. 
yealowe like those of Lampsana. The seed is small browne somewhat longe, hairie at the toppe, not inclosed in downe, but within small heads, made of small short crooked hairie sharpe pointed husks, not exceedinge half an ynch in lenght, which open when the seed is ripe and spread abroad like larkes clawes starr fashion, and not before. The root is small hairie, full of milkie iuyce, as is also the whole plant, and perisheth when the seed is ripe.-MS. f. I01; Ger. emac. 1625 .

\section{Rhagadiolus edulis Gaertn.}

Hieracium stellatum Boelij.

22 Aug. I621

This plant is in round, hairy, straked, branched stalks, and longe, rough, blunt indented leaves like to Hieracium falcatum, but scarce a foot high : the flowers are also yellow three times smaller: which past, there succeed long crooked slender sharpe pointed cods or huskes, neere an inch long, spreading abroad, star-fashion, wherein a long seed is contained : this hath no heads or woolly down like any of the rest, but onely the said crooked coddes which doe at the first spread abroad. The root is small, threddie, full of milkie iuice, as is also the whole plant and it perisheth when the seed is ripe.MS. f. Ior ; Ger. emac. 1625.

\section{Tolpis barbata Gaertn.}

Hieracium medio nigrum flore maiore Boelij.

22 Aug. 1621

This hath at the first spreading upon the ground many long narrow, green, smooth leaves bluntly indented about the edges, like those of Hievacium falcatum, but smaller: amongst which rise up three, foure, or more, small, smouth, straked round stalks, divided into other branches, which grow longer than the stalks themselves leaning or trayling neere the ground : the flowers grow on the tops of the stalks, but one together, composed of many pale yellow leaves, the middle of each flower being of a blackish purple colour.-MIS. f. IOI ; Ger. emac. I625.

[In last line but one the MS. has 'yealowe flowers', doubtless rightly corrected to 'yeilow leaves' by the editor.]

Tolpis umbellata $\beta$ minor Lange.

Hieracium medio nigrum flore minore Boelij.

[22 Aug. I621]

This is altogether like the last before described in stalkes and leaves: the flowers are also of a blackish purple in the middle, but they are three times smaller.-MS. f. I0I ; Ger. emac. 1625.

Hieracium intybaceum $\mathrm{L}$.

Hieratium intybaceum.

[22 Aug. I62I]

This sendeth forth from one small root many rough leaves like 
those of wild Cicorie very much iagged and devided even to the midle ribbe a mongest which rise uppe many short round hairy straked browne redd little stalks a foot high or higher devided into one or two branches bearinge a fewe leaves lesser then the former at the topps of the branches growe greate doble flowers (bearinge many more leaves then Clusius spakes of) sometimes single only havinge the outer border of leaves of a pleasant reddish purple color. The seed is very longe \& browne with much white downe at the toppe inclosed in heads made of crooked husks or codds like those of Hieratium falcatum.-MS. f. $10 \mathrm{I}$.

Hieracium andryaloides Vill.

Hieracium lanosum.

[22 Aug. 1621]

There groweth from one root three, foure or more round upright soft cottonie stalks, of a reasonable bignesse, two foot high, divided into many branches. especially neere the top, whereon groweth at each division one broad sharpe pointed leafe, divided into corners, and very much crumpled, and also very soft cottonie and woolly, as is the whole plant: the flowers are small, double, of a pale yellow colour, very like those of Pilosella repens, growing clustering very many together at the tops of the stalkes and branches, forth of small round soft cottonic heads: these foure ${ }^{1}$ plants grew from seed which I received from $\mathrm{M}^{\mathrm{r}}$. Coys, 1620, and I made these descriptions by the Plants the 22. of August, 1621.-MS. f. IOI; Ger. emac. $1625-6$.

\section{Androsace maxima L.}

Androsace altera Mathioli. Ger. p. 425.

23 Aug. 1621

Hath many leaves spread abroad uppon the ground like those of plantaine but lesser with three sinewes, of a pale greene color, notched by the sides, full of iuyce, in tast somewhat sharpe: amongest which rise uppe six sometimes more small stallis a span high of an herbic color sometimes purple, naked somewhat hairie, which in the verie toppe hath a little crowne made of 5 smalle leaves hairy and notched like the lower leares but smaller from where growe forth $j$ or more little footstalks bearinge a little herbie hairie huske made also of 5 leaves notched also by the sides, which hath a small white flower in the midle devided into five parts.-MS. f. 102.

Bartsia Odontites Huds. var. alb.

Euphrasia 2 Dod. flo. albo.

Apud Bellmere pond.-MS. f. $53 \mathrm{v}$.

1 The MS. has ' 6 ', including the two descriptions not printed in Ger. emac. 
Climbing Fumitory. Corydalis claviculata DC. Fumaria claviculis donatis. Phyto 246 (4).

30 Aug. I621 At Southsea Castle in flower 30 Augusti 1621.-MS. f. $53 \mathrm{v}$.

\section{? Lapsana Zacintha L.}

Cichorium verrucatum.

I Sept. 162I

Hath at the first many longe iagged greene leaves like those of Cicorie but smaller, a little hairy \& very bitter, amongst which springe uppe round straked stalks 2 or 3 foot high, hairy belowe, smooth above, devided into branches, bearinge leaves on the lower parte like the former, but smaller towards the toppe. The flowers are like those of Cicorie but very small, yealowe \& growe on very short footstalks, forth of the bosomes, on the sides, and on the topps of the branches, which turne not into downe but into hard hedds, with a little tuft at the toppe, composed commonly of eight knotts, corners or bunches sett orderly round, wherein is the seed.

The root is white and short not much unlike that of Rapunculus, full of small branches \& little thredds. UThe whole herbe perisheth when the seed is ripe.-MS. f. I02.

Scorpinurus subvillosa L.

Scorpioides multiflorus Boelii.

I Sept. I62 I

This Plant is in creeping branches and leaves like the common Scorpioides bupleuri folio: the flowers are also alike, but a little bigger, and grow foure or five together on one foot-stalke: the cods are rougher, and very much turned round, or folded one within another: in all things else alike-MS. f. IO2; Ger. emac. 1627.

Scorpiumes vermiculata L.

Scorpioides siliqua crassa Boelii.

I Sept. I62I

This is also like the other in creeping branches and leaves: the flowers are something bigger than any of the rest, and grow not above one or two together on a foot-stalk: the cods are crooked, without any rough haire, yet finely checkquered, and seven times bigger than any of the rest, fully as big as a great Palmer-worme, wherein is the difference: the seed is almost round, yet extending somewhat in length, almost as big as small field Peason, of a browne or yellowish colour. This also perisheth when the seed is ripe.-MS. f. 102 ; Ger. emac. 1627.

$\mathrm{Sea} \mathrm{H}$ eath. Frankenia laevis L.

Polygonum alterum pusillo vermiculato, serpilli folia Penae. Ger. $453(3)$.

3 Sept. 1621

Hath many small round smooth hard woodie branches, somewhat 
reddish, traylinge on the ground 9 ynches or a foot longe: whereon by short distances on small ioynts grow tufts of very small short blunt topped smooth greene leaves, in a manner round, like those of the smallest time, but much smaller and without smell, devidinge it self at the bosomes of those leaves into small branches, on the topps of which branches growe small flowers, one flower on a branch and no more, consistinge of fower small round topped leaves a peece, of a faint or pale purplish color. I observed no seed. The root is woodie blackish without, very bitter with some tast of heate and groweth deepe into the ground. The leaves are nothinge so full of iuyce as Aizoon.

I found it flowringe the 3 of Sept. 1621 on the diches bancks at Burseldon Ferrey by the seaside in Hampsheire-MS. f. 89 and Ger. emac. 567 .

\section{Glasswort. Salicornia herbacea L.}

Kali album. Dodo. p. 81. minus, Adversar. p. I70. 3 Sept. 1621 Ger. hath it not.

Hath many small round straked branches sometimes standinge upright, sometimes traylinge on the ground. devided into other smaller branches, sett full of small longe narrowe whitish greene leaves, very full of saltish iuyce. The bosomes of the leaves are thick fraught with very small bunches, husks or little buttons, $\therefore$ hich opened there appeare very small short pale yealowe cheives, which are the flowers. The seed followeth which is [a blank space]. The root is verie small white threddie and perisheth at winter. This plant doth at the first viewe before you come very neere it appeare like yonge broome--MS. f. 1 II .

Nigella sp.

Nigella flore albo pleno.

[3 Sept. 162I]

is the fourth in Ger. p. 925 accordinge to the description.-MS. f. $1 \mathrm{~J} 1$.

\section{Nigclla Damascena L.}

Nigella multiplex.

Melanthium Damascenum flore pleno Clus.

$5^{\text {to }}$ Sept. I62I

The doble damaske Nigella hath small round smooth tough stalls, devided into verie many branches, whereon growe the leaves which are exceedinge small like thredds, veric finclie iagged and of a darke greene color: at the toppe of ech stalk and branch groweth one faire doble flower of a pale or whitish blewe color, and close underncath ech flower groweth five iagged leaves altogether like those on the stalks. The seed is inclosed in a head like the 
former and is [a blank space]. The root is small and yealowe with some threeds. The whole plant (except the doblenes of the flowers) is like the single Damaske Nigella.-MS. f. II I.

\section{Nigella hispanica L.}

$5^{\text {to }}$ Sept. I62 I

Nigella elegans ex Hispania.

This beutifull Nigella hath small round straked upright stalks, devided into branches, whereon growe iagged leaves of a pale greene color, whose iaggs are not so broad as those of Nigella flore albo pleno, nor so narrowe or small as those of Nigella Damascena. At the toppe of ech stalk and branch groweth one greate pleasant flower, bigger then anie of the other sorts of Nigella, made of 5 sharpe pointed wrinckled leaves, everie leafe beinge about an ynch both in lenght and bredth, of a beutifull purple color above, and of a whitish greene with a little shewe of purple underneath. In the midle of the flower groweth the head havinge sometimes but 7 or 8 most comonlie 12 or 13 hornes, at the first small of a deepe murrey or obscure browne redd color, about which groweth manie cheives of the same color, next and close above the leaves of the flower, there groweth spread abroad 8 small forked leaves of a blewe color, with a reddish line crossinge them at the first, and afterwards havinge a white line close adioyninge, and one small short pointell appearinge neare the midle of ech of those leaves. The leaves of the flowers beinge readie to fall away, the heads appeare greater, and are rough sett as it were with fine redd spotts, and the hornes are wound or turned round in the end.-MS. f. II I.

[Both of these descriptions of Nigellas were sent to Johnson but were not included in the Herbal, cf. p. I085.]

\section{Convolvulus purpureus L. var.}

Convolvulus coeruleus Bryoniae nigraefolio.

flos Noctis. non script.

Hath manie small weake round hairie browne redd branches, growinge from one root, windinge wrappinge and turninge them selves against the sunne, round sticks or poles that are sett by them for that purpose: whereon by certaine distances growe greate broad leaves, in a manner round, yet picked at the toppe, without anie corners like Ivie leaves, verie like those of Bryonia nigra but rounder, somewhat rough above and smooth underneath. Forth of the bosomes of the leaves growe longe slender hairie footstalks, on the toppe whereof growe 2 or 3 most beutifull flowers, not flowringe all at a time but one after another, those that will open in the morninge make some small shewe overnight, onlie wound together, and not of half their growth, erlie in the morninge they appeare in 
their full lenght, but ioyned close together with 5 corners, which after in a short time open and are round like a little bell, like those of white Bindweed, but of a delicate Azure or as it were a color of blewe and redd mixed together, with five straight strakes or lynes in the inside like redd darke colored crimson velvet. This glorious shewe continueth but awhile, for towards night the same daie that they open, they beginn to vade and fold themselves in together at the toppe, and never open againe, and the next daic fall quite away. Quaere, whether they do always so.-MS. f. IIo.

\section{Centanrea salmantica L.}

Stoebe Salmantica $j^{m a}$ Clusii foliis Cichorei.

8 Sept. 162 :

Hath at the first large leaves about a foote and a half longe spread abroad uppon the ground unorderly iagged eren to the midle ribbe and those iaggs are indented about the edges sawe fashion, but not devided into other iaggs, ech small indentinge endinge with a weake sharpe prickley point verie thick sett with fine softe cotton-like hairines somewhat like the devided leaves of Cichorie amongst which riseth uppe a round straked stalk $j$ or six foot high. devided into many branches, of a browne reddish color, with a softe hairines like that on the leaves towards the root, whereon growe leaves like the former but lesser and lesser upwards on the stalk, the stalk and branches beinge very little or nothinge at all hairy towards their topps, and bearinge very narrowe prickley topped leaves almost without haires, not devided like the former, but onlie deepelie indented, endinge with sharpe but weake pricks. At the toppe of ech stalk and branch groweth one head sett on the outside with smooth scales, ech scale endinge with a very small short harmelesse prickle, out of the toppe whereof groweth abundance of pale purple cheives very like the flowers of Carduns vulgatissimus, or Carduns bulbosus monspel. and not unlike the flowers of Jacea, but havinge no larger spreadinge flowers on the borders like it, or like the flowers of Cyranus.-MS. f. 92.

Anthemis tinctoria L.

Buphthalmum vulgare. primum Matthioli.

9 Sept. 1621

Hath manie small round straked brittle branches cominge from one root about 2 foot high, and those againe devided into other branches covered with a little thinne white cottonlike woollines whereon growe the leaves of a whitish greene color, spreaci abroad devided into many parts and those small devisions are finelie iagged or minced like the leaves of Tansic but much smaller. On the topps of the stalks and branches growe the flowers somethinge like those 
of Chrysanthemum segctum but smaller no bigger then Camomill flowers not onlie havinge a greate yealowe ball or dish in the midle but also those small leaves which compasse the ball and likewise of a bright yealowe color and are finely nickt at the toppe and comonlie two, three, fower or five \& twentie in number.-MS. f. IIO.

\section{? Papaver hybridum L.}

Argemone Pavio.

9 Sept. I62I

Hath manie round hairie stalks or branches proceeding from one root about 3 foot longe whereon growe longe iagged leaves full of white milk-like iuyce as are also the branches. At the topps of the branches growe greate flowers havinge 4 greate round topped leaves a peece of a light redd or crimson color. The heads or seed vessells are small smooth three quarters of an ynch longe, wherein is contayned plentie of exceedinge small seed of a yealowish redd color. The root is small and perisheth when the seed is ripe. This herbe is like Papaver Rhoeas in leaves, stalks, flowers \& milkie inyce, but the stalks are longer, the flower much paler $\&$ the seed vessels longer.-MS. f. II 3 .

Papaver Rhoeas $\beta$ setigerum Boenn.

Papaver Rhoeas Baeticum.

[9 Sept. I62I]

I cannot discerne wherein it differeth from our comon Papaver Rhoeas.-MS. f. I1 3 .

\section{Achillea nobilis $\mathrm{L}$.}

Achillea sideritis. Tanacetum minus Dodo: Achillea Math: p. 213 . Achillea, sine millefolium nobile Gerardo, p. 915. 9 Sept. 162 I

Hath sometimes 4,5 or more round hard stiffe straked stalks proceedinge from one root, and those sendinge forth even from the root to the toppe many small side branches, whereon growe very manie small iagged leaves, devided into many smaller parts, somethinge like those of Buphthalmum $j^{m}$ Matthioli but not so finelie minced or iagged, the small side branches of the leaves verie well resemblinge Cormu Cervinum Lobelij, of a whitish greene color and of a stronge smell but not unpleasant, verie hott and bitter in tast. On the topps of the stalks and branches growe large umbells of small white flowers verie like those of Comon yarrowe in smell like the herbe.-MS. f. II 3 .

\section{? Alchemilla alpina L.}

Heptaphyllum maius. Phyto. 65I. (8).

II Sept. 162I

The stalks growe upright and are round firme somethinge hairie of a reasonable bignes 2 or 3 foot high devided neare the toppe into many small branches, the leaves growe on longe hairie 
footstalks out of order, everie leafe beinge usuallie devided into 7 leaves deeplic notched or indented by the sides, and those that growe next the ground are comonlie 4 or 5 ynches longe and neare 2 ynches broad altogether like in color and fashion to the Comon Cinckfoile. The flowers growe on the branches of a pale yealowe color, made of 5 broad topped leaves, with a blunt nick at the toppe of ech leafe, and are manie in number and flower one after another, whereby it continueth longe in flowringe: the seed is small and browne contayned in leafie husks or hedds. The root is short and small brown without and white within with many strings or small roots growinge from the upper parte thereof, and is perennis.- $M S$. f. 113 .

\section{Lamium Orvala L.}

Lamium Pannonicum $2^{m}$ exoticum Clusij, p. xxxviij. I I Sept. I62 I

This strange Lamium the first yere after it is sowen, hath leaves almost round, very like nettle leaves, but for the most parte much bigger, with a fine softe hairines, and whilest they are yonge covered with a fatt clammie matter as it were a dewe, indented by the sides, growinge on longe softe hairie footstalks; amongest which leaves, the springe after the sowinge, there groweth uppe hollowe stalks, 3 or 4 foot high, eyther fower square or with six corners (for there are comonlie of both sorts growinge from one root) also covered with a softe hairines, alongest which by certaine distances, on short footstalks, growe sometimes 2 sometimes 3 leaves, allwaies one right against another lesser and shorter then the other: out of whose bosomes growe sometimes 2, sometimes 3 (accordinge to the number of the leaves) small hairie footstalks, an ynch longe bearinge 3 or + flowers or more, of the bignes of a pease, which are of a pale yealowish greene color, hollowe within, with a small hole at the toppe, out of which groweth a fewe small short cheives; after the flowers there succecd small sharpe pointed heads almost like those of flax, but more like those of the Common Scrophularia, full of very small black seed. The root is crooked with many small hairie threeds like that of the nettle, whose stalks perish in the winter sendinge forth other againe at the springe, and sometimes before winter, and flowringe againe as at the springe.

II I receaved the seeds which produced this plant, with many other from the most worthic English Herborist, my very good frend Mr. William Coys often remembred.-MS. f. I1 2.

\section{Clary. Salvia Verticillata L.}

Horminum silvestre tercium Clusij, p. xxix.

? [ 13 Sept. 162I]

Hath at the first hairie leaves spread uppon the ground about 
five ynches broad and 5 ynches longe, bluntlie indented by the edges, almost round at the toppe: amongest which rise uppe square hairie kneed stalkes about a foot or cubite high, bearinge leaves by cooples one opposite against another, like the former but lesser and more sharper pointed, sometimes with two little leaves like eares growinge on the footstalks of the leaves, of no ill or stronge smell, the stalks devide them selves into braunches at the bosomes of the leaves. The flowers are of a blewish purple colour (lesser then the flowers of Clarie, and scarce bigger then Lavender flowers) growinge in whorles to the verie toppes of the stalks and braunches makinge longe spikes, which comonlie bowe or turne their toppes downewardes, without anie leaves growinge amongest them. The seed [blank]

The roote is greate of a finger bignes growinge downeward into the earth, a foot deepe or more, with a fewe side braunches, black without, hard lastinge, yerelie sendinge forth newe braunches.

It groweth not wild in England, the seed hereof I receaved from Mr. William Coys with many other, in Anno I620.-MS. ff. I I, I I 5 .

[Rough draft of a description sent to Johnson, March 5, I633, but not acknowledged by him.]-MS. f. I I.

\section{Cynosurus echinatus L.}

Gramen cristatum Baeticum Boelij.

I3 Sept. I62I

Hath many round ioynted stalks growinge from one root, a cubite or 2 foot high, and greate longe leaves like Barley. At the toppe of ech stalk groweth one eare or rather a one sided bunch, an ynch broad and somethinge above an ynch longe, onlie growinge on one side of the toppe of the stalk, so that it maketh as it were half an eare, with small queveringe cheive-like flowers, like those of other grasse, and, verie thick sett with small whitish haires makinge the whole eare appeare like a catts beard; the seed is small longe and brownish somewhat like that of Psyllium, but nothinge so black, inclosed in very small whitish bearded husks. The root is verie small beinge nothinge but verie small white threddie strings, and perisheth when the seed is ripe. II This grasse is not yet described that I find of. The seeds were gathered by Boelius a lowe Contrey man in Baetica a parte of Spaine and given to that diligent preserver of simples Mr. William Coys often with very good cause remembred, who imparted seeds hereof to me in Anno 1620.-MS. f. 99.

[Goodyer himself noted that this species was 'Gramen alopecuroides spica aspera' and that it was found 'by $\mathrm{y}^{\mathrm{e}}$ adiacent pts of Shepey'. $M S$. II, f. I33. See p. 59.] 
Briza maxima L.

Gramen tremulum maximum.

13 Sept. 1621

an Phyto. p. IO. No. xxxviii. Gramen lupuli glumis Boelij.

This hath many small round smooth ioynted stalks, 2 or 3 foot high, with longe broade smooth leaves like those of otes or barley. at and neare the toppe of ech stalk groweth scatteringlie or somewhat farr apart, about 7 or 8 flatt eares the topps hanginge downwards, about 3 quarters of an ynch longe, and a quarter of an ynch broad, made of 2 rowes of fine thinn scales, curiouslie foldinge one within another, verie like those of the comon Phallaris pratensis but 8 times bigger, which eares in a close roome you cannott hold so still, but they will wagge and tremble, their footstalks beinge so longe and small, no bigger then small haires. The seed is verie small, flatt and browne, in a manner round, one seed and no more inclosed at the inner end of ech scalie huske. The root is made of small white thredds, and perisheth when, the seed is ripe. i) The seeds also of this grasse were given by Boelius to Mr. William Coys by the name of Gramen lupuli glumis, who afterwards in Anno I620 sent seeds thereof to me.-MS. f. 99.

\section{Lactuca virosa $\mathrm{L}$.}

Lactuca silvestris vera ingrato odore.

Hist. lug. p. 547 , optima figura. Phyto. p. $202 \mathrm{~N}^{\circ}$ xii.

This wild lettise hath at the first many broad leaves spread uppon the ground, like to garden lettice leaves, whiter on the underside then above, sometimes a foot longe and 5 yinches broad, broadest neare the toppe, with a greate ribbe or sinewe underneath full of sharpe pricks, and many other small branches sinewes full also of little pricks, very little nicked and crisped by the sides, but nothinge at all gashed, yet also full of small pricks, amongst which groweth uppe a sreate upright round stiff prickley browne reddish stalk, full of white pith like that of the elder, usuallie 5 or 6 foot high, (sometimes 10 foot high as I observed this yere I62I) devided into many parts or branches, on the lower parte whereof groweth leaves like the former, but upwards on the stalk they are smaller shorter without footstalks, gashed or devided with decpe devisions. The topps of the stalks and branches are garnished with manie small yealowe flowers, like in forme and bignes to those of the common lettice, flowringe one after another, which maketh it longe in flowringe: the flowers past there succeed flatt blackish seed like to lettice seed, with downe at the toppe and is caried away with the wind and reneweth itself by the fallinge thereof, 
which quicklie groweth and sendeth forth such broad leaves as aforesaid spread uppon the ground and remaine greene all the winter, sendinge then forth such stalks as is aforesaid. The root is hard woodie sometimes devided into branches yealowe without \& groweth deepe into the earth. The whole herbe and root is full of clammie white iuyce like milk, and of a very loathsome stinkinge smell, which on the stalks sometimes turneth into a yealowish gummie matter.

|| This wild stinkinge lettice I found wild on the walls and dry bancks of earth at Southampton. Anno I6I8.-MS. f. 99.

\section{Lactuca agrestis $\mathrm{L}$.}

Lactuca agrestis.

I3 Sept. I62I

This hath not leaves spread abroad uppon the ground like the former, but riseth uppe presentlie with a small round stiffe stalk prickley only belowe 3,4 or 5 foot high, devided into very manie branches, whereon growe manie pale greene plaine smooth leaves with many pricks on the midle ribbe on the lower side and also by the edges, the sides or edges are somewhat indented but not at all crisped gashed or devided, sometimes 6 or 7 ynches longe and 3 ynches broad or broader, broadest comonly in the midle and narrowe towards the toppe. The flowers are also yealowe like those of the lettice, and turne into a small grey seed with downe at the toppe which is caried away by the wind, by the fallinge whereof it encreaseth and sendeth forth other yonge plants, with short tender stalks, which remaine greene all the winter, and in the springe growe uppe as aforesaid. The root is hard threddie and yealowe without. The whole herbe is also full of white, milk-like iuyce and of little or no smell at all, and perisheth when the seed is ripe. $-M S$. f. 100 .

\section{Oenothera biennis L.}

Lysimachia virginiana.

13 Sept. 1621

This riseth uppe with a stalk about 3 foot high, which is round straked firme hard brittle full of pith within, reddish neare the root, devided into manie branches, and spotted with very small purple spots: whereon growe the leaves out of order without footstalks 5 or 6 ynches longe and above an ynch broade, smooth sharpe pointed verie bluntlie indented about the edges, with a whitish midle ribbe, hott in tast and bitinge the tonge. The flowers are yealowe and growe forth of the bosomes of the leaves neare the topps of the stalk flowringe upwards by degrees, whereby it continueth longe in flowringe, and growe uppon longe tender stems everie 
flower havinge 4 broad topped leaves, and a short yealowe pointell not appearinge above the topps of the leaves of the flower, devided in the toppe into 4 parts, cverie part beinge bigger then the lower parte of the pointell, and also yealowe cheives growinge from the nailes of the inner partes of leaves of the lenght of the pointell, which flowers are of a strong fulsome smell, and both they and their tender stems fall away, and there groweth uppe greate longe blunt topped, round straked codds, without anie footstalks, makinge a longe spike of codds, wherein is contayned much small round wrinckled seed which when it is ripe the codd openeth into 4 or 5 parts at the toppe and the seed falleth forth and at the next springe groweth uppe whereby it mightelie increaseth. $M S$. f. 100 .

\section{Nicotiana Tabacum var. brasiliensis Comes.}

Petum indicum folio pene obtuso.

I3 Sept. I62I

Ye figure in Hist. Lug. p. I 895 resembleth it well. Peti primum genus Clusii, p. ex: 309 .

This groweth uppe with a greate round stalk devided into many braunches, five or six foot high, verie hairie fatt and clammie; whereon growe greate broad leaves, somewhat round towards the toppe yet endinge with a sharpe point, narrower \& crompled towardes the stalkes, without footstalkes, imbracinge or growinge 2 or 3 ynches downe on both sides of the stalk, belowe the fasteninge or growinge of the midle ribbe to the stalke, about 20 ynches longe, and above a foot broad, also verie fatt clammie and rough, of a yealowish greene color, of a good savor and verie sharpe tast. The flowers growe on the toppes of the branches, and are longe, hollowe, in manner of a little pipe or bell, broad at the toppe, endinge with corners most comonlie 5 sometimes 4 somewhat blunt not verie sharpe, of a pale or whitish purple colour; which fallen there cometh small longe round sharpe pointed heddes or seed vessels lesser longer and sharper pointed then those of yealowe IIenbane, in which is included abundance of exceedinge small blackish redd seeds, much lesser then poppie seed. The roote is thicke, woodie, branched and yealowish. The whole plant perisheth at the first approach of winter, if it be not planted in an earthen pott or other fitt vessell, and putt into a close place to defend it from the iniurie of the cold.

The seedes of this Tabacco I receaved Anno 1620 from my worthic friend, and most diligent observer and preserver of simples Mr. William Coys of North-okington in Essex.-MS. ff. 93, IJ 4. 
Nicotiana Tabacum var. fruticosa Hook. f.

Petum indicum folio Hydrolapathi acuto.

$I_{3}$ Sept. I62I

The stalkes are also round and branched, somewhat hairie and clammie, the leaves growe also without footstalkes half compassinge the stalkes, yet sometimes exceedinge narrowe towards the stalkes, generally much narrower and longer then the former, comonly 2 foot, 2 foot and a half and sometimes 3 foot longe, and usuallie 6 or 7 ynches broad or broader, not round towards the toppe like the former, but verie sharpe and slender pointed, smoother greener and nothinge so clammie as the other, also of a sharpe bitinge tast, and are in forme like the leaves of the greate water docke, the flowers are also of a light purple colour, but smaller endeinge with 5 sharpe pointed corners, much sharper then the former. The seed is like the former inclosed in the like huskes, but somewhat sharper pointed. The roote is also like and must be preserved from the cold as the other.

In Anno 16I9 I receaved the seedes hereof from Mr. Anthony Uvedale who that yere intended to plante greate store hereof, and was hindered of his purpose by a proclamation sett forth by Authoritie.-MS. ff. 93, II 4 .

Nepeta tuberosa L.

Cattaria tuberosa radice Boetica Boelii. non scripta.

14 Sept. 1621

Hath 2, 3 or more square upright stalks, somewhat hairie, two foot high or higher, sometimes leaninge towards or lyinge flatt on the ground, devided into many square branches growing allwaies one right against another, whereon growe leaves by cooples one right against another, sometimes with short hairie footstalks, but most comonly espetially on the upper parte of the stalk, with very short or no footstalks at all, full of crumpled vaines or sinewes, and large blunt notches by the sides, like those of the comon neppe, but not so broad, of the same pleasant smell, but not so stronge, and but a little hott and bitinge the tonge, sometimes covered all over with a softe hairie cottonie whitenes, as though a white frost laie thereon. On the upper parte of the stalks and branches growe by certaine distances one from another crownetts or whorles of manie small scalie leaves, somewhat reddish at the topps and by the sides, compassinge the stalks : whereof two that are lowest and biggest, and growe allwaies one right against another, amongst which on the upper parte growe many blewish purple flowers (those small scalie leaves and flowers makinge the entier whorle or crownett) in fashion like those of the comon neppe, but neare as 
bigge againe, of verie little smell: the severall whorles makinge a spike sometimes of above a foot longe.

The seeds hereof I receaved from Mr. Coys in $\mathrm{A}^{0} .1620 .-M T S$. f. 96.

Nepeta media.-MS. f. $9^{6 .} \quad(?=$ Nepeta Cataria L. var.)

[No description.]

? Sinapis alba L.

Sinapi sativum alterum Penae.

Adversar, p. 68. Lob. icon. p. 277. pte $2^{\mathrm{a}}$.

[? I4 Sept. I62I]

Hath one stalk growinge from the root, which is round hollowe straked hairie or rough 2 or 3 foot high, without knees devided into verie many branches even from the root. The leaves are greate and growe at the devisions of the stalk, with a verie little roughnes, torne and devided into many partes even to the midle ribbe. The flowers growe on the topps of the branches floweringe upwards and are yealowe, very like those of comon musterd but bigger, and so like those of comon cherlock that they are hard to be knowne the one from the other, contayninge + broad topped shrivelled leaves apeece: after the flowers cometh rough hairie codds growinge all alongest the upper parte of the stalk and branches, bigger and more spreading abroad then those of Cherlock, half whereof in lenght towards the toppe is broad and flatt like to the point of a speare yet blunt topped, and in the lower parte thereof towards the stalk is contayned 2 rowes of seedes, havinge 3 or 4 round seeds in ech rowe, either of a white grey or reddish color; three times bigger then comon musterd seed, and sometimes neare as bigge as Radish seed, hott and bitinge the tonge like pepper, bunchinge out the codd where they lie, and when they are ripe doe fall out with a light touch leavinge behind on the stalk the midle(?) devision which is a thinn cleare membrane or skinne and the speare like point of the codds which continueth on a longe time after. The root is small white threddie and perisheth when the seed is ripe, and reneweth it self yerelie by the fallinge thereof.-MS. f. 96 .

Bluc Fleabane. Erigeron acre L.

Conyza coerulea acris, C. Bau. Conyza odorata. 20 Sept. I62I

Hath at the first many hairie leaves 2, 3 or 4 ynches longe, spread uppon the ground without footstalks, veric slender and narrowe belowe, and half an ynch broad towards the toppe, plaine and not indented by the edges, hott in tast and bitinge the tonge, of a reasonable grood smell: amongest which rise uppe 2,3 or more small round browne redd straked hairie stalks, full of white pith within, a foot or a cubite high seldome devided into branches on 
the lower pte, whereon growe hairy leaves out of order without footstalks, like the other but much shorter and smaller, about an ynch and a half longe, and a quarter of an ynch broad comonly turninge downewards, with other very small short leaves growinge forth of their bosomes, or els very short stubbed branches. On the upper pte the stalke is devided into many small short branches, bearinge at the toppe of ech branch one little head, made on the outside of many verie slender narrowe hairie stalks comonly reddish, on the upper parte of the head groweth verie manie small narrowe short leaves no bigger than cheives of a pale or light purple color, seldome spreadinge abroade, but growinge upright, which together with the head are about half an ynch in lenght: next within these leaves and verie neare of their lenght even at their first openinge, appeareth a round circle of pale yealowish downe, which in the midle of the flower is of a dark browne color and in the ende spreadeth abroad and contayneth underneath much small yealowish seed, which together with the downe is caried away with the wind. The whole head rubbed betwene the fingers is of a good smell. The root is nothinge but small white thredds and dyeth not at winter. || I first found this herbe growinge wild on the walls at Winchester in Hampsheire, afterwards in other places on dry bancks, but very seldome.-MS. f. 95 .

\section{Ivy-leaved Toadflax. Linaria Cymbalaria Mill.} Cymbalaria Italica. 20 Sept. I62I

Cymbalaria with us in England, where it is sowen runneth and spreadeth on the ground and clymeth and hangeth on walls even as Ivie or Chickweed doth, the branches are verie small round and smooth, limmer and pliant neare like the hampering threeds of Cuscuta devidinge it self plentifullie into other branches and sendinge forth other small threddie roots takinge hold therewith on the earth or walls. The leaves growe on long round footstalks and are like those of Ivie smooth and devided into moe corners, the flowers growe also on longe footstalks forth of the bosomes of the leaves like single violetts but smaller, nearer like the flowers of Elatine consistinge of 2 leaves, whereof the uppermost is on the upper parte of a light purple color and devided at the toppe into a parte, the lower leafe is three times bigger, of a pale or whitish color with a verie light dash of purple, and the midle or chappe is yealowe, devided belowe into 3 pts, with a small purple taile behind hanginge downervards, which fallen there succeedeth in the place of the flower some little round knappe or button contayninge small seed. 
II I never saw this growinge but in the garden of my faithfull good frend Mr. William Coy's in Northokington in Essex, and in my garden at Droxford of seeds receaved from him in Anno 1618.MS. f. 95 .

[The first mention of English Cymbalaria is in Coys' Garden-List of 1617, p. 317 . It is a pleasure to note that after the lapse of 245 years the original station for this plant in Great Britain should be noted by Gibson, Flora of Essex, 1862, on the authority of Edw. Forster, as 'Old wall at Stubbers', and we ourselves found it there in 1921. Parkinson noted the plant 'about Hatfield' in 1640.]

Scabiosa atropurpurea L.

Scabiosa flore rubro. Scabiosa sexta Indica Clusii. 8 Oct. I621

Hath one round tender stalk proceeding from the root, about 3 or + foot high, devided into branches ymediately from the root: whereon growe leaves by cooples much devided as it were leaves sett uppon a midle ribbe and are verie narrowe towards the toppes of the stalk and branches, almost smooth yet havinge a little soft hairines as have also the stalk and branches, in forme like those of Scabiosa minor sive Columbaria lobelii. The flowers growe on the toppes of the stalk and branches like the said Scabiosa media, but of a delicate redd color like to redd velvett, with many small cheives, with quaveringe topps, at the first of a light purple, after of a dustie whitish color, ech head beinge composed of many small flowers closelie thrust together, and ech flower is devided into 5 ptes or leaves those that growe on the outside or border of the head are greater and longer then those in the midle, allwaies having close underneath ech head, a rowe or circle of small short narrowe greene leaves growinge starr fashion. The seed

The root [MS. incomplete].

\| This plant I sawe flowringe and bearinge ripe seed in the garden of my most worthic friend and diligent preserver of plants Mr. William Coys, in Northokington in Essex, the 29 of September 1622. Seeds hereof I also receaved from him in Anno I620.MS. f. 94.

Jacea palustris Bactica Boelii.-MS. f. 94.

Io Oct. I62 I

[No description.]

Centaurea nevadensis Boiss. \& Reut.?

Jacea capitulis hirsutis Boelii.

Io Oct. 1621

This hath many small conered stralied hairie trayling bramches growing from the root, and those arain divided into many other branches, trailing or spreading upon the ground three or foure foot 
long, imploying or covering a good plot of ground, whereon grow hairy leaves divided or iagged into many parts, like the leaves of Iacea maior, or Rocket, of a very bitter taste: at the top of each branch groweth one scaly head, each scale ending with five, six, or seven little weake prickles growing orderly like halfe the rowell of a spurre, but farre lesser: the flowers grow forth of the heads of a light purple colour, consisting of many smal flowers, like those of the common Iacea, the bordering flowers, being bigger and larger than those of the middle of the flower, each small flower being divided into five small parts or leaves, not much unlike those of Cyanus : the seed is small, and inclosed in downe. The root perisheth when the seed is ripe.

\| This plant hath not been hitherto written of that I can find. Seeds of it I received from $\mathrm{M}^{\mathrm{r}}$. William Coys, with whom also I observed the plant, Io October. I62I. he received it from Boelints a Low countrey man.-MS. f. 94; Ger. emac. 729.

Cucurbita Pepo L. var.

Macocks Virginiani.

10 Oct. 1621

The Virginian Macocke, or Pompion.

This hath rough cornered straked trailing branches proceeding from the root, eight or nine foot long, or longer, and those againe divided into other branches of a blackish greene colour, trailing, spreading, or running alongst the earth, covering a great deale of ground, sending forth broad cornered rough leaves, on great grosse, long, rough, hairy foot-stalks, like and fully as big as the leaves of the common Pompion, with clasping tendrels and great broad shriveled yellow flowers also like those of the common Pompion: the fruit succeedeth, growing alongst the stalkes, commonly not neere the root, but towards the upper part or toppes of the branches, somewhat round, not extending in length, but flat like a bowle, but not so bigge as an ordinarie bowle, beeing seldome foure inches broad, and three inches long, of a blackish greene colour when it is ripe. The substance or eatable part is of a yellowish white colour, containing in the middest a great deale of pulpe or soft matter, wherein the seed lyeth in certaine rowes also, like the common Pompion, but smaller. The root is made of many whitish branches, creeping far abroad in the earth, and perish at the first approch of Winter.-Ger. emac. 9I 9 .

Citrullus vulgaris Schrad.

Melones Aquatici. The Virginian Water-Melon. Io Oct. 1621

This Melon or Pompion is like and fully as bigge as the common 
Pompion, in spreading, running, crecping branches, leaves, flowers, and clasping tendrels: the fruit is of a very blackish greene colour and extendeth it selfe in length neere foure inches long, and three inches broad, no bigger nor longer than a great apple, and grow alongst the branches forth of the bosomes of the leaves, not farre from the root even to the toppes of the branches, containing a substance, pulpe, and flat seed, like the ordinary Pompion: the root is whitish, and disperseth it selfe verie farre abroad in the earth, and perisheth about the beginning of Winter.-Ger. emac. $92 \mathrm{I}$.

\section{B a sil. Ocimum Basilicum L.}

Acinos odoratissimum.

Il Oct. I6 21

This herbe hath foure, five, or more, foure square hard wooddy stalkes growing from one root, divided into many branches, covered with a soft white hairinesse, two or three foot long or longer, not growing upright, but trailing upon the ground; the leaves grow on little-short footstalkes by couples of a light greene colour, somewhat like the leaves of Basill, very like the leaves of Acinos Lobelij, but smaller, about three quarters of an inch broad, and not fully an inch long, somewhat sharpe pointed, lightly notched about the edges, also covered with a light soft hoary hairinesse, of a very sweete smell, little inferiour to Garden Marjerome, of a hot biting taste: out of their bosomes grow other smaller leaves, or else branches; the flowers also grow forth of the bosomes of the leaves toward the tops of the stalkes and branches, not in whorles like the said Acinos, but having one little short footstalke growing forth of the bosome of each leafe, on which is placed three, foure, or more small flowers, gaping open, and divided into foure uncquall parts at the top, like the flowers of Basill, and very neare of the likenesse and bignesse of the flowers of Garden Marjerome, but of a palc blewish colour tending towards a purple. The seed I never observed by reason it flowered late. This plant I first found growing in the garden of $\mathrm{M}^{\mathrm{r}}$ William Yalden in Sheete near Petersficld in Hampshire, Anno 1620, amongst swecte Marjerome, and which by chance they bought with the seedes thereof. It is to be considered whether the seedes of swecte Marjerome degencrate and send forth this herbe or not, II October 1621.-Ger. cmac. 677.

[See 1620.]

Jerusalem Artichokc. Hclianthus tuberosus L. Heliotropium Indicum.

I7 Oct. 1621

Flos solis Pyramidalis, parvo flore, tuberosa radice.

This wonderfull increasing plant hath growing up from one root, 
one, sometimes two, three or more round green rough hairy straked stalks, commonly about twelve foot high, sometimes sixteene foot high or higher, as big as a childs arme, full of white spungious pith within. The leaves grow all alongst the stalkes out of order, of a light green color, rough, sharp pointed, about eight inches broad, and ten or eleven inches long, deeply notched or indented about the edges, very like the leaves of the common flos solis Pervanus, but nothing crompled, and not so broad. The stalkes divide themselves into many long branches even from the roots to their very tops, bearing leaves smaller and smaller toward the tops, makinge the herbe appeare like a little tree, narrower and slenderer toward the top, in fashion of a steeple or Pyramide. The flowers with us grow onely at the toppes of the stalkes and branches, like those of the said flos solis, but no bigger than our common single Marigold, consisting of twelve or thirteene straked sharpe pointed bright yellow bordering leaves, growing foorth of a scaly small hairie head, with a small yellow thrummie matter within. These flowers by reason of their late flowering, which is commonly two or three weeks after Michaelmas, never bring their seed to perfection, \& it maketh shew of abundance of small heads neere the tops of the stalkes and branches forth of the bosomes of the leaves, which never open and flower with us, by reason they are destroyed with the frosts, which otherwise it seemes would be a goodly spectacle. The stalke sendes foorth many small creeping roots, whereby it is fed or nourished, full of hairie threddes even from the upper part of the earth, spreading farre abroad: amongst which from the maine root grow forth many tuberous roots, clustering together, sometimes fastened to the great root it selfe, sometimes growing on long strings a foot or more from the root, raising or heaving up the earth above them, and sometimes appearing above the earth, producing from the increase of one root, thirty, forty, or fifty in number, or more, making in all usually above a pecke, many times neere halfe a bushell, if the soile be good. These tuberous roots are of a reddish colour without, of a soft white substance within, bunched or bumped out many waies, sometimes as big as a mans fist, or not so big, with white noses or peaks where they will sprout or grow the next yeare. The stalkes bowed downe, and some part of them covered over with earth, send forth smal creeping threddie roots, and also tuberous roots like the former, which I have found by experience. These tuberous roots will abide alive in the earth all winter, though the stalkes and rootes by the which they were nourished utterly rot and perish away, and will beginne to spring 
up againe at the beginning of May, seldome sooner.-MS. f. I I6;

Ger. emac. $753-54$.

[For Goodyer's descriptions of The Place and The Vertues which follow see p. 24 , also p. 109.]

Y ew. Taxus baccata L.

Taxus glandifera baccifera.

19 Dec. 1621

The Yew bearing Acorns \& berryes.

The Yew tree that beareth Acornes and berries is a great high tree remaining alwaics greene, and hath usually an huge trunke or body as big as the Oke, covered over with a scabbed or scaly barke, often pilling or falling off, and a yong smooth barke appearing underneath; the timber hereof is somewhat red, necre as hard as Box, universally covered next the barke with a thicke white sap like that of the Oke, and hath many big limmes divided into many smal spreading branches: the leaves be about an inch long, narrow like the leaves of Rosemary, but smooth, and of a darker greene colour, growing all alongst the little twigs or branches close together. seldome one opposite against another, often having at the ends of the twigs little bunches composed of many leaves like the former, but shorter and broader, closely compact or ioyned together: amongst the leaves are to be seene at all times of the yeare, small slender buds somewhat long, but never any flowers; which at the very beginning of the Spring grow bigger and bigger, till they are of the fashion of little Acornes, with a white kernell within: after they are of this forme, then groweth up from the bottomes of the Acornes a reddish matter, making beautiful reddish berries more long than round, smooth on the out side, very clammie within, and of a sweet taste, covering all the Acorne, onely leaving a little hole at the top, where the top of the Acorne is to be seene: these fallen, or devoured by birds, leave behinde them a little whitish huske made of a few scales, appearing like a little flower, which peradventure may deceive some, taking it to be so indeed: it seemes this tree, if it were not hindred by cold weather, would alwaies have Acornes and berries on him, for he hath alwaies little buds, which so soone as the Spring yeelds but a reasonable heate, they grow into the forme of Acornes: about the beginning of August, seldome before, you shall finde them turned into ripe berries, and from that time till Christmasse, or a little after, you may see on him both Acornes and red berries.MS. f. 119; Ger. emac. 1370. 
Ma le Yew. Taxus baccata L. or.

Taxus tantum florens. The Yew $w^{\text {th }}$ only flowers.

The Yew which onely beareth flowers and no berries, is like the

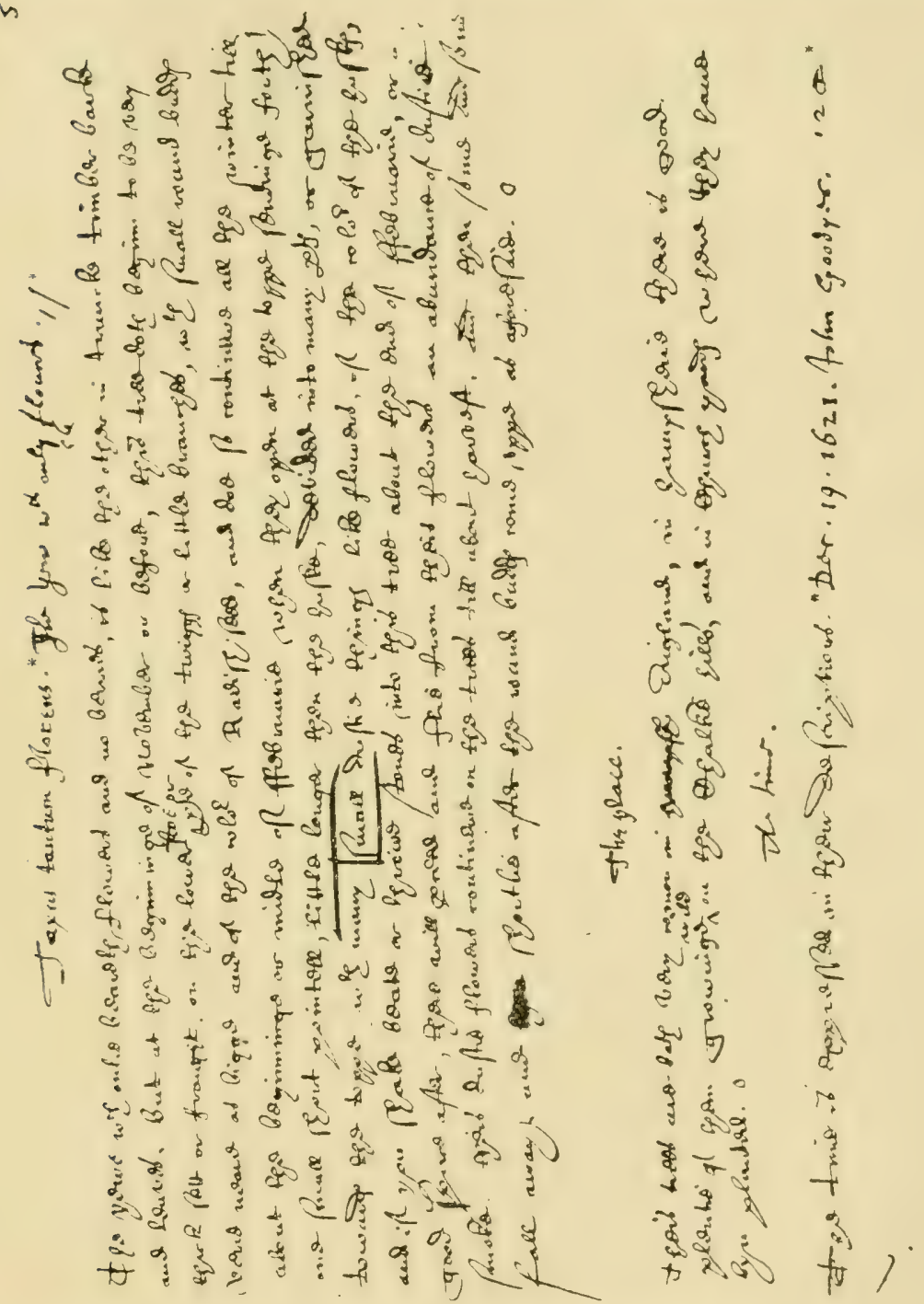

GOODYER'S DESCRIPTION OF THE YEW WITH ADDITIONS IN JOHNSON'S HAND **.

other in trunke, timber, barke, and leaves; but at the beginning of November, or before, this tree doth beginne to be very thicke set or fraught on the lower side or part of the twigs or little branches, 
with small round buds, veric necre as big, and of the colour of Radish seed, and do so continue all the Winter, till about the beginning or middle of Februarie, when they open at the top, sending forth one small sharpe pointell, little longer than the huske, divided into many parts, or garnished towards the top with many small dusty things like flowers, of the colour of the husks; and if you shall beate or throw stones into this tree about the end of Februarie, or a good space after, there will proceed and fly from these flowers an aboundance of dustie smoke. These dusty flowers continue on the trees till about harvest, and then some and some fall away, and shortly after the round buds come up as aforesaid.

\section{The Place.}

Theis trees are both very comon in England, in Hampsheire there is good plentie of them growinge wild on the Chalke hills, and in Church yards where they have byn planted.

\section{The Time.}

The time is expressed in their descriptions.-MS. f. II9; Gor. cmac. I370-7I.

[The first record of the Male Yew in Hampshire.]

\section{Calathian Violet. Gentiana Pnenmonanthe L.}

Pneumonanthe.

[After 9 Nov. I62I]

hath a small round stalk 3 or 4 ynches high, on wch growe small narrow leaves, half an ynch long, which are curvd in the midle very like $y^{\circ}$ leaves of savery, sett thick but orderly by cooples one opposite ye other on $y^{\circ}$ toppe of ye stalk groweth one flower an ynch longe of the fashion of a bell, devided at $y^{*}$ brim into 5 sharpe pointed corners of a perfect blewe color, except 5

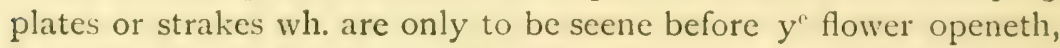
extending from $y^{\mathrm{e}}$ bottome of ye flower to corner, which are not so pleasant a blew color, the seed I observed not. Ye root is small divided at ye upper parte into a fewe small (yet of a sufficient bignes for ye stature of $y^{\ominus}$ herbe) yealowish lyner branches or fibres. Both leaves and rootes are bitter, and ye root more bitter than the leaves \& bitinge ye tonge-MTS. f. $9 \mathrm{v}$.

\section{Marsh Cinquefoil. Potentilla Comamm Nutt.}

Quinquefolium palustre.

[After 9 Nov. I62I]

The stalks are lyner bendinge pliant round smooth a foot long as bigg as a wheate straw of a reddish color towards ye root, ioynted, at ech ioynt groweth a [lcafc] foot-stalk which whooly beclippeth the knott or ioynt, on whose toppe groweth five leaves of 
ye fashion of other cinckfoyles nicket about ye edges, of a mealish greene colour above and whitish underneath, ye 5 leaves not growing on the very upper parte of the footstalk like ye other cinckfoyles, but 2 of them growinge lower about a quarter of an ynch from $y^{\theta} 3$ which growe at the extreme part, $y^{e}$ flowers I observed not. The root creapeth in $y^{e}$ water \& mire, besett with thousand of very small haires, thicker \& smaller then the haires of ones head.-MS. f. Io v.

[Roughly drafted descriptions on back of Laurence Davis' letter of 9 Nov, 162I.]

[c. $1620-1622$.

round buttons or knapps, as bigge or little bigger then the pease wherein in each button is 2,3 or 43 -winded seeds almost as bigg as Radish seed. The root is small white, single and groweth downright, with a fewe threddie shoots with side branches. Both herbe and root doe perish at winter.-Fragment of a description, MS. f. I I v.

'Capon's Tail Grass.' Not Festuca Myurus L.' Gramen $\alpha \lambda \epsilon \kappa \tau \rho \nu$ vóvvpos. Alectryonurum. Io Feb. 1622

[Mentioned with date but without locality.-MS. f. 54.]

Gramen murorum spica longissima.

'I cannot omit this elegant Grasse, found by M. Goodyer upon the wals of the antient city of Winchester, and not described as yet by any that I know of. It hath a fibrous and stringy root, from which arise leaves long and narrow, which growing old become round as those of Spartum or Mat-weed: amongst these grassie leaves there growes up a slender stalke some two foot long, scarce standing upright, but oft times hanging down the head or top of the eare: it hath some two ioints, and at each of these a pretty grassy leafe. The eare is almost a foot in length, composed of many small and slender hairy tufts, which when they come to maturitie looke of a grayish or whitish colour, and do very well resemble a Capons taile; whence my friend, the first observer

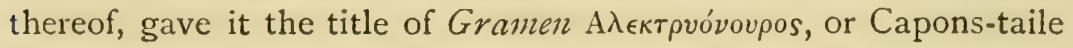
Grasse: by which name I received the seed thereof, which sowen, tooke root, and flourishes". (Johnson )-Ger. emac. pp. 30, 29.

1 The correctness of the determination of this grass as Festuca Myurus L. by Druce is doubted by D. Stapf. 
Curled Parsley.

Apium crispum.

I7 Feb. 1622

At Idsworth, 17 Feb. I622.-MS. f. 5 I v.

[Hill in 1574 printed the following prescription for Parsley. 'If you will have the leaves of the Parcely grow crisped, then before the sowing stuffe a tennis ball with the seedes, \& beat the same wel against the ground, wherby the seedes may so be a little brused, and then sowe them in the ground, or when the Parcelye is well come up go over the bed with a waighty roller, whereby it may so presse the leaves downe, or els treade the same downe with thy feete." Th. Hill, Arte of Gardening.]

Calamagrostis.

Calamagrostis Epigejos Roth.

This sedge sendeth forth many 3 cornered straked stalkes, about 2 foot high, beareinge at yc toppe a spike or eare about 3 ynches longe devided into 12 or 13 lesser scaly eares, and those againe into smallcr, the whole spike not spreadinge abroad, but growinge neare together, so that the thicknes is not above an ynch, of a brownish color before the flowers come forth, which appearinge are nothinge but an infinite many of small dustie things like cheives, at ye first opening whitish afterwards yealowe like ye flowers of other grasses.

[The seed is small contayned in chaffie scales, of a brownish chestnutt color, neare 3 cornered \& broad belowe and sharpe pointed without any manifest tast. 8 Julii 1622.$]$

The leaves are narrowe about 2 or 3 foot longe growinge ymediatelie from ye root, as it were 3 cornered, and very rough espetially if you slide your fingers from their topps downewards, and so sharpe that they cutt one's fingers even as a knife, as doth also $y^{\prime \prime}$ stalk; which usually is without leaves, yet sometimes hath one very small one growinge close belowe ye spike, neare a foot longe. The rootes are infinite of the bignes of ye rootes of gramen canimum couch gras) or bigger of a reddish color without, closely mattinge togrether, and gathering the mudd or dirt amongst them Growinge downeright of a greate lenght, and makinge a greate stronge tuft, no herbe or gras like it, for they are so stiffe \& stronge, that growinge in ye middest of water, a man máy goe on them \& steppe from tuft to tuft, ye water \& mud beinge of a good depth betwixt them.-MS. f. I 2 I.

\section{Oak. Quercus robur.}

Cachrys quercus.

28 Apr. 620 \& 9 May 1622

The Cachryes ${ }^{1}$ are conceived eyther in a budd with the leaves, or

1 'The term cachrys is one that appears to have been used for the you ng cones 
in a budd alone by them selves. Those that are conceived within ye leaves come forth together with them, and growe at the ioynt stoppe or knott betweene the last yeres twigge and the newe shoot, sometimes on the lower part of the newe shoot, those that are conceived by themselves, soe come forth without any leaves or shoot, and these growe by the sides of $y^{\ominus}$ last yeres shoot. This cachrys is composed of small yealowish crudled bunches or clusters growinge a little asunder, on a footstalk about 2 ynches longe, 3 or 4 forth of one budd, and some wither and fall away, seldome continuinge above a weeke or two. When there are plentie of these cachryes, it is a signe there will followe good store of Acornes.

9 Maii. Forth of the bosomes of the leaves on the newe shoot come forth small foot stalks on $y^{\theta}$ toppes whereof growe 2 or 3 or more very small redd flowers: ech flower beinge no bigger then a small pinnes head, and devided into 3 ptes (not worth the name of leves) at the toppe, in the place whereof cometh uppe the Acornes.

4 Maii. In the springe when the leaves first beginn to come forth there often groweth from the topps and sides of the last yeres shootes certaine swellinges as bigge as little aples, not altogether round but bunched out here and there, reddish on that part towards the sunne, contayninge an austere or harsh spongie matter

of conifers, for catkins, and for the winter buds of the deciduous trees. Though much used by the early botanists, it appears to have dropped out of use at the end of the seventeenth century, and is not even included in many later lists of technical words. Fuchs in 1542, in his Explicatio of difficult words, defined the term as follows:

Cachryes sunt oblonga panicularum modo nucamenta, quae squamatim compacta propendent è ramis. Crescunt hyeme, vere dehiscunt in flavescentes squamulas, et folio prodeunte, decidunt : qualia in abiete, picea et aliis permultis videre licet. Plinius pillulas nominat. - F w uchs, Hist. Stirp. f. $\beta 3$.

'The Birch, the Nut, the Walnut, and the Plane Tree have on them things in Greek called Cachryes in English Catkines or Catstailes, if I mistake not which are there the most part of the winter. They are of a burning quality in Physick' (Coles, Art of Simpling, 1656). And this is the meaning given in the New English Dictionary. According to Parkinson (1642) Cachrys is the fifteenth 'Excrescence of the Oke'. It was borrowed from Theophrastus iii. 7 to mean ' $a$ round conception or gathering together of leaves, growing betweene the last yeares shoote, and the young bud for the next to come'. And they are borne on 'the Firre tree, Larch, Pitch, Line, Nut, and Plane trees' as well as on the Oak, all of which 'doe beare a Cachrys after the leaves are falne, abiding on all the winter'. Elsewhere he defines it as 'a scaly tuft of leaves growing in winter, and falling away, say some, in the Spring : but others think that it is but the bud, which spreadeth into branches with leaves after Winter, when the Spring is come on'.(Park. Theatrum, 882). 
within, and towards Autumne hath eyther maggotts, flics or some livinge creature within it, this hangeth many times two yeres on the twiggs, and then also have had maggotts within them as I have seene.

Gallae foliorum quercus.

There is often to be seene in Autumne on that part of the leaves which is next the ground a round pill or ball without a footstalke, sometimes 8, 10 or more on one leafe, reddish on that parte next the sunne, smooth on the outside, or with little sharpe extuberances, verie like both in forme and bignes to the trewe galls, onlie wantinge hardnes, but contayninge a softe spongious matter within, and often a maggott, and a hole by the side. These beginn to appeare most comonlic about the middest of July, of the bignes of a pease, sometimes by the middest of May of that bignes, as the I 5 of May I 622 when I only sawe them. $-M S$. f. 85 .

W a Inut. Fuglans regia $\mathrm{L}$.

Cachrys Juglandis.

The Cachryes beginn to appeare in Aprill a little before the leaves are seene, and doe thrust themselves forth of the sides of the last ycres shootes, but one in a place, a little above the place where the footstalks of the leaves were fastened and are at the first closelie compacted and finclie chekered without anic footstalke or leaves cominge about or neare them; afterwards they growe more rare or looser, about two ynches in length neare as bigge as the little finger, not continuinge two weekes before they wither and fall away.-MS. f. 85 .

Chestnut. Castanea sativa Mill.

Cachrys Castaneae.

The Cachryes begin to springe about the midle of May together with the newe shoots forth of the bosomes of the yonge and tender leaves, but one out of the bosome of one leafe; composed of a midle ribbe or footstalke about 7,8 or 9 ynches longe when they are at their full growth about July, which midle ribbe is thick sett by the sides with small scalelic bunches, which about the middest of July open, and there appeareth out of ech bunch many small short cheives of a very pale or light yealowish color as are also their topps, they appeare very slender in respect of their length, and soone after their cheives open or appeare they wither and fall away. These begin to come forth about the beginning of July, like rough hedgehog-like pills or husks, without any flowers, only bearinge at ye toppe a fewe whitish things like cheives, theis 
husks growe cluster-wise 7 or more together, on one newe shoot.MS. f. 85 .

Alder. Almus glutinosa Medic.

Alder.

I5 Maii 1622

The strobilus or fruite of the Alder cometh forth at the beginning of the springe when the leaves first appeare, they growe from the toppes of the last yeres twigges, clusterwise though not so neare together as the berries of the vine, about 8 or 9 in a cluster, at the first small, yet of their full length which exceedeth not half an ynch, in shewe like Cachryes, afterwards growinge like in fashion to an olive not fullie so bigge as a sparrowes egge, composed of many brownish scales standinge verie neare one another betwene which the seed lieth. These usuallie hange on a yere or more.-MS. f. 86 .

\section{Birch. ${ }^{1}$ Betula alba L.}

[Unnamed by Goodyer.]

Undated.

Ye leaves are small, smooth broad below, growing to a large point nicked by the sides, in some like those of the black poplar but smaller.

At $y^{\theta}$ very first coming forth of the leaves, there cometh forth with them a round thinge like a Cachryes, but is indeed the fruite, about 3 quarters of an ynch longe, and nere a quarter of an ynch over, composed of flatt scales closely sett together, each scale contayning one seed of a browne color with a white kernell within. The scales with a light touch fall apart when $y^{e}$ seed is ripe, the seed being neare ripe then cometh forth at $y^{\theta}$ toppe and by the sides of $y^{\circ}$ same yeres shoot small Cachryes.

The leaves and fruite come forth towards $y^{e}$ later end of Aprill, 26

the seed is ripe at ye later end of July, the Cachryes beginn to appear at ye begining of July.-MS. f. $3 \mathrm{v}$.

Tribulus.

2 June 1622

[The year ' 1622 ' may be an error of Johnson. Goodyer's own MS. has ' 2 June I62I', which see.]

Wood Club Rush. Scirpus sylvaticus L. Cyperus gramineus Lobelii.

8 Julij 1622

This hath about 7 or 8 smooth leaves growinge from $y^{\theta}$ roote 3 foot longe, half an ynch broad, as it were 3 cornered, sharpe on ye edges especially, if you drawe your fingers on them downewards, amongest which growe uppe one ioynted smooth stalk, belowe neare as bigge as ye little finger, three cornered, but obtuse, blunt or

${ }^{1}$ Identified by A. H. C. 
roundish, not sharpe cornered like galangall. Whereon at everie ioynt is placed one leafe cloathinge or inclosinge ye stalk upward above ye ioynt an ynch and a half or more, about a foot and a half longe, and somewhat broader then $\mathrm{y}^{\mathrm{e}}$ former, at ye toppe of which stalks growe usually 3 like leaves but much shorter, from which spring forth 6 or more little stalks or branches, after ye manner of galangall, 4,5 or 6 ynches long except ye midle branch which usually growes not an ynch above ye divison, and all these are againe at their toppe diversly devided into many parts, bearinge little knobbs, scales or buttons very like those of Rushes, contayning very small yealowish 3 cornered seeds sharpe pointed at both ends, which together with ye little buttons in ye beg[inninge] of July fall off. The rootes at ye upper parte next ye leaves, are infinite of small white threddy strings, sendinge forth underneath other rootys (?) bigger then wheate strawes like those of Arundo vallatoria ioynted, white at ye first after of a brownish yealow, without smell, by which the plant exccedingly increase, growing high in aboundance together,-MS. f. $7 \mathrm{v}$.

On ye west parte of Gloster Hall by Oxford.

5 Julii 1622

The stalk is round rough or hairy, ioynted, neare as bigge on ye lower parte as ye little finger devided towards the toppe into a fewe branches, bearinge at everie ioynt one sharpe-pointed leafe without or with a very little footstalk about 5 ynches long and an ynch and half broad or hairy like ye stalk, not indented by ye sides, but sometimes with small excrescens as may be seen on ye leaves of Plantans standinge farr apart. Ye flowers growe at ye topps of ye stalks \& branches on long slender footstalks, of a yealowe color, ech flower beinge composed of 5 greate broad topped leaves, which beinge full blowne is neare 2 ynches broad, contayning within many small yealowe chives. The roots growe forth at certaine ioynts on ye lower parts of ye stalks within ye water and mudd, made of many small hairy strings. This herbe at ye first tastinge seemeth not to be hott, but beinge held in a little space in ye mouth heateth \& burneth little inferior to ye rest of his kind.-MS. f. $7 \mathrm{v}$.

\section{Great Water Parsnip. Sium latifolium L.}

Pastinaca aquatica latifolia at Oxford.

5 Julii 1622

[Rough draft for the next description.]-MS. f. $7 \mathrm{v}$.

Pastinaca aquatica maxima.

$5^{\text {to }}$ Julii 1622

Sium maius Gerardo Phyto. p. 270. No. II.

The stalkes are greate upright straight and tall, not inferior to 
the garden parsneppe beinge neare as bigge as a mans arme, and as high as a tall man, with greate corners deepe chamfers, and hollowe within, devided into many braunches; whereon growe greate broad leaves like those of the garden parsneppe, composed of 5 or 6 sometimes 7 or 8 indented smooth leaves sett on ech side of a longe midle ribbe, and one at the toppe, of a stronge smell. The flowers were not come forth.

[Two lines left blank, perhaps for a description of the flowers.]

The rootes are infinite growinge at the lower ptes of the stalkes within the water and mudd, white, as bigge as wheatestrawes, and they againe sendinge forth abundance of threddy strings, by which rootes the plant encreaseth, usuallie 3 or 4 stalkes together from one tuft. This I found growinge wild plentifully by the Rivers sides and in the water diches about Oxford, $5^{\text {to }}$ Julii $1622 .-M S$. f. $82 \mathrm{v}$.

\section{Stachys germanica L.}

Stachys. Wild Horehound.

[? 8 Julii 1622 ]

564 Stachys. - Wild Horehound is also like to comon horehound. There rise from the root hereof a greate number of stalks high or ioynted, and out of everie ioynt a coople of leaves, opposite or sett one against another, somewhat hard, a little longer than those of comon horehound and whiter, as also ye stalks are sett with soft haires and of a sweet smell. Ye flowers doe compasse ye stalk about as those doe of comon horehound, but they are yealowe and $\mathrm{y}^{\mathrm{e}}$ whorles be narrower. The root is woodie and durable. $-M S$. f. 7 .

Calamagrostis.

8 Julii 1622

[See 27 Apr. 1622.]

$\mathrm{S}$ weet Flag. Acorus Calamus L.

Acorus legittimum Clus. 23I. Acorus, Ger. 56 .

6 Julij 1623

Acorus hath the leaves allmost of the greater narrowe leaved Iris [Iris angustifolia], but much longer, and of a most pleasant greene, the midle nerve or rib somewhat appearinge forth on both sides as in ye leaves of Xiphium whose forme they sufficiently resemble; and like them or that moorish plant which brings forth yealowe flowers like ye flowers of Iris, which some call Iris palustris, the better skilled more trulie Butomus. They come one out of another, but the midle leafe is most comonlie longer than the rest; but although they be of a tast somewhat bitter, yet not unpleasant, and beinge crushed they yeld a pleasant and aromaticall smell, which also they retaine 
manic yeres after beinge dryed and without iuyce. About the beginning of winter they wither and are dryed, but in the beginninge of springe they shoote anewe as in narrowe leaved Iris, moreover it produceth not a stalk betwene the leaves as the Irides, but out of the side of $y^{e}$ root comes a leafe stalk of the same lenght with $y^{e}$ other leaves, that is sometimes from the midle unto $y^{e}$ toppe is plaine and like the rest, but and narrower, and as it were fashioned into a triangular stalk it beginns to be extenuated and made plaine it sends forth out (sometimes but very seldome two) not greater in ye beginning appearinge and stanndinge up a pright partinge (or cutting) themselves acrosse when it opens itself full of consistinge of fower small leaves, afterwards untill it gett the lenght and thic greene knobbes, in such a comelie order cone of the wild pine. It hath upper parte when it lies hid in ye earth, exceedinge white in the inner parte, distinguished stronge, of a good smell, of a somewhat bitter and sharper tast, endewed with many and whitish and sweet smellinge threeds growinge to it in ye lower parte, but it creeps and spreads itself on the toppe of the earth, sendinge forth from the sides and almost everie ioynt or knott yonge ones, one after another, obliquely (or crookedlie) so that in a short time it takes uppe a greate space.

2I Julij [1624]

a. two corners standing so neare together that they make a hollowe like a furrow.

b. at the upper end of the furrowe.

c. without any footstalk.-MS. f. I25.

* [Page torn.]

[The date shows that this description was made from the Acorus ' in flower in Mris. Mervin's garden $6^{\text {to }}$ Julii 1623 '.-MS. f. 5 I.]

Papaver Argemone L.

Argemone capitulo longiore Ob. p. I44.

24 Julii 1623

In Durford garden.

Sanfoin. Onobrychis sativa Lam.

Caput Gallinaceum Belgarum.

24 Julii 1624

In flower 24 Julii 1624 between Langford \& Stapleford in Wiltes by ye way on ye south side of ye river.-MS. f. 52 . 
Shrubby Suaeda. Suaeda fruticosa Forsk.

Chamaepytis vermiculata.

Io Sept. 1624

The stalks are woodie not fuller of a finger bignes, a cubite or 2 foot high of a blackish or dark ash color devided into many branches whereon grow multitudes of small round fatt leaves of $y^{e}$ fashion of $w$.. es very like those of comon stone croppe full of iuyce, of a salt tast, of a darke green colour. The rootes are also woodie branched of a blacker color then ye stalks. This plant continueth greene continually as it seemeth, and increaseth by the root growinge in thick tuffets close together. I observed no flowers nor seed.-MS. f. I 27 .

[A roughly written note on the back of the statement of 'Tenth mony' received by Edward Cole in I608. See p. 373.]

Common Spleenwort. Asplenium Trichomanes L. Trichomanes mas.

- Jan. 1624

- Mr. Goodyer saith that in January I624, he saw enough to lade an horse growing on the bancks in a lane, as he rode between Rake and Headly in Hampshire neere Wollmer Forest.'-Ger. emac. II 46 .

Cow ba ne. Cicuta virosa $\mathrm{L}$.

Sium alterum olusatri facie.

I6 Sept. I625

Found by Mr. Goodyer in the ponds about Moore Parkc (Ger. cmac. 257) and at Denham in Hertfordshire in standinge motes sine caule. $-M S$. f. 58 .

Knotted Pearlwort. Sagina nodosa Meyer. Alsine palustris foliis tenuissimis. I2 Aug. I626

This hath a great number of very small grasse-like leaves, growing from the root, about an inch long, a great deale smaller and slenderer than small pinnes; amongst which spring up many small slender round smooth firme branches some handfull or handfull and halfe high, from which sometimes grow a few other smaller branches, whercon at certaine ioynts grow leaves like the former, and those set by couples with other shorter comming forth of their bosomes; and so by degrees they become shorter and shorter towards the top, so that toward the top this plant somwhat resembleth Thymum durius. The flowers are great for the slendernesse of the plant, growing at the tops of the branches, each flower consisting of five smal blunt roundish topped white flowers, with white chives in the middest. The seed I observed not. The root is small, growing in the myre with a few strings. This groweth plentifully on the boggy ground below the red Well of Welling- 
borough in Northampton shire. This hath not becne described that I finde. I observed it at the place aforesaid, August I 2 I626.-Ger. emac. 568.

Grass of Parnassus. Pamassia palustris L. Gramen parnassi.

12 Aug. 1626

In the boggy ground below the Red Well of Wellingborough in Northamptonshire-Ger. emac. 840.

Cerinthe minor L.

Cerinthe minor flore albo veris luteis.

23 Sept. 1628

This in stalks and leaves differeth veric little from the other, the flowers in shape are like, the color from the midle to the brim is of a whitish or pale yealowe, the brim itself a much deeper yealowe, the midle hath a ringe or circle of a reddish purple from that circle backward that is to the fasteninge of the huske, of a deepe yealowe, the seeds are like the other but as small againe. MS. f. 120.

[The 'other' is Cerinthe flore rubro, 9 July I62I.]

Golden Lung wort. Hieracium muromu L. Pulmonaria Gallica sive aurea latifolia. 27 May I63I

'I received some plants of this from Mr. John Goodyer, who first found it May 27, $163 \mathrm{I}$ in flower; and the 3 of the following May not yet flowring in a copse in Godlemen in Surrey, adioyning to the orchard of the Inne whose signe is the Antilope.'-Ger. emac. 30.5 .

\section{Triticum vulgare $\mathrm{L}$.}

Wheat ear with Oats.-Ger. emac. 65. See p. 62.

Water Plantain. Danasonizm stellatum Thuill. Plantago aquatica stellata.

The roote is nothinge but a multitude of very small white thredds like hairs growinge in the myre amonge which springe the leaves, their footstalks are about 3 ynches longe, at the toppe of ech groweth igrosse plainc smoth leafe, not indented, an ynch long, a quarter of an ynch broad or somewhat broader, sharpe pointed, with two eares belowe sometimes, but most comonly without.

The stalks growe uppe amongest them, in number 5 or 6 plain smooth round firme not hollowe, small, as bigge as a small straw, on ech stalk groweth an umbell, consisting of 7 footstalks, 6 of them having at the toppe of ech a starr-like fruite, of six sharpe pointed husks like the rowell of a spurr, the seaventh footstalk bearcth an other umbell, with 3 or 4,5 or 6 footstalks \& starr-like husks like the former. 
Neare London highwaie in the watery plashes at the east end of the greate Comon betweene Sandie Chappell and Kingston, neare the bridge as you ride out of the Comon by a small Cottage there.

I saw no flowers.-MS. f. J37.

[A note scribbled on the back of a list of men of the Tithing of ... [name obliterated], p. 38r.]

[Goodyer first found this plant in 1618 growing on Hounslow Heath, the station quoted by Johnson.-Ger. emac. p. 418.]

Ferns.

Filix mas varietates \& differentiae.

I have observed fourc sorts of Ferne, by most writers esteemed to be the male Ferne of Dioscorides: by Anguillaria, Gesner, Casalpinus, and Chisius, accounted to be the female, and so indeed doe I thinke them to be, though I call them the male, with the multitude. If you looke on these Fernes according to their severall growths and ages, you may make many more sorts of them than I have done; which I am afraid hath beene the occasion of describing more sorts than indeed there are in nature. These descriptions I made by them when they were in their perfect growths.-MS. f. I38; Ger. emac. II 29.

$\mathrm{Broad} \mathrm{Shield-fern.} \mathrm{Aspidium} \mathrm{dilatatum} \mathrm{Sm}$. Filix mas ramosa pinnulis dentatis.

4 Julii 1633

The roots are nothing but an aboundance of small blacke hairy strings, growing from the lower parts of the maine stalkes (for stalkes I will call them) where those stalkes are ioyned together. At the beginning of the Spring you may perceive the leaves to grow forth of their folding clusters, covered with brownish scales at the superficies of the earth, very closely ioyned together: a young plant hath but a few leaves; an old one, ten, twelve, or more: each stalke at his lower end neere the ioyning to his fellowes, at his first appearing, before he is an inch long having some of those blacke fibrous roots for his sustenance. The leaves being at their full growth hath cach of them a three-fold division, as hath that Ferne which is commonly called the female: the maine stalke, the side branches growing from him, and the nerves growing on those side branches bearing the leaves: the maine stalke of that plant I describe was fully foure foot long (but there are usually from one foot to foure in length) full of those brownish scales, especially toward the root, firme, one side flat, the rest round, naked fully one and twenty inches, to the first paire of side branches. The side branches, the longest being the third paire from the root, were nine inches long, and shorter and shorter 
towards the top, in number about twenty paire; for the most part towards the root they grow by couples, almost opposite, the neerer the top the further from opposition: the nerves bearing the leaves, the longest were two inches and a quarter long, and so shorter and shorter toward the tops of the side branches; about twentie in number on each side of the longest side branch. The leaves grow for the most part by couples on the nerve, eight or nine paire on a nerve; each leafe being gashed by the sides, the gashes ending with sharpe points, of a deep green on the upper side, on the under side paler, and each leafe having two rowes of dusty red scales, of a browne or blackish colour: toward the top of the maine stalke those side branches change into nerves, bearing only the leaves. When the leaves are at their full growth, you may see in the middest of them at their roots the said scaly folding cluster; and as the old leaves with their blacke threddy roots wholly perish, they spring up; most yeares you may finde many of the old leaves greene all the IVinter, especially in warme places. This groweth plentifully in the boggy shadowie moores neerc Durford Abbey in Sussex, and also on the moist shadowic rockes by Mapledurham in Hampshire, neere Petersfield; and I have found it often on the dead putrified bodies and stems of old rotten okes, in the said moores; neere the old plants I have observed verie many small yong plants growing, which came by the falling of the secd from those dusty scales: for I beleeve all herbes have seeds in themselves to produce their kindes, Gen. i. I1. \& 12.-MS. f. $138-9$; Ger. emac. II 29.

[I thought to have called this Dryopteris, but that is described by Cordus and Tragus to be a very small tender ferne not above 9 inches high with creeping roots like those of Polypodium (erased).]-MS. f. $\mathbf{I}_{3}^{8}$.

The three other have but a twofold division, the many stalks and the nerves bearing the leaves. The roots of them all are blacke fibrous threds like the first, their mainc stalks grow many thicke and close together at the root, as the first doth: the difference is in the fashion of their leaves, and manner of growing, and for distinctions sake I have thus called them:

Male Shield-fern. Aspidium Filix-mas Sw. Filix mas non ramosa pinnulis latis densis minutim dentatis.

4 Julii 1633

The leaves are of a yellowish greene colour on both sides, set 
very thicke and close together on the nerve, that you cannot see betweene them, with marvellous small nickes by their sides, and on their round tops: each leafe hath also two rowes of dusty seed scales; the figures set forth by Lobel, Tabern., and Gerard, under the title of Felix mas, do well resemble this Ferne. This growes plentifully in most places in shadowie woods and copses.-MS. f. 139; Ger. emac. 11 29-30.

Nephrodium Filix-mas, Sw., var. affinis (Newm.). Filix mas non ramosa pinnulis angustis, raris, profunde dentatis.

4 Julii 1633

The leaves are of a deepe greene, not closely set together on the nerve, but you may far off see betwixt them, deeply indented by the sides, ending with a point not altogether sharpe: each leafe hath also two rowes of dusty seed scales. I have not seene any figure well resembling this plant. This groweth also in many places in the shade.-MS. f. 140 ; Ger. emac. 1130.

Prickly Shield-fern. Polystichum aculeatum Sw. var. lobatum Syme; or Angular Shield-fern. $P$. angulare Presl.

Filix mas non ramosa pinnulis latis auriculatis spinosis.

The leaves are of a deeper greene than either of the two last described, placed on the nerve not very close together, but that you may plainly see between them; each leafe (especially those next the stalke) having on that side farthest off the stalk a large eare or outgrowing ending, with a sharp pricke like a haire, as doth also the top of the leafe: some of the sides of the leaves are also nicked, ending with the like pricke or haire. Each leafe hath two rowes of dusty seed scales. This I take to be Filix mas aculeata maior Bautini. Neither haue I seene any figure resembling this plant. It groweth abundantly on the shadowie moist rockes by Mapledurham neere Petersfield in Hampshire.-MS. f. I40; Ger. emac. II 30 .

Marsh Shield-fern. Dryopteris Thelypteris Asa Gray. Dryopteris Penae \& Lobelii.

6 Julii 1633

The roots creepe in the ground or mire, neere the turfe or upper part thereof, and fold amongst themselves, as the roots of Polypodium do, almost as big as a wheat straw, and about five, six, or seven inches long, coal blacke without, and white within, of a binding taste inclining to sweetnesse, with an innumerable com. 
panie of small blacke fibres like haires growing thereunto. The stalkes spring from the roots in severall places, in number variable, according to the length and encrease of the root; I have seene small plants have but one or two, and some bigger plants have fourtcene or fifteenc: they have but a two-fold division, the stalke growing from the root, and the nerve bearing the leaves: the stalke is about five, six, or seven inches long, no bigger then a bennet or small grasse stalke, one side flat, as are the male Fernes, the rest round, smooth, and green. The first paire of nerves grow about three inches from the root, and so do all the rest grow by couples, almost exactly one against another, in number about eight, nine, or ten couples, the longest seldome exceeding an inch in length. The leaves grow on those nerves also by couples, eight or nine couples on a nerve, without any nickes or indentures, of a yellowish greene colour. This Ferne may be said to be like Polypodium in his creeping root, like the male Ferne in his stalke, and like the female Fcrne in his nerves and leaves. I could finde no seed-scales (n the backesides of any of the leaves of this Fernc. Many yeares past I found this same in a very wet moore or bog, being the land of Richard Austen, called Whitrow Moore, where Peate is now digged, a mile from Petersfield in Hampshire; and this sixth of Iuly, 1633 , I digged up there many plants, and by them made this description. I never found it growing in any other place: the leaves perish at Winter, and grow up againe very late in the Spring.-MS. f. 140 ; Ger. emac. II $35^{-6}$.

[There is a sketch by Goodyer of a fern on the same page as this description].

Ulmus campestris Sm., U. montana Stokes, U. glabra Miller, U. minor Miller.

Elms.

[For Goodyer's descriptions of the four species of Elm see p. 3S.]

Among the undated notes and species contributed by Goodyer to Johnson's second edition of Gerard were the following. The descriptions must therefore be earlier than 1633 and several may date from $c .1621$.

\section{Marsh $\mathrm{Helleborine.} \mathrm{Epipactis} \mathrm{palustris} \mathrm{Crantz.}$} Palma Christi, radice repente.

[Before 1633]

'It growes also plentifullie in Hampshire within a mile of a market Towne called Petersfield, in a moist meadow named Woodmead, neere the path leading from P'etersfield. towards Beryton.'

[Johnson (Ger. emac. 227) prints this locality without acknowledgement, but it was doubtless communicated to him by Goodyer. The 
description of the species is unfortunately illustrated by a wood-block of Goodyera repens, an orchid of a genus named by Robert Brown in honour of Goodyer, thus unfortunately connecting his name with a plant which he had probably never seen. Goodyer's 'Palma Christi' or 'Creeping-rooted Satyrion' has been identified by Canon Vaughan as Epipactis palustris, a species to be found in boggy situations in several parts of Hampshire. Brown, thinking that it was the same as a rare northern orchid, found in certain fir-woods in Cumberland and Scotland, gave it the name of Goodyera repens in honour of our Hampshire botanist, who, it is suggested, might possibly have met with a specimen of this rare northern plant in the low-lying grounds between Petersfield and Maple-Durham.]

Rampions. Phyteuma orbiculare L. Rapunculus corniculatus montanus.

[Before 1633]

Jchnson 'received sceds and ronts hereof from Mr. Goodyer who found it plentifully growing wilde in the inclosed chalkie hilly grounds by Mapledurham '.-Ger. emac. 455 .

Sea Bindweed. Convolvulus Soldanella L. Soldanella marina.

n. d.

[The local Isle of Wight name, 'Scurvy Grass,' given to this plant, supports the truth of the following remark of Johnson:] 'My friend $\mathrm{Mr}$. Goodyer hath told me that in Hampshire, at Chichester, and thereabout, they make use of this for Scurvie-grass, and that not without great errour, as any that know the qualities may easily perceive.-Ger. emac. 839 .

Golden Saxifrage. Chrysosplenium oppositifolium L. Saxifraga aurea.

[Before 1633]

Mr. Goodyer hath also observed it abundantly on the shadowie moist rockes by Maple Durham in Hampshire.-Ger. emac. 842 .

[The first record for Hants.]

Geranium lucidum L.

Geranium saxatile, Thalii.

[Before 1633]

Master Goodyer found it growing plentifully on the bankes by the highway leading from Gilford towards London neere unto the Townes end.-Ger. emac. $93^{8}$.

[First record for Britain.]

Phyllitis Scolopendrium, Newm., var. multifida.

Phyllitis multifida. Finger Harts-tongue. [Before 1633 ]

Mr. Goodyer found it wilde in the banks of a lane neere Swaneling, not many miles from Southampton.-Ger. emac. II 39. 


\section{Digitalis ferruginea L.}

Digitalis ferruginea.

This is a verie comely plant growinge like a pyramide.

The maine stalk is 3 or 4 foot high, greene, smooth, with some edges, not hollowe but filled with a white spungie pith, growinge upright as strait as an arrowe, not farr from the lower part it sendeth forth many branches, not growinge so high as the stalk.

The leaves arc many, \& spread uppon the ground before the stalk groweth uppe, greene \& smooth on both sides, without nicks by the sides, usuallie with 5 ribbes, like those of quinque nervia plantayne: about - ynches long \& - ynches broad. Also such leaves growe on the stalks and branches, but small and shorter towards the toppe, not by cooples but heare and there.

The flowers make a comely spike, \& as the stalk and branches growe so they flower still upwards nere their topps hollowe, of the bignes of the toppe of the little finger, the upper side half an ynch longe, the lower side hath lipps stickinge forth of a quarter of an ynch, \& on ech side of the flower ther is one excrescence or like the toth of a sawe, in the inside there is usually + cheives growinge to the upp part of the flower, the whole is of a rustie iron color, with many purplish strakess, \& somewhat hayrie both without \& within.

The flowers fallen, the seed vessels playnely appeare makinge a longe spike, besettinge the stalks and branches round about, in forme round and sharpe pointed, but half as bigge as the flower half an ynch large at the lower part of ech seed vessell groweth fower scalic leaves, half as bigge but fully as longe as the nay-le of the little finger.-MS. f. I $37 \mathrm{~b}$.

Tooth cress. Dentaria bulbifera L.

Dentaria baccifera $v$ bulbifera.

6 Aug. 1634

At Mayfield in a wood of Mr. Stephen Penckhurst called Highreed and in another wood of his called ffox-holes.-MS. ff. 53, 62.

Procumbent Pearlwort. Sagina apetala L.

20 June 1634

l'erianthos 4 greene blunt-topped leaves hollowed sherie fashion, spreading open, one opposite against another crossewise.

The flower 4 very small white blunt-topped. leaves, not so bigg as a small pinnshead a quarter as bigg as ye perianthos spreading iust between them, making a duble crosse. 
pointell Small white \& short open at $y^{\ominus}$ toppe into $4 \mathrm{pts}$, one parte lyenge iust over ech flower.

chives $\quad 4$ white chives standing just as farr out as the top of ye pointell and ech pointell standinge iust opposite to ech leafe of ye perianthos.

pericarpium hath 4 greenish leaves in form of those of the periantos, closed fast together till the seed is ripe.

seed the seed is small, smaller than that of sweet margerom and ... of colour like it, many lyeng in one pericarpium.-MS. f. I4.

[The identification of this unnamed description has been due to my friend Mr. A. H. Church. It is the earliest English account of the plant.]

Horse-shoe Vetch. Hippocrepis comosa L.

Ferrum equinum Germanicum siliquis in summitate. 9 Aug. I 634

On Buttersworth Hill, 9 Aug. 1634: ripe seed.- MS. f. $53 \mathrm{v}$.

Marsh Isnardia. Ludreigia palustris Ell. Herba aquatica rubescens, facie Anagallidis flore luteo.

19 Aug. 1645

The stalks are smooth almost round, sometimes some parts of them a little square, reddish, firme within, not hollowe, sometimes allmost a foot longe, of the bignes of those of orgamen.

The leaves growe by cooples, on the stalkes \& branches, on short footstalks somethinge like those of Anagallis flo. luteo. ${ }^{1}$ The biggest are nere 3 quarters of an ynch longe \& half an ynch broad, also reddish, smooth, nothinge at all indented by the edges; those on the toppes of the stalkes \& branches are shorter and smaller; the ioynts about the middest of the stalkes are allmost an ynch apart but towards the topps of the stalks \& branches, they are very neare together. The branches come forth at the bosomes of the leaves, \& thereby increase very much. The roots are like small threeds \& come forth at the ioynts of the stalks \& branches, \& take hold in the mudd.

The flowers come forth at the bosomes of the leaves towards the toppes of the stalks \& branches, usually forth of ech bosome but one, sometimes two, in one bosome \& but one on that opposite to them; they are small, scarce to be called flowers. but are like the huskes of many herbes that containe the flowers before they be opened, this huske or flower is not half a quarter of an ynch longe, and is divided into 4 parts, or leaves at the toppe, ech leafe beinge sharpe pointed \& little bigger then a small pinnes head of a greenish

\section{Lysimachia nemorum L.}


colour, \& does not fall offe as the leaves of other flowers doe but continue on till and after the seed is ripe.

The seed is contayned in that huske, \& is white \& as small as dust.

The whole herbe is of a reddish colour, and flotes in or uppon the water and prospers well when all the water is dryed from it, \& then flowers, seldom before. I could never observe any flowers but on those plants from which the water was dryed away, and that in August.

I have long observed this plant, as I found it growinge in the rivulett on the east side of Petersfield, runinge and a heathy comon about the middest thereof. I cannot yet tell what genus it is, nor what name is most proper for it.-MS. f. I $4 \mathrm{r}$.

[The Marsh Isnardia is one of the very rarest of Hampshire plants, and Goodyer's description has not been printed before ; indeed it was not known that he had noted it about a quarter of a century before the date of the first 'record' given by Townsend. After Merrett had recorded Goodyer's discovery in 1666, the plant does not appear to have been seen again until about 1835 ? when it was rediscovered by Miss Rickman and J. Barton; 'and in the moist summer of 1848 , Dr. Bromfield found it plentifully (he had searched for it unsuccessfully in previous dry summers) in marshy spots, into which expanded at intervals the shallow stream which drains the great pond at Petersfield. I am not aware of the plant having been found at Petersfield since 1848 , though it has been repeatedly searched for. The shallow stream above described is now so circumscribed that even during the wet summer of $I 879$ it expanded into no marshy spots in which Isnardic could have a chance of growing. I searched the stream through the Common and along its course downwards for about a mile, but without success. The plant is now extinct in Sussex, the only other county in which it has been found in Great Britain.' 'Mr. Bolton King's patient determination to rediscover the plant [in the Brockenhurst neighbourhood, where it had been found by Borrer in I 843] was rewarded by finding it abundantly in 1878 in another spot in the neighbourhood.' $]^{1}$

Fagus. Beech. Fagus sylvatica L.

I found one much varying in his leaves, some were whole as those of the ordinary, others much jagged or divided.-Goodyer quoted by How, Phytologia, p. to.

$$
1650-1656
$$

The notes on the following nine plants occur in HoIV's handwriting in his interleaved copy' of the Phytologia Britannica. They must therefore have been written betaecn I650, when the book was published, and 1656, when he dicd.

1 Townsend, Flora Hampshire, p. 158. 


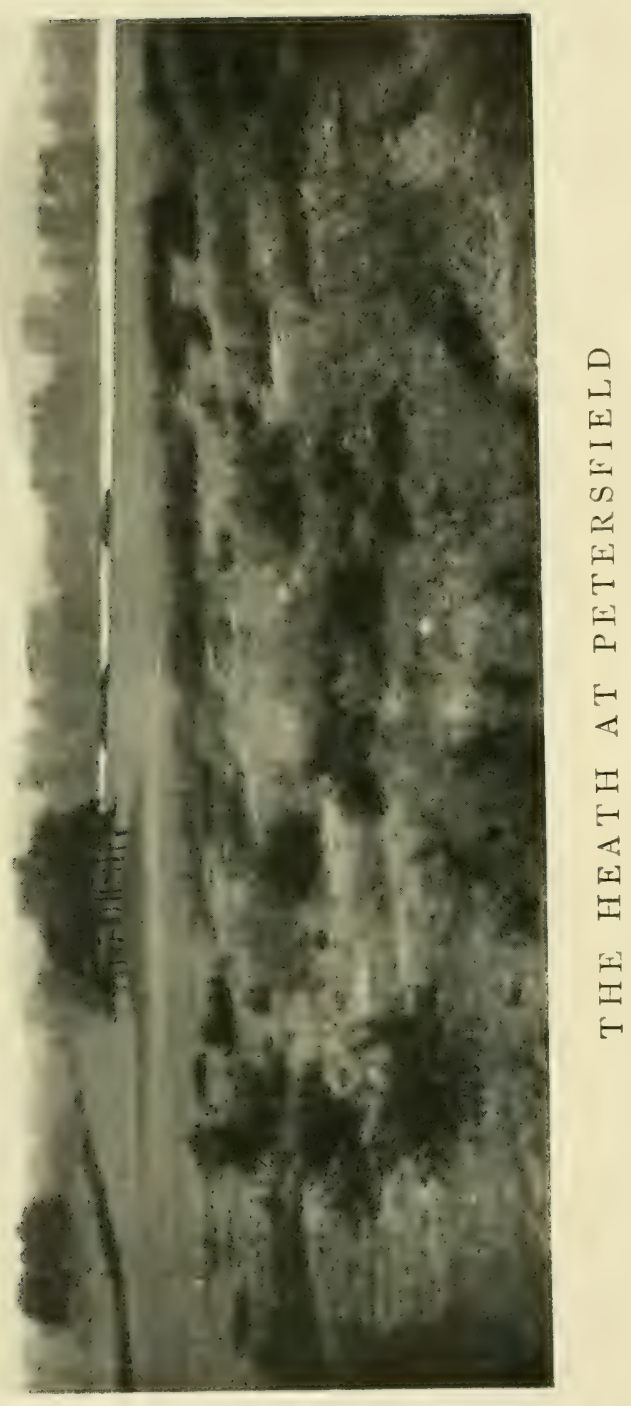





\section{Cardamine impatiens L.}

Cardamine flosculis minoribus, sive impatiens.

From rills and ditch sides about Bath.

Dr. Johnson was mistaken in saying yt this was Sium minimum, Alp. I have both ye plants. I admonished him of this error but he lived not to amend it. J. Goodyer.-p. 2 I.

[Johnson died in I644.]

\section{Polypodium Dryopteris L.}

Dryopteris, Trag. Tree-fern.

It growes on a bottome called Rogers Deane in ye parish of Faringdon in Hampshire, about a mile and a half from ye church, a furlong from one John Trybes dwelling house on ye north east part of ye house about 2 miles from Alton about a mile north east from Dogford Wood. Great antient beeches kept ye sunne from shining on ye Plants. Ann. I654 many of those trees were cut downe. The Plants ye sunne shone on $y^{t}$ summer ' 54 were short, ye leaves growing on short stemms neere ye earth as Tabernaemont pictureth it, p. 501 tom 2 under ye title of Filicula petraea fem. 3 . Those yt grew under ye trees were much higher agreable to Tragus figure p. 538. John Goodyer.'-p. 35 .

\section{Ye least Furze. Ulex namus Forst.}

Park. des. of Genista spinosa minor p. 1003 accords not with ye Least Furze; ours beares no leaves at all. They are but ye first sproutings of ye thornes or prickles, even as of ye great furze (bee hee what hee will $\mathrm{y}^{t}$ willes ye contrary) ye cods have furze, even as ye cods of ye greater furze. I cannot find from whence Park. rec his fig. I suppose it was made by imagination. J. Goodyer.p. 45 .

[Dr. Stapf, who has kindly assisted in the determination of Goodyer's furzes, writes that in his opinion and in that of Mr. Sprague Genista spinosa minor Park., p. 1003, is entirely dubious. The figure in Parkinson goes back to the 1588 edition of Tabernaemontanus, where it is meant to illustrate Nepa Theophrasti of Pena and Lobel, but Tabernaemontanus himself says he is not sure whether it fits that plant. There is no indication where it was drawn from. Lobel's Nepa Theophrasti is evidently Ulex parviflores, and it may be that the figure is just a very bad illustration of that species. This Ulex would probably not be hardy in England.]

Gorse. Ulex Europaeus L.

Genista spinosa flore albo Park. 1003 .

[A whitish flowered variety.] 
Ulex parvifloms.

Genista spinosa major brevibus aculeis Bauh. Pin. p. 394.

This I suppose groweth not in England. Pena and Lobel in $A d v$. p. 354 had seene it nowhere but in Province wch is a hott country, and Lob. lived time enough in England before ye $A d v$. was written to have observed it if it had growne but half so common as ye lesser Furze. ${ }^{1}$ Cam[erarius] in hort. med. pag. Io6 saith ' in fichlibus asservanda' wch argues yt it will not endure abroad in a cold countrie in ye winter. The Icons yt were made for Nepa in $A d v$. p. 354, in Tabern. Ic. p. 408, in Hist. Lugd. p. I64 agree not with ye lesser Furze. Parkinson sayes yt his Genista spinosa minor p. 1003 is ye Nepa of Lob. This duly considered I am confident to affirme yt our lesser Furze is not yet described. John Goodyer.-p. 45.

[Druce (Goodyer, p. 26) is all at sea in the transcription of this paragraph. Dr. Stapf writes, "The Bauhinian species is evidently a mixture. To judge by the first synonyms (Anguillaria and Pena and Lobel) it was very probably meant for Ulex parviflorus, but through the additions (Tabern. \&c.) it got confused. See my observations sub U. names.']

Toad rush. Funcus bufonius L.

Gr[amen] holosteum Alpinum minimum. Bauh. Prod.

'Male a Johnsono Holosteum pumilum non descriptum, pervenit in ericetis. Joh. Goodyer.'-p. 53 .

? (See p I7I.)

Gramen murorum spica longissima. Capons taile-grasse.

'Mr. Goodyers upon ye walls of Winchester.'-p. 54.

Oenanthe angustifolia.-p. 81. (See under 18 June 1620.)

Pulnonaria angustifolia L.

Pulmonaria maculosa.

How substitutes the name of Goodyer for that of Loggins as the authority for the locality. 'Neer Kings-wood in Hampshire.'-p. Ico. [See under 25 May 1620.]

Vicia sylvatica L.

Vicia maxima sylvatica.

Great wood Vetch from a wood nigh Bath.

How has changed name to V. max. sylvatica 'spicata Bathoniensis Goodyeri '.-p. 129.

[How's MS. note in his Phytologia.]

1 Ye lesser furze. Parkinson uses the term 'lesser furse bush' for Genista spinosa minor. Does not Goodyer use it in the same sense, just as an English translation of that name?-O.S. 


\section{Geranium columbinum L.}

Geranium columbinum foliis magis dissectis, pediculis longissimis.

Aug. 1654

I found it wild in ye beginning of August 1654 . It is not described or pictured yt I find. John Goodyer.

$\mathrm{Qu}$ [ery] ye place of growth and des[cription] for this and [the next plant] following.

'In several places of Hampshire. J. Goodyer.' Merrett, Pinax 45.

[Druce's reading of the passage giving the locality as White Chapell is not justified.]

Sisymbrium Irio L.

Erysimum ii Tab. Qu[aere] locum.

[Before 1656 ]

Grows in ye streets near White Chappell east from Aldgate, London. J. Goodyer.

[Note in How's handwriting at end of his Phytologia.]

\section{Bunias orientale $\mathrm{L}$.}

Rapistrum aliud non bulbosum. P. 862.

[Before $165^{6}$ ]

'In the broad street by White Chappel, Mr. Goodyer.' Merrett, Pinax 103.

[Although this record was not printed before I666, it is probable that Goodyer found the plant with 'Erysimum ii 'on the same visit to London. If this be so, it must have been before the date of How's death in 1656.$]$

Wild Madder. Rubia peregrina.

Rubia sylvestris.

I2 Aug. 1655

[Recorded by Turner, I 551-68.]

The stalks are fower square, hollowe within smooth, one, two, three foot high, sometimes higher, with ioynts three or fower ynches apart: at the ioynt somethinge about the ground growe forth two side branches \& the like side branches at everie ioynt upward on the maine stalk, and those branches at the ioynts send forth other side branches after the same manner. At each ioynt of the greater stalk growe the leaves in a circle which are smooth, $6,7,8$ sometimes 9 at ech ioynt, the biggest leaves sometimes are about 3 quarters of an ynch longe, and broad, at ech ioynt also of the branches growe such leaves, but are smaller \& smaller towards the toppes of the stalkes \& branches.

The flowers growe abundantlie neare the toppes of the stalkes and branches, racematim, and are white, everie flower havinge 4 small sharpe pointed leaves. The seeds are small, round, manie times two growinge together. The rootes are small, with some threeds, 
creepeth farr in the earth, the barke thereof beinge of a yealowish redd color, \& stickie hard in the midle.

The stalks \& branches die everie yere, the rootes continue manie yeres.

It usuallie growes in drie chalkie grounds, in barren places the stalks are short, a foot or little longer, \& needes no supporter, in richer grownds they are much longer, in hedges \& amongest bushes, longest and needs supporters, as doe Gallium album.-MS. f. I 42.

\section{Apium imundatum Reichb. f.}

Sium pusillum foliis variis.

2 Junij i 656

The leaves before the plants have stalkes are like those of fennell but much smaller, growinge in abundance in the mudd within the water. The stalkes are hollowe as bigge as a wheate strawe, greene for the most parte sometimes reddish \& a foot long or longer \& growe uppe amongest the leaves not upright but swimming sidelonge in the water, the toppes only appearinge above it, wch at the ioynts devides into severall branches. At each ioynt on the stalk within the water growes one leafe, like fennell as the former, but shorter \& smaller, towards \& on the toppes of the stalkes \& branches with eyther and a little above the water, or swimminge on it are leaves much broader then the former, in forme \& fashion to those of Eruca palustris minor [Water-Rocket ${ }^{1}$ ]. Tab[ernaemontanus] pictured in his Icons p. 447 ; only these have not above 2 or 3 paire of small leaves on the midle ribbe of ech leafe, \& that hath 4,5 or more.

At the ioynts of the stalks towards their toppes growe the footestalks about an ynch of length, ech footstalk for the most parte devided towards the toppe into 2 parts, on ech of which parts comonly groweth $2,3,4$ or 5 small white flowers, clusterwise together, ech flower havinge 4 small sharpe pointed leaves, ech leafe beinge no bigger then a small pins head.

In their places come 2, 3, 4 or 5 seeds as bigge, and of the forme of Caraway or parsley seeds clusteringe also together.

The rootes are as small as threeds \& growe at the ioynts of the stalks \& fasten them selves in the mudd whercby it mightelie increaseth. It flowers about the beginninge $\&$ midle of May.

This plant growes comonly in small lakes, \& water plashes, but not described before that I know of. 2 Junij $165^{6}$ I made this description when the plant hadd almost done floweringe, \& much of the seed was of its full growth.-MS. f. I43.

\footnotetext{
${ }^{1}$ Nasturtium syliestre R.Br.
} 
Holosteum.

2 Junii 1656

See 'Herba aquatica' ig Aug. 1645.

Marsh Ragwort. Senecio paludosus, L. Conyza aquatica laciniata.

I9 July 1656

Growes in greate plentie in the fenns in Norfolk near Downam markett neare Linn, by the relation of John Meader of Downam markett, a grocer.-MS. 9, f. I 86 a.

\section{Samphire. Crithmum maritimum L.}

Crithmum chrysanthemum Ger. em.

Grows by Hurst Castle, Hants, by relation of John Meader of Downham.-MS. 9, f. 20 I a.

? S mooth Tare. Vicia tetrasperma Moench.

Viciae sive Craccae minimae species cum siliquis glabris Joh. Bauhini. Tom 2, p. 3I5. JG. 626. An Vicia segetum singularibus siliquis glabris. Pin. C. Bauh. p. 345 (b. 3). 4 Junii 1657

The stalk, a verie little above the ground \& so upward sendeth forth at the bosomes of the leaves severall other stalkes or branches, angular not round, a foot, a foot \& half high or longe, little more or lesse.

The Leaves growe on the stalkes or branches, about an ynch apart not by cooples, but one in a place, ech leafe beinge composed of a midle ribbe, endinge with a tendrell with which it taketh hold of what groweth neare it and on ech midle ribe 3 or 4 paire of leaves, ech leaf being about half an ynch longe and not fullie one eight part of an ynch broade.

The flowers growe on footstalks forth of the bosomes of the leaves, usuallie one footstalk out of ech bosome \& no more, ech footstalk beinge about an ynch longe as small as a small threed. The flowers come forth in May \& June \& growe on the toppes of the footstalkes, one, two or three at the most, yet seldome above one on ech footstalk, a quarter of an ynche longe, of a blewish or purple violett color, of the fashion of those of Aracus sive Cracca minima Lobelij.

The codds succeed the flowers, ech codd beinge about half an ynch longe, half a quarter or the eight part of an ynch broad, \& are smooth not hairie or woollie.

The seeds are contained in the codds, 2,3 or 4 seeds in ech codd, and are [unfinished].

The roote is small accordinge to the proportion of the plant devided into severall strings or thredds \& perisheth when the seed is ripe. $-M S$. f. 145 .

[? First evidence for Hants.] 
The next seven records are from Goodyer's MS. entries in How's interleaved copy' of his Phytologia (MIS. I 8) received by Goodycr on 30 Apr. 1659.

Rumex Acetosa L.

Acetosa maxima.

After 30 Apr. 1659

Goodyer MS. in How, Phyt. MS. I8, p. 2.

Alsine aquatica verna. Springe chickweed.

MS. I 8, p. 4 .

Arctium Lappa L.

Arctium montanum et Lappa minor Galeni Lob. Button Burre.

Mangerfield in Master Langlie's Yard. ${ }^{1}$ MS. 18, p. Io.

Galeopsis Tetrahit L., var. bifida Boenn.

Cannabis spuria altera flo. purp. Netle Hempe.

C. spuria altera sylvestris, Lamium quorundam Lob. Icon. 527 .

In agris.-MS. 18, p. 20.

Carex vulpina L.

Gramen palustre Cyperoides Lob. Ger. Great Cyperus Grasse. MS. I 8, p. 54 .

Viola tricolor L.

Viola sive Jacea tricolor sylvestris parva. Wild Pansies.

In agris. $-M S .18$, p. I 30 .

Common Ragwort. Senecio Facobaea.

Jacobaea Pannonica 2 Clus.

4 June 1659

Mr. Tho. Bartar ${ }^{2}$ of Petersfeild, schoolemaster gathered this imagined Pulmonaria Gallica Lobelii, on Ladle Hill in flower and brought it to J. G. the 4 of June 1659.

1 Druce, Goodyer, p. 25, notes that this record is not included in the Flora of Hampshire. Why should it be? The Manor of Mangotsfield was purchased in 1612 by Mr. Philip Langley who lived in Rodway Hill Manor House, still a fine survival of the time of King Henry VIII, three of whose wives may have visited it (Emlyn Jones, Our Parish: Mangotsfield). It was here that Johnson' and his socii were entertained in so grand a manner by 'that truly noble and generous man Philip Langley' when on their herborizing journey in July 1634. Evidently finding his own words inadequate to describe the luxury of the house and the sumptuous meal provided for his company, Johnson fell back on Virgil, and quotes a passage descriptive of some similar occasion when 'laden tables crowned with wines', huge goblets, drinking cups, \&.c., marked the feast (White, Flora of Bristol, p. 54).

2 Druce has misread this name as 'Geo. Burton', in the Rcp. Bot. Exch. Club Suppl. 1916, p. 23. 
It is Jacoboea Pannonica 2 Clus. C. Bauh. p. I 3 I (b. 8) \& it is Jacoboea angustifolia in this booke ${ }^{1}$ p. $280 .-M S$. I8, p. Io.

[Then follows a recipe taken from Parkinson, Theatrum, p. 518 , for an Alkanet ointment prepared by boiling 20 earthworms in good sallet oil.-MS. in How, Phytologia, p. 10.

Ladle Hill, crowned by a circular camp, is near Burghclere in the north of Hampshire.]

Cloudberry. Rubus Chamaemonus L.

Cloudberry.

I5 Apr. 1663

Mr. Tho. Thornton parson of Sutton ats Sulton in Sussex in Arundel Rape, borne at Bentham in Yorkshire, 2 miles from Yngleborowe hill, I5 Apr. 1663 promised Cloudberry.-Goodyer's MS. note in his copy of Ray, Catalogus Plantarum circa Cantabrigiam nasc.

Species of plants described in Goodyer's MS. and included by MERRETT in his Pinax by permission of Edmund Yalden in 1666.

Alsine flosculis conniventibus.

Montia fontana L.

Anagallis aquat. flore parvo viridi caule rubro. Ludvigia palustris

Elliot.

Aria Theophrasti fol. obtusis.

Caucalis pumila segetum.

Pyrus Aria L.

Geranium columbinum fol. magis dissectis.

Gramen Paniceum. Bearded Panick grass.

Juniperus sterilis.

Lathyrus maior angustifol. fl. pallidè rubro.

Lychnis sylv. flore carneo odorato.

'Ex Misto Gooderiano.'

Nidus avis.

Oenanthe angustifolia, Lob.

Pulmonaria foliis Echii.

Caucalis arvensis Huds.

Ger. columbinum L.

Panicum Crus-galli L.

Funiperus communis $\mathrm{L}$.

Lathyrus sylvestris $\mathrm{L}$.

Lychnis dioica $\mathrm{L}$.

Neottia Nidus-avis Rich. Oenanthe Lachenalii Gmel. Pulmonaria angustifolia $\mathrm{L}$.

Quercus serotina, procerior foliis fructuq. minoribus, Dor-Oak.

Linwood Hill, Bramshaw, Wilts.

Rapistrum aliud non bulbosum.
Quercus robur $\mathrm{L}$. agg. Bunias orientale L.

Rapunculus sylvestris flore rubro albescente. Campanula patula L.

' In the pastures \& hedgesides on the North-west of the Moor not far from the great bog neer Petersfield, Mr. Goodyer.'

Sedum Divi Vincentii, ND.

Serpyllum foetidum.

Sium umbellis ad caulium nodos.

Taxus tantum florens.
Sedum rupestre L. var. minus.

Thymus Serpyllum L. Apium nodiflorum Reicho. Taxus baccata L.

1 Gerard emaculatus.

O 2 
Veronica mas recta.

Vicia Bathoniensis vel maxima sylvatica.

Veronica officinalis $\mathrm{L}$. Vicia sylvatica L.

MERRETT also notes the following nine species as occurring in or near Petersfield, a locality possibly supplied by Goodyer.

Caryophillus saxatilis Ericae fol. umbellatis corymbis, C. B.

Probably Arenaria tenuifolia L. ${ }^{1}$

In the middle way betwixt Lippock and Petersfield.

Chamaepeuce foemina seu polyspermos. Lycopodium clavatum L.

A mile on this side Lippock in Hampshire.

Esula minor seu Pithusa G. 502 .

Euphorbia sp.

In divers corn fields near Petersfield.

Fungus corallinus ad antiquarum arborum radices.

Clathrus cancellatus $\mathrm{L}$.

In the Woods near Peters Field.

Gramen Paniceum procumbens.

Panicum sanguinale $\mathrm{L}$.

In a Lane \& watery places and Ditches near Petersfield.

Gramen Piperinum, Pepper-grass. Pilularia globulifera L.

Near Petersfield.

Gramen Secalinum maximum. The greatest Rye grass. P. II44.

Hordeum sylvaticum Huds.

In the Woods a mile west from Petersfield.

Holosteum repens juncifolium. Probably Scirpus fuitans L. ${ }^{1}$

At the bottom of the Moor on the East side of Petersfield.

Rapunculus corniculatus montanus. Ger. em. 455 .

Phyteuma orbiculare L.

Between Selbury Hill and Beacon Hill in the way to Bath, and in the Chalkey hills by Maple-Durham, Hampshire.

Species attributed to Goodyer by Ray, and not included in preceding lists.

'Flea-grass.'

Carex pulicaris $\mathrm{L}$.

Cyperoides pulicare Mcrret, Pinax, 'observed first by Mr. Goodyer and by him named Flea-grass, from the likeness of its seeds, both for figure and colour'. Ray, Synopsis. The locality is given as 'a mile East of Oxford', but whether Goodyer himself found it there is not stated.

'Species determined by B. D. J. 


\section{GOODYER'S LIBRARY}

AT his death in 1664 Goodyer bequeathed his collection of books de Plantis to Magdalen College in Oxon, 'to be kept entirely in the library of the said College for the use of the said College'; and one Compton, described in the College Accounts as 'auriga de Petersfield', was paid $£_{2}$ for bringing the books to Oxford. The librarian, ${ }^{1}$ who incorporated the bequest, inscribed the greater number of the volumes with the words 'Ex dono Joh. Goodyer, generosi ', and entered a list of them in a Book of Benefactors: a few volumes were, however, left unmarked. At first the books were more or less kept together, but the changing needs and views of successive generations led to their being scattered throughout the library, some being removed to a distant room in the Founder's Tower. In about 1909 Canon Vaughan, the distinguished Hampshire botanist, when preparing an article on John Goodyer, entitled 'A forgotten Botanist of the Seventeenth Century', could get no adequate idea of his predecessor's library. Eventually, however, the original list was discovered and copied. It is headed thus:

'A. D. 1664. Johannes Goodyer generosus idemque Botanicus celeberrimus libros sequentes (qui fere universos de re herbaria tractantes complectuntur) ad valorem plus minus I $20^{\text {lib }}$ amoris ergo moriens Collegio Magdalenensi Legavit',

which may be translated as follows: "John Goodyer, gent., and a most distinguished Botanist, bequeathed at his death to Magdalen College as a token of his affection the following books (which comprise almost all the authorities on botany) to the value of about $£$ I 20. .'

Canon Vaughan at once realized the value of the books. But let him speak for himself. "The names and descriptions of the volumes, reveal a most splendid legacy of botanical treasures. I had already recognized in $\mathrm{Mr}_{\mathrm{r}}$. John Goodyer a botanist of high repute, but that he possessed such a library I never for a moment suspected. The discovery came to me as a revelation. With the exception perhaps of the British Museum, the Bodleian Library, the Cambridge University Library, and the Library of the Linnean Society,

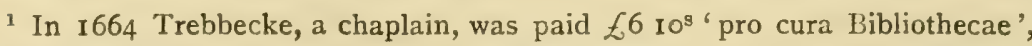
and John Clitheroe received the customary salary of $£ \mathrm{I}$ 'pro supervisione Bibliothecae'. 
there can be few, if any, such collections of botanical works of the sixteenth and first half of the seventeenth centuries in this country.'

When appointed to the charge of the library in I9I9 I was quite unaware of Canon Vaughan's correspondence with my predecessor, and the transcript of the list of the Goodyer books was not in the library. Using the old list in the Book of Benefactors as a guide, the work of bringing the scattered volumes together was begun, and with it the compiling of a new catalogue of those works which are still in the library. It is a matter for congratulation that the collection is far more extensive than a somewhat imperfect list printed in the Supplement to the Botanical Exchange Club Report for 1916 would lead one to expect, and that with few exceptions most of the volumes mentioned in the original list can be identified. All the books in the collection have now been marked with serial numbers and with the canting crest of the Goodyer family. There are about 239 separate printed treatises bound up into 134 volumes which in size are about equally divided into folio, quartos, and octavos. Of incunabula or works printed in the fifteenth century there are a few examples, chiefly from the famous press of Aldus in Venice; about a hundred of the treatises belong to the sixteenth, and the rest to the first half of the seventeenth century.

The wealth and variety of the collection is clearly shown by the catalogue, but the personal associations of particular volumes with contemporary botanists, as well as the marginal annotations. indexes, and notes, which Goodyer so freely added to the works he used, give a unique value to many of the books.

Some sixty-four of his books have the day of their acquisition and the price paid clearly written on the first fly-leaf. It is moreover a matter of interest that of the twenty works published and purchased by him between 1650 and 1660 no less than seven were acquired by Goodyer in the year before publication: a clear proof that his enthusiasm for his science led him to keep in the closest touch with the booksellers.

He appears to have started the practice of dating his books on $3^{1}$ January 161.5 when he acquired Bauhin's 1.59 .8 folio edition of Matthiolus for 20s. The subsequent dated additions to his library were as follows:

Date of acquisition.

13 Novemb. 1616 12 Decemb. 1616

$$
\begin{aligned}
& \text { Price. Tille and Year of Publication. } \\
& \mathrm{s} \mathrm{d} \\
& 26 \text { Clusius, Curae posteriores, I6II. } \\
& 16 \circ\{\text { Rariorum plantarum, I60I. } \\
& \text { Pona, Monte Baldo, fol. 1601. }
\end{aligned}
$$


Date of acquisition. Price.

s d

I 5 ffeb. 1616

28 ffeb. I6I6

Io Marcii 1616

12 Mar. I6I6

17 Mar. I6I6

9 April 1620

I8 May I623 Binding

7 September 1623

I 3 October 1623

30 Oct. 1623

30 Novemb. 1623

26 Junii 1624

I7 Novemb. I627

Io Novemb. I627

18 April 1629

Io Novemb. I63 I

I4 Novemb. I63I

13 Novemb. 1632

2 October 1632

Io Octob. 1632

I8 Maij I633 bindinge

28 Oct. 1634

30 April 1634

24 Aug. 1640

27 April I64I

In quires

The bindinge

? 1648

I9 ffeb. I65I

15 March 165I

22 March I65I

15 July 1652

I Decemb. 1652

II Aug. 1653

Io Feb. 1653

7 Septemb. 1654

7 Septemb. 1654

I9 Februarij I654

I 5 June 1654

16 Apr. 1654

30 Marcii 1654

31 Augusti I 654

7 Sept. 1654.

20 Marcij " 655

4 Aprill 1655

I9 Aprill 1655 li

3
3510
Title and Year of Publication.

Clusius, Exoticorum, 1605. Paged by G.

Bauhin, Phytopinax, I 596. Full of G.'s notes.

Lobel, Plantarum, 1605 . $2^{\text {nd }}$ part.

$I^{\text {st }}$ part

the binedinge them together. $\int 9^{\mathrm{s}} 6^{\mathrm{d}}$

Dodoens, Stirpium, I6r6.

2 o. Sprecchis, Antabsinthium, 16II.

$--\}$

I5 6 Theophrastus, Opera, I 54I.

I6 o Columna, Minus cogn. stirpium, I6I6.

6 o Lobel, Kruydtboeck, 1581 .

receaved this booke from bindinge. Bauhin, Pinax, 1623.

36 Bauhin, Prodromus, I620.

4 - Caesalpinus, De Plantis, 1583.

Io o de Passe, Hortus Floridus, I6 5.

9 - Pona, Monte Baldo, 1617.

- I8 Dioscorides, de curationibus, $\mathbf{1} 565$.

- I2 Thevet, Amerique, 1558.

- 6 Plat, 1608.

200 Matthiolus, Comment. 1583.

4 - Matthiolus, Compendium I 57 I.

$46) 4^{\mathrm{s}} 7^{\mathrm{d}}$. Donati, de semplici di Venetia, o I I63I.

Johnson, Mercurius, 1634, ex dono Th. Johnson.

40 Dodoens, De Frugum. 1552.

$\begin{array}{ll}36 & 0\end{array}$

30

39. Parkinson, Theatrum, I640.

Johnson, Mercurius Pars altera.

Thurneiser, 1578 , bound.

50 Culpeper, English Physician, I652.

Bauhin, Historia plantarum.

Sent Dr. Dale for Johes Bauhin 3 volumes. for the portage to \& from Dr. Dales.

to John Symonds to carry up the money. to William Mychell for bringing the bookes down.

36 Pemel, Simples, I652.

I I4 o Hernandez, Planta Mexicanorum, I65I.

' to a porter for carriage to Dr. Dale. Portage down in Mris Elz. Heathes Trunck.'-I I Dec.

46 Renealmus, Specimen, 16II. [Purch. by How.].

Io 0 Bauhin, Theatri botanici, 1658 .

Duval, Phytologia, I647.

76 Laurenberg, Horticultura, I654.

Lobel, Stirpium illustrationes, 1655 .

86 Dioscorides \& Nicander, I499.

Lonicer, (imp.).

Matthiolus, Les Commentaires, 1566.

26 Aristotle \& Theophrastus, 1552.

Amatus in Diosc. 1558.

3 - Binding Dioscorides MS

I 4 Coles, Art of simpling, '56.

25 o. Matthiolus, Kreutterbuch, I590.

3 o Brunyer, Hort. Blesensis, I653. 
Date of acquisition. Price.

19 Aprill 1655

5 Aprill 1655

I Junij 1655

Io May 1655

25 May 1655

25 May 1655

25 May 1655

25 May 1655 unbound

28 Junij , the bindinge

25 May 1655 in quires

28 Junij 1655 the bindinge

6 Sept. 1655

I 5 Julij 1657

I5 Julij 1657

16 Decemb. I657

16 Decemb. 1657

11 Mar. 1658

2 Dec. 1658

30 Apr. 1659

30 Apr. 1659

1659

21 March 1660

Io May 1660

26 Sept. I66I
Title and Year of Publication.

Vigna, Animadversiones.

Cooke, Chirurgery, I 648.

" Supplement, 1655.

Iufret, Healih, 1655 .

Troxiten, 1595.

Dioscorides, Laguna transl. 1555.

Curtius, 1560 .

$5^{s} 8^{\mathrm{u}}$. Guilandinus, Theon, I 558.

$15^{\mathrm{S}} 4^{\mathrm{d}}$. Lonicer, Kreuterbuch, 1630.

Tabernaemontanus, 1625 .

Theophrastus, ed. Gaza, 1644.

10 Moscardo, 1656.
42 Langham, 1633.

Coghan, Health, 1636.

Neander, Tobacologia, 1626. [Ex dono R. Downes.]

I 2 Everartus, Panacea, I659.

3 - Dodoens, Herbarius, 1563 \} 'Basingstoke'

4 D Dorsten, Botanicon, I 540 ' Basingstoke.'

[How], Phytologia, I650.

$6 \circ$ Lovel, Hist. Animals, 166I.

26 Ray, Cat. Pl. Cantabrigiensis, 1657.

4 O Binding Theophrastus MS.

\section{Signatures or Personal Memoranda IN GoOdyeR'S BoOKS.}

The numbers are the reference numbers stamped on the backs of the volumes.

Hendrik Alberts.

Guilielmus Barlous Anglus.

$J B$ ex dono $C B$ consang.

Evidently a gift from Caspar to Jean Bauhin.

O. Bilson. .2

Henry Blount.

Magister Bowden.

De Brina

Lancelot Brozene, M.D., $1598 .^{3}$

F. Bust 1577 .

Jacob Cole. ${ }^{4}$

D. Daile in Long Aker.

Dr. Dale.
Dodoens. II.

Dioscorides. II3.

Thurneiser. 37.

Turner. I 3.

Neander. 67.

Dodoens. I I.

Clusius. Io6.

Caesalpinus. 59 .

Joubert. 128.

Dodoens. 96.

Hernandez. 26.

Hernandez. 26. Bauhin. 43.

1 JeAn BAUhin, 154I. CASPAR BAUhin, 1560-1624. Converted the chaos of plant nomenclature into order in 1623. Goodyer entered biographical notes on Bauhin on a fly-leaf of his Phytopinax.

2 O. BILSON. See p. 96 .

${ }^{3}$ Lancelot Browne, M.D. Fellow of Pembroke Hall and of the College of Physicians, 1584; first physician to Queen Elizabeth. He is quoted on the subject of the Balsam tree by Gerard, to whose Herbal 1597 he contributed a eulogistic epistle. He died in 1605 .

- James Cole. Son-in-law of Lobel, see p. 247.

5 DR. DALE. See p. 294. 
Ric. Downes. ${ }^{1}$

Joannes Freame.

Ricus Garth.2

Rob. Garth, Juris Nat. Consult.

25 Martij 1598.

Alexis Gaudin.

Rich. George, pharm. of Reading.

Jl. Gilbou[ rne]?.

John Gooche.

Jo: Gaoodier.

Johes Goodyer.

E. Gray, 'heboriste'.

Hen. Harvey et amic.

Tho. henry.

\section{W. Howe.}

R. Huchenson.

Susan Ironsmith.

Thomas Johnson. ${ }^{4}$

Johan Jull.?

Bartho: Kempe.

G. Le Fevre. ${ }^{5}$

Matth. de Lobel. ${ }^{6}$

Alexander Massa.

Geo. Medeleye.

W. Monnt. ${ }^{7}$

Dr. Martin Ramerius. ${ }^{8}$

$G$. Rondelet.

Anth. Rous.

Antony Srolms.

H. W. (? Henry Wotton, M.D. ${ }^{9}$ )

John Yates, barber \& chirurgion.
Neander. 67.

Kyber. 105.

Caesalpinus. 59 .

Caesalpinus. 59 .

Dioscorides. 5 .

Dodoens. II.

Porta. I30.

Lonicer. 14.

Monardus. I 26 .

Passe. 8I.

Turner. I3.

Stephanus. 95.

Cooke. 1 I 8.

Matthiolus. $3^{8}$. Renealmus. I4. Johnson.99. Tábernaemontanus. 46. How MS: I8.

Dodoens. 97.

Matthiolus. 32 .

Johnson. 105. Brunfels. 29.

Fuchs. 35 .

Dodoens. I2.

Hess. 100.

Lobel. I7.

Fuchs. II2.

Dorsten. 9.

Lobel. 79 .

Lobel. I 7 .

MS. 13 .

Soranus. 6.

Fuchs. 8.

Ruellius. 34 .

Dodoens. IO.

1 The Samuel Downes, M.D., who made the collection of dried plants presented by J. Downes in 173 I to Shrewsbury School, may have been related to Richard Downes.

${ }^{2}$ RICHARD GARTH. See p. 237.

${ }^{3} \mathrm{E}$. GRAY, 'heboriste'. It would be interesting if he should turn out to be Gray the apothecary (f. 1570), who introduced Pistacia officinalis (Lobel, Adv. 4I3) and had trees of Diospyros Lotus L. and of Celtis australis L. in his garden under London Wall (Ger. 1308, I310).

4 Thomas Johnson. See p. 273.

${ }^{5}$ G. LE FEVRE. At a later date two of this name appear on the Roll of the R. College of Physicians. Sebastian Le Fevre, L.R.C.P., I684, Joshua Le Feure, F.R.C.P., 1687.

${ }^{6}$ LOBEL. See p. 246.

${ }^{7}$ W. Mount. See p. 253 .

8 Martin Rhamneirus, M.B., a Spaniard, a native of Cordova and a Bachelor of Medicine, was admitted a Licentiate of the R. College of Physicians, 1584.

${ }^{9}$ Henry Wotton, M.D., Student of Christ Church and Fellow of Corpus Christi College, Oxford, F.R.C.P., 1571-2. 


\section{PERSONS FROM WhOM BOOKS WERE ACQUIRED.}

Dr. Dale

Vendor.

Carrier.

Eliz. Heath

Name of work.

Dr. Dale

Humplirey Robinson ${ }^{1}$

Bernard Robinson

Foln Martin

Octavian Pulley'n²

William Wells

Mr. Allestre

William My'chell Fohn Symonds ; Bauhin, Hist. Pl. $+3-4.5$.

Hernandez. 26.

\section{Donor. \\ Richard Downes}

Dr. Willian How

Perhaps a vendor

Thomas Folnenon

Bauhin, Theatr. 52 .

Tabernaemontanus. 46-47.

Matthiolus. 38 .

Renealmus. 68.

Neander. 67.

Renealmus. 68.

Tabernaemontanus. 46-47.

Matthiolus. 38 .

How \& Lobel. 72 .

How, Phyt. MS. I8.

Johnson. 99.

Mercurius. 105 .

Books Containing Goodyer's Notes.

Goodyer wrote notes in almost all the books with which he worked. Chief of these were

Tabernaemontanus, Eicones, I590.

[Lobel], Icones, I59I.

Bauhin, Phytopinax, 1596.

And doubtless his copy of Gerard's Herbal, 1597, was similarly annotated and corrected, but it is unfortunately no longer in the Library. ${ }^{3}$ He numbered the pages or chapters of

Bauhin, Hist. plantarum, I650. G. numbered 6524 columns.

Besler, Hort. Eystettensis, I6r3. To p. '854'.

"Fasc. rariorum, 1616 .

Clusius, Exotica, I605.

Dioscorides, 1499.

Theophrastus, 1497.

He numbered or named plants described or figured in

Bauhin, Animadversiones, I6or.

1 HUMPHREY ROBYNSON of London appears in a book of Richard Napier's astrological practice in $\mathbf{1 6 0 6 . ~ M S . ~ A s h m o l e ~} \mathbf{I} 8 \mathbf{1}$.

${ }^{2}$ OCTAVIAN PUlleyn described himself as mercator librorum Italicorum in an inscription inside the cover of a book (Tower F. I) given by Sam. Lee to the Wadham library. An Octavius Pullin (? the same man) had been a student at Padua in 1638-9 (Andrich, De Natione Anglica, Pataviis I 892). See p. 294.

${ }^{3}$ I shall be most grateful for any information which will enable me to trace the whereabouts of the lost volume. It should be readily recognizable by Goodyer's notes. 
Johnson, Iter, 1629

" Mercurius, 1634 .

$" \quad$ I64I. de Passe, Hort. Floridus, I615.

Thalius, Sylva Hercynia, 1588.

Tragus, 1552.

Goodyer was an indefatigable indexer. In some cases, in which several works are bound up together in the same cover, he not only corrected the pagination of the separate works, but carried the page-numbers right on. He made indexes to the combined works of Turner (No. I3), to de Bry's Anthologia, I626, and to Clusius, Rarionum Plantarum (MS. 8. iii). His index to Gerard's Herbal ( 597 ) is in a small 8 vo parchment-bound volume (MS. 16). The manuscript indexes to the following works are bound with MS. II.

Johnson, Mercurii I and 2, MS. II, ff. 29-32.

How, Phytologia, MS. I1, ff. 33-7.

\section{Catalugue of the Goodyer Library.}

The notes quoted in small type are mostly in Goodyer's hand. AlBuCASIS.

6 Libri tres Chirurgicorum.

Bound with Horatianus.

fol. Argent. Schott 1532

Alpinus, Prosper.

6I $\left\{\begin{array}{l}\text { De plantis Aegypti. } \\ \text { De balsamo dialogus. }\end{array}\right\}$

4. Ven. 1592

With notes to plates.

62 De plantis exoticis, libri duo; ed. ab Alp. Alpino auctoris fil.

4. Ven. 1627

With G.'s references to Parkinson.

92 De rhapontico disputatio.

4. Patav. 1612

'Bauhinus transmisit novā Piperā Indicam-Pinax I03 (a 7).'

Amatus, Lusitanus.

82 In Dioscoridis ... de Materia Medica. 8. Lugd. $155^{8}$

'7 Septemb. 1654-58.'

Apuleius, Lucius.

86 De medicaminibus herbarum, lib. I. Edited with a commentary by Gabriel Humelberg. 4. Isinae I 537

De herbarum virtutibus historia ; at end of SORANUS, q.v.

Aristotle.

[fol. Basil. I 528]

2 Problemata, Mechanica, Metaphysica.

fol. Ald. 1497

Bound with Theophrastus, De historia plantarum.

I38 Historia animalium etc. 8vo. Lugd. I552

Alexander Aphrodisiensis.

2 Problemata. fol. Ald. I497

Bound with Theophrastus, De historia plantarum. 
BAUHINUS, CASPAR.

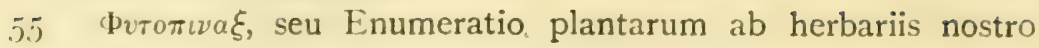
saeculo descriptarum cum earum differentiis etc. et cum iconibus; [libri octo].

' 28 ffeb $1616-3^{\mathrm{s}} 6^{\mathrm{d}}$.'

4. Basil. I 596

Numerous notes by G., including notes on Bauhin's life.

Animadversiones in historiam generalem plantarum Lugduni editam. Catalogus plantarum circiter quadragintarum eo in opere bis terve positarum.

(De homine oratio in medicorum Lycaeo I614.

Plants numbered by $\mathrm{G}$.

4. Athen. Rauracis [1614]

Icy De remediorum formulis Graecis, Arabibus et Latinis usitatis.

12. Francof. 1619

De corporis humani partibus externis.

$69 \Pi_{\rho \circ \delta \rho o \mu o s}$ theatri botanici. ' 26 Junii $1624-3^{8} 6^{\mathrm{d}}$ '.

I 2. Basil. 1588

4. Francof. I6 20

$56 \Pi \iota v a \xi$ theatri botanici ; sive index in Theophrasti, Dioscoridis, Plinii et aliorum qui de plantis scripserunt; [libri duodecim].

'Receaved this booke from bindinge 30 Novemb. I623.'

Interleaved. A few notes on pp. 2, 52, 96, last leaf.

I23 Catalogus plantarum circa Basileam sponte nascentium.

8. Basil. 1622

52 Theatri Botanici, sive historiae plantarum liber primus.

fol. Basil. I6,58

'Io ffeb. $1653-10^{8}$ a Johanne Martin.' Marginal references by G.

BAUHINUS, JOANNES.

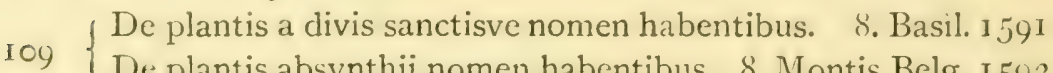
De plantis absynthii nomen habentibus. 8. Montis Belg. I593

$88\left\{\begin{array}{l}\text { De aquis medicatis libri quatuor. } \\ \text { De variis fossilibus, stirpibus et insectis. }\end{array}\right\}$ 4. Montis Belg. I6 I 2 Reference on p. 194 by G.

7 Historiae plantarum generalis prodromus.

(With CHERLER, J. H.)

Reference on p. 7I by G.

43-5 Ilistoria plantarum universalis, quam recensuit et auxit 1)om. Chabraeus, juris publici fecit Fr. Lud. à Graffenried.

'March the $15^{\text {th }} 1651$

3 vols. fol. Ebrod. 1650-I

bought of my Master Humphrey Robinson

the 3 vollumes of J. Bauhinus which I do warrant

to be pfect per me Bernard Robinson.'

Columns numbered I to 2064 and I to 2172 and I to 2288 . 
Inscription by Goodyer

I651 22 March

sent Dr. Dale for Johes Bauhins 3 volumes

for the postage to and from Dr. Dales

to John Symonds to carry up the money

to William Mychell for bringing the bookes down

$$
\begin{array}{cccc}
3^{\mathrm{li}} & 2^{8} & 6^{\mathrm{d}} \\
0 & \mathrm{I} & 0 \\
0 & 1 & 0 \\
\circ & 1 & 4 \\
\hline £ 3 & 5 & 10 \\
\hline
\end{array}
$$

Bayfius, see Stephanus, C.

Bellonius, P.

4I Observationes.

Translated \& edited by C. Clusius. fol. Plantin, I 605

Bellus, HoNorius.

39 Epistolae de rarioribus quibusaiam plantis agentes. fol. I601 (With Clusius, No. 39.)

BESLER, BASIL.

29* Hortus Eystettensis.

large fol. s. 1. I6I 3

Paged by G. to 854 . Plant names written on some plates, e.g. 540.

80 Fasciculus rariorum et aspectu dignorum, varii generis etc.

Pages numbered.

fol. Norib. I6 6

Blesensis, see BRUNYER.

Bock, H., see TRAGUS.

Brasavolus, Ant. Musa.

I03 Examen omnium simplicium medicamentorum; with Aristotle's Problemata quae ad stirpium genus et oleracea pertinent.

8. Lugd. I 537

86 De herba Vetonica ; with a commentary by Gabriel Hummelberg; with L. Apuleii libro De medicaminibus herbarum.

4. Isin. 1537

Two ff. of Latin MS. with marginal notes. No notes by G. A bill of 4 items on p. I 'Coyse $3^{8} o^{d}$, Fan $3^{\mathrm{s}} 2^{\mathrm{d}}$, Apuleius $2^{\mathrm{s}} \mathrm{o}^{\mathrm{d}}$, Plato $0^{\mathrm{g}} 6^{\mathrm{d}}$ '.

BREDA, see BROSTERHUSIUS.

Brosterhusius, JoH.

I34 Catalogus plantarum horti medici illustris scholae Auriacae, quae est Bredae. $\quad$ 8. Bredae, I647

BRosse, GuY DE LA.

7 I Description du jardin royal des plantes médicinales.

4. Par. I6 66

I08 De la nature, vertu et utilité des plantes, divisé en cinq livres.

On back of title ' $\mathrm{I}^{\mathrm{lb}} \mathrm{O}$ '.

8. Par. 1628 
Browne, W., see Stephens, P.

[BRowne, SiR T.

Hydriotaphia. Missing.

London, $\left.165^{8}\right]$

BRUNFELS, O.

29 Onomasticon medicinae continens omnia nomina herbarum.

fol. Argent. ap. Jo. Schottum, I534

' 20 Nov. 1634 Tho. Johnson bought him for $3^{8}$.'

Bound with Hildegard, Physicae. G. has added names to the list of writers on fo. $k$ ii.

On the title-page is an inscription in the handwriting that we have called that of Dr. Dale, who may have owned the book after Johnson's death in 1644 .

7 Herbarium. Vol. I. Herbarium. 2. Novi Herbarii, I 536. 3. Tomus Herbarii III, I536. Appendix, I539.

'I 537 Hen. 8vi 28.'

fol. Argent. ap. Jo. Schottum, I 537

Brunyer, ABEl.

20 Hortus regius Blesensis.

'I9 Aprill $1655-3$ '?

fol. Par. 1653

BRUYERINUS, JOANNES.

124 De re cibaria, lib. xxii.

8. Francof. I 600

BRY, J. T. DE.

25 Anthologia Magna.

fol. Francof. 1626

MS. Index by G.

[BuMaldus, MONTALBANUS.

Bibliotheca Botanica. Missing. 12 Bononiae, 1657]

Caesalpinus, Andreas.

59 De plantis, lib. 16.

'I7 Nov. 1627-48,

4. Florer.t. $15^{8} 3$

On title:- 'Ricũs Garth praeciũ $\quad x^{8}$

Sum Lanceloti Brunii medici Reginei ex dono amicissimi viri Mri. Rob. Garthii Juris Nationalis Consult 25 Martij 1598.'

2 Titles of books (Durante \& Rondelet) noted.

65 De metallicis, lib. 3. 4. Romae, I 596

Ref. at end to p. 152 'liber de questionibus Peripat. c. Magnet'.

In binding is a writing relating to - Scott of Sutton, 1608.

CAESAR, see CORNARIUS.

Calceolarius, F.

$5^{8}$ Iter Baldi.

8. Francof. I 586

With Matthiolus.

CAMETiRIUS, JoACHIMIUS.

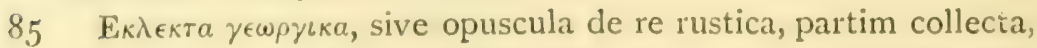
partim composita a J. Camerario.

4. Norib. 1577 
89 Hortus medicus et philosophicus, in quo plurimarum stirpium breves descriptiones etc. continentur. 4. Francof. 1588

89 Icones accurate delineatae praecipuarum stirpium, quarum descriptiones tam in Horto quam in Sylva Hercynia suis locis habentur.

References to "Icones'.

4. Francof. 1588

Kreutterbuch 1590 , see Matthiolus, No. 38 .

[CATO, M. PoRCiUs.

De re rustica. Missing.

I 2 Col. I 536]

Probably disposed of as a duplicate of the copy presented by A. Throkmorton.

Ciiemititz, Joannes.

92 Index plantarum circa Brunsvigam nascentium: Appendix continens icones plantarum.

4. Brunsvigae, 1652

Cherlerus, see Bauhin, J.

Clavenas, Nicolaus.

$92\left\{\begin{array}{l}\text { Historia absinthii umbelliferi. } \\ \text { Historia scorzonerae Italici. }\end{array}\right\}$

4. Venet. I610

Clusius, Carolus.

I07 Historia rariorum aliquot stirpium per Hispanias observatarum.

8. Ant. 1576

I06 Historia rariorum aliquot stirpium per Pannoniam, Austriam et vicinas quasdam provincias observatarum. 8. Ant. ${ }_{1583}$

Stirpium nomenclator Pannonicus (Beithii). " " I 584

On title, 'huius libri pretium- $3^{\mathrm{B}} 4^{\mathrm{d}}$. De Brina'. Name of an owner erased. On last p. 'Costa soldi tre, dico $S_{3}$ moneta sterlinga I583, 25 Decemb.'

4I Exoticorum libri decem, quibus animalium, plantarum, aromatum aliorumque peregrinorum fructuum historiae describuntur; item P. Bellonii observationes C. Clusio interprete.

fol. Plantin. 1605

With a copy of the Curae posteriores, and Oratio funebris at end.

' 15 ffeb $1616-15$.'

Pages numbered by G., beginning p. ' 825 '. Marginal references.

$39\left\{\begin{array}{l}\text { Rariorum plantarum historia. } \\ \text { Fungorum in Pannoniis observatorum historia. }\end{array}\right\}$ fol. Ant. I60I

This work has been repaged by $\mathrm{G}$., who also compiled an index to it.-Goodyer MS. 8.

Curae posteriores.

fol. Plantin, I6 II

With G.'s references to Phyto. and Pinax.

'I3 Novemb. 16I6. Cur. poster. $2^{8} 6^{d}$.

12 Decemb. 1616

Oratio funebris in obitum C. Clusii (by E. Vorst).

fol. Plantin, I6 I I 
Coghan, THOMAS.

I32 The Haven of Health, chiefly gathered for the comfort of students; hereunto is added a preservation from the pestilence, with a short censure of a late sickness at Oxford. $4^{\text {th }}$ edit.

'I6 Decemb. 1657.'

8. Lond. $163^{6}$

Coles, W.

I2 I The art of simpling; an introduction to the knowledge of gathering plants; whereunto is added a discovery of the lesser world.

8. Lond. 1656

'20 Marcij $1655-1^{8} 4^{d}$.'

In binding a fragment of deed mentioning 'Lady Jane late Queene' and 'Lady Ann' at 'Bower'.

COLlaErt, Adrian.

80 Florilegium.

oblong $4^{\text {to }} \cdot$ n. d.

Columella, Lucius J. M.

I Io De cultu hortorum.

I2. Argent. I530

Columna, Fabius.

87 Фvтоßaбavos, sive plantarum aliquot historia; accessit ctiam piscium aliquot historia.

8. Neap. I 592

Refs, to Pincrx.

Minus cognitarum rariorumque nostro coelo Orientium stirpium $\epsilon \kappa \phi \rho \sigma \iota \varsigma$, item de aquatilibus aliisque animalibus quibusdum paucis libellus. In two parts. 4. Rom. I6I6

Purpura ; et aliorum aquatilium observationes.

'I3 Octob. 1623-16'.'

'Fabius Columna was but 25 yere old when he sett forth his Phutobasanos p. 210 \& he set forth his P. ten yers before he wrote this story, p. 219. Diosc. graecus codex MS. p. 7 I.

Johannis Carbonarius of Naples hath many old Manuscripts p. 7 I. Johannis Baptista Raimundi idem p. 72, 142.' Go's notes.

Contarini, see Pona.

COOKE, JAMES.

I 8 Melleficium chirurgiac, or the marrow of many good authors on the art of chyrurgery.

8. Lond. 1648

' 5 Aprill $1655-2^{8} 4^{\text {th'? }}$

Name of former owner 'Tho' 'Thenry' on front page.

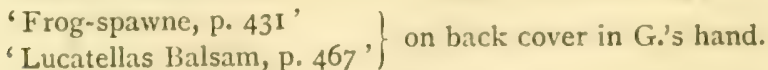

I19 Supplement to the marrow of chyrurgerie. 8. Lond. 1655

'I Junij 1655-2 $2^{3} 4^{\text {cl }}$.'

'Swellings of the lunges 228.' 'Ricketts-243.'

[Select observations on English bodies. Missing. 8. 1657] 
CORDUS, EURICIUS.

102 Botanologion. 8. Col. ap. J. Gymnicum ${ }_{5534}$

[CORdus, Valerius.

Annotationes in Pedacii Dioscoridis Anazarbei de materia medica libros quinque.

Historiae stirpium, cum iconibus, libri quatuor.

Sylva de fossilibus in Germania.

De artificiosis extractionibus.

Compositiones aliquot medicinales rariores. fol. Argent. I 56 I ]

Missing : perhaps duplicated by the copy in the Gibbarde Collection and sold.

\section{Cornarius, J.}

123 Constantini Caesaris selectarum preceptarum de agricultura libri viginti, interprete Jano Cornario. $\quad 8$. Basil. $I_{540}$

With marginal notes (cut by binder) in early hand.

'DUUM em C. h. g. o' on last p.

'the orderig of vynes // liber quint / fo.'

CORnutus, Jacobus.

6I Canadensium plantarum aliorumque nondum editarum historia; Enchiridion botanicum Parisiense.

Notes to figures: refs. to Parkinson.

\section{Costaeus, Joannes.}

90 De universali stirpium natura. Libri duo. 8. Aug. Taur. 1578.

\section{Crescentius, $\mathrm{P}$.}

I De plantis, animalibus et agricultura. In contemporary Oxford stamped leather binding.

Pagination added by G. MS. list of ten goodwives. See p. $38 \mathrm{I}$.

\section{Cuba, Johannes DE.}

9 Hortus sanitatis de animalibus et reptilibus, de avibus et volatilibus de piscibus et natatilibus, de gemmis et in venis terrae nascentibus.

With Dorsten.

fol. Argent. p. Matth. Apiarium I 536

\section{Culpeper, Nich.}

23 The English Physician.

'I9 ffeb. I65I-58.'

'Vale et diu vive.'

fol. London 1652

Curtius, Benedictus.

$3^{5}$ Hortorum, libri triginta.

' 25 May $1655-15^{8}$.' 
Dalechampius, Jacobus.

I35-6 Historia generalis plantarum. 2 vols. fol. Lugd. $5_{586-7}$ The copy in the Sherardian Collection in the Botanic Garden has the name of Goodyer's great friend William Coys written on the title-page.

\section{Dioscorides, Pedacius.}

4 Opera Gr.

' 15 Junii $1654-8^{8} 6^{d}$.'

fol. Ven. Ald. I 499 Ed. pr.

Paged, and chapters numbered.

5 Opera trad. de lengua Griega en la vulgar Castellana por Andres de Laguna. ${ }^{1} \quad$ fol. Anvers. 1555 '25 May $1655-25^{8}$.'

'Alexis Gaudin' (owner's signature on title). Silver stamp on binding.

II3 De materia medica, ab Andr. Matthiolo emendata.

'Guilielmus Barlous Anglus $6 \frac{1}{2}$ bats 1567.

I2. Lugd. I 554

Prescription 'contra pestem D. Cratonis' on last page.

83 De medicinali materia Gr. Lat. 8 libb. cum castigationibus.

Lat. transl. by J. Ruellius.

8. Paris 1549

With Paragraphs numbered throughout and cross references to Matthiolus by Goodyer.

$73\left\{\begin{array}{l}\text { De simplici medicina. } \\ \text { De naturis et virtutibus aquarum. }\end{array}\right\} \quad$ 4. Lugd. I512

With medical prescriptions at end in an old hand.

84 De curationibus morborum per medicamenta paratu facilia lib. 11 8. Argent. 1565

With Latin translation, partly by J. Moibanus, partly by C. Gesner. 'ro Nov. 1631-1 8d'

A few marginal notes by G., pp. 258, 593. At end 'Antidotus Saxonica 830. Inflatio stomachi, 533.'

On title initials of former owner 'RS.' In binding, part of an English theological MS. on parchment.

DODOENS, REMBERT.

$9^{6}$ De Frugum Historia.

' 30 April $1634-4^{8}$ '

12. Antv. 1552

'Jacobi Colei.' His marginal notes on p. $14 \mathrm{v}$.

1 In the copy of this work in the Botanical Department of the British Museum I found an inscription, presumably by the translator:-

Doctor Andreas Lagouna hunc librum Johanni

Mutier amico suo, dono dedit anno 1557. 
L'histoire des plantes; traduite de bas Aleman en François par Charles de l'Escluse.

fol. Anvers. I 557

With G.'s references and many old notes. At end 'John Yates, barber \& chyrurgion'. 'hope helps hevie harts.'

Of Lentiscus he notes:

' $\mathrm{I}$ se thys tre at benys marks in London at one $\mathrm{M}^{\mathrm{r}}$. Hennege hys howse of the previ chamber to quen elizabeth.' p. 547.

'The leves of saven mayd in powder \& droken with alle kylleth worms in the bellye.

'Also $y^{\theta}$ sayd powder cast uppon warts in ye yard of man kylleth ye warts, \& if it be swelled it wyll dyssolve it.' p. 538.

' 30 Apr. 1559-3 $3^{\mathrm{g}}$. Basingstoke.'

'Hendrick Alberts-I 570' on last page.

'Richardus George pharmacopeus de Reading est verus possessor huius libri, ex dono Magistri Bowden, Julij 9 die 1619.'

With many MS. translations into English of the Dutch text, which Mr. George evidently had difficulty in comprehending.

A neewe herball or history of plantes; first set forth in the Doutche or Almaigne tongue, and nowe first translated out of French into English; by Henry Lyte.

'Bartho: Kempe.'

fol. Lond. Gerard Dewes, I 578

Cruydt boeck, met buivoegsels achten elck capittel .. . Carolus Clusius.

fol. Leyden, 1608

42 Stirpium historiae pemptades sex, sive libri triginta.

' 9 April $1620-20^{8}$. the carrier $I^{8}$.'

fol. Antv. I6I6

With a few references to Phyto. (p. 125) by Goodyer.

97 Purgantium, aliarumque eo facientium, tum et radicum, convoluulorum.

8. Antv. I574

'R. Huchenson.'

\section{Donati, Antonio.}

92 Trattato de semplici, pietre et pesci marini, che nasceno nel lito di Venetia.

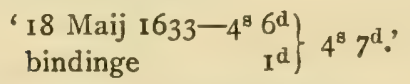

4. Venetia $166^{1}$

DORSTENIUS, THEODORICUS.

9 Botanicon, continens herbarum aliquotque simplicium, quorum usus in medicinis est, descriptiones et iconas ad vivum effigiatas. fol. Franc. Christ. Egenolphus I540

' 30 Apr. 1659-48.' Basingestoke. Many old notes.

Name of earlier owner 'George Medeleye, $\mathrm{vi}^{\mathrm{B}} \mathrm{viii}^{\mathrm{d}}$ ' on title.

DURANTE, Castor.

2 I Herbario novo, con figure.

fol. Rom. 1585 
Duval, Guillelims.

98 Phytologia; sive philosophia plantarum. '7 Septemb 1654.'

Eder, Gulielmus.

I IO Synonyma Plantarum seu Simplicium ut vocant, circa Ingoldstadium sponte nascentium ... in usum Scholae Medicae Ingolstadiensis collecta. I2. Ingolstadii. I6I 8

EGENOLPH, C.

(Plantarum arborum fruticum et herbarum effigies ... Bäume, Stauden, Kreuter, etc., cum Indice sextuplici. 8. Franc. C. Egen. ${ }_{5}{ }^{62}$
Animantium terrestrium, volatilium et aquatilium effigies.

I9 pp. 8. Franc. C. Egen. I562 At end is a Petition of Richard Chambers to Parliament $c .1644$. $\mathrm{E}[\mathrm{vELYN}], \mathrm{J}$.

24 Sylva, or a Discourse of Forest Trees. fol. Lond. I664 Everartus, AEgidius.

I 20 Panacea, or the universal medicine; being a discovery of the wonderful vertues of tobacco taken in a pipe, with its operation and use both in physick and chirurgery; transl. from the Latin with an introductory epistle: by J. R.

' 2 Dec. $1658-1^{8} 2^{d}$.'

8. Lond. I659

Purchased by Goodyer before publication.

Ferrarius, J. B.

74 De florum cultura $4 \mathrm{libb}$, editio nova accurante Bern. Rottendorffio.

4. Amst. 1646

Fiera, J. BAptista.

I 10 Coena de herbarum virtutibus, et ea medicae artis parte, quae in victus ratione consistit.

Old notes on p. 22 and at end.

Fragosus, JoH.

95 Aromatum, fructuum et simplicium aliquot medicamentorum ex India utraque in Europam delatorum, historia brevis, Latine reddidit Israel Spachius.

12. Argent. i6oI

FuCHS, LEONHART.

II2 De historia stirpium commentarii, cum imagrinibus ad naturac imitationem effectis. I2. Lugd. I555

'Alexandri Massa' ' $47^{8} 6^{\mathrm{l}}$.' English names of plants in margins. Ditto. fol. Basil. Isingrin, 1542 'Johannis Jul . .?' 'Hen. 8. 34.' 
8 New Kreüterbůch.

fol. Basell. Isingrin, I 542

Coloured copy.

Imperfect, title missing. Inside cover many verses and mottoes in French, quoted from Rombout Martens and others.

At end 'Sum Antony Swalms et Amicorum?.

Gansius, Joh. Ludovicus.

102 Corallorum historia.

'Charle Knolfts' at end.

8. Franc. 1630

Gesner, Conrad,

117 Historia plantarum et vires ex Dioscoride, Paulo Aegineto, Theophrasto, Plinio etc.

I 2. Par. Jo. Roigny I54I

IO2 Ditto.

8. Basil. Ro. Wynter I 54I

IOI Apparatus et delectus simplicium medicamentorum.

93 Catalogus plantarum, Latine Graece Germanice et Gallice.

8. Lugd. I 542

4. Tiguri 1542

In binding are two copies of an Order to Churchwardens and Constables of Parishes to assess sum due for relief of maimed souldiers of City of London according to Act of Parliament 43 Eliz. and to pay same to W. Antrobus, Treasurer, at his house in Parish of St. Gregory, S. Pauls Churchyard.

Mizaldus 104 contains a copy of the same document.

Io9 Epistolae aliquot a C. Bauhino editae.

8. Basil. I 591

Praefatio de rei herb. scriptores:

Preface to TraGuS, de Stirpium, q.v.

GERARD, JOHN.

[Herbal. Missing.

fol. Lond. I597]

50 The herball, or general historie of plants; very much enlarged and amended by Thos. Johnson. fol. Lond. I633

i io Gueroaldus, Guillermus, see Macer.

Guilandinus, MELCHIOR

9I $\left\{\begin{array}{c}\text { Theon, seu apologiae adversus Pet. Andream } \\ \text { Matthaeolum. } \\ \text { De Stirpibus aliquot epistolae quinque; item } \\ \text { descriptio manuco-diattae, seu aviculae Dei. }\end{array}\right\}$ 4. Patav. I $55^{8}$

Commentarius in C. Plinii Majoris capita aliquot.

'25 Maij 1655, vnbound $4^{\mathrm{s}} 6^{\mathrm{d}}$ rd edit.

4. Lausaniae $I_{57} 6$

28 Junij 1655 , the bindinge $\left.\mathrm{I}^{\mathrm{s}} 2^{\mathrm{d}}\right\} 5^{\mathrm{s}} 8^{\mathrm{d}}$.'

122 Papyrus, hoc est commentarius in tria C. Plinii majoris de papyrocapita, recensente Henrico Salmuth.

12. Ambergae ${\text { I } 6 r_{3}}_{3}$ 
75 Herbarius in Latino cum figuris.

4. s. 1. et a.

In original binding. English plant-names written in.

HERNANDEZ, Franciscus.

26 Nova plantarum, animalium et mineralium Mexicanorum

historia ; in volumen digesta per N. Ant. Recchum, cum iconibus; et cum notis et additt. J. Terentii, J. Fabri, et Fab. Columnae, cumque aliquot tabulis phytosophicis principis Federici Caesii.

'I Decemb. 1652

to a porter for carriage to Dr. Dale

II Decemb. portage downe in Mris Elz. Heathes Trunck fol. Romae 165 I

In another hand:

Ili $14^{8}$ od $^{d}$

$\circ 00$

'D. Daile in Longe Aker over agst ye freinte ordinary.'

Hess, Paul.

I00 Defensio xx Problematum Melchioris Guilandini adversus quae Petr. Andreas Mattheolus ex centum scripsit.

'G. Le Fevre.'

I2. Patav. I $_{562}$

Hesychius.

3 Dictionarium.

fol. Hagenoae 1521

Hildegard.

29 Physicac.

fol. Argent. I533

Bound with Brunfels, Onomasticon, q.v., and therefore presumably one of T. Johnson's books.

Horstius, Jacobus.

(Herbarium Horstianum, seu de selectis plantis et radicibus, duobus libris edente Greg. Horstio.

94 Opusculum de vite vinifera ejusque partibus.

Appendix cultori plantarum exoticarum
necessaria.

8. Marpurg 1630 o.' (- 


\section{JOHNSON, THOMAS.}

92 Iter plantarum investigationis ergo susceptum a decem sociis in agrum Cantianum A.D. I529. Ericetum Hamstedianum.

With list of plants added by Goodyer.

4. s. 1. (1629)

99 Descriptio Itineris plantarum investigationis ergo suscepti a decem sociis in agrum Cantianum A.D. I632. Ericetum Hamstedianum, sive plantarum ibi crescentium observatio habita.

I2. S. 1. 1632

The author's own copy with his MS. index and additional notes by How, MS. 19. See pp. 232 and 277.

50 The Herball of Gerard 'very much enlarged and amended'.

I05 $\left\{\begin{array}{l}\text { Mercurius botanicus. } \\ \text { De thermis Bathonicis tractatus. }\end{array}\right.$

fol. Lond. 1633

8. Lond. 1634

Ex dono Thomae Johnson.' G.

Plant names picked out with yellow colour.

9.5 Mercurii Botanici, pars altera.

'27 Aprilis 1641.'

With G.'s notes. Several plant names picked out in colour.

JOUBERT, LAURENT.

I28 $\left\{\begin{array}{l}\text { Medicinae practicae priores libri tres, edit. } \\ \text { tertia. } \\ \text { Isagoge therapeutices methodi. }\end{array}\right\}$ 8. Lugd. I577

'F Bust $1577^{\circ}$ ptium iijs vid.'

12. Lond. I64I

out in colour.

KYBERUS, DAVID.

I05 Lexicon rei herbariae trilingue.

With C. Gesner's Tabulae at end.

' Joannis Freame est verus possessor huius libri,'

Notes in his hand (?) on $\mathrm{pp} .302,303$.

\section{LANGHAM, William.}

76 The garden of health; 2nd edit.

' 16 Decemb. 1657 pretiū $4^{s} 2^{d}$.'

8. Argent. I 553

Laurenbergius, Petrus.

63 Horticultura, duobus libris. 4. Franc. ad Moen. 1654 Apparatus plantarius primus, duobus libris, i. De plantis bulbosis; ii. De plantis tuberosis. 4. Franc. ad Moen. I654 ' 7 September $1654-7^{\mathrm{s}} 6^{\mathrm{d}}$.'

End papers cut from a deed mentioning John Smith, Thomas Marshall, and Thomas Read of Parish of St. Mary Hill.

Signature of Ja. Ireland.

LEMNiUs, LEVINUS.

129 De plantis sacris. See VAllesius. 
LEONICENUS, NiC.

86 De Plinii et aliorum in medicina erroribus liber; accedunt de herbis et fruticibus, animalibus, metallis, serpentibus, tiro seu vipera.

4. Basil. H. Petrus I 529

LERIUS, JOAN.

I25 Historia navigationis in Brasiliam, quae et America dicitur.

8. Genev. I 586

In original vellum binding, with title on back of binding in Goodyer's hand.

Lobel, MatThias DE.

I Plantarum seu stirpium historia : cui annexum est adversariorum volumen per $\mathrm{M}$. de $\mathrm{L}$. et P. Penam.

fol. Antv. I 576

'D. Doct. Martino Ramerio veteris amicitiae et perpetuae memoriae ergo d. dedit Matth. de Lobel Insulanus.' On title.

I $8\left\{\begin{array}{l}\text { Ditto-with Animadversiones in G. Rondeletii methodicam } \\ \text { pharmaceuticam officinam. } \\ \text { Balsami, opobalsami, carpobalsami ct xylobalsami cum suo } \\ \text { cortice explanatio. }\end{array}\right.$ 'Io Marcij 1616 Adversa. 2da pars-4

I2 Mar. 1616 Adversar. $I^{2}$ pars $-4^{8}$

I7 Mar. 1616 the binedinge them together $-1^{\mathrm{s}} 6^{\mathrm{d}}$ $9^{s} 6^{d}$

I9 Kruydtboeck, oft beshrijuinghe van allerleye ghewassen, kruyderen, hesteren ende gheboomten.

' 30 Oct. $1623-6$;.'

fol. Antv. Plantin. I 58 I

79 Plantarum seu Stirpium Icones. 2 vols.

Obl. 4. Antv. Plantin. I 58 I

Purchased by Gulielmus Mowntius (=William Mount) for $9^{\mathrm{s}}$ on May 20, 1582, and inscribed with numerous notes in his hand. The binding bears his stamp 'W. M.'. It was acquired by Goodyer before 1633, probably long before.

A few notes in another hand are extracts from W. Bullein's $B u l-$ warke of Defence against all Sicknesse, 1562.

78 Icones stirpium seu Plantarum tam exoticarum quam indigenarum. In 2 parts, with an index.

Obl. 4. Antv. Plantin. I59 I

With full notes in Goodyer's hand, including transcripts of Mount's notes in the 1581 edition (No. 79). On p. 647 Goodyer noted that 'Potatoes' = Batata Hispanorum, Camotes sive Amotes et Iguanes. He acquired this volume before 1633 .

72 Stirpium illustrationes, plurimas elaborantes inauditas plantas subreptitiis Joh. Parkinsoni rapsodiis sparsim gravatac ; cjusdem adjecta sunt ad calcem Theatri botanici $\alpha \mu \alpha \rho \tau \eta \mu \alpha \tau \alpha$; accurante Guil. How.

4. Lond. I 655

'Rec. I9 ffebruarij-1654.' 
LONITZER, AdAm.

I4 Naturalis historiae opus novum ; 2 voll. fol. Francof. I 55I 'Joh. Gooche.'

I5 Kreuterbuch. fol. Francof. I 557

Title missing.

'Rec. 16 Apr. 1654.'

I6 Kreuterbuch der bäume, stauden, hecken, kräuter, etc.; item von den fürnembsten gethieren der erden, vögeln, fischen und gewürm; deszgleichen von metallen, ertze, edelgesteinen; corrigirt und verbessert durch Pet. Uffenbachium. fol. Franc. I63o $\left.\begin{array}{l}\text { (25 Maij } 1655 \text { in quires } 12^{\mathrm{s}} \\ 28 \text { Junij } 1655 \text { the bindinge } 3^{\mathrm{s}} 4^{\mathrm{d}}\end{array}\right\} 15^{\mathrm{s}} 4^{\mathrm{d}}$.?

LOVELL, ROBERT.

I 5 A compleat history of animals and minerals. 8. Oxf. I66I '21 March 1660-6.'

[A compleat Herball.] Missing.

Probably replaced by the and edit., 1665, pres. by Emes.

\section{LULLY, RAYMoND.}

IOI Secreta secretorum in libros tres divisa. ${ }_{12} 2^{\mathrm{mo}}$. Colon. $\mathrm{I}_{592}$

Lyte, Henry. See Dodoens.

MACER, FLORIDUS.

I IO De herbarum viribus; cum commentt. Guillermi Gueroaldi. 12. [Franc. I540]

96 De herbarum viribus; cum schol. G. Pictorii. I2. Basil. I 559 Manelphus, Joannes.

96 De helleboro disceptatio. _ . 8. Rom. 1622

Maranta, Bartholomaeus.

85 Methodi cognoscendorum simplicium libri tres. 4. Ven. I 559

Marcgravius, Geo. DE Liebstadt.

53 Tractatus topographicus et meteorologicis Brasiliae cum eclipsi solari. fol. Lugd. I648

With $\mathrm{W}^{\mathrm{m}}$ Piso, Hist. Nat. Brasiliae.

Maronea, Nicolaus.

65 Commentarius in tractatus Dioscoridis et Plinii, de Amomo.

4. Basil. 1608

64 Descrittione dell' Amomo indiano; trad. dal Latino da Francesco Pona.

4. Venet. 1617 


\section{Matthrolus, Petrus Andreas.}

32 Commentarii aucti in libros sex Pedacii Dioscorides de materia medica, adjectis quam plurimis plantarum et animalium imaginibus.

De ratione distillandi aquas.

' 2 Octob. $1632-20$ '.'

fol. Venet. $15^{8} 3$

Note on Sig. b. 2. " A harde kernel or impostumi in ye bodye."

At end (erased). . . In yeare... lord 1624 .

$7^{\text {th }}$ of June, be my munday

cost of this booke $4^{8} \ldots$

two month after...

Susan Ironsmith.

3I Les Commentaires de M. Pierre André Matthioli, sur les six livres des Simples de P. Dioscorides; trad. de Latin en Francoys. Edit. 2.

fol. Lyon 1566

'Rec. 30 Marcij I654.'

Figs. crudely coloured.

I37 Compendium de Plantis omnibus. With Calceolarius, F. Iter Baldi montis.

8 vo. Venet. I57 I

'Io Octob. $1632-4^{8}$.'

This volume was sold out of the Library about 1745 by the Librarian T. W.[est], whose note to that effect is written below the College book-plate on the back of the title. As these pages were in process of being made up, the owner of the volume, Mr. Gilbert R. Redgrave, spontaneously wrote to inform me that it was in his possession. He has since generously restored it to the College to be once again placed among Goodyer's books, after an absence of a century and three-quarters.

33 Opcra quae extant omnia, cd. Caspar Bauhino. fol. Basil. I 598

' 31 Januarij 1615-20".'

Goodyer's marginal references throughout, and notes on end papers. Defensio : see Hessus.

38 Kreutterbuch verfertigt durch Joach. Camerarium.

Figures coloured.

fol. Franc. 1590

'Aprill ye $4^{\text {th }} 1655$.

Sold then to Dr. How this Mathiolus in Dutch and colored for wch I have twentie five shillings per me William Wells at the Princes Armes in Little Brittaine Bookseller.
Aloyis: Mundillu: $8^{\circ}$ :
Fragosa in Span:
$0: 1: 6$
$0: 0: 6$
Camerarius in marantham
$0:$ I : :

William Wells.

Ye Camer: wanting the title and Fragosa the last page in ye Index, if they displease, you may returne per next.'

Epitome utilissima de plantis ... aucta ... a Joach. Camerario.

4. Franc. 1586

Perhaps Goodyer's first botany book. The marginal headings and English names may have been added by him as a boy. 
Mizaldus, Ant.

( Historia hortensium quatuor opusculis contexta; i. Hortorum curam ornatum et secreta ostendit; ii. insitionum artes proponit; iii. auxiliares et medicas hortensium utilitates percurrit; iv. medicamentorum hortensium olerum, radicum et artificia explicat.

Opusculum de sena.

De hominis symmetria, proportione, et commensuratione. An caseus edendo sit salubris. I2. Col. Agr. 1576 Alexikepus seu auxiliaris et hortus medicus.

Artificiosa methodus comparandorum hortensium fructuum, etc.

12. Col. I 579

In binding are two copies of the 'Order' described under GESNER 93, which must have been bound at the same time as this volume, which also contains a Churchwarden's Receipt for maimed soldiers.

MonaRdus, Nicolaus.

I28 De simplicibus medicamentis ex occidentali India delatis, quorum in medicina usus est, interpr. Car. Clusio.

8. Antv. 1574

126 Joyfull newes out of the newe founde worlde, wherein is declared the rare and singular vertues of diuerse and sundrie hearbes, trees, oyles etc. Englished by Iohn Frampton.

'Jo: Gæoodier' on title.

4. Lond. E Allde 1596

With a MS. index of fruits, \&c.

4I $\left\{\begin{array}{l}\text { De lapide Bezaar et herba Scorzonera. } \\ \text { De ferro dialogus. }\end{array}\right\} \begin{array}{r}\text { at end of Clusius, } \\ \text { Exotica, q.v, }\end{array}$

Montanus, Petrus.

I Io De Morborum generibus, ex satyra imprecatoria. At end of Columella de cultu hortorum, q.v. $\quad \mathrm{I}^{\mathrm{mo}} \cdot \mathrm{n}$. d.

MosCaRdo, Lodovico.

27 Note overo memorie del museo di Ludovico Moscardo.

'I5 Julij 1657-10'.'

fol. Padoa 1656

MUfFet, Thomas.

I33 Health's improvement ; or rules comprizing and discovering the nature, method and manner of preparing all sorts of food used in this nation; enlarged by Christopher Bennett.

'Io May $1655-3^{8} 6^{d}$.'

4. Lond. I655.

'John Mouffetts elder brother of Aldham hall in Essex.' 
Mulberry Trees.

92 Instructions for the increasing of Mulberie-trees, and the breeding of Silke-wormes, for the making of Silke in this kingdome; Whereunto is annexed his Majesties letters to the Lords Liefetenants of the seuerall Shieres of England tending to that purpose.

4. Lond. 1609

Musa. See Brasavolus.

Myrepsus, Nicolaus, Propositus.

73 Dispensatorium ad aromatorios.

' 20 Maij 1639-28.'

On title 'Richard Hamon de London ge Willm Bosone sc psn' 'maste Hamond prey Hyll mr. chr.'

Gerrad's Herball. Henry Jones, price iiijs.

Jos. Quercitanus. [Author of Diaeteticon, Paris, 1606.]

Oratio Salamonis fol $x \mathrm{l}$. $\mathrm{W}^{\mathrm{m}}$ Bofn' $(?=$ Bosum $=$ Bossom $)$.

NeANder, Johann.

67 Tobacologia.

Richard Downes 1658.'

8. Lugd. 1626

' II Mar. 1658 Liber Johis Goodyer ex dono D. Rici Downes.'

'Si fa zara su'l Dado Henry Blount.'

'Liber Rici: Downes ; ex dono D. Henrici Blount.'

A Richard Downes was Vicar of East Meon and Steep in I68I.

NICANDER.

4 Theriaca.

Bound with DIOSCORIDES, I499, q.v.

fol. Ven. 1499

Odonus, Caesar.

$8_{5}$ Theophrasti sparse de plantis sententiae in continuatam seriem ad propria capita revocatac, nominaque secundum literarum ordinem disposita.

'vide Vanderlinden p. 108.' G.

4. Bonon. I 561

Ölhafius, Nicolaus.

92 Elenchus plantarum circa nobile Borussorum Dantiscum sua sponte nascentium. 4. Dantisci 1643

[PaAw, Petrus.

[8 Lugd. 1601 ]

Hortus publicus Academiae Lugduno-Batavae. Missing.

[PARey, Ambrose. Chirurgery.]

This work was bequeathed by Goodyer to John Westbrook, a witness to his will.

Parkinson, John.

22 Paradisi in sole paradisus terrestris; or a choice garden of all sorts of pleasant flowers.

With notes for the Theatrum, 1640 .

fol. Lond. 1629 
5 I Theatrum botanicum, the theater of plantes; or, an universall and compleate herball.

'In quires $3^{6}$ 'The bindinge $\left.3^{8}\right\} 39^{3}$.'

In many places, Goodyer has indicated the species described by numbers in the margin, and has marked with a ' $\mathrm{P}$ ' those which the author claims as ' not having been remembered by any other (author) before'. The chapter on The Elme (p. 1403) is marked ' $J G$ ', probably to note that it is based on a description by Goodyer, and other passages in which the second edition of Gerard is quoted are indicated by the marginal note ' $T J$ ' for Thomas Johnson, the 'corrigider' as Parkinson styles him of Gerard.

There are a few notes in the hand which we have referred to Dr. J. Dale.

At end is part of an account, dated $\mathbf{1 5 7 2}$, relating to public preachers attached to the parish of S. Martin in Leicester. Among the names mentioned are Thomas Furner, a benefactor; the mayors Richard Davy, Richard Darker, John Eyrick (a kinsman of Herrick, the poet); the preachers Th. Sparke, Fellow, and L. Humphrey, President of Magdalen, and T. Sampson, Dean of Christ Church.

\section{PASSE, CRISPIAN DE.}

[Obl. 4. Utrecht I6I5

81 Hortus Floridus, or A Garden of Flowers. In two parts.

'Io Novemb. I627 10/- Johes. Goodyer.' Figures numbered by G.

PAYNE, JOHN.

80 Flowers, Fruicts, Beastes, Birds and Flies exactly drawne. With their true colours lively described. [2,8 plates.]

Sold by Compton Halland over against the Exchange.

PEMELL, RoB.

$$
\text { Obl. 4. [?c. I620] }
$$

I3 I A treatise of the nature and qualities of such simples as are most frequently used in medicines. 4. Lond. $165^{2}$

' 15 July $1652-3^{\mathrm{s}} 6^{\mathrm{d}}$.' 'Cambogia. Kap. 35. Yealowe Jaundice.'

The second part of the treatise on Simples. 4. Lond. 1653

92 A treatise of the diseases of children. 4. Lond. 1653

Philoponus, Joannes, Grammaticus.

3 Commentaria in Aristotelis libros de anima. fol. Ven. I535

Pictorius, Georgius.

96 Scholia to Emilius Macer de herbarum viribus.

Carmen de quadam herba exotica cuius nomen mulier est amara.

12. Basil. I559

Pilleterius, Caspar.

I14 Plantarum tum patriarum tum exoticarum in Walachria, Zeelandiae insula, nascentium synonymia. I2. Mid. I6 10. Piso, GuL.

53 De Medicina Brasiliensi. ' 1 li $2^{\mathrm{s}}$.'

fol. Lugd. 1648 
Plat, Hugh.

I34 Floraes Paradise.

12. Lond. 1608

' 13 Nov. $1632-6$ '.

\section{Platearius.}

73 De simplici medicina.

4. Lugd. 1512

PONA, Jo.

39 Plantae seu simplicia, ut vocant, in Baldo monte, et in via ab Verona ad Baldum reperiuntur.

fol. Ant. I6oI With Clusius, Rariorum, I6or.

65 - edit. secunda. 4. Basil. 1608 With notes to Pinax, pp. 87, 89 .

Part of deed dated 1608 bearing name 'Sutton' in binding.

64 Monte Baldo descritto da Giov. Pona, trad. dal Latino per Fr. Pona.

' 18 April 1629-98:' Notes and references to Pinax.

Porta, Jo. Baptista.

I30 Phytognomonica, octo libris contenta.

8. Franc. 1608

'J. L. Gilbou[rne].'

60 Villae.

4. Franc. 1592

'Pret vjs.' Notes, but not by $\mathrm{G}$.

4. Ven. 1617

Propositi Dispensarium, see Myrepsus.

Ray, John.

98 Catalogus Plantarum circa Cantabrigiam nascentium. I657 Index Plantarum agri Cantabrigiensis. I2. Cant. I660 Appendix ad Catalogum Plantarum circa Cantabrigiam nascentium.

' 10 May $1660-2^{\mathrm{B}} 6$ '.'

'written (Mr. John Nid, who is dead

by $\{$ Mr. John Wray of Trinitie Colledge in Cambridge.

' Receaved this instruction of Mr. John Mapletoft, tutor to the Earle of Northumberlans son and of Mr. John Snagge an Apothecarie of Petworth 23 July 1659.

Mr. John Nid

Mr. John Wray

Mr. Thomas Pockley

Francis Willuby Esq.

Mr. Peter Curthop

All of 'Trinitie Colledge in Cambridge.

Francis Willughby Esq. of Midleton neare Coleshill in Warwickshire, $\mathrm{S}^{\mathrm{r}}$ Francis Willughby's son.

Mr. Peter Courthop of Danny in Sussex on this side Lewes.

Mr. Tho. Thornton, parson of Sutton als Sulton in Sussex in Arundel Rape, borne at Bentham in Yorkshire, 2 miles from Yngleborowe hill, I5 Apr. 1663 promised Cloudberry.' 
Recrabed this in Strattion of 23 fily In $^{k}$ John TMarpetoft, tutore to thr. Eorke. of 1699 and of mefohon Sragger an Apotheroonir

$m \times$ forn $)$ id

$m^{2}$ fohn vicay

$m^{2}$ thamas tockley

Francis wirluby $E_{y}$

merestre. Curctfiop

Allr of J rinitie Corrs dgre in cambeidge

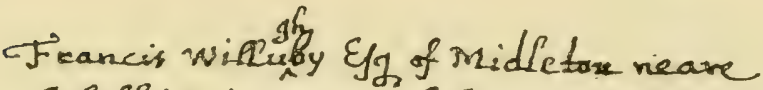

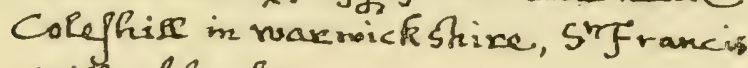
wide ughloys fou.

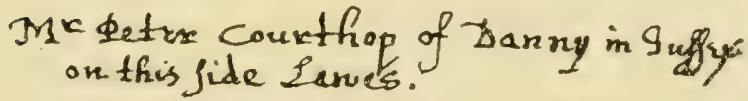

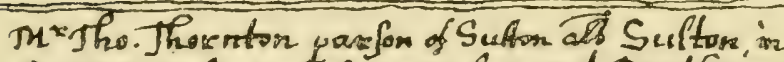
Buffey ine Anundef Rape, bown at Bentram

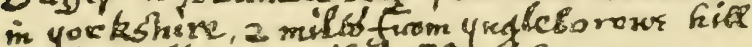

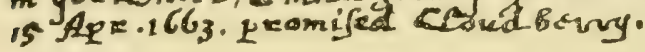

10 Maiy $2660-2^{86} 6^{2}$

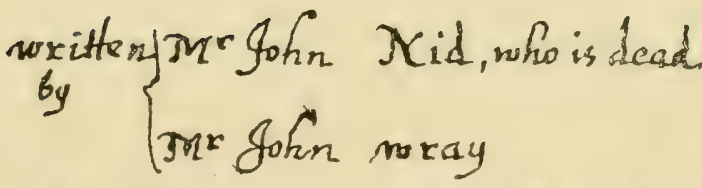

of Trinitic corredye Caingrige

GOODYER'S NOTES IN NO. 98. 
Renealmus, Paulus.

Specimen historiae plantarum cum iconibus. 4. Par. I6II

68 Crambe, viola, lilium a J. A. Thuano versibus illustrata a

P. Renealmo edita. 4. Par. I6 I I

'II Augustj 1653-4 6 d $^{\text {'. }}$

'Dr. William Howe bought him of Mr. Allestre in Pauls Churchyard.'

RUAEUS, LAURENTIUS.

6 Hippiatria sive Marescalia.

fol. Paris 153 I

With MS. notes in an early hand on pp. 136, 139 and at end.

An early prescription on the first of 12 blank pp. at end.

'ffor the bargett

R. ffengreke black ornamet. long pep : annyse seed. rew. rosmary. sage. sethe al $y^{\text {se }}$ to gether $w^{\text {th }}$ vergys. \& iij or iiij heads of garlek \& put it to $y^{\ominus}$ herbs \& when al the herbes ar sodyn then put to $y^{e}$ juse of ye same for every oon ij eggs shells \& all. When ye have geven $y^{\text {e }}$ best drynk, dryve hym up $\&$ down half a $\mathrm{q}^{\text {tr }}$ of an hour $\&$ put to eṽy drȳk of a cowe an handful of salt $\&$ after ye best have drn̄k rub y $y^{\ominus}$ tūg $w^{\text {th }}$ salt.'

At end, old prescriptions 'For a hors that ys seke'. 'Pro tussi equino'. 'A soveren medicyn for achys, brokynes or swellyngs callyd $y^{\mathrm{e}}$... oyntment ... It must be made in Maye or between $\mathrm{y}^{\mathrm{e}}$ Lady days'.

Rubeus, Hieronymus.

89 Disputatio de melonibus; acc. responsum medicinale pro asthmate cardinalis Bonifacii, auctore Vincentio Alsario a Cruce.

4. Venet. 1607

Ruellius, JOANNES.

34 De natura stirpium libri tres.

'H. Spes nō cōfūdit. W.

Jy silētio et spe.'

With old notes in hand of H. W. (?) on pp. 342, 630. A similar inscription is written in a copy of Aristotle, de Hist. Animalium, and Theophrastus, de Plantis, fol. Basil 1 534, in the library of the Oxford Botanic Garden. This copy afterwards passed to 'Robt. Leedes', 'N. Johnson', and Sherard.

RUEUS, FRANCISCUS.

129 De Gemmis, I652. See VALLESIUS.

RyfF, Gualterus H.

102. De memoria artificiali quam memorativam artem vocant; item de naturali memoria quomodo medicinae beneficio excitanda, augenda, et confirmanda, etc. 8. s.1. 154 I

SCALIGER, JULIUS C.

100 In libros duos, qui inscribuntur de Plantis, Aristotele authore. 
SCHWENCKFELT, CASPAR.

90 Stirpium et fossilium Silesiae catalogus. 4. Lips. 1600

[SHARROCK, R.

History of the propagation \& improvement of vegetables, by the concurrence of art and nature. Missing. 1660]

SORANUS.

6 In artem medendi isagoge; Oribasii fragmentum de victus ratione; C. Plinii Secundi de re medica libri quinque.

$$
\begin{aligned}
& \left.{ }^{\prime} A \mathrm{R}_{\text {ous }}^{\text {ossessor }}\right\}{ }^{10} \\
& \text { ntho }
\end{aligned}
$$

fol. Basil. in aed. And. Cratandri 1528

[Anthony Rous, armiger, co. Devon, matric. Broadgates Hall, 18 March $160 \frac{2}{3}$.]

[SOWERBY, LEONARD.

The Ladies Dispensatory.

Missing. 8 Lond. 1652]

SPIGELIUS, ADRIAN.

90 Isagoges in rem herbariam libri duo.

4. Patav. 1606

\section{SPRECCHIS, POMPEIUS.}

92 Antabsinthium Clavenae.

$$
\left.\begin{array}{lll}
\text { ' } 18 \text { May } 1623 & 2 & 6 \\
\text { Bindinge } & 1
\end{array}\right\}=\quad 7 \text { ' }
$$

Stengel, C.

III Hortorum, florum et arborum historia in duo tomos distributa.

8 Aug. Vind. $165^{\circ}$

'14 Decemb. 1654-3'.'

\section{Stephanus, Carolus.}

De vasculis libellus, adulescentulorum causa ex Bayfio descriptus; addita vulgari Latinarum vocum interpretatione.

Seminarium sive plantarum earum arborum quae post hortos conseri solent.

I03 De re vestiaria libellus ex Bayfio excerptus; addita vulgaris linguae interpretatione; secunda editio.

De re hortensi libellus, vulgaris herbarum, florum ac fruticum qui in hortis contineri solent nomina Latinis vocibus efferre docens. 8. Par. Rob. Stephanus. 1536

'Curtius' on last page.

STEPHANUS, RoberTus.

[12. Lutet. 1545

95 De Latinis et Graecis nominibus arborum, etc., ex Aristotele.

On title: 'Sum Henrici Harvey et amicorum

Quanto maior iminet nec

cit aut fac. tanto magis viget.' 
Stephens, P., \& Broune, Gul.

IJ 4 Catalogus horti botanici Oxoniensis. 12. Oxon. I658 The second part of the Catalogue of the Trees \& Plants of the Physick Garden. I2. Oxford 1658

\section{Sweertius, Emanuel.}

8o Florilegium amplissimum et selectissimum, quo non tantum varia diversorum florum genera, sed et rarae quamplurimae Indicarum plantarum, et radicum formae, ad vivum partibus duabus, quatuor etiam linguis, offeruntur et delineantur.

fol. Franc. 1612

TABERnAEMONTANUS, JaC. THEOdoRUS.

46-47 Neuw kreuterbuch, mit schönen, künstlichen und leblichen figuren und conterfeyten, allerhand gewächs, blumen, kräuter, etc. 2 vols. fol. Frankof. I625

' $\operatorname{Rec}^{\mathrm{d}}$ this 6 of September 1655 of the right wor'th Dr. How the summ of fifty foure shillinge in full for this booke 2140 I say Octavian Pulleyn.' With old deeds used as guards.

77 Eicones plantarum seu stirpium arborum nempe fructicum, herbarum fructuum, lignorum . . . curante Nic. Bassaeo.

obl. 4. Francof. I590

Annotated by Goodyer with modern names throughout, with cross references to Lobel.

THALIUS, JOANNES.

89 Sylva Hercynia; sive catalogus plantarum sponte nascentium in montibus et locis vicinis Hercyniae, quae respicit Saxoniam. 8. Francf. I 588

With refs. to Pinax.

THEOPHRASTUS, ERESIUS.

2

De historia plantarum, libri decem.

De causis plantarum, libri sex

Metaphysica.

Contemporary stamped leather Italian binding.

Chapters numbered by $G$, who probably used this copy for his translation.

3 Opera omnia Gr. cum praefatione Joach. Camerarii.

'Sept ${ }^{0}$ September 1623 pr. $15^{8} 6^{d}$ ',

fol. Basil. Operini I54I

End papers with account for timber and carpentry, signed Thomas Herytage.

I38 De historia plantarum. (With Aristotie.) 8. Lugd. I.552

30 De historia plantarum, Gr. Lat. ex interpr. Theod. Gazae; totum opus absolutissimis cum notis, tum commentariis, item rariorum plantarum iconibus illustravit Jo. Budaeus 
à Stapel ; acc. Julii S. Scaligeri in eosdem libros animadversiones, et $\mathrm{R}$. Constantini annotationes. fol. Amst. 1644 ' $15^{\text {to }}$ Julij $1657-30^{8}$.'

104 De suffruticibus, herbisque ac frugibus libri quatuor, Theod. Gaza interprete.

8. Argent. Sybold, s. a.

[With Mizaldus.]

Pagination added.

THevet, ANDRÉ.

6I Les singularitez de la France antarctique autrement nommée Amerique; et de plusieurs terres et isles decouvertes de nostre temps.

4. Par. $155^{8}$

'Novemb. 14 163i-I2d.'

'. . . anguinea vitae.' On title three names of former owners erased.

\section{THURNEISSER, LEONHARDUS.}

Historia, sive descriptio plantarum omnium, tam domesticarum quam exoticarum, earundem virtutes et icones proponens; atque una his partium omnium corporis humani, ut externarum ita internarum, picturas, etc., complectens.

'Vixi satis si Christe sat vixi tibi

fol. Berlini. ${ }_{57} 8$

JB ex dono CB consang.'

Evidently a gift from Caspar to his brother John Bauhin.

In binding is a folio Proclamation dated 24 May 1648 printed by Cotes, London. And used as a guard is part of a letter ending 'millitia' and endorsed 'Castle baynard', the name of one of the Wards of the City of London, to the south of St. Paul's Cathedral.

TRADESCANT, JOHN.

134 Plantarum in horto Johannem Tradescanti nascentium catalogus. $\quad$ 8. s.1. 1634

A unique copy. See p. 334 .

Tragus, Hieronymus.

I27 De stirpium, maxime earum, quae in Germania nostra nascuntur, usitatis nomenclaturis propriisque differentiis, etc., commentariorum libri tres, ex ling. Germ. in Lat. conversi D. Kybero interprete.

With G.'s references to plants, cf. p. 73 .

$48\left\{\begin{array}{l}\text { Kräutterbuch .... verbessert durch Melchiorem Sebizium. } \\ \text { Teutsche Speisskammer. }\end{array}\right.$

Treveris, Peter.

$28\left\{\begin{array}{l}\text { The grete herball. } \\ \text { 4. Lond. in Southwarke by Peter Treveris I } 526 \\ \text { The great herball newly corrected. }\end{array}\right.$

4. Lond. in aed. Tho. Gybson I 532

Q 2 
TROXITEN.

20 Horn des heyls menschlicher blödigkeit ; oder Kreütterbuch, darinn die Kräuter des Teudschenlands, ausz dem liecht der natur, ... beshriben durch Philomusum anonymum; nachmals durch doctorem Troxiten in truck geben.

'25 May 1655-8'.'

fol. Strasb. I 595

TURNER, William.

I 3 The first and second partes of the herbal of William Turner, lately oversene corrected and enlarged with the thirde parte lately gathered and nowe set oute with the names of the herbes, in Greke, Latin, English, Duche, Frenche, and in the apothecaries and herbaries Latin.

fol. Collen, by Arnold Birckman, I 568

With a MS. index and notes by Goodyer.

A booke of the natures and properties, as well of the bathes in England as of other bathes in Germanye, and Italye.

fol. Collen, by Arnold Birckman, I 568

'To Mr. O. Bilson from E. Gray heboriste.'

VALLA, GeORgius.

I34 De simplicium natura liber unus. 8. Argentinae $I_{52} 28$

Vallesius, Franciscus.

129 De sacra philosophia, sive de iis, quae in libris sacris physice scripta sunt; liber singularis. 6th edit. 8. Lugd. 1652

With Lemnius, de Plantis sacris, and Rueus, de Gemmis.

End papers are part of a printed Proclamation of the House of Commons concerning spirits who steal children, dated 166r, printed by Rich. Hodgkinson living in Thames Street over against Baynards Castle I66r.

Veslingius, JoAnNes.

85 Paraeneses ad rem herbariam. p. 85.

De plantis Aegyptiis observationes et notae ad Prosp. Alpinum ; cum additamento aliarum ejusdem regionis.

Opobalsami veteribus cogniti vindiciae. p. 2 I 7 .

4. Patav. 1638

With Prosp. Alpinus, de plantis Aegyptis, q.v.

Vigna, Dominicus.

66 Animadversioncs sive observationes in libros de historia, et de causis plantarum Theophrasti; addita fuit tabula studio et opera Andreae Checcaccii. 4. Pisis. 1625

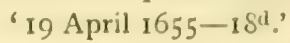

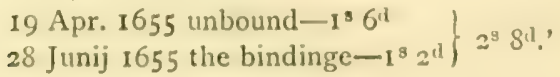


WOLPHiUs, CASPAR.

IOI De stirpium collectione tabulae.

I2. Tiguri 1587

WORMIUS, Olaus.

54 Museum Wormianum.

fol. Lugd. 1655

Two of the titles in the old list have hitherto proved untraceable. They are

'Anatomia Sambuci' and 'Alb. Montani Isagoge Physico-magico-medica'.

\section{The Goodyer Manuscripts.}

MS. I-6. Goodyer, J., and Heath, J. Translation of Dioscorides into English with interlinear Greek text. 4,540 pages 4to, bound in six vols., dated 1653-5.

See p. 85.

MS. 6*. Goodyer, J., and Heath, J. Translation of Saracen, Scholia on Dioscorides, into English. 300 pp. folio.

MS. ends abruptly on p. 292 with a note, 'Joh. Heath clericus obiit 25 Nov. 1656'. See p. 89.

MS. 7. Goodyer, J. Translation of Theophrastus, $\pi \in \rho \iota \phi v \tau \omega \nu$, into English. 494 pages, interleaved, one vol., sm. folio, dated 1623 .

De Plantis, pp. 1-238. De Causis Plantarum, pp. 239-494. In the binding is part of a deed: 'Witherdon de Stone' in Kent and 'Joh. Sharpe' are mentioned. See p. 50.

MS. 8. [? DALE, J.] i. Descriptions of English Grasses. 80 pp. folio.

Not in Goodyer's hand, but enlarged with additions by him. Reasons for referring these MSS. to John Dale are given on p. 296.

ii. Descriptions of Plants headed 'Ex manuscriptis Turn. Annexis Lobelii Observationibus'. $30 \mathrm{pp}$. folio, dated Jan. 22, 1651 .

In the same handwriting as No. i. The date of Lobel's work was about 1576 .

iii. Goodyer, J. Index to Plants described in his copy of C. Clusius, Rariorum Plantarum Historia and other works bound up therewith. $20 \mathrm{pp}$. folio.

MS. 9. [? DALE, J.] i. Index of British Plants, c. 1650-1656.

The work, written on about 250 leaves folio, is based on C. Bauhin's Pinax Theatri Botanici, 1623, which Goodyer acquired before 30 Nov. 1623. The handwriting is that of the author of MS. 8. i and ii. 
References are given to the following works: Bauhin, Pinax, 1623; [Lobel], Plantarum seu stirpium icones, 1581; Icones Stirpium, I591 ; Gerard, Herball, I 597; Johnson's Gerard, 1633; Parkinson, Theatmm, I640; How, Phytologia, 1650; Johnson, Mercurius Botanicus, 1634 .

The entries from the last book have been marked with yellow paint by Goodyer, who made a few additions to the two last pages and to Pin. 81, 131, 155, 265, 288, the two last being dated I9 July 1656. The following extracts illustrate the author's style and notes:

Raprenculus folio oblongo spica orbiculari. (Pin. 92.)

= Merc. 64 Rapuntium corniculatum montanum, Col.

' $\mathrm{D}^{\text {ns }}$ Goodyeerius semper suspicabatur haec duo novissime proposita non ipse nisi ejusdem plantae, ratione soli vel Arigosioris vel laeti, variantis diversa nomina.'

Melampyrum latifolium. (Pin. 234.)

'Mali coniunxit emaculator Sideritium pratensem luteum Lugd. et Crataeogonon, Lob. quae sunt diversae Plantae. Sideritis pratensis lutea Lugd. non habetur apud Lobelium. Inquirendum an Sideritis lutea Mri. Stonehouse ad hanc Sideritem possit referri.'

Blattaria alba. (Pin. 24I.)

' Huc etiam referimus Blattariam $f$. viridi et Blattariam ff. albo flavescente, indignus quae novam speciem facerat.'

ii. List of I53 British Plants. 'Plantae ad Methodum Pinacis reducendae quibus Botanographi nostratis ortum tribuere Britannicum.' Dated the last day of April r6 59. By John Dale?

The list is in the same hand as the Index, and like it has been annotated by Goodyer, who was evidently in correspondence with the writer, e.g. after No. '8. Gramen Parnassi' Goodyer adds, 'This you have putt into the draught of your Catalogue'.

MS. IO. Hortus siccus.

Among the MSS. received by Magdalen College from Goodyer were two Herbaria, listed as 'Hortus hyemalis fol.' and 'Hortus hyemalis minor fol.'. The former is missing, but the latter may be represented by this small herbarium of Io leaves folio.

It contained a small collection of Mosses and Ferns, made c. 1620 and mounted on the leaves of a MS. Botanical Glossary, English-Latin, beginning with ' Anise seade Anisum ' and ending 'Yerrowe Nose bleede. Stratiotes millefolia. Militaris Millefolium'.

All the dried plants have been removed, but the following names on paper straps are legible:

f. 3. Lichen arborum. Lichen cinereus. Muscus peltatus. Muscus pyxidatus. [ ] sylvestris, 3 Jul. 1620.

4. Phillitis digitata. Ceterach.

5. Filix palustris.

6. Polypodium.

7. Filix spinosa. Chamaefilix marina anglica. 
MS. II. Goodyen's Miscellaneous Papers.

The more important of these are published or referred to in this volume as MS. II, f. - , or more briefly as MS. f. - , with the leaf number but without the number of the manuscript.

MS. 12. LOBEL. Stirpium Illustrationes; plurimas elaborantes inauditas plantas subreptitiis Joh: Parkinsoni rapsodiis (ex codice MS. insalutato) sparsim gravatae: edited by $\mathrm{W}^{\mathrm{m}}$ How. 37 leaves folio.

The original MS. from which the work was printed in 1655 . See p. 252.

MS. 13-15. LOBEL. Stirpium Illustrationes.

An unpublished work in preparation about 1612. About 835 plants are described. See p. 253.

MS. I6. Goodyer, J. Index to Gerard's Herbal (1597). Sm. 8vo. With localities of British Plants.

MS. I7. [Stonehouse, W.] Catalogus Plantarum Horti mei Darfeldiae. Anno 1640. With plan I 2 mo.

See p. 348.

MS. 18. How, IV. Additional Notes to his Phytologia Britannica 1650. Written I650-1656. See p. 276.

An interleaved copy with many corrections, notes, and MS. lists of plants by the author who died 30 Aug. 1656. Goodyer, according to a note inside the cover, received the book on 30 Apr. 1659, and then added marginal references throughout and notes on six plants printed on p. I 94.

On the inside of the cover is a receipt dated July 29 and unsigned, probably written after 1659, when the book was in Goodyer's possession. 'Rec. of Mr. Goodier ten pounds for Mr. Bold's use.' The Mr. Bold was probably Arch. Bold, one of the witnesses to Goodyer's will.

The notes in How's handwriting are partly his own; and partly from information received from Goodyer, Hunnibon, and William Browne of Magdalen College. Their source is acknowledged both where they occur and generally on the front page. 'Gaine I was for Goodyers Plants and des. $y^{e}$ like for Brownes, Lobells [and Pennyes MS. wch review for names etc.]' (struck out). Inserted are 7 coloured and 3 uncoloured drawings of plants.

Passages from this volume have been frequently quoted by Druce, but we have not found any evidence for his statement that 'on the death of Goodyer the book probably came into the possession of $\mathrm{W}^{\mathrm{m}}$ Browne '.1 It would have passed into the possession of the College direct, with the rest of Goodyer's library in 1664 .

1 Druce, Flore Berks., 1). ciii. 
MS. 19. Jolinson, T., and How, W. Additions to T. Johnson's Descriptio Itineris Plantarum investigationis in agrum Cantianum A. D. 1632 .

Formerly in the possession of W. How, and previously Johnson's own copy. See p. 276.

Additions in T. Johnson's handwriting:

On p. 3, 1. 10 'Alga membranacea' has been struck out.

On p. 6 to the list of plants obtained in the Isle of Thanet, Absinthium vulgare has been added. On p. 9 'Sarxifranga, Dod.' has been added after 'Serpillum' in 1. 3. On p. 37 , to the Flora of Hampstead Heath are added

'Coronopus Ruellii, Cornu Cervi alt. vulg.

'Scabiosa minor sive ovina, Dod. Cam., media, Lob.

'Scabiosa media serrato angustifolio, flore Globularia. Adv., Rapuntium alterum leptophyllum capitatum, Col.'

At back of plate is a note of 'Trifolium pumilum ... White dwarfe Trefoile'.

All these are printed in the Phytologia.

Eighteen leaves are bound in at the end.

ff. I and 2. Blank.

ff. 3-6. Index to genera mentioned, including the MS. additions. In Johnson's hand with additions by How.

f. $6 \mathrm{v}$. Notes by How.

ff. 7-Ir. Alphabetical list of about I90 species of English plants not included in Johnson's lists. In How's hand.

ff. I 2-I7. Blank.

ff. 17 v., I 8 . Notes by How.

This little volume has the great sentimental interest of being the germ from which all British Floras are descended. The first index comprises all the plants mentioned in Johnson's book, and is written, I believe, by the author himself. The second list contains names of English plants, including those quoted by How as derived from 'Dr. Iolunfons. MIf.', in How's hand, with additions by him at a later date. Unfortunately these plants are not localized. How's rough notes on the last two pages are evidently memoranda used when preparing the Phytologia, our first British Flora.

If my interpretation of the handwritings be correct, this volume would probably have passed from Johnson (d. I644) to How, who would have used it in the compilation of the Phytologia (r650), and after How's death in 1656 it would have passed to Goodyer, perhaps with How's copy of the Phytologia, in 1659. 


\title{
NOTES ON CONTEMPORARY BOTANISTS
}

\author{
MOSTly From GoOdyer's BoOKS AND Papers
}

IN the England of John Goodyer, the stream of Botanical learning was flowing along a very small channel. So small was it, that viewed from the present time after the lapse of three hundred years, the water appears confined to a few isolated pools and backwaters with no certain channel between them. The number of true men of science, as opposed to herbalists, could be counted on the fingers of one hand, and the untimely death or defection of any one of them might have put back the progress of botany for a century.

The following notes on Goodyer's friends or contemporaries were gleaned from, or suggested by, the study of his own manuscripts. By their publication we may perchance bring to light an occasional fact which reveals the course of the stream of botanical learning.

The names of previous owners of his books have been listed: his manuscripts suggest material for more extended notes on some of the following botanists, the others emerged during our research: they are not to be found in the Biographical Index of British Botanists. The identification of the handwritings of some of them was by no means an easy matter : two are still doubtful.

i. Thomas Penny, c. I530-I589.

ii. THE 1570 BOTANIST OF OXFORD AND WINCHESTER.

iii. RIChaRd GARTh, $d$. I597.

iv, v. William and Sir John SAlusbury, 1567-1613.

vi. M. LOBEL, $153^{8-1616}$ and How.

vii. WM. MOUNT, I 545-1602.

viii. Richard SHANne, $1561-1627$.

ix. John PARKinson, 1567-1650.

X. WAlter StonehouSe, I 597-1655.

xi. Thomas Johnson, c. 1600-1644.

xii. William How, I619-1656.

xiii. JOHN DALE, $d$. 1662.

xiv. William BROWNE, I629-I678. 


\section{i. Thomas Penny, c. 1530-89.}

Thomas Penny, M.D., of Trinity College, Cambridge, B.A. 155 I, F.R.C.P. I 582 , contributed to a natural history of Insects, which, begun by Edward IVotton and amplified with extracts from Conrad Gesner, was finally completed by Thomas Muffett of Oxford. Muffett died in 1604 , leaving the book in manuscript. It was eventually published in 1634 by Sir Theodore de Mayerne.

Penny's botanical reputation has been rescued 'from an almost total obscurity' by Pulteney, who points him out as 'A second Dioscorides, for his singular knowledge in plants'. He had resided in Switzerland and had visited the island of Majorca. He was personally acquainted with Gesner, Camerarius, and Clusius. From Majorca he brought Geranium tuberosum, Szucrtia perennis, and Hypericum balearicum, which Clusius named 'Myrtocistus Pennaei' in his honour. ${ }^{1}$ Clusius $^{2}$ in 1583 thanked him for a drawing of Cnicus heterophyllus Roth., sent in ${ }^{1} 5^{81} \mathrm{I}$, and noted ${ }^{3}$ his discovery of Cormus suecica L. in the Cheviots. We have Mount's statement that he grew Acorus Calamus in his London garden before $15^{82}$, Penny communicated the following plants to Camerarius, who describes him as a leading London Physician 'rerum naturalium peritissimus, amicus meus singularis'. Hort. med. $5_{588,}^{8}$ p. $3^{6}$.

Caryophyllata vulgaris or C. altera alpina with white flowers. Monte Lupo in France.

Lactuca sylvestris ' odore prorsus Opii'.

Matricaria tertia fl. pl. in Anglia frequens.

Rhodia radix. Ingleborrow.

Geum reptans L.

Lactuca virosa $\mathrm{L}$.

Matricaria parthenium $\mathrm{L}$. Sedum Rhodiola DC.

And Lobel, Adv. 367, associates 'Myrrhis altera' (My'rrhis odoratu Scop.) with him.

The mention of the name of Penny by How at a date subsequent to 1650 in an erased passage quoted on p. 280 is of importance, because it may throw new light on his botanical MSS. Pulteney's account of the matter is that 'Dr. Penny died in 1589 , and is said by Jungerman to have left his papers to Moufet and Turner; but, in this account, there is surely a very striking anachronism since Turner himself died in the year $1568^{\prime}$. It is clear, therefore, that Penny's zoological MS. on Insects went to Muffett, and that his botanical MSS. could not have gone to IVILLIAM, but to some other Turner. As a possibility, a man who would have valued them would have been the well-known astrological botanist, ROIERT

$$
1 \text { Ger. emac. 434, 946, 1279. } \quad 2 \text { Stirp. Pannon. Hist. } 1583 .
$$

${ }^{3}$ Rar. Plant. Hist. i. 59, I601. 
TURNER, ${ }^{1}$ whom we have suggested as identical with the 'Turn.' owner of the Lobel MS. mentioned below. Robert lived at Holdshot in the north-east corner of Hampshire: 'Turn.' was in correspondence with Goodyer and Dale(?), either of whom might have shown his MS. to How, without however giving permission for publication by the latter.

\section{ii. The i 570 Botanist of OXford and Winchester.}

[? DR. WALter BAYLEY, I529-92.]

On looking through some of the older books in the Botanical Department of the British Museum I was rewarded by finding twenty-nine plant records, some dated I570-2, in the hand of an unknown botanist, who appears to have lived at Oxford and Winchester. In accordance with a practice very usual in those days, he wrote English names of plants in the margins of his Latin botany book, Du Pinet, Historia Plantantm, Lugd. ${ }_{5} 6 \mathrm{r}$, and in a few instances added the names of persons and localities. The names are Watson, Jeames, Barnabye, Norton, Strowde, Heiden, Basket, and Crosse. The localities are mostly the several gardens of these persons; and a few places, all near Winchester, are noted as stations of common Hampshire plants.

When the preceding clause was already in type, I happened to see an autograph inscription in a precious little volume by Dr. Walter Bayley of New College, ${ }^{2}$ printed privately and issued anonymously as a New Year's gift to a friend. The writing at once caught my eye on account of its resemblance to the writing of our unknown botanist. Both writings are in the style of the period; and without further specimens of each, it is impossible to be certain of identity, but Dr. Bayley was certainly the kind of man who might have entered botanical memoranda in a Du Pinct.

WALTER BAYLEY was educated at Winchester and New College, becoming a Fellow there in $\mathbf{I} 55^{\circ}$. When Junior Proctor, he demanded the degree of Bachelor of Physic, and supplicated for leave to practise medicine 'per totam Angliam'. He was Queen's Professor of Medicine at Oxford from I561 to 1582 . In 158 I he was appointed Physician in Ordinary to Queen Elizabeth.

The $D u$ Pinet, I56I, would therefore have been the newest botany book out at the time of his becoming Professor, and the marginal notes would have been written about the middle of his

${ }^{1}$ A Robert Turner was born at Reading at h. 9.48 a.m. on 30 July 1626 (MS. Ashm. 183).

${ }^{2}$ The property of Sir D'Arcy Power: see his Dr. Walter Bayley, Med. Chir. Trans. xc. 
tenure of the chair. Besides those printed below, one other entry may be mentioned. Under 'Piper indicum' $\mathrm{p} . \mathrm{I} 2$ is noted ' a kynd of pepper groweing in India: husked'. It may only have been a coincidence, but Bayley happened to have been greatly interested in Peppers, for some years later he printed, for distribution among his friends, $A$ short Discourse of the Three Kindes of Peppers in cummon use and certain Medicines made of the same, tending to the preservation of health, $\mathrm{I}_{5} 88$. The discourse contains one personal note which bears on the author's movements: 'I have often seene at Poole at Dorsetshire and also in London, the whole clusters of pepper preserved in brine and in salt'. It is unnecessary to point out that an old Wykehamist journeying from Oxford to Poole would naturally break the journey at Winchester.

If we accept the dates $1570-2$ and the identifications of the species, these brief notes are among the earliest known evidences for the occurrence of eight species of plants in Hampshire, two of which are the first localized notices for Britain.

Halimus or Atriplex marinus, p. 62.

'Upon hāble bankes in great quantitie.'

Atriplex littoralis $\mathrm{L}$.

[The river Hamble is not far from the locality where Lobel noted the plant. His, the first printed record, dates from I655.]

Conyza media, Du Pinet, p. 390.

Pulicaria dysenterica Gray.

'In diches evrywhere about Winchester.'

Sium, p. I7I.

'In ye dych towards Nortons.'

Nasturtium officinale $\mathrm{R} . \mathrm{Br}$.

Clematis altera Dioscorides, p. 442.

Clematis vitalba L.

'White vyne. In every hedge about Winchester.'

Thlaspi.

'In Mr. Strowdes garden and medoe, 1572.'

Eupatorium Avicennae, p. 476.

'In ye dyche toward blak Bridge.'

Tithymalus masculus, p. 605 .

'In cops by Cathe of ij sorts.' 1

Personata altera, p. 559.

'Close by the river sydes.'

Cynocrambe, p. 635.

Thlaspi arvense $\mathrm{L}$.

Eupatorium cannabinum L.

Euphorbia anygdaloides L.

'Oxon.'

[An evidence more than 200 years earlier than the first record in the County Flora.]

For the notices of garden plants see p. 304 .

1 My friend Mr. H. Salter tells me that Black Bridge over the Itchen is near the west end of the Warden's Garden, and suggests that 'Cathe' may be an abbreviation for St. Catherine's Hill. 


\section{iii. Richard Garth, $d$. I597.}

Richard Garth was an accomplished botanist whose contributions to science are better remembered in the works of Clusius and other foreign botanists than in his own country. He was the son of Edward Garth, one of the six Clerks in Chancery, and owned a property at Morden in Surrey in 1564 . Between 1581 and ${ }_{159}$ I his relations with Brazil enabled him to bring several of the plants of that country, including the 'Papyrifera arbor', the 'Juni-pappeeywa Brasiliorum', the 'Phaseolus Brasiliorum', and some exotic fruits to the notice of Clusius, who described them in his Libri Exoticorum in 1605 . In return Clusius gave him a Solomon's Seal, a root of which he 'very lovingly imparted' to Gerard, who not unnaturally described him as 'a worshippfull Gentleman, and one that greatly delighteth in strange plants' (Ger. 757). So far as the English flora is concerned his name should be associated with the Great Toothwort (Lathraea squamaria L.) which grew on his land at Groutes, not far from Croydon. ${ }^{1}$

In 1592 Garth purchased the manor of Drayton from Robert, Earl of Sussex. He died in I597, having married, firstly, Elizabeth Dixon ${ }^{2}$ and secondly Jane da. of ... Busher, co. Linc., who survived him, living at Drayton Manor facing Haylinge Island, two miles from Portsmouth. After his death, Lobel appears to have visited her garden there, and to have found 'Alopecuros altera maxima Anglica paludosa sive Gramen Alopecuroides maxima' 3 and a variety of Bindweed, 'Helxine cissampelos alt.', 4 growing wild near the house. She seems to have refreshed him with Metheglin of her own brewing, and to have given him her recipe for it, which he printed (Advers. alt., I605, p. 473).

Lobel speaks of Garth as Senior Clerk in Chancery ("Diplomatica Curia'), an office to which he had probably succeeded by inheritance, and as most learned in the natural history of Indian as well as of our native English plants. Hugh Morgan, James Garret, the communicator of the vegetable discoveries of his brother Peter and of those who accompanied Sir 'Walterus Raulaeus' to Guiana,

${ }^{1}$ Ger. emac. 1585 . In the author's copy of this work there is on p. 762 an old MS. note relating to the Greatest Wolfe-bane, now Doronicum Pardalianches L. 'This growes wild in the Orchard of a house called Grouts in the parish of Mordon in Surry lately belonging to Mr. Garth, Lord of that Mannour. It floures in Aprill.'

2 The Heralds Visitation of London mentions a Richard Garth of Moorden, co. Surrey, who m. Dorothy Style.

3 Polypogon monspeliensis Desf.

- Lobel and How, p. 127 ; Park. Theatrum, p. 173. 
and Richard Garth were the principal authorities in this country on tropical plants in the sixteenth century.

His copy of Cacsalpinus is in the Magdalen Library. The titlepage bears his signature, and in the body of the book he underlined passages relating to the properties of Tobacco, p. 344, and of Scorzonera, p. 427 , and added the name 'Battato' for 'Castaneae terrestres', on p. 427. The volume passed in 1598 from his son Robert Garth (d. I6I3) to Dr. Lancelot Browne, the author of a prefatory eulogy in Gerard's Herbal, 1597, and then to John Goodyer.

iv. William Salusbury, 1520?-I600?

v. Sir John Salusbury of Lleweni, I567-1612.

Some few years ago I had the satisfaction of finding in the Library of Christ Church a copy of Gerard's Herbal, with a few dated marginal notes of plants found in 1606-1608 in North Wales, and with notes on the medicinal propertics of others. The Herbal is inscribed 'Sir John Salusbury his booke', and the notes are evidently in his own handwriting. They illustrate the manner in which Gerard's work encouraged the practice of recording exact plant-localities at the time when Goodyer was a boy, even in quite remote parts of the country. They are not mentioned by any botanical writer with whom I am acquainted, nor do the recent historical notes on the flora of Denbighshire by Dallman take us farther back than Waring's letter of 1772. Salusbury's date was 1606 , and though there is no chance of his ever being forgotten as an historical character, he also deserves to be remembered by compilers of county floras: moreover, unlike his cousin, William, he wrote in English. He received his first education at Oxford at Jesus College.

By all accounts Sir John Salusbury of Lleweni, known as 'the Strong', was no ordinary man. He came of a remarkable family, one member of which, William SALUSiURY (I 520?-I 600?), the first translator of the New Testament into Welsh, is stated to have been the author of a Welsh Botanologia which is said to have been an original work showing close observation of plant life in IVales. It is possible, however, that William's great literary reputation has led his biographer to overstate his botanical achievement (D.N.B.). I believe the 'Welsh Botanologia' of the D.N.B. to be the I.lysiculy,y Middy'siniaithol, recently (19I(1)) edited by Mr. E. Roberts. It is a Herbal in Welsh, a compilation of extracts from Fuchs, Turner, and Dodenens translated into Welsh before 1597 by 
William Salusbury, with the Welsh names of the plants, and a few (very few) localities added. Mr. Roberts points out that the more detailed localities are those nearest Llansannan and Llanrwst where William Salusbury is known to have lived. Lleweni is thrice mentioned, and both author and work must have been well known to Sir John Salusbury: the names of plants localized by William are printed below.

John's mother was the celebrated Catherine Tudor of Beraine, popularly known as 'Mam Cymru' or Mother of Wales, celebrated alike for her numerous descendants and her four marriages. ${ }^{1}$

Sir John has been stated to have had two thumbs on each hand. His gardening is not remembered as well as is his huge strength. The Denbighshire tradition that he used to 'tear up forest trees by the roots' is reminiscent less of his interest in botany than of a fondness of displaying his physical powers. ${ }^{2}$ He married Ursula, daughter of Henry I4th Earl of Derby, and left three sons and two daughters, the eldest of whom, Sir Henry Salusbury, Bart. (d. I632), also wrote his name in the Herbal (in I627), and entered notes on two plants growing on the Chirk estate of his father-in-law, Sir Thomas Myddleton ( $5550-1631){ }^{3}$

On a recent pilgrimage to Denbigh to visit the site of Sir John's gardens at Lleweni, chance made me acquainted with Mr. A. Foulkes-Roberts of Denbigh, himself a lineal descendant of Catherine of Berain. He at once took the greatest interest in the quest and drew attention to the fact that Sir John Salusbury

1 CATHERINe of Berain was a great granddaughter of Henry VII and therefore cousin to Queen Elizabeth. She $m$. 1. Sir John Salusbury. 2. Sir Richard Clough (and from this marriage was descended Mrs. Thrale, the friend of Dr. Johnson). 3. Morris Wyn (as his third wife). 4. Edward Thelwall. The story goes that after the funeral of her first husband she left the church in the company of Mr. Wynn who then and there offered her marriage. She declined on the ground that, on her way to church, she had promised Sir Richard Clough !

2 "A popular tradition credits him with having killed a mythical and much dreaded beast that had its lair in the cliffs below the castle, and having also slain a great white lioness with his naked fist in the Tower of London, thus earning for his estate the name of Lleweni, Llew being the Welsh for the king of beasts. $\mathrm{He}$ also overthrew in a wrestling match a famous giant, Edward Shon David, whose walking-stick was the axle-tree of a cart with a crow-bar driven through it. Syr John, too, was accustomed to show off his strength, when he had no worthier object for it, by tearing up forest trees by the roots.'-Bradley, North Wales.

${ }^{3}$ SIR T. MYdDLeton was elected Lord Mayor of London on the same day that his brother Hugh opened the New River Head. He had purchased the estate of Chirk Castle in 1595. 
was already known by his poems, and that the MSS. of some of the poems are in the Library of Christ Church in Oxford. ${ }^{1}$

On returning to Oxford, through the kindness of Canon Cooke; I was given the earliest possible opportunity of examining the two volumes known as Christ Church MSS. 183 and 184 and Professor Brown's notes thereon, and then learnt, what has been known to Shakespearean scholars for some years, that Shakespeare, Marston, Chapman, Jonson, and 'Ignoto' contributed 'Diverse Poeticall Essaies' on the subject of the Phoenix and Turtle, as a supplement to a poem by Robert Chester entitled Loves Martyr, and that the whole collection was dedicated to Sir John Salusbury of Lleweni.

The personal association of Salusbury with the great Elizabethans is also shown by the presence of a poem written in Jonson's own hand among the Salusbury MSS. at Christ Church, and by the lines in which Robert Chester welcomed his patron home from London, where

The swanns that laue their blacke feet in the streames,

Have in their sweetnes sang you golden theames:

Court-bewtefying Poets in their verse,

Homerian like sweete stanzoes did rehearse.

Robert Chester may well have been a member of the Salusbury household, who knew Lleweni and his patron's love of flowers. Indeed, in his $W_{y}$ nter garland of Sommer flowers made in manner of A Nerveyeares gyfte to the Right Worshipfull John Salusbury" Esq ${ }^{r}$ of the body to the Queenes most exelcnt Maiestye, $1598,{ }^{2}$ he may have drawn inspiration from plants actually growing at Lleweni. He mentions twenty-seven in thirteen stanzas of his poem.
Jelliflower.
Daphadill.
Organy.
Orice.
Honysuckle.
Rose.
Ladies Nauel.
Oleander.
Stickadoue.
Touchmenot.
Agnus Castus.
Hartsease.
Ladies Seale.
Yooke Elme.

Venus Looking glasse.

Hyacinthus.

Strawbery.

Angellica.

Basill.

Lauender.

Virgins bower.

Sweet Marierome.

Rosemarye.

Arkeangell.

Ladies smock.

Youthwort.

Lady lacies.

A selection of Sir John Salusbury's own poems was printed in $\mathbf{I} 597$ in a small volume dedicated to him by Robert Parry, gent.,

1 Carleton Brown, Poems by Sir John Salusbury and Robert Chester. Bryn Mazur College Monographs xiv, Pennsylvania, 1913.

${ }^{2}$ MS. I 84, f. 45 a. 
of which only one copy is known. His Certaine Necessary obscrvations For Health, a poem illustrating his interest in practical hygiene, was printed as a broadside, of which a copy is bound up in his 'booke of notes', MS. 183 (f. 4), and is dated (in MS.) I 596, though a copy of the poem itself, written by a clerkly hand, is dated 1603 (MS. I84, f. 77 b). The volumes of MSS. contain many verses in Welsh, praising various members of the Salusbury family, copies of letters from Sir Henry Sydney, the Earl of Essex, Sir Walter Raleigh, and other notabilities, English poems by Sir John Salusbury and his circle, a few medical recipes, and stray quotations and verses.

Sir John's own muse drew less from a knowledge of plants than did the muse of Robert Chester, though there are, as in all Elizabethan poetry, references to 'choyse and sweetest flowers', sweet Briere and sweet Eglantine. And one of his verses, on Pride, entitled $A$ Conceite, ends with the lines

And those that grow of sundry seeds

At last do proue but stinking weeds

And if pure wheat be sowde in tares

The wheat Assuredly it mars.

finis John Salusbury.

but they can hardly be cited as showing exceptional cultural lore.

The names of many herbes are contained in his medical recipes, of which the following is a specimen:

Tacke a certain amand milke mayde Whit these ierbes Tacke plantain, ribbe Whorthe, knott grasse, cheaper purse, confery of evere one a handfull, strabury leaves, sanicula, of evere one halfe a handefull. Let this by boylet in a quantitie of faier Water of this Liquor macke an amand milke.

This is excelent against a consumcion, waste, or runninge of the raynes, or brekinge of a vayne \& within the boodie, or anye foule matter wthin manes boodye.

[Christ Church MS. 184, f. $33^{1}$

${ }^{1} \mathrm{By}$ another hand in the same volume is $A$ Dietary for those who have weak backs, in ten 4-line stanzas:

I. Good sir yf you lack the strengthe in your back and wolde have a Remediado

Take Eryngo rootes and Marybone tartes Redde wine and riche Potato.

2. An oyster pie and a Lobsters thighe hard eggs well drest in Marow

This will ease your backes disease and make you a good Cocksparrowe.

4. An Apricock or an Artichock Anchovies oyle and Pepper

These to use doe not refuse twill make your backe the better.

I0. The milke of an Asse will bringe to passe all thinges in such a matter.

When this is spente you must be contente with an ounce of Synamon water.

[Christ Church MS. I 84, f. 35 
Sir John was evidently of a most cheerful disposition, and we wish that a page had not been mutilated on which was written A notable sentence wherezvith Sir John Salusburye was zuoonte to solace him $S[$ elfe.

Often with a mery thought, do I myselfe well please it is a thing that coste me nought, yet dooth .... [paper torn].

[Christ Church MS. I 84 , f. I

Three of Sir John's notes referring to plants which he grew in his garden at Lleweni are printed with accounts of other garden plants below, but his other notes all refer to stations of native Welsh plants, and are usually authenticated with the addition of his name in full, 'Sir John Salusbury, Knight'. The records are the earliest known to me for Denbighshire and the adjoining counties.

The plants, though interesting, are not very rare and had mostly been localized by William Turner, or by Gerard, in England. The locality for Matthiola simuata appears, however, to be the earliest given for this plant in Britain.

\section{William SALUSBURy's LOCALITIES, c. 1597 .}

Radish (? Raphanus sativus). Transplanted by W. Salusbury from meadow adjacent to the Abbey at Maenan, near mouth of the Llugwy, to his garden at Llanrwst.

Radish sp. Llannefydd; Denbigh ; Llantwrog.

Marsh Mallow (Althaea officinalis). Llansannan.

Rest harrow (Ononis spinosa). Plas yn Llewini.

Gromell (Lithospermum officinale). Denbigh; Whitford; near Mostyn.

Chamomile (Anthemis sp.). Llannefydd; Llewini; near Llangollen; Dolgelley.

Mistletoe (Viscum album). 'I saw it with berries in March near the Bontvaen near Chirk, and without berries all the way to Ludlow.'

Fig. Conway ; 'maesglas yn tegeingl, $2 \mathrm{~m}$. from. Holywell.'

Great Cat's tail (Typha latifolia). Whittington Castle, $2 \mathrm{~m}$. from Oswestry.

Great Water Plantain (Alisma plantago). In a pool by the great house of Sir John Salusbury [presumably at Lleweni].

Rye. Plas Llewini 1555 .

Maidenhair Spleenwort (Asplenium trichomanes). Bettws y Coed.

Harts tongue fern. $\quad$ Talacre in Flint; in a wooded glen near Llannefydd.

\section{Sir John Salusbury's Localities, I606-8.}

\section{Papaver argemone $\mathrm{L}$.}

This hearbe is to be found by Llansanan hard by Ryd y Rienn or at Aber in Carnarvonshire.

Crambe maritima L.

English Sea Colewort, 'by my weare at Llanddylas upon the Baich and brine of the Sea, where there is no Earth to be seene but sande \& pible stones '. In flower 30 May 1606. 
Matthiola simuata $\mathrm{Br}$.

Purple sea stıck Gilloflower, 'by seaside by Sir John Salusbury his weare theare at Llandulas'.

\section{Rubus Idaens L.}

The Ruspie Bush or Hindebery doth growe by Moelvodiar ${ }^{1}$.in Rees Tailors tenement \& in grove of woodde Kylynllwyn behind the house of Berain, where I Sir J hhn Salusbury found plentie of them growing wild yet naturally there. It is also found in Merionethshire, very comon by hedge ows and in th topps of old thatched houses, and so likewise in the upp partes of Denbighshire at Sputty and other places thereabouts.

Rosa spinosissima L.

I Sir John Salusbury found the Rose Pimpernell very comon in Garth snodnay Parke by Denbighe. Also in Merionethshire..

\section{Sedum acre $\mathrm{L}$.}

Castle wall of Harden Castle. J. S.

\section{Parnassia palustris L.}

Mr. Tho. Williımes, Clarke \& phision, sent it mee Sir John Salusbury Knight, for another hearb. It groweth in a meade of Sir John Winn Knight.

Silaus pratensis Bess.

English Saxifrage in the Copic in Llewenny parke next the newe stable over the high stile upon the right hand of the footway that leadeth from Llewenny Hall to Denbighe I found it the 23 Maye 1606.

\section{Daucus Carota L.}

Copic of Llewenny 23 Maye 1606.

\section{Scabiosa arvensis L.}

Purple flowered Scabious groweth neere St. Michells well or Fynnon Mihangil by Carwys, in the field that is above the well named Blorant, ${ }^{2}$ in many other places neere Skewiog [Ysceifiog] Church, in the field adioyning to the highe way upon the left hande as you come from Denbighe to the mountayne as you ride to Chester.

'Conyza maior'? = Erigeron acre L.

Llewenny.

Gnaphalium erectum L.

Coten weede or Comon Cudweed groweth by Llewenny Brewhouse near to the Causaye theare.

Vaccinium myrtillus L.

This groweth in most of the montaynes of Wales.

Lysimachia nummularia L.

Herb twopence. Newburghe in Llewenny Park \& in wood called Kylynllwyn.

1 Three miles west of Henllan. I am inciebted to Mr. Edwards, the Librarian of Jesus College, for help with the spelling of Welsh place-names and for the loan of the Herbal of William Salusbury.

${ }^{2}$ Blorant in Parish of Aberwheeler near Bodfari. 
Erythraea Centaurium Pers.

24 May 1606 Llewenny.

Scrophularia nodosa L.

Groweth in the Orchard at Chirck Castle.

Digitalis purpurea L. var.

Foxglove with white flower growes in a Parke of the Right Worthy Sir

Thomas Myddelton called [? Castle] park [of Chirck ?].

Veronica officinalis $\mathrm{L}$.

Fluellen 8 Oct. 1609.

Veronica spicata $\mathrm{L}$.

Veronica serpyllifolia L.

Salvia verbènacea $\mathrm{L}$.

Wild Clarie in great plentie in litil Park by the wall of the Castle of Denbigh.

Prunella vulgaris L.

Selfe heale or ye graite ynnos groweth plentifullie in Lleweny parke \& the white flowered Self heale is found in a meadow of John Wyn mathenor of Lleweny green.

Ajuga reptans $\mathrm{L}$.

Bugle or Middle Comfrey also white flowered Bugle I, Sir John Salusbury, Knight, found both in Lleweny park in the Coppice adjoining upon the River Cloyd where the herbes Adders tonge \& Twiblade growe I found them the $\mathrm{xx}^{\text {th }}$ of May 1606 growing there plentifullie.

Plantago coronopus L.

Buckeshorne. Weare at Llandulas on the side of the Bancks neare the weare. 3 May 1606.

Euphorbia paralias L.

Sea Spurge. Llanddylas 'risinge furthe of the Sandes' and Baiche of the Sea in very great plentie. $30 \mathrm{May} \mathbf{1} 606$.

Ophrys ovata L.

Twyblade is liketvise found neare Carrwis in a place called Cadnant, where a faire well springeth called St. Michael's well, in Welsh ffynnon Mihangel. [And in the] Castle Park of Chirche in a close next the lower Barnes (belonging to the Rt. Hon. Sir Tho: Myddelton). Twiblade are found by Chambers wood in a field called Ravenscroftes field in Wales neare Denbigh and likewise is found hard by Cloyde in a field of John ap Roberts of Pont Gruffith \& uppon the banks of the river Wheler. neare the house of the parson of Botuarry. The Herbe Addertonge groweth likewise in the lower end of Ravenscioftes field,

Paris quadrifolia L.

Herbe Paris is found neare Carrewis in a place called Cadnant, where a faire well springeth called St. Michael's well, ffynnon Mihangel within a boult shot of the well down the spring, one that side of the water as Carewis standeth, where like wise is found the hearb Twyblade and by reason of the ranknes of the place there are found a greate store of herbe paris with five leaves apece, but the yeare $\mathbf{1} 606$ I found the same with six leaves.

Sir John states that he planted them in his garden in 1608 . 
Ophroglossum vulgatum $\mathrm{L}$.

The Herbe Addertonge groweth likewise in the lower end of Ravenscroftes field. [See above.]

Botrychium Lunaria Sw.

Lunaria minor is found in Cunnygree of the Right Hon. Sir John Salusburys, Knight, lying betweene Botuarry [Bodfari] \& Carewis, and great plenty of them are found in Place y Chambers fielde lying hard by Snodioge parke ${ }^{1}$ neare Denbigh being the highest \& the next field to the parke on the left hand as you go to Henllan from Place y Chambers, in a place of Llanywith called Ogoyr graig uppon the side of the banke theare, and are found in the littel park of Denbigh in the syde of a hill... [continuation cut in rebinding].

Poisonous Fungi.

Let my advice perswade thy mynde not to truste any of that kynde such as be takenn for the beaste doe prove as poisnusse as the reste.

J. S.

With these notes are others concerning the medicinal properties of herbs, on which Sir John Salusbury was also an authority. But in none does he show his wisdom as clearly as in two lines in his poem on Certaine Necessary observations for Heath, 1603.

Apothecaries shop of drugges let not thy stomack be :

Nor use noe phisick till thou neede, thy frende adviseth thee.

\section{vi. The MSS. of Mathias de L'Obel and William How.}

Among the papers which came to Magdalen College with the botanical Library bequeathed by John Goodyer in I664, were some thousands of printed slips cut from Lobel's Adversaria, I576, Observationes, I576, and Icones Stirpium, with the author's corrections and MS. additions. These had evidently formed part of a pasted-up copy prepared by himself for a projected work which he did not live to publish, but from which How printed a selection under the title, perhaps the same as the one Lobel himself would have chosen, of Stirpium Illustrationes.

The first question that occurs to one is, To what extent do these MSS. throw light on the life and work of Lobel ?

Lobel was born in Flanders in 1538 . Like d'Aléchamps (1513I588), Clusius (1526-1609), Pierre Pena and Jean Bauhin (154I) he studied at Montpelier under Guillaume Rondelet, who is said to have taken such a liking to the serious young student, that he

1 'Snodiog Park' is marked as a round enclosure between Lleweni and Denbigh in old maps of the county. 
bequeathed his botanical manuscripts to him. In the Goodyer collection there is a parchment cover that was used to hold loose papers, which bears cvidence to the association, for inside is written Rondclet de Febribus. It may have originally served to contain notes taken by Lobel at Rondelet's lectures.

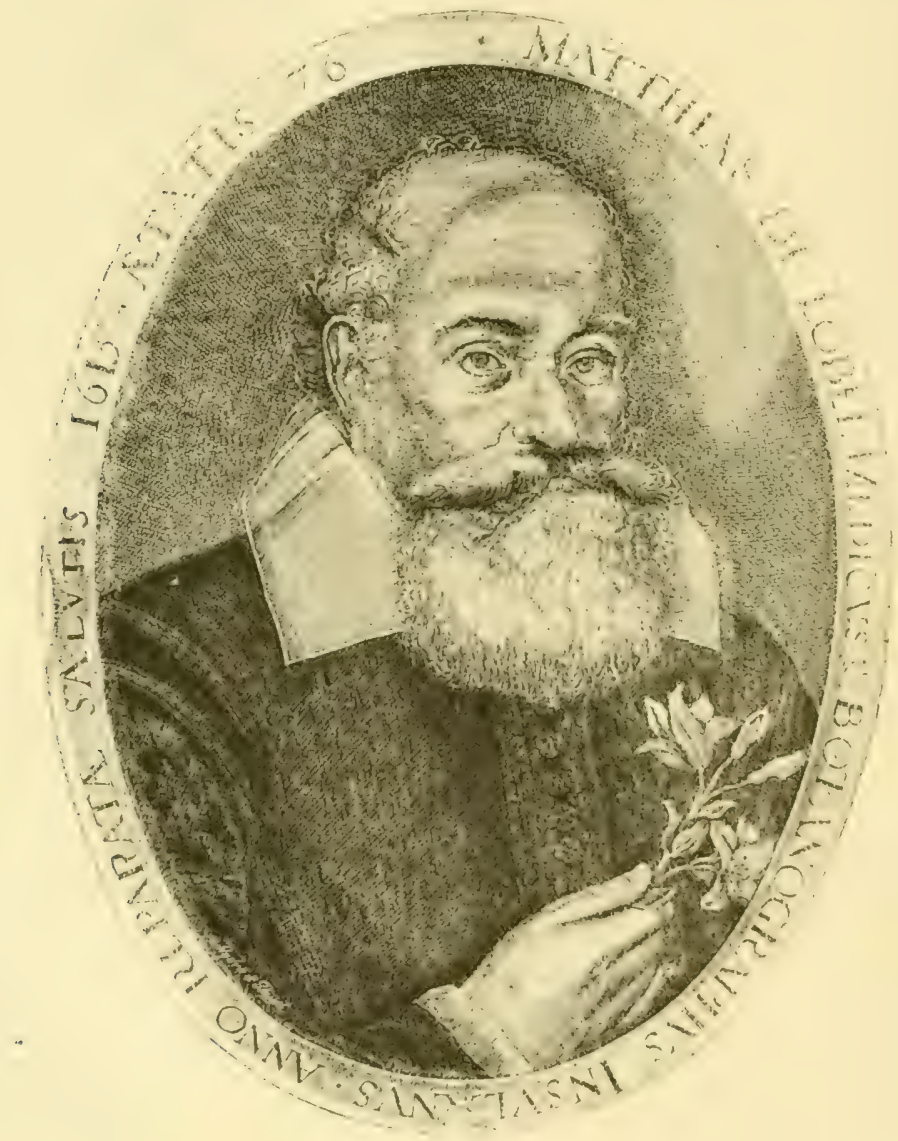

LOBEL.

Some ten years later we find Lobel living in England. Driven from his native land by civil war, he described himself as being unable to make a home on a sea tossed by incessant tempests, or to indulge his peaceful love of gardens and flowers on lands watered with human blood. He came over to England to produce his first great work, the Adversaria, and in return for English hospitality he dedicated the work to Queen Vizabeth. The book was printed in London in 1570 . It was our first scientific Botany. In Turner's 
Herball the plants were arranged in alphabetical order. In Lobel we find the first striving after a natural classification, and for the first time the straight-veined plants, now called Monocotyledons, were partly separated from those with net-veined leaves (Dicotyledons).

Five years later we find him back in his native country and in close alliance with Plantin, printing his Stirpium or Plantarum Historia illustrated with I, 486 wood blocks, to which the De Succedaneis of Rondelet was added. And six years later he moved to Delft to superintend a Dutch translation of his work, the Kraydboeck printed there in $15^{81}$.

At the age of fifty-four he was again in England, superintending a Botanical Garden which had been established by Lord Zouch at Hackney. In this he was probably in friendly rivalry with Gerard, who, seven years his junior, was cultivating eleven hundred kinds of plants in his garden in Holborn. Lobel in fact prefaced the I596 catalogue of Gerard's garden with a printed letter of eulogy, but a note in his own hand in the copy in the British Museum (N.H.), 'haec esse falsissima M. Lobel,' is distinctly unkind. Dr. Daydon Jackson tells me that this is the only specimen of Lobel's handwriting that was known to him before he saw the Goodyer manuscripts.

About I606 Lobel was honoured by being appointed King's Botanist to James I, but feeling the weight of his sixty-eight years, retired, it is believed, to live with his son-in-law James Cole at Highgate. The will of JAMES COLE, ${ }^{1}$ a document of great interest, presents a graphic picture of the wealth of Lobel's son-in-law, who evidently maintained intimate relations with the Low Countries to his dying day. He was engaged probably in the spinning, and certainly in the importation of silk into this country. He left his house at Highgate to his wife Louisa, then to Abraham Bush, his sister's son. His house in Lyme St., held on lease from the Carpenters' Company, he left to his nephews Henry and Peter Cole, and Henry was also to have a 'gilte cuppard with the arms of Antwerpe graven therein' and his chain of gold. To Abr. Bush

1 IVill (P. C. C. Barrington 42) written on six leaves of paper, dated 31 Dec. I627, with a codicil witnessed by Eliz. van de Bossche and Louise Cool, proved May 1628. It is to be hoped that one day a more complete account of Lobel's relations will be forthcoming. In addition to James Cole, he mentions another son-in-law Ludovic Myres, an authority on pharmacy, Abraham Hoguebat, pharmacist, son of his second wife, and Michael de Lannoy ' affinis meus'. His second wife may have been related to the Hugobert mentioned by Goodyer, cf. p. 59. Was de Lannoy synonymous with de Laune? 
' all my bookes ${ }^{1}$ as well concerning my. Latin studies, as picturenge with all my printes, little pictures, shells, marbers, statues, and all my antiquitics and old Coines and such like rarities commonly shutt within my Counting House in Lyme St.' To numerous friends and relations with Dutch names he bequeathed silver cups and pieces of plate.

Under Cole's roof Lobel probably added the last touches to a compilation, the manuscript of which is now before us, and which we may call the Stirpium Illustrationes. The date of the work is settled by the imprimatur which bears the signature of Thomas Moundeford in his official capacity of President of the College of Physicians. He filled this post from $16 \mathrm{I}_{2}$ to $\mathrm{I}_{6} \mathrm{I}_{4}$.

The original testimonials with which Lobel had provided himself for two of his works are still extant. They are both from the College of Physicians, and are signed by the most eminent doctors in London. The names on the earlier document take us back a long way, to 1605 , two years before Harvey became a Fellow of the College. The signatures are headed by:

Thomas Langton ${ }^{2}$ as President ; then follow John Craig, ${ }^{3}$ who is said to have given Napier a hint that led to the invention of logarithms; Sir William Paddy, ${ }^{4}$ Sir T. Turquet de Mayerne, ${ }^{5}$ Henry Atkins, ${ }^{6}$

1 Two of James Cole's books are known to me. One a Dodoens in the Goodyer collection; the other, Clusius, Per Hispanias, formerly in the British Museum, but turned out as a duplicate in 1769 , and now in the possession of my friend Dr. Daydon Jackson. Both books have his signature Jacobi Colei on the title-page.

2 Thomas Langton, M.D. Cantab. F.R.C.P. 1581; President, 1604, $5,6$. d. 1606 .

3 John Craig, M.D. of Bâle. First Physician to James VI of Scotland. F.R.C.P. I604. He attended James $I$ in his last illness.

${ }^{4}$ Sir W. PADDY, M.D., of St. John's College, Oxford, where a monument records his great benefactions to the College. Physician to James I. President of the College of Physicians, 1609-11, and in 1618.

${ }^{5}$ Sir Theodore de Mayerne, M.D. b. Geneva 1573, d. I655; M.D. Montpelier I597; F.R.C.P. 1616. Physician to Anne of Denmark, Charles I, and Charles II.

${ }^{3}$ Henky Atkins. President of the College of Physicians, on seven occasions, 1606-25. He started with the naval expedition of 1597 as physician to the Earl of Essex, but was so bad a sailor that he had to be put ashore at Plymouth, and the College was ordered by the (gueen to select another medical man to accompany the expedition. The choice fell on Dr. Moundeford. Dr. Atkins was chosen by James I to fetch his younger son, subsequently Charles I, then an infant from Scotland. $\pi_{0}$ 1635. His will has recently been acquired by the College of Physicians. 


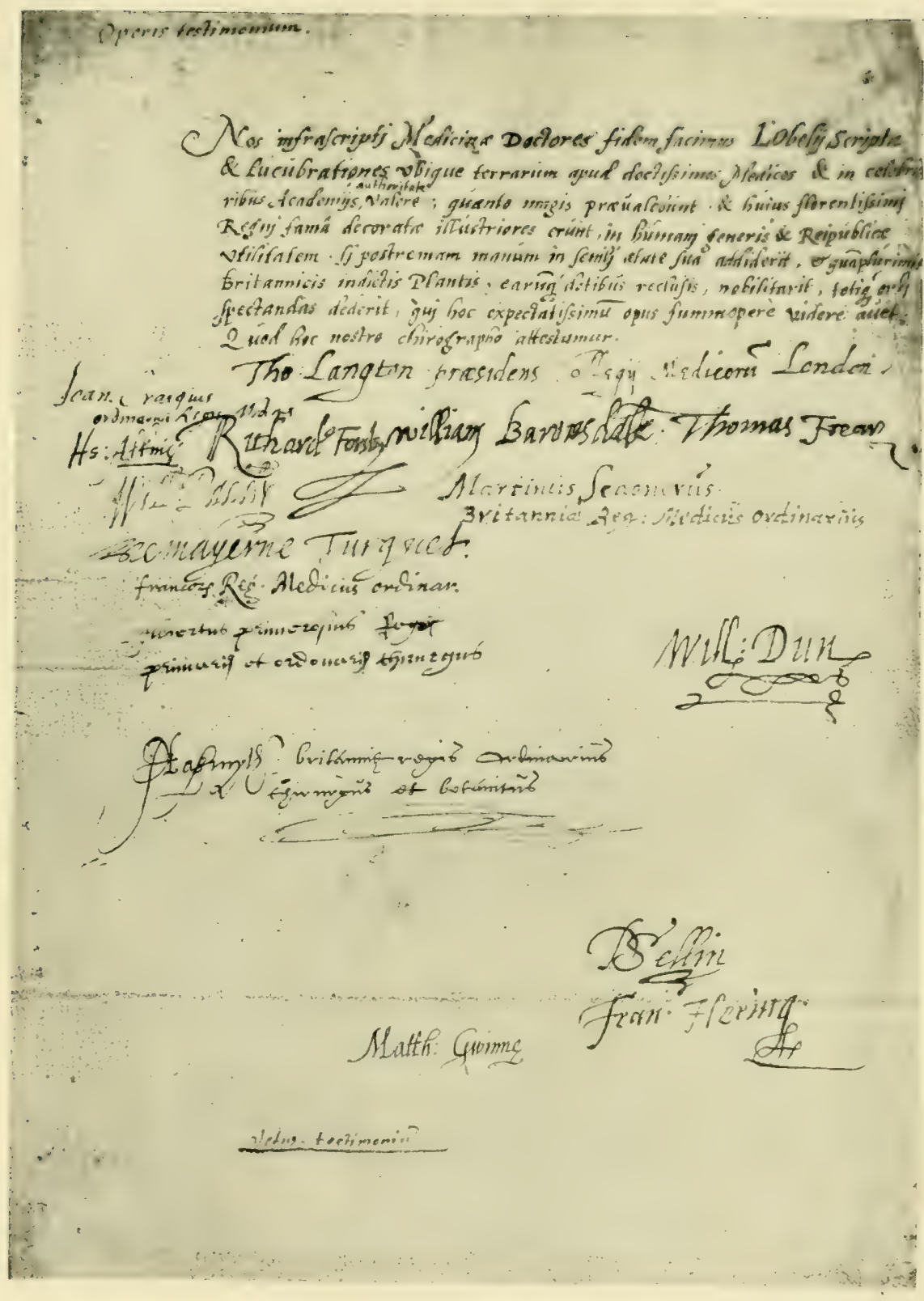

OLD TESTIMONIAL TO LOBEL

Signed by the President of the College of Physicians. and by other eminent Doctors 




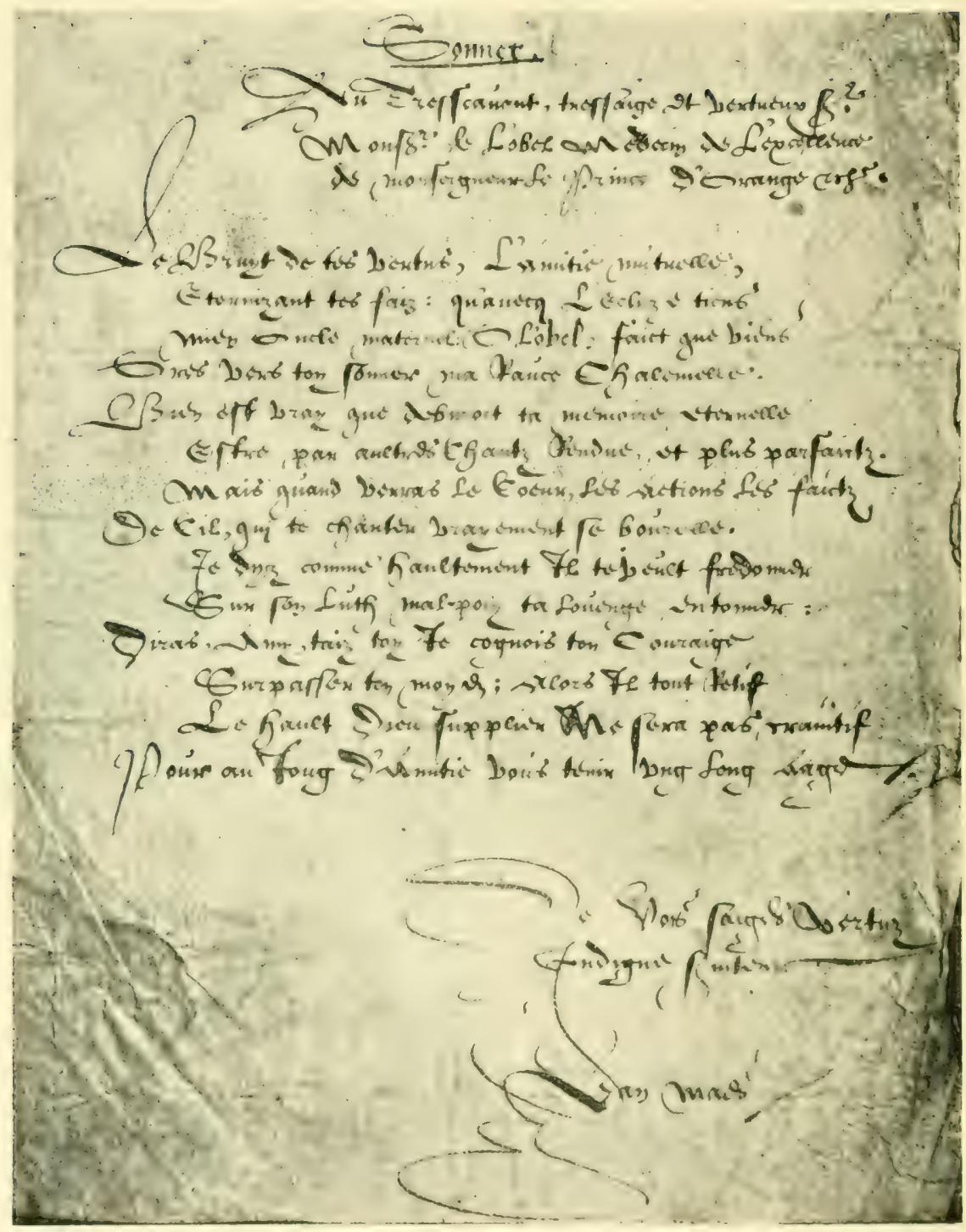

SONNET DEDICATED 'TO LOBEL BY MIAS 
Richard Forster, ${ }^{1}$ William Baronsdale, ${ }^{2}$ Thomas Frear, ${ }^{3}$ William Dun, ${ }^{4}$ D. Sellin, ${ }^{5}$ Francis Hering, ${ }^{6}$ Matthew Gwinne, ${ }^{7}$ all in Munk's Roll of the College. Gilbert Primrose, though not on the Roll, was the father of James Primrose who was; J. Nasmyth, ${ }^{8}$ surgeon to James VI of Scotland, had only recently arrived in London in attendance on his royal patron. Gwinne's Vertumnus was acted at Magdalen College in 1607 . Nasmyth had already presented Lobel with some plants which the latter had already acknowledged in print. This testimonial was accompanied by a eulogistic Sonnet written by Jan Maes. Neither testimonial nor sonnet appear to have been published.

The later testimonial is signed by Thomas Moundeford, ${ }^{9}$ President, Henry Atkins, Richard Forster, Thomas Friar, Mark Ridley, ${ }^{10}$

1 RICHARD Forster, M.D., of All Souls College. F.R.C.P. about 1575; President, 1601-3, and 1615. Author of Ephemerides Meteorologicae, ad anmum 1575, secundum positum Finitoris Londoni. -8vo Lond. 1575. When out walking with Dr. Herring and Lobel he found a new grass, 'Gramen supinum Monspeliense inter Islington et altam portam, vernaculè Highgate'. (Lobel.)

${ }^{2}$ William Baronsdale, M.D., of St. John's College, Cambridge. President of the College of Physicians, 1589-1600. He died before 7 June 1608.

${ }^{3}$ Thomas Fryer, M.D. of Padua, of Trinity College, Cambridge. F.R.C.P. 1572. He incorp. Doctor of Physic at Oxford, $28 \mathrm{Feb} .1623$.

${ }^{4}$ William Dunne, of Exeter College. F.R.C.P. 1592. Died before I6 May 1607.

${ }^{5}$ Daniel Selin, M.D., of Magdalene and Christ's Colleges, Cambridge. F.R.C.P. I599. d. 1615.

${ }^{6}$ Francis Herring, M.D., of Christ's College, Cambridge. F.R.C.P. I599.

He was present at the finding of 'Gramen supinum Monspeliense' between Islington and Highgate, and wrote a Latin poem Epigramma in Opera novissima L'Obelii as a mark of his 'Iove and friendship', which was printed at the end of Lobel's Animadversiones in G. Rondelletii Pharmacenticam Officinam. Lond. 1605 .

7 MatThew Gwinne, M.D., Fellow of St. John's College, Oxford. F.R.C.P. I605; First Gresham Professor of Physic, 1598-1607; author of the Latin comedy Vertumnus, acted before James I at Magdalen College. $d .1627$.

8 James Nasmyth. Surgeon and Botanist to James I.

Provided Lobel with new drawings of 'Hyacinthus stellatus Peruanus' and 'Narcissus Indicus rubro flore', one of Robin's new plants. Lobel, Adv. alt. p. 482. He evidently had a garden in which he grew and flowered

Frittillaria nigra Pyrenaea. 1605. Lobel, Adv. alt. p. 496.

Crocus Byzantinus serotinus candidus. p. 498.

Colchicum minimum tenuifolium Gallaecium. p. 500.

Plantago Umbilicata. Staghorn fern. (Platycerium aethiopicus). p. 506. I604-5.

3 Thomas Moundeford, M.D., of Cambridge. Pres. R. C. P. I612-14, I62I-3.

10 MARK Ridley, M.A., of Clare Hall. F.R.C.P. 1594. Died before I624. 
250

LOBE

Edward Lister, ${ }^{1}$ Richard Palmer, ${ }^{2}$ John Argent, ${ }^{3}$ and Matthew Gwen. It was printed by How in 1655 together with an original letter from Dr. Argent, who will always be remembered for having obtained from Bermuda the original bunch of Bananas, which was exhibited in Johnson's shop on Snow Hill.

Lobed died in 1616 (four years before the birth of his editor, William How). James Cole inherited his manuscripts, and Parkinson, when collecting all available material for his Theatrum botani-

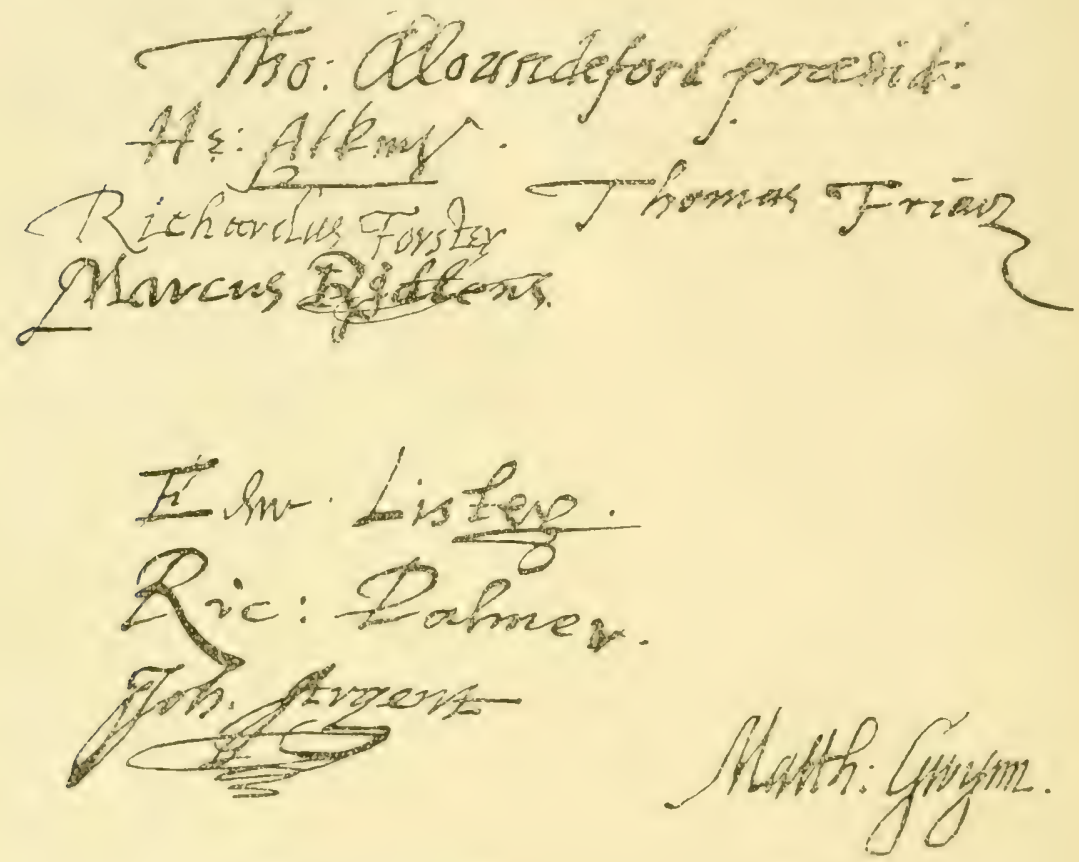

Signatures to LOBEL'S SECONd 'Testimonial.

cum, was undoubtedly permitted to see some or all of them. Label wrote in Latin: Parkinson would therefore have had to translate, and a strict sense of honesty in the obligation to make acknowledgement may have become blunted in the process: he merely mentioned Lobel's help in general terms, for Lobed was a foreigner, dead, and perhaps no one cared.

1 Edward Lister, M.D., King's College, Cambridge. F.R.C.P. I593. Physician in ordinary to Queen Elizabeth and James I. $d .1620$.

2 Richard PALMER, M.D., of Christ's College. Took part in the consultation at the death-bed of Henry, Prince of Wales.

3 John Argent, M.D., of Peterhouse. F.R.C.P. 1597; President, 1625-7, 29-33. d. May 1643. An autograph letter from him to Lobed is among the Goodyer MSS. He is remembered for his enterprise in causing his man to 
Ten years later William How, a young doctor of St. John's College, Oxford, was assiduously collecting notes for the first British Flora. Concise in the choice of its information and scrupulous in its duty of quoting authorities, the Phytologia Britannica of How was the antithesis to the Thcatrum of Parkinson. It was printed in 1650, almost certainly before the author had acquired the Lobel MSS. About 22 Jan. 165I Lobel MSS., or some of them, appear to have been in the hands of a man of learning, ${ }^{1}$ who then copied out many Latin descriptions of plants (Goodyer MS. 8, ff. I04-2I).

How was a most indefatigable hunter after exact localities of plants. He would have searched the Theatmun in vain for information which he afterwards found clearly given in Lobel's MS., and which he would have assuredly included in the Phytologia, had only Parkinson quoted authorities: and Parkinson had still further transgressed by taking Lobel's credit of priority to himself.

This appears to be one explanation of the violence of How's criticisms of Parkinson's lapse from the higher standards of literary honesty. My friend Dr. Church has suggested another motive which might well repay a more extended inquiry. Parkinson was a Puritan, whereas How was probably, like Goodyer and his friends, a Royalist.

It is reasonable to suppose that How's first idea after realizing the originality of Lobel's work was to publish it in toto. It was, however, in Latin, and the market had already been spoilt by the appearance of two popular works, Johnson's Gerard emaculatus in 1633 and Parkinson's Theatram in 1640, and no publisher would undertake a third.

Yet Lobel's 'volumes were compleat, The Title! Epistles! and Diploma affix'd'. How, indignant that Parkinson had, as he put it, 'murdered his (Lobel's) genuine scrutiny in treacherous oblivion,' and perhaps dimly conscious that his time for work through failing

follow the roots of a species of 'Pease' by scrapping away the beach between Orford and Aldborough, 'vntill hee got some equall in length vnto his height, yet could come to no ends of them'. Ger. emac. 1251. And during the last year of his Presidency of the College of Physicians, he gave Johnson the first bunch of Bananas that was ever exhibited in a London shop. Ger. emac. 1515.

1 The handwriting of the unknown commentator is characterized by the frequent use of scrolls. We have noted it in Goodyer MSS. $8^{\circ}$ and 9 and in Goodyer's copy of Parkinson's Theatrum, and have evidence that the writer was closely associated with Goodyer about 1650 to 1659 . There is reason to believe that the writer was Goodyer's friend and neighbour, Dr. John Dale of East Meon and of Long Acre in London, who died in 1662. 
health was short, made a selection of Lobel's descriptions under the title Stirpinm Illustrationes; plurimas claborantes inauditas plantas subreptitiis Iol: Parkinsoni rapsodiis (ex codice MS. insalutato) sparsim gravatae. The work was printed by Thos. Warren for Jos. Kirton of St. Paul's Churchyard in $1655 .^{1}$

We have the original manuscript from which the book was printed before us, with the excerpts from Lobel, with How's additions pasted or pinned thereto, and the leaves of the MS. exactly as they were marked for the compositor, and returned by the printers to the editor.

After How's early death on 30 Aug. 1656, his own annotated copy of the Phytologia passed to John Goodyer on 30 Apr. $16_{59}$, and with it probably the Lobel MSS. as well, but too late for them to be of real use, for Goodyer's working life was drawing to a close. Except for their disarray through having been ungummed and misplaced, we may assume the papers to be in the state in which How left them.

In this volume there are thirty-seven leaves.

First comes the original imprimatur with the signatures of Tho. Moundeford, the President of the College of Physicians, and of eight other members. Then the Preface, with many lines erased in Lobel's hand, and some eulogistic verses by Alexander Rhedus of which the last eight lines were not printed. Next follow some introductory remarks by How, and his Index and list of erratula in his own hand.

Then Lobel's descriptions of 223 kinds of plants, a large number of which were apparently claimed by Parkinson as his own discoveries. How's notes, which appear in small type near the margin of his printed book, are intercalated in the Lobel MS., and show that the selection and arrangement of the volume was entirely the work of How, and not of Lobel.

How evidently had Lobel's materials for the larger book before him. He cut out the descriptions which appeared to him to be of the greatest importance. There are also included original letters from JOANNES DE MONNEL ${ }^{2}$ and from JOHN ARGENT, dated 'Wood Street 2 June 1608 ', and also notes on various plants from Montpellier communicated by, and apparently in the handwriting of, Pellisserius. At the end is one leaf of a

1 John Goodyer received his copy on I9 February 1654.

${ }^{2}$ JOHN MONNEL of Tournay was a correspondent of Clusius. Parkinson associates him with 'Anagallis tenuifolia $\mathrm{fl}$. coeruleo' which he received from Cadiz and grew in his garden at Tournay. Theatrum, p. 559. 
autograph, in which more than a score of Parkinson's errors are pointed out.

The remainder of Lobel's materials and the manuscript of his projected Stirpium Illustrationes have now been bound in three volumes, for convenience in handling.

Volume I contains the classification and description of 223 kinds of grasses. Lobel had evidently become acquainted with a great many more species than the some forty-five he knew when he printed his Historia plantarum in 1576 . But evidently the very novelty of the newer descriptions has brought about the spoiling of the MS.-from which How cut out accounts of ninety-eight different grasses, for his book printed in 1655 .

Lobel had evidently worked hard at his grasses. The different kinds described have been numbered and renumbered in some cases four times over, and many alterations have been made in the MS.

The last fourteen leaves of this volume are from a pasted-up copy of the Adversaria which has been much cut about.

Vols. 2 and 3 are built up out of a further portion of the pasted-up copy of the Adversaria, the leaves of two copies of the I 576 edition being pasted on leaves of paper. The greater part of the text has been struck out, and marginal references to the pages of the Observationes, 1576 , have been added. In vol. 2 the leaves have been roughly numbered by How (?) I to I34, and in vol. 3 the leaves run from 135 to 25 I. The plants are numbered up to No. 835 .

Between the leaves so prepared he intercalated the leaves of a printed copy of the Observationes (edit. I 576 ), and between them again the illustrations from his I59I edition of Icones Stirpium printed by Plantin. In many cases the page-margins are filled with Lobel's additional MS. notes on the plants.

There are no references to Goodyer, nor traces of his handwriting, on these Lobel MSS.

\section{vii. William Mount and his Records of Kentish PLANTS IN I $582-4$.}

Among the books in the Goodyer Library are two editions of the Icones Stirpium by Lobel, printed by the Plantin press. The earlier copy of $15^{8} \mathrm{I}$, according to a note on the title-page, was purchased by 'Gulielmus Mowntuus' for I9 shillings on May 20, I 582. This note was written by Mount himself, and his initials, 'W. M.', are stamped upon the leather binding. Several notes, 
written in the margins of the illustrations, appear to have been added by him within a few months of his acquiring the volume. In this, the earlier of the two volumes, there are no notes by Goodyer; but in the later edition of $159 \mathrm{I}$, containing no notes in Mount's hand, there are numerous notes by Goodyer, including copies by him of all Mount's notes on plants growing in Kent, taken from the copy of $158 \mathrm{I}$.

It seems likely that Goodyer having first acquired the later edition, copied Mount's notes into it, perhaps borrowing them for the purpose. He subsequently obtained possession of the earlier copy and owned both volumes before 1633 .

It has been ascertained ${ }^{1}$ that Mount was born at Mortlake in 1545, was educated at Eton and King's College, Cambridge, of which he was admitted scholar in $1_{5} 6_{3}$ and fellow in $1_{5} 66$. He resigned his fellowship before Lady Day 1570. It appears that he owed much to the patronage of Secretary Sir Thomas Smith and Lord Burghley. ${ }^{2}$ In a letter addressed to Sir William Cecil on 20 Oct. 1567 , he professes his great satisfaction in being placed at the University under the patronage of the former, his 'most honoured Mecaenas'. Medicine was the first object of his studies: later he took orders and was appointed Master of the Savoy in January I593-4, and died in December 1602.

It was known that Mount had taken considerable interest in the making of distilled waters, an art which he probably learnt as part of his medical studies, and that he had written some Latin verses prefixed to Lobel's Balsami, Opobalsami, Carpobalsami et Xylobalsami explanatio in 1598 , but he has not as yet received from botanists the credit which he deserves of having been the first to record the provenance of several plants in the county of Kent, nor for his knowledge of the construction of perpetual calendars.

In the collection of medical books which my friend the late Sir William Osler bequeathed to $M^{\mathrm{c}}$ Gill University, there is a manuscript to which Mr. Craster has recently drawn my attention : it throws a new light on the knowledge of the Kentish botanist. It is ' A shorte declaration of the meaning and use of a perpetuall calendare or almanack' by W[illiam] M[ount], in eleven chapters, with dedicatory preface to Sir Thomas Bromley, Lord Chancellor of England, whose chaplain the writer was, and whose arms are blazoned in colour on p. vi. The work, which is the author's holograph, is illustrated by coloured tables and diagrams. Three

1 Cooper, Athenuc Caniah. ii, p. 271.

${ }^{2}$ Cirlendar State Papers Dome'stic, 1547- So, pp. 294, 3or. 
of the latter contain the arms respectively of the Universities of Cambridge and Oxford, and of Queen Margaret of Anjou, foundress of Queen s College, Cambridge.

It was written by William Mount in $15^{83}$; and the hand is identical with that in which the entries in Goodyer's copy of Lobel's Icones at Magdalen College. are written.

Mount's botanical localities were mostly within four miles west and north-west of Maidstone, indicating that he was living in Kent in $15^{81}$ at Fast Malling, where he had an orchard. And even in the case of plants for which Mnunt gives no localities, it may safely be assumed that he was referring to specimens growing near his Kentish home. His notes appear to have been written between I 582 and 1584 . The plants which he may then have observed in Kent, and for which his are the earliest references, are about thirtythree in number. Of these thirty-three plants we find that Gerard, who wrote thirteen years later than Mount, mentions only eight, and to these Johnson adds only eleven more in his various works printed 1629 to 1633 , forty-five and more years later. These notes of William Mount, therefore, constitute an important contribution to a first Flora of Kent, ${ }^{1}$ with a few notes on the virtues of imported garden and medicinal plants; and it must be remembered that they were compiled in days when the idea of local floras was as yet unknown.

The modern names of some of the plants for which he has recorded dates and localities are included in the following lists.

\section{NATIVE PLANTS.}

Modern Names.

Poa pratensis, L.

Poa trivialis, L. (?)

Eragrostis major, Host.

Phleum pratense, L., var. nodosum. Mount's 'Alderes'.

Carex acuta, L.

Juncus acutiflorus, Ehrh.

\section{Localities recorded by Mount c. 1582.}

East Malling.

Snodland.

\section{First printed \\ records.}

Gerard, 1597.

Ger. 1597.

Johnson, 1629.

Curtis, I670.

Johnson, 1632 .

1 I have found some other references to plants dating from the sixteenth century in a copy of Lyte's Herbal, I578, belonging to the Radcliffe Trustees in Oxford. Two of the notes certainly refer to Kent, possibly the others may too. There was a Smallbrydge in the manor of Horsmonden.

Ground pyne (Ajuga Chamaepithys L.) 'luxuriat in Cantio'.

Rhus sylvestris Plin. (Myrica Gale L.) 'Canterberyie Call and Cole'.

Rhamnus (Rhamnus catharticus L.) ' au pres de la forest de Hatiele' (?).

Buckthorne (Hippophae Rhamnoides L.) 'au pres de small bregge'.

Plane (Platanus orientalis L.). Planted in England 'at Small brege'.

The signature of the recorder is doubtless on the title-page, but it has been obliterated by over-scribbling. 


\section{Modern Names.}

Hordeum murinum, L.

Luzula vernalis, DC.

Eleocharis uniflorus, Reichenb. (?)

Triticum repens.

Agropyrum junceum, Beauv. (?)

Cynodon Dactylon, Pers. or

Digitaria glabra.

Sparganium ramosum, Huds.

Narcissus pseudo-narcissus, L.

Scilla autumnalis, L. (?)

Allium ursinum, $L$.

Bupleurum rotundifolium, L.

Coronopus Ruellii, All.

Stellaria media, Vill.

Lysimachia Nummularia, L。

Rhinanthus Crista-galli, L.

Digitalis purpurea, $\mathrm{L}$.

Tussilago Farfara, L.

Nymphaea lutea, L.

Bryonia dioica, $\mathrm{L}$.

Tamus communis, L.

Potentilla anserina, $\mathrm{L}$.

Pedicularis palustris, L.

Fumaria officinalis, L.

Ceterach officinarum, Willd.

Botrychium Lunaria, Sw.

Asplenium Ruta-muraria, L. Rhamnus catharticus, L.
Localitics recorded by Mount c. 1582.

About London.

Mount's Orchard.

Sandwich, Dover.

Addington.

Addington.

Addington, $158 \mathrm{I}$.

Leybourne.

'Very common', prob. in Kent.

Sea-coasts of England.

Wrotham.

Common.

East Malling.

Maidstone, 1583.

Blackheath ; near Rochester.
First printed

records.

Turner, I548.

Ger. 1597.

Ger. 1597

Ray, 1688.

Hooker, 1829.

Johnson, 16:9.

Ray, 1724 .

Park. I629.

Martyn, 1763 .

Johnson, 1629.

Ger. 1597.

Turner, 1735.

Johnson, 1632 .

Johnson, 1629.

Johnson, 1632 .

Johnson, I629.

Jacob, 1777.

Johnson, 1629 .

Johnson, 1629 .

Johnson, I629.

Merrett, I667.

Ger. 1597.

Park. 1640

Lobel, I 570 .

Ger. 1597.

Dover-Folkestone, 1582 . Ger. I 597.

\section{GARDEN AND EXOTIC PLANTS.}

Zea Mays, L.

Acorus Calamus, L.

Gladiolus communis, L.

Crocus sativus, $\mathrm{L}$.

Colchicum autumnale, $\mathrm{L}$.

Saponaria Vaccaria, L.

Ipomaea Jalapa.

Anthriscus cerefolium.
Morgan's garden.

D. Penny's garden.

\{ Morgan's garden, 1578.

$\{$ Mount's Malling garden, 1583 .

Saffron Walden.

Mount's garden, 1583 ; and at Bath.

Lord Abergavenny's garden, 1584 .

Root used medicinally in England, 1580 .

\section{The Manuscript Notes of William Mount.}

\section{On Title-Page.}

$$
\text { 'Gulielmus Mowntuus } 19 \text {. Maij 20. 1582.' }
$$

Page.

I. Gramen pratense.

'Great leavyd Medowe grasse very vulger.'

Poa pratense L.'

I. Gramen minus.

'The lesser vulger Grasse.'

Poa trivialis L. (?)

${ }^{1}$ Lobel's illustrations of these grasses have been determined by Dr. Stapf, who notes that they are 'mostly too crude for us to name from them critically, and Mount would not have been in a better position, except perhaps in so far as he may have been supported by some tradition that is lost to us'. 
7. Gramen paniculosum Phalarioides.

Eragrostis major Host. ${ }^{1}$

'Grasse called in Surrey, braunched grasse in Coarne: and in orchardes, \& shaddowye places usually mowen. They seathe $y^{t}$ in water $w^{\text {th }}$ purselane and small Peysons for wormes, in the sommer tyme, and gyve $\mathrm{y}^{\mathrm{t}}$ commonly to very younge chylderen.'

ro. Gramen typhinum.

Phleum pratense L., var. nodosum.

'An other Sedge Grasse in watery moyste places-in my Alderes \& (?) muche.'

I I. Gramen palustre maius.

Carex acuta $\mathrm{L}$.

'The sharpe edge grasse flaggis he in black brookes [in Est mallinge] growinge in Tuffettes, very Common.'

I2. Gramen aquaticum alterum.

Juncus acutiflorus Ehrl.

'Ponde grasse growinge in a Ponde in Snodelande, wch ys sometyme allmoste drye.'

I3. Panici effigie, Gramen simplici spica.

Hordeum murinum $\mathrm{L}^{2}$

'Barley grasse: because $y^{t}$ resembleth Barleye in hye wayes, and pathes about London.'

I6. Gramen hirsutum nemorosum.

'Hearye or hoarye Grasse in my orcharde.'

I7. Gramen iunceum marinum dense stipatum.

Eleocharis uniflorus Reichenb. (?) ${ }^{3}$

'Pusshye grasse: in the sandes by the Castles betweene Sandwyche and Douer (in Kent).'

20. Gramen Canarium.

Triticum repens $\mathrm{L}$

'In all places where the wryters use this worde: Gramen: It ys to be understoode $y^{t}$ they meane Quycke or Couche grasse, whereof there be dyverse kyndes well knowen. The best in my opynyon hathe longe greate rootes creeping in lengthe ij yeardes greater than wheate strawes full of ioyntes agroinge wth ye shape, $\mathrm{fol}^{\circ} .23$. Yt groweth in Addington in Kent in the sandy drye dustie hye wayes there. The same prevayleth against the straw, and against wormes in my experience.'

22. Gramen caninum longius radicatum marinum alterum.

? Agropyrum junceum Beauv.

' Of Dogges Grasse, or Couche grasse, thus writeth Poena, and Lobell, fol. 2. ... I have used the Grasse with ye great roote, growinge in sandye wayes set downe here, folo. 23 : growinge in Addington in Kent and doe fynde yt muche better then the usuall Couche grasse. Wm: Mount.'

23. Gramen caninum alterum.

Cynodon Dactylon Pers., or Digitaria glabra Beauv.

'Quyche grasse growinge in sandye wayes the very trewe Cowche grasse whereof the Phisiciones wryte. It groweth in the sandy hie waye plentifullye betweene Wrothame and Addington

1 Dr. Stapf writes: 'How this came to be noted down for Kent is a puzzle, unless he saw it in a garden. Tabernaemontanus says it was grown in gardens, and as it had an old popular name "amourette", it may not have been unknown in English gardens of the period.'

2 The figure and name are of Setaria viridis Beauv. (O.S., J.).

${ }^{3}$ The figure is Scirpus caespitosus L. (O.S.); the name belongs to Bromus asper (J.). 
in Addington in Kent. (I there fownde $y^{t} a^{0}\left[{ }_{5}\right]_{8} \mathrm{I}$ and have synce often used it against wormes $w^{\text {th }}$ good successe and ye stoane allso euen in my selfe for ye stoane.'

33. [Quotation from Pena and Lobel.]

40. Milium indicum rubrum.

Zea Mays L.

'Redd Indyan Myllitt, which I have seene in Mr Morgan hys house, the Queenes apothecarie in London.'

49. Harundo saccharina Indica.

Succhanum officinarum $\mathrm{L}$.

'The suger Canes which yielde us our best suger of it selfe suger without compoundinge, or connynge which ys in deede good and comfortable: the other here in Suger houses by pollycie denyed, ys perchaunce more profitable to the maker or merchaunte, then healthfull to the partie, which ys to use it.'

55. China.

Smilax China L.

'The diet roote Chinee whereof we have none growinge in Englande and yet muche used: it hathe byn in Englande for the Great pockes, allso for all deseases proceadinge from a moiste brayne and the lyuer obstructed. Hereof I referre the reader to Vesalius whoe hath lardge writen in his book de radice Chyna lardgelye thereof.'

57. Acorus Diosc. \& Acoros Theophrasti, Officinis falsò Calamus.

Acorus Calamus L.

' $I$ have hearde $M^{r}$ D. Pennye often saye that he hath thys roote in his garden in London.'

59. Iris nostras vulgaris.

Iris Pseud-acorus L.

80. Sparganium \& Butomus Theophrasti. Sparganium ramosum Huds.

'The sharpe edged burre Hagge. It groweth in watery dytches about Leybourne in Kent, smale use thereof in Phisick or Chyrurgie.'

98. Gladiolus Narbonensis.

Gladiolus communis L.

'Coarne flagge or Coarne gladdyn. I have $\mathrm{y}^{\mathrm{t}}$ my garden Mr. Morgan gave yt to me a ${ }^{0} 578$ at London yt groweth nowe with me $a^{\circ}{ }_{5}{ }^{8} 3$, at Mallinge.'

I I 2. Narcissus poeticus. Daffodil. Narcissus Pseudo-narcissus L. and others.

'Theis herbes which are set here under the name of Narcissus we calle Daffadowndyllyes: they be very common, and of them (as here they be set) dyuerse sortes of dyuerse colores.'

137. Crocus sine flore. Croci flores.

Crocus satizuns L.

'Safforne withoute flower I have never sëne here : safforne with the flower I have sëne plentye at Safforne Walden in Cambridgeshyre as I thinck yt ys and in many other places in Englande. Allso yt ys concluded amonge all the most approued Authors $y^{t}$ or Englishe Safforne ys the best and hath the greatest virtues.

The Qualities of safforne shall followe as the Roöme wyll permytt soe farre as there ys aney mency one by shape or picture made of safforne.'

143. Colchicum sive Strangulatorium Ephemerum Crocifolium.

Autumn crocus. Colchicum autumnale $\mathrm{L}$.

'Thys we calle Hermodactylus: $y^{t}$ was gevin me $a^{0}{ }_{578}$; and groweth now in my garden $a^{\circ}$ I 583 ; very trewly $y^{t}$ agreeth wyth thys shape [cf. figure in Lobel, Icones, I58I]. I did neuer see 
aney flower but only poddes, as here set downe yet $\mathrm{y}^{\mathrm{t}}$ may be that $y^{t}$ hath the flowers here underset and soe I thinck $y^{t}$ hathe.

D. Symyns ${ }^{1}$ tould me, that $y^{t}$ groweth plentifully about the bathes in Somerset shyre or Wyltshyre when he sawe yt in pastures whereof when casually their catle chaunce to feed, they become daungerus syck untyll ye herdsman or keper have well starved them euen allmoste to sweate; and thin $y^{e}$ swellinge and other accidents doe diminishe, allso they kepe ye cattell from drynck whyle they be yll. Thys ys Mr. D. Symyns observacon of thys herbe in that countrye, as I took the same from hyme by note.?

[Turner (Herbal, I568, p. I 56) figures the Widdowe Saffrone from Bath both in flower and seed, but appears not to have known of its dangerous qualities to cattle. He is eloquent about it in relation to man.

'It is good to knowe this herbe that a man maye isschewe it. It will strangell a man and kyll him in the space of one daye, even as some kinde of Todestolles do. The roote is swete and provoketh men thereby to eate of it. If anye man by chaunce have eaten anye of thys, the remedye is to drinke a great draught of cowe milke.'

'It stirreth up tossinges, wamlings, windinesse and vomiting' (Lyte, I578, p. 367).]

I 50. Cepe.

Onion. Allium Cepa L.

'Unyones fynely slysed, and in faier water one night steiped; the water $y^{8}$ next morninge geven to chylderen which have the wormes wonderfull effectuallye helpeth them. Lonicerus, fol. I93. Tragus allso first used yt, fol. 739.'

I 5 I. Scillas. Cepa marina. Scillaverna Huds. confused with S. maritima L.(J.)

'The sea Onyone or purginge onyone plentifull in England uppon the sea coastes.

It ys allso knowen, and to be bought at the Apothecaries only, by the names of Scylla, squylla or sea onyone: very muche used in phisicke. The syrupe thereof purgeth very well clammye, rawe, flegme, yet not without suspicione of some daunger and paynes. And therefore yt ys the better used in $\mathrm{Sr}$ [? summer] tyme, when all phisick muste be conveyed into our bodyes without offense of taste, and worcke without sense of the least grypinge, or troble that may, and muste be.'

I69. [Error for $x_{53}$.]

Ascalonites antiquorum.

Shallot. Allium ascalonicum L.

'Ascalyones muche used by the poore husbandemen and welsh men which love leeks wonderfull well. Theis rude people which be acquaynted with thys harde hotte foode doe fynde noe inconvenience therein, and the opinion of the very learned alloweth the same for them to be right good and holesome that the same allso ys to them meate and medicyne, because yt norrisheth and so pryserueth them against all infectiones of the hotte tyme of the somer when they doe moste use yt with cheese. To those which seldome taaste theis hotter herbes they are concluded to bee perilouse.'

${ }^{1}$ John Symings, M.D. of Oxford, F.R.C.P. I555; President of Coll. of Physicians, 1569 and 1572 ; died at his house in Little St. Bartholomew's Smithfield, I588. (Munk, Roll R. C. P.) 
I 54. Shoeno prasson.

Chive. Allium Schoenoprasum L.

'I tak theis to be set for ye Cyues.'

Porrum vulgare.

'The vulgar Leëke (Sett).'

r55. Porrum tonsile.

Leek. Allium Porrum L.

'The unsett Leeke which they cutt to the potte.'

I72. [Error for I $_{5} 6$.]

Allium sylvestre tenuifolium.

' Wylde garlyck.'

I58. Allium.

Crow garlick. Allium vineale L.

'Garlyck.'

I59. Allium ursinum latifolium.

Allium sativum $\mathrm{L}$

Ramsons. Allium ursinum L.

'I thinck thys to be set for our Ramsynes, whereof there groweth great plentye about fourde in Kent in Wrotham parishe, and ys esteamyd very good against the stoane.'

228. Botrys.

Chenopodium Botrys L.

'Oake of Jerusalem.

It heateth attenuateth diuideth or cutteth, openeth and purgeth. Matthiolus.

It pryuayleth against all flegmatycke, mattered or putrified affectiones of the breast, and lunges; allso yt healpeth such as consume, be trobled with shorte breathinge, and stuffinge or makinge noyse in the breathinge pipes; as well the herbe in the decoctione of liquirishe druncke as the decoctione of the herbe onlye, maney dayes taken with violate or Rosate honney. Matthiolus lib. 3, cap I r9, fol. 852.

To suche as spytte mattered, ( The same author in the same place.'

229. Cichorium sativum, coeruleum.

Cichorium Intybus L.

'Succorye well knowen.

'Amonge the residewe of suche as by my very long experience, and certen credytt and fidelitie, have been prooued: I commende the infusion of Rhewbarbe in Endyue water or Succorye water against aney obstructiones or lingeringe agewes. For I neuer sawe Agewe (by obstructione) not cured with this Remedie if aney will continewe the use thereof. Because euen the most thyck, clammye, cleaninge and stuffed, choakinge humores, obstructiones allso, which by weaknes of naturell heats coulde not be eased or removed: by the takinge and use of Rhewbarbe I have seene cured. I have accustomed therefore to take a pynte of Endyve water, wherein I infuse or steepe the weight of fyfteene pence of fynelie slyced Rhewbarbe. tyed in a thynne woven lynnen clothe. After every daye of the same infusione (ye Rhewbarbe still beinge pressed or wringe into the same) fower ownces (which ys about a dosen sponesfull) I geve in charge to be geven in ye mornynges, and this ys the quantitie for childeren. Neither doe I discontinewe the same, untill I see the obstructiones and Agewe wholye gon and taken awaye. For without all doubt all wil be safe, quickly removed, and health regayned yf all thinges be herein well don, and convenient to the Cure. Montanus, libro de Componendis medicamentis, Consilio pro puero

consilio quinto, fol. ro5.' 
352. Isatis sylvestris Vaccaria dicta.

Saponaria Vaccaria L.

'I sawe yt grow in the garden of the very honorable the Lord Abergavenny, his garden in Kent 'a ${ }^{0} .1584$ '

[A casual introduction from Continent.]

374. Aloe. Sempervivum marinum. Aloësuccotrina Lam. or A. Perryi Baker.

'Aloë or aloë succotrina best knowen by that name. To be bought at th'apothecaries only: a singuler, good and very safe purger. W. \& L.

Amonge all other medicines the use of Aloe marvelous well pleaseth me. Noe man nedeth to feare the heat thereof, euen in the Somer tyme. Although the vulger phisiciones speake their pleasure. Baptista Montanus, Veronensis, Consultat. xci. De preservat. a calculo. The weight thereof is $3^{\mathrm{d} s}$ before supper halfe one hower or lesse.'

396. Perfoliatum vulgatius, flore luteo, fo. umbilicato.

Hare's Ear. Bupleurum rotundifolium L.

'Thorowe waxe or Perfoliata. Is unto chylderen broken use to give the seed hereof in mylke meates, allso the destilled water thereof with good success. 'Tragus, fol. 484.'

438. Coronopus repens Ruellij \& Cornu Cervi alterum vulgi.

Wart-cress. Coronopus Ruellii All.

'The Englyshe in moste places call this Swynes Cresses and not Harteshornes in aneye place to my knowledge.'

459. Alsine, sive Hippia major.

Stellaria aquatica Scop. (J.)

'The great Chyckweede.'

' Of Chyckweede thus writeth Lonicerus, folo. r68. S. media L.

The distilled water of Chyckweede in virtew ys equall with Purselane; wyth wine or simple alone wythe good successe yt ys geven to those which pyne, and waste with longe sycknesse. Unto chylderen in immoderate and unnaturall heate yt ys good to give because yt coaleth the inwarde heate and mitigateth or quyte takethe awaye those terrible accidentes whiche chylderen have by suche extreame heates as Crampes, palsies, tortures and schreamynges, schrychynges, cryinges, startlinges, bowynges and sudden bendinges sometymes forwardes sometymes backwarde and suche like accidentes which chylderen be subject unto. Lonicerus, fol ${ }^{\circ}$. $168^{\circ}$.

The decoction of Chyckweede or ye Decoctyone of the rootes of great grasse or of purslane, or ye rootes of Male fearne with spotted leaves aney one alone sodden in water with a lytle whyte wyne or male or possit ale ys excellent in my proofs against ye agew and worm in chylderen. Fiorananta lib॰. (Capricei medicinali).'

474. Nummularia sive Centimorbia.

'Herbe twopence (allso Woundeworte).

'In water $w^{\text {th }}$ suger, yt ys geuen againste the exulceratione of the Breast and Lunges, yt helpeth the coughe and those which hardely breathe. Chylderen which hardely receaue medicines trobled with a drye coughe are cured herebye. Lonicerus, fol. 208. Tragus, allso, folo. 808.'

529. Crista Galli Herbariorum.

Yellow Rattle. Rhinanthus Crista-galli L.

' Ratle grasse in meddowes very vulger.' 
572. Digitalis purpurea.

'Foxegloues.'

'Hereof Loniceros writeth fol. 74 that yt doth attenuate, clense, purge, loase, cut flegme or grosse humores: and all virtewes and qualities which Gentiane hathe, yt allso hathe.'

589. Tussilago, Farfara.

Coltsfoot. Tussilago Farfara L.

'Foole foote, horse houe (loote leafe, the father before the sonne, coulte foote).

It may allso be called Coughe worte. It groweth moste in wheate lande, and fallowed feildes. This shape aptlie agreeth with the herbe when yt freshe springeth in March and Aprill.

Tragus colored hathe the herbe moste trewlie shewed, muche better then this, the one syde hoarlye whyte next the grownde, and the upper syde freshe grene; the leaves then theis more rownde. The roote medicinal against the coughe; and imperfectiones of the lunges.'

594. Nymphaea lutea.

Nymphaea lutea L.

'The Yellowe Nymphye or water lyllye.

The roote or seede of ether of theis Nymphies sodden in redde wyne and drunck (noe remedie otherwyse healpinge) stayth $y^{e}$ immoderate courses of women. Lonicerus, fol ${ }^{\circ}$. I77.'

622. Vitis alba, Bryonia. White Bryony. Bryonia dioica L.

'Herbe bryane, hedge vyne, agew roote, tetter burye roote, and Bryonie. The great whyte roote.

625. Vitis, vel Bryonia siluestris. Black Bryony. Tamus communis L.

'Blacke Bryonie, wylde vyne.'

625. Peruuiana Mechoaca Mechoacae Prouinciae planta Bryoniae similis. Ipomaea Jalapa L.

'The Mechoane or Mecoacane: from the Indianes muche used in Englande, $a^{0}$ 1580, untill muche hurte ensewed ye boulde undiscrete practize thereof; beinge a simple not without great daunger. Hereof Garzias ab Horto, and Monardus the Spaniarde, allso Clusius have wryten. Soe maney other have don, but none doe warraunt yt safe thoughe they commende yt in some cases, beinge prescribed with the advyce of the learner, and those which very well knowe its virtews and qualities thereof.

The best ys brought from ye Citie Mexicho: they have 2 sortes, the one lesse daungerous then the other. In my opinione theis 2 doe resemble our 2 Bryonies, and of my mynde, I fynde the moste learned of my tyme in Englande, allso diuerse out of Germanye, and Fraunce icompe with us, the difference of Soyle only cause the varietie of effectes in operatione.

The weight of $7^{\text {tl }}$ or a french crowne in houlder(?), drunck in twelve sponisfull of seck, will aboundauntly purge bothe wayes in common but in moste by stoale onlye. The rootes only ys used, halfe soe muche of our Bryonie wyll worck wonders if it be prepared specially, or simple of it selfe.'

693. Argentina, Potentilla. Silver weed. Potentilla Anserina L. 'Wylde Tansie. Anserina Tragi, folo. 480.

The herb sodden in wyne redd or lihyte and drunck healpeth those which have paine in their backes and torments there: allso suche women as be trubled with their whytes immoderately this 
herbe euen so used cureth : for it byndeth and strengtheneth as Pimpinella Italica. Tragus, fol $^{\circ} .48$ r.

The destilled water thereof is very good to cure redd eyes. Idem ibidem.

Against the Dysenterie and lienterie, which is the blooddie flix and passinge of foode by stoal undigested and against all fluxes and flixes this herbe is used in our adge. Idem, fol ${ }^{\circ} .480$.

Tragus estemeth it drye because it bindeth there.'

748. Pedicularis. L. $43 \mathrm{I}$.

Marsh Red-rattle. Lousewort. Pedicularis palustris.L.

'Lowzye weede becaus the catle feadynge thereof will become lowzye: thereof very muche groweth in black brookes in Estmallinge in Kent.'

757. Capnos, Fumaria.

Fumitory. Fumaria officinalis L.

'Fumytarie; the distilled water thereof wyth Tryacle before the purgatione certaine dayes drunck ys very holesome for suche as labor of the Frenche euyll. Because yt purgeth the infected bloode. Lonicerus, fol ${ }^{\circ}$. I67. The same ys good against the Plague and the desease called the Englishe sweate; allso good when aney shall purpose to Bathe and sweate. The same author there.

The Decoctione thereof with Fennyll openeth the obstructiones of the Lyuer and forceth oute the Jaundyce by uryne. The Juce thereof and the roote of Esula, eche one drachme which ys in weight $7^{\mathrm{d}}$ mixed and drunck with hott water dryueth ye Dropsie and .... (?). In same author, fol ${ }^{\circ}$. 167 .'

807. Asplenium. Scolopendria. Ceterach officinarum Willd.

'Splene worte. Yt groweth uppon the southwest ende of Est Peckham churche in Kent : allso uppon ye Pallace walles in Maydston, from where I did transferre $\mathrm{y}^{\mathrm{t}}$ to my garden walle, where it groweth. $a^{0} .83$.'

807. Lunaria racemosa. L. 470. Moonwort. Botrychium Lunaria Sw.

'I haue sene thys lunarie or Moneworte growe in black heathe ; allso nere Saynt Margaretes, nere Rochester.'

81 o. Adianthum album et nigri Plinii. A. $36 \mathrm{r}$.

Wall Rue. Asplenium Ruta-murana L.

'Thus wryteth Matthiolus of Ruta muraria in the chapter of Paronichia.

Moreover this moueth uryne and grauell.'

Vol. II.

I80. Rhamnus primus Diosc. creditus. L. 598 .

Evidently intended for Sea-Buckthorn. Hippophae Rhamnoides L.

'This Rhamnus I founde betweene Douer and Foulkestone by the sea syde under the Clyffes, $a^{\circ} .1582$, with reddish beries Orenge colored.'

280. Cerefolium descriptum.

Chervil. Anthriscus Cerefolium L.

'Cheruyle. It is used with meate as Perslye of a meane temperature betwene hott and coulde; But principally to force out clotted or brused bloode "as it is called" the same herbe to be of wonderfull efficacie certen sure experience hath approued. Tragus, fol $^{\circ} .472$. The Juce of the herbe, the destilled water allso, dissolueth the congealed blood of contusion, or strype, and is of force against the stoane in the kydnes. Idem ibidem.' 


\section{viii. Richard SHANne, 1561-1627.}

In the Goodyer MS. there is a note of the name of Richard Shanne, at the head of a paper upon which are recorded two localities for north country plants, but there is no further indication as to who he might be.

Pyrola groweth in shadowed woods in Craven, in a place called Craggie Close in Lanscale.

Monophyllon groweth in Lancasheir in Dingley wood and in Harwood neare to Blackburne.

Both localities are given in Gerard.

During a visit to the British Museum in June last, a happy chance made me acquainted with 'The Shanne Family Book' (Addit. MS. 38599. I $\%$ ), from which I discoyered that Richard Shanne of Woodrowe was a considerable horticulturist, who was living near Methley ${ }^{1}$ in Yorkshire in Goodyer's time, and who certainly deserves to be better remembered. I have no doubt but that he is the authority whose name is quoted by Goodyer. It is not unlikely that Goodyer may have got into correspondence with him through Walter Stonehouse, the friend of John Savile of Methley, whose neighbour Shanne was.

Richard Shanne sonne and heire of William was borne the tenth of Auguste beinge Thursdaie $156 \mathrm{I}$ he maried Amy Burton daughter of Richard Burton alias Carver the $i^{\text {th }}$ daie of June 1588 and had issue by hir, Thomas. He maried his second wife Marie Chamber...

This Richard was of reasonable tallness stright of bodie, he was somwhat paile of complexion, his heire of his head mouse colored, he was verie light and nimble of foote, his chefest delite was in plantinge and grafting all maner of herbes \& trees, and had growinge in his gardinge a great number of rare and straunge plants, there was not allmost anie herbe growinge but he did knowe the severall names therof, and the nature and opperation of the same, he did practise both in phisicke and specially in Chirurgerie and did cure verie manie daungerous wounds and ulcers. He made three bookes of the Nature and operations of herbes and Trees and drew with his pen the trew picktures of everie plante, set downe in what ground everie herbe and tree was to be found and the tymes of their springinge, florishinge and sedinge. He planted three Orchards of his owne, the first at the Mickletowne which he sett in anno domine 1577. The Springe of Aspe trees he planted 1596. The Orchard at the East more syde he planted in divers yeares, first in 1607 \& 1613 (?). The

1 Methley gardens should be famous in the history of horticulture. For at Methley lived John Savile, the friend of Walter Stonehouse; there also in Mr. Witham's garden, gold-streaked Pansies growing spontaneously 'mightily beautifie the border of an hedge'; in the Wood-close flourished the Blush coloured Bugle (Ajuga reptans L.), and at no great distance grew Lunaria minor in John Nun's cow-pasture. Witham's son contributed localities of some Oxfordshire plants. Merrett, Pinax, pp. 17,65, 74. 
Springe of Elme trees by the Moorsyd was planted in 1613 . The little Orchard in the end of the More house field he compassed about with quicksetts in anno 1616 , and the trees was set in anno 1617 . He maid two large bookes diologge wyse of Phisicke \& Chirurgerie, He delited much in reding Granados meditations, and was verie seldome seene in anie rude companie, but avoyded companie as much as he could and took much pleasure to walke in woods and to be solitarie. He lyved in the daies of Quene Elizabeth, Kynge James \& Kinge Charles when he was fiftie $\&$ nine yeares oulde he mayd a large booke of prayers \& meditations which he did drawe out of sondrie learned authors. The meditations are of all the miseries of man from his verie birth unto the daie of his death. Allso of the torments which the wicked do suffer in hell...

He died of consuming consumption at the age of six and three score wanting one moneth.

[His garden list is printed on p. 310.]

[ff. $83 \mathrm{v}, 84$.

A most interesting extract from Shanne's diary was made by Antony Wood when he consulted it in October 1674 , by permission of the then owner. It contains a most lifelike description of the Ruff (Machetes pugnax L.), a bird that was not described by Turner in his book on Birds, so that Shanne's is probably the first English description.

Anno I588, there was taken at Crowley in Lincolnshire in the winter time 5 strange fowles of divers colours, having about their necks as it were great monstrous ruffs, and had underneath those ruffs certaine quills to beare up the same, in such a manner as our gallant dames have now of wier to beare up their ruffs (which they call supporters). About their heads they had feathers so curiously set togeather and frisled, altogeather like unto our nice gentlewomen who do curle and frisle their haire about their heads. Three of these strang fowles was brought into Sir Henrie Leese, and they would walk up and doune the hall as if they were great states, and sometimes they would stand still and lay their heads together as if they were in a secret counsell. It made the beholders to wonder therat. They cast them corne to eat, but they refused to tast of any meat and so at length died. Mr. Richard Shann, of Wodrow in Medley, Yorks., drew a picture of one of them which he placed in his herball. Two men that had set lime twigs to catch birds withall did find them taken therin. The like never seen or heard of before.

\section{ix. JOHN PARKINSON, 1567-1650.}

Several pages of notes in the Goodycr collection on American, Bermudan, and Oriental plants are written in a hand that was at first unknown to me, but which I have since been able to identify beyond doubt as that of the well-known herbalist John Parkinson. Certain of these notes are written on the back of a letter, every word of which was so completely scribbled over as to be quite unreadable. By slow and careful erasure with a sharp knife I found it possible to remove sufficient of the ink-scrawling from the 
surface to bring into view the following letter, signed by him. It is a unique possession, as being the only signed specimen of his hand-writing known.

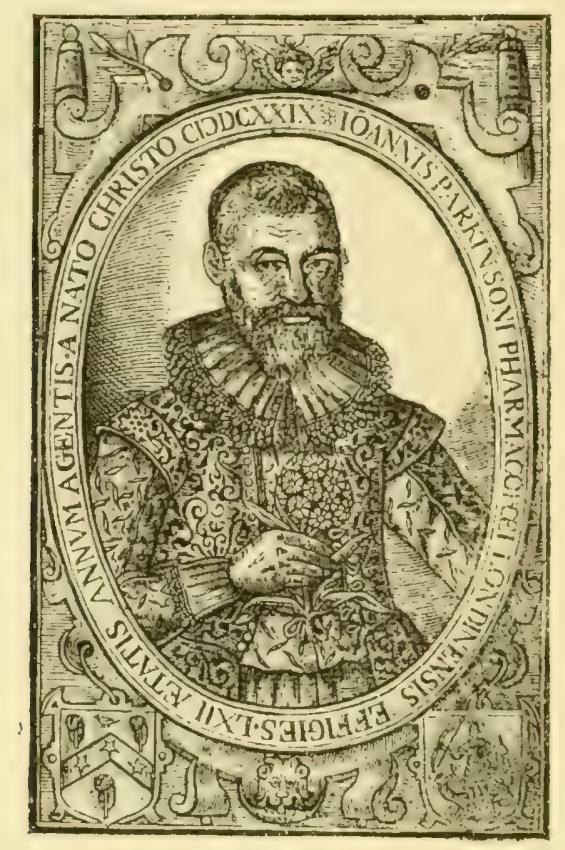

PARKINSON.

To the worthy Gentlewoman

$$
\begin{aligned}
& M r^{\text {es }} \text { Geeres } \\
& \text { geve these. }
\end{aligned}
$$

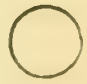

GOOD MRS. GEERES, I hav by this messenger sent you the ij trees wherof I tould when we were last together at yor howse. I brought them thither on the Saterday you were so earnest with me to come to dinner where I thought to have met with you, but missing you I carried them home again \& laid them in the ground wherin they have been safe without taking any harme. I do also think that then you would have pleasure, and with that you promised \& have long expected it. I pray you doe not wearye me with deseyre which is worse then denyall as you please appoint Mr. Codemer to doe it speedily. So shall ever remaine,

\section{Yors JOHN PARKINSON.}

[MS. f. 168 v.]

A comparison of the text of several of the notes with passages printed in the Theatrum in 1640 confirmed the view that they are indeed the author's own notes, and were probably the actual notes used by him in the preparation of his book. Some of them are 
printed with the lists of exotic plants on p. $3^{6} 3$. The following horticultural notes were evidently extracted by Parkinson from Francis Bacon's Naturall Historie, Century v, I627; but another possibility should not be lost sight of, namely that Bacon may have derived part of his horticultural knowledge from the distinguished botanical writer who two years later dedicated his Paradisus in Sole to Queen Henrietta Maria.

\section{Notes on Horticulture by Parkinson.}

The steepings of Wheate seede in horse dung, cowe dung, pigeon dung, urine, chalke, bay salt, claret wine, soote, ashes, malmesey, \& spirite of wine: the urine, soote, ashes, chalk \& salt shooting within six dayes, the best \& lustiest of them was first from the urine, then dung, next chalke, then soote \& then ashes, \& last the salt therewith wines not at all except the claret wine. [Bacon, Sylz. sylv. \$ 402.]

The drawing of boughes of a tree or vine to the inside of a roome where fyre is continually kept doth accelerate the fruite a moneth sooner. [ $\$ 405$.

The removing of living plantes into new freshe $\&$ loose earth once in a yeare doth accelerate \& enlarge them. [\$ 406.]

The grafting of Roses in Maye will cause them to beare flowers the same yeare but late. [ $\$ 4$ I8.] The binding also of the bark worketh the like effect. [\$ 419.] Grafting upon contrary stocks will never thrive long, as Peaches on Cherryes etc., the cause is the cyon overruleth the stock quite, the stock is but passive onely \& giveth aliment but no motion to the graft. [\$ 421 .]

The laying of a heape of flinte or other stones about the roote of a wild tree doth make it prosper twise as much as without them, because the stones retaine moisture longer \& not to be consumed so soone, it keepeth also the tree from cold blastes \& frosts \& geveth more warmth at all tymes. [ $\$ 422$.

To boare a hole in a tree that beareth not is usually done to cause it bearing ; too much repletion may be the cause opprest with his sap. [\$ 428.] As also to cleave 2 or 3 of the cheife rootes \& to put a peble into eache to keepe them open for els they will close againe. [ $\$ 429$.

To drawe the bough of a tree through a wall to the south sun hath been practised by some to ripen the fruite the better, but it sorted not. [\$ $43 \mathrm{I}$.]

It were good to trye whether a tree grafted lowe \& the lower boughes maintained, the upper ones being continually proined off, would not make larger fruite. $\left[\S_{432 .]}\right.$

It is expected that trees will growe greater \& beare better fruite if you putt salt, lees of wine or blood to the roote which are more forcible. [\$ 457.]

It is also delyvered before that if one take the bough of of a lowe fruit tree newly budded \& drawe it gently without hurting it into an earthen pot perforate at the bottome \& set in the slant \& then cover the pot with earth, it will yield a very large fruite within the ground, the like will be effected by an empty pot without earth in it, put over a fruit propped up with a stake as it hangeth on the tree, the pot being perforate to let in aire. [\$ 470.] [MS. II, f. 168]

On the same paper are several entertaining notes in Parkinson's handwriting relating to Brazilian and Peruvian plants and their 'vertues'. 


\section{The Vertues of some' Exotic Plants.}

Giniber is a tree growing in Brasill about Pernambuco, whose fruite is bigger then those of an Orrenge, but of a darck greene colour from whence with one kind may be crushed out a liquor very like both for colour and consistence unto the whey of milke: this liquor or water hath such a qualitie that what parte of the skin of the bodye be washed therwith it will colour it so black as no black inck or dye can doe more \& so likewise the haire in any parte of the bodye, which colour will abide so strongly fixed therin for the space of eight dayes that if all the remedies to whiten the partes againe were applied they would be of none efect; but of itselfe the colour will fade after that tyme \& the partes will become as white as they were before. This water is also as it issued is of espetiall propertye to encrease haire. Other thinges this water doth performe without the least daunger or harme.

The Brasilians have a familiar medicine that is common \& well knowen to most of them, beinge a most certaine remedye to staye or stanche the blood that flowes from any part of man or woman.

This is made of a certaine herbe which groweth in the high \& rockye mountaines which therupon the Portugalls call Rais de serra that is Radix montium, the Roote of the Mountains, because the roote onely of this herbe hath that effect to staunche blood, the leaves herof are said to be like unto Plantaine leaves \& the roote unto a Cicharye roote both for forme and colour which roote being a little burned in a cleane earthen pot or vessell \& afterwardes rubbed into partes \& a scruple in weight taken fasting with Plantaine or Rosmary doth most rertainely staye the fluxe of blood issuing from any parte of the bodye. Petrus de Osma cited by Monardes testifyeth the vertue that many herbes have that hidden propertye to stay bleeding by the example of some Negros that constrayned through hunger to cut of the calves of their legs to eate, $\&$ by layinge a leafe of a certaine greene herbe did whollye staye the fluxe that not a droppe of blood was seene to be shed. [Cf. Park. Theatr. 1622.]

There is a certaine kinde of Rushe growing on the hilles in Peru, which they there call Jeho or Yoha, very like onto the Spanish rushe called Spartum wherof the fraile are made that they putt Raysins \& figs; \& wherwith the metalline bodyes are sooner melted by its flame than by much wood, \& separated from the Quicksilver that is put into them for that purpose. The fumes also of this Rushe (a wonder to be spoken) taken under a Canopay or close covering, causeth all the Quicksilver, that abideth in the bodies of those that have ben annointed therewith to helpe the Frenche poxe, to sweate out of all partes of the bodyes, without any maner of sense of paine.

Lakeka is a kind of gum gathered in Martaban in the East Indies, whose propertye is to expell drunckeness if pieces therof being put on a thred or stringe \& wounde on the bare arme, so that whosoever shall drinck much \& strong wine shall not be overtaken therwith.

Lapis Lipis is a kinde of blew minerall stone found on the hills of Potosi called Lipis of the citye neere them. And is of a transparent blew colour, very hard to breake yet brought into small picces, sharpe and bitinge in taste so that being put to the tongue it will with the heate oxalegrate it, it is brought as merchandise being cut into tablets \& so sold: it is (saith Zacutus Lusitanus) so like Anil Indica that a form of it might be taken for Indico $\mathcal{S}$ being made 
into pouther \& put ... water will colour the water blew within an hour. All fowle ulcers eyther of the mouth or privy partes of man or woman beinge washed will presently cleanse them \& take away or restrain their virulancye. $4 \mathrm{gr}$. in p. to $3 \mathrm{ij} \mathrm{aq}{ }^{2}$ rosay $\mathrm{p}$ hora.

Coque... is a certaine tree well knownen to all in Brasill growing plentifully in the woods about Pernambuco very like unto the Lentisk or Mastick tree whose barck being boiled after a pound thereof hath ben cut small in 16 poundes or pintes of water to the halfe, adding therto 3iij of allom in the boiling, wch when it is strained \& setled will become of so pure a purple colour as if it were made of ostrum or the purple fishe, or of the colour of the red Feild Poppye. The face washed with this water besides that it coloureth the black spotts in the face, it geveth to the face \& lips so beautifull a Rose colour that it would be a brave fucus for women: but this colour will not abide above eight dayes although before that tyme it will not be blemished by many washings, but after that tyme the colour fading it will change into a dark Rose colour and after 4 dayes more will be quite consumed; yet those black spots that were in the face before will no more appear, but by using this water againe upon the face etc the fresh colour will be apparant againe: If this barck were brought us it would redound much to the good of women, who to beautifye them selves with Arsenicum sublimatum, Cerussa, Camphire \& other such thinges doe exchange their good for wrinckles, fowle ulcers in their gums, blacknes of teeth, rottennes and stincking of the breath.

The Cabbage Tree groweth to an incredible height neere unto 200 foote bare without branches unto the very toppe as most of the kindes of Palme-trees doe, where among the long leaves groweth this round heade or cabbage, to gett which they usually cut downe the tree at the roote. The stemme or bodye therof having not much above 2 inches thickness of wood, the rest being of a pithy substance. From this tree likewise they drawe wine as from the Coco \& other Palmito trees by boring a hole \& applying a tappe or other convenient thing with a gourd or the like to receave the liquor that droppeth therfrom, \& in 12 howres will by droppes fill the vessel \& so will it doe from tyme to tyme by boring new holes one after another beginning above \& so descending: what fruite this tree doth beare, our men that have had the benefit herof were never so wise or industrious to observe, feeding like swine on the mast but never looking higher.

The water destilled in glasse vessels from Cloves while they are greene, besides the excellent smell they yeld, it hath ben found by good experience not onely to expell windye humours in the bodye, but that disease also called Priapismus and that effectually. The like is thought may worke the destilled water of the fresh flowers taken from the Cinamon trees or from the fresh Cinamon itselfe.

The fruite or nutt called Cola growing in Guiney \& like a chesnutt hath ben often used and found very effectual for chapt lipps, and the descomities of the skin, the itching of womans partes, the raggednes of the nailes, the rednes of face, much Dickwek often castings, the falling of the haire, ... and many other diseases that proceed from the heate and distemper of the liver, as also against fevers \& burning agues, very profitable drincking some endive water after it. The tree is like to the Chesnut tree \& so is the nut both for forme \& greateness but of a pale reddish colour on the outside \& a little bitter in taste. 
Amivil with the Persians is a tree like to the Chesnut tree whose rootes the deaper the better being tied about the neck or worne on the arme so that they touch the flesh doe induce a mightye hatred for wine espetially to those that are geven to love it much $\&$ be often drunck therewith. Gesner reciteth 2 espetiall thinges available for that purpose, viz. a greane frog that is found often in the springes of water put alive into wine \& there suffocated. And an Eclosus formed also in wines: this hath ben often urged so before, especially if 2 ounces of the blood of Cates (?) be put into 3 measures of wine. Opium also is thought to performe the like cure \& so be the more prone $\&$ strong to venery.

[Written by John Parkinson on the back of his letter to Mrs. Geeres. MS. f. 168 v.]

Among his other writings are Lists of Foreign plants, see pp. $35^{8-70}$; a List of II6 plants, including many bulbs (MS. I I, f. $I 64)$, grouped under numbers ' 36 to 69 ', evidently referring to plates in the Anthologia magna, I626; a list of 48 plants (MS. I I, f. I 57 v.) described by Clusius in his Appendix altera ad Rariom Plantarmn Historiam, issued with the Exotica in 1605 ; two lists of Evergreens, ${ }^{1}$ one headed Arbores sempervirentes fol. 44 (MS. I I, f. I.56), the other headed Perpetua coma virentes variis provinciis (f. I. $5^{8 \mathrm{v} .}$ ); and a brief note on plants used for tanning skins by Mediterranean peoples.

Parkinson was appointed Apothecary to King James and also King's Herbarist. He had a garden in Long Acre, where Goodyer no doubt saw the many rare plants of which he has preserved a list. The following account is in a hand that appears to me to be Parkinson's: if so, it may refer to an accident to the wall of his garden in Long Acre in 1636 . A search for the workmen's names in the local parish register might settle the question.

The charge of my outer wall blowen downe the $4^{\text {th }}$ Novembr 1636.

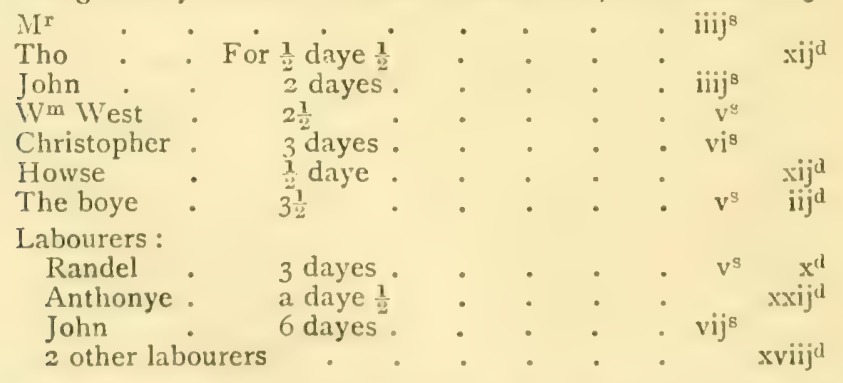

1 It may be noted that at a somewhat later period Sir Richard Browne, writing from Paris to Sir Edward Nicholas on 5 July 1658, states that he was then at work on a Catalogue of evergreenes, but had lost the help of a Mr. Keipe, who had left for England. He adds 'Alaternes beare a graine like that of privet, which beinge sowed comes upp and prospers without difficulty'.

[Camien Socicty, xxxi, p. 65, 1920.] 


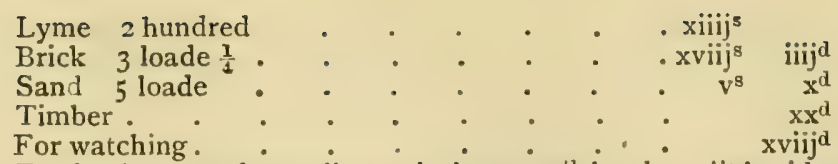

For watching.
For fensing the other wall next the howse $w^{\text {th }}$ bordes in the bordes.

[MS. f. 154.]

\section{WALter Stonehouse, I 597-1655.}

An account of the manuscripts which led to the identification of Mr. Walter Stonehouse the Botanist with the Rev. Walter Stonehouse the Divine has recently appeared in the Journal of Botany for July 5920. As regards his biography it is known that he was a Londoner, born in 1597 , and a relative of Sir William Stonehousc, Bart., of Radley. since he referred to Sir William's daughter, Mrs. Langton, wife of the President of Magdalen College, as 'cousin'. He came up to Oxford as one of the first Scholars of the newly founded Wadham College. There, at the age of 16 , he wrote a Turcarnm Historia generalis in $2 \mathrm{I} 3$ pages. He took his B.A. on 25 th Feb. $161 \frac{6}{7}$, and came to Magdalen as a Fellow in 1617 , filling the office of Praelector in Logic in I6I9-20. He remained in residence for some years, preaching occasional sermons at the University Church and in the College, including the funeral sermon at President Langton's funeral in I626. The original MS. of the Statutes of Eynsham Abbey, near Oxford, appears to have come into his possession at this time, for in $\mathrm{I} 62 \mathrm{I}$ he gave them to the Bodleian Library. It is now numbered Bodl. MS. 435. In 1629 he took his degree as Bachelor of Divinity and resigned his fellowship, probably on marriage, since his son Walter was born in the following year. The University presented him to a rectory in the diocese of Canterbury, 7 th March $163 \frac{0}{1}$, and it may have been then that he made the acquaintance of Thomas Johnson, then engaged on the description of his second botanical tour in Kent (published I6 62 ).

Stonehouse was presented to the rectory of Darfield by John Savile ${ }^{1}$ of Methley, who held him in great esteem. He became a member of the literary circle of Sir J. Jackson of Hickleton, in which Lightfoot, Sir H. Wotton, and Bishop Morton were sometimes found. With Laud he is remembered as being one of the first Englishmen to make a collection of coins and medals : these

1 The Saviles were connected with the Garths through the marriage $c_{0} 1578$ of Sir John Savile (1545-1607) with Jane, the daughter of Richard Garth, see p. 237. 
eventually formed the basis of that department of the very curious museum formed by Thoresby in his house at Leeds (see Hunter, South Yorkshire).

In 1639 Thomas Johnson organized an expedition of the 'Socii Itinerantes' of the Pharmaceutical Society of London to the mountains of North Wales: an account of the expedition is given in his Mercurii Botanici pars altera ( $164 \mathrm{I}$ ) reprinted in facsimile in Opuscula omnia botanica Thomae Folnusoni edited by T. S. Ralph (London, 1647). The constitution of this travelling club is thus stated by Johnson in the preface to his Iter Plantarum Investigationis 'susceptum a decem Sociis in Agrum Cantianum: Anno Dom. 1629', and published in the same year: 'Paucis abhinc elapsis annis, consuetudo vero laudibilis inter rei herbariae studiosus crevit, bis aut saepius, quotannis triduum aut quadriduum iter Plantarum investigationis ergo suscipere'. Stonehouse joined the party at Chester, having spent the previous night at Stockport, where he had not been favourably impressed with the inn. Their route took them by Conway, Penmaenmawr, Bangor, and Carnarvon to Glynn-lhivona, where they were the guests of Thomas Glynn, to whom Johnson dedicated his account of the expedition. After discoursing on the perils of climbing Snowdon, Johnson gives a list of the plants found by the party. At Beaumaris they enjoyed the hospitality of Richard Buckley, visited his vivarium, and collected seaweeds. They then recrossed the straits to Lhan-Hechid, climbed Carnedh-Ihewcllyn in a mist and in fear of nesting eagles, but saw little of botanical interest. After a farcwell visit to Glynn-lhivona, the party journeyed to Harlech and Barmouth. Their homeward journey lay through Merionethshire; at Guerndee Stonehouse left them and went home through Shropshire to Darfield. Here he remained for a time in quiet enjoyment of his garden, to the Catalogue of which, drawn up in 1640 , reference has already been made; some of the plants in Johnson's list are included in the Catalogue, and were probably obtained on the Welsh expedition.

About I 648 we learn from Walker's Sufferings of the Clergy' that Stonchouse was forcibly ejected from his living by the Parliamentary Commissioners and imprisoned. On his return, probably in 1652 , his spirit as a horticulturist seems to have been broken, for he then wrote in the Catalogue a pathetic note in Latin, to the effect that but a few of his plants had survived-Novamque despero coloniam, -'I have no hope of a new colony'. After this he would appear to have lived in London, to have made or renewed acquaintance with the younger Tradescant, and to have written some intro- 
ductory verses to the Catalogue of Tradescant's Museum, published in 1656 :

To John Tradescant the younger, surviving.

Anagr.:

JOHN TRADESCANT.

Cannot hide Arts.

Heire of thy Fathers goods, and his good parts,

Which both preservest, and augment'st his store,

Tracing th' ingenuous steps he trod before :

Proceed as thou begin'st, and win those hearts,

With gentle curt'sie, which admir'd his Arts,

Whilst thou conceal'st thine own, and do'st deplore

Thy want, compar'd with his, thou shew'st them more

Modesty clouds not worth; but hate diverts,

And shames base envy, ARTS he CANNOT HIDE

That has them. Light through every chink is spy'd.

Nugas has ego, pessimus Poëta

Plintarum tamen, optimique anici

Nusquam pessimus aestimator, egi.

Gualterus Stonehousus.

Theologus servus natus.

By re-arranging the letters of John Tradescant's name he composed the anagram Cannot lide Arts, and by a similar process his own name, Gualterus Stonehousus, became Theologus servus natuswords quoted by Macray, who, however, did not grasp their meaning, as occurring on the title-page of a volume of his Sermons in Magdalen College Library.

These verses, his only printed work, were not published until I 656 , the year after his death (probably in London) at the age of 58 .

\section{xi. Thomas Johnson, c. I600-I644.}

The outlines of the life of this distinguished botanist are well known. Trained as an apothecary, with a business on Snow Hill, he attained to be the best herbalist of his age in England and a trusted physician. In 1643 he had the rank of LieutenantColonel to Sir Marmaduke Rawdon. During the siege of Basing House he led several sorties with success. "When a dangerous piece of service was to be done, this doctor, who publickly pretended not to valour, undertook and performed it. ${ }^{1}$ On one occasion he had a hand to hand struggle with Capt. Clinson, but at last in the affair of 14 Sept., he was shot in the shoulder, whereby contracting a fever he died a fortnight after, his worth challenging funerall tears,

1 Fuller, Worthies, I662, p. 204. 
being no less eminent in the garrison for his valour and conduct as a soldier than famous through the kingdom for his excellency as an herbarist and physician.'

Johnson had a wide circle of friends and helpers in addition to the socii itinerantes who took part in his botanical excursions. Among others he mentions GEORGE Bowles of Chiselhurst in Kent; Sir John TUnstal, gentleman usher to the Queen, owner of a garden at Edgcomb, Surrey; HugII MORG.AN, apothecary to the Queen; ROBERT ABвот of Hatfield, a learned preacher; JoIn REDMAN, 'a skilful herbarist' of the north of England. The manner in which his friends used to make use of his services is shown by a letter that is still extant from the Provost of Eton, Sir Henry WotTon. ${ }^{1}$

To my very loving and learned friend Mr. Johnson, apothecary, at his house on Snowe Hill, London.

MY GOOD FRIEND MR. JOHNSON, 2nd of July 1637.

I have addressed this my servant unto you at the present with two or three requests. First, that you would direct him where he may buy one of your Gerrards, well and strongly bound; next, where I may have for my money all kinds of coloured pinks to set in a quarter of my garden, or any such flowers as perfume the air. Thirdly, I pray let me consult you whether you know any sick of that fastidious infirmity, which they call melancholia hypochondriaca, wherewith I have been troubled of late, but more with a symptom very frequent in that passion (as the great Fernelius describes it) ...

HENRY IVOTTON.

Johnson's carly death was a great blow to Goodyer. In his will (P.C.C. II Twisse) dated II May I635 he described himself as Citizen and Barber surgeon of London. He left legacies to his aunt, Mary Cave, 5 s., to William Parker 40s., to Eliz. Parker 50s., to Richard Parker, son of Wm. P., £5 to set him forth to prentice, and to his wife Alice Johnson, his sole exor., the residue of his estate. The will, witnessed by W. Parker and Mary Vudell, was proved in July 1647.

1 SiR Henry Wotton (1568-1639) of New College, Queen's, and Eton, diplomatist and poet, is best remembered by his exquisite poem The Character of a Happy Life. His letters allude to contributions to English horticulture during the second tenure of his office as Ambassador at Venice. They mention:

'Seeds and roots and slips of rare flowers and plants' to Sir R. Winwood.

Oct. 1616.

'The most excellent choice of those seeds which his Majesty desireth' to James I. Dec. I62I.

'More melon seeds of all sorts' to James I. Dec. I622.

'Finocchio' or Italian Fennell (with full directions for cooking and eating) to

Tradescant. Probably about the same time, but not recorded until 1656 .

Parkinson, Paradisus.

To James he wrote that he intended to examine some of the best hortolani of Chioggia and other places about the manner of cultivation. He was in close correspondence with Lord Zouch, and may have also sent plants to the Hackney garden. P'carsall Smith, Wotton. 
The intimate relations between Johnson and Goodyer at the time when the former was preparing his second edition of Gerard's Herbal ${ }^{1}$ have often been alluded to. The Goodyer MSS. throw further light on their intercourse by providing us with a detailed list of the plant-descriptions which Goodyer lent to Johnson and subsequently received back again with the printers' marks upon them.

The copy of Johnson's Iter Plantarum in agrum Cantianum, I629, in the Magdalen Library, appears to have been a presentation copy to Goodyer. It is of historical importance as being the first English local catalogue, and is marked with the following corrections by the author (?).

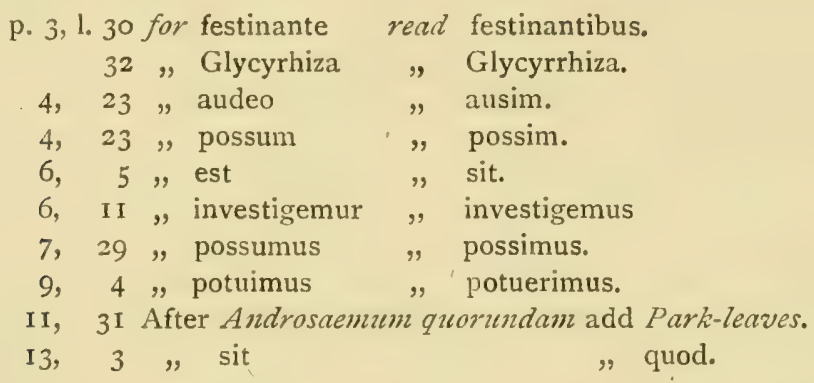

At the end Goodyer has added the following list of plants :

Solanum lethale.

Helicacabus.

Viburnum.

Antirrhinum minus.

Mille grana minima.

Centaurium fl: albis.

Lysimachia lutea.

Alsine serpilli folio.

Osmunda regalis.

Eupatorium Can: mas et femin:

Angelica sylvest:

Herba paris.

Eleborine.

Aleca.

Spergula altera flo: purp. minor.

Ascyrum supinum hirsutum. " palustre rotundifolium.

Pentaphyllum supinum tormentillae facie.
Tricomanes seu Capillus Veneris verus. Dryopteris.

Alleluia.

Epicrion.

Alchimilla

Sanicula.

Acer minor.

Betulus.

Calamintha agre: Belgarum.

Petasites.

Gramen Bufonium.

Cynocrambe.

Allium ursinum.

Xyris.

Rhamnus catharticus.

Rubia flo: carneo angustifolia. , flo: rubello.

Chamaepitys.

Aphaca.

The copy of the $163^{2}$ edition of the same work appears to have been the author's own copy with his MS. index, afterwards extended by How and used in the preparation of his Phytologia (I650).

${ }^{1}$ A presentation copy of this book to the Apothecaries Company was the first contribution to their Library. With their other books it was probably burnt in the Great Fire of London. 
xii. William How, I6r9-1656.

(See p. 251.)

How's botanical reputation rests upon his Phytologia Britannica natales cxhibens indigenarum Stirpium sponte conergentium, the book in which for the first time all the known plants of Britain were garnered together with their localities. He was a Master of Arts of five years' standing of St. John's College, Oxford, and his list comprising $\mathrm{I}, 220$ plants is a memorable achievement for the time. Apparently owing to his private means being insufficient to permit of much travelling, he had to rely upon information sent by other botanists, with the result, as Ray pointed out, that many exotics and garden-escapes got included in his lists. 'The rare plants were almost wholly communicated by his friends, Mr. Stonehouse, Dr. Bowles, Mr. Heaton, Mr. Loggins, Mr. Goodyer and others, and he drew some from a MS. of Dr. Johnson.'

Goodyer may have become personally acquainted with How at Oxford, and in any case they were in close correspondence both before and after 1650 when How was living in London, either in St. Lawrence Lane or in Milk Street.

The newly discovered writings of How appear to belong to the periods immediately preceding and following the publication of the Phytologia Britannica. Though not extensive, they throw valuable light on his relations with contemporary botanists; and if his notes be somewhat slipshod, we must remember that they were not intended for our perusal, and that he had but recently done duty as Captain of a troop of horse in the King's army.

First in time and in importance are his list of plants and notes written at the end of what I believe to have been Johnson's own copy of his Descriptio Itineris . . . in agrum Cantianum, A.D. I632, with MS. index. This may have come into How's possession after the death of Johnson in 1644 . He supplemented it with a further list of indigenous plants from the Herbals of Gerard and Parkinson and from other sources; and then no doubt he developed the idea of including all British plants in one comprehensive, alphabetical list. A few rough notes on the last pages almost certainly refer to his programme of work, but as they are mostly crossed out with ink lines, it is impossible to give a complete transcript of them. The meaning of such remarks as 'Review both ye Herballs againe and take all', is clear, and the references to persons may be of historical importance. The names mentioned I belicve to be those of T. Johnson, Parkinson, the Rev. Walter Stonehouse then exiled from his Darficld living, Bobart of Oxford, Lconard Buckner and lidward 


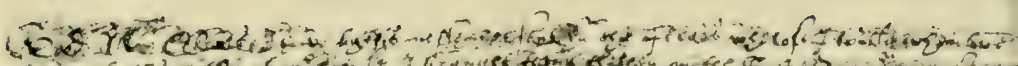

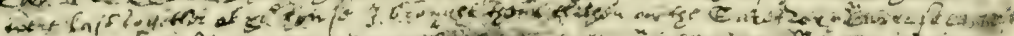

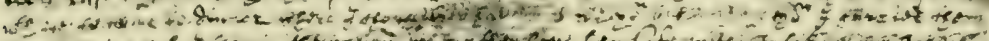

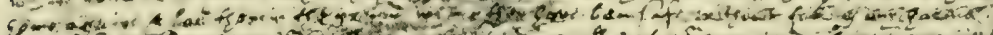
1. at

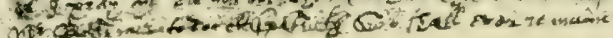

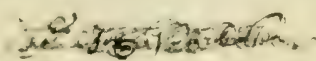

OBLITERATED LETTER BY JOHN PARKINSON

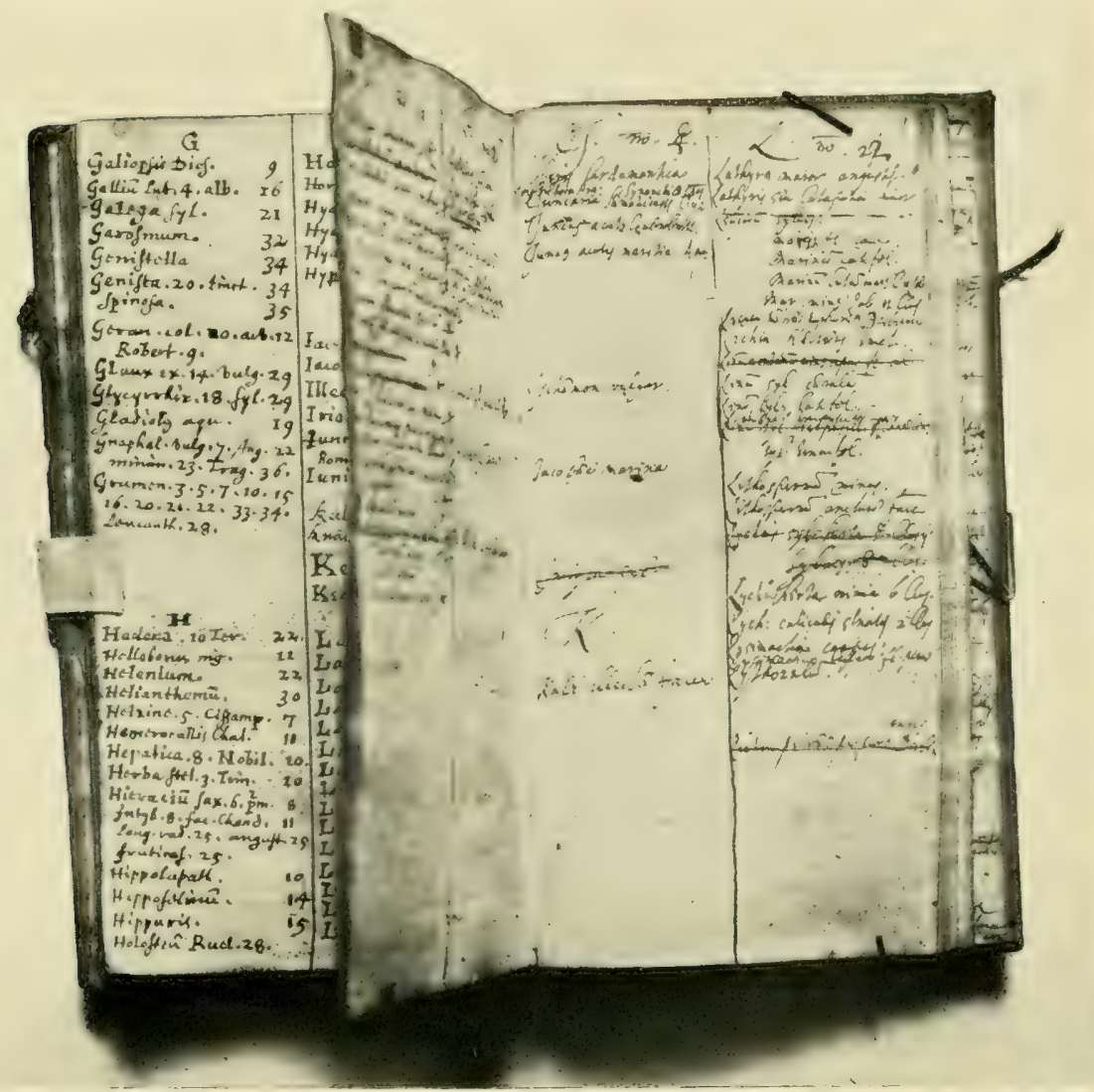

Jolunson's Index

How's 'additionated plants'

FIRST DRAFT OF A BRITISH FLORA BY HOW MIS. additions to Johnson's Descriptio Itineris in Agrum Cantiamum, 1632 

Morgan of Westminster. His notes for planning his work, such as 'Remember ye English names to bec last placed', 'Remember to give ye proper name in Latin of ye place where each plant flourisheth', \&c., have the appearance of being the advice of some botanical friend of experience.

The following extract gives an idea of his controversial style of writing:

Anchusa Alcibiadion "A $\gamma \chi \Varangle \sigma a$. Fucus herba. Onocleia.

Buglossa Hispanica, Red Alkanet, crescit isola Thanet.

$\ddagger$ Ger, ema.: I doubt whether our author found any of these in the place here set downe, for I have sought it but failed of finding; yet if he found any it was only the first described, for I think the other three are strangers.

$\ddagger$ Our Johnson uses not his usuall charges for heere hee gooes about to confute with a 'for-I-thinke', and seconds it with as good an argument from an Hypothesis (if hee found any, it was onely ye first), and why not as well ye other three, since hee confesses afterwards in both his Catalogues ye Anchusa minor, ye $3^{\text {rd }}$ of these, to bee our countrey plant.

Anchusa lutea. Yellow Alkanet.

[How MS. in Johnson's Desc. Itin. Cant. 1632, f. 6 v.]

At the end of the volume are the following memoranda, but so dreadfully scored over as to be almost illegible:

$Q u$. whether some plants which are given by Johnson in his Itineraries to bee non descript., are not described by Parkinson?

Putt him nondes nere ye additionated plants and ye.... and see whether they be contained (?) in Mr. Holybyn's Catalogue.

$\ldots \ldots$ montanum sylvestre Anglicum ut agagua $\mathrm{Cl} \ldots \ldots \ldots$.

Remember ye English names to bee last placed. Consult how many plants wee have added in our treatise by telling ye old, ye remainder, ij ye number.

Mr. Holloway hath Stonhous papers manuscript.

To all Johnsons new plants, put Jonh. MS.

Remember to ye plants to put their titles, as $\mathrm{D}^{\mathrm{r}}$. Bowle, $\mathrm{M}^{\mathrm{r}} . \mathrm{M}, \quad$ and So every man's name to his plant.

Remember to give ye proper name in Latin of ye place where each plant flourisheth, and to bee carefull to $\mathrm{f}$....

Review ye spelling of names of Townes by Cambden's Brittan : vid. 2 Eriffe.

$$
\begin{aligned}
& \text { [1. Wulwich] } \\
& \text { [2. Eryth] }^{1} \quad \cdot \quad \cdot \quad \cdot \quad \cdot \text { Kent }
\end{aligned}
$$

1 In Johnson's writing.

Review both ye Herballs againe and take all. Remember to insert againe Apium sylvestre. See whether you putt downe ye Aristolochia.... Anonis you must adde to Anonis 3 more..... Auricula muris repens ... Auricula see $w^{\text {ch }}$ of them growe wild. Birds' eyes, see them-none wilde. 
Remember to insert Jonhsons (sic) Author (?) nere Parkinson's .... Borrowe a Coopers Dictionary. English Cątalogue.

Asarina. ......

Consult ye place amicorum benevolentia.

[t lines illegible.]

Send to Bobert about ye Millegrana non descr. whether to Gr. d. E. . . Remember Mr Bucner to send for ye Bupleur and Caucalis. Send to Dr. Browne and asist Mr....

Abrotanum non antea repertum in descript. Then each plant's place of ....... and ye places you have found out, faithfully dealt all ye English fruites which are not described, ye pharmacutists about such as Bedaguar Fungus sambucinus met of ye Parson of St. James.

Ubi sativus inveni vulg. . . . . . sativus.

Observe, ye same letters in our printed peece as there is in ye Welsh Catalogue. Those which have...

Send to Stonehouse. Consult Morgan about Orchis. Mr. Crosse. Reade ye Catalogue Epistle onlye.... all plants yt are to be blotted out better be done on ye former Catalogue, because they are worse described there.

[How MS. at end of Johnson's Desc. Itin. Cant. 1632.]

How published his Phytologia in 1650: though anonymous it must at once have made his reputation as a botanist, and have brought him into correspondence with other plant-lovers who sent memoranda of plants which he had omitted. The names of these he entered in an interleaved copy of his book which he kept carefully corrected with a view to a revised and enlarged edition. Among those who gave him valuable help were Goodyer, Browne, and Hunnibon, ${ }^{1}$ and he for the first time had the advantage of looking through the manuscripts of Lobel and of Dr. Penny. That Goodyer put his knowledge freely at the service of all true workers alike, is proved by the fact that at this time he was also assisting another person, believed to have been Dr. Dale, in the compilation of a very similar Catalogue of British Plants. That the idea of a complete British Flora was very much to the fore in Goodyer's mind is proved by his communications to Ilow (NIS. 1 $\$$ ), by his abstracts from the Phytologia (MS. ff. $33-7$ ), by the Dale (?)-Goodyer Cataloguc of British Plants (MSS. 8 and 9 ), and by his Index to the English plants localized in Gerard's Herbal (MS. I6).

Further information concerning How's activities in the period immediately following the issue of the Phytolugia is contained on a small scrap of paper measuring $3 x+$ inches, with his memoranda. characteristically struck out.

1 'Dr. How had 2 Apothecaries to help him in composing $y^{\circ}$ Phytologia brittanica.' John Ward's Diary. Perhaps Hunnibon was one of them. 
My Ld. Hatton's letters with seeds. Morines plants. Dr. Morisons 2 Correspondence. Exper: Phy: Brit: Deliver Anderson's letter. Qu. way of Correspondence. Goades buisinesse (?).

Sends Ld. L. at Tibr:

Monday Committee

Kay pro horse, Statim.

Proyne Wild, Anderson Phyt. Str. Ill. pro Stone,

Ye preparacon of sublimatum $\mathrm{Cu}$ pum vide ye Paper. Seeds sent by Cadell dead since in these partes, which I hope you have. ४

Parthenium

Lilac

Answere both Dr. Morisons letters

have

I have all Plant bookes for dressing Pinax, what bookes I am about.

[How MS. bound with Goodyer MS. I1, f. I69.]

Dr. Morison was at this time abroad in charge of the Duke of Orleans' garden at Blois. Full of energy and enthusiasm for his subject, he wrote to How about the Phytologic, and sent him a pressing request for a number of plants which we have printcd on p. 355. If How ever executed the order, some of the additions then made to the Duke's garden should appear in the Catalogues ${ }^{1}$ that were printed in 1653 and 1669.

Lord HATTON transmitted his interest in Botany to his son Charles, who acquired the Boccone MSS. that were edited by Morison in 1674 .

MORINE may have been the 'ordinary gardener' of Paris who became 'one of the most skilful and curious persons in France. . . . His garden is of an exact oval figure, planted with cypress cut flat \& set as even as a wall : the tulips, anemones, ranunculuses, crocuses, etc., are held to be of the rarest, and draw all the admirers of that kind to his house during the season'.2

\section{MS. Additions by How to his copy of the 'Phytologia Britannica'. Between I650 and 1656.}

A certain number of the plant-names and notes that How wrote in his interleaved Phytologia have been quoted by Druce and others. They are of sufficient historical importance to be worth printing in full-or at least as far as they are legible.

1 Brunyer, Hortus Blesensis, 1653; Morison, Hortus Regius Blesensis, I669.

${ }^{2}$ Evelyn, Diary, 2 April 1644. The plants that Tradescant had from him in I63I are noted on p. 331 . 


\section{How's $\rightarrow$ MS. notes on $f$. I.}

Plantae in aspectu in convictu nobis, semperque ad manum, nec fuga, nec ullis proripiuntur latibulis.

Universus fere ager amoenissimum viridarium.

Rariores quaedam et nondum quoad sciam exhibitae, ac a me observatae cum suis descriptionibus plantae commemorantur, ut quae adhuc laterent publico vix donarem, et ut quisque de iis, earumque facultatibus apptius indicaret.

Denique suas cuique plantae vires aut proprietates quam brevi ac dilucide fieri potuit annexi nec quisquam sibi nomina varietati tanquam labyrintho incumberet sed cum iisdem facultates etiam exploratas haberet.

$$
\text { Vid. Phyt. Pion } 4^{\text {to }} \text {. }
$$

Gaine I was for Goodyers Plants and des[criptions]: ye like for Brownes, Lobells [and Pennyes MS. $w^{\text {ch }}$ review for names etc. (erased)].

Insert fig: iterum in Desc[riptiones].

Herbidos campos perlustratur.

Hanc nostratem 'Avтократ аvтаркі́⿱一⿻上丨匕 Botanicae.

Vid. Epis. alt. libr: ad Coll. Med.

Cynoglossum flore albo neere Redding.

Arctium montanum et Lappa minor Gal. Lob. Button burr. Mangersfield in Mr. Langlyes yard, ill left out in yore Catal.

Acinos Anglica flore albo in Salisbury feild neere Basing stoake. D. Dale.

Verbascum syl: sive 4. Math: groweth naturaly about ye seate of $\mathrm{S}^{\mathrm{r}}$ Th: Hanson called Toplow neere Maydenhead.

Erica tenuifolia caliculata, Ger: hirsuta Anglica, Bauh: ericeto Hamstediano.

Cardamine maior flore albo.

Bugula flore carneo.

Urtica foliis variegatis.

Speculum veneris maius in a ditch adioyning to St. Georges feildes.

$\left.\begin{array}{c}\text { Primula veris flore pleno viridi } \\ , \quad, \text { sive Paralysis fatua }\end{array}\right\}$ ? Morg[an], an inser:

Arum non maculatum, Park.

Arundo anglica multifida, Park.

Malva syl: flore albo, Morg.

Millefolium pennatum, Bauh. neere Cambridge.

Ballote flore albo neere [Cholsy erased] at Tadenham ye south side of Mr. Crofts house Warwickshire.

Filago minor, Lob: neere Petersfield.

[Holosteum non descr. ? ye place Goodyer (erased).]

Alsine aquatica Portulacae fac: left out. 
Hieratium montanum at Mangersfield in Mr. Langtons yard.

Cannabis spuria altera flore purpureo. I Cat.

Saxifraga antiquorum, not inserted.

Absinthium marinum spica erecta.

[Bellis flore herbaceo globoso non descr., M. (erased).]

Foeniculum at Rie - Leucoii folii. Qu. D.

Primula veris polyanthos, M. at great Wulford Wood.

Agrifolium folio variegato Hampsted and in ye North.

Serpillum magnum latifolium neere [Sr. W. Walters Oxfordshire erased] at Sarsden betweene ye house and ye pond garden of Sr. W. Walter.

Geranium columbinum flore albo.

Carduus vulgatissimus fl. albo in little Wulford field, Warwickshire.

Geranium Rupertianum flore albo in a close betweene little Wulford and Bacton, Warwickshire.

Perfol: purp. vulg. fl. albo by Whichford wood, Warwickshire.

Consolida maior fl. cinericeo. Redding.

Chamomelum nudum bullato flore. Tuthill feildes.

Peryclymenum dissectis foliis. St. John Wood.

Lamium elegans f. lut. foliis variegatis neere Wulwich.

Tubera terrae.

Polium montanum neere Maidstone.

Lamium rubrum pumilum.

Lamium rubrum non serratum. Q Q . an diff: a. I

Lamium rubrum foliis variegatis.

Beta marina neere Lewis.

Tapsus barbatus fl. albo at Weston.

Folio 2

Carduus lanceolatus fl. alb., M. St. James.

Rosmarinum syl. minus nostras, Park.

Scabiosa ovilla flore albo., M.

Sideritis hederulae fol., Park.

Senecio foliis variegatis.

$\left.\begin{array}{l}\text { Typha. } \\ \text { Senecio sentilis? }\end{array}\right\}$ Q. D.

Vicia bisiliq. Qu. G.

Alsine (Qu. Holilas sen) minor. Androsace alterius Mathioli facie, Bauh Prod.

[Found by Mr. Halilah, Apothecary, in Lincolnshire. Merret, Pinax.]

G. spartium capillaceo folio minimum, Ger. em. Ericet: Hamp:

Quercus lapidea, Lithoxylum, Ligna lapidea. Ad. Lob.

Sium maius angustifolium.

Serpillum vulgare flore albo.

Nymphaea lutea minor flore parvo, Catal. I.

Pulegium regium vulg. maius, Park. 
Lychnis minor Anglica, Park.

Atriplex syl. Halimi fol, eiusd.

Pilosella minima, eiusd.

Muscus ex cranio humano.

Caucalis Anglica fl. rubente, Park. 9r 9. ${ }^{1}$

Pimpinella saxifraga minor nostras, eiusd. 946.

[Genista spinosa minor, Park. (erased).]

Rubus saxatilis Alpinus.

Lotus corniculatus frutescens, P. I I02.

Lotus corniculatus minor pilosus, ibid.

Hordeum spontaneum elatius, sive maius, P. I 147.

G. bromoides maximum hirtum, I I 49 .

G. avenaceum pratense, ibid.

G. bromoides segetum latiore panicula, ibid.

G. avenaceum murorum erectum, ibid.

G. avenaceum supinum arvense.

G. avenac: sup: flosculis secalinis, ibid.

G. avenaceum exile mollicellis foliis, ibid. All theese oaten grasses grow in ye feildes of this land according to Park. ; bold assertions yett hee has no such warrant from Lob. Ill., from whence hee gathered them for rendring this exile mollicellis foliis spontaneall.

G. arundinaceum panicula miliacea, I I 53 .

G. montanum panicula miliacea sparsa, 50 in Prod., G. miliaceum alterum, P. I I 53 , sine Ic.

G. arund: Sorghi panicula sparsa, 52 Prod., G. Sorghinum alterum, P. I 553 , sine Ic.

G. paniceum syl. Anglicum, P. I I 55, sine Ic.

G. cristatum Anglicum, P. I I 6, cristatum Britannicum, L. S. Ill。 ${ }^{2}$

G. cristatum spica multiplici, P. I 160 .

Phalaris pratensis maior, P. I 164 .

G. alopecuroides cuspidatum maximum Anglicum, P. I r67, L. S. Ill.

G. alop: spica aspera brevi, et longa, P. I I69.

G. alopec: cuspidatum minus et minimum, ibid.

G. cyperoides Anglicum parum lanosum maius et minus, P. Ir72, neere High gate. ? L. S. Ill. 2 variet.

G. iunceum medium et minus, P. Ir9o, in ye woode neere highgate, ? I. S. Ill.

Juncus capitulis equiseti alter, P. I I95, L. S. Ill. Juncellus capitulis equiseti fluitans, P. I 196.

Spartum minimum Anglicum, P. I 199.

Equisetum omnium minus tenuifolium, P. 1201.

Anagallis aq: sive Becabunga maior, P. I237. An: aq: ma: fol. subrot. Bauh.

1 These references are to Parkinson, Theatrum Botanicum, 1640.

"Lobel, Stirpium Illustrationes. 
Sagittaria minor angustifolia, P. I246.

G. Arundin: sericea molliore spica, P. I 273 , L. S. Ill. 45.

G. maritimum vulgato canario simile, P. I278, L. S. Ill. 24.

Muscus arboreus nodosus, sive geniculatus, P. I3II.

Muscus aridus crustatus, $\mathrm{P} . \mathrm{I} 3 \mathrm{r} 3$, vid. loc. Bauh. Pin.

Fungus Cambro-Brit. Corallii rub. colore multis lineis nigricantibus

maculisque luteis orbiculatis insignibus, P. I22 I.

Fungus parvus nigricans crenatus, P. 1322 , about Hackney.

Fungus cinarae formae, P. 1224, at Ripton neere Ashford in Kent.

Acer montanum, P. I426.

Primula veris Raii, M. Qu. loc.

Quercus natalitiis Dni virens, ye Christmas greene oake, P. I646, neere ye Castle of Malwood Hampshire, Kg. J. went to visit and caused it to bee paled about.

Glycirrhiza syl: alt: fl: puniceis fol. Arachi, Glaux quaedam leguminosa herbariorum Adv: Bauh. Hist. P1. 1. I 7 juxta agrorum viarumque margines obviam sese dat in Anglia.

Hieracium Chondrillae fol. glabrum, Bauh. Hier. 5, sive Aphacoides, Tab. Ger.

Ulmus foliis luteis at Fulham.

Hieracium Alpinum asperum Conyzae facie Bauh. Hierac. Brit., vel 4 Clus.

Pan. et Hist. H. latif: mont: Genevense fol. long: maior: Monsp.

J. B. H. P. 1. 24, p. I026. Borealibus Britanniae regionibus sponte crescit.

Lychnis syl: foliis variegatis fl. albo. $Q u$. M.

Virga aurea subrotundo fol. in Surry.

Ascyrum, sive Hypericum bifolium glabrum non perforatum, Bauh.

Hypericum in dumetis, nascens I Trag: Hyper. Ascyron dictum, caule quadrangulo J. B. H. P. l. 29, p. 382 , ic. ib.

Androsemon, Tur. In vinario sionis saepe observavit.

Gentianella brevi fol., Bauh: non procul Douera.

Anchusa Echii foliis et floribus, Bauh: arvis argillosis.

Anthyllis chamaepityides frutescens, Bauh.

Paralysis inodora calycibus dissectis, Raii: . not farre from Kynlett ${ }^{1}$ in

Worcestershire: P. Par.

Euphrasia coerulea not far from Canterbury, Mr. Hunnibon.

Pseudonarc. f. plen. Ger. Angl, fl, plen. P. P. ser.

Serpillum foetidum Goodyeri, on ye chalkie downes 2 or 3 miles from

Petersfield.

Papaver cornutum flore phoeniceo, Adv. 24I.

Gentianella brevi fol: Bauh., minima L. ob. copiose provenit Angliae septentrionalis collibus.

${ }^{1}$ Probably Kinlet in Shropshire near Cleobury Mortimer, about a mile from the Worcester border (T.R.G.-P.). 
Mollugo mont. angustif: B: vulgatior Herbariorum. L. Ob.

Corallina fruticosa purpurea, B: rubens Antiphatis faire, L. Ob.

Imperatoria Ad. Lob: Tab. Ger: about Morpeth in ye north parke, Tur. p. 37.

Ribesium fructu rubro Dod: Ribes Fuch. Turn: by a water's side at Clover in Somersetsh:

Cyclamen in ye west country of Engl: Turn: in his booke intituled Ye names of Herbes.

Jacobaea montana neere Lewis.

Hieracium lonchites, Bauh. B. Plants.

Lactuca agnina rosea, neere red Morly.

Capillus veneris verus, neere Lydberry.

Cynoglossum fl. carneo, neere Bath.

Alsine foliis Trissaginis variat $\mathrm{fl}$. albo.

Chamaedris syl: variat. fl. albo.

Sedum aestivum minus.

Plantago latifolia serrata.

Lagopus maximus fl. rubro, P. nere red Morley.

Folio 3.

Ranunculus fl: lut: galericulato, at Yatton.

Geranium batrachoides fl. variegato, neere Kidermaster Pitts.

2. Pin: Gentiana maior ii Clus: fl: coeruleo neere Bath.

Artemisia foliis variegatis neere Alchurch.

Anagallis maxima latifolia neere Lidborough.

Cracca minima variat. flore albo.

Ascyrum maius neere Worcester.

Muscus stellatus roseus, Bauh: Park. neere red Morly.

Daucus proliferus, Qu. lo: Jolyff.

Verbascum nigr. salvifol: purp. A. Adv: $24 \mathrm{r}$. ii et nigrum latifolium luteum eiusd. 242 .

Juncus capitulo lanuginoso, sive Schoenolaguros, in Prod: Juncus Alpinus cum cauda Leporina. J. B. H. P. Moss crops. In ericetis nudis, Cambro-Britann. et Comit: Salop.

e Lob. MS.

Equisetum minus omnium tenuifolium.

Synanchia altera Angliae, sive minor.

Rapistrum aliud syl. non bulbosum, P. 862. Rapistrum fl. lut. alterum L. S. Ill.

Cardamine alpina sive media, vid. Clus: cxxvin.

Thlaspi alterum siliquosum.

Planta juxta Heigate reperta, vid. nom. in Pin. Bauh.

Sonchus laevis alter I anicus aut Anglicus folio profundis laciniis sinuato f. lut.

Hier: alt: fol. obtuse laciniatis fibrosa radice, Qu. MS. L. S. Ill. 
Brassica marina folio suaverubente, L. S. Ill.

Beta maritima syl. spontanea eiusque varietates.

Beta maritima syl: minor.

Atriplex maritima altera Osyridis aut Scopariae fol., sive minima.

Atripl. maritim. angustifol: 2 et 3 .

Limonium medium Anglicum.

Hellebor. 2 Clus. sterilis planta.

Campanula coerulea supina.

Lychnis arvensis anglica.

Pulegium vulg: maius minus repens cubitalis altitudinis.

Scabiosa montana minor capitulo squarroso, Bauh. Pin. 270 , in collibus

Kantii non procul Kingshey.

G. vulgatiss: pratense elatius tertium.

G. ruderum etiamque arvorum, L. S. Ill. 6, multis locis Ag. Lond. gaudet.

G. quoddam modo supinum vulg: latiusculo binum et ternum unciarum complicato folio.

G. maritimum vulgatissimo pratensi gramini congener aut str.

G. marit. alt. sive 2 elatius.

G. marit. 3 vulgari str., supinum, exigua avenacea gluma.

G. dulce udorum, vid. Bauh. pag. 2, Gr. vi.

Gr. minimum Anglo-Brittan.

Folio 4 .

Gr. exile vicinorum maris aggerum, P. i 278 , numerosa gracillimorum latiusculorum uncialium foliorum sobole.

Gr. omnium minimum, Anglo-Britan. alterum.

G. aquat. longius radicatum spicata avenacea gluma.

G. tenuifol. exile Britan: ex genere Xerampelini graminis

G. maritimum Vectis Insulae Anglo-Britt.

G. cuspid: tenui torosa villosa spicata gluma, Panici granulis prodita.

G. phalaroides tremulum max: comosa elegantius gluma provenit in quibusdam collibus Britan.

G. tremulum minus alterum Aquitanicum et Anglicum.

G. hirsutum nemorum latioribus maioribusque foliis praecox vernum.

G. hirsutum sive exile ferrugineum.

G. Anglo-Britan: exilis hirsuti graminis differentia Boelii.

G. cyperoides aculeatum, sive .. (?) natum aquaticum alterum.

G. cyp: minimum panicula subflava, Lob. Ad: part. 2.

G. cyp: minimum nigricante panicula, Lob. Ad. p. 2, nullis uliginosis pratis Anglo-Br.

G. cyp: palustre longius spicatum Anglo-Brit: acerosum et echinatum.

G. cyp: minimum Boel: tenuifol: puis per caulem dissectis torulis: Provenit in Angl.-Britt.

G. cyp: sparsa panicula altae portae (=Highigate). 
G. cyp: aquat: tenui, triquetro, longoque caule, medulloso, junceo, bicubitali altioreque caule.

G. cyp. comosa torulis distincta sparsa panicula palustre. Anglo-Britan.

G. cyp. eleganti multifera congesta spica. Anglo-Britt.

G. cyp. sylvarum tenuius spicatum.

G. cyp: gracile alterum glomeratis torulis, spatio distantibus.

G. iuncoides alterum minus granatum, comitat: Kantii.

Gramines parvus gracilis Juncellus Altae Portae.

G. iuncoides tenuissimum subfuscis torulis apiculis carentibus proditum.

G. iunc: minimum An.-Britt. Holosteo Math: congener, aut Bufonis gramini Flandrico et varietas.

Mentha syl: verticillata tetri odoris.

G. Xerampelinum exile. Ang. B.

Angl. B. Panici effigies Gn. syl: L. S. Ill.

Verbascum nigrum flore albo betweene Chesilhurst \& Greenwitch.

Plantago latifolia incana spicis variis, Bauh. Pin. 789 .

Pl. peregr. latif: Gareti Clus. Hist.

Plantag. latif. rosea multiformis, P. 494.

Pl. ros. incana latifol: L. MS. gave ye Engl. name of Park.

Pl. angustif. rosea, Park. 495.

P1. 5-ner. alt: sive angustif: roseo, folioso, sparso radiato fastigio. L. MS.

In borealibus Angliae tractibus utramque latifoliam, incanam roseam et hanc spontaneam esse intellexi.

Sium foliis dissectis.

Sium umbellis ad caulem nudis. $\{u$. P. ye name place.

Pimpinella saxifraga maxima.

Spina acuta biflora Britannica. Park. 1025, sive Oxyacantha.

Erynus Math: in Hampshire.

Juncus triquetrus by ye horsferry.

Sambucus laciniatis foliis Dr. Jolyff ${ }^{1}$ neere Winchester.

Origanum roseum surculis densis, on Polstead downe in Compton parish nigh Gilford.

Geranium violaceum at Putinham neere Gilford.

Orchis foliis sessilibus non maculatis, Bauh.: 5 Clus. rar. Plant. pag. 268. Similem etiam observabam MDXxicr in pratis urbi Londinensi in Anglia proximis, ubi et aliam eruebam grandiore paulo florum purpurorum spicâ teterrimi foetoris.

Gentianella angustifolia autumnalis minor floribus ad latera pilosis, Bauh. Gent. autumnal: fol: Centaur: min: flor: coerul: Eyst:, Gentianella

1 Probably George Joyliffe, who entered Wadham College in 1637, migrated to Pembroke, and took his M.A. in 1643, being then a lieutenant under Lord Hopton in the Royalist army. He, with Dr. Clayton, discovered the Lymphatics in the liver about 1651. Samuel Pepys was one of his patients. Power, Trans. $\mathrm{HCd}$. Soc. xl. 
autumnalis Centaur. minor fol: Park: pag. 406. Among his names there hee informes you yt it is ye $\mathrm{x}$ Gentian of Clus: wch if you compare theire Icons you will find it to bee Gentiana I I minima Clus: pag. $3 \mathbf{1 6}$, and further affirmes it to be Gentiana minima of Lob: wch Plant Bauh: worthily rankes under ye following title, not farre from ye ruines of ye old Citty Verulam neere St Albans.

Gentianella brevi fol:, Bauh: Gentianella minima, Lob: Gentiana x sive Gent. fugax 4 Clus: rar. Plant. pag. 3I5. Memini et in Britannia observare, non procul Douera Sept: partim dilutiore colore florentem partim semine pregnantem.

Alsine hirsuta minor, Bauh:, prope Rochester.

Fucus marit. alter tuberculis pauciss:, Bauh. marinus 4 Dod.

Fucus spongiosus ramosus.

Fucus folliculaceus foeniculi folio longiore, Bauh. Ferulaceus, Lob.

Helleborus pratensis latifolius, it growes in meddowes about Lichborough in Northamptonshire.) Br. lett

Serratula flore albo. $\quad$ non descr.

\section{How's MS. additions on leaves introduced in body of book.}

Acorus verus offic. falso Calamus cum Julo, Calamus gromaticus vulgo Ger.em. pag. 63. I received from Mr. Th. Glyn of Glynrlhinon in Carnarvonsh: ye pretty Julus or flower of this plant, which I could never see heere about London, though it groweth with us in many gardens and yet in great plenty. I rec ${ }^{d}$ : divers of them wth elegant flowers in June from Dr. Browne ${ }^{1}$ who found them in severall places of Norfolk, theese grew in Witton fens.

Alnus nigra baccifera, Tab. Lob. Frangula, Matth.

Est et species Frangulae fructu rubro proveniens in Angliae Comit. Somerset: prope aedes D. Thyn, an Vaccinium Plin: Lugd:

Althaea Ibiscus. Marsh Mallowes.

Variat maioribus foliis et stipite littoreis circa Gravesend.

Anagallis foemina flore caeruleo. Female Pimpernell.

Faemina folia habet paulo quam in mare maiora, ima parte punctis nigricantibus multis insignita. Crescit copiose inter segetes iuxta Stanford.

Anonis foliis maioribus leniter crenatis flore luteo, in viis pratis non procul Bristolia.

Aquilegia flore caeruleo. Columbine. In a wood within to miles of London Kent.

Arbutus unedo. At Bellamont 3 miles from Dublyn.

Asarina foliis Asari, Bauh: Asarina, Math: Nec dispar foliis et odore Asarina devexa angusta via qua itur Clover versus Mendiep ubi effoditur plumbum. Florem videre non contigit illo tempore quo illac iter faciebam cauliculis serpit.

Ballote, Marrubium nigrum foetidum. Stinking Horehound.

Variat flore albo neere Gravesend.

1 The well-known author of the Religio Medici. 
Bellis minor vulgaris. Little Daisyes.

Bellis minor flore viridi globoso, at Mr. Sheldens wood at Weston, Warwickshire.

Betonica vulgaris. Betony.

Variat in sylvis angustioribus aut rotundioribus foliis.

Calamogrostis huc referenda pro Calamog: Syl. D. J. Bapt: vid. non . . . Pin: Bauh: Calamus aromat. vid: Acorus verus.

Campanula media. Ista campanulae rotundifoliae similis, sed magna ex parte caulem habet unicum aliquando tamen plures sed hoc rarius, striatum, folia alterna per caulem rapuntii fere, sed latiora nec adeo longa, caules et folia sunt leviter hirsuta. Flores omnino purpurei campanulae praedictae floribus similimi, sed maiores et longiores multo. Radix parva paucis fibris. Provenit copiose inter Herefordiam et Kyneton, ac per totum Wye Flu: tractum.

Cannabis spuria altera flore purpureo. In agris. Nettle-hemp.

Cardamine pumila Bellidis folio. Alpina, Ger. emac. Rock-cresses.

By Shawford neere Gilford abundantly.

Christophoriana. Herbe Christopher.

Ad radices montis Ingleborrowe copiose inter saxa.

[A coloured drawing inserted.]

Cirsium Anglicum. Single-headed Thistle.

Radix nigricans fibrata quindoque per magnas fibras fere propagans ut in figura.

[A coloured drawing inserted.]

[? The last or] C. Anglicum minus, Park.

Crescit in pratis ad radices montis Ingleborrow totius Angliae altissimi in Comitat. Eboracensi 12 miliaribus a Lancastria.

Cochlearia rotundifolia sive Batava, Lob. Round-leaved Scurvy-grasse. It groweth nigh unto a castle in ye Peake of Darbyshire which is 30 miles distant from ye sea.

Cochlearia rotundifolia marina.

About ye walls in Bermonice abundantly.

Echium flore alb. Vipers Buglosse.

Et in Cretaceis collibus ad Thamesim prope Greyn-hey tribus miliaribus a Gravesend.

Erica tenuifolia, Ger.

Coris fol. 6 Clus: rar. Plant: pag: 43. Nascentem hanc vidi in Anglia supra Windesoram mense Sept. florentem (Angli Boreales Ling vocare). ${ }^{1}$

Erica coris folio 6 Clus: flore albo.

Erica coris folio 13 Clus: flore albo Saepius reperiuntur in ericetis circa Worplesdowne in Comitat. Surriae.

Gentianella alpina.

In ye mountaines betwixt Gort and Galloway abundantly, Mr. Heaton.

1 In Goodyer's copy of Parkinson's Theatrum, in the margin of p. 1480 , is a note in the handwriting of the botanical friend of Goodyer (? Dr. J. Dale) who wrote MS. 9. Referring to Fig. 2, Erica vulgaris hirsutior, Common rough Heath, the writer observes, "The 2 is the figure of Lrica Coris folio, Clus. hist. p. 4I, and not of the Ericae myricae folii similis found by Clusius about Windesor'. 
Gramen plumosum elegans. Fetched grass.

Vepretis et quibusdam aridis agrorum marginibus Dorcestriensis AngloBritan: gaudet priori inutile.

Gramen tremulum. In upland cornefeilds at Hatfeild.

Gramen typhoides maximum spica longissima. The largest Catstaile-grass. With a very large eare at ye entrance into Chelsy feilds.

Hederula aquatica. Water Iry.

In a ditch by Bermondsey house neere London.

In aquis residibus iuxta Petriburgum.

Hieracium alterum foliis obtusa laciniatis fibrosa radice. Londinensis agri pratensibus, via Hackneum, Stepneum, et alibi passim obviam. foliis item humi stantis, hirsutis, duas uncias cum dimidia ternasque longis, obtusis dentatis laciniis: cauliculis dodrantalibus et pedalibus floribus luteis papposis Hieracio longius radicato paribus et similibus donatis radice tamen non ita longa, sed fibrata.

Hieracium lactescens frutex est sesquicubitalis quandoque altior, caules multos ab radice fibrata satis, emittens, tenues tristes, intus fungosos et medulla alba plenos. Folia oblonga, serrata leniter, mucronata, parte ima modice pilosa, alterna per caulem, multis vel brevissimis pediculis cauli habentia, obscure virentia. Flores versus summos caules e cavis foliorum exeunt, pediculis longiusculis Tragopog: floribus omnino similes sed minores, lutei cuius foliola in extremis in quatuor partes dissecta. Flores nocte clauduntur mane sese expandunt. Floret Augusto, Septembri vero in pappos abeunt: Semen parvum oblongum sapore est ex dulis subamon, flores foliis sunt amariores paulo. Tota planta lactescit. Crescit in sylvis Comitat: Hertford.

Horminum sylvestre Lavendulae flore.

Nascitur satis frequens ad Regium oris (?) Grenwicii Hippodromum.

Hyoseris mascula, Ger. Male Swines Cichory.

Non diff: ab Hieracio minimo Clus: pag: cxlii. Provenit inter segetes locis parum arenosis, et terra friabili; frequens in Anglia multis in locis.

Jacobaea, sive Senecion minimum. Radice pro plantae proportione maiuscula fibrata; folia Bellidi fere sed breviora parum incana 5, 6 vel 7 supra terram strata, e quorum medio caulis assurgit dodrantalis aut minor singularis in quo una, 4,5 vel 6 quandoque folia sunt alterna, angusta mucronata. Caulis et folia lanugine candida sunt obducta. In summo caule flores sunt quatuor, 5, 6 rarique 7 breviusculis pediculis Senecii maioris, sive pubae Jacobaeae, pappescentes. Radix fibrata non vaga. Floret Julio et initio Augusti. Crescit in Agro Cantabrigiensi in parvis collibus non procul a Stapleford.

Jacobaea 3 Clus. Pann: latifol: s[essi]lis Planta Flore intense luteo et folio nigriore, vulgari Jacobaeae fere paribus, rivulorum sectatim Anglo-Britaniae.

[With a coloured drawing.]

Juncaria salmaticensis. Small stone Woodrooffe of Spain. At ye lower end of Grayes Inne lane by London neere ye water course.

Linariola parva planta dodrantalis aut brevior, caules aliquot a radice teretes et duriusculi, in quibus folia fere lini bina per intervalla. Flosculi parvi lini fere sed albi ex quinque foliolis in summis ramulis. Semina valde minuta lini effigie fusca. Floret Junio, Julio et Augusto in pratis Angliae frequens a nullo descripta.

[With a pen-and-ink drawing.] 
Militaris aizoides, Lob. Water soldier.

Si non est Stratiotes Dios: certe similima est, sed non sine radice vivit. Copiose prope pagum Over Jun. Julio et Augusto floret in aquis stagnantibus et fossis limosis Eliensis Insulae.

Muscus coralloides lacustris.

Corallii fere modo crescit, sed plures caules ab una radice, certo tamen spatio a se modice (?) distantes, utpote tres, 4,5 , et quandoque sex caules dodrantales aut paulo longiores emittit minimi fere digiti crassitudine, teretes, spongiosos, ut et substantia totius plantae spongiosa est et porosa, et spongiae fere consistentiam in aqua habet.

Sicca vero dura et friabilis est, ex caulibus unus vel duo quandoque tres in summo sunt ramosi, in duos vel tres ramos ad cornu cervi similitudinem sunt divisi. Nec folia alia, nec flores nec fructum profert (quantum potui observare). Radix lapidibus in fundo adhaeret, supraque eos sese expandit. Tota planta unius est coloris, in aqua viridis saturate cum quadam nigredine, sicca vero diluta virescit. Invenitur in fluviis ex arborum truncis vel radicibus in aquis exiens ut in fluvio iux! a Petriburgum.

[An early description of the Fresh-water Sponge, Spongilla fuviatilis, illustrated with an excellent coloured pen-and-ink drawing.]

Myrrhis. Fuch., Cicutaria, Ges. hort. Wild Sweete Cherville.

Napus syl: minimus Montosis agris hoc pusillum Napi syl: genus iuxta pistrinam ventillatam sive ventimolam D. Rich. Garth semiliari ab aedibus antiquis Drayton vocatis e regione Vectis Insulae reperi; tota planta admodum parva est, foliis Napo syl: longe minoribus, angustioribus, parum... [4 lines of description follow].

Nidus avis flore et caule violaceo purpureo colore an Pseudo-limodoron, Clusii, hist. rar. Plant. pag. 270: A mile from Alton in Hamshire. Mr. Goodyer.

[To this printed note, How has added in MS.] Limodoron Austriacum Clus. Hist. Orchis abortiva violacea, Bauh:

Orchis minor flore carnato Eyst: Pannonia 4 Clus: Cynosorchis minor Pannonica, Ger. em: The lesser Austins dog-stones. On Scosby lease. Mr. Stonehouse.

Oxalis major. Great leaved Sorrel.

Ad Shackerforth-mill loco uliginoso.

Papaver corniculatum flore rubro. Copiose crescit Vectis Insula.

Paronychia.

Folia radici proxima superne obscure rubent, interne virent. Lobelii mutilam et depravatam iconem Lugd:, Dod:, Ger, em., Park. etc. exhibent Omnes esse sequest (?) maturam e vivis naturae typis exhibeo.

[With a coloured drawing.]

Pedicularis flore albo. White Ratlle.

Severall places of Warwickshire.

Polygonum minimum.

Plantula vix unciam altitudine excedit, ramosa, ut arbor assurgit, surculosa, erecta magna ea parte, foliola parva binatim coniuncta, e geniculis exeuntia. Flores in summo parvi numerosi, albicantes. Radice nititur minima singulari paucis fibris, crescit locis hyeme udii, aestate veneniatii. An potius ad Alsines speciem referenda?

[With a small neat drawing in pen and ink.] 
Pulsatilla vulgaris. Purple passe-flower.

About Oxford.

Pirum foliatum.

[Coloured drawing of a pear, with well developed green leaves growing from the apex.]

Pirum supra pirum.

[A fruit with a second pear growing among the leaves at the apex.]

Ranunculus minimus Septentrionalium herbido muscoso flore. Dwarfe Cronvfoot, or Sinall Bunikins Hollwortell.

In Anglia frequens praecipue versus Septentrionem Folia odorem epirant moscho similem, sed valde imbecillum.

Fumaria cubica vel capnos Moschatella Cordi.

[A coloured drawing marked] Haec effigies praeferenda.

Ranunculus montanus, Cam. globosus. Globe Crozufoot.

Floret in fine Jun et Jul: ad radices montis Ingle-borrow. Angli boreales. Locker-Gowing vel locker goling, a flore clauso non est venenatus.

Ranunculus pumilus floribus deciduis.

The whole plant seldome exceeds 3 inches in compasse and in his full strength and flowring is not above an inch or 2 high, amongst a hundred plants of them yt I found not far from Oxford though it were in ye time theire flowring I could not find one with a whole flower, severall of these had 3,4 or 5 little yellow leaves of flowers, about a small thrum of yellow pointells, and every plant had fresh yellow pointells, with the leaves as it were new fallen of. [it has not yett flowred in my garden.] ${ }^{1}$

Rosa sylvestris odora Eglenteria. Sweet Briar bush.

Oritur in Bathonica Angliae proximis collibus non procul ab aedibus D: Laur. Hyde. [Quoted from Lobel, Obs. 618.]

Rubia sylvestris laevis radice perenni.

Omnino priori similis sed radice vivace ac perenni, humi maxima ex parte procumbit planta et multis surculis brachiata, folia paulo latiore stellatim disposita leniter serrata flores coerulei ex quatuor foliolis mucronatis. Caules quadranguli geniculati, e singulis geniculis folia stellatim decussata quinq, quatuor, sex septem et octo. Radix longa fibrata valde rubescens. Juxta Harwica prope littora maris.

Sagittaria minor. Small Arrow-head.

Radices-multas fibrosas, pallidas vel albicantes, prolixas inter quas aliquas utpote 4, 5 vel 6 maiores radices chordis maioris Lyrae instar reliqui longiores in extremo bulbosas bulbi oblongi mucronati, incurvi, membranulis duabus aut tribus tecti, colore ex albo et coeruleo mixto, bulbi magnitudine inaequales, nucis avellanae magnitudinem aequantes, quorum caro alba, solida.

[A pen-and-ink drawing entitled] Sagittae minoris radix cum bulbis.

Sambucus foliis variegatis neere Totnam.

Sedum arborescens Anglicum. Frutex est varius multis lignosis duris, cuius folia sunt magis longa, similiter disposita, non adeo carnosa, nec crassa, Sedum vulgare situ et ortu aemulantia, radice satis longa, et crassiuscula non multis fibris. Crescit in Insulis Hooms vocatis sinus Bristoiensis, Oceani Anglici.

${ }^{1}$ Erased. 
Sium alterum Olusatri facie. Long-leaved Water Cresses.

In fossis prope Petriburgum frequens, nec non procul ab Oxbridge in quibusdam puteis Londinum versus iuxta viam publicam.

Spartum spica secalina. Great English Mat-rveede.

On ye further side of ye Isle of Tenet.

Trachelium majus Belgarum. Giant Throat-wort or Bellfower.

Pratensibus ad radices cretaceosas collium prope Dartfort et Greehyth.

Trifolium flore viridi foliaceo elegans.

In mine owne Orchard at Darfield: it grew with mee one yere plentifully but I have not since observ'd it. I have now sent some of it dried as it was gathered about 9 yeeres since. Mr. Stonehouse.

Turritis major. Towers Mustard.

Non procul a meta antiquissima diruta, miliari a Colchestria et in agris prope Dedtfort.

Typha minor crescit in fluvio Petriburgum praeterfluens nusquam alias vidi.

Vaccinia nubis. Cloudberry.

Chamaemcrus Anglica, Park. Chamaemorus Cambro-Brittanniae sive Lancastriense vaccinium nubis. Radix utcunque nodosa, et ex nodis fibras paucas dimittit; radice se propagat (sicut Cirsium Anglicum vid. fig.) et quam longissime serpit adeo ut brevi tempore maximum spatium occupet.

Vicia maxima sylvatica nondum descripta, spicata Bathoniensis Goodyeri.

Umbilicus Veneris.

About Bath and North Wales plentifully.

Umbilicus Veneris maximus Anglicus rudentibus foliis maior ac elegantior quam precedens est. Pilleter. Plant: Synon: pag. 126.

\section{MS. additions at end between pp. $\mathrm{I} 32$ and $\mathrm{I} 33$.}

Cotula non foetida flore pleno latiore.

Chamaebuxus fl. colutea, Bauh: sive Rhus Plin: myrtifol:

Carduus lanceolatus $\mathrm{fl}$. alb et $\mathrm{fl}$. purp: Q. Chyrurg: for ye places of theese plants growth from Morgan.

Taxus tantum florens on ye chalky hills in Hampsh. J. Goody:

Persic. minor non urens sine maculis in Tuthill Feilds.

Antirrhinum medium Hispan: flore albo, Hunnibon and what other spontaneally hee hath with all other simples.

[Species of Cynoglossum, Hypericon, Orchys, and Sium from Browne See p. 302.]

Oxyacanthus flore rubro

Alsine foliis variegatis Qu. Hunnibon.

Seseli pratense

Qu. ye Sium in ye pott with small leaves per Phy. Br.

Gentiana altera dubia Anglica punctato medio flore.

Helleborines uti superior forte cognata, L. St. Ill.

Gentiana dubia Anglica, Park.

Q. Newarkes Turritis. Pentaphyllum.

Q. ye Opuntium marinum on Oyster shells. 
Nymphaea foliis hederaceis. Qu. Stevens.

[Species of Carduus, Plantago, and Echium from Browne. See p. 302.]

Prunella vulg: fl. al. incarnato et fl. purpureo.

in Chappell on ye heath. Bobert.

Stevens his Becabunga maior Plantago Aquat. latif. maior.

Geranium columbinum foliis magis dissectis, pediculis longissimis flore magno. I found it wild in ye beginning of August 1654, it is not described or pictured yt I find. John Goodyer. Q. ye place of growth. vid. Phyt. 47.

Erysimum ii Tab. Q. locum.

growes in ye streetes neere white chappell east from Algate London. J. Goodyer.

Anonymos aquatica rubida, foliis Anagallidis flore luteo. This growes in a little lake in a heath neere Petersfeild in Hamshire, in a hott summer some parts of ye lake are drie in August, sometimes before, there and then ye flowers are to bee seene.

Holosteum perpusilfum growes in ye same lake ${ }^{1}$ in ye East part of ye said heath greene all ye winter under water, and flowers when ye water is vanished in August, and sometimes much sooner. I first observed this plant in a pond neare Holburie in ye new Forrest in Hamshire. J. Goodyer.

1 The waters of this lake this 2 of June 1656 about 4 of ye clocke in ye afternoone was well neere as warme as ye Bathwater at Bath in Summersetshire although ye day was cloudy.

Holosteum juncifolium repens Goodyeri copiose inveni in Comit: Surriae juxta Purbright (an diff: a priore, Qu. Goody).

But How's good intentions for a revised edition of his Flora were not destined to bear fruit. Chance appears to have cast the Lobel manuscripts in his way: he purchased them with his own money, but his store of vital energy was unequal to the task of producing a second Phytologia Britannica.

The circumstances of his dealing with these manuscripts have been often described. A contemporary account of the matter is given by the Rev. J. Ward in his Commonplace Book: 'Dr. How hath put out a piece showing what Plants Parkinson stole out of a manuscript of Lobel's wch. never was put out, but came by chance to Dr. Modesy's [ = Morison's] hand.' How has been universally reproved for the violence of his language, re Parkinson, first by Pulteney and then by later historians, who, however, quote his remarks with some gusto.

If How had found the Lobel MSS. in anything like the disorder in which they were when I first saw them, and if he attributed the mutilations to Parkinson, his expressions might be considered as 
well justified. It is more likely that the vigour of his language was partly due to haste consequent on failing health, and perhaps to a presentiment of death and to the knowledge that his time and resources were insufficient to do his author more than scant justice. How died in $165^{6}$, a few months after the publication of his book.

We have consulted William Howe's will (P. C. C. Berkeley 3 I5) at Somerset House. He described himself as of Milke St., co. Middlesex, Gent., 'being in perfect memory though much crased in Body'. He willed that his body should be 'very humblie interred in St. Margaret's Church, Westminster, on the left side of my mother. The earth to be taken up att least 6 foote, my funeral I desire may be observed about ten at night. I would not have above 6 of my choyce friends accompaning'. His wife Elizabeth Howe was appointed absolute executor, but as regards his Library he 'would have her advised by some knowing person to putt of, and by no means to part with any particular book from the whole'. Will proved, 22 Sept. $165^{6}$.

It is probable that Goodyer then acquired a selection of his books and manuscripts. The most important of these, which are still in the Library at Magdalen College, are the Lobel Manuscripts, How's own annotated copy of his Plytologia, Johnson's Descriptio Itineris 1632 , both with the MS. additions printed below, certain loose papers including Goodyer MS. II, ff. $169-73$, described on p. 355 , and a few printed books including editions of Tabernaemontanus, Matthiolus, and Renealmus.

William Cole or Coles of New College gratefully acknowledged the help that How gave him in the preparation of his Adam in Eden 1657. 'Furnished' with How's 'best advice and with some of his select and choicest papers for perfecting his design', it is a pity that Coles did not produce a sounder book.

\section{xiii. DR. JOHN DALE, d. $\mathbf{1} 662$.}

In the Latin introduction to his Pinax rem naturalizm Britanmicarmm, Dr. Christopher Merrett, F.R.S., tells us that the one and only comprehensive Flora of Britain that had ever been printed was almost out of print, and that Pulleyn, ${ }^{1}$ a publisher living in St. Paul's Churchyard, had asked him to undertake a new Catalogue

1 Octavian Pulleyn was the publisher of How's Phytologia in 1650; Cave Pulleyn published Merrett's Pinax in 1667. Octavian sold to How the copy of Tabemaemontamus which was afterwards acquired by Goodyer: his signature is inside the cover. See pp. 202 and 226. 
of all the British plants then known, to be followed by a History, and that the work was to be done in association with a DR. DALE, 'Botanologus peritus'.

The only botanist of that name in Merrett's time who is at all well-known, or indeed appears in Messrs. Britten \& Boulger's Index of British Botanists, is Dr. Samuel Dale of Braintree, who in after years gave such valuable assistance to Ray, and was often mentioned in his botanical works. It is, therefore, but natural for an uncritical reader, on encountering a solitary mention of Dr. Merrett's proposed partner Dr. Dale, to assume unconsciously that the reference was to Dr. Samuel Dale. Merrett was, however, writing at the College of Physicians in August I666, a few days before the outbreak of the Great Fire, and Samuel, who is believed to have been born in Whitechapel in 1659 , could not then have been a distinguished 'Botanologist'. Nor must he be confused with William Dale of Queen's College, the helper of the younger Bobart. ${ }^{1}$

John Ward, ${ }^{2}$ writing in 1662 , also mentions Dr. Dale, and rather as if he were the originator of the idea of re-editing the Phytologia Britannica; and, lastly, John Ward's editor, Sir D'Arcy Power, notes that 'no record of his (Dale's) attainments in botany seems to have survived'. Ward had, however, a high idea of him: 'there are in London but two doctors $y^{t}$ have any great skill in simpling, $\mathrm{y}^{\mathrm{t}}$ is Dr. Moddesey (i.e. Morison) and Dr. Dale'; and in I66I he noted one of his prescriptions.

'White Mullen or Higtaper: wash itt and fume itt and boyl itt with hog's grease, $\mathrm{y}^{\mathrm{n}}$ add Red Lead and Linseed Oil. It is said to bee excellent good against $\mathrm{y}^{\ominus}$ piles. Dr. Dale. I find ye same in a manner in Gerard's Herbal with but very little difference.' ${ }^{3}$

Except in a single instance I have not met with any mention of the name of Dale among the Goodyer papers, but nevertheless there are good grounds for attributing to him the authorship of certain manuscripts, and a few notes in the margins of Goodyer's copies of Parkinson's Theatrum; Turner's Herbal, p. Io; Thalius

1 'Mr. Bobart, the Botanist, was greatly assisted in the $I I^{d}$ vol. of ye Oxford History of Plants, by Mr. Dale of Queen's College, who revised the whole and put it into proper Latin for him. Presently after the Death of the said Mr. Dale, I had a sight of a Folio Book in MSt drawn up by himself, being Tables \& Explications on Aristotle's Rhetorick' (Hearne, Diary 1705, Nov.6).

${ }_{2}$ The Rev. John Ward of Christ Church had taken his M.A. in 1652. His sixteen commonplace books are now preserved in the library of the Medical Society of London. (D'Arcy Power, Ann. Med. Hist. ii, p. 123.)

: Information from Sir D'Arcy Power, who has been kind enough to transcribe for me the paragraphs relating to Dale in J. Ward's Diary'. 
Syli'a Hircynia, p. 5I ; Gerard emac., p. 800, and other books. At any rate, it appears more likely that Dr. Dale, rather than any one else, should have written them.

Dale's botanical partnership with Goodyer dates at least from $165 \mathrm{I}$, as is shown by the latter's entry in his copy of J. Bauhin's Historia Plantarum. This work was purchased of Robinson on ${ }_{5} 5$ March $1_{5} 1$, and sold by Dr. Dale, then living in Long Acre, to Goodyer on the 22nd for $£_{3} 2 s$. $6 d$.

The Goodyerian Lists and Descriptions of British plants were undoubtedly written during the sixth decade of the seventeenth century. One paper is dated 22 January 1651, another April I659, and during part of this period the writer was evidently in close touch with Goodyer himself. The four principal manuscripts are:

1. Descriptions of Plants extracted from Lobel's MSS. (in Latin).

2. A Catalogue of Grasses, foreign as well as British, with brief descriptions and synonymy, comprising 203 species, written two on a page, on IOI leaves.

3. A Catalogue of British plants, with synonymy, comprising 922 species (including 70 grasses), written four on a page (with blanks), on 276 leaves.

4. A Supplementary List of British plants comprising I 53 names. If these are to be regarded as different from the 922, the British Flora as known to Goodyer and Dale (?) in 16.59 would comprise I,075 species-a figure which comes very near to the 1,050 of Ray in the ycar r669. How, by including varieties and exotic plants, had accumulated I,220 names in the Phytologia of $165^{\circ}$.

The work is exactly what would be expected from the author of a new Phytologia. None of Dr. Dale's plants are quoted under his own name in the printed Phytologia of 1650, but among How's MS. additions (1650-6) we have noted

'Acinos anglica flore albo in Salisbury feild neere Basing stoake, D. Dale.'

'Foeniculum at Rie. - Leucoii folii: Qu. D.'

'Typha

He was the first person to point out 'Juncus caule Triangulati' (? the rare Galingale Cyperus longus) growing at the Horse ferry at Westminster and to record "Vicia fol. graminco siliqua porrectissima' about Tyburn and Maribone Park. Merrett, who printed these records in $1667,{ }^{1}$ designates him as 'insignis Britannicus'.

1 Merrett, Pinax, 67, 125 . 
There can, therefore, be no doubt that there was such a person : the trouble is to identify him among the numerous Dales who were living at the time. Unfortunately his christian name is nowhere mentioned. I was at first inclined to think that Sir D'Arcy Power, who has the credit of a first attempt, was right in identifying Dr. Dale with the Dr. Robert Dale, said to be of Magdalen College, who was admitted an Extra-Licentiate of the College of Physicians in $1663 .^{1}$ But this is rather too late a date for our botanist. Merrett alludes to his death, but not as if it were a recent event. It may have occurred before the Fire and the Plague, probably shortly before Goodyer's own death in 1664 , for else it would be hard to explain the presence of Dale MSS. among the Goodyer papers.

While engaged in an unsuccessful hunt for Robert Dale's will at Somerset House, I found the will of Dr. John Dale, which connects many of the clues and is a surer guide to the identity of our botanist.

JOHN DALE, Doctor of Physick, of the parish of St. Martin's in the Fields, bequeaths to poore neighbours of St. Martin's Parish $\mathcal{L} 5$; to poore of East Meon $£ 5$; to poore of Petersfield $£ 5$; to poore of Gosport $£ 5$; to Mr. Hunt $£ 5$; to Mr. Gray $£ 5$; to brother Andrew Vidian and wife $£ 5$; to sister Codd 20s., to sister Browne 20s., to Mr. Darlaston and wife $40 S_{\text {., for }}$ rings; to wife Blanche Dale, his sole exō, lease of house in Long Acre and lease of his impropriate parsonage of East Meon. Brother-in-law Andrew Vidian and 'my very good friend John Goodyer of Petersfield ' to be overseers and to have a ring of 40s. Will dated $30 \mathrm{Apr}$. in the presence of W. Darlaston, Mary Robinson, Eliz. Coleman. Proved 27 May I662, after the death of Blanche his widow.Abstract of P. C. C. Laud. 63.

We hope that some local genealogist will follow the family further. 'Sister Browne' may have been related to the Brownes of East Hoo, already mentioned; and Mr. Gray may have been the herborist friend of O. Bilson (p. 20I), but the names are too widespread to be a trustworthy guide.

1 Munk records that Robert Dale was a Bachelor of Arts of Magdalen College, Oxford, who practised medicine at Stourbridge in Worcestershire and was admitted an Extra-Licentiate of the College of Physicians of London on October 1st 1663. (Roll of the Royal College of Physicians.) But I have not as yet been able to find any Robert Dale in the books of Magdalen College. John Ward elsewhere refers to an incident in the practice of a ' $\mathrm{Mr}$ ' Dale, and, in the next sentence, to 'An ichneumon frequent about Sturbridge'. Unfortunately Ward nowhere mentions his Dales' Christian names. Sir D'Arcy Power, to whom I mentioned the difficulty, has again investigated the matter, and has found among the Prattinton MS., vol.3I, at the Society of Antiquaries, an entry: 'Robert Dale Ludimagister of Free school at Stourbridge, 9 Nov. I66I'. 
It secms probable that Goodyer, if not already in possession of Dale's botanical papers, would have annexed them as part of his duty as overseer of the will, and on his death (1664) they may have been among those which Yalden lent to Merrett.

Dr. John Dale, unlike Robert, does not appear to have been licenced by the College of Physicians, of which institution Dr. Merrett was the resident Librarian. The College of Physicians was then situated in Amen Corner-very near the house of Pulleyn, the fricndly publisher who persuaded Merrett to co-operate in the proposed work. 'I could not strive against his honourable wishes', as Merrett afterwards put it. How far Dr. Dale did co-operate, we are not told. He died before the day of publication.

Merrett certainly engaged in the work with great energy. $\mathrm{He}$ purchased $8 \mathrm{co}$ figures of plants, which Johnson had caused to be engraved, with the intention of using them to embellish his book. He engaged Thomas Willisel to search for plants in those distant. parts of the kingdom which, owing to his London duties, were beyond his range. His son, Christopher, also made excursions for the same purpose, and he procured the loan of Goodyer's MSS. from Edmund Yalden.

By the inclusion of exotics and many varieties, which he had not the critical acquaintance with the subject to omit, he brought up the list of the British Flora to some $\mathbf{I}, 400$ species, a number which, only three years afterwards, was reduced to $\mathrm{I}, 0,50$ by the 'accurate Mr. Ray'。

xiv. William Browne, I629-I678.

Several of the plant-records of William Browne are quoted in the interleaved copy of How's Phytologia Britannica bequeathed to Magdalen College by John Goodyer. They are all in the handwriting of William How.

William Browne was known to Wood as his examiner, and also to Peshall as a native of Oxford, his father being described alternatively as William Brown, a Mercer of Oxford, ${ }^{1}$ or as John Browne, a Bailiff of the City." He had a distinguished career at Magdalen College, becoming B.A. in 1647, M.A. in 1650 , and B.D. in 1665 . He succeeded to a Fellowship in 1657 , was Praelector of Moral Philosophy in 1658 , Dean of Divinity in 1659 . and Vice-President in $1669-1670$. He died suddenly about the age of fifty, and was

1 Peshall, City of Oxford, add. 29.

2 Wood, Hist., p. 344, ed. Gutch. 
buried in the Antechapel of his College. A gravestone of black marble preserves his memory:

H. S. E.

GULIELMUS BROWNE S. T. B.

HUJUS COLLEGII SOCIUS

VIR

INDUSTRIAE INDEFESSAE,

ERUDITIONIS PERSPECTAE :

QUI S. THEOLOGIAE HORAS COMPOSITAS

REI BOTANICAE SUCCESIVAS

IMPENDENS,

IN UTRAQUE EMICUIT

APOPLEXIA CORREPTUS SUCCUBUIT

FATO MULTUM LUGENDO

NISI VIXISSET INDIES MORITURUS.

OB. MAR. 25, AN. AET. $49^{\circ}$

MD CLXXVIII.

Canon Vaughan ${ }^{1}$ favours the view that the presence of so wellknown a botanist at Magdalen College would account for Goodyer's gift of botanical books to the College; and this idea would gain in probability if we could establish a close kinship between William Browne of Magdalen and Goodyer's Hampshire neighbour of the same name. But so far we have not found any evidence on this point.

Mr. Druce (Flora Berks., p. cvi) is not quite right in saying that no certain writing of Browne's has been discovered, for we have specimens of his signature at Magdalen, and for several reasons we believe that Druce is also mistaken in suggesting that the MS. notes in one of the Bodleian copies of Lyte's Herbal were made by Browne: they are obviously by an earlier member of Magdalen College who had studied at Padua.

Browne is best known through the Catalogus Horti Botanici Oxoniensis prepared by Bobart, Dr. Stephens, the Principal of Magdalen Hall, and himself in collaboration, but both Anthony Wood and Merrett agree 'that he had the chief hand in it', and the MS. copy in the British Museum gives his name as that of the author.

Attention has been drawn to the fact that in this edition the authors have, in every instance where it was possible, not only adopted the scientific appellation given by Gerard and Parkinson

${ }^{1}$ Cornhill Magazine, 1909, p. 802. 
to each plant, but also quoted the page of their works. Druce ${ }^{1}$ claims priority in England for this procedure for the authors jointly. It is quite likely that Browne, rather than Bobart, was responsible for the innovation, but as the quotation of authoritics by pages had been the usual everyday practice of Browne's friend Goodyer for the past thirty years, any credit for priority or precept in this matter should be given to the latter.

There are many citations from him printed in Dr. Merrett's Pinax, and although he does not appear as one of the contributors to the Phytologia, perhaps because How was not acquainted with him before 16.50 , or because he had not then paid much attention to botany, yet he was able to supplement that work with several valuable additions which How duly entered in his interleaved copy of the Phytologic already referred to. Most of these citations are distinguished by a peculiar mark, a $\Delta$ in a square.

\section{The Plant Records of William Browne, entered by How in his copy of the 'Phytologia', 1650-1656.}

Anagallis aquatica, sive Becabunga flore albo. Veronica Beccabunga L. in fossis aliquibus sub colle Heddington prope Oxonium. Guil. Browne Oxon:

Atriplex marina latifolia tota rubra.

Atriplex patulu L.

E radice tenui et fibrata caules exit sesquicubitales ramulis donatos frequentissimis folia ferentes in extremitate angusta et acuta in media et una parte lata et acuminata ubique densa et admodum rubra hortis translata ruborem fidelissime servat, flosculi ex viridi rubescunt, semina sunt angularia, et eiusdem ruboris cum Asteris (?) plantae partibus occurrit ad maris littus prope Shoram comitat: Sussexi. Guil. Browne Oxon:

Behen album hispidum.

Silene Cucubalus Wib.

Planta est ubique obvia adhuc tamen non descripta. Guil: Browne Oxon.

Colchicum Anglicum purpureum duplici serie foliorum in flore.

Colchicum Anglicum saturationis purpureae.

Colchicum Anglicum florum foliis ex albo et purpureo dimidiatim variegatis.

Colchicum autumnale $\mathrm{L}$.

Haec tria proveniunt in prato amoenissimo prope pagum vernaculem Combe, Comit: Oxon:, ubi flore albo plurima sunt et vulgaris purpurae millia. Guil. Browne Oxon.

1 Druce, Flora Oxford, p. 373. 
Colchicum Anglicum, foliis elegantissime striatis.

in prato prope Corneberry, Comitatu Oxon., gramen striatum. pulchritudine multum superat colores horto meo pluribus annis iactavit. Guil. Browne.

Cotula alba. Mayweed.

Anthemis Cotula L.

Et flore pleno ex luteo viridi reperitur [juxta Oxon. erased] Dorcestria versus Comit. Oxon. via regia vulgo Honey Fixlong. Guil. Browne Oxon.

Geranium columbinum minus foliis magis dissectis et foliis minus dissectis in agris sterilibus, variat. flore albo. Guil. Br. Oxon.

Geranium molle L. and $G$. dissectum L.

Lysimachia, sive Gratiola latifolia flore albo in pagulo vulgo Purbright Comitat: Surriae. Guil. Browne Oxon. Scutellaria minor Huds.

Orchis Antropophora trunco pallido, brachiis et cruribus saturate rubescentibus. The Red Shanke. Roy Satyrion. Hasce Orchides rariores in cretaceis quibusdam collibus observant non procul a via communi qua itur Wallingfordio Reddingam per Comitatum Bercherium. Guil. Browne Oxon. Orchis simia Lam.?

Orchis, sive Cynosorchis militans holosericea, hanc orchidum merito reginam inveni juxta mediam partem viae communis inter Nettleton et Bathe communicante D.D. Stevens Botanico perito. G. Browne Oxon.

Orchis militaris L.

Orchis, sive Cynosorchis Austriaca flore albo colle Chilswelliensi prope Oxonium. Guil. Browne Oxon:

Orchis ustulata L.

Periclymenum syl: 3 plici serie florum ex luteo virentium, alioqui toto habitu a vulgari non dissimile, colle vulgo Shotover juxta Oxonium.

Lonicera Periclymenum L.

Periclymenum alterum quercinis foliis, perelegans planta; observavi in colle Chilswelliensi prope Oxonium. G. B. Oxon.

Plantago quinquenervia fimbriis latis ex aureo argenteis, hanc nitidam plantam juxta Corneberry exploravi Comitat: 'Oxon. Guil. Browne Oxon.

Plantago major L. var.

Ranunculus pumilus floribus deciduis.

? Ranunculus parviflorus.

The whole plant seldome exceeds 3 inches in compasse and in his full strength and flowring is not above an inch or 2 high, amongst a hundred plants of them $y^{t} \mathrm{I}$ found not far from Oxford though it were in ye time of their flowring I could not find one with a whole flower, severall of these had 3,4 or 5 little yellow leaves of flowers about a small thrum of yellow pointells, and every plant had fresh yellow pointells, with the leaves as it were new fallen of. [It has not yet flowered in my garden. Erased.]

Rosa pimpinella foliis flore suaverubente, in agris sterilibus prope Worcestriam. Guil. Browne Oxon:

Rosa spinosissima L. 
Saxifraga aurea, maior, foliis, pediculis longis insidentibus. Juxta radicem tenuem albam et repentem folia edit rotunda ex luteo virentia innata itaque hirsuta, paediculis paene triuncialibus saniculae guttatae foliis non dissimilia; cauliculos profert plurimos palmares juxta summitatem parum divisos vel plurimum unico tantum folio, aliquando altero ornatos; flosculi aurei foliis plurimis decore lutescentibus longescunt. Hanc saxifragam vere auream copiose inveni in paludoso nemori non procul ab aedibus D. Fanteleroij in pago vulgo Hedley vocato Comitati Hamptonis ubi Dryopteridis Trag. iuxta et Calami Aromatici cum Julo ad humanam altitudinem assurgentis gliscit copia. Guil. Browne Oxon.

Chrysosplenium alternifolium $\mathrm{L}$.

Solanum marinum Dulcamarae congener. Solanum Dulcamara L.

E radice longa dura et perenni, caulem profert crassum glabrum atque humi procumbentem, pedalem vel sesquipedalem longitudinem nunquam superantem ubi sponte emergit, folia ferentem Solani lignosi duplo densiora et saturationis multo viriditatis, Augusto floribus ornatur et albis et violaceis, utrius coloris copiose: reperitur ad maris littus iuxta Shoram Sussexio. Guil. Browne Oxon:

Trachelium minus flore albo in pago Worplesdowne vocato, Comitat. Surriae locus floribus albis admodum insignis. Guil. Browne Oxon: Campanula glomerata L.

On blank page at end.

Cynoglossum foliis variegatis.

Hypericon flore albicaster.

Orchys Sphegodes fiore albo.

Mrs. Yalding about Guilford.

Sium cubitate fol. variis non des[criptum]: a very beautifull plant about Redding plentifully. An diff. a Sio foliis variis Phyt.? Apium inundatum Reich. f.

Qu. Br.

Carduus pratensis caule folioso is a common plant about 3 foote high and has ye same filmy stalk as ye Aster Virg. caule membranaceo Park: wee often find it with white flowers. C. pratensis L. var.

Plantago marina foliis tenuissimis, haec singulis partibus alteri non dissimilis est, sed foliolis multo tenuioribus praedita.

Echium scorpioides minus flosculis luteis Bauh. Pin. 254 growes within 3 miles of Redding plentifully. Myosotis versicolor Sm.

On blank page, f. 4 v.

Helleborus pratensis latifolius, it growes in meddowes about Lichborough in Northamptonshire. H. viridis.

Serratula flore albo. (Serratula tinctoria L.) Qu. Br. lett non. descr. 


\section{EARLY LISTS OF PLANTS GROWN IN ENGLISH GARDENS.}

Hugh Morgan of Coleman St., I569-87. See under No. xiii

i. OXFord AND Winchester Gardens, I570-2.

ii. Sir John Salusbury of Lleweni, I596, i607-8.

iii. Simon Forman, 1597-1608.

iv. LORD SAlisBURY, I6I I.

v. Richard Shanne of Woodrowe, Methley, I6I5.

vi. William Coys of Stubbers, I604, I6I6, I62 I-2.

vii. Franquevilles' Garden in Long Acre, 1600-4, $161 \%$.

viii. JOHN PARKINSON, c. I618-20.

ix. JOHN GOODYER, 1622, \&c.

x. John Tradescant, the elder. Hatfield, 16II. Lambeth, I629-34.

xi. GeORGE Gibbes, ? and I6 34 .

xii. Walter Stonehouse of Darfield, I640-4.

xiii. Edward Morgan of Westminster, I662, and Hugh Morgan, I $569-87$.

xiv. ROBERT MORISON of Blois, c. I65I ; of London, I66I-2.

The earliest English garden list that has been published is that of the Holborn garden of John Gerard, which, first printed in I 596 and again in 1599, has been re-edited in a valuable form by my friend Dr. Daydon Jackson in 1876 . One of the first results of the re-examination of the Goodyer books and papers was the recognition of one of his manuscripts as a very early list of the garden of the Rev. Walter Stonehouse at Darfield Rectory in Yorkshire, I640-I644. By the courtesy of the editor of the Gardener's' Chronicle, this was printed in full in the numbers of that Journal for May I 5, 22, 29 and June I2, I920. No sooner had this list been identified than in the same collection of papers, several other garden lists were found that successively antedated the Stonehouse list and one another, and finally gave the clue to the finding of the list of a garden that is probably older than that of Gerard.

First in importance is the unique copy of the printed plant list of the Lambeth garden of the elder John Tradescant, in which more than 750 plants are named. It is the only work known to have becn printed for the author in his lifetime: it is dated 1634 .

Then were found short lists of the gardens of John Franqueville and George Gibbes of Bath, both extending the list of plants 
alrcady known to be grown by them, and the highly interesting lists of the gardens of VVilliam Coys of Stubbers in Essex and of John Parkinson in Long Acre. Lastly, the mention of the name of Richard Shanne has led to the rediscovery of his, the oldest garden list of all that are still unprinted, in the British Museum.

The Goodyer MSS. have thus provided a richer store of definite horticultural facts relating to special English gardens, and dating from the first half of the seventeenth century, than any that has yet been published. To this material we have added a few other contemporary notes and lists, not previously published, which we came across when searching for matter relating to the early annals of English horticulture.

\section{i. OXFORd AND Winchester Gardens, I570-2.}

The following notes of plants growing in gardens in Oxford and Winchester are written by a sixtcenth-century botanist in his copy of Du Pinet's Historia Plantarum, now in the library of the Butanical Department of the British Museum: ${ }^{1}$ When no locality is mentioned, we provisionally assume the garden to have been in or near Winchester. In one case only is another county mentioned: the Olive, 'Olea sativa', p. 8I, 'at belnys nothers in Suffolk (that is not wild)', showing that in spite of Tacitus's adverse opinion of our climate the olive was being grown in England a full quarter of a century before the date of Gerard's garden list. We have suggested that the writer may have been Dr. Walter Bayley of New College, p. 235 .

\section{Henry Crosse's Oxford Garden, I570.}

The friend of the unnamed botanist may be identified with Henry Crosse, Bedell of Theology, who was Registrar of the University from ${ }^{5} 56$ to 1570 . His house and garden are of great historic interest, because there in after years (1654-68) Robert Boyle lodged, had his laboratory, and invented his famous airpump. ${ }^{2}$ There on the south side of the High Street, and not far from the quarter of the ancient Apothecaries in Oxford, Henry Crosse cultivated simples which may have been of value to his successor (and ? descendant), Crosse the apothecary, ${ }^{3}$ whose drugs

1 Sce p. 235 .

2 An engraving of the front of Crosse's house is reproduced in Gunther, Early Science in Oxford, 1920, p. I1.

${ }^{3}$ Perhaps we owe the first evidence of the Lily of the Valley as an Oxfordshire plant to Crosse. 'Lilly of ye Vallies, Crosse, ye Apothecarie, had a basket full of ye flower. They grow about Stokenchurch.' John Ward's Diary', 1665. (Information from Sir D'Arcy Power.) The first frinted 'record' for the Lily of the Valley in Oxfordshire is 'Bluckstonc, 1746'. 
and scientific entourage doubtless proved no small attraction to Robert Boyle.

Our author mentions the garden thrice.

Hedysarum aut Securidaca, Du Pinet, p. 402.

'In Crosses Garden at Oxford in 1570.'

Aethiopis, p. 557.

'In Crosses Garden at Oxford.'

Scorpioides, p. 639.

'At Oxford in Crosses garden 1570.'

Coronilla varia, L.

'In Mr. Watson's booke.'

Salvia Aethiopis, L.

Ornithopus scorpioides, L.

\section{[John] Watson's Winchester Garden, I572.}

Six of the plant-records are associated with the name of a Watson, who I think must be the John Watson (I $520-84$ ) who took an M.D. degree at Oxford, and began life practising as a physician. A native of Evesham, he became a Fellow of All Souls in 1.540. 'At length, about the time Queen Elizabeth came to the throne, if not happily before, he entred into holy orders, was made prebendary of Winchester, archdeacon of Surrey, and Master of the Hospital of St. Cross near Winchester' (I 559). In the fifteenth year of Queen Elizabeth, I572, the date of our notes, he was made Dean of Winchester. He evidently kept up his early interest in medicine, for in $\mathbf{1} 575$ he was admitted to the degree of Dr. of Physick. He became Bishop of Winchester in I580.

Some of the notes refer to a 'booke' which we take to be a Hortus siccus, which may have also included wild plants. His garden is likely to have been at St. Cross.

Myrica s. Tamarix, Du Pinet, p. 55.

Tamarix gallica, L.

'In Mr. Watson's booke and garden 1572. Of this there is said to be 2 kyndes, the greater bearing fruit like to the lesser oake apples or gaules, the other bearing grayeish leaves without fruite.'

Ornithogallum, p. 207.

Ornithogalum umbellatum, L.

'In Mr. Watson's booke.'

Gratiola, p. 290.

Gratiola officinalis, L.

'A kynd of the lesser Centaurie in Mr. Watson's and S. Cross, 1570.'

Althaea Ibisc, p. 420.

Althaec officinalis, $\mathrm{L}$.

'Mr. Watson's garden.'

Althaea sive Bismalva, p. $42 \mathrm{I}$.

Malva Alcea, L.

'Mr. Watson's garden.'

Centaurium maius, p. 270.

'In Mr. Barnaby's garden and Mr. Watson's booke.'

\section{JAMES' Winchester GaRden.}

Cornus, p. 108.

Cornus mas, L.

'In Mr. Jeames garden at Winchester.' 


\section{BARNABY'S GARDEN.}

Cicer, p. 136.

'Chiche. Mr. Barnbyes garden.'

Centaurium maius, p. 270.

Cicer arietinum, $\mathrm{L}$.

Centaurea Centaureum, L.

'In Mr. Barnaby's garden and Mr. Watson's booke.'

Acanthus, p. 277.

Acanthus mollis, L.

'Mr. Barnbyes garden.'

Ammi, p. 329.

Ammi majus, L.

'Mr. Barabyes garden.'

Alchimilla, p. 57 r.

Alchemilla vulgaris, $\mathrm{L}$.

'Mr. Barabyes garden.'

\section{Heyden's GARDEN, I570.'}

Aristolochia longa, p. 268.

Aristolochia longa, L.

'In Mr. Heden's garden.'

Stachys, p. 366.

Stachys germanica, L.

'In Mr. Heiden's garden I 570.'

Hypecoum, p. 4 Io.

Hibiscus trionum, L.

'In Mr. Heidens garden.'

Mandragoras, p. 5 I2.

Mandragora officinalis, L.

'In Hedans garden.'

Galega, p. 584 .

Scandix Pecten-Veneris, L.

'Sheperds neydle. In Mr. Heidēs garden.'

Tithymalus cyparissias, p. 6og.

'In Mr. Heidēs garden.'

Euphorbia Cyparissias, L.

The Gardens of NORTON, Wallop aND BASkET, AND TIIAT OF DUMMER RECTORY.

All names are well known in Hampshire. The Nortons owned land in Nutley, which is near Dummer.

Anemone altera, p. 250.

Anemone sp.

'In Norton's garden.'

Trifolium odoratum, p. 372.

Melilotus officinalis, $\mathrm{L}$.

'In Mr. Basket's garden.'

Antirrhinum, p. 579.

Antirrhinum majus, L.

'At Dümer in the p̄stes garden.'

Cupressus, p. 40.

Cupressus sempervirens, L.

'Wallops Gardens at hāpton.' [? Southampton.]

[Sir Henry Wallop was a very important personage at the time.]

ii. Sir John Salusbury's Garden at Lleweni, 1596, 1607-8.

The botanical records entered by Sir John Salusbury in his copy of Gerard's Herbal have already been described, p. 243. Tivo documents in Oxford mention the Lleweni gardens in the seventeenth

1 A Benjamin Heyden of Hants matric. at New College in 1586, and became a master at Winchester College. 
century, and it has been suggested that a passage in a poem by Salusbury's friend and 'Court poet', Robert Chester, described the site. $^{1}$ Elsewhere Chester records in verse a failure of fruit due to an unusually cold spring about the end of the sixteenth century. ${ }^{2}$ The lines were written for A merrimt of christmas at the house of the Right Worshipfull Fohn Salusbury of Lezveny, Esq. After stating that the occasion was one on which 'we of Arcadia sometime frolique swaines'

'should heare present as newe yeares homely gift peares Apples fild bieres or the hazell nut or other fruite that this faire clymatt yelds but nipping winter and a forward spring blasted our trees and all our summer budds whose blossomes should have yelded dainty fare'

the poet goes on to propose a hornepipe, songs, and a dance.

Sir John grew three novelties which he considered worthy of mention in his Herbal. Two of them he raised from seed, which he may have obtained from Gerard, and to his evident satisfaction they proved true to the pictures in the Herbal.

\section{Helianthus annuus, L.}

'This galant greate sunflower grewe in Sir John Salusbury's Garden at Llewenye \& cam to the full perfection of this portraiture the yeare 1607.

Datura Metel, L. The Smooth Thorn Apple introduced by Gerard from Robin.

'This faire herbe grewe to full perfection accordinge to the portraiture in

Sir J. S. his Gardeyne at Lleweny in the yeare of our Lord 1607.'

Paris quadrifolia, L., he transplanted to his garden in 1608 .

Marks in the margins of the book show that he was well acquainted with a large number of garden plants, but the only one that is

1 Chester, Love's Martyr, p. II :

Hard by a running streame or crystall fountaine,

Wherein rich Orient pearle is often found,

Enuiron'd with a high and steepie mountaine,

A fertill soile and fruitful plot of ground,

There shalt thou find true Honors lovely Squire,

That for this Phoenix keepes Prometheus fire.

$\mathrm{His}$ bower wherein he lodgeth all the night,

Is fram'd of Caedars and high loftie Pine.

An ancient well-head is one of the antiquities at Lleweni, and there still remains the stump of a very old cedar that is figured in one of the engravings of the old Hall near the artificial lake.

${ }^{2}$ It has already been noticed that the weather about this time was most unpropitious. 'For a series of years, wet summers had raised the price of corn, and in 1596 wheat in London reached the famine price of $£ 540$ per quarter; this too when the purchasing power of money was fully six times its present value.' Jackson, Gerard's Catalogue, vii. 
further described is a variety of Clove Pink: 'At Seaton in Northumberland at the House of the Right Worthy Sir Ralphe Delavale ${ }^{1}$ is a Clove Gilloflower almost perfecte blacke.' The production of artificial varieties among Gilliflowers was known to Shakespeare, see p. 6 I.

Sir John's garden continued to flourish long after his death. I have recently found unexpected evidence as to its state in the year I680 in a letter contained in the Hortus siccus of Edward Morgan in the Bodleian Library (Ashm. MS. 1797). This collection of plants seems to have been begun in 1672 , and to have received additions until 1682 ; unfortunately the plants, which are arranged alphabetically are not localized. The collection includes specimens of Vicia Bathoniensis Goodyeri and of the four species of Elms described by him.

The letter is addressed

ffor Mr. Edward Morgan living att

Bodesclen, theis deliver with a Basged with Care. MR.

MORGAN my humbell servis to you returning you humbell thanks for my plants \& seeds I have send you theis seeds folwing which I thought would bee exceptabell to you. And I have send you what plants as I know of what you have send for and if you have a mind of any thing that you know to bee in Leweny gardens I shall bee redy to serve you in other plants or seeds; and so with my humbell serveis to you I rest and remane to serve you whilst I am

Lleweny $20^{\text {th }}$ day of Sept. [c. 1680$]$

Dubell wh popy

evear lasting pece

Dubell throtwort

Sweet William out of ye potts

Jarman Cachfley

Pollyanthus

Scarllet Popys

Ross Larkheell

Bedford pinke

2 faces under a hood

blew bodell

THO THORNES.

Littell snipt Canpion

Venus Lookinglas

Pollyanthus out of ye Litell Garden

ffenill flower

Marsh mallows

harey sen Johns wort

hashed fish

Sweet Scabious

dubell Collanbine

Vulnearia for yor oneld (oueld ?) Cock

I pray if you have any of theis plants to send mee a few of

Sanicell

Parsly Ston broke

Barren wort

As bodill

Anons

Fraxsenella ore Dittany

Dragon wort

Glass wort
Spare wort

Laser wort

Iron wort

Mony wort

Moth wort

l'ony wort

Corall wort

Cross wort

Fig wort

Mr. Harisson presents his servis to you and Will. Tomas \& Coocke.

[At end Morgan's List of Plants in the Appendix to his Hortus siccus.]

${ }^{1}$ Craster, Hist. Northumberland, Tynemouth, describes his coal-mining. 
At the present day, alas, the splendours of Lleweni are no more. The far-famed agricultural wealth of the Vale of Clwyd has not proved sufficient to maintain the larger country houses of the Tudors, let alone their gardens, and the great house of the Salusburys is now only represented by a couple of large farm houses, the one in the stables and the other in the offices of the old mansion. A huge walled orchard still remains, though the trees have run wild and its high walls have been partly removed for building material; and there are scattered fruit trees in the woods.

The original flower gardens seem to have been altered before the demolition of the house, in accordance with the cult of the 'landscape' inculcated by the eighteenth-century school of Kent and Capability Brown, while the architecture of the house was being remodelled in the style of Adam. The present tenant, Mrs. Roberts, informs me that the present garden is largely within the lines of the foundations of the old Hall, but that all tradition of the original gardens has been lost.

iii. Dr. Simon Forman's Lambeth Garden, I608.

The strictly scientific character of Goodyer's writings, revealing the practical attitude of his mind, is remarkable in an age when so many of his 'scientific' contemporaries were seduced by the specious promises of astrology, alchemy, and divination, legacies from Arabian civilization. The astrological gardening of the time is illustrated by a fragment from the diary of a former member of Magdalen College, which will at any rate be of interest to those who make a detailed study of the topography of London.

Thurneiser, Winckler, and Cúlpeper have all emphasized the importance of gathering roots and 'enchanted herbs' under particular stars, but Forman evidently believed in the influence of the moon on planting as well.

The first entries evidently refer to the acquisition of the site.

I 596. 29 Jan. at 4 I went first to see the garden. On $30 \mathrm{Jan} . .$. I went to spek with Mr. Katerins for his garden.

1597. This yere betwen Michelmas and Christmas I toke Lambeth House and entred yt a moneth after Christmas. Lambeth House at Westminster, nota. 1607 .

I5 July at 7 p.m. I began to cut and bush up the garden of Roses at Lambeth Marsh ${ }^{1}$ and I began in the north west part and made som dossen bushes or better.

3o Aug. I put the gilliflowers in the flower (?) garden.

${ }^{1}$ Lambeth Marsh was due east of the end of Westminster Bridge. Seven houses only are shown there in a map of 1560. 


\section{Trees planted in 1608 .}

Anno 1608 the 29 of November post mer. I set the framboy trees under the west pall all along at Lambeth Marshe post mer. at 30 p. 3 in Haufilds garden.

The 7 dai Decemb. $\bar{q}$ I set the willowes all alonge towarde the Lane, and at afternon at 33 set the first rose tre at the bankes end toward the door by the Lane $\mathbb{\theta}$ in $\gamma \sigma \bar{\omega} \psi$

The 8 dai 4 p.m. at 2 , I set the rest of the rose tres all along the bank towards the Lane $\mathbb{a}$ in $\succ \ldots$. pt a $q$ ap $\triangle \sigma^{7}$ in \& \& 6 more rose tres on the bank at Davies syd toward the lane.

The 9 dai o I set all the other rosse .... toward Davies syd from the pryvi Doun toward the Lane but only 6 which wer set the night before those that stand towards Davies syd towards the Lane.

Also the 9 dai December I set the 6 philberts and the 2 pech trees and they stand right against the postes at the ends, vz. toward the lane 1 towards the hous. The camonill on the banck by the pryvi and the premrose were set the 9 dai at 3 p. merid.

The 16 dai of Decemb. 9 p.m. I set the roses and 2 apple tres all along by the palle toward Hammons garden \& Mr. Walters garden except those west the arb exept to Mr. Walterers garden \& in $m$.

The roses by the gose berryes and all the small roses under Waterers pall wer set I 609 the 4 of January a.m. between 9 \& II of the pmeks (?).

The first beanes I set this year 1609 wer set the 7 dai of January $\mathbf{l} \ldots$ between $8 \& 9 \&$ they wer set in Haufilde garden all along from the corner of the pall from the pryvi by the Raspis \& so along by John Davies garden to the lane, \& all along the banck by the lane in both gardenes, $\&$ they wer watered 24 howares befor, 4 daies befor the $\mathbb{\text { was }}$ at full.

[MS. Ashm.2402, f. 37.]

\section{iv. Lord Salisbury's Garden at HatField, i6 II. See below under J. TRADESCANT.}

\section{v. Richard Shanne's Garden List, I6I5.}

See p. 264.

Richard Shanne of Woodrowe near Methley in Yorkshire was planting woods and orchards as early as 1577 . The entries in his diary come down to 1617 , so that it is exceedingly probable that many of the plants named in his list were being cultivated by him long before the date of the writing out of the list. His observations on the weather are of great local interest.

\section{THE NAMES OF ALL THE HERBES \\ growinge together at this daic in my Garden, and fyrst of the plants called gramen striatum.

$$
\text { RICHALD SHANNE. } 1615 .
$$

Ladies Girdle.

Blewe flower de luce.

Purple ," ,

Whit ", "'

Narrowe leaved flower de luce.

An other flower de luce.

Velvet
Bulbed blewe flower de luce.

Bulbed Chaungable flower de luce.

An other bulbed

Stinkinge Gladon.

Kings Speare.

Gladeolus cleare red. 
Yellowe Lillie with - blades.

Day

May

Whit

Great red "illie.

Small red

Pearle red

Calcedonian Lillie.

Mountaine

,

Swete yellowe

Imperiall

Hyachinthus Whit flo:

$\begin{array}{ll}, & \text { purple. } \\ , & \text { Ash cullour. } \\ , & \text { Skye collour. } \\ \text { " } & \text { Botroides. } \\ \text { bush topp. }\end{array}$

Narcissus yellowe Circle.

$$
, \quad \text { redd Circle. }
$$

" doble flowers.

yellowe flowers.

Tulipa $w^{\text {tha }}$ yellowe flowers.

Tulipa precox with yellowe flowers.

,$\quad$ with flowers redd \& yellow.

, bright red flowers.

, darke red flowers.

, whit flowers.

" apple blome cullour and thirtie or fortie more varieties.

Fritillaria Chekered Daffodilly.

Doble Daffodillie.

Snowe Dropps.

Saffron three kynds.

Starr of Jerusalem.

Starr of Bethlem.

Scodoraprasum.

Sarpents Molie.

Raphanus.

Dittander.

Tarragon.

Succorie.

Endive.

Orach whit.

, redd.

Winter cherries.

Yellowe henbane.

Doble poppie divers kynds.

Anemone scarlet coullour. blewe flowers.

Munkes Ruberbe.

Bistorte.

Scurvie grasse.

Adders tounge.

Herbe Trewlove.

Lunaria minor.

" maior.

Rose plantaine.

Goulden Rodd.

Sopewort Gentian.

Bell flowers.
Dames violetts.

Doble campions.

Flower Constantinople.

Lysimachia blewe flower.

$$
\text { , purple flower. }
$$

Thorowe leafe. yellow flower.

Tutsan.

Time of Candie.

Yellow Time.

Winter Savourie.

Sommer

Dodder.

Whit Hyssope.

Yellow

Greene

Lavander gentle.

$$
\text { , spike. }
$$

Maile Lavander.

Gilliflowers manie kindes.

Sweet Williams.

London Tufts.

Thrift.

Sneese wort.

Gromell.

Everlastinge.

Cost Marie.

Maudlaine.

Doble Tanseie. , feverfewe.

Germander.

Sweet marjerome.

Pott

Yellow "

Pennie Riall.

Mints divers kynds.

Calamints.

Balme.

Motherwort.

Avicen's Agrimonie.

Sawwoorte.

Betanie $w^{\text {th }}$ whit flowers.

Mountaine Scabious.

Great blewe Bottell.

Marigoulds all the kynds.

Sage divers kynds.

Claray.

Oculus Christi.

Doble Cowslipps.

Double Primrose.

Bears eare.

Spotted sanicle.

Sanicula alpina.

Ladies mantle.

Enula campana.

Borage $w^{\text {th }}$ whit flowers.

" blewe "

Comfrey. $w^{\text {th }}$ whit , , purple,

Cowslipps of Jerusalem.

Dragon. 
Assarabacca.

Whit Double Violets.

Blew

Ladies Bower or Virgins Bow.

An other Virgins Bower.

Periwincle $w^{\text {th }}$ whit flowers.

\section{Asclepias.}

$$
\text { purple flowers. }
$$

blewe flowers.

Salamons seale.

Double holihocks sundrie collours.

Single , divers kynds.

Mary mallowes.

Musled Cranes bill.

Double Gouldins.

Globe flowers.

Wolves baines two kynds.

Hellibor Blacke.

Bastard Hellibore.

Double peonie redd.

Female ", the lesse.
Maile ", " great.
Angellica.
Bastard pellitorie.
Herbe Gerard.

Clounes Allheale.

Lovage.

Corianders.

Smallage.

Alexanders.

Fennell (giant).

Dill.

Chervill.

Myrhis or Sifilis.

Spignel.

Filipendula.

Setwall Valerian.

Grekish ,

Larkes peele redd, white \& blew.

Columbines all cullours doble.

Romaine wormwood.

Oke of Jerusalem.

Lavander Cotton.

Asparagus.

Madder.

Carduus benedictus.

Ladies thistle.

Artichokes.

Cirsium.

Kidnie beanes.

Lupines.

Rewe.

PLANTS OF WODDIE SUBSTANCE

Red Rose.

Whit,

Damask Rose.

Provence , ,

Yellowe ,

Cynamon ,

Muske ,

Gelderland ",

Rosmarie.

Woodbine thorow leafe.

Leneholans.

Pescod tree.
Yellowe Goosberies.

Red Goosberies.

Savey Tree.

Tamariske.

Privitt.

Chesnut Tre.

Sycamor Tre.

Quince Tre.

Medler Tre.

Mulberie Tre.

Job's teares.

Firr tre.

\section{vi. WiLlian COYS' ${ }^{1}$ GARDEN I604-I6I6.}

William Coys' garden at Stubbers in Essex has already been described, p. I7. It will always be remembered in horticulture as the classic locality where the Yucca first flowered in England,

' Mr. C. B. Russell has very kindly supplied extracts from the Parish Register of North Ockendon which show that William Coys was buried on 9 March 1627, having lost his wife Mary ten years previously. His tombstone which is not now visible, is stated in the Essex Archaeological Society's Journal, to have borne an inscription, the dates of which do not agree with those given in the Register. It probably ran as follows:

Here under ly buried the Bodies of William Coys of Stubbers in this parish Esquier, who decessed the 6 day of March 1627 and of Marie his wife, the second daughter of Giles Aleyne of Hasleigh Hall in the County 
and whence Goodyer obtained so many. Spanish plants from the stock recently imported by the traveller William Boel. We now know that it was the station whence the newly imported Ivy-leaved

Noulagloriofe elata or opinata YVCA.

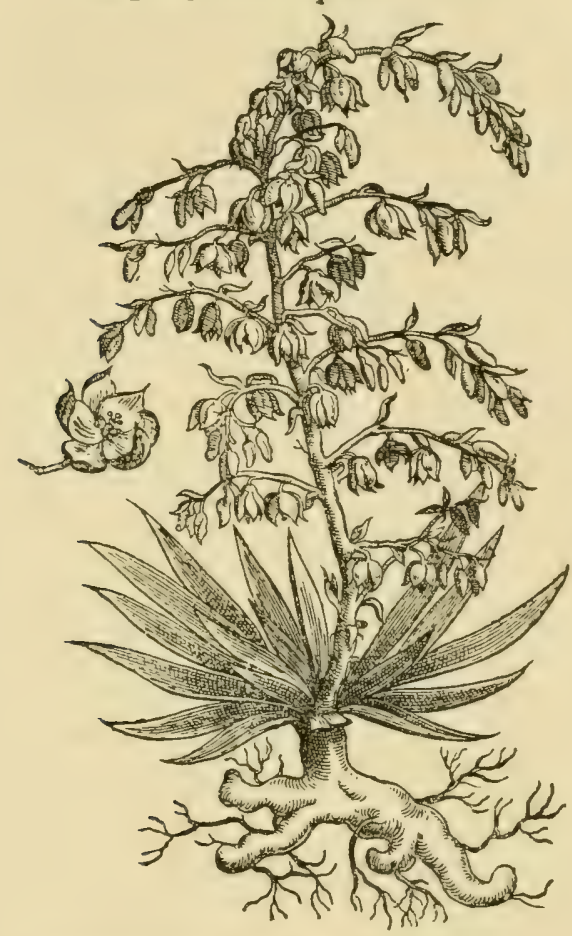

fatim Clariffimus \& piiffimus V.D. Guil.Coys

COYS' YucCa, AFTER LOBEL, I605.

of Essex, Esq who decessed ye $13^{\text {th }}$ Day of March 1617 who had issue 8 sonnes and 6 daughters

And here's the worst that envious Death could doe

Let loose two soules that long'd to Heaven to goe.

Of his fourteen children, Matthew, bapt. 1594, bur. I595 ; Daniel, bur. 1595 ; Maralah, b. 1596; Matthew, bapt. 1596; and Sylvanus, bur. 1613, are all mentioned in the Register. Giles Coys, whose children were born between 1627 and 1632 , was the eldest son. The signatures of both William and Giles Coys are written on the title-page of a copy of Daléchamp's Historia generalis Plantarum, 1587 , now in the Sherardian Collection in the Botanic Garden at Oxford. Both volumes are inscribed 'Liber Gulielmi Coys, ab $M^{\text {ro }}$ Rimee Junii 18, 1604, munc vero Aegidii Coys Sept. 4, 1627'.

By inquiry at Somerset House I found his will (P.C.C. 37 Skynner). It was dated 8 Dec. 161 8 and proved 2 April 1627, Giles Coys being named as sole executor. 
Toadflax spread over England, where Goodyer learnt about a new species of $\mathrm{E}: \mathrm{m}$, saw many other plants for the first time, and whence he stocked his Hampshire garden at Droxford.

\section{Yeast and Beer.}

If in 15 I5 so supreme a genius as Leonardo da Vinci did not despise the petty details of the preparation of his national drink, and wrote letters thereon deprecating a bad habit of making wine in uncovered vessels, so that the essence escaped to the air during fermentation, surely a scientific history of cultivators of plants should take cognizance of the first advances in practical brewing. With the name of Coys may be associated some of the earliest recorded experiments of an exact nature in what is the most fundamental operation in the whole of Biochemistry-the production of alcohol from malt. Beer has not always been the national drink of the Englishman. Only a very few years beforc Coys' childhood, an English author on Dyctary thought it necessary to define in print what this new drink, beer, really is. 'Bere is made of malte, of hoppes, and water: it is a naturall drynke for a Dutche man. And nowe of late dayes it is moche used in Englande to the detryment of many Englysshe men.' ${ }^{1}$

The older recipes give hardly more detail than this." Without knowing of its existence as a plant William Coys had made a detailed study of the culture of the Yeast plant, the results of which he communicated to Lobel, who printed them in $1605^{3}$ It is clear that he knew from experience that a small rise or fall of temperature would profoundly alter the working of yeast, and that he introduced improvements in the brewing of beer. Coys may not improbably have received his first lessons in the art of brewing from persons who could recall a time when no hopbrewed beer was made in England, for hops, it is believed, came to lingland from Flanciers on one and the same ship with 'peacocks and heretics', or, more precisely, between 1520 and 1524 . An account of brewing as practised in France had recently been published in 1600 in Surflet's translation of the Marison R'ustiqui by Charles Stevens (Estienne), but the use of yeast is not as well

1 Boorde, Dyetary, x. 256. 1542.

= Possibly Dr. Walter Bayley's MS. entitled 'Explicatio Galeni de potu . . . et praecipue de nostrae Alae ct Biriac paratione, might be helpful, but though said to have been in the Library of Robert, Earl of Aylesbury, it is not now to be found ' (D'A. Power).

Lobel, Adversaria pars allera, 1605, pp. 471-2. 
explained as in Coys' account. Owing to the improved methods of brewing advocated by Coys and others, English Beer made from Barley and Hops, became ' famous in Netherland, for England yields plenty of Hops '.'

The following is a somewhat free translation of Lobel's Latin version of Coys' recipes.

The fullest and most precisc directions in the Englislu language for the brewing of the most agrecable and wholesome of all German \& English Cerevisia or Beer, that is at once most suitable for use in warm countries, received from the illustrious Mr. William Coy's, the highly skilled Botanist.

$\operatorname{Rec}$ Heat 40 gallons of river water, but do not let it boil. Draw off a third part into a tub and soak in it one measure of the best malt, crushed soft, for a whole hour or longer, but without heating. At the end of this time the liquor, known in England and Belgium as Wort, is strained into a suitable vessel by withdrawing a spigot from a hole at the bottom of the tub. While the straining is in progress, heat another third of the water, as described, and pour it on the liquor that has been strained for an hour.

But if you wish to brew a larger quantity of rather stonger beer, pour the second part of the hot water on to the strained malt and let it infuse for an hour or an hour and a half. At the same time heat the strained wort first prepared with 4 ounces of flowers of Hops-and for the same time ( $\mathrm{I}-\mathrm{I} \frac{1}{2}$ hours), then strain through a hair sieve and cool by pouring it into a tub. In this tub the wort must not be more than a foot in depth, though in winter it may be a little deeper. When it has got cool in summer (but luke-warm in winter), take up a fair quantity in a convenient vessel, and put to it half a pound or $8 \mathrm{oz}$. of the best barm of beer, called in English Yeast, in Belgian Gyst, and in French Gy. The yeast should be diluted and thoroughly stirred in another vessel or pitcher with three or four times its quantity of the strained wort. The pitcher is stood in the remainder of the wort in the tub, and the scum frothing up in the pitcher is allowed to overflow into the strained wort in which the pitcher is standing, so as to work up the whole of the strained wort into a state of boiling and fermentation. The second infusion of strained wort is then poured in gently, so as not to hinder the boiling. All this is done until the barm has risen sufficiently; it often rises a foot, and without reheating; and the beverage begins to smell like the strained liquor, but not bitter (for Cerevisia rapidly acquires a flavour of vinegar). Finally, the Cerevisia is kept in vessels that are filled and closed after the effervesence is over.

Light Beer. If you want a light beer (such as we usually find agreeable in summer), mix the first and last strained liquors : heat, add a sufficient quantity of hops, and proceed as aforesaid. Pour the third and last part of the hot water on the malt to yield the weakest beer of all: let it soak for two hours, and then proceed as before.

1 Moryson, Itinerary, I617. 
Then follow recipes for making:

ClREVISIA MARTIA (March Beer) invigorating, most mutritions, very lasting, keeping a year.

ALE, an agreeable drink, of the flavour of wine, as used by the first nobility of England.

\section{Coys' Garden I604-5.}

Several early printed references to plants grown by Mr. Coys show that he was the most enterprising amateur grower of his day of new and rare plants in England. His success with Primulas was praised by Lobel, ${ }^{1}$ who noted three new kinds at Stubbers, 'Primula acris semino flore, altiro superiore luteo, alteri inferiore viridi innato', two varieties of the "Primula veris ex lutcolo subviridi altius laciniata aut fimbriata', and 'Primula veris flore viridi umbellifera'. At that time, c. 1604-5, Coys had in his garden:

Allium silvestre perpusillum, Iuncifolium moschatum. Rec. from D. Leister ${ }^{2}$ from Montpelier.

Bellis spinosa elatior et fructicosior Herbariorum.

Colchicum minimum tenuifolium Gallaecium.

Crocus syl. Byzantinus serotinus candidus.

Frittillaria nigra, Pyrenaea. $\mathbf{1 6 0 5 .}$

Gladiolus minimus. flowered in May.

Narcissus Cyprius luteus polyanthes, flore pleno. Dec. 1604. Introduced by Lete ${ }^{3}$ from Cyprus.

Parvulus Hyacinthus stellaris vernus. April 1605. Received from George le Seigneur.

Yuca gloriosa. July 1604 .

The English names in italics, taken from Gerard, are given in the case of those plants which can be identified as having been included in Gerard's garden list of I599. The plants without English names, were presumably not cultivated by Gerard. The difficult task of the determination of the greater number of the species was undertaken by Dr. Daydon Jackson who in the most friendly way gave up a part of his Christmas holiday to the work.

1 Lobel, Stirpitum adversaria nowa, altera pars. Lond. 1605.

2 Perhaps Dr. EDward Lister, c. 1556-1620. Physician to Queen Elizabeth.

${ }^{3}$ NiCHOLAS LETE a London merchant 'greatly in love with rare and faire flowers' traded in the Levant. In the Bodleian Library there is an Account of his, dated $1601-3$, to Richard Sandy for $£ 20$ worth of drugs, including Salsaperiglia, Sassafras, Rebarbe, Licoris, and Agarick. There are notes on the ailments of himself and his family in the same book. One of the symptoms of his malady, recorded by his astrologer-physician, was that 'he picketh his nose'. He died 'about a quarter of a year after'. MS. Ashm. I 8 r, f. 66 b. 


\section{Mr. Coys his Garden. 24 \& 25 of March 1616-16r7.}

Thymbra Boelii.

Cymbalaria italica.

Cochlearia mi.

Chamaelia tricoccos.

Cistus foe.

, ledon.

" mas.

Lamium 2 Clus.

Alaternus.

Cytisus maior semp. virens.

Arbor Judae cum flo.

Chamaedris laciniatis fol.

Eryngium Alpinum.

Echium flo. rubro.

", angustifol.

, omnium maximum.

Scrophularia lusitanica.

Heliotropium indicum.

* Jacea capitulis hirsutis.

",$\quad$ albo flore.

" repens luteo flo.

Caput monacorum.

Melilot German alb. flo. "Italica.

Gratiola.
Hieratium indicum belgicum an Pylosella Syriaca.

Iudas tree. Cercis Sitiguastrum L.

The herbe Masticke. Thymus Mastichina L.

[Linaria Cymbalaria Mill.]

Cochlearia danica L.

Widow waile. Cneorum tricoccos $L$.

Female Holly Rose. Cistus salvifolius L. Cistues ladaniferus $L$.

Male Holly Rose. Cistus parviflorus Lam. Scropluularia vernalis $L$. Rhannus Alaternus $L$. Cytisus canariensis Steud. Jagred Germander. Eryngium alpinum $L$. Echium violaceum $L$. Echium creticum $L$. Echium australe Lam.? Scrophularia frutescens $L . ?$ Helianthus tuberosus $L$. ? Centaurea nevadensis $B$. \& $R$. Centaurea scabiosa $L$.

Great Knapweed. Centaurea solstitialis $L$. Cnicus eriophorus Roth. Germain Claver. Melilotus L. Italian Claver. M. italica Lam. Sweete wilde Horehound. Sideritis syriaca L.?

Galeopsis Clus. " flo. rubeo Clus.

3 Cattaria media.

Cynoglossum boeoticum.

Scorzonera latifolia. E.R. " angustifolia.

Valeriana flo. albo.

Salvia indica.

Tithymalus characias monsp. " serratus.

Sesamoides argentea.

Teucrium arborescens.

Stoebe Sarmantica altera.

Hungarie Dead Nettle. Lamiun Orvala L. Lamium var.?

Nepeta Cataria L.?

Cynoglossum pictum Ait.?

Vipers grasse. Scorzonera hispanica L. Scorzonera angustifolia $L$. Centranthus ruber $D C$. var.

Indian white Sage. Salvia officinalis $L$. Spurge. Euphorbia Characias L. [Euphorbia serrata L.] Astrocarpus Clusii J. Gay? Tree Germander. Veronica Teucrium L. Great Silver Knapweede.

Centaurea salmantica $L$ : vel $C$. splendens $L$.

Cnicus alter Clusii.

Carduncellus caeruleus Less.

* Jacea palustris lusitanica. n. d[escriptum]. ${ }^{1}$

Phaieris bulbosa.

Centaurea Seridis $\beta$ maritima Lange?

Beros ex Hispa. g. Barbarae spec.

Phalaris bulbosa $L$.

Barbarea praecox R. Br.?

Cirsium maius. $\quad$ Cnicus dissectus Willd., vel Cn. heterophyllus Roth.

${ }^{1}$ Dr. Jackson considers that this must be the 'Jacea marina' of Parkinson. 
Matricaria grata odore. Sweete Feverfew. Pyrethrum Parthenium Sm.

2 Hieratium Baeticum.

Telephium legittimum Imperati.

Cnicus Acarna L.

Petroselinum virginian." Selinum. Conioselinum canadense Torr. EN Gray? Anthyllis valentina, vel Herniaria Boelii.

Aconitum liteum ponticum.

Yellow Wolfes bane.

Frankenia hirsuta L.

Aconitum Lycoctoinum L.

" flo: Delphinii. Larkesheele Wolfesbane. Delphinium elatum L.

3 Nepitella vel Cattaria minima. Nepeta Cataria L., vel $N$. Nepetella Koch. Cattaria tuberosa.

Daucus cretensis.

Nepeta tuberosa L.

Gramen plumosum. Calaunogrostis Epigeios Roth, vel Stipa pennata $L$.

Branca ursina.

Acanthus silv. acculeatus.

Scolymus Theo.

Pimpinella agrimoniaefolio.

Primula veris minima.

Smyrnium creticum.

Hedysarum clipeatum.

Alisanders of Candie.

Smyrnium rotundifolium Mill.

Buckler Hatchet Vetch.

Hedysarum coronarium $L$.

Rha Ponticum verum. ${ }^{2}$

Rheum rhaponticum $L$.

, Helenii folio.

Centaurea Rhaponticum $L$.

Abrotanum foem. Female Southernwood. Artemisia arborescens $L$.

Buglossum scorpioides.

Echium vulgare L.?

Hipposeli[n]um marittim. Quick. ${ }^{3}$

Valeriana petraea.

Smyraium Olusatrum L.

Buphthalmum i Mathioli.

Foeniculum silv. lusitanicum.

Lychnis vectensis.

Valeriana tripteris $L$.

Anthemis tinctoric $L$.

Mentastrum montanum.

Alsine major baccifera.

Bellis spinosa.

Viola mariana.

\section{Creeping Chickrveede. Cucubulus baccifor $L$. \\ Chrysanthemum flosculosum $L$. \\ Marian Violet, or Coientrie Bels.}

Silene maritima $L$.?

Nepeta muda $L$.

Canpanula medium $L$.

1 There is no 'Petroselinum' in the flora of U.S.A.

2 'Found wilde in some of the Iles about our own land by Mr. William Quicke, a worthy Apothecarie in his time, who gave me and Mr. William Cois a famous gentleman, and a great lover of plants, some of the seede, supposing it to be differing from the common sort, but after they were growen up, we all saw there was no diversitic.' Parkinson, Theatrum, p. 930.

${ }^{3}$ Perhaps the first dated mention of Rhubarb in an English Garden. Parkinson, Theatrum, p. 157, narrates how it was brought from Thrace to Prosper Alpinus at Padua, from whence some Apothecaries in Venice had it; and Master Doctor Matthew Lister, being in Venice, obtained 3 or 4 seeds, which he sent to Parkinson who flattered himself that he was the first to grow the plant in England. His plants seeded within two or three years and he was able to furnish 'many other his friends, as well in England as beyond Sea': Coys may have been among the number. 
Myagrum thlaspi facie.

Oenanthe apii folio.

„\& cicutae folio.

Hysopus flo. albo.

Millefo ium odoratum.

Carduus Aspho, radice monsp.

Trachelium gyganteum.

Herba Doria.

Oenanthe pimpinelloides $L$.

Hemlocke Dropwoort. Oenanthe crocata L. White flowred Hyssope.

Hyssopus officinalis L. var. Achillea odorata $L$. Cnicus pratensis Willd.?
Giants Throatewort. C.latifolia L.
Captain Doreas Woundwoort. Senecio Doria L.

Erysimum cheiranthoides $L$.

Cnicus pratensis Willd.?
Giants Throatewort. C. latifolia L.
Golden rod. Solidago Virgaurea L.? Absinthe insipida. Unsavorie Wormwood. Artemisia inodora Mill. Oxalis franca. Round-leafed Sorrell. Rumex scutatus L. Selicio Italorum. Sea cabbage rom. Brassica oleracea, var. sabellica DC. Chondrus dens leonis ... lob. [writing indistinct]. Leontodon tuberosus L.? Chamaemelum albo duplo. flo. Double Cammomill.

Anthemis nobilis L. Al pleno.

Betonica maior Danica.

, " albo flore.

Colus Iovis.

Betonie. Stachys Betonica Benth.

? Stachys Betonica, Benth. var.

Heptaphillon maius.

Jupiter's Distaffe. Salvia glutinosa $L$. Alchemilla alpina $L . ?$

Levisticum verum Gerrar. Siler mont. Lob. True Lovage.

Geran. haematodes rubro flore Clus. Storks bill.

Laserpitium Siler $L$.

Geranium sanguineum $L$.

Clematis surrecta Pan. Clus. Ladies Bowre. Clematis Viticella L.

Libanotis.

Seseli.

Herbe Franckincense. Seseli Libanotis Koch.

Mentha Romana.

Ranu[nculus] globosus. Globe Crowfoote or Locker gowlons. Spanish Toothpikes. Ammi Visnaga Lam.
[Mentha spicata L.]

Trollizes europaeus $L$.

Anemone nemorum albo pleno flo. Double Wild White Windflower.

Anemone nemorosa L. var.

Crassularia maior Hispanica.

Ptarmica imperati.

Great Orfin. Sedum Telephium L.?

Arisarum latifol. Broad leafed Friers Hool. Arisanm wnigare Targ. Lactuca virgiana.

Hypecoum Clusii luteo flore.

Lactuca canadensis L.?

Horned wilde Cumin.

Rosa sine spinis.

" semper virens.

Hepatica coerulea mult.

$\mathrm{N}$ Asphodelus bulbosus maior.

Rhamnus Clusii.

Cyclamen Rom.

, hederac.

Flos Adonis.

Hypecoum procumbens L.? Rosa alpina $L$. Blew Linerwoorts.

Rosa sempervirens $L$.

Hepatica triloba Chaix. var. ? Bulbous Asphodill.

Ornithogalum pyrenaicum $L$. Rhamnus Alaternus $L$. Cyclamen europaeum $L$.

Sozubread with leanes like Inie.

Cyclamen hederifolium Willd. Adonis flower. 'Adonis autumnalis $L$.

[Melilotus Italica (erased).] 
Pulmonaria maculata.
, non maculata.

Scabiosa montana.

Cerinthe flo: rubro.

Abies vel Biota.

Cerinthe ancior $L$.

? Cerinthe major $L$.

Picea excelsa Link.

Halymus surrect. Clusii. Bastard Sea Purslane. Atriplex Halimus L. Periclymenum rectum.

Honisuckle. Lonicera alpigena $L$.

Eruca maior flo. albo.

Eruca sativa Mill.

Laburnum.

Papaver spinosum.

Hyosciamus albus.

Lysimachia flo. coeruleo.

Laburnum anagyroides Medic. Argemone mexicana $L$.

White Henbane. Hyoscyamus albus $L$. Silybum minus flore nutante (hanginge downwards). Carduus lacteus.

= Silybum eburneum Coss. \&o Dur.?

The lists next following are written on the same sheet of paper, though not under the same heading, so we cannot tell for certain whether the plants mentioned were cultivated by Coys or not.

g. ${ }^{1}$ Aster atticus. Some of them are like to Hieracium, no mention of Milk 392. Blew Starwoort. Aster Amellius L.

g. Hieracium atticus, ${ }^{2} \mathrm{I}, 2,3$. have milk in $\mathrm{y}^{\mathrm{e}}$ roots, whether all have or no. Inula crithmoides $L$.? var.

g. Rapuntium.

g. Ammi vulgare.

g. Blitum.

g. Argemone. 300.

g. Pulsatilla. 304.

g. Virga aurea. 348.

g. Perchepier. 453 .

g. Colus Jovis. 627.

Barbarea. 188.

Battata virginiana.

Pyrethrum.

Eriophorus.

Stramonium peregri et Spinosum. Great Spanish Orpin. Sedum Telephium L.? Bishops weede. Ammi majus $L$. Amaranthus Blitum $L$. vel $A$. sylvestris Desf. Argemone mexicana L.? Purple Passeflower. Anemone Pulsatilla L. Golden rod. Solidago Virgaurea $L$. Parsley piert. Alchemilla arvensis Scop. Jupiter's Distaffe. Salvia glutinosa $L$. Winter Cresses. Barbarea vulgaris R. Br. Ipomoea pandurata Mey'.? Anacyclus Pyrethrum DC. Andryale integrifolia $L$. $[S$. peregrinum $=$ Sinooth Thornapples, Datura Mctel L. $]$ [List of Virginian Plants.]

Pishimon. Prunus Virginianus.

Maracocc.

Attamusco bulbus.

Mosarus (?).

Aquascomense inter asterem et iaceam. (Some Composite.)

${ }^{1} \mathrm{~g}$. probably added by Goodyer to indicate plants described in Gerard's Herbal.

${ }^{2}$ Dr. J. notes that the false concord suggests that Goodyer must have written 'Hieracium' in place of 'Aster' from its yellow, not purple, flowers. 
anapcor (?). Pepo.

Cerastus virginianus. ${ }^{x}$

Vitis virginiana.

Periploca.

Sumac Anonymos virginianum.

Solanum virginianum.
Cucurbita Pepo L.?

Prunus virginiana $L$.?

Vitis Labrusca L. Gonolobus suberosus R. Br.?

Rhus typhina $L$. Solanum carolinense L.?

Alopecuros altera maxima Anglica paludosa. 469 .

Polypogon monspeliensis Desf.

Beane. 47I.

Vicia faba L.?

Pabulus Hyacinthus stellatus vernus. 486. Starrie Iacint.

Nar. Cyprius. 49.

Frittillaria nigra Pyrenea. 496.

Bellis spinosa. 508.

$\mathrm{T} /$ /acori Clu. 48 .

Jucca.

Gladiolus minimus. 5 I I.

Scilla bifolia L.?

Italian Daffodil. Narcissus Tazzetta L.?

Fritillaria pyrenaica $L$. Chrysanthemum flosculosum $L$.

Yucca aloifolia $L$.

Yucca gloriosa $L$.

Gladiolus imbricatues $L$.

[MS. ff. $24 \mathrm{v}, 25$.

\section{William Coys' Second and Third Garden Lists.}

Later lists in Goodyer's handwriting, dated 1621,1622 , probably include many of Coys' plants described by Goodyer either at Stubbers, or when they flowered in his garden at Droxford.

Yet another list of Coys' plants is contain 'd in a comprehensive list of garden plants known to Goodyer, which we have printed in the form of an index. Coys' plants are marked with the letter C. 324 names are so marked. See p. 387 .

In the 1622 list, plants already included in the 1621 list are omitted, but are marked with an asterisk in the $162 \mathrm{I}$ list.

$$
\text { I62I. }
$$

1622.

Acarna flo: rubro.

Aethiopis.

Alsine maior baccifera.

Antirrhinum.

Arum quorundam.

*Aracus maior Boet.

Argemone Pavio.

*Asperula flo: coeruleo.

*Astragalus marinus Lusit.

Astrantia nigra.

Atractilis flo: luteo.

Behen rubrum monspel.

Beros ex Hyspania.

Beta marina.

" alba.

" rubra.

Blattaria flo: albo et luteo.

Beta candida et rubra.

Borago sempervirens.

1 Cerastus, probably $=$ Cerasus. 
I62r。

Blitum spinosum Creticum.

Brassica monospermos.

Caltha silvestr. Baet.

Capons taile gras.

Caput monachorum.

Carduus globosus.

Cerefolium vulgare.

* Cerinthe flo. rubro.

${ }^{*}$ Christophoriana.

Chrysanthemum inscript. Baeticum. $" \quad$ creticum flo: luteo.

" tenuifolium Baet.

*Cicer rubrum.

Cicutaria marina.

Clymenum Matthioli. Lathyrus.

*Cochlearia Batavorum.

Convolvulus coerul. minor Baet.

Conyza odorata.

Cucumer agrestis.

Cyanus varius.

$"$ flo. albo.

Delphinium elatius variorum colorum.

Etrioselinum.

*Eringium Alpinum flo. albo.

Ervilia.

Faba veterum.

„ foliis serratis.

Flos Adonis.

Flos Africanus maior multiplex.

${ }^{*}$ Foenum graecum.

Geranii Baet. spēs.

* Geranium Creticum.

Gramen cristatum Baet.

*,$\quad$ lupuli glumis.

*Heptaphyllon maius.

Herba Doria Narbonensis.

Hieratium stellatum. " falcatum.

, intibaceum.

Hippolapathum rotundifol.

Hordeum nudum.

Hyosciamus luteus. Nicotiana.

Hypecoum Clusii.

Lagopus flo. ruberrimo.

Lamium $2^{\text {m }}$ Pannonicum exoticum Clus.
1622.

Botrys.

Brassica multifida.

Calamintha mont praestantior.

Caucalis maior Baet.

Centaurea ma us.

Consolida regalis.

Eringium Alpinum flo, coeruleo.

Hedysarum clypeatum.

Holyhock.

Hormium flo. coeruleo.

Hyssopus flo, albo. 
I62I.

Lapathum sativum Rhabarbarum monachorum.

Linaria minor aestiva.

Lathyrus Dumetorum Baet.

$" \quad$ flo. miniato.

$" \quad$ palustris Lusit.

" edulis Baet flo. albo.

" Baet. flo. coeruleo.

" aestivus flo. luteo.

Legumen pallidum. vlissiponensis.

Lens maior.

* ", minor.

Lychnidis Baet. spes.

Lychnis Calcedonica flo: carneo.
"
"
flo. rubro.

Lychnis coronaria flo: suaverubente.
", " flo. rubro.

* Lysimachia virginiana.

* $"$ flo: coeruleo.

* Malva flo. amplo Baet. aestiva.

Medica maxima spinosa spes.

* Medica maioris Baet. spes prima.

* $, \quad, \quad, \quad$ spes altera.

Medica Anglica minor.

Medica maior pericarpio plano.

* Melilotus Italica.

*,$\quad$ Indiae orientalis.

* , Germanica.

*,$\quad$ officinarum flo. luteo.

* Melissa Turcica.

Mill mountaine.

Myagrum monospermon.

*,$\quad$ Thlaspi facie.

Napellus vulgaris.

Nasturtium hortorum vulgare.

$$
\text { " crispum. }
$$

Oenanthe angustifolia.

Orobus hebariorum receptus.

Panax heracleum alterum.

*Panicum.

Papaver multiplex variorum colorum. , Rhoeas Baet.

\section{*Perfoliata.}

Petroselinum virginianum.

Petum Indicum folio pene obtuso.

*Phalaris maior. " minor Baet. semine nigro. Phu minus.
1622.
Millium nigrum.

Millefolium odoratum.

Myrrhis.

Good neighbourhood.

Nigella Damascena.

Papaver cornutum fio: rubro.

Phalaris Baet. 
1621 .

Pisum maculatum.

", quadratum.

*Pomum spinosum flo. albo.

*Psillium.

*Ptarmica Imperati.

Raphanus hortensis radice albo toto. " niger

*Rubia spicata.

Scabiosa montana maior flo. luteo.

-Scorpioides Bupleuri folio.

$$
\text { " siliqua crassa. }
$$

, Matthioli.

Scorsonera latifolia.

* Securidica maior.

, minor.

Silibum minus flo. nutante.

Sinapi sativum alterum.

*Solidago Saracenica.

Sonchus Africanus Boëlio.

Tanacetum inodorum.

*Thlaspi Drabae folio.

Trifolium odoratum.

Vaccaria.

Valeriana graeca flo. coeruleo.

* , mexicana.

Verbascum $4^{\text {tum }}$ Matthioli.

*Vicia Indica fructu albo.

Vrtica Romana.

136.
1622.

Pimpinella Agrimoniae foliis.

Sanicula guttata.

\section{Smyrnium Creticum.}

Stachys genuina Gerardo.

Spina solsticialis.

Redd storks bill.

Tanacetum incipidum.

Trachelium flo. coeruleo et albo.

Tragopogon foliis laciniatis.

Viola Mariana. flo: purpureo.

Sent 23 sheets wherein are 103 descriptions.

1 EDWARD LORD ZOuCH had a fine Physic garden at Hackney, of which Lobel had charge. He had travelled abroad and introduced to English gardens the Thorn Apple from Constantinople, the 'Small Candie Mustard' (Iberis umbellata L.) which grew in 'Austria, Candy, Spain, and Italy, in untoiled places and by high waie sides', and the Great Honie woort (Cerinthe major L.) (Gerard, Herbal, pp. 207, 277, 431). Lobel tells us that his plants included 'Sedum Norvegicum minus', 'Linaria lutea minima altera', 'Betonica Danica maxima', 'Phaseolus ... Indicus', and that in 1605 he had a 'new Physic Garden' in which (presumably) he grew 'Hyacinthus stellaris Bizantinus alter elegantissimus serotinus bullatus' from Constantinople, 'Moly luteum Botanicorum, fl. 1604' and 'Pancratium Indicum alterum vernum, fl. 1605', Lobel, Adv. altera pars., pp. 467, 486, 502 . 


\section{Seeds rec. from Mr. Coys 22 Marcii 1622.}

The greater aples of love.

Smaller aples of love.

blewe sommer byndweed.

Rose Columbines.

White rose Columbines.

Partie cullered Columbines.

Duble redde Columbines.

flower gentle.

fether grasse.

greate Larkes peeles.

the lesser duble french marigolds.

the greater duble french marigolds.

Duble nigella.

Spanish Nigella.

Duble Pansyes.

The marvells of Peru.

The square pease.

Crimson Scabious.

flowers of $y^{e}$ sun wth white seed. wth black seed.

Trefoyle wth a crimsen bush. 5

Balme tyme.

In toto 22 .

This seed list being in Goodyer's handwriting probably relates to seeds sown by him at Droxford.

vii. The Franquevilles' Garden, 1605, I617.

The List of Plants seen in Franqueville's garden is very short. It does not even include the Jerusalem Artichoke, in connexion with which his name will always be famous, for he supplied the original two roots to Goodyer in 1617 . It is possible that he had no very great collection of novelties at the time of Goodyer's visit.

There were two John de Franquevilles, senior and junior, and it is now impossible to distinguish their respective horticultural successes. Both were described by Lobel in 1605 as 'mercatores Cameracenses', or merchants of Cambrai, and their trading was evidently with France and the eastern Mediterranean.

\section{Franqueville's Plants noticed by Lobel c. I600-4.}

Acorus indicus aromaticus from Th. Warner from the West Indies.

Colchicum polyanthes sive multiflorum. Collected by J. Franqueville in Cambrai - a mile from ' Niervi'.

Colchicum polyanthes candidum eleganti rubore varium.

Corona polyphyllos sive foliosa. 
Crocus luteus. 3 vars.

Gladiolus minimus. May.

$" \quad$ flore albo. From J. Robin in 1601

Hyacinthus minimus serotinus elegans.

" stellatus Byzantinus v. exoticus Someri.

Iris bulbosa alba.

Lilium Corona platicaulos, sive laticaulis. $\mathbf{I} 600$.

Lilium montanum luteum. 3 vars.

Lilium sylvestre-Martagon imperiale.

Moly luteum botanicorum. Pyrenees. 1604.

Narcissi toti lutei praecocis Septentrionalium.

" floris lutei multiplicis varietates.

Narcissus Cyprius luteus polyanthes fl. pleno.

Ranunculus tripolitanus.

20 Marcii 1617 in Franquevils.

[g. = In Gerard's Garden List. $]$

Agnus castus.

Vitex Agmus Castus L

hellebo alb. ver. flo. rubente. (See below).

g. Clem[atis coerulea surrecta] Pan[nonica Clusii]. Bush Ladies Bowre.

Mart[agon] alb. flo.

Clematis integrifolia $L$.

Phalan[gium] Allobrogicum.

Anthericum Liliastrum $L$.

Leucoium magnum.

Hy[acinthus] lilij bulbus.

Jesi luteum seu Trifolium fruticans. Yellow Jasmine.

Jasminum fruticans $L$.

g. Anagyris.

Beane Trefoile. Anagyris foetida $L$.

Rhuum (?) plantaginis foliis albo $f$.

g. Tulipa pumila.

Tulipa sp.

g. Pseudo-nar[cissus] ampl. calice.

g. Lilium conval[lium] flore rubente.

g. Lotus arbor.

Daffodill. Narcissus.

May Lillie with red flowers.

Convallaria majalis $L$. var.

Nettle Tree. Celtis australis $L$.

Cerasus pumilus.

Prunus cerasus pumila $L$.

Seseli Peloponense alter.

g. Condrilla coeruleo flore.

Mentha Danica.

g. Ribes... ruber.

[Cf. p. 339.]

Sowthistle with blew flowers.

Lactuca perennis $L$.

Mint. Mentha sp.

Red Corrans. Ribes rubrum L.

[MS. f. $25 \mathrm{v}$.

Of the \& plant-names marked F in Goodyer's List of P'lants (I 620?), the following are not included above.

g. Chamaecerasus.

Dwarfe Cherrie Tree. Lonicera alpigena L.

g. Helleborus albus flo. dp. atrorubente. White Hellebore with flowers of

Laurocerasus Clusii.

a dark red colour. Veratrum nigrum $L$. 


\section{viii. John PARKInson's GaRden LIST, c. I620.}

'There is no separate list of Parkinson's plants that is identifiable, but there are convincing reasons for the belief that Goodyer, in his comprehensive list of Garden Plants, p. 387, marked those which he knew to be growing in Parkinson's garden, or which he had obtained from Parkinson, with a capital P. 250 plants are so marked.

\section{ix. JOHN GOODYER's GARDEN Lists.}

None of the many separate lists of garden plants preserved among the Goodyer papers can be indubitably produced as that of his own garden at Droxford or at Petersfield. The long list in his handwriting which we print as an index includes names of many plants known to him, and not grown either by Coys or Parkinson, but we cannot be sure that he grew them himself. And the same criticism applies to several short lists of plants in his handwriting to which neither date nor locality is attached. Such are the lists on MS. II, ff. $23,26,27,28,45,83$.

The following short list on f. 28 certainly seems to refer to his own plants.

my Cameline similis is Leucoium sylvestre Clusii.

my Sium agrorum is Petroselinum macedonicum parvo semine.

Esula rotunda.

Drabis.

Thysselinum.

Stoebe.

Oenanthe angustifolia. \& altera.

Digitalis ferruginia. Acanthus. minor flo. luteo, seed.

Mercurialis.

Herniaria.

Stachys.

Trifolium fruticans.

Blattaria purp.

Iris Italorum.
Pomum spinosum flo. albo.

Phyteuma mons.

Buphthalmum, it came for Millefolium rubrum.

Pseudodictamnus.

Cochlearia minima.

Galega.

Helleborus niger.

Scorzonera by Sorbus.

Arbor vitae.

Geranium Romanum.

Daucus Hispanicus like wild chervile. Tabaco.

Carduus globosus.

Leucoium melancholicum.

[MS. ff. I 8, 28 .

And the list of 95 names dated I6 Januarii 1620 (MS. II, f. 83) has every appearance of being a list of the more interesting plants in some private garden, with references to the pages in Gerard where they are described. This list includes 'Trinidado Tabacco'.

More probability attaches to two lists of plants dated I62I and 1622 and ending with a list of seeds obtained from William Coys in the latter year. We believe that these, or a fair proportion of them, flowered in Goodyer's garden at Droxford, and were described by him then and there. 


\section{x. The Garden Lists of John Tradescant, the Elder, d. 1638 .}

\section{The Garden of Lord Salisbury at Hatfield, I6II.}

In I6II Tradescant was in the service of Lord Salisbury, who had planted an extensive vineyard at Hatfield on a property which had been given to him in exchange for Theobalds by James I in 1607. The site was on the north side of the River Lea, on a piece of ground sloping to the south, hedged in with privet and sweet briar. The vineyard had been stocked with some 30,000 vines sent by Mme. de la Broderie, wife of the French ambassador, 500 vines from the Qucen of France, and the few Muscats mentioned below. In the winter of 161 I Cecil commissioned Tradescant to plant his garden with a selection of good fruit trees and flowers then in cultivation by the best Dutch and French growers. The original bills, still preserved at Hatfield, contain several items of horticultural interest.

Fohn Tradescant his bill for Routes flowers, seedes, trees and plants by him bought for my Lo: [the first Earl of Salisbury]. 3 and 5 Fanuary, $I 6 I 1$.

Roots of fiowers, of Roases and shrubs of strang and rare bought at Leyden in Holland $£ 3 \circ$ o

Anemones (C. Helin of Harlem)

Aprycoke, The whit

" (the archedukes gardener called Peere Vyens)

Number.

Price.

Total.

f s. $d$.

Arbor vita trees (C. Helin)

[Cherries]

Rathe ripe cherry trees (C. Helin)

Archedukes cherye (prob. of Peere Vyens)

Biggandres (Robyns)

Boores cherye, an excedyng greatt cherye (Harlem)

Currants Great Blacke (Harlem)

Great red (C. Helin)

[Cypress] Sypris trees (? Robyns) ${ }^{2}$

Echatega, double (John Jokkat)

Frittelarias (C. Helin)

Fyg trees, Whit (Robyns)

Genista hispayca (Parrys)

$\begin{array}{cl}\text { Gilliflowers, Dubble whit stok } & \text { (? Robyns) } \\ \text {, } & \text { Other }\end{array}$

Irys "calsedonye $\quad$ John Jokkat

" susyana

M"artygon pompone blanche

Martygon pompone blanche
, pompong orang coller ,"

$\begin{array}{rl} & \\ 1 & 6 s . \\ 10 & 2 s \\ 2 & 6 d . \\ 32 & 4 s . \\ 12 & 1 s . \\ 24 & 2 s . \\ 1 & \\ 12 & 1 d . \\ 6 & 2 d . \\ 200 & 1 s . \\ & \\ 40 & 3 d . \\ 2 & 2 s .\end{array}$

$\begin{array}{ll}5 & 0 \\ 6 & 0\end{array}$

200

I 0

680

120

200

120

i 0

I 0

1000

Medlar, Great M. of Naples (Brussels)

2 2s. 6 d.

100

40

20

30

200

50

1 Abstracted from the History of Gardening, I 895, by the Hon. Alicia Amherst to whom I am also indebted for the loan of the portrait blocks of Lobel and Parkinson. The items have been arranged in alphabetical order.

2 Tradescant's son introduced the American Cypress from Virginia. 
Mulbery (C. Helin)

", Blak (? Robyns)

Myrtil tre

Ollyander

Orrang trees of on years growthe grafted

[Peaches] Alberge

(? Robyns)

" Male cotton peach

$$
\text { " The Troye }
$$

Pomgranat withe many other small trees at the root (Parrys)

Quince, Lion's

" Rath ripe Portingal

Rose, Province (C. Helin)

Tulips (Harlem)

Vines, Muscat (Master Robyns)

,

?", (Brussels)

,$$
\text { , }
$$

\section{(Parrys)}

Number. Price.

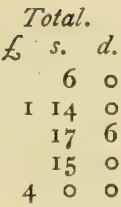

$\begin{array}{rl}2 & 3 s . \\ 17 & 2 s . \\ 7 & 2 s .6 d \\ 6 & 2 s .6 d \\ 8 & \text { Ios. }\end{array}$

$2 s$.

80

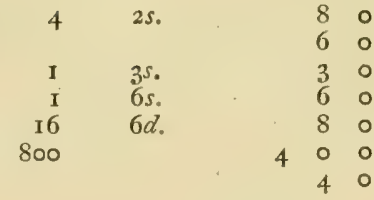

The plants were.purchased in France and Holland. Cornellis Helin lived at Haarlem. 'Master Robyns' was Jean Robin (1550-1629), a famous botanist of Paris and first curator of the 'Jardin des Plantes': several of his introductions are mentioned by Gerard to whom he sent Apocynum rectum (Marsdenia erecta), A. repens (Periploca graeca), Christophoriana (Actaea spicata, L.), Crocus luteus, Epimedium alpinum, Tropaeolum majus, Lepidium sativum, L. var., Geranium lucidum, L., Datura Metel, L. ; 'peere vyens' we have interpreted as the name of the Archduke's gardener; the name of Vines is still remembered in connexion with the Cambridge School of Botany, but in Tradescant's bill it may denote a particular kind of vine. A re-examination of the MS. might settle the question. Of Mr. John Jokkat we have no further information. A few of the plants grown in a French garden of the period are exquisitely depicted in an album recently exhibited in the S. Kensington Museum for its beautiful late sixteenth-century binding. 'The volume contains the name de Morogues, and may turn out to be a horticultural work of great interest. ${ }^{1}$ The watermark of the paper is French, c. 1570.

To this first period may be referred the interesting collection of coloured drawings of fruit-trees, popularly known as 'Tradescant's Orchard', now in the Bodleian Library (MS. Ashmole I46I). It has been suggested that the artist was the Alex. Marshall mentioned in Musaeum Tradescantianum, p. 4I. Among the names of the fruits, written by some person who was evidently quite as illiterate as the elder Tradescant, is an entry "The Amber Plum which J.T. as I take it brought out of France and groweth at Hatfeld'. This shows that the writer of the names is not likely to have been Tradescant himself. The collection of trees illustrated, which are arranged in the order of fruiting, may have been similar to the selection chosen by Tradescant for Lord Salisbury: the pictures were certainly painted as a guide-book for the use of visitors to the garden; on the first page is written 'Heare by the figures you may finde each fruite'.

For the sake of facilitating comparison, we have printed the

${ }^{1}$ Since identified by Mr. S. Savage as the work of 'Jaques le Moyne dit de Morgues Paintre', author of La Clef des Champs, 1586. 
names of the fruits in italics in the right-hand column alongside Tradescant's own fruit catalogue of $16_{34}$. See p. 343 .

In 1618 Tradescant was engaged in 'A Voiag of ambasad' to Russia with Sir Dudlic Diggs, ${ }^{1}$ and had, botanically speaking, a most successful campaign. After rounding the North Cape on 6th July, he landed at Archangel on the 16 th, and finding a 'bery growing lowe' (the yellow Cranberry), which was eaten by the people 'for a medsin against the skurbi', he proceeded forthwith to dry 'sume of the beryes to get seed whearof' he 'sent par to Robien of Parris'.

On 20 th July he had 'one of the Emporer's boats to cari him from Iland to Iland to sec what things growe upon them', and there he found 'pinks growing natturall of the best sort we have heere in Ingland, withe the eges of the leaves deeplie cut or jaged very finely', also the Rosa Muscovita that he grew in his Lambeth garden later. None of the other plants observed by him on the Rose Island or elsewhere can be proved to have been introduced to western horticulture by him at this time.

In 1627 Tradescant was botanising in the Island of Rhé, where he went as a member of the Duke of Buckingham's expedition, ${ }^{2}$ and whence he obtained the 'greatest Sea Stocke Gilloflower' (Matthiola simuata).

\section{Lambeth Garden, I629-33.}

Thanks to Goodyer and Ashmole, we have unexpectedly full notes of the plants that the elder Tradescant grew in his garden at Lambeth from 1629 onwards. He appears to have kept notes of additions to the garden on a few blank pages at the end of his copy of Parkinson's Paradisus, printed in I629. This copy was acquired by Ashmole, who also wrote in it, and it has recently been added to the Bodleian collections at a cost of $£ 28 .^{3}$

1 MS. Ashmole 824.

${ }^{2}$ A MS. account of this adventure is in MS. Ashmole 824 , ff. 187-192, immediately after Tradescant's autograph account of the Russian Expedition, so that it may also have belonged to him.

${ }^{3}$ The volume has been described in the Bodleian Quarterly Record and in greater detail by Mr. Boulger in A seventeenth-century Botanist Friendship, J. Bot. 1918, p. 197. There is stated the evidence for the identification of the MS. additions as the work of Tradescant and Ashmole, but the quotations from them leave much to be desired in point of accuracy. is are often transcribed as $t^{\prime}$ s, $p$ as $q$, 16 as i $6, \& c$. It should be mentioned that the entry of Elias Ashmole's monogram-signature in the body of the book is dated 1680 . 
Reseved since the Impression of this Booke.

In primis.

Sittissos Amarantinum.

Barba Jovis.

Polygolan.

Digitalem lutem maior.

Frittillaria Aquitanica.

Rosam Vittriensem.

from Morine. The great whyt Renunculus single.

on other sort of whyt Renunculus single.

Renunculus Drape de Argent.

Anemone Duble Greene with a littill leafe.

A thrice fayer Duble Anemone whyt Anemone.

on other sort of Dubble whyt Anemone.

from Mr. Robine. Tulipa perte maior.

Cardinalis planta 2.

from Holland.

on Aster.

on Vyola matronallis.

$\left.\begin{array}{l}\text { Plattanos arbor } \\ \text { Cogciggra or shumahat }\end{array}\right\}$ from Mr. Humfry Slaynie.

from France

Robyne.

Iris Affracanis.

Iris pertyca.

6 Anemones tenuifollio Duble.

4 latifollio Duble Anemones.

from Mounser

Robyne.

on German Rose of Mr. Parkinson from Mounser Robine, whiche is called Rosa Austriaca flore phenissio.

4 more Roses whereof Mr. Tuggy hathe two.

on strang vyene.

on Red Honnysoccle.

Two Irisses without name.

Arbutus slipes.

Tragacantha slipe.

Reseved in the yeare 1630 from forrin partes.

on Narciss.

from Constanti-

noble. Sr

on Ciclamen.

4 Renunculuses.

Tullipe Caffu.

Tullipe perte.

4 sortes of Anemones.

Reseved in the yeare $163 \mathrm{I}$.

$W$.

T. S.

Mr. Colfe.

on Tulype called the Coronell \& on of hir owne.

on Tulipe Brewer 3 collers sh welcom Hom Best Golyathe.

on Palmer more good Tulipes unknowne.

on Tulipe Beau without a Circle.

Blanck swisant.

Unick De Armenitier.

Mr. Groves olyas.

Hollias Beu.

From W. Win. Blienborgh Admirall of 3 collers olli van Dusport.

flamed Red \& Whyt Crowne.

Mr. Rene.

Two Holliasses.

Reseved in the yeare ${ }^{16}{ }_{31}$ from $M r$. Rene Morine. ${ }^{1}$

In prinis.

Renunculus Asiaticus flore duplice luteo.

Narcissus Jacobei, Narcissus indecus, Narcissus flore rubro.

Semper eternum flore luteum.

Geranium noctu odorato.

1 Cf. p. 279. 
From Bruxsells. 6 Hiasinthes.

Narcissus medio luteo.

" Narboniensis.

", Mussart. ${ }^{1}$

In the yeare 1632 .

Lotus libica.

Phillerea.

Sarsaparilla.

Smilex aspera.

Lentiscus.

Agnus Castus.

Cittissis maranthe.

Absinthum arborescente.

Cittisus panonicum Clusii.

Pseudo Dictamnum.

Vyburnum.

Lauristinus folio glabro.

Cistus folis chrispus.

", popelium folyo.

, mas.

Cortusa Americana.

Thimum verum verum Hispanicum.

Hisopium tenuifolio.

Tragacanthum.

Amanker lobelii.

Frutex Coronaria flore pleno.

Mirtis florence.

Sesely Ethiopicum.

Caradathe Americana.

Narcissus Tobago.

Ornithogalum arabicum.

Iris percicus.

Absinthium umbelatum. , folio lavendulum.

Auriggunum verum Hihipanicum.

Tumariscus Itallica.

Lutea Creatica.

Linaria odorata.

Feratium Indicum.

Serpentaria.

Arum mius.

Iris gloriossa.

Coulchicum frittilaria.

Fraxinello flore rubro.

Fraxsanela minor.

Herunde Hispanica.

$$
\text { In the yearc } 1632 \text {. }
$$

Fraxinella flore albo.

$$
\text { " minor flore albo. }
$$

Dronicum maior.

Eupatorem Nove Belgicum.

$$
\text { In the yeare } \mathbf{1} 633 \text {. }
$$

Abrotanum unguentaria.

Androsaca Mathioli.

Renunculus Lusetanycus odorata luteo. Colis Jovis.
Chama Iredis 3 sorts.

Iris Anglica variagata.

Dentaria Herundelesie.

, trefolia.

setfolia.

Telethium maius \& minus.

Moluka.

Sentaurum magnossi.

Ciclamen flore albo.

Hulimus.

Geranium 3 spetius.

Tithemali caratius.

Pistolochia.

Hiasithus flore albo.

Chamalea tricockos.

Tulipe Chistmaker.

Tulipa se bloome.

Tricoler Nomvull.

Ratabet.

The Lyon.

Brandinburg

Oudenard.

De Turbone.

Tulipe swice.

Crowne.

Canadense.

Otho Demeine.

Oliva Cappadocia.

From the frencheman.

The whyt Crown Tulipe.

Hiasinthus Brumalis.

Narcissus totus albus. Constantinopolis.

From Mr. Plowes brother.

Narcissus virginianus. , totus albis.

, De Diverse specie.

Millefolium flore luteum.

Virga Aurea virgine.

from Brussells 16 tulipes.

Papaver Reas flore luteo, Radx papot1. (?).

Pulegium servinom.

Frutex Canadencis Epimedium folio.

Aquilegi variagata rubro et albo.

Bellis maior Americanum Arboressente proliffra.

Cepe Lobellii.

Aspeck.

${ }^{1}$ Query David Mostart, mentioned by Clusius, Cur. Post., p. 19. 
Buglosa minor sempervirente.

Fumaria arboressente flore luteo semper virescente variagata.

Asarum maius Americana.

Absinthium innodorum.

Poligon Creticum verum luteo.

Phalangium virginianum flore albo.

Scabiosa Alpina vera.

Galliosus panonica Clusii.

Teucrum arboressente.

Aposinum Americana foliis Ascle. poydes floribus purpureo.

Viola luteo Americana arboressente.

Tordillum maius sive Sesseli Crettica.

Alkamilla pese leonis.

Stelaria argentina.

Fillapedulla altra.

Campanella lactencis piramdalis.

Barba hersi Coronopi folio.

Cetterache.

Millifolium flore luteo.

Cianus Constantinopilus.

Cottila marinum.

Absinthium tridentinum.

Hisopium mirtifolio.

Mar Rubium.

Renunculus minor bulbose flore pleno.

Sanicula guttata montana.

Aster 4 speties.

Abrottinum altra.

Cardus bulbosus monspellesis.

Balsamum sive Osimum oderatum.

Ciclamen vernale flore rubro odoratissimum.
Ciclamen Antiochum \& withe them 2 others.

Narcissus Virginnianum.

$" \quad$ Indicus squamosus.

Ciclmen flore pleno, albo et rubro.

Denis caninis flore luteo.

Frittilari flore luteo.

Hispanica.

Hiasinthus Indicus tuberosa radice.

Prumela flore flore purpureo.

Gladiolus Canadencis.

Alowaye mucronata.

Mirtis flore pleno.

Sedum arboressence.

Casie Quorundum Clusii.

Hipericon arboressence.

Mispilis arona.

Piemetum realie.

Alipum motcsetie.

Annagiris feotida.

Jugibie Arabum.

Zisipha Capadocia.

Carobie.

Limonium minus angusti folio.

Mariaranum sempevirence.

Sabina bacsiffira.

Phlirea lattifolio.

Sicorum grumosa radice.

Capris vera.

Gnapphalium marinum et Cotonuri vulgi sive Bumbax humlis.

Martigon Canadencis.

Saldanella Alpina.

Philex bacciffera.

In 1634 , the year of the printing of the Catalogue, Tradescant's Museum and Garden were one of the sights of London, and were described as such by Peter Mundy whose manuscript is preserved in the Bodleian Library. ${ }^{1}$

'Haveing Cleired with the Honourable East India Company whose servant I was, I prepared to goe downe to my freinds in the Countrey.

In the meane tyme I was invited by Mr. Thomas Barlowe . . to view some rarieties att John Tredescans, soe went with him and one freind more, where wee spent that whole day in peruseing, and that superficially such as hee had gathered together...

Moreover, a little garden with divers outlandish herbes and flowers, whereof some that I had not seene elswhere but in India, being supplyed by Noblemen, Gentlemen, Sea Commaunders etts. with such Toyes as they could bringe or procure from other parts.' ${ }^{2}$

1 MS. Rawlinson A. 315.

${ }^{2}$ Hakluyt Society's reprint of Mundy's Travels. 
The existence of a printed list of plants grown by the elder Tradescant in his Lambeth garden appears to have been quite unknown to bibliographers until the recataloguing of the Goodyer Library once more drew attention to this unique possession, which I had the pleasure of describing in the Fotmal of Botany in 1920. It is of course possible that the little book was never published, and that the copy in the Magdalen Library is to be regarded as a proof of a work that was never put into circulation. And this view derives some support from a glaring grammatical mistake on the title-page, which we reproduce. No printer of repute would have permitted such a blunder to issue from his pręss.
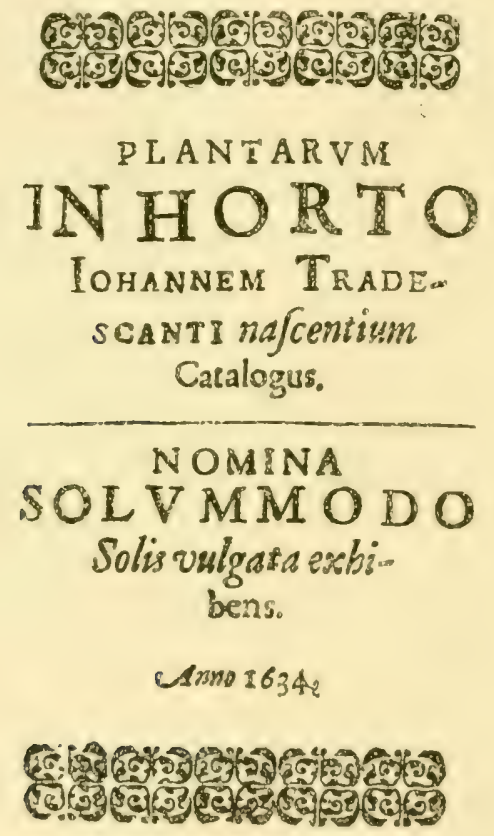

Abies.

Abrotanum mas. cyperissus.

*Abrotanum montanum.

*Absinthium arborescens.

" folio Lavandulae.

" marinum, id est, Seriphium. ${ }^{1}$ umbellatum Clus. vulgare.
Acanthus sylvestris.

sativus, id est, Branca ursina. Acetosa Hispanica major.

" Franca rotundifolia lobelii. "Indica.

Aconitum coeruleum, id est, Napellus. * ", lycoctonum ; Luteuin hiemale. Aconitum luteum ponticum majus. Acorus verus. luteum ponticum minus. Ageratum.

* Plant names marked with an * do not appear in the later cition of the catalogue printed in the Museum Tradescantianum in 1656.

1 First sent over from I. of Rhé by J. Tradescant. Ger. cmac. Ic99. 
Agnus castus, id est, Vitex.

Agrimonia.

Alaternus.

Alcea Veneta, id est, Alcea vesicaria.

Alkakengi.

Allium sativum.

" maius (i) Scorodoprassum.

*Alopecuros vulgaris.

"spica aspera.

*Alsine repens maxima.

Althaea arborea flore purpureo. " arborea flo. alb., montis Olb[iae].

Alyssum Clusii, .i. Alyssum Plinii.

*Amaranthus spersa Pannicula.

Ammi vulgatius
Amomum Plinii.

tricolor.

holosericus.

Amygdalus.

Anagallis tenuifolia flore coeruleo.

Anemone latifolia Pavot. ma. flo. plen.

" latif. Calcedonica flo. plen. latif. la Bruyne flo. plen. latif. rosea flore pleno. latif. albicans flo. pleno. latif. coccinea flo. pleno. latif. potorine flo. pleno. latif. superisse flo. pleno. latif. Constantinopol. flo. plen. latif. aliae diversae species. tenuifolia rubro flore pleno. tenuif. albo flo. plen. tenuif. albo dilut. flore pleno. tenuif. mutabilis flore pleno. tenuif. viridis flo. pleno. tenuif. carnea vivacis. flo. pl. tenuif. scarlata flo. pleno. tenuif. Pink colour, flo. plen. tenuif.pl.Coma-amaranthina. tenuif. flore ple. roseo. tenuif. flore pleno variegata. tenuif. flore pleno purpureo. dilutior. tenuif. flore pleno purpureo

Anemone tenuif. flo. simplici Brancion. " flore simp. diversae species.

Angelica sativa.

*Anthora.

Anthyllis leguminosa erecta flo: rubro. Antirrhinum maius flore albo.

, minus flore variegato.

* $\quad$ minus flore albo.

*[Apium, see Petroselinum.

Apocynum Americanum.

$$
\text { , alterum. }
$$

Aquilegia variegata albo \& purpureo. , variegata albo \& rubro. $"$ rosea.

*Aquilegiae magna diversitas.

Aracus Baeticus. " clematites.

Arbor vitae vel Thyia. " Judae.

Arbutus, sive Unedo.'

Aristolochia clematitis. ${ }^{2}$

,$\quad$ rotunda radice.

Armeria holoserica. , flore pleno.

, flo. simpl. magna diversitas.

Arum sylvestre.

, maculato folio.

" maius.

Arundo Hispanica, Donax.

Asarum vulgare.

Asclepias flore albo.

$$
\text { " flore nigro. }
$$

Asparagus sativus.

Asperula flore albo.

Asphodelus minor, Clusii. , Lusitanicus.

Aster" caeruleus serotinus fruticans.

* ,, alter minor fruticans \& precocior.

Astragalus Baeticus. , Marinus.

Astrantia nigra.

Atractylis.

Atriplex baccifera maior.

" minor

Atriplicis varietates.

Avellanae diversitates.

Avena nuda.

\begin{tabular}{|c|c|c|}
\hline " & $"$ & flore luteo maximo. \\
\hline " & " & folio glabro. \\
\hline " & " & folio luteo medio. \\
\hline , & , & oo \& rubro variegata. \\
\hline " & $"$ & z purpu \\
\hline
\end{tabular}

Auricula ursi flore albo. gata.

Auricula ursi flore holoserico.

$\begin{array}{lll}, \quad & \text { flore rubro. } \\ \text { " } & \text { "flore violaceo. } \\ \text { " } & \text { " } & \text { hore fusco. } \\ \text { " } & \text { " } & \text { altera, Potrine. } \\ & \text { maxima Tradescantiflore }\end{array}$
obsoleto.

Auricula ursi diversae species.

Balsamina foemina.

Barba Jovis frutex.

Barba Hirci Tragi. ${ }^{3}$

1 Two trees, 'the largest I have seen', noted as still living in the garden in I 749 by Sir W. Watson (Phil. Trans. xlvi).

${ }_{2}$ A. Clematitis L. reported by Sir W. Watson in 1749, l.c.

3 'Parba capri" was noted by Johnson in 1633 . 
Be[he]n album.

Bellis maior.

$$
\text { rubrum. }
$$

Bellidis minoris magna diversitas.

Beta sativa.

"spinosa Cretica, Bauhinii.

Betonica maior Danica.

Bistorta maior.

Blattaria flore luteo.

, flore albo \& violaceo.

, maxima obsoleta.

" maxima odorata flo: luteo.

Borago flore albo.

, semper virens. ${ }^{1}$

Botrys.

, flore caeruleo minima.

Brassica marina latifolia.

$\begin{array}{ll}\text {, } & \text { perfoliata. } \\ \text {, } & \text { stiis crispis. } \\ \text { ", } & \text { Hispanica. } \\ \text { " } & \text { Sabaudica, varietas. }\end{array}$

Brunella flore albo.

Bolbocastanum maius.

Buglossa sativa.

Buxus maior.

" minor.

Calamintha montana praestantior.

Calceolus Mariae.

Calendula flore pleno. prolifera.

Caltha palustris, flore pleno.

Canna Indica flore rubro.

Indica flore luteo.

Cardamine flore pleno.

$$
" \quad \text { trifolia. }
$$

Carduorum diversae species.

Carduus globosus.

* , chrysanthemus.

, Benedictus.

* Carlina, i. Chamaelaeon albus.

Carobe Americana.

Caryophyllata montana.

Caryophyllorum elegantium magna varietas.

Caryophyllus globosus latifolius.

*Cassia quorundam, Clusii.

Castanea equina.

$$
\text { , vulgaris. }
$$

Centaurium maius fol. Helenii.

$$
\text { , } \quad \text { maius flore luteo. }
$$

Cerasorum diversae species.

Chamae-cerasus.

Chamae-irides variac.
Chamelaea tricoccos.

Chamaepitys secunda.

Chelidonium maius.

Chond"rilla.

$$
\text { maius fol. quernis. }
$$

Christophoriana.

Chrysanthemum Creticum.

Cichorium sativum.

segetum bellidis fol.

Cinara sylvestris Boetica.

Cistus annuus Clusii.

, mas.

, foemina.

, ledum.

, flore albo.

"flore albo alter.

", foliis crispis. ${ }^{2}$

" ledum primum Clusii.

" ledum latif: secundum Clusii.

, ledum quartum Clusii.

" ledum septimum Clusii.

, Halimi folio.

" quintus Clusii.

Clematis flore pleno.

" flore coeruleo.

, flore rubro.

, Virginiana.

Cochlearia Batavorum.

Coccigria.

Colchicum atropurpureum.

, vernum.

, flo: albo.

, flore pleno.

fritillariae facie.

, Bizantinum.

, variegatum.

" vulgare.

, ex Insula Chios.

Colutea vesicaria.

, scorpoides.

Coniza major vera.

Convolvulus minor folio Althaeae.

Coriandrum.

Cormus.

Cornus fructu rubro.

, fructu albo.

,$\quad$ sylvestris.

Corona imperialis.

Coronopus maior.

Cortusa Matthioli.

, Americana.

Crocus, Neapolitanus.

, flore albo.

, Maesiacus luteus.

"Maesiacus flore albo.

". flore luteo.

, violaceus maior.

1 Anchusa sempervirens reported by Sir W. Watson in $17+9$, l.c.

2 Cistus laxus, crispus, populifolius, and monspeliensis were introduced by. Tradescant. Loudon, Arborctum, p. 50. 


\section{J. TRADESCANT, SENIOR}

Crocus, violaceus minor.

" flore cinereo.

" Maesiacus argentinus.

" Maesiacus luteo Duc.

Croci flore variegato diversae species.

Cruciata Gentiana.

Crupina.

Cucumer asininus.

Cyanus maior.

Cyani hortensis varietates.

Cyclamen flo. albo.

, folio Hederae.

, folio Hederae Italicum.

Cynoglossum minus.

*Cyperus longus. non descriptum.

Cypressus. ${ }^{3}$

Cytisus Maranthae.

, primus Clusii.

" secundus Clusii.

Delphinium flore pleno.

Dens caninus flo. albo.

" caninus flo. rubello.

Dentaria tryphylla.

"septifolia.

Dentillaria Rondeletii.

Digitalis flo. albo.

, alba maior.

, variegata.

" ferruginea maior \& minor. ${ }^{2}$

Doronicum Americanum.

Draba flo. albo.

Draco herba.

Dracuntium maius, Serpentaria."

Echium.

Elleborus albus. ${ }^{5}$

, albus flo. atrorubente.

Elleboraster. niger.

Endiviae species.

Epemedium.

Equisetum Marinum.

Eruca perigrina Clusii.

"Aragonica.

Eryngium Constantinopolitanum.

, planum.

, flore luteo.
Eryngium marinum vulgare.

Esula major.

, montana.

, minor.

Eupatorium Novae Belgiae.

Faba Americana.

Fabarum diversae species.

Ferula Galbanifera.

*Ficus.

, Indica.

Flamula Jovis.

Flos Africanus.

, " flo. pleno.

"Constantinopolitanus f. Miniato.

"Constantinop: flore rubro.

"Constantinop: flore pleno.

"Passionis.

, solis maior.

," solis prolifera.

Foeniculum.

Fragà fructu albo.

" fructu maiora.

, fructu viridi.

" spinosa sive hispida. communia.

Fraxinella flo. albo minor.

, purpur. maior.

, flore rubro.

Fritillaria flore rubro.

, flore albo.

, vulgaris maior \& minor.

" Aquitanica.

Frumenti Turcici variet. triplex.

Frutex Canadensis Epimedii folio. " Coronaria flo. pleno, Syringae flore.

Galega flore albo.

" flore carneo.

Genista Hispanica.

", hortensis.

Gentiana maior.

" foliis Asclepiadis.

Gentianella alpina Helvetica.

Geranium Virginianum.

" odoratum longius radicatum.

, muscatum.

1 Tradescant's Virginian Cypresse 'Cupressus Virginiana Tradescanti' in the I656 catalogue does not appear in 1634 . It is Taxodium distichum Rich. Parkinson reported English seedlings in 1640 .

${ }_{2}^{2}$ Seen in 1632 by Johnson.

3 Dracunculus vulgaris L. seen by Sir W. Watson, 1749 (Phil. Trans. xlvi).

4 'Gladiolus.' 'Iohn Tradescant assured mee, that hee saw many acres of ground in Barbary spread over with them.' Parkinson, 1629 , p. 190.

${ }^{5}$ White Ellebor (Veratrum album L.) grew ' in some partes of Russia, in that aboundance, by the relation of that worthy, curious, and diligent searcher and preserver of all natures rarieties and varieties, my very good friend, Iohn Tradescante,... that as hee said, a good ship might be loaden with the rootes hereof, which he saw in an Island there'. Park. 1629, p. 346. He accompanied Sir Dudley Digges to Russia in 1618 , and was the first man to investigate the flora of that country. 
Geranium Creticum.

Indicum nocte odoratum.
$" \quad$ tuberosa radice.
non descriptum Dodonaei.
Gingidium.

Gladiolus Byzantinus. [See note ", , flo. albo. p. 337.]

Glaux aestiva supina Lusitanica.

Gnaphalium flore albo.

Gramen striatum.

Graminis diversae species.

Gratiola.

Grossularia maxima.

maxima longa.
,$\quad$ coerulea.
rubra major rotunda.
$", \quad \begin{aligned} & \text { media species longa. } \\ & \text { rubra minor. }\end{aligned}, \quad$ spinosa.

Guaiacum Patavinum.

Halimus arborescens.

Hedysarum clypeatum Lob.

Helleborus, see Elleborus.

Hepatica flore albo [twice].

" flore coeruleo major.
rubris.

Hepatica coerulea flo. pleno.

Herba Doria.

coerulea flore pleno altera.

Hesperus Italica.

Hieracium medio nigrum.

,$\quad$ lanuginosum flore luteo.

". dentis leonis facie.

Hippoglossum.

Hippomarathrum Lusitanicum.

Horminum sylvestre Lusitan: florealbo. ruleo. sylvestre Lusitan: flore coe-

Hyacinthus botroides flore albo. botroides flo: coeruleo.

" brumalis.

" comosus.

" Orientalis flore albo.

", Orient: flore coeruleo.

" Orient: atro-rubiens.

., Peruvianus flore albo.

"Peruv: flore coeruleo.

, paniculatus.

"Pyrenaeus flore albo.

"Pyrenaeus flore coeruleo.

, flore obsoleto, Clusii.

Hyoscyamus albus.

, albus medio-purpureus.

Hypericum latifolium Lusitanicum.

Hyssopus sativa.

$\begin{array}{ll}" & \text { prolifera. } \\ " & \text { alba. } \\ " & \text { tenuifolia. } \\ & \text { comosa. }\end{array}$

Jacea maxima odorata.

, spinosa.

" flo, luteo.

" aestiva elegans.

Jacobaea.

", marina.

, latifolia.Baetica

Jasminum Catalonicum flo: albo.

$\begin{array}{ll} & \text { flo. albo. } \\ & \text { flo. luteo. } \\ & \text { Persicum. }\end{array}$

Ilex.

Impatiens herba Dodonaei. Persicaria siliquosa.

Irides maiores variae.

Iris gloriosa.

" Susiana major.

"Clusii flore pleno.

"Clusii flore albo.

"Clusii flo: coeruleo.

" bulbosa Anglica maior flore albo.

" minor flore albo.

", bulbosa Anglica flore coeruleo.

"Persica.

" bulbosa Africana.

" bulbosa Anglica variegata.

", bulbosa flore luteo.

Iridis bulbosae aliae diversitates.

Irides humiles sive Chamaeirides variae.

Juniperus minor.

Jucca.

Keyri maius simplex.

, maius ferrugineo flo. pleno.

" flore albo simplex.

"flore pleno pyramidale.

" flore pleno vulgare.

" flore pleno auratum.

Laburnum maius.

minus.

Lagopus flore rubro.

Lapathum hortense.

Lathyrorum elegantium variae species.

Lavendula.

Laurea cerasus.

Laurus tinus.

, tinus folio glabro.

". Alexandrina.

, Gallica.

*Lentiscus.

Leucojum bulbosum maius.

" bulbosum minus.

" arbo. flore pleno rubro.

, arbo. flo. pleno albo.

", arbo. flo. pleno purpureo.

", arbo. flo. pleno rubro variegato.

Leucojum arbo. flo. pleno purpureo variegato. 
Leucojum marinum. ${ }^{1}$

Libanotis.

Liliasphodelus flore luteo.

Lilium album. flore albo.

" Convalium flore albo.

, Convalium flo: rubro.

" flore luteo.

" Constantinopolitanum.

Lilac Matthioli. ${ }^{2}$

Limonium minus angustifolium.

Linaria odorata.

Locusta Virginiana arbor ${ }^{3}$

Lotus arbor. ${ }^{4}$

" Lybica.

", coronata maxima Hispanica.

Lupinus Indicus.
" candidus ex Candia.
" flore luteo.
" flo. coeruleo minor.

Lutea Cretica.

Lychnis sativa rubra flore pleno.

" coronaria pleno flo. albo.

" coronaria pleno flo. rubro.

, sylvestris Pyrenaeus.

Maiorana.

Malva arborescens.

, maxima Hispanica striata.

" segetum Lusitanica.

Malum arantium.

$"$ limonium.

" granatum.

Mandragoras mas. ${ }^{5}$

Marum.

Martagon Panonicum spadaceum. " Pompon.

Matricaria.

" flore albo punctato.

, flore pleno.

Medica spinosa maior.

$" \quad$ transversis spinis.

" scoparia.

" elegans Catalonica.

" minor spinosa.
Medica doliata echinata.

" doliata ramosa.

, clypeata.

Melilotus Italica flore luteo.

, arborescens flore albo.

Melissa.

Mentha.

Meum.

crispa.

Mezereon album.

Milium nigrum.

album.

Millefolium atro rubente flore.

Mollugo.

Morus.

" alba.

", Virginiana.

Muscari flore luteo.

", flore albo.

Myagrum monopermon.

Myrrhys sativa.

Myrtus latifolia.

" angustifolia.

" florida.

Napellus.

Narcissus medio Croceus
" Anglic. flo. pleno Wilmot.
," roseus maximus flore pleno

Tradescanti. ${ }^{6}$

Narcissus Africanus odoratus.

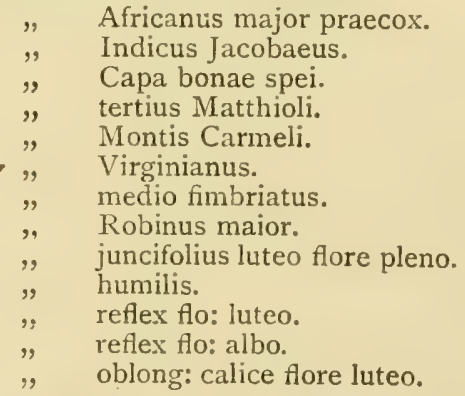

1 The greatest Sea Stocke Gilloflower (Matthiola sinuata L.) was brought out of the Isle of Ree [Rhé] by Rochel by Mr. John 'Iradescant, when the Duke of Buckingham was sent with supplies for Mounsieur Soubise (1627). Park. Theatrum, 624.

2 The Lilac, Syringa persica L., was introduced by Tradescant. Loudon, Arboretum, P. 49

s Robinia Psendacacia L. 'A very great tree and of exceeding height with Master Tradescant,' in I640. Parkinson, Theatrum, I550. Mentioned by Ashmole, in I662 (?), but not by Watson in 1749 .

1 The Date Plum (Celtis australis L.). 'Lotus arbor Virginiana' (Celtis occidentalis) was in the garden in 1656 .

5 The Male Mandrake. Some years previously Parkinson 'saw in my Lord Wootton his garden at Canterbury, whereof Mr. J. Tradescant had then the keeping, an other sort'. Theatrum, p. 343 .

6 'The greatest donble yellow bastard Daffodill, or Iohn Tradescant his great Rose Daffodill. This Prince of Daffodils belongeth primarily to Ioln Tradescant, as the first founder thereof. . . W Whether raised from seed, or gained from beyond Sea, I know not.' Parkinson, 1629. 
Narcissus oblongo calice flore albo. calice brevi.

titesose.

va Hecuus.

omnium maximus.

montanus.

Non-parell flore albo.

Non-parell.

Constantinopolitanus.

totus albus.

Matineus.

Nasturtium Indicum.

Nigella flo: pleno.

, citrina.

, flo: simplici.

Nux juglans Virginiana

, juglans Canadensis.

, juglans Angliae novae.

", juglans maior.

" juglans minor.

,

Oenanthe bulbosa marina venenosa.

Olea sylvestris.

Oleander flore albo.

flore rubro.

Ononis non spinosa Pyrenaea.

, non spinosa oderata flore luteo.

" non spinosa aestiva minor flore luteo.

Origanum verum Hispanicum,

Ornithogalum Neopolitanum.

Orobus Venetus.

" $\quad$ Arabicum.

Paliurus.

Paeonia mas.

" foemina flore simplici.

$" \quad$ foemina flore pleno.

" flore pleno incarnato.

$" \quad$ flore purpureo.
Papas Americana flore albo.

"Americana flo. purpureo.

Papaver rhaeas f.luteo radice perpetua.

" rhaeas flore simplici.

" rhaeas flore duplici.

" nigrum capit. rotundis.

,. corniculatum flore luteo.

Paralysis flore viridante simplic.

„ fatua.

" inodora geminata.

" flo. \& calice crispo.

Pepo Americanus luteus.

Americanus viridis.

Periclymenum rectum 2. Clusii.

" fructu cerasino.

, hortense.

,Germanicum flo. rubro.

Periploca.

Petroselinum crispum.

$$
, \quad \text { hortense. }
$$

, Virginianum.

Phalangium Alobrogium Clusii.

$$
\text { , Virginianum Tradescanti. }{ }^{2}
$$

Philyrea angustifolia.

Pimpinella maior.

, sativa.

"

Pinus.

Pinaster.

Pistachia sativa. ${ }^{3}$

Pistolochia smilacis folio.

Vir

" perennes.

" bacciferum.

" maculatum.

", quadratum.

Plantago rosea.

"serrato folio.

Platanus. ${ }^{4}$

Polium montanum.

Polygala Valentina I. Clusii.

1 'Nux vesicaria' in the 1656 catalogue may be our common Bladdernut Staphylea pinnata L., but it should be remembered that Parkinson, Theatrum, p. I 17 , says that 'Mr. Tradescant hath brought a sort from Virginia, having divers nuts in the bladder'. Loudon, Arboretum, p. 49, attributes the introduction of Staphylea trifolia to Tradescant.

2 'Tradescant his Spiderwort. This Spiderwort is of late knowledge, and for it the Christian world is indebted vnto that painfull industrious searcher. and lower of all natures varieties, Iohn 'Tradescant (sometimes belonging to the right Honourable Lord Kobert Earle of Salisbury, ... and then vnto ... the Lord Wotton at Canterbury in Kent, and lastly vnto the late Duke of Buchingham [assassinated 86277 ), who first receiued it of a friend, that brought it out of Virginia, thinking it to be the Silke Grasse that groweth there, and hath imparted hereof, as of many other things, both to me and others." Park. 1629 , p. 152. In 1617, Tradescant (who may have then been in Wotton's service) paid the expense of a passcnger to Virginia under 'Captain Argall'. Boulger, J. Bot. 19i8, p. 200.

3 Pistacia Tercbinthus L. was introduced by Tradescant acc. to Loudon, Arboretum, p. 49 .

${ }^{4} \dot{p}$. orientalis. "There are one or two yong ones at this time growing with Mr. Tradescant.' Ger. emac. 1633 , p. $1489 . \quad P$. occidentalis is believed to have been introduced by Tradescant the younger. 


\section{J. TRADESCANT, SENIOR}

Polygala Valentina 2. Clusii.

Polygonatum maius. ${ }^{1}$

$" \quad$ maius angustifolium.
$" \quad$ minus.
,$\quad$ alterum.

Polygonon marinum Lobelii.

Pomum amoris medium.

Primula veris flore albo.

,$\quad$ veris albo flore pleno.

" veris flore pleno viride.

" veris angustifolia flore albo.

" veris angustifolia flore rubro.

" veris flo. viride \& albo simpl.

Pseudo dictamnum.

Ptarmica vulgaris.

Pulegium regale.

Pyracantha.

cervinum.

Radix cava maior flore purpureo.

" cava minor flore albo.

Ranunculus albus flore pleno.

" Asiaticus sang. flo. pleno.

luteo.

Ranunculus Asiat. flore albo.

" Asiaticus flore rubro.

" Asiat, flore luteo.

" Asiat, folio papaveris.

tine."

Asiat. Drape de Argen-

Ranunculus Illyricus.

Raphanus niger. aliae diversitates.

Rapunculus.

Reseda maior.

Rhodia radix. ${ }^{2}$

Rhus myrtifolia. ${ }^{3}$

Ribes fructu rubro.

" fructu albo.

", fructu nigro.

Ribesium dulce.

Rosa Provincialis.

" Provincialis flore albo.

"Provincialis flore rubro.

" vitriensis flore pleno.

" incarnata.

" flore luteo pleno.

" flore luteo simplici.

" muscata flore pleno.

" Italica.
Rosa cinamomea.

, cinamomea flore albo.

, Francofurtiana.

" Batavica.

" alba variegata.

"flo: pleno elegans variegata.

" flore simplici pomifera.

"Virginiana.

" Moscovitica. ${ }^{4}$

" canina flore pleno.

"Eglanteria flore pleno.

" Eglanteria.

", holoserica.

" sempervivens.

", flore rubro.

" flore albo.

" Damascena.

" Austriaca flore Phoeniceo. Rosmarinus.

* Ruta canina. ${ }^{5}$

Sabina.

Salvia variegata.

" hortensis rubra.

" hortensis viridis.

" maior foliis crispis.

". minor odoratissima.

Sambucus aquatica.

" foliis laciniatis.

Sanicula Alpina guttata.

Saponaria flore pleno.

Saxifraga aurea.

Scabiosa Hispanica major.

" Hispanica Clusii.

" Indica.

"Indica Clusii.

Scorpioides Portulacae folio.

" bupleurifol. siliq. crassa torosa.

Scorpioides minor.

Scorzonera. minor elegans.

Scrophularia Montis-Serrati.

Securidaca minor.

Pannonica Clusii.

" maior.
Sedum majus.
", arborescens.
elegans.

${ }^{1}$ Solomon's Seal was found living in the Lambeth garden by Sir W. Watson in 1749 (Phil. Trans. xlvi).

2 Rhammes catharticus is absent from this list, but is in the 1656 list. In $1749 \mathrm{Sir}$ W. Watson reported a tree 'about 20 feet high and near a foot in diameter' (l. c.). Perhaps the younger Tradescant planted it.

3 Rhus Cotinus L. was introduced by Tradescant acc. to Loudon, Arboretum, p. 49.

4 No doubt one of the spoils of Tradescant's Russian expedition of 1618 . Cf, Boulger, First Russian Botanist. J. Bot. 1895.

5 Probably in error for Rosa canina..] 
Serpentaria.

Seseli Aethiopicum frutex.

Sinapi Castiliae novae.

Smilax aspera folio rotundo.

, aspera folio maculato.

, aspera levis.

Solanum Lethale.

Spina Solstitialis.

Staechas Arabica.

$$
\text { , Citrina. }
$$

Stachys Hispanica.

$$
\text { , spuria. }
$$

Stachylodendrum.

Stoebe Salamantica.

Stramonia flore albo. flore purpureo.

Superbae diversae species.

Tamariscus Italica.

$$
\text { , } \quad \text { minor. }
$$

Tanacetum.

$$
\text { " crispum. }
$$

, inodorum.

Telephium maius.

$$
\text { ". minus. }
$$

Terebinthus vera.

Thalictrum Virginianum.
Thapsia Neronis Carotif. Lob.

Thlaspi umbellatum.

Thymum verum Hispanicum.

Tithymalus Charachia.

Tithymalorum diversae species.

Trachelium album flo. pleno.

$$
, \quad \text { coeruleum flo: pleno. }
$$

Trifolium barbaricum stellat. Tradesc. ${ }^{1}$

Triticum spica multiplici.

Tuliparum eligant: maxima diversitas.

Tulipa Num. 50. diversae species.

Valeriana Graeca flore coeruleo.

, Graeca Dodon. flore albo.

" Dodonaei.

Verbascum salvifolium.

$$
\text { " blattariae folio. }
$$

Vergae aureae quatuor spec.

Veronica mas.

, foemina.

Vinca pervinca maior. minor.

Viola Matronalis flore pleno.

Vite sylvestris.

VImaria perigrina Clusii.

Vmbilicus Veneris.

" " Hispanicus.

\title{
A Catalogue of Fruits. ${ }^{2}$
}

\author{
Apples. ${ }^{3}$ \\ Ribon Apple \\ Pome Mater \\ Russet Pippin \\ Puffing Apple \\ French Pippen \\ Snouting \\ Blandrille \\ Torne Crab \\ Great Russeting \\ Summer Beiliboon \\ Quince Crab \\ Pome de Chastania \\ Pome de Renet \\ Pome de Carpandu \\ Pome de Caluele
}

D

Octor Barchams Apple

Pome de Rambure

Master Williams

Yellow Russeting

Harry Apple

Dutch Pearmaine

Black Apple

Barfolde Queninges

Smelling Costard

Iohn apple

Red master Williams

Quince apple

Summer Permaine

Winter Pearemaine

Gillefloure Apple

1 Pulteney (Biogr. Sketches, i. 176) states that Tradescant brought Trifolium stel. latum L. from the Island of Formentera. This visit may have been during the Algerian campaign of 1620 .

2 To the names in the 1634 catalogue, for the most part printed in Roman type, we have added in the right-hand column and in italics the names and dates of ripening of the fruits depicted (? by Alex. Marshall, see Mus. Trad., P. 4I) in a book known as Tradescant's Orchard now in the Bodleian Library (MS. Ashmole 146I).

s Shakespeare's apples, the John apple, Bitter-sweet or sweeting, Crab, Codling, Leather-coat ( = Yellow Russeting), Pippin, and l'omewater are all in this list, but curiously enough, though Tradescant had a Poperin pear, he does not mention the Warien pear by that name. 
Violet Apple

Darling Apple

Stoken Apple

Sack and Sugar

Pidgions bill

The Kings apple

M. Molines apple

Grey Costard

Winter Belliboorne
Little sweeting

Yellow Spising

Dari Gentles

Livinges

Mother Pippin

Russet Peare apples

Keelings

Ginitings

Black Pipin

An Early ripe Apple good in taste

Peares.

$\mathrm{B}$ Infeild Peare Gergonell Sir Nathaniel Bacons great Peare Red Peare

Rose water Peare

Greenefield Peare

Dego Peare

Scarlet Peare

French Popering

Snow Peare

Winter Boon Critian

Summer Boon Critian

Arundell Peare

Pallas Peare

Prince Peare

Greene Peare

Hedera De Besa

Michaelmas Peare

M. Motts Peare

Paynted Peare

Sliper Peare

Greene Rowling

Kings Peare
Poyer Messer Ian

Nutmeg Peare

Bishops Peare

Orenge Burgamott

May Peare

Swise Peare

Summer Burgamot

Hony Peare

Mid-summer Peare

Winter Burgamot

Poyer de Poydre

Portingale Peare

Sugar Peare

Double floure Peare

Bloud Peare

Poyer Fran Rial

Winter Winsor

Summer Winsor

Poyer Irish Madam

Poyer Dangobet

Poyer de Valet

Poyer de Samoyse

[TRADESCANTS ORCHARD.']

The greet 16 ounce peere

The grete winter peere

The Jerusalem Pere

A french peare called $R$. Collanit ripe Aug. 29

\section{Quinces.}

The portingegale Quince

\section{The peare Quince Oct. 5}

$\mathrm{M}$ Oroco Plum Spanish Plum

Red peascod Plum

White Plum

Plum Dine

Rath ripe Damaske violet

\section{Plums. ${ }^{2}$}

Red plumordin Plume ripe July $\mathbf{1 2}$

Vilot plum , July 24

Maraco plame "July I5

Early whight pere plum", July 30

Denny plum , Aug. 6

Grene Oysterly plum , Aug. 9

Grene mother plum ,Aug. I4

1 To this is prefixed a pleasing coloured drawing of 'Martagon vel Leli novae Angliae'.

2 Plums. 'The choysest for goodnesse, and rarest for knowledge are to be had of my very good friend Master John Tradescante, who hath wonderfully laboured to obtaine all the rarest fruits he can heare off in any place in Christendome, Turky, yea or the whole world,' Parkinson, Paradise, 1629, p. 575. 
Damaske Violet

Verdoch Plum

Friers Plum

Bowle Plum

Nutmeg Plum

White Rath ripe Plum

Peake Plum

Apricocke plum

Orenge Plum

Michaelmas damaske Plum

Red Mirabolane

White mirabolans

The Monsiers Plum

The Perdigon Plum

The Kings Plum

The Queenes Plum

The white Perdigon

The pruneola Plum

The Diapre Plum of Malta

The Diapre Plum

The Imperiall Plum

The Date Plum

The Musle Plum

The Damascene Plum

The Irish Plum

White Damaske violet plum

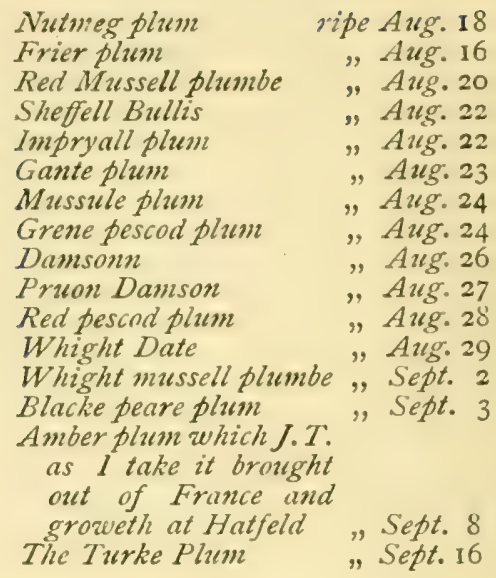

Cheries.

$\mathrm{S}^{\mathrm{N}}$

Wertes Cherie

Seelinars Cherry

The great bearing Cherry

The Spanish cherry

The Luke Ward Cherry

'The Agriot Cherry

The Chamelion Chery

The dwarfe Hungarian chery

Tradescants Chery ${ }^{1}$

The white Chery

The cluster Chery

The double floure Chery

The May Chery
The Arch-1)ukes Cherry ${ }^{1}$

\begin{tabular}{|c|c|}
\hline $\begin{array}{l}\text { Harte Cherry } \\
\text { Corone Cherry } \\
\text { Naples Cherry }\end{array}$ & $\begin{array}{r}\text { ripe June } 24 \\
\text { "June II July I } \\
\text { "July }\end{array}$ \\
\hline Luke ward Chery & "June 10 \\
\hline $\begin{array}{l}\text { Dwarfe Cherry } \\
\text { Tradescant Cherry } \\
\text { Whighte Cherry } \\
\text { Cluster Cerry }\end{array}$ & $\begin{array}{l}\text { "July I } \\
\text {, June } 21 \\
, \text { June } 24 \\
\text {, June I } 5\end{array}$ \\
\hline May Cherry & 「Ju \\
\hline
\end{tabular}

Apricocks.

B Arbarie Apricocks 2 sorts $^{2}$

B Small Holland Apricocke

Masculine Apricocke

Longe muske Apricock

The ordinary Apricocke

\section{Round Apricock ripe Aug. I5 \\ The Apricooke that is \\ both long and great ,Aug.23}

1 'Tohn Tradescantes Cherrie is most usually sold by our Nursery Gardiners, for the Archdukes cherric, because they have more plenty thereof, and will better be increased.' Parkinsun, l.c., p. 574.

2 The Argier Apricocke "with many other sortes John Tradescante brought with him returning from the $\Lambda$ rgier voyage, whither hee went voluntary with the Fleete, that went against the Pyrates in the yeare 1620.' J'arkinson, l.c., P. 579. 
Nectorins.

$\mathrm{T}$

ward Sillards ed Nectorine

Sir Edward Sillards ed Nector

The white Nectorine
Roman Reed Nectrion ripe Sept. 2

Bastard Red Nectrion , Sept. 4

Cluster Red Nectrion,"Aug. 22

Yellow Nectrion "Sept. 13

Grene $N$. , Sept. 5

Peaches.

$\mathrm{T}$ Radescants double floured Peach The Queenes Peach The White Peach

The Nutmeg Peach

Peach de Troas

Newington Peach

Carnation Peach

Spanjsh Peach

Devine Peach

Lions Peach

Roman Peach

Peach Pavi Iaune

\section{Grete early yellowe peech Blake pech red all within Whight peech}

The peach Dutroye

Nuingetonn Peeche

Round Carnation peech

Graunde ," ,

Bell ", ",

which pealleth like a codling ", Sept. 3 The Russet Blud peech

or Durosynus

The Mallycotone peche

A late ripe yellow peech

but very good firme peech

"Sept. 25

Sept. 26

"Oct. Io

Vines.

The buxtet Grape wich very seildum rip

The blue grape

ripe Sept. 27

The Fronteneac Vine

The great blew Grape

The Potbaker Grape

The reison Grape

The currans Grape

with divers other.

The Grat lieson Grape "Oct. Io

The smalle Reson Grape ", Sept. 12

FINIS.

The grete Roman Hasell Nut

The great French Fragara, ripe the 20 of May.

A contemporary notice of this catalogue occurs in the Diary of Georg Christoph Stirn of Nürnberg (MS. Bodl. Add. B 67). Stirn left Dieppe for England on 2 July 1638 . His sightseeing in London included the Tower, York House, and the Tradescant Museum, and he wrote in his diary that in the garden were all kinds of foreign plants, the names of which are to be found in a special little book which Mr. Tradescant has had printed about them. This 'special little book' now shares with Gerard's first Catalogue ( $159^{6}$ ) the honour of being among the scarcest of printed botanical works in the world.

The contents of the Lambeth garden were again listed by the younger Tradescant, who printed the second Catalogus Plantarum in Horto Fohannis Tredescanti nascentium in 1656 . And a few years later Ashmole drew up a list of all the trees still surviving in 
the garden, and wrote it out at the end of his copy of Parkinson's Paradise, now in the Bodleian Library.

\section{Trees found in Mrs. Tredescants Ground when it came into my possession. [1662.]}

Platinus orientalis verus.

Platamus orientalis $\mathrm{L}$. " occidentalis, aut Virginensis. , occidentalis $\mathrm{L}$. Arbor siliquosa Virginensis spinosa, Locus nostratibus dicta. "Robinia Pseud-

Cerasus racemosa putida ${ }^{1}$ Padus Theophrasti dicta.

Periclymenum rectum ${ }^{1}$ flore rubro.

Nux Vesicaria, altera Virginensis.

Euonymus Theophrasti.

Lotus Arbor.

Sambucus Rosea.

Arbor Judae.

Cornus Mas.

, foemina.

Latana, sive Viburnum.

Guaicum Patavinum.

Syringa alba.

Pyracantha.

Alaternus.

Arbutus.

Castanea equina.

Pinaster.

Laurus Tinus.

Tillia. " Lusitanicus flore glabro.

Tamariscus.

Acer majus latifolium.

Rhus Virginiana.

Vitis Virginensis.

Apocynum, sive Periploca repens.

Althea arborea flore albo fundo purpureo Montis Olbiae.

Seseli Æthiopicum frutex.

Prunus Padus L.

Lonicera alpigena L.

Staphylea trifolia L.

Euonymus europaeus L.

Celtis australis $\mathrm{L}$.

Viburnum Opulus var. sterilis.

Cercis Siliquastrum L.

Cornus Mas L.

Comus sanguinea L.

Viburnum Lantana L.

Diospyros Lotus L.

Syringa vulgaris L. var. alba.

Pyracantha coccinea Roemer.

Rhamms Alaternus L. Arbutus Unedo L.

Esculus Hippocastaneum L.

Pinus Pinaster L.

Viburnum Tinus L.

Prunus lusitanica L.

Tilia vulgaris Hayne.

Tamarix anglica Webb.

Acer Psendo platanus L. Rhus typlizia L.

Vitis quinquefolia Lam. Periploca graeca L.? Hibiscus syriacus L. Bupleurum fruticosum L.

\section{xi. George Gibbes' Garden Lists, undated And 1634.}

George Gibbes had a garden at Bath which was visited by Thomas Johnson and the Socii itinerantes on their tour in the west of England in 1634 . There is a short, undated list of Gibbes' plants among Goodyer's papers, though it is not in his handwriting. It is headed 'To have from Mr. Gibbes'. Johnson printed a list of II 7 of Gibbes' exotic plants in the Mcrcurius Botanicus, of these only six (marked below with double asterisks) occur in the short list.

It will be noted that none of the plants imported by Bocl from Spain occur in either list, whereas they do occur in the Stonehouse

1 Mr. Boulger, who saw the MS. in 1917 before it had been purchased by the liodleian, by reading the word 'putida' as 'qubida', and conjecturally amending it as 'quibusdam' (!), has illustrated the danger of not minding one's p's and q's. In the next line he read 'erectum ' in error for 'rectum'. I have, however, placed implicit trust in his determination of the modern equivalents of the names. 
list of I640. Parkinson has an interesting note on Gibbes in his note on a Virginian Aster, which was evidently imported after the date of Johnson's list.

Aster Virgineus luteus alter minor.

"We have had scarce time enough to observe it thorowly since we got it from Virginia by the means of Master George Gibbes Chirurgion of Bathe, who brought in his returne from thence, a number of seeds \& plants he gathered there himselfe, \& flowred fully only with Mr. Tradescant.' Parkinson, Theatrum; 1640, p. 133.

\section{Gibbes' Garden 1634.}

Plants marked* are in the Goodyer list only. Plants marked** are in both lists.

Abrotanum mas.

Absinthium tenuifolium, quibusdam Romanum, aliis Ponticum.

Ageratum.

Allium max. radice simplici.

Allium vulgare.

Antirrhinum majus flo. albo.

*Aquilegia angustifolia, mult., simpl.

Arbor vitae.

Aristolochia Clematites.

*Armerius latifol.

Asclepias flore albo.

Aster I talorum.

**Astragalus Lusitanicus.

Astrantia nigra.

Auricula ursi.

Blattaria purpurea.

* ", alba.

*Bistorta minor.

Bolbonach, sive Lunaria Greca.

Branca Vrsina.

*Buphthalmum.

* Buxus versicoloribus foliis.

*Calceolus mariae.

Caltha fio. multiplici.

* , palustris.

Campanula Persicifolio, Lob.

Caryophyllorum hortensium variae spec.

Cerinthe.

Chamaecyparissus.

Chamaedrys.

*Chamaeiris latifol.

* ,, angustifol.

Chamaexyris, Lob.

Chrysanthemum Creticum.

Cochlearia Batava.

Colutea vulgaris.

Consolida regalis.

** Convolvulus coeruleus minor.

Coriandrum.

Costus hortorum.

Cotyledon minus montanum, Palmaria Tab., Vmbilicus veneris minor, Gr.
Cotyledon altera Ger. emac.

Crocus vernus.

**Cucumis asininus, Offic.

Cyanus flo. albo, carneo et. " major.

Doronicum Romanum.

Faba Graecorum.

Fragaria fructu magno, Boëmica, Quorund.

Flos adonis.

*Flos africanus.

Flos solis major.

Gentianella verna flo. amplo.

Geranium longius radicatum, Lob. ,' Moschatum.

Gladiolus Narbonensis. Romanum variegatum

Gnaphalium Americanum.

Glycyrrhiza vulgaris.

Gramen Lupuli glumis, sive Tremulum max. Bauh.

**Helleborus niger verus.

Hepatica nobilis.

* , albida fl. rub.

Hipposelinum

Hyssopus vulgaris.

,$\quad$ foliis aureis.

Imperatoria.

Iris bulbosa.

, latifolia vulgaris.

Iacea tricolor flo. amplo lut.

, vulgaris.

Iasminum album. luteum, sive Trifolium fruticans, Polemonium Ger.

Laurus vulgaris.

Lavendula vulgaris. "flo. albo.

Leucoium bulbosum et alia verna, quae tunc temporis non apparuerunt. 
Leucoium flo. albis et purp.

Lilium album. " montanum.

" non bulbosum.

Lotus hortorum, Lob. sive Trifolium odoratum.

*Lupinus albus, max., coer., aur., et luteus.

Lychnis Chalcedonica. " hortensis. " syl. flo. multipl.

Lysimachia coerulea. , lutea Virginiana.

Majorana.

Marum sive Mastich Gallorum et Anglorum.

Mentha sativa rubra.

Meum.

Muscipula.

Myrrhis sativa.

Napellus coeruleus.

Nigella Romana.

Oxalis rotundifolia.

Papaver sativum simp. et multipl. flo.

Parthenium flo. multipl.

Pentaphyllum surrectum.

Periclymenum perfoliatum.

*Peucedanum.

Phalangium non ramosum.

Polium luteum. Virginianum.

Psyllium.
* Radix cava. flo. carn.

Raphanus rusticanus, Offic.

Rha rotundifolium.

Rhabarbarum Monachorum.

$$
\text { " verum. }
$$

*Rosmarinum aureum.

* , latifolium.

Ruta.

Sabina.

Salvia angustifolia.

" major vulgaris.

", variegata.

Saponaria flo. multipl.

Scabiosa montana max.

Scordium.

Scorzonera.

Serpilli 3. spec.

Stoechas vulg. Offic.

Sumach Virginianum.

Tamariscus Narbonensis.

Thalictrum majus Hispanicum.

* , virginianum.

**Thlaspi Creticum.

Thymum durius.

Trachelium majus flo. albo.

Tragopogon flo. purp.

Tuliparum varietates plurimae.

Umbilicus Veneris sive Cotyledon altera, Ger. emac. Sedum serratum.

Valeriana Graeca.

Vinca pervinca, sive Clematis Daphnoides.

Viola mariana.

" matronalis fio. pleno.

\section{xii. Walter Stonehouse's Garden List, i640-I644.}

The garden of the Rev. Walter Stonehouse at Darfield Rectory is described in a neatly written vellum-bound 12 mo volume of 44 leaves, with a leaf with plans of the garden, known as Magdalen College MS. No. 239, or as Goodyer MS. I 7. It is entitled Catalogus Plantanum Horti mei Darfeldiae Quibus is instructus est Anno Domini $I 6 f o$, and though anonymous, is convincingly identified as the work of Stonchouse by his anagram 'Theologus servus natus' (= Gualterus Stonchousus) on $\mathrm{f}$. 5 of the MS. The same anagram occurs in a MS. volume of Sermons in the Library of Magdalen College and at the end of his poems in the Musaeum Tradescantianum (1656).

Stonchouse's notes and plans show that the rectory grounds comprised a 'best garden', measuring 34 yards by 30 yards, the 
Saffron Garth, a long rectangular strip running north and south for 82 yards, and the orchard. The plans are clearly drawn to scale and are marked with numbers which corresponded to his lists of plants. We have even his notes of the exact dimensions of the garden in terms of his own paces, from which we may infer that he was a man of no great stature. ' 2,624 of my usuall paces made an English mile of 1,056 paces Geometricall : that is 5,280 feete and 1,760 yards. The garden 15 times half round is just a mile; I 6 times is a mile and 57 yards.'

Though we have their orientation, we have no clue as to how the three parts of his garden were disposed, but may conjecţure that the Rectory stood in the angle of the best garden. Plums, Peaches. Apricots and a Pomegranate covered the west and north walls; a vine was trained against a wall, possibly of the house. Several rectangles drawn at the ends of paths may represent garden ornaments; an arbour or summer house seems to have stood in the north-east corner.

The beds in the style of the sixteenth century may have been the work of an earlier incumbent. They were laid out in five 'knots', perhaps enclosed with tile, stone or Box edgings, which bordered the 'forthrights', as the broader walks were called. According to the plan the beds in the knots were two and three feet in width, and would, as Parkinson (1629) recommended, have contained the greater part of the herbaceous collection.

'The Safforn-garth 9 times round wants 50 yards of a mile; and 10 times about it is a mile and 140 yards. The long streight walke in the Safforn-garth is 82 yards; so that this gone 22 times single, or II times double, is a mile and 44 yards.

The name recalls the fact that in the sixteenth century 'Crocus', or Saffron, was perhaps the most paying crop that it was possible to raise in a garden. 'Our English Honey and Saffron,' wrote Bullein in 1588 , 'is better than any that cometh from any strange or foreign land.'

\section{'A little of ground brings Saffron a pound,'}

and in $539-40$, Doncaster Saffron was sold at more than $£$ I per pound weight. Saffron Hill and Saffron Walden recall an extinct British horticultural industry, but Darfield Rectory, as the present Rector informs me, is noted for a Crocus border I 70 yards long.

Most of Stonehouse's fruit was grown in the Safiron Garth and the Orchard, both of which were walled in. In the former he had 33 wall-trees, planted 6 feet apart, against the walls on the north 
and west sides, and a selection of 30 Apples and Pears 'in the open plotte', as well as some more recent acquisitions from the garden of his neighbour, Sir John Reresby.

The best varieties of the original stock were probably obtained from Parkinson's 'very good friend, Master John Tradescante', who had made a speciality of all fruit trees, "the choysest for goodness, and rarest for knowledge,' and especially of Plums 'fit for an orchard'.

In the orchard there were fruit walls along the north and east, and a raised walk or 'mount' along the wall on the west side. This 'high walke' probably dated from before Stonehouse's time, for he refers to 'olde plum trees' upon it. The 'open plotte' was stocked with Apples of various kinds, with a row of Pear trees along the north walk.

'The high walke in the orchard, 66 times single gone, or 33 times double (that is backward and forward) is a just mile- 5,280 foote.'

'The orchard 9 times round about is a mile and 4 yards.'

In the open the fruit trees were planted about I 8 to 20 feet apart. Their positions are clearly indicated upon his numbered plan, from which the illustration in Fig. 2 has been redrawn for purposes of reproduction. (See Gardeners' Chronicle, 1920.)

The Sir John Reresby, from whom he obtained several varieties of Apples and Pears, was a neighbour living at Thrybergh, some six miles south of Darfield. His son, of the same name, was the well-known Governor of York, who wrote memoirs containing a secret history of the Courts of Charles II and James II.

The manuscript concludes with an epitaph in Latin verse by Stonehouse. to his favourite cat, Delia, which died when kittening and was buried in the garden.

\section{IN FELEM DILECTAM, INTER PARTUS DOLORES EXTINCTAM.}

Delia (sic fertur) coelum invadente Typhoeo.

Sub Felc, in terris, condidit ora latens.

Partubus illa praeest; sed et illa (heut) sacpe vocata, Tardat, parturiens dum milhi Felis obit.

Ah, factum, Lucina, male! Ah, ea gratia Divae est, Praesidii ut possit non memor esse sui.

The present Rector of Darfield, the Rev. A. E. Sorby, informs me that the house has been greatly enlarged and probably covers the beds at $T$ and the geometrical beds at $S$. 'The other four beds, V. IV , Y, Z, with the star in the centre, are still in existence, though 
not in the same geometrical position. The Saffron Garth is, I think, undoubtedly in the walled garden between the Rectory and the School Street. The measurements do not agree with the existing garden, but the shape is the same and the Saffron Crocus borders are still there. To the north of the Rectory and of the walled garden is a large orchard, where the Saffron Crocus up till lately also flourished and bordered the paths. ... O Our soil is very light and most suited to bulbs.'

The list of plants in Stonehouse's own hand was evidently compiled at different times. The first list, in strict alphabetical order, was completed on or shortly before the 27 th of August, I640. The names are very clearly written: ten lines on a page, on alternate lines for additions. The later entries are therefore readily distinguishable. They are in blacker ink, and may with confidence be referred to the next four years. Probably the greater number of new plants was added in 1644 . Stonehouse estimates that he had 450 perennials in 1640 , or 651 at the later date (probably 1644 ), as well as 215 annuals and biennials raised from seed, making 866 in all.

Then, no doubt, came the period of his persecution, banishment and imprisonment. A pathetic little note tells us that in 1652 he again visited his garden. It is in Latin and appears to mean that of the 866 plants, 'Alas! but few are there to-day, and I have no hope of founding a new colony'.

The lists enumerate I4 species from Virginia, 5 from Guinea, and 4 from New England, including Juglans, Terrae glandes, 'Maiz' and Pepo. Sir David Prain informed me that he knew of no earlier record of English garden plants from this last locality.

The plant lists have been printed in extenso in the Gardener's'

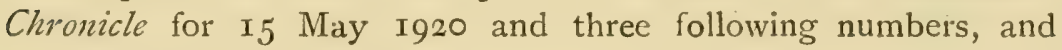
reprinted with corrections. ${ }^{1}$

\section{xiii. The Westminster Garden of Edward Morgan, c. I619-c. 1677 .}

Edward Morgan, 'rei herbariae studiosus,' a Welshman, was one of the Socii itinerantes who accompanied Johnson on his famous excursion to North Wales in July I639, and acted as interpreter. ${ }^{2}$ He then made the acquaintance of Walter Stonehouse to whose garden he contributed a plant of the Leopard's Bane of America 'Doronicum Americanum majus' (1640). Morgan had a garden at

1 Gunther, Garden of the Rev. Walter Stonehouse, 1920.

2 Johnson, Mercurii Botanici pars altera, Lond. I64I. 
Westminster, where he grew the first Polyanthuses, obtained from Great Woolver Wood in Warwickshire, and possibly also Phlomis purpurea, which he is stated by Aiton to have been the first to introduce. His name is associated with the following British Plants by How in MS. notes which must have been written between 1650 and 1656 . He evidently knew where to find white and purple Spear Thistles in London.

Primula veris fl. pl. viridi.

, , sive Paralysis fatua.

Malva syl: flore albo.

[Bellis fl. herbaceo globoso non descr. (erased).]

Scabiosa ovilla fl. albo.

Carduus lanceolatus fl. alb. St. James.

Lychnis syl: foliis variegatis fl. albo. Qu. M.

Carduus lanceolatus fl. alb. et fl. purp. $Q$. Chyrurg: for ye places of theese plants growth from Morgan.

On Io June I6 58 John Evelyn 'went to see ye Medical Garden at Westminster, well stored with plants under Morgan a very skilful botanist'. In I 662 the garden was visited by the Rev. John Ward, who recorded in his diary ${ }^{1}$ that Dr. Morison commended 'Ned Morgan's for ye best collection of plants in England', and the admiration appears to have been mutual, for Morgan affirmed Morison to be the best botanist of his age in London, and next to him are 'Dr. Dale, Dr. Merit, and Mr. Goodyer'. A few of Morgan's plants of special interest are noted in Ward's diary. They included

Leucojum bulbosum. 3 sorts.

Iris persica, a very pretty Iris, 'Ye flowers open with a mouth like Snapdragon'.

Cinara spinosa et aculeata.

Muscus filicinus, 'winged like ferne. Much of it gathered in Hamden woods'.

Gramen innatans and fluviatile.

and Burri (= Burre grasse), ' as it hath a yellow spike on top'.

I. Ilex coccigera.

2. " glandifera.

3. ;, aktae-foliis.

4. ", ye common.

Medler tree.

Strychnos Nux vomica, ye Physic nut
Yellow Jessemine

Zizipha, ye Bead tree.

Glaux maritima.

Cruciata marina.

1 D'Arcy Power, The Oxford Physic Garden, Ann. Bled. Hist. ii, p. In. 
Absynthium arborescens 'July 3'.

, insipidum et inodoratum, ' a very pretty plant, very like common wormwood, July $3^{\prime}$.

A pretty hedge of Spanish broom.

In 1667 we again get news of the garden through Merrett who added five of Morgan's plant records to the Vegetabilia in his British Pinax.

Malva arborea marina nostras.

Lavatera arborea L.

'Mr. Morgan received it from the Isle of Wight.'

Plantago aquatica major muricata.

'In a small pond betwixt Clapham and South Lambeth-Common. Mr. Morgan.'

Primula veris Polyanthos.

'In great Woolver Wood in Warwickshire, Mr. Morgan, qui transtulit in hortum suum instructissimum Westmonasteriensem.'

Fungus campani formis, niger, parvus multa semina plana in se continens.

'Mr. Morgan's Garden Westminster, call'd in.Wostershire, Corn bells, where it grows plentifully.'

Fungus rotundus supernè concavus et translucidus coloris succini.

'In Mr. Morgans garden, et alter coccinei coloris, in St. James's Park in the Winter time on old decayed Trees.'

Edward Morgan's Hortus Siccus, ${ }^{1}$ comprising some two thousand dried plants, is contained in three large folio volumes of about I60 leaves each, now preserved in the Bodleian Library. The specimens give us a very complete illustration of the plants, which were probably grown in his Westminster garden in 1672 , when the collection is believed to have been begun. At least two of Morgan's garden plants found their way into the Morisonian Herbarium at Oxford. One is the Basil-leaved Red Dead Nettle (Lamium purpureum L. var. ocymifolium Boulger), and the other is the Phlomis purpurea L. mentioned above. His name is also associated with 'Chamaecyse Virginianus E Morgan' (Euphorbia maculata L.) ${ }^{2}$

In 1676 the plants were removed from Westminster to the newly founded garden of the Apothecaries Company at Chelsea; and in 1677 , 'Mr. Morgan, the gardener, asked for increased "consideration" for keeping the garden and for his plants'.

The exact site of Morgan's garden is not known. It appears to me that it may have been the same as the one by which RALPH TUGGY, the correspondent of Johnson, had previously made his name as a famous grower of pinks, carnations, and auriculas. Bobart referred to him as 'Tuggie in Westminster, beyond ye

${ }^{1}$ Noticed on p. 308. I am not quite convinced that Edward Morgan of Bodesclen is the same person as Edward Morgan of Westminster.

${ }^{2}$ Vines \& Druce, Morisonian Herbarium. 
Abbey '. We know that Tuggy died before 163.3 , when his widow was keeping up the garden, but he is mentioned by Tradescant in 1629-30, see p. 331. A Richard Tuggy and Edward Morgan appear in 1657 as co-signatories to a letter printed by W. Coles at the beginning of his Adam in Eden.

On the other hand, Edward Morgan has to some extent been confused ${ }^{2}$ with HuGH MoRGan, 'the Queen's Apothecary' and 'a curious conserver of rare simples', who had a garden near Coleman Street, where he had a tree of Celtis australis L. Coleman Street was of course in the City, leading north from Lothbury. Hugh Morgan introduced Clematis viticella in 1569 , and is quoted by Lobel as having also introduced to English horticulture

Althea arborea Olbia in Galloprovinc. Adv. p. 294.

Buphthalmon, Oculus bovis, Millefolii folio, Chrysanthemi flore. Adv. p. 343 .

Cicercula altera, an Phaseolus Diosc?. Adv. p. 394.

Mount (see p. 256) mentions Maize and the Gladiolus in Morgan's garden in 1578 . A panegyric advertisement of Hugh Morgan addressed to Dr. Bayley 'by your assured loving friend B. G.' and dated Alvingham, I4 Aug. ${ }^{5} 87$, is bound up with the Bodleian copy of Walter Bayley's Discourse of the three Peppers. Obviously Hugh belonged to a generation before Edward Morgan.

xiv. Lists of English Garden Plants wanted by Dr. ROBERT MORISON, A CORRESPONDENT OF DR. WILLIANI How, For the Royal Botanic Garden of Blois, c. I65I.

These three lists were evidently enclosed in a begging letter from an unnamed correspondent, endorsed 'For his much respected friend Dr. V. How'. They are written on 5 leaves, measuring II inches $\times 4$ inches. The writer was evidently exceedingly anxious to obtain the plants. Of the 51,92 , and 70 plants included in three lists, $2 \mathrm{~J} 3$ in all, How appears to have been able to supply the 42 indicated by numerals and crosses in his handwriting. It will be noticed that these include a proportion of new plants from Virginia 'not yet described'.

A comparison with the Morison MSS. in the Oxford Botanic Garden has convinced me that these lists are in the hand of Dr. Robert Morison, a pupil of the Frenchman Vespasian Robin

1 Bobart MS. note in his Cat. of Oxford Garden at Oxford.

2 Amherst, History of Gardening in England, 1895, p. 223. 
who in the year of the publication of the Phytologia had been appointed Curator of the Royal Botanic Garden at Blois. ${ }^{1}$

A chance presentation to Charles II in February I660 resulted in his being offered an appointment as Regius Professor of Botany in London, to which he added the Chair of Botany at Oxford in I669. In a book primarily about John Goodyer and his contemporaries, I have nothing good to say of Morison. He was practically a foreigner, and unlike Ray, he ignored the work of English botanists. In the words of Sir Arthur Shipley 'He seems to have been a somewhat selfish man of science, self-assertive, taking every credit to himself, while allowing little to his predecessors and contemporaries.' 2

\section{LIST I.}

Semina harum primo quoque tempore ad me mitti desidero plantas vero tempestate idonea.

[Followed by an illegible note in How's hand]:-

Rememb. Vina max. syl. by sending in ...

I. Abrotanum Indorum.

2. " $"$ unguentarium.

3. Absynthium album umbilicatum.

4. Acinos anglica Clus.

5. ", , fl. albo.

Anonis flore purpureo.

6. Armeria syl. humilis $f$. vineo rubello.

7. Beta maxima.

8. Cachrys verior Galeni.

9. Calamintha pulegii odore.

10. Makenbuy valde aneo scire quid sibi vult et planta haec ipsiusque nomen.

II. Oxys lutea virgineana.

12. Chelidonium minus fl. pleno.

I3. Juniperus major.

Cochlearia vulgaris Britannica.

, vera rotundifolia minima.

14. Matricaria fl. Bullato aureo.

15. Mentha crispa.

I6. Solanum lignosum virginianum.

17. Lysimachia lutea fl. globoso.

1 It may be noted that while Morison was cataloguing his garden at Blois, an Englishman, Sir Richard Browne, then resident in Paris, was at work on a Catalogue of Evergreens in which he had been helped by a Mr. Keipe. In a letter to Sir E. Nicholas, dated 5 July 1658 , he noted that 'Alaternes beare a graine like that of privet, which beinge sowed comes upp and prospers without difficulty'. Camden Soc. xxxi, p. 65. Goodyer had noted Rhamnus Alaternus in Coys' garden in 1616.

${ }^{2}$ Schuster \& Shipley, Britain's Heritage of Science, p. 234.

A a 2 
18. Persicaria virginiana.

Trifolium pumilum supinum flosculis longis albis non descriptum. ,$\quad$ nodiflorum.

19. Salvia germanica non descriptum.

20. Saxifraga aureá sane sanicula guttata non descripta.

Atriplex marina latifolia tota rubra non descripta.

21. Periclymenum foliis quercinis non desc.

Plantago quinquenervia fimbriis lat. ex aureo argent. non descripta.

Acer florescens virginianum non descriptum.

" odoratum virginianum non descriptum.

22. „, virginiana non desc.

Apocynum virginianum latifolium majus $\mathrm{fl}$. albicast non desc.

23. ", minus virginianum angustifolium fl. albo non desc.

, virginianum minus $\mathrm{fl}$. elegantissimo miniato non descriptum.

24. A pium virginianum. virginianum minus roris marini folio non descr.

25. Arbor tinctoria virginiana non desc.

26. Aster Novae Angliae.

27. Artemesia (?) foliis variegatis.

28. Aster foliis (?) et flore minore Novae Angliae.

29. Battatas virg.

Beta foliis variegatis.

30. Bistorta minor nostrarum.

Blitum majus repens fl. virid. Novae Angliae.

Calceolus Mariae.

Caucalis apii foliis floribus rubeis.

Digitalis flore variegato.

3I. $" \quad$ virginiana angustifolia.

32. $" \quad$ virginiana fl. luteo.

33. Lupinus perenni radice virginianus.

Mentha variegata.

\section{LIST 2.}

Plantac excerpta ex Phytologia Britannica quas desidero aut saltem annuaria semina.

[This list contains 92 names, of which How supplied 7 plants only.]

34. Anonis non spinosa purp. Ger.

35. Bardana rosea s. Lappa rosea.

36. Bugula s. Consolida media.

37. Cardamine pumila Bellidis folio.

38. Cerasus syl. fructu minimo cordiformi non descripta.

39. Foenum graecum syl.

40. Vina maxima syl. nondum descripta.

\section{LIST 3.}

Plantae solis Johannis Park[inson] scriptae quarum communicationem aut seminibus aut radicibus peroptarem.

[A list of 70 plant names, of which How marked two with numbers.]

41. Lychnis arvensis minor anglica.

42. Platanus occidentalis s. virginensis. 
Harum praedictarum tam in primo quam secundo, $3^{\text {io }}$ Catalogo contentarum semina penes te, ad me mitti primo quoque tempore non dubito quia hic apud nos appropinquat serendi tempus.

Quin oratum et exoratum te velim ut ex 400 sponte in Anglia provenientibu adjiciendisque aliquot rariora semina (quorum tibi est copia) ad me mittas.

[MS. f. 169-73.

In 1661 and 1662 Dr. Morison, established in the Keepership of the King's Gardens in London, was visited by John Ward. ${ }^{1}$ Under Feb. 166I-2, Ward noted that, unlike Goodyer, Dr. Modesay ' never studied grasses and mosses'. 'Att ye King's Garden Dr. Modesie showed us some of his very rare plants as

Marum Syriacum.

Crithmum spinosum.

Barba Jovis.
Mastick.

Samphire.

Silver bush.

and the conversation turned on Lysimachia purpurea spicata, Chelidonium majus and minus, the Sycamore, and Rabelais. Ward evidently enjoyed the visit, for he repeated the experience on I Sept. I662, remarking "itt is a very rare thing to discourse with him'. This time he noted

Jacobaea crithmifoliis

Capparis Fabago

Cappadiis

Capsicum polygala

Valentina Clusii

and many other rare plants.

${ }^{1}$ D'Arcy Power, Oxford Physic Garden, Amn. Med. Hist. ii, p. 122. 


\section{LISTS OF EXOTIC PLANTS.}

THE greater number of Lists of Plants in Goodyer's handwriting are of English indigenous and garden plants, and are written on odd pieces of paper of quarto width. Among them are several lists of forcign plants (now bound with Goodyer MS. II), very closely written on narrow slips of paper, 3 or 4 inches in width, which have become crumpled, rubbed, and foul with dirt, as if they had been carried about in a pocket. They have all the appearance of hand-lists of desiderata, such as a London merchant might have furnished for the use of travellers visiting foreign regions, who required in compact form, catalogues of local plants with native names. Some of the lists were obviously restricted to tropical produce of economic value: others may be regarded as among the earliest exotic floral lists known in manuscript. The handwriting of certain of the lists appears to be that of John Parkinson, and their date to be about $16_{3} 6$, but several are no doubt earlier.

These early lists with their flavour of foreign travel recall Rauwolff's allusion to 'the great Troubles and Dangers those that have written of Exotick Plants have sustained and incurred in their foreign Peregrinations, would not be grievous to me, did I not fear that it would extend this Dedication to too disproportionate and tedious a length' '.

FRANCE. List of 5 I plants taken from and with references to Lobel's Adversaria, written by Goodyer on the back of the draft of a letter dated I6 Fan. $163 \mathrm{I}$. Not printed.

[MS. f. $132 \mathrm{v}$.

Glossary of French names of Plants, evidently abstracted by Parkinson from P. Bcllonius De neglecta Cultura Stirpium (issued with Chusins Exotica), pp. 224, 226. Not printed. [MS. f. I56 v.

List of Plants, mostly from Italian Localities, abstracted from Camcrarius, Hortus medicus et philosophicus i 588, presumably' ly' F. Parkinson.

Abutilon Indicum.

Acacalis. Alisma Matth.

[f. I 62

Adonis flore pallido in Thuringis segetibus e Suevia.

Alnus nigra, Frangula. Siler Plinii non multis (?).

Amygdalo persicus pulpa persicum nucleus amygdalum sapit.

1 Epistle Dedicatory to Rauwolft's Travels in Ray's Collection of Curivus Travels, 1693. 
Antirrhinum pulcherrimum flore luteo, grandi, sponte nascitur inter Savonam et Genuam.

Apocynum verum non repens.

Aristolochia rotunda vera. In montibus Euganeis prope Patavium crescit. Asphodelus autumnalis sive maior ex Italia missus: hyemem non fert nisi in fictili asservetur.

Camphorata Monsp. ${ }^{1}$ [Carduus bulbosus.] Card. pineus Narbon.

Chamaelaea Germanica flore albo.

Chelidonium minus flore pleno. Francofurt. [ex horto A. Keck].

Cistus flore luteo Ledi [Ladani] folio Italici. Florentia.

Clematis altera flo: albo; Flammula repens Dodon.

Clinopodium Matthioli flore albo.

Colchicum vernum subobscuro flore circa Tigurum Helvet.

Corcorus sive Melochia.

Corydalis Fumaria lutea montana. Splith.

Cotinus Coccygria Plinii frequens in Trident. Alpibus.

Cyperus rotundus. Cyperus dulcis, Trasi dulce.

Cytisus Columellae, Glaux quibusdam. Pisa et Samnitibus oritur et Bononiensi agro.

Cytisus niger sive maior Pseudocytisus Cordi elegans planta est, et tota aestate florens topiariis idonea.

Daucus Creticus verus in montibus Vicentinis, Baldo et monte prope Comum.

Elaphoboscus, Florentia.

Ferulago.

Flammula recta.

Galeopsis flore luteo, folio longo, rectis caulibus.

Halicacabum sive Solanum Indicum. Florent. [a J. de Casa bona].

Hissopoides ad portam S. Julianae [Justinae] Patavii \& intra moenia.

Jacea pumila, seu Carduus pineus Narbae.

Jacea Montana Narbonensis.

Juniperus maior Italica baccis rubris.

Libanotis cachrifera quae rotundis foliis prodit e semine cum pleraeque aliae umbelliferae oblongis oriantur.

Libanotis altera semine lato, nigricante, odorato.

Lilium non bulbosum sive Arundinaceum flore subcroceo et alterum luteo odorato admodum. Profert interdum germina in summitate caulis ubi flores sine semine deciderunt, quae terrae comissa statim radices agunt.

Muttelina ex Arba monte Helvetiorum ; inter Carum et Meum ambigua.

Paeonia ochranthemos flore pallescente.

Paeonia hispanica pumila.

Panax Heracleum in Apennino, in Alpibus Scalae dictis. non procul Bononia et in Samnitibus ubi Rampe d'orso veñ.

Panax Asclepias folio Ferulae tenuiore et Foeniculi crassiore. In Creta Seseli vulgo. Sicilia Peucedanum vocant.

[f. $162 \mathrm{v}$.

Perfoliata montana Gesneri et Lugdunensis radice perenni, [foliis quodam. modo Limonii seu Pyrolae fruticantis Clusii parfoliata quasi ca . . lis Smyrnii, floribus medio multiplicatis itemque et seminibus dense stipatis.] ${ }^{1}$

Perfoliata crispa seu muscosa multiplici florum et foliolorum tenuissimorum farctum. Sterilis ut Cannabis foem. ex semine vulgari oritur.

1 Not in Camerarius, Hort. med. 
Polyacantha, raro in alterum annum durat.

Pulegium Anguillarae, ex Mentastro non multum dissidens foliis rotundis et gratiore odore. Plurimum nascitur Patavii tam extra quam intra urbis moenia.

Quamoclet planta nova ex India allata, et Ducis Florentiae horto Josepho de Casa bona.' $[=$ Ipomoea Quamoclit L. $]$

Rosa Hierichuntica pulchrè ex semine nata.

Sagapeni planta vulgo dicta: Costus spurius Apuliae Matthioli. Sagapenum in Italia gigni. Plinius autor est sed in totum transmarino alienatum.

Saxifraga magna Matthioli; alia ab Hyrcina [sit l'impinella saxifraga].

Saxifraga Bavarica in petris nudis musci more innascens, foliolis thymi sed virentioribus flosculo stellato candido quinque foliolis constante, elegant.

Scammonea Antiochena aliquot annos apud nos durat asservata in fictilibus per hyemem, et aestatis initio floret, sed semen nunquam absolvit.

Scammonea Monspeliensis maritima. Crescit etiam copiose prope Tripolim in maritimis ubi incolae vocant Meudheudi.

Scordium secundum Plinii, Salvia syl. 'Tragi. Scorodonia Cordi. Odorem habet Scordii nonnihil Teucrii referens.

Scorpioides folio Bupleuri r. Dodonaei, Thelephium Anguillarae.

Scrophularia peregrina.

Sena Italica apud nos fuit annua planta. Alexandrina ne quidem in Italia ultra annum dura ideoque pro frutice haberi nequit. Contrahit nocte folia sicut multa alia eius generis leguminosa.

Sesamum verum.

Seseli Aethiopicum alterum folia fert Aquilegiforme similia sed nuulto ampliora: semen aliquantulum Cinamomum representat odore et sapore. ex illustriss. principis Landgr. Wilhelmi Cassellano horto.

Seseli Massiliense. Lucas Chinus ${ }^{2}$ excellens rerum simpliciun censor, circa viginti plantas Seseleos Massiliensis descriptioni convenientes se novisse affirmavit.

Siler Creticum quo nomine ex Italia missum foliis Cicutae sed latioribus et paucioribus, semine incurvo, grandi, hirsuto et fusco.

Sison interdum ex semine provenit, pro Amomo habetur in officinis.

Solanum somniferum.

Sphaerocephalus flore albo.

Symphitum petraeum Neapoli missum foliis Thymi sed maioribus et longioribus nonnihil hirsutis aliquantum sed minus, odoratis, capitulis Thymi, flosculis purpurascentibus.

Telephium Matth. flore albicante et rubro. Radice instar aloes suspensa in aere crescit.

Thalictrum i. Italicum Dodonaeo tertium.

ii. Germanicum latifolium. Dodon, primum.

iii. Angustifolium.

iv. Parvum Dodonaeo quintum.

v. Flore purpureo Dodonaeo quartum.

vi. Flore albo.

1 Joseph de Casa bona, Duke of Tuscany, corresponded with Camerarius. The Aloe spinosa sive Americana flowered in his garden in 1586, throwing up a spike to a height of over 12 cubits.

${ }^{2}$ Luca Ghini delivered botanical lectures at Bologma which were attended by William Turner about 1542 . 
Thora Italica, Napello congener.

Thymelaea multis locis Italiae in Monte S. Juliani Hetruriae et per Apuliam.

Thymus verus capitatus seu Creticus in Italia circa Neapolim et in Sycilia qui tamen annuus fuit.

Trifolium Halicacabum sive Vesicarium aliis cicer sylvestre, quibusdam etiam satis inepte Dorychnium, folia plerumque quaterna vel quina gerit ut Loto annumerandum videatur.

Trifolium hepaticum sive Aureum, Hepatica nobilis, flore rub. circa Corbachium Westphaliae, flore albo Cadelburgi in sylvis.

Trinciatella ex Italia. Denti leonis planta similis sed tenerior, foliis quoque magis crispis, laciniatis gustu dulcibus, floribus minoribus et elegantioribus, semine oblongo, lato, membranaceo, superiore parte duriusculis aliquot pilis munito, eo ipso anno quo seritur flores et semen producit et si per hyemem in fictili servetur etiam in plures annos perdurat: alioquin radices quae dulces sunt ut universa planta primo frigore leduntur et intereunt.

Valeriana Alpina multo odoratior, flores enim Citrii pomi odorem referunt [ex Allobrogum montibus ad me missa a C L. Medico Ioanne Antonio Saraceno 1.

Verbascum sylvestre foliis Salviae. Secundum Anguillaram in Italia provenit apud Marsos ad arcem quandam Pisinan dictam Suchamele incolae vocant.

Violae speciem Bysantii coli Costaeus in Mesuem annotavit caetera Martiae similem, sed flore infinitis foliolis constructo et aequante Rosam Iamascenam magnitudine et odore etiam nostratis superante. Huius recentem florem unum atque alterum prima mensa sumptum alvum subducere instar recentis rosae Hyeronimum Capellum Venetum rerum naturalium peritissimum observasse tradit.

[MS. ff. 162-3.

\section{Andalusian and other Spanish Plants collected by Boelius and described by Goodyer.}

Guilhaume Boel in the year 1608 brought to Parkinson two Trefoils which he had gathered in Spain 'with about two hundred other sorts of seeds, besides divers other rare plants, dried and laide betweene papers'. By sowing the seeds Parkinson 'saw the faces of a great many excellent plants, but many came not to maturitie' with him and most 'by unkindly years that fell afterwards perished'.

Theatmum, I 108 .

Aracus maior Baeticus Boelii.

Astragalus marinus Lusitanicus Boelii.

Cattaria tuberosa radice Baetica Boelii.

Caucalis maior Baetica.

Chrysanthemum Baeticum Boelii inscriptum. " tenuifolium Baeticum Boelii.

Convolvulus coeruleus minor Baeticus.

Faba veterum serratis foliis Boelii.

Geranium Baeticum sp. Boelii. 
Gramen cristatum Boelii. tremulum maximum.

Hieratium Narbonense falcata siliqua L'Obelii.

, stellatum Boelii.

, medio nigrum flore maior Boelii.

", lanosum (?).

Jacea capitulis hirsutis Boelii.

Jacea palustris Baetica Boelii.

Lagopus trifolius maior Baeticus.

Lathyrus aestivus Baeticus flore coeruleo Boelii.

, " $\quad$ edulis Baeticus flore albo Boelii.

, palustris Lusitanicus Boelii.

" aestivus dumetorum Baeticus Boelii.

Legumen pallidum Vlissiponense Nonii Brandonii.

Malva flore amplo Baetica aestiva.

Medica maioris Baeticae species prima, spinulis intortis.

Nigella elegans ex Hispania. spinosae, species altera.

Papaver rhoeas Baeticum.

Phalaris minor Baetica Boelii semine nigro.

Phalaris bübosa B̈oelii. , semine albo.

Pisum maculatum Boelii

Scorpioides multiflorus Boelii.

" siliqua crassa Boelii.

Silibum minus flore nutante Boelii.

Sonchus Africanus Boelii.

Robert Teav's List of 69 Plants from Russia, 1632.

Glaux Diosc. Clusii

Genuina syl. pasticha

Aster Italorum

Chamaerododendros mont.

Linum marinum luteum

Scabiosa maior satorum

Saginae spergula

Chamaelinum syl. flo, albo

Eruca nasturtio cognata

Thlaspi narbonense

Helxine cissampelos altera attriplicis effigie

Hieratium alterum grandius

Condrilla coerulea

Origanum hieracleoticum

Blattaria flo. luteo

Cannabis syl. spuria

Nucula terrestris

Ranunculus tomentosus

Scrophularia maior

Pimpinella maior ffuchsii

Agrioriganum
Coniza media

Campanula minor rotundifolia

Anthillis leguminosa

Gnaphalium minus montanum

Muscus clavatus

Muscus alter clavatus inscriptus

Clynopodium

Viorna

Buphthalmon

Gnaphalium Anglicum et

Cruciata minima Belgicum

Thalictrum

Geranium batrachoides

Veronica recta herbariorum

Ledon foliis Rorismarini

Gramen iunceum marit.

Milleum

Herba paris

Lysimachia lutea

Chamaenerion

Coniza helenitis 
Mellita incana

Astragaloides altera herbariorum

Hieracium Sabaudicum

Veronica mas Matthioli

Helleborine seu Epipactis

Dentaria altera herbar.

Alabastritis altera

Rubus Idaeus

Cicutaria latifolia

Coniza maior vera

Aconitum luteum ponticum

Carduus pratensis Tragi

Barbarea
Anagallis aquatica

Ranunculus flo. albo

Gramen parnassi

Gentiana minima

Gentianella alpinà

Monophyllon

Phaseolus ex phaseolis diversus

Polygonatum

Ranunculus min. sept.

Sorbus syl.

Ribes nigra

Ribes Arabum

Pyrola

\& many other which I know not \& are not to be found in my herball, I will have their effigies drawne $\&$ will hereafter send them you with their leaves \& Russe names \& vertues.

Mosco. I 2 Junii 1632

Robert Tewe.

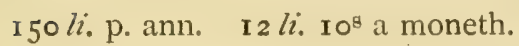

[MS. f. I 35 .

\section{Abstract of Adrian Spigelius' Isagoges in rem herbariam, 1606. In the hand of Parkinson.}

Pimpinalla ad radicem quadam in Polonia granula rubra gerit quibus lana purpureo colore inficiuntur. Isagogis Spigelii. fol. I 5.

Cachrys pilula est quae Latino caret nomina, urendi vim habens in medecina. hanc arbores aliquot praeter proprium fructum pariunt hyeme durantem postquam folia cecidere ut Quercus, Abies, Larix, Pinus, Tilia, Nux Juglans, Platanusque; sed in Pino Juglandeque saepius quam in aliis arboribus conspicitur. Is crescit hyeme deciditque, vere cum pilula aperitur. fol. I 7 .

Lysimachia purpurea trifolia Patavina Spigelii. fol. I 2.

Sophonia Plinii nonnullis Blitum tricolor. fol. 24.

Ononis non spinosa Senensis capreolos, ut Vicia odore iucundissimo. fol. 39 .

Hieratium flore purpureo. [fol. 4r.]

Junci odorati caulis rotundus est, foliis alternatim obsitus, in quorum alis floras continentur, folia Gramini similia, cuius potius est species. Et cur Juncum appellatur miratur cum neque caulem, neque folia Junci habeat. [p. 42.]

Linum syl. fl: coeruleo, albido, rubescente et luteo.

Osiris flores edit luteos a fronte latiusculos, clausosque, os ranae imitantes: cauda angusta est et inflexa, ut Consolidae regalis; foliis Lini, qualia etiam in Esula minori conspiciuntur. [p. 43.]

Linaria odorata et Linaria Valentina Clusii quorum folia Lino non sunt similia sed flores tantum Linariae.

Vrtica foetida seu Galeopsis ideo dicta quia Galei id est mustelae faciem et rictum flores quodamodo referant.

Blattaria flore rubro.

Phlomis a foliorum hirsutie appellatur.

[Continuation of MS. (68 lines) is not printed.]

[MS. f. I 59 


\section{Graecorum Turcarum et Arabum appellationes.}

MS. f. $T 55$.

[Abstracted from P. Bellonius, Observationes, transiated into Latin by Clusius and printed with his Exotica in 1605. A Traveller's list of Native names, closely written by Parkinson on a folded paper measuring $7 \frac{3}{4}$ in. $\times 3$ in.]

\section{Plantarum Cretarum indigenarumque ramun nomina.}

[This list containing about 125 names of plants was evidently abstracted by Parkinson from Bellonius, Observationes, loc. cit., pp. 23-5.]

Acer. Cistus. Coris. Anagyris. Ferula. Ilex. Cupressus. Tithymalus dendroides, 2. hominem alt. Picea. Thapsea. Libanotis. Pinaster. Seseli. Dictamnus. Pseudodictamnus vulgo Cromido filo. Oxycedrus. Ferula, Artica dicitur.

Aristolochiae quartum genus Clematitide similis arbores scandens et premens.

Tria Origani diversa genera. Onitis peculiariter inter scopulos. Heracleoticum contra humentibus locis gaudet. Sylvestre neutrius naturae particeps circa sepes crescit.

Tragacantha non gumnifera in Candia.

[MS. f. I 57 .

[Fifty lines omitted. This list is followed by lists of about 20 plants growing in LEMnos and 23 growing on MOUNT ATHOS. Both lists were derived from Belon, pp. 31 and $42-3$.

\section{Plants of Gallipoli, Sinai, and Palestine.}

[MS. I I, f. I $58 \mathrm{~V}$.

[Practically a table of contents of the plants described by Belon, very closely and neatly written on the back of the paper with the Cretan List.]

\section{List of Arabian and Indian Plants, Desiderata compiled for the guidance of a Traveller in the East.}

The first eight items are not in Parkinson's handwriting.

\section{Per Cayr et Alexandria.}

Folium indicum is a leafe of a tree \& hath 3 ribbes in every leafe it tasteth somwhat hott like cloves or spice: the Arabians in their language doe call it Gadegi Indi \& some doe call them Famalapatra. The freshest in coullour \& the quickest in taste is the best but remember the true have ribbes onely on every leafe both on the backside \& the lowerside, and none true have none.

[Probably a form of Cinnamomum Zeylanicum bireyne.]

Costus is a certaine whitish roote that tasteth very hott $\&$ somewhat bitter withall. The Arabians call it Cost or Cast \& some of them Costi. If it be fresh it will smell very sweete. At Guzarate it is called Vylot $\&$ in some places Pucho.

[Root of Aucklandia Costus.] 
Amomum is a certaine fruite that is clustering together having about 7 or 8 or 10 berryes on a stalke, every berry somewhat like a greate grape but whitish or yellowish \& is skinnye on the outside \& conteyneth divers browne seedes within them that smell very hott \& are very sharpe biting the tongue. The Arabians call it Amana.

[One of the many kinds of Cardamons. Clusius received Amomust Cardamonum L., in 1605.$]$

Calamus gromaticus is a certaine drogue not very well knowen to us $\&$ therefore can give no true description, yet we understand it is to be had in those East partes: we would faine see the true. The Arabians call it Cassabalderira.

[Acorus calamus $\mathrm{L}$., received by Clusius in Western Europe in 1574 ]

Squinant is a certaine small rushe that tasteth hott like spice: the whole countrye of Arabia aboundeth as plentifully with it as other countryes with grasse \& rushes. The Arabians call it Adhar \& Adher. The smaller \& finer the rushes are, the hotter in taste \& the better: the greater rushes are courser.

[Herba Schoenanthi vel Squinanthi from Andropogon laniger Desf.]

Acacia is the iuyce of the fruite of a tree called Akakia growing in Egypt \& Arabia, thickened \& made into small cakes very astringent \& binding in tast. There is also a fine small white gum that is taken from the same tree Akakia wherof we would fayne have some. The fruite of the tree are certaine codds wherwith they use \& dresse lether in Egypt. We wold faine have store of those codds which are like beane codds to be sent unto us also.

[Gum of Acacia arabica was known in I $7_{\text {th }}$ cent. B.C. and is mentioned by Theophrastus, Dioscorides, and Pliny.]

Ameos is a small seed smaller than persly seede \& tasteth somwhat hott, it is called Ameos I thinck every where.

[This is doubtless the species described as Ammi parvum folits foeniculi (Park. Theatrum, 912) = Carum ammoides B. \& H.]

Balsamum is a whitish oyle thin \& cleere that cometh from Mecha \& other places in Arabia gathered distilling from a tree there growing which they call Balessan of a sweete \& sharpe sent somwhat like Turpintine but thiner \& whiter, \& if a droppe be put upon water it spreadeth on the toppe of the water like common oyle, \& wil be whitish if it be gathered together from off the water with a little stick or other thinge.

The berryes of the tree likewise we wold have some store they are brownish round berryes with a sharpe pointe or end \& smell somwhat stronge like the oyle.

The small sprigges \& branches of the same tree Balessan likewise we want with smell of the oyle, if they be fresh are of a darke browne collour on the outside $\&$ are a little gumye \& will stick to ones fingers espetially if they be fresh and new.

[Balsanodendron Gileadense.]

The remainder of the items were written by Parkinson himself.

Cate so called of most both Indians, Arabians and Persians is a thick blackish substance allmost like Opium but a little harsh or astringent and bitter withall. The tree is full of thornes and is called by the Indians Hacchhic \& we call it Lycium : we would faine have some of the beryes or fruite that growe upon this tree.

[Perluaps the Lycium of Dioscorides prepared from Indian species of Berberis. Parkinson spells the word Hattych]. 
Sandal of the Arabians \& Chandama of the Indians is that wood called Saunders white and yellow.

[In $16{ }_{3,5}$ the duty levied on the wood of Santalum allinm L., was Is. per lb. on the white, and $2 s$. per lb. on the yellow.]

Caxcax is the greate heade of a Poppy that will hold a pinte of liquor.

[Pupaver somuiferum L.]

Imgu \& Imgara of the Indians is a kinde of Gum or iuice \& is called of the Arabians Altiht \& Antit: the plante from whence this iuice is taken is called Anguiden \& Angeidan \& in the Latine tonge Laser. If it were possible to gett some seede of the plante which is broade $\&$ flatt almost like unto a short rounde wing of a bird.

[Ferula asafoctida. Description taken from Garcias, Park. Theatrum, 1569.]

Calambac of the Indians of Malacca is the best Lignum Aloes: and Garro is the worst. The Arabians call this last, which is the worser, Aquilage \& Haind.

[The best Aloes wood, for use as incense, comes from Aquilarin Agallocha, Roxb. Garo de Malaca is $A$. ovata. "Selectissimi fragmenta' of this wood were seen by Clusins in England in $158 \mathrm{I}$ in the collections of Hugh Morgan and Jaines Garet.]

[MS. f. 165.

\section{List of Indian and Arabian, E'c., names of Plants, and Vegctable Products of Economic Value.}

Aloes, the Arabs \& Turks call Cebar. p. I49. ${ }^{1}$ Opium. Caphura or Camphora. p. I60.

Lacca called Luc Sumutri of the Indians of Pegu \& Martaban that doe not use the Arabian wordes Luc. It is called Trec. p. I58.

Tabaxir is a drogue unknowen to us: it is like a graye gum or blackish sugar. p. 164 .

Sambarane is a wood like unto Saunders. p. I74.

Macra is the barke of the rootes of a tree. p. 264.

Coru, Cura, \& Curodapala is all but one thing.

Pavate in Malabar, of the Portug. Arbol contra las erisipolas. p. 266.

Cubebe be berryes. p. 184 . Araca is a fruite. p. 189 .

Cocos be greate nuts as big as a childes heade. p. r9r.

'There be 5 sortes of Myrobalanes called after this manner by the Indians.

Aritiqui be those we call Citrini, some call them Arare. p. 194.

[Terminalia citrina.]

Anuale we call Emblici. 'These 2 sortes are espetially these we gladly would have ayther yong trees if it were possible or els the stones of the fruite as fresh as maye be brought.

[Emblica officinalis.]

Rezanuale are called with us Indi Gotin be Bellerici. Aratca be Chebuli.

\section{[Terminalia chebulica.]}

Garcias ab Orta doth call them Canarini which inhabit those sea coasts of Decan and Guzarate (aunciently called Gadrosia), lib. 1. cap. 2.

Tamarinde is a sowre pulpe of a fruite. p. 196.

Anacardii be certaine big beanes black and fashioned somwhat like an harte. p. 272 .

1 The page numbers refer to Clusius' Exotica, 1605. 
Spica Nardii. p. 273. Nardus Indica.
Costus.
Ambargrise.
Meske.

Rhabarbarum, we call it Rubarbe, a purging roote. p. 274.

Radix China the Chineses call it Lampatan. The Turkes, Persians \& Arabians Chophehma.

[Smilax China, L.]

Curcum of the Arabians \& Saroth of the Turkes is that we call heare Turmerick.

[Curcuma longa, L.]

Galanga is of 2 sortes, one is a small reddish roote hott in tast \& is called of the Chineses Lavandou. 'The other is a farre greater roote blackish on the outside \& white within. The Indians call it Calcharu the Arabians call it Calvegian. They of Java Lancuare. Park. p. I 585 . Moringa is a tree \& the fruite of the same is so called also, but the Turkes \& Arabians call it Morian, they at Guzarate Turiaa: the roote of this tree is a singular remedy against poysons.

Park. 1650.

Bezoar is a stone of greate valew if it be true \& naturall \& not artificiall as a greate many are that are brought frō thence.

Negundo is a small berrye like pepper : the Turkes, Arabians \& Persians call it Bache.

Jaca or Panax is a fruite as big as a pompion set with thick shorte thornes but not pricking.

P. I6 39 .

Durione or Duriaen the fruite is as big as the Jaca \& hath sharpe thornes on the rinde of it very dangerous to touch: it hath divers stones within it like unto Peache stones. P. I640.

Mangas is called of the Turks \& Arabians Amba \& is a delicate fruite. Another kinde herof called Mangas bravas is a most strong \& violent poyson.

P. 163 .

Ananas is a delicate fruite like the heade of an Hartichoke the Portugals \& Spaniards call it Pinas.

Carcapuli is like an Orenge when the red outer side is taken awaye \& the "meate $w^{\text {thin }}$ somwhat like, but will not be separate in $y^{t}$ manner.

Carambolas the fruite is of the bignes of an hens egg or bigger, yellow on the outside with fowre ribs on the outside: in the middle it hath seedes that are of a sowre or sharpe tast yet pleasant.

Jamboli of the Indians \& Tupha Indi of the Arabians \& Persians, is a most excellent fruite well smelling \& of a pleasant taste of the bignes of a greate peare: there are herof 2 sortes one is of a darke red collour allmost black \& for the most parte is without kernell, the other is of a pale red collour \& conteineth a hard white stone of the bignes of a peache stone. It beareth fruite divers tymes in a yeare $\&$ is never without flowers \& fruite.

Ambares is a fruite as big as a wallnut and of sowre yet somwhat tarte \& pleasant when it is thorough ripe it hath within a hard gristly kernell.

Bangue is a smaller seede then Hempeseed \& of a darker collour.

Pinones de Maluco so called of the Portugalls.

Charameis the Arabians, Persians, \& Turkes call it Ambela. They are of 2 sortes, one is of the bignes of an haselnutt with ringing corners, of a pleasant sowre tast. The other is bigger.

Brungara aradua is otherwise called the Herbe of Maluca \& is an excellente herbe to make salves to heale any sore. We wold faine have the seedes of it. 
Tamalapatra be certaine leaves of greate use in Phisick wch the Arabians call Cadegi Indi \& are like unto Pomecitron leaves but narrower towarde the end wth three ribs only running along the leafe \& doe somwhat smell like cloves.

[MS. fol. I6o.

[MS. continues with several items included in the list on f. 165 , printed above. The descriptions of the last ten items agree closely with those in Parkinson's Theatrum and with those added by him to the last docuinent].

\section{List of Plants growing in the Bermudas. \\ In the handwriting of Parkinson.}

The poisoned weede is like our English Ivie, being touched causeth rednes itching \& lastly blisters wch after a while passe awaye without further harme. [Rhus toxicodendron.]

The red weede a tall plant whose stalke being all over covered with a red rinde therupon termed the red weede, the roote wherof being soked in any licour or a small quantitye of the iuice druncke procureth a very forcible vomitt $\&$ is generally used of the people $\&$ found very effectuall for the paines \& distemper of the stomach.

The purging beane is a kinde of Woodbinde very comonly growing by the seaside \& ruñeth upon trees twining like a Vine: the fruite somewhat resembleth a beane but somwhat flatter, the which anyway eaten worketh excellently in the nature of a purge but very vehemently yet without any perill.

The Costive tree is a small tree.

Another plante like a Bramble bushe which beareth a long yellowe fruite whose shell is very harde \& within it a hard berrye that beaten \& taken inwardly purgeth gentlye.

Red pepper a fruite like our Barberies whose taste is terrible hot for the tyme if it be chewed betweene the teeth, \& therefore it is swallowed downe whole $\&$ is founde to be of the same operation with red pepper \& thence borrowed the name.

\section{[Capsicum sp.]}

In the bottome of the Sea upon the Rocks there is found growing a large kinde of plante in the forme of a Vine leafe but farre more spreade with veines of a pale red colour very strangely interlaced one into another which they call the Feather whose vertue is altogether unknowne.

There are since their plantation nourished white red \& yellowe Potatos Pineapples, Papaws, Plantains, the America breade, the Cassado roote, the Indian Pumpion, Water Melon, Indicos etc.

Cassado a roote of a wonderfull encrease \& maketh very good white breade but the iuice rank poison, yet boiled is better than wine.

\section{[Manihot utilissima.]}

Pineapples neare as big as Artichokes, the most daintye tast of any fruite. Apples, Prickly Pears \& Pease, all differing from ours.

A Pepper groweth in a little red huske as big as a Wallnutt 4 inches long \& small cods.

Twoo sortes of Cotton: the silke Cotton as in the East Indies groweth upon a small stalke as good for beds as downe: the other upon a shrub \& beareth a cod bigger then a Wallnutt, full of Cotton wooll.

Locus tree, hard timber, 2 or 3 fadome about, of a greate height beareth a cod full of meale will make breade in necessitye.

[IIymenaea courbaril.] 
Sope berries like a Musket bullet that washe as white as sope \& goode to eate: in the middle of the roote is a thinge like a Sedge, a very good fruite: we call them Pengromes.

[Sapindus.]

A Pappaw is as greate as an apple, coloured like an Orrange \& good to eate.

[Carica papaya.]

A small hard nutt like a hasell nutt groweth close to the grounde $\&$ is like that groweth on ye Palmetas : we call them Mucca nuts.

A greate tree whose leaves are used to make a Mustarde.

The Mancinell tree the fruite is poyson, it is an apple of a most pleasant sweate smell of the bignes of a Crab: the Swine \& birds eschewe to eate of them.

[Hippomane mancinella.]

A tree like a Pine beareth a fruite so greate as a Muske Melon: hath alwayes ripe fruite flowers \& greene fruite which will refresh 2 or 3 men very comfortably.

Plum trees many, the fruite greate \& yellowe, which but strained into water will in 24 houres make very good drincke.

Wild figge trees the fruite feede the hogs etc.

The Gwane tree beareth a fruite so bigge as a Peare, good \& wholsome.

Palmetos of 3 severall sortes.

[Chamaerops glabra, C. excelsa.]

Cedar trees tall \& greate.

[The Pencil Cedar, Juniperus Bermudiana.]

Fustick trees the wood yellow, good for dying.

[Maclura tinctoria. $]$

Anotto.

[Bixa Orellana.]

[MS. f. 167.

[This list, both in the order of the plants and in the wording of the descriptions, so closely resembles Parkinson's list of Bermudan plants printed in 1640 at the end of his Theatrum Botanicum, p. I67I, that it is probable that the printed version was taken from this copy in an abbreviated form.]

\section{List of Nuts, Fruits, and Seeds, desiderata' To have from Virginia, Nere England etc.'}

Ciprasse nuttes or young trees.

The ripe Ackornes of their White Oake or red scarlet Oake \& Black Oake.

Black \& White Walnutt \& a greate one.

Cedars the berryes \& the leaves, to see of what kinde they be.

Firre \& Pine trees young \& their apples.

Grapes white \& red \& a smaller black Grape growing in the Islandes, some ripe \& sweeter.

Cherryes in clusters like grapes but not so good.

Black \& Yellowe Plumes as big as a Damson.

White Thorne berryes are as big as English Cherryes \& esteemed better than Cherryes. 
A white Poplar tree with greate leaves broade pointed.

Sassafras trees young \& the berryes.

The Cassado roote or Jocka, Hiucca?. Sarsaparilla, all the sortes.

The Maracoc Apples.

The Maye Apples or seedes.

The Snake-roote freshe plantes \& seede.

Virginia Lentills.

Divers sortes of Lillias.

Maidenhaire.

Penni marva is Silke grasse.

Musquaspen a small roote of a fingers bignes as red as blood wherewth they dye their mattes.

Poconas is a small roote in the mountaines which they use for swellinges and so painte their faces.

A small lowe tree whose white flower is like a small hedge Honysuckle.

Puchuming are plumes sweete like dates.

Red flat cods of a tree whose red flowers they use for salletts.

Arbor Judae.

The Locus tree the cods wth seede.

Checinquamins are small Chesnuttes.

A plante that beares a Scarlet flower.

Flower de luces. Lillyes. Colombines.

Or any other herbe or seede growing there allthough you thinck we have the same in England for we finde most thinges to diffarr.

[Lentills of that countrye.]

[MS. f. 20.

List of Secds imported from Virginia, $16{ }_{3} 6$.

Virginia seeds recd from Mr. Morrice ${ }^{1}$ i 8 March 1636.

I. A scarlet flower requiring a moist ground. Cardinalis forte.

2. A yellow wood called Locust long flat blackish browne pods, black round flatt seede kidney like.

[R'obinia pseudacacia.]

3. A poisonous berrye black rugged round berry with blackish seede straked like a tick.

4. Arbor Judae forte thin flat browne cods with somewhat flat round shining browne seede. Sent for a tree whose gredeline (?) flower is an excellent sallat.

[Cercis canadensis.]

5. A black round rugged berry like large peper cornes with 3 square black shining seeds sent for a running vine $y^{t}$ bears no flowers.

1 Who Mr. Morrice may have been, we do not know. A Richard Morrice was Master of the Barber Surgeons Company in 1634. But there was also a Iohannes Mauritius or John Morris, a friend of Parkinson, who extolled the excellencies of the Theutrum Botanicum, and the worth of its author, in three pages of éloges, in two languages. Two of his lines lend colour to our suggestion that he was interested in Virginian plants. Morris addresses Parkinson with the words

$$
\text { ... neither dost thou spare }
$$

T'insert whatsoere the other world doth beare.

A remark which would come naturally from a poetaster who had also given Parkinson seeds of plants from the New World. 
6. Nux vesicaria forte brownish bladders $w^{\text {th }}$ ij round pale coloured shining seeds like ours but farre lesse. Found on small trees in the woods.

[? Staphylea trifoliata.]

7. Euonymus forte growing on a dogwood tree: a reddish great seed $w^{\text {th }}$ huskes like it.

8. A kind of Hawes much eaten by the Indians blackish flat kernells like the Pishamin: w $^{\text {thin }}$ black shining thin huskes with little or no pulpe.

9. Virginia silke growing in a long white thick cod : flat browne seede with silken dowe Periploca forte.

Io. Palma christi brought thether \& thrives well.

[Ricinus communis.]

II. Maye Apple seede a blackish browne seede lesse than Stramonium, the flower white \& the fruit much eaten by them.

I2. The greate Snake roote small long yellowish seed like Langdebeefe but scalye \& downy among, being greene it hath a milke more bitter than aloes.

[In the Morisonian Herbarium at Oxford is ' The great Rattle Snake root of Virginia, a rare Cordiall, Mr. Willis I676'. It is Asarum virginicum L.]

I3. A kinde of Persicaria but higher by much then ours, a brownish black ... flattish seed in whitish skin, huskes or skins.

14. A kinde of double Yarrowe.

I5. Found in the woods. A pale browne pointed berrye set in a fine long-leaved huske like Guaiacana \& 3 or 4 halfe round crested or straked kernells or skin.

I6. The berrye of a plante whose juice is good red incke. Solanum Virginianum sorte.

I7. Seede of the herbe Carales, so called frō a Captain that said it was much eaten in East India \& in a tyme of scarsitye there also : a small black shining seade like Amaranthus purpureus, not Miliun nigrum.

r8. Small Snake roote seede. No 7 .

19. A duskye roundish forme or solid graine as big as the heade of Scrophularia, with a white kernell in it: common in the woods.

20. A long duskye gray pod small at the lower ende \& bigger round $\&$ crooked pointed at the other opening in 2 partes with one rugged brownish pease there lying \& the shewe of another at the bottome, but emptye. Found on small lowe imbracing vines.

2I. Virginia Lentills small short blackish thin cods somwhat thick on both edges or sides \& much smaller black lentill-like seede within.

22. Water melons flat darck graye seede like Citrulls.

23. Red water melons flat darck graye seade like unto the other but a little longer pointed.

24. Stramonium forte: it came without name.

[MS. f. 2 I. 


\section{APPENDIX}

\section{GOODYER'S MISCELLANEOUS PAPERS}

GOODYER's miscellaneous papers and letters have recently been sorted out and bound up in one folio volume (GOODYER MS. II). They include :

I. Descriptions of new or rare plants, mostly written on ff. $8 \mathrm{I}-\mathrm{I} 46$, including many rough drafts of descriptions scribbled on the backs of other papers. See pages 109 to 193 of the present volume.

\section{Notes of Botanical Excursions, $1617-1658$.}

Goodyer rarely allowed a summer to pass without an excursion to some part of south Hampshire, Southampton, the sea-shore at Hayling, or the New Forest. There is evidence of journeys to Essex in 1616, 1620, 1621; London, 1617, 1628, 1654; Wiltshire, I6I8, I624; Oxford, I622; Northamptonshire, I625; Surrey, 1634 ; and Bath, 1638.

3. Lists of Garden Plants.

4. Lists of Exotic Plants.

5. Lists of Medicinal Plants and Materia Medica.

6. Sundry Medical Prescriptions.

7. Lists of Books.

8. Letters addressed to GOODYER and drafts of letters written by him.

1618. Nov. 7. G. at the Red Lion in Fleet Street to some person believed to be Coys, describing the botanical results of his excursion in Wiltshire. p. 29.

On back. Addresses of Nicholas Everenden, Sedlescombe, Samuel Shute, Thomas Coltherste at the albus Lion in Deanside.

Last poem by Sir Walter Raleigh, 'Even such is time... p. 32 .

n. d. GOODIER to person unknown. Concerning payment for Canary Wine on back of a Terrier of Durford Priory. p. 9.

162I. Nov. 9. LAURENCE DAVIS to JOHN (jOODIER at I)roxford. Concerning gold weights sent by Maye the carrier. p. 48 .

1631. July 13. GRIFFith Hinton to JOHN CoODYliR at Maple Derham. Concerning the Bishop of Winchester. p. 56.

1631. Nov. 15. GRIFFITH HINTON to JOHN (iOONVEAR at the sygne of the Angell neer Denmark House in the Strand. Concerning fruit trees. p. 58 .

1631. Jan, 16. G. communicating a list of plants indigenous in France to a traveller. p. 39.

G. to MR. WRAY enclosing the above. p. 60 . 
1632. June 12. ROBERT TEWE in Moscow communicating list of Russian plants. p. 362 .

1634. June 24. G. to Mr. WORLiDGe about date of Surrey Assizes. p. 73.

9. Other letters.

n. d. JOHN PARKinson to the worthy gentlewoman MRS. GeERES. Scribbled over and almost indecipherable. p. 266.

n. d. [DR. MORISON] to DR. V. How, asking for plants, of which he gives a list. p. 355 .

n. d. DR. ARGENT to Lobel. p. 252.

n. d. J. DE MONNEL to Lobel. p. 252.

10. Miscellaneous Papers.

\section{Of the Tenth mony due at Christmas 1608 received by Edward Cole and left with Roger Cole.}

Thomas Hull received to my Lord's use the 22 of January 1608

Mr. Myers received the $\mathrm{v}^{\text {th }}$ of January 1608 to my Ls use

Thomas Hull received more upon my Lords noate is Febry 1608

Edward Cole hath payd to my Lord in money the 29 of Aprill 1609

iiijli
xxxijti
iijjti
lxx $^{\dagger i}$

Of the sixth payment of the subsedy due the xxvjth day

of March I 909 (sic) \& by him received in Swod.

Edward Cole hath payd to my Lord in mony

$\operatorname{lxx} x^{\dagger i}$

[MS. f. 127.

Summons to Fohn Rowland, Tithing-man of Ropley. I6I4. Southt.

Theis are in his maty name to will and require you that ye uppon the receipt hereof you repaire unto me at Bishopps Waltham, or to some other of his majties Justices of the peace within this Countie neare adjoyninge to take you Corporall oth for the dewe Execution \& performance of the office of Tithingman-shippe for the Tithinge of Roplie, And hereof I require you not to fayle at your perrill dated at Newe Alresford under my hand and seale the xxiii of September 1614 .

To John Rowland of Roplie deliver theis.

On back

[MS. f. 3 .

[Description of a tree bearing Cachryes, p. I75.]

\section{Terrier of Durford Monastery.}

Domum et Scitum omp monasterii de Durford cum ptinent, videlē duo prata, cont. p. estimac. quinq. acr. quorum un vocat. le mill meade \& alterum vocat. le kechyn meade; duo alia prata sine clausa vocat Smithes meadowes, cont. p. estimac. octo acras, un. aliud pratum sine clausa vocat. le wish meade at le wash meade cont. p. estimac. viginti acr.; uñ clausū pasture vocat. le Brydgfield cont. p. estimac. duodecim acr.; uñ aliud clausū pasture vocat. le Smithfield contin. p. estimac. duodecim acr., uñ aliud clausū pasture vocat. le Rye cont. p. estim. sex acr., uñ aliud clausū terre pastur vocat. le Conduit field cont. p. estim. viginti quinq. acr., uñ aliud clausū terr. vocat. le North field cont. p. estim. trigint. quinq. acr., tria crofta sine terre pasture vocat. le Chapell Croftes cont. p. estim. triginta acr., duos campos vocat. le Rydgfields cont. p. estim. trigint. acr., duo alia crofta terre past. vocat. Robyns fields cont. p. estimac. duodecim acr. Ac tota illa terre Vastr. Bruera et rampua in Durford Hethe et Westherting Hethe, cont. p. estim. ducent. acr.; uñ mesuagium sive Tenementum vocat. Hethe Howse in Petersf. in Com. Sowtht, dcto monasterio spectañ. cont. p. estim. centum acras. 


\section{Summary.}

2 prata
2 ,"
I "',
I claustum
$1 \quad$,
2,
I ",
I ",

Acres.

$\begin{array}{lr}\text { North field } & -\overline{35} \\ \text { Chapell Croftes } & 30 \\ \text { Rydg fields } & 30 \\ \text { Robyns fields } & \text { I2 } \\ \begin{array}{l}\text { Durford Hethe \& West- } \\ \text { herting hethe }\end{array} & 200 \\ \begin{array}{l}\text { Hethehowse } \\ \quad \text { Total }\end{array} & \\ & \end{array}$

Myll meade Se Kichin meade.

Smith's medowes.

20 Wash meade.

I2 Brydg field.

3 Calfes lease.

20 Dame Annys.

I2 Smythfield.

6 le Rie.

25 Conduit field.

[MS. f. 6.

[Dureford Abbey was a small house of Premonstratensian canons founded in the reign of Henry II, and suppressed in $\mathbf{1 5 3 6}$. Its last days were passed in great poverty, the buildings were in ruins, the canons reduced in number. Layton, in a letter to Cromwell, describes the poverty of Dureford, 'which might better be called Dirteforde-the poorest abbey $I$ have seen, as this bearer, the abbot, can tell you-far in debt and in great decay. This young man, for his time, has done well, and I have licensed him to repair to yon for the liberty of himself and his brethren'.1

A seal of the Abbey is in the possession of Magdalen College.]

\section{Draft receipt for $£ 250$ received by $W$. Inkferbie \& Richard Bell from Sir T. Bilson. I620. In Goodyer's handwriting.}

Mem. that the $x^{\text {th }}$ day of No: we $y^{0}$ within mentioned WV Inkferbie \& Ric Bell have had and receaved of $y^{\theta}$ within-mentioned $\mathrm{S}^{\mathrm{r}}$ Tho. Bilson Knight the within-mentioned some of $250^{\text {ti }}$ of lawfull Eng. money at his mansion house called Westmapledurham in the Countie of South by virtue of $y^{e}$ withinmentioned power given us by our mother in law Philipp Bynwyn als Benwyn, and have delivered upp the within-mentioned deed according to $\mathrm{y}^{\ominus}$ said power within given us to the said Sir Th. Bilson Knight: In witness whereof we here unto sett our hands, receaved the said $250^{\mathrm{Ti}}$ and $\mathrm{d}$ [eliver]ed in ye presence of

\section{[1I Januarij 1620.]}

Wels I have sent

[The INkFORBYE family fairly invaded Magdalen College in the sixteenth century. Of the four children of Andrew Inkforbye, a Merchant of Ipswich, two gained Fellowships, one married a Fellow, and one married the President of the Collegre, Lawrence Humphrey, by whom she became the mother of three Demies. William Inkforbic, the brother-in-law of the President, held several College offices, and eventually accepted a Winchester Rectory in 1592, which lie held with that of Selborne after 1596 . It is difficult not to believe that he or some near kinsman was the William Inkforbie mentioned above. Inkforbie's wife is mentioned below, p. 382.$]$ 


\section{Draft of Commission to Overseers of the Poor. 1621.}

Overseers of the poore of the parish of appointed by us this present yere viz the

nominated and shall by vertue hereoff levie all such somes of money as by them shalbe asseassed for the releife of the poore within the said parish, And shall distraine and sell the goods of everie person that shall refuse to paie accordinge to their taxation rendringe the overplus to the ptie. Geoven at Southwick under our hands \& seales the daie and yere above written.

[MS. f. $87 \mathrm{v}$.

John Pitt of Chiddien in Hamelden [ = Chidden, a tithing in Hambledon hundred] to have the peace against Elias Pelie of Hameldon [Hambledon was the village where 30 years later Charles II spent the night at the house of his guide, Col. Gunter's brother-in-law].

' [MS. f. 87.

\section{F. Waller's Petition to Sir Thomas Bilson. Before 19 Fuly I621.}

Most humbly Intreating yo ${ }^{\mathrm{r}}$ good worship $\mathrm{S}^{\mathrm{ir}}$ Thomas Bilson and to you \& yo ${ }^{r}$ man mar Goodyer greeting: the Cause is this. my wryting unto you $\mathrm{S}^{\mathrm{r}}$ is for to request \& desire yo ${ }^{\mathrm{r}}$ worships ayd and assistance concerning the two Buls and the fower Heffers $w^{\text {ch }}$ the sayd Ilesley was committed by yo ${ }^{\mathrm{r}}$ worship for, desiring for two know whether I may not lawfully have them praysed and so for two sell them, and (= if) it may be possibell good yox worship aid me in hit, for the Cause is thus I must step asid and aivay. for beecause freeman of Durley or of Frogmill have forth as I understand an Execution agaynst me for his counter band $w^{\text {ch }}$ the sayd freeman hau not bine dainnified one penny, but onely in suing for to bring in the bands, \& soe forth $w^{\text {th }}$ arrested the sayd Ilesley's bease, and I was pledge for two bring him to his answer and could not paye the money being Eightenne pounds full, and tooke up the bands \& went to the sayd freeman desiring for to have his Harmeley's band in to, and so to end hit, karying forthwith to hime his sayd Charges before divers witnesses, and hee would not for hee would hand the fantage or forfit of his counter bande being Six Score \& Eight pounds and theireof $\mathrm{S}^{r}$ I think it mete for two acquaint yo $^{r}$ worship with hit. Other good men, for I must be droven to put forth my land and so to distribute my goods for a tyme untyll I canne take som corse in it, I would $\mathrm{yo}^{\mathrm{r}}$ worship should thinke that although I am forst to goe that it is for no misdemannors although I sayet my selfe nor for one penny or pound of debt but onely thus to be the cause meaning the Execution. Further mor sir I would request of $\mathrm{yo}^{\mathrm{r}}$ worship for to know whether I may not send to the Sises some lawfull deputi, meaning some honest frend for to frame a bill of inditment against the said Ilesley. Requesting for two send me in two or three words in wryting and I would be much thankfull to $\mathrm{yo}^{\mathrm{r}}$ Worship for hit, and so $\mathrm{w}^{\text {th }}$ wepping teares I wayt theise few words wishing $\mathrm{yo}^{\mathrm{r}}$ worships health you $\&$ yo ${ }^{\mathrm{rs}}$. Yor poore Oreator for to Command

Deliver this to Sir Thomas Billson Knight. fra Waller.

[MS. f. 8.

\section{Deposition of Arthur Hyde relating to a distraint levied on Weston Farm in the possession of Sir Thomas Bilson.}

Arthur Hyde of Weston in the parish of Buriton in the County of South ${ }^{t}$ yeoman aged fiftie eight yeares or thereabouts, deposeth that aboute sixteene yeares nowe last past, this deponent being tenant unto the late most gracious Queene Elizabeth of Weston farme, by reason of the recusancie of one Stephen Vachell Esquier deceased, duringe which tyme one of the Servants of the then gen'all Receivoures of $y^{\theta}$ said Queene Eliz. reaveannes, in the said County of Sowtht, came upon a peace of Lande of the said Weston farme, called the 
Readons. And have distrained certaine Cattell of his deponente for Arrearage of rent of abowte fyve pownds, supposes to be done unto the said Queen Elizabeth for which this deponent entered into bande in the some of [blank] pounds, upon condicon either to paie the money, the then next Tearme folowinge, or otherwise to discharge yt, whereupon the Corte beinge moved, $\&$ fyndinge this deponent to be Tenante unto the said Quene Eliz. of all Weston farme, under a certaine Rent, by reason of the Recuzancie of the said Vachell, and that the said Reasone was but a small parcell of the said Weston farme, And that this deponent, by the covenants of his Lease during the Recuzancie of the said Vachell, was to be discharged of all Rents \& charge payinge the Rente reaserved in his Lease, the said Corte therupon detayned the said deponents bande, \& toke order for the staye of the leavyinge of the said Arrearage duringe the said Vachell Recuzancie. Sithence $w^{\text {ch }}$ tyme the said Vachell being deade, And the said Weston farm being in the possession of Sir Thomas Bilson Knight. And then the said II eston farm being discharged of Recuzancie, there hath been leavied by the Sherif at sundry tymes the some of Nyne pounds \& tenne shillings by $\mathrm{xx}^{\mathrm{ti}}$ shillinge on ye pound only, under coloure of the said deponents bande, which was taken for the said supposed Arrearage. And yet none (notwithstanding so much payed, as aforesaid) theare is a newe seisure, diverted to the said Sherif for the leavyinge of abowte six poundes, owte of the said Lands called Readons, for the same Arrearage.

And this deponent further saieth, that he hath not beane Tenante, unto the said Readons sihence the ende of his said Lease, which ys now about some tenne yeares last past, and yet being tenant unto some other part of Weston farme, by reason of the said bande ( $w^{\text {ch }}$ was only taken for the said Arrearage of Readon) he this deponent with some other of the possessors of Weston farme, hath alreadie payed Nyne poundes \& tenne shillings, besides twoe shillinge at any sevall tyme of seisure, to the Sherif his Bailies, $\mathrm{w}^{\mathrm{ch}}$ cometh unto $x$ viii ${ }^{8}$ more.

[MS. f. 5.

[Weston is a tithing in the parish of Buriton whicl seems to have been, to some extent, co-extensive with the manor of West Mapledurham. According to the authorities quoted in the Victoria County History of Hampshire, iii, p. 90, Stephen Vachell was part lord of Weston in 1579 . In September 1600 he forfeited two-thirds of his lands and possessions for recusancy, and in December I60o the queen granted the capital messuage called Weston farm and lands in the parish of Buriton to Arthur Hide, for a term of 2 I years. It is doubtful, however, whether Arthur Hide ever gained possession of the manor, for in 1598 Vachell and others conveyed it to Nicholas Hunt and his wife, from whom in 1607 Thomas Bilson, Bishop of Winchester, purchased it. After the purchase Weston formed part of the manor of West Mapledurham.]

\section{Draft of a Petition from the Tithing of Weston concerning payments towards repair of Redbridge. In handweriting of Foln Goodyer.}

The names of those who were to goe to paie viijs towards the repairinge of Redbridge beinge required of the Inhabitants of this Tything, after they had paid their proportionable hereinafter said rights as anciently they have don.
$\mathrm{S}^{\mathrm{r}}$ Tho: Bilson
Hen: Bl:
Hen: Vok
Jo. Tayler
John sen.
Tho: Wyse
Tho: Kent
W'in: Hall [or Hull]

who made with one accord this answer, that the inhabitants of the Upper half hundred of Finchdeane have alwaies hetherto paid two parts and the Lower half hundred but one pte of the said impostes uppon the sd Hundred, towards the repations of the sd Bridge, and that they of the sd Tything of Weston have latelie paid [blank] being their pte of the said third parte.

And that nowe they refuse to paie the sd $8^{*}$ beinge a some imposted in them, apportionable with the somes inposed on the other parts of the before said lower half hundred, . . . the lower half hundred equall in payment with the Upp, which they never did. And that they pray to have their case heard 
this next mich ${ }^{23}$ Sessions when they hope to obtain an order that the lower half hundred shall paie but a third part thereof as anciently it did.

And this rate now imposed, being not after the ancient manner, but an encrease of charge to the lower half hundred by making them equall in payment to ye upper half hundred, whose lands are allmost twice as good, the tything of Weston being a small member of the lower half hundred, humbly pray they may be heard this Sessions what they can say with the rest of the lower half hundred for themsealfs.

[MS. f. 12.

\section{Portion of a deed concerning lands at Bramshott and Kingsley in which Foln Goodyer was concerned.}

This Indenture made the $\mathbf{I}^{\text {th }}$

God of England, Scotland France and Ireland

[Dorothy his wife of the one part and] ' John Goodyer

[pounds] ${ }^{1}$ of good and lawfull money of England unto

the ensealing and delivery of these presents

[Release and Confirmation bearing even date] ${ }^{1}$

[Sambrooke of London knight and Administrator ${ }^{1}$

[payment receipt and Satisfaction of which said] ${ }^{1}$

[doth acquitt release and discharge the said John Goodyer his heirs] ${ }^{1}$

bargained sold and confirmed and by these presents doeth grant $b$ [argain sell and confirm and Parcefeild with all and singular the rights members and app gardens Orchards Courts Courtyards and backsides thereunto bel $[$ onging

Bramshott and Kingsley some or one of them in the said County [of Southampton quantityes of acres hereinafter menconed (that is to say) the planted

estimacon Tenn acres three quarters of an acre and eight perches

One quarter of an acre and six perches Great frith containing by e[stimacon

acres three quarters of an acre and thirty two perches affeild

thirty perches Garden ffeild containing by estimacon eight acres

perches Great Waterfeild containing by estimacon Tenn acres \& by estimacon Six acres and halfe an acre and thirty two perches $G r$ estimacon twelve acres and a quarter of an acre and sixteen perches two Heathffeilds containing by estimacon one and twenty acres and and Sixteen perches Upper Wassells containing by estimacon ffour Lower Mead containing by estimacon eight acres and two perches three quarters of an acre and twenty perches The Green before th acres Upper Mead containing by estimacon three acres Middle Me [ ad containing by estimacon acres and an halfe of an acre and eighteen perches and also all and wood ground thereunto belonging and also all those severall called Woolmore containe together in the whole by estimacon Sixt Mead and one Cottage with the Land thereunto belonging scituate Closes and grounds are severally and respectively called or known and possession of the said Andrew Wall and also all that dwelling house and all those severall Closes or grounds severally and respectively cal[led or known and likewise menconed that is to say The Upper Six acres containing by e[stimacon thirty two perches the four acres containing by estimacon ffour acres Homefeild containing by estimacon six acres and a quarter of an containing by estimacon eight acres and an halfe and one and twe perches Hillffild containing by estimacon ffour acres three quar tenn perches ('utward Heathffeild containing by estimacon seven .... Green ffeild containing by estimacon seven acres three q

[This portion of a deed, in which Goodyer's name is mentioned, was used as a wrapper of a document belonging to Mrs. Ruck-Keene of Swyncombe, Oxon., who, discovering it at the very moment of the discovery of Goodyer papers at Magdalen, has kindly permitted its publication with them.

In the Victoria County History for Hants, $\mathrm{ii}, \mathrm{p} .493$, are notes that Ludshott Manor was acquired by Andrew Wall in 1638 from the Knight family (Feet of F. Hants. Hil. I 3 Chas. I), and that in I 704 Samuel Diggle acquired the manor of John Goodyer (Feet of F. Hants., Mich. 2 Anne).

A Sir Jeremiah Sambroke, Knight, Merchant, was on board the Earl of Barkley's ship 31 Jan. 1681 and died 27 Apr. 1705. .

1 erased. 


\section{Goodyer's note relating to Rents in Wiltslire.}

Chappel. Crine.

Richard Bedelcombe of Weeke in Dounton parish, aetat. So vel ultra, gathered of Henry Davys of Chestgrove in Tisbury parish in Wilts, aetat. 72, who was tenant to Edward Willowby gent, yerely as a Cheif Rent vjs, viijd. He was gatherer as longe as $M^{*}$ Barrowe was lord. Mr. Willowby never denied the Rent, but denyed $y^{\ominus}$ service to Mr. Estroud in $y^{\theta}$ open Court.

Mr. Willowby sould it to George Stable gent, whether he paid it or not, they know not, he byd $M^{r}$ Dawley shew wherefore he should paie it.

Mr. Staple sould it $M^{r}$ Westfeild of Tilsford 7 or 8 mile beyond Warminster.

Hester Abell widdowe in the High St. at Salesbury nere to the Close gate.

[MS. f. $5 \mathrm{v}$,

\section{Draft of an Order concerning the discharge of the Watch of the Beacons in Portesdown Division. In the hand of F. Goodyer.}

Whereas I have receaved letters from Sir R. T. knight one of ye deputy livetenens of this County of Southh. concerning the watch of the Beacons within this Division of Portesdowne, which Beacons must be well kept \& repaired, and the watch of them to be presently discharged. Theis are therefore to require you to cause the watch of ye Beacons within your hundred (if there be any) presently to be discharged, and $y^{\ominus}$ rest performed according to $\mathrm{y}^{\mathrm{e}}$ contents of ye said letters,

And hereof faile not as you will answer the Contrarie (?) at your peril. Dat. 7 .

[MS. f. $5 \mathrm{v}$.

[The Sir R. T. would have been Sir Robert Tichborne, who was living in 16I7.]

\section{Goodyer's rough notes of Accounts i9 July 1621.}

James Rabson of Hamelden Carpenter $10^{5}$ due onto Katherine his wiffe, for wages long since due.

Stephen Woley.

hog $\operatorname{rec}^{\mathrm{d}} \mathrm{y}^{\mathrm{e}}$ last year

rec $^{\mathrm{d}}$ this year

hog spent this year

recd as appeareth

$\left.\begin{array}{r}\text { I6 } \\ 96\end{array}\right\} \begin{array}{r}\text { II } \\ 96 \\ 16\end{array}$

has rec $^{\mathrm{l}}$ ye last yere

bought this yere

spent this yere

recd as appeareth
Wheate spent $166^{\mathrm{ti}}$

Otes spent li. 196

Joh R

William Browne de Hoe infra parochia de Subberton ${ }^{1}$ gent, To paie lxxijjt $\mathrm{X}^{\mathrm{s}}$ the $\mathrm{I}^{\text {th }}$ of November next.

Will ${ }^{\mathrm{m}}$ Hatch de Clanfeild yeoman
Simon Hatch bondeth John Parker in $20^{\text {th }}$

Simon Hatch Blacksmith

iV ${ }^{\text {in }}$ Hatch bondeth (?) S. $\mathrm{k}$ : in $40^{\text {in }}$ to store harweste.

[MS. f. 8 v.

[Then follows a Description of 'Ye lesser Bellflower'. See p. I32.]

1 [The Manor of East Hoe, Soberton, passed to W. Browne, senior, of Hoe in 16I9, then to W. Browne, junior, his son.] 
Note conceming certain inhabitants of Soberton c. July 1622.

Willmus Arnold de Soberton yoman. : . . . . $\mathrm{v}^{\text {ti }}$

Willmus Perrin de Subberton husb. . . . . $v^{\pi}$

Johes Lower de Soberton husb. . . . . . $v^{\text {ti }}$

That Margery Lower to keape $y^{e}$ peace ags ${ }^{t}$ Susan Talbott spinster.

[MS. f. 7.

Assessment in Goodyer's handzeriting. After 9 Nov. I621.

\begin{tabular}{|c|c|c|}
\hline & [Acres ?] & {$[t$} \\
\hline $\begin{array}{l}S^{r} \text { Tho. [Bilson] } \\
\text { Kent }\end{array}$ & $\begin{array}{l}433 \\
125\end{array}$ & $\begin{array}{l}3 \\
\mathbf{I}\end{array}$ \\
\hline Chaw & 56 & \\
\hline Petter & 23 & \\
\hline Ra: Tribe & 51 & \\
\hline T. Deed & 20 & \\
\hline Wm. Tribe sen. & 36 & \\
\hline John "Tribe & I 5 & \\
\hline $\begin{array}{l}\text { John Iribe } \\
\text { Blackman }\end{array}$ & 63 & \\
\hline Silvester & 56 & \\
\hline & 915 & \\
\hline
\end{tabular}

Anne the wiffe of John Ilsley of Prelingworth in

T.... husb. to have the peace against Tho: Ilsley.

[On the back of Laurence Davis' letter, dated 9 Nov. I621.]

[MS. f. 9.

Note of proceedings at a Court held later than 9 Nov. 1621, affecting persons living at Sisanmore and Chedden.

Edward Collyn de Swanmor husb:

... Tho: Cludlie de eadem Carp. in $8^{\text {ti }}$

To paie $4^{\overline{1}} 8^{8}: 20$ Sept. 1622 in Tho: Cludlie's house.

$\mathrm{W}^{\mathrm{m}}$ Drewe of Hamelden served Thomas Pina and John Rynd and $y^{\ominus}$ rest of $\mathrm{y}^{\ominus}$ parishioners of Chedden as their comon shepherd.

Nic: Brittaine de Swanmore husb. ... Jaspen in $20^{\text {th }}$.

To paie $1^{\text {t1 }}$ the $20^{\text {th }}$ Sept. 1622 in this C[ourt] house.

[A Botanical Fragment. Description of Thlaspi I 4 July I62I.]

[MS. f. II.

Descriptions copied from Lobel's Adversaria of four plants. Perhaps in preparation for a botanical excursion to Portland.

\section{Anthyllis \\ Sedum Portlandicum \\ Hederacium Thlaspi \\ Papaver Cormutum.}

\section{Goodyer's Notes 1625.}

[MS. f. I3.

The 2 of May to have $100 \mathrm{Be} \quad, 8$ foot longe $\& 4$ foot 7 ynch lenght.

Robt Westbrooke ${ }^{1}$ of Steep husb.

$\mathrm{W}^{\mathrm{m}}$ Hinde of Sheet

$$
3 \text { teneri pr. to paie } 16^{\mathrm{ti}} \mathrm{I} 3^{\mathrm{s}} 4^{\mathrm{d}} \text { the } 22 \text { of July next. }
$$

Ewie sat about 4 a clock to take fagotts.

[MS. f. I3 a.

[Below : the itinerary of a botanical excursion for Sept. 1624. See p. 5I.]

1 Robert Westbrooke was a tenant of Magdalen College in the Spain Petersfield, about I 580 (Magdalen College, Ledger G. f. 10). 
Rough notes made by Goodyer in November $163 \mathrm{I}$.

The names of those $w^{t}$ were taxed to paie the muster Master's entertaynment.

Bilson 2 corsletts 2 musketts -at $9^{11}$. $\cdot 6^{\text {s }}$

Hen. Vok
Tho. lee for I corslett . . . I 6

Tho. Kent $\} 12$

Jo: Trybe for I corslett . . . I 6

$W^{\mathrm{m}}$ Hall for I corslett. . . . . I 6

Jo: Horwood for I muskett • . . I 6 )

Of all those above named I have demanded the somes they were taxed at And they all do answer me they ought not to paie it.

Diett at Gilford $\quad \cdot 13^{8} 8^{d}$

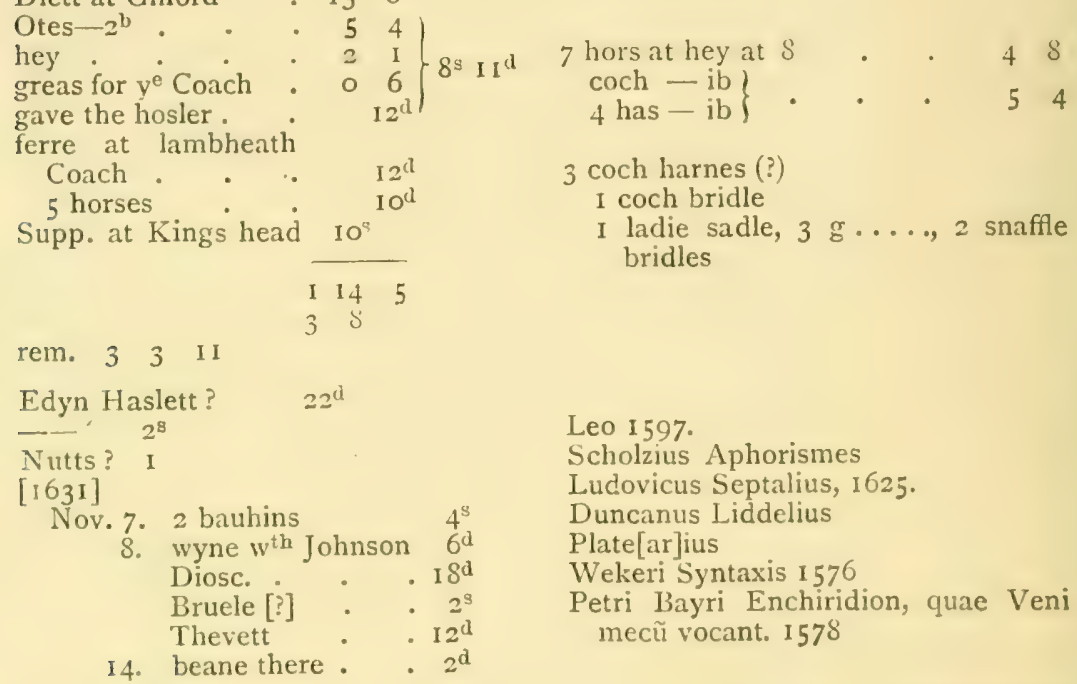

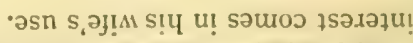

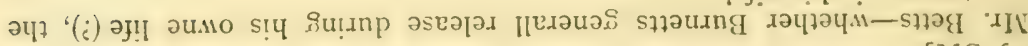

[MS. f. I2.

Roll of Armour-bearers, Pioneers, and Spearmon of Buriton.

(Before 1633. Not in Goodyer's hand.)

\section{Beritun}

The earmur bearers.

Robberd Heath with a muscet.

and Jasper Hillis with a muscet both of $\mathrm{M}^{\mathrm{r}}$ Watkers.

Randol Jouning for John Benet his muscet.

Richard Searl with a muscet.

Neckolas Greenwood with a muscet.

ab. Thomas Linter.

ab. John Pinssers.

Stceven Pit.

ab. William Barker, the elder.

William Tayler.

ab. Richard Cheas. 
The names of the Peionors.

[Larence Plidger and Richard Paige] (erased).

John Barker, hors post.

John Pitter, foote post.

Vitllers John Luf and Richard Plidger the younger.

Carters Arter Cornwel, Benge Paige and Henry Burch.

Spear Men.

musk. James Poell.

- Peeter Heath.

- Umphery Biges.

- William Parker.

musk. John Weiet.

ab. William Chrispe.)

ab. Francis Miles.

ab. William Hide.

ab. Andrew Hickman. musk. Thomas Paterick.

Larenc Brasier.

ab. Larenc Pinssers.

ab. Robberd Holt.

ab. John Hide.

- William Barker the younger.

- Neckolas Bokkis.

- James Bate.

- Thomas Horn.

The Names of the Spare Men within Tythinge of [Sheete](?).

Henry Beale.

William Whitcher.

Robert Whicher.

John Stummer.

Robert Wells.

[William Hide] erased.

John Inwood.

Robert Brigger.

Robert Betsor.
Nicholas Polen.

Humfrey Deane.

Thomas Jacob.

Arthure Tanner.

Edward Polen.

John Wiat.

Thomas Yalden.

Thomas Hunt.

Rychard Jenman,

\section{Tythingman.}

[MS. f. I $37 \mathrm{v}$.

\section{List of ten Hampsire Women concerned in the payment of certain} sums of money (? early I th cent.).

Goodwife Hardinge of Hakle
,$\quad$ Gaman of Hakle
,$\quad$ Sharpe of Steepe
,$\quad$ Eames of Lesse
$" \quad$ Tyler of Leese
$" \quad$ Chilese
$" \quad$ Rose of Leese
$" \quad$ Wheatle of Leese
,$\quad$ Veryam of Hearting
Bakere of Frokesfeeld
Margerie Winnige

$\begin{aligned} & \text { iiij of medlee } \\ & \text { ij } \text { of medlee } \\ & \text { ij } \text { of medlee } \\ & \text { iiij of medlee } \\ & \text { iij of medle } \\ & \text { ij } \\ & \text { ij } \\ & \text { iij } \\ & \text { iij } \\ & \text { iij }\end{aligned}$

[Written on blank leaf in the binding of Goodyer's copy of Crescentius.]

Goodyer's Notes relating to a shopping excursion to Winchester.

Edward Williamson of Lippock Butcher to release to Richard Costen of Shidfield, ${ }^{1}$ husb., all actions.

\begin{tabular}{|c|c|}
\hline $\begin{array}{l}\text { Seaminge lace } \\
\text { Edginge lace } \\
\text { Edging lace } \\
\text { Lace for ij Capps } \\
\text { One ell of Halland }\end{array}$ & $\begin{array}{l}\text { ij yards } \\
\text { I yard } \\
\text { I yard } \frac{1}{4} \\
\text { j ell } \\
\text { for ij Capps }\end{array}$ \\
\hline Vinton & \\
\hline
\end{tabular}

[Goodyer's rough draft of a description of the Broad-leaved Elm is on the same sheet.]

1 Shedfield, South of Bishops Waltham.

[MS, f. 4 . 
Goodyer's Mcmoranda for shopping for a lady, probably' in London. c. $162 \mathrm{I}$.

20 yards of galome lace.

4 doz. buttons.

Homs (?) fustian 2 yards 3 qters.

Canvis j ell.

8 skeynes of sticching
8 skeynes of sowinge

2 oyle skins.

half a yard of Jeynes Fustian.

Cambrick $\mathrm{j}$ ell \& qter at $3^{\mathrm{s}} 6^{\mathrm{d}}$ or $\ldots q^{\mathrm{r}}$ ell.

Mris Benwyn at the little Mineries neare Algate. if she wil paie to gev a discharge from Holman, windmil (?) and Inkforbies wife.

The fan of a pinke color. Morgan to doe.

8 yards of $4^{\mathrm{d}}$ rebon of $\mathrm{y}^{\mathrm{e}}$ same pinke color, to desire $\mathrm{M}^{\text {rls }}$ Ison for a patterne of ye bredth \& color.

6 yards of $2^{d}$ rebon of $y^{e}$ same colour. The fans handell to be doble gilt.

Mr. Bull was pd $5^{\text {s }}$ for $5 \mathrm{q}^{\text {ters }}$ ended $\mathrm{y}^{\mathrm{\theta}} 3 \mathrm{oth}^{\text {th }}$ of Januarie $162 \mathrm{I}$.

Mr. Wilson of Barbican.

50 needles of all sorts, none to bigge.

a girdle of stuff $18^{\mathrm{d}}$ pise russet color.

a pound of Annis seed comfitts.

half a pound of English liquerish.

[A list of books on same page.]

[MS. f. 46 .

Memorandum relating to Corn. I63I.

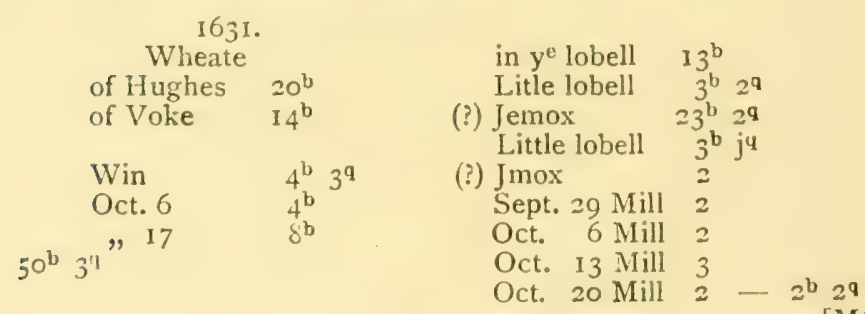

[MS. I. 132.

An account of purchases, probably for his wife, in 16.34 .

I yard ha. \& ha. qter of white Cotton at $12^{d} \quad{ }^{1} 7_{1}^{1}$

1 skyn.

3 yards of fustian Rebon

Io paire of hooks \& eyes

(3) $\quad \cdot \quad \cdot 02^{11}$

Silk . . . . . . . . 02

6 Buttons : : $: \quad: \quad: 01$

Making the hose . I 2

310

lengthening the other . $s$

$\frac{110}{5 S}$

[MS. f. 14. 
Accounts $1646-50$.

Paye 7: y: behind $4^{\mathrm{ti}} 13^{\mathrm{g}} 4^{\mathrm{d}}$ of this

$\operatorname{Rec}^{\mathrm{d}} 1646: 6^{\mathrm{s}} 8^{\mathrm{d}}$ and in May $1647 \mathrm{I}^{\mathrm{ti}}$

payd all but since Michaelmas 1649 .

Stocker oweth besides this half I Is

Tomlinson d I3 9 ${ }^{\mathrm{ti}} \mathrm{I} 8^{\mathrm{s}}$

ded: $1^{1 \mathrm{i}} 12^{\mathrm{s}}$

A Long (?) ded: ded: I

Receaved owes $4^{8} 2^{\mathrm{d}}$ to Keens to

Paied $I^{\mathrm{s}} 8^{\mathrm{d}}$, do a rent $3^{\mathrm{s}}$ I $\quad 7^{\mathrm{s}} 8^{\mathrm{d}}$

Collins ded. $134 \quad 7$ 10 0

Baker on high ded $124^{d}$

Cariage payd

Rd. Eomes ded: $3^{\mathrm{s}} 2^{\mathrm{d}} \&$ 4 II and

L. Rent $\mathrm{I}^{\mathrm{s}} 3^{\mathrm{a}}$

Eomes last ded: $I^{\text {s }}$ 6l till the $\mathrm{R}$ day
Midsommer 1650.

[4 lines illegible]

$\begin{array}{llll}\text { Knight } & \circ & 4 & 0 \\ \text { Wayd } & 0 & 1 & 0 \\ \text { Bold } & 0 & 13 & 4\end{array}$

This half ded: 10

Hall to ded: $a^{1}$ p. annum 1 i 0

King 0

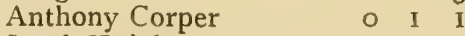

Isaak Knight $\quad$ o 34

Girdler $\quad 0 \quad 3 \quad 4$

Thomas sen. $\quad 0$ II 6

John Pescod o 68

R. Rogers Life O I5 O

J. Roke behind o yr

besides this halfe $\quad 0 \quad$ I 8 Lady day 1650.

\section{PRESCRIPTIONS AND MEDICINAL NOTES.}

Goodyer's views on medicine were evidently those of his senior by nine years, Lord Herbert of Cherbury. Lord Herbert conceived it a 'fine study, and worthy a gentleman to be a good botanic, so that he may know the nature of all herbs and plants'. A gentleman should know how to make medicines himself.

\section{Tonic for a horse: a smuff: purchase of tobacco.}

880. e. Anisum

557 g. calamintha

$702 \mathrm{f} . \mathrm{n}$. violetts

I 28 c. Spartium sp: broome:

Richard Skillinge: ${ }^{1} \mathrm{I}^{0} \mathrm{Feb}$ :

Muscadine I pint pound ye sugar candy

Sugar candy an ounce. \& putt in ye yolks

Yolks of Eggs iij with ye musc. \& mak, it luke warme \& geve it your horse when you travell.

Euphorbius putt into ye nose to sneese.

Tabaco $4^{\mathrm{d}}$

Pulletts $4^{\mathrm{d}}$

Alresford $4^{\mathrm{d}}$

[MS. f. 4 .

1 The Skillings were a well known Hampshire family. A.Richard Skilling sold the Manor of Lainston in $16 \mathrm{I}_{3}$ (Vict. County Hist. Haints, iii, p. 445). 


\section{Ointment for the Splecn, c. 1621.}

Unguentum et emplastrum per liene

4 olei de capparibus)

$\left.\begin{array}{l}\text { de absinthio } \\ \text { amygdal: am: } \\ \text { aceti scillini }\end{array}\right\}$ anã

Misceantur probe, et inbregatur plen per dies 7 mane

et vespi, dein apponatur emplastrum sequens

4 gummi amoniaci clari in aceto scillini solut piperis nigri

olibani puri ana $3 \mathrm{vj}$

In mortario calido misceantur et applicetur parti calide.

Put a little vinegar in a hot morter, and you putt the amoniacum and stirr it with a pestell and it will quickly be a plaister.

Mr. Michaell Easton an apothecary on $y^{\ominus}$ south side of $y^{\theta}$ greate conduit neare Cheape Side And pray him to have the trewe Ammi.

[MS. f. $46 \mathrm{v}$.

\section{List of plants.}

Beta candida

rough Hyssope. Hyssopus incana

Acinos odoratissimum

Angelica

Auena nuda

haves of glassenbury thorne

Astrantia nigra

Eruca peregrina Clusii

Cochlearia out of $y^{\theta}$ north
Condrilla rara fiore purpurante. eb. I 6

Aster conyzoides Virginiana

Helianthemum radice repente Virginianum

Ephemerum Virginianum

Sumach vir.

Sium segetum \& agrorum, Honewort

Cuminum Candiae

Seseli massilense. thapsia.

[MS.f. $46 \mathrm{v}$.

\section{Prescription.}
4 conserv. florū fumariae et
Radicum cichorei , ana $\bar{j}$ fs
pulpae cassiae 3iij

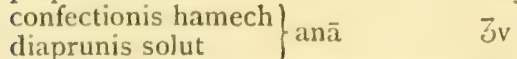
pulv. subtilissimi foliorum Sennae 3iij
tartari albi $\quad 3 j$ is
pulveris electuaij triasantali 3 fs

Misc \& cū syrupo de citron compos.

cü Rheo fiat electuarium instar opiatae.

[Goodyer has copied out this prescription twice over.]

[MS. f. I2S.

Recipe, c. 9 Ficb. 1627.

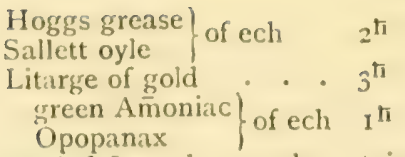

Boyled \& made uppe by art into a plaister, the gummes must be clarified w vinegar \& made uppe into a true body.

[MS. f. I29. 
Recipe: fragment of a petition: note on ailments of Folm Neale: note on local maladies of Selborne.

Rosen that is blackish 20 Mar. 1662.

Fresh lard a wallnutt

Crowne sope a wallnutt

Boil till it sets clere. H . . . .

Elder keepe stirringe.

Som ....

[This recipe is written in a shaky hand.]

Mar. 22. John Neale in Lippock, the howse is called Gurmes, hadd a third

Ague, \& hath lost him about a moneth \& nowe hath a great cough.

The Line of Selborne Goute

Scurvic

Dropsie.

[These notes are written by Goodyer on a fragment of a Petition of Glasier and Good of earlier date.] desistinge from youre Crueltyes and insolencyes, for ye entreatyes and Elizabeth Good, as of strangers and lookers on, intreatinge but forbearance untill harvest tyme was paste, for ye mowinge of ye grasse,-

[MS.f. I6.

Note of Localities of northern plants, perhaps supplied by Shanne: notes of books: method of taking Laudannm.

Richard Shanne.

Pyrola groweth in shadowed woods in Craven, in a place called Craggie Close in Lansdale.

Monophyllum groweth in Lancashire in Dingley Wood \& in Harwood neare to Blackburne.

[Quotation from Gerard emac. p. 409.

Iatrionices medicamentorum Simplicium liber 2 continens eo quos ad probus, ventrem, interanea que attinent.

Viaticū novū per Casparū Wolphiū 1565.

Laudanū $\bar{\jmath}$ fs gr. 2 to be given w. a little conserve of Roses or any other Conserve, and mare ale after it.

\section{List of Chinurgical Works.}

[MS. f. 15 .

John Vigo $w^{\text {th }}$ certayne works published as by Tho: Gale.

Philippe Barone works of Chirurg.

Ambrosius Parrius

Chametans

Tagaultius

Franciscus Arcaeus

Jacobus Ruess de generacione hominis

Variorumque Scotus or Chirurgie magnie

Chirur:

Margarita Chyrurgica by S: $\mathrm{H}$ : student in Pliysicke.

Schola Salerni.

Banisters Chirurgerie.

English Phlebotomy by Nicholas Guyer.

Pathway to Health.

Chimicall Phisicke and hermeticall Phisicke written by Josephus Luersitanus, translated by Tho: Tyme, minister.

The secrets of Alexis of Piemount.

The secrets of Albertus Magnus.

Bord his brevary of Health. 
I lalls boke of Chirurgerie.

Antidotarium speciale a Ju: Jacobo Vueckero.

Bartholomewe Glanfeild translat per Stephen Batman, Chaplayne to the Erle of Oxford.

Cochinelo ground mingled with water gumme water.

Fernelius Judgement of Urines.

[MS. f. I 31.

Weather record for the last part of May I62 I (?).

\section{May}

$22 \sigma \sigma^{7} D$ thunder

23 o 8 D 9 a. winds \& clouds.

24.24 D temprate

25 full moon

26 var cur.

27 Rayne

$28 \Delta q$ lo a

$29 \Delta 4 q D$ II a.

$30 \Delta \odot D$ II a.

3I $D$ in apog.

[Written on a paper on which Goodyer afterwards wrote his draft description of the Jerusalem Artichoke on 17 Oct. 1621.]

[MS. f. II6.

\section{Miscellancous Notes. Lists of Fruit Trees and Plants. Dates of Assizes.}

Rec. 9 Feb. 1627 of Christopher Potecary of Stockton 5 myle from Venny Sutton Clother.

1. Burgomaster peare till Easter

2. Kingekaterine 3 grafts till All S.

3. Painted peares

4. Norwich peare

1. Harvey aple

2. Quadlinge aple

bunch cherry

lilli: convall: flo: rubro

Aconitum luteum Ponticum

Lamium Pannonicum

Southt Wed. 5 Mar. Wimbor[ne]

Dor. lun. Io Mar. Dorchester

Somers. wed. 12 Mar. Chard

Cornub. wed. 19 Mar. Lanceston

Exon. civit. lune 24 Mar. Exon Gildhall

Devon. Eadem die apud Cash ...

Wiltes martii jo Apr. apud Sarum Is Maij rem. $4^{\mathrm{ti}} 5^{\mathrm{s}} 4^{\mathrm{d}}$ ob.

[MS. f. I29.

Salvia versicolor

Yucca

Paliurus?

Pistachio

Laburnum leaved trefoile

Colutea minor

Anisum

Digitalis minor lutea

Astragaloides

Balsamita flo. alb.

Aconitum flo. delphinii

Geranium creticum variegatum

Paralisis flo: viridi simplici

Sedum serratum

Cotiledon minor

Gelsimum luteum

Fragaria fructu aculeato

Geranium gratia dei batrachoides albo, coerul. et variegat.

Thlaspi vaccariae folio

Jacea Baetica

Thlaspi Mechlinense

$$
\text { , Creticum }
$$

Hissopus latifolia

Periclimenum rectum

Laurus Tinus

Trachelium

Rosmarinum

Nardus montana

Gentianella verna.

Ranunculus thalictri folio

Polygonatum Virginianum

Ignotum ex Virginia

Tanacetum striatum et hissopus

an Meum alterum

Cicer arietinum flo. ... et fructu albo

Cicutaria max.

Acanthus syl.

Keyri max.

Sorbus legittimus

Jacea lutea

Pimpinella fl. albo

Cirsium mont. maius

[MS. f. 129. 


\section{INDEXES}

\section{GOODYER'S PLANT LISTS}

THE following Alphabetical List (Index I) includes plants with which Goodyer was acquainted, or which happened to interest him. The great majority were in cultivation in English gardens or were those whose native habitat he had discovered. That it was not exclusively a garden-list is indicated by the presence in it of 'Quercus marina' and of other seaweeds, but it may have been a catalogue of one of his Horti sicci. There are two copies of this list in Goodyer's handwriting (MS. II, ff. 47-59). The fair copy seems to have been written out in the winter of $16 \mathrm{I} 7$ and it remained in use for many years, for several additions dated $1618,1625,1628$, 1634, \&c., have been made later. A few of these added nôtes are printed below, in the form of foot-notes, but the greater number, being dated, have already been included among his descriptions of plants on page rog et seq. The names are mostly those used by Gerard and Lobel, with a few taken from Dodoens, Clusius, Deleschamps, and Matthiolus, a fact which points to the date of the compilation of the original list being anterior to the appearance of Bauhin's Pinax. Goodyer quotes references to pages of Lobel and Gerard (1597) throughout, but these, and his synonyms, have been omitted for the sake of economy of space.

We interpret the letters $C_{\text {. }}, \mathrm{P}_{\text {., or }} \mathrm{F}$. in the margin as meaning that the plants so marked were growing in the gardens of Coys, Parkinson, or Franqueville respectively.

These two lists, written out as they were within a few months of one another and including additions up to the year 1634 , are therefore of importance for tracing the spread of plants in English gardens. In the earlier list the number of plants marked $\mathrm{P}$ (Parkinson) is 239 , in the later list 264 , and the numbers of plants marked C (Coys) are 147 and 324 in the two lists respectively. Eight are marked as growing in Franqueville's garden.

The indexes do not include the names in Tradescant's lists, printed on pages $33^{1-4} 6$, which should also be consulted. 


\section{INDEX I \\ P'LANT-NAMES USED BY GOODYER.}

Names in ordinary type are printed from Goodyer MS. I I, ff. 47-59. Names in italics occur in Goodyer's other MSS., and are probably of later date than the others.

$$
\begin{aligned}
& c=\text { grown in the garden of Coys. } \\
& \mathrm{P}=\text { " " } \\
& F=\quad, \quad \text {, }
\end{aligned}
$$

C Abies.

Abrotanum mas.

$\mathrm{C}$

Absinthium marinum album, Seriphium vulgare. $28 \mathrm{I}$

y' Absinthium folio Lavendulae.

Acanthium album.

C Acanthus sylvestris aculeatus. sativus, Branca ursina. $3 \mathrm{C} 6,3$ I 8

C Acarna flo. rubro, like Carduus mariae, but higher\& lesser. 145 Acer maior. We call this a Sycomore tree.

Acer minor: $275,2 S_{3}$

Acetosa maxima. Achillen sideritis.

155

Acinos. $\quad 120,166,280,296$

1) Aconitum hyemale.

CH

$\mathrm{CP}$ Delphinii.

luteum Ponticum. 318 lycoctonum Hore

Adianthum album et nigrum. 263 Adonis.

136,319

C Aegylops.

CP Aethiopis.

F Agnus castus. $\quad 326$

Agrimonia.

C. Amroriatnum.

Aizoin.

152

(I) Alaternus. $270,317,346,355$

(1) Alcea peregrina.

I' , vulgaris.

, vulgaris albo flore. III

Alchimilla.

275,306

Alleluia offic. Opis alba. 275

c , offic. Opis luten.

Alliaria recentiorum.

II 1

Allium.

, ursinum latifolium.260,275
Allium silvestre tenuifolium.

Alnus.

260,316

, nigra.

175,287

26 I

c Alopecuros gramen.

Alsine corniculata.

CP , repens maior baccifera.

1) , maior

, minima

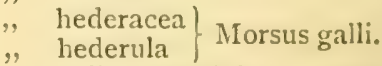

" foliis trissaginis. 284

, myosotis. 129

"palustris. 179

., aquatica. 194, 280

"flosculis comiencutibus.

195

, serpillifolio. $\quad 275$

Althea. $\quad 287,305,346,354$

Alyssum Dioscoridis.

Amara dulcis.

(1) Amaranthus purpureus.

(v) Ammi vulgatius. 306, 320

(.1) Amomum Plinii. 320

Amygdalus.

Anagallis. $\quad 284$

CP,$\quad$ foemina coerulea. 287

, lutea. $\quad 187,293$

, aquatica.

I $95,282,300$

, aquatica tercia. 111

F. Anagyris. $\quad 326$

1) Anclusa lutea. $\quad 277$

C , supina Jusitanica non script.

Androsice. $150,28 \mathrm{I}$

Androsaemum; Climenon Italorum.

$28_{3}$

1. Anemone flo, pallido. I cannot sett downe the varieties I have secne. 306

Anemone Cardinals Hatt. 
Anemone pleno rubro.

c , coeruleo.

fl" nemorum albo pleno

Anemone nemorum albo. nemorum purpurea.

C Anethum.

Angelica sativa.

", silvestris.

Anisum.

Anonis.

$277,287,355$

CP Anthora.

Anthyllis leguminosa Belgarum. " montana Deles. II 50. Anonymos lini folio Clus. 324 ; Leguminosa Belgarum Lo. $O$. 87. Ger. I06o. Gerard's figure of Lagopus max. p. 1023 is likewise a trewe figure of this.

II 7

C Anthyllis Valentina Lo. 421; Herniaria Boelii Clus. Cur. post. p. 37. Ger. p. 452 hath a false figure.

3 I 8

Antirrhinum album.

306

C

C

flore rubro.

Aparine.

Aphaca.

Apium hortense.

C

" crispum. linum.

minimum.

purpureum.

mus.

I I $5,143,275,292$ maius Baeticum

Aquifolium sive Agrifolium.

P Aquilegia.

I have seene of more colors than I can nowe remember.

287,347

c $\quad$ multiplex.

C Aracus maior Baeticus. " minima.

Arantia.

P Arbor vitae.

C ", Judae.

317,346

Arctiun montanum. 194,280

C Argemone.

I 55,320

" capitulo longiore. I 78 Aria Theo[phrasti] Lo. 0. 167.G. 1146. Why he calleth it a hawthorne I knowe not. Deles. 202 hath a very trewe figure of it. We call it quick beame.

CP Arisarum latifolium.

CP Aristolochia clematitis. $\quad 306$
Armeniaca malus.

Armeria alba et rubra, \& of severall colours on one stalk.

C Armeria varia. $\quad 346$

Artemisia. $\quad 284$

Arum offic. 280

Arundo Vallatoria. I 76,280

P Asarum.

Ce Asclepias flore albo.

CP,$\quad$ flore nigro.

Ascyron. 275, 283-4

Asparagus sativus.

Asperula.

CP flore coeruleo.

Asphodelus. $\quad 145,319$

Asplenium. $\quad 263$

" silvestris Tragi.

$\mathrm{CP}$ Aster Italorum.

CP " conizoides ex Virginia.

$\begin{array}{rlr}\mathrm{P} & \text { Astragalus. } & \text { I2C, } 347 \\ \mathrm{CP} & \text { I6, } 347 \\ \mathrm{P} & \text { Astrantia nigra. } & 140 \\ \mathrm{CP} & \text { A } & 347\end{array}$

CP Atractylis flo. luteo.

Atriplex marina repens. 285,300

, sativa alba.

" sativa purpurea.

,$\quad$ silvestris.

P " olida.

Avena vesca.

Avenaria ustilago.

P Auricula ursi flore rubro. , flore purpureo.

P Baccharis Monspeliensium.

C Balsamina foem.

Balsamita mas.

c $" \quad$ foem. flo. albo. Ageratum.

Barbarea. 320

C , species. Beros ex Hispania. 317

Bardana minor. $\quad$ I2 $\delta$

Batata Virginiana. $\quad 320,356$ Hispanorum at $\mathrm{Mr}$. $\mathrm{W}^{\mathrm{nt}}$ Ÿaldens 21 Aug. 1637.

Bellflower, Lesser.

Bellis maior. " maior silvestris. " hortensis multiplex flore rubro.

Bellis hortensis multiplex flore albo.

Bellis hortensis multiplex variegatus.

C Bellis spinosa. $316,318,321$

Berberis. Holythorne.

Beta rubra. , alba. 
Beta marina. " Cretica.

281,285 I 36

Betonica.

Betula. . maior Danica.

$$
\text { " fo. albo. }
$$

Betulus.

Bifolium

p Bistorta maior. Reddshancks or leggs.

$\mathrm{P}$ odoratissimo.

Blitum.

C , seu Amaranthi species sem. nigro, like Amaranthus tricolor.

C Blitum spinosum Creticum. 136 Bonus Henricus.

C Borago hortensis.

C,$\quad h o r t e n s i s$ flo. albo. , semper virens.

CP Botrys.

Brassica vulgaris sativa. 128

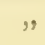
florida botrytis.

, marina monospermos.

285

, capitata alba.

, capitata rubra.

prolifera. Colewort.

Bromos sterilis.

Bryonia alba. 262

, nigra. 127, 262

Buglossa hispanica. 277

Buglossum angustifolium.

CP $\quad \quad \quad$ scorpioides. I 3I, 3 I \&

Bugula. 280

Bulbocastanon.

I' Bupthalmum Lod. $\quad 327,354$

C,$\quad$ primum Mathioli. Gerard hath the same fig. under the title of Iuphthalmum album p. 607.

Bursa pastoris.

I 54,318

Butomus.

177,258

Buxus.

P Cachris verior. Gerard, p. 858, hath the figure of Seseli massiliense Mathi. for it.

Calamagrostis.

172, 288

c. Calamintha montana praestantinr.
Calamintha montana vulgaris. , aquatica Belgarum.

P Calceolus Mariae. 275

Calendula simplici flore. 347 i, multiflora.

, prolifera.

C $\quad$. silvestrismediofusca Boet.

C Calendula silvestris medio lutea Boet.

Caltha palustris. 347

r , palustris multiplex.

(P) Canspanula persici-folia. fo. albo et caeruleo. 347

Campanula minor rotundifolia.

Cannabis sylvestris spuria altera. , sylvestris tercia. "spuria. 194

CP Capnos altera fabacea radice.

Capsicum. $26_{3}$

Caput gallinaceum Belgarum. I 78

Cardamine altera. Ladysmocks.

" impaticns. I 189 280
189

Carduus acaulis septentrionalium.

145

1) Carduus Mariae lacteus.

145,320 tante. tante.

CP Carduus globosus maior. " globosus minor.

, stellatus.

" criocephalus, see Corona fratrum. $\quad 320$

C Carduus stellatus flo. luteo monspel.

Carduus Benedictus.

.. spinosissimus.

., bulbosus monspel.

144,319

,, viarum flo. purpureo)

, viarum flo. albo

I 12,145

We have a kind here that smells like Musci.

Carlina silvestris.

I 12

C Caryophyllata maior rotundifolia.

v Caryophyllata vulgaris.

Caryophyllus marinus. $\begin{array}{ll}\text { " } & \text { proliferus. } \\ \text { ", } & \text { multiplex. I have }\end{array}$ seen more varieties of them than I can set downe. 
Carum.

Castanea.

I 74,346

Catanance

Cataputia minor.

Cattaria tuberosa. $\quad 16 \mathrm{I}, 3 \mathrm{I} 8$

C Caucalis maior Lusit. $\quad 128$

G , vulgaris albis floribus.

C $"$ nodoso echinato semine. II4

Caucalis alterum script.

, pumila.

195

Cauda muris.

Centaurium floribus luteis.

$$
\begin{array}{lll}
\text { CP } & \quad \text { maius. 275:305-6 } \\
& \quad \text { parvum. }
\end{array}
$$

Cepa alba.

, rubra

Cerasus nigra.

, Virginianus.

" vulgaris.

, vulgaris duplici flore.

C Cerefolium vulgare. 263

CP Cerinthe flore luteo, $\quad \mathbf{1 2 8}, \mathbf{1 8 0}$ C " flore rubro. 128,320 Ceterach.

FP Chamaecerasus.

Chamaecyparissus. G. 952 , which is the figure of Muscus terrestris clavatus alter Mathi. p. 120. Most authors take this plant to be Abrotanum foem.

1 knowe not where there is a trewe figure of our Lavender Cotton.

Chamaedrys.

C ,

sylvestris. $\quad 284$

Chamaeiris. $\quad 347$

CP Chamelaea tricoccos. $\quad 317$

Chamaemelum.

C

CP

albo duple flore.

" nudum odora-

tum.

P Chamaemespilus Gesneri.

P Chamaemorus.

p Chamaenerium Gesneri. II

Chamaepytis mas. 275

CP Characias monsp.

vermiculata. 170

C ", anygdaloides, our Woodspurge.

Chelidonium maius.

P Chondirilla semine I I5, 359 purpurante.

F Chondrilla coeruleo flore. 326

CP Christophoriana. 288, 329
C Chrysanthemum creticum. I34

C ", spinosum Boeticum.

Chrysarthemum segetum. G. 605 a false figure. I35

C Chrysanthemum Boeticum non scriptum.

I 35

Chrysanthemum tenuifol. Boeticum.

I 35

C Cicer rubrum vel arietinum. 306

P Cicercula Clus: 236 , it is like to Lathyrus. 354

Cichorium sativum coeruleum.

$\begin{array}{lll} & & \text { silvestre. } \\ \text { C } & \text { " } & \text { flo. rubro. } \\ & \text { verracatum. I5 I }\end{array}$

Cicuta.

P Cicutaria latifolia foetidissima.

, fatua.

, palustris.

", tenuifolia. G. 905. It

is ye fig. of Myrrhis Math. p. 814. Turner 2 pt. fol, 60 calls it Mock Chervell, but what Casshes there mentioned should be, I knowe not.

P Circaea lutetiana.

Cirsium anglicum. $\quad 288$

CP " maius. 317

C Cistus mas. $\quad 317$

C " foemina. 317

C " ledon. 317, 359

C , annuus semine albo.

C Clematis peregrina flo. rubro.

CP,$\quad$ daphnoides maior. 348 , daphn. minor flore albo.

Clematis daphn. minor flore coeruleo.

Clematis daphn. minor flore purpureo pleno.

FCP Clematis coerulea Pannonica.

Cochlearia Batava.

$$
\begin{aligned}
& \text { Britanica. } \\
& \text { ", rotundifolia maior. } \\
& \text { rotundifolia minor. }
\end{aligned}
$$

317

Colchicum flo. albo et purpurec.

$\begin{array}{rlr}\text { C Colus Jovis. } & 110,300 \\ \text { CP Colutea Theophrasti. } & 319,320 \\ & \end{array}$

P ", scorpioides.

Coniza media.

", minima.

, aquatica laciniata. 193

See also Index II and p. 334. 
Coniza coemulea.

162

(; Consiligo Ruellii.

I) Consolida regalis.

$28 \mathrm{I}$

, regalis florcpurpureo.

"regalis albo.

", regalis rubro.

, regia segetum.

Concolountus minor

\section{coeruleus minor \\ Biaticus.

Convolvulus coeruleus Bryoniuc folio.

C Coriandrum.

153

C Cornu cervium ex Italia.

P Cornus mas.

us mas.

foemina.

305,346

Corona fratrum. $109,127,146$

Coronopus.

p Cortusa Mathioli. repens Ruellii. 26r

Corylus persimilis Aeno. Nux avellana.

Corylus sylvestris.

Cotonea mala. Quince tree.

Cotula foetida. We call it Margin.

Cotyledon aquaticum.

Crassula.

maior Hispanica. 310

Crateogonon rubrum. IIS

Crista galli offic. 261

Crithmum. I93, 357

Cruciata minor. $\quad 352$

C Cucumis asinints. $\quad 347$

P Cupressus. 306, 337

Cuscuta. II2, 163

I) Cyanus maior.

, vulgaris flo, coeruleo.

C , varius.

(1) Cyclamen folio Hederae.

284,319

(I) Romanum orbiculato folio. 319

(. Cymbalaria Italica. $16 \hat{3}, 317$

Cynara maxima.

, maxima alba.

c " sylvestris.

Cynocrambe. G. 263 hath ye fig. of Phyllon Achenogonon for it.

Cynoglossum maximum.

$$
147,284
$$

C

folio"

Boeticum Buglossi

English Galingale.

Cyperus gramineus.

175

CI Cytisusmaior sempervirens. 317
C Daucus Cretensis. $284,318,359$

Hispanicus.

327

Dens leonis vulgaris. $\quad 115,319$

P Dentaria bulbifera. 123,186

1) Digitalis ferruginea. 186, 327

P,$\quad$ flo. pallido luteo. 327

" purpurea. 262

Dipsacus sativus.

, silvestris.

PC Doronicum Romanum. 347

Draco herba.

Dracontia angtina.

Dryopteris. $183,189,275,302$

p Ebulus.

II I

Echium vulgare.

C " flo. rubro. $\quad 317$

c ," angustifolio. 317

c , omniummaxinum Lusitanicum flo. carneo. $\quad 317$

Elatine Dioscorid: Veronica foemina Fuchsii altera. $\quad 163$

Endivia.

Enula campana.

Epicrion.

P. Epimedium.

Equisetum. $282,28_{4}$

Erica. I have not observed the differences. $280,28 S$

C Eruca maior flo. albo. 320 , palustrisminor. 292 , sativa.

silvestris.

1) Ervila.

$16,1+1$

Erygeron.

CP Eryngium coeruleum Alpinum.

C , Alpinum flo. albo.

(1),$\quad$ luteum Monspel.

Mediterraneum.

" marinum.

Erysime similis.

(1) Erysimum Italicum \& Mathioli. , Diosc.

, Theo.

" ii Tiub. 191, 293

1) Esula maior. 263

, exigua.

retunda. 327

Euonimus Theophrasti. $\quad 346$

Eupatorium cannabinum foem.

" mas. 275

Euphrasia. $\quad 283$ " $\quad 2^{a}$ Dodonaci. 117 2" Dod, flo. albo, I 50

Faba maior recent.

c1 , silvestrisGraccorum. Faba veterum.

140 
C Faba veterum serratis foliis. I 40

Fagus. 188,189

Ferrum equinum Germanicum siliquis in summitate. $\quad 187$

CP Ferula.

Ficus.

$p \quad, \quad$ Indica.

$\mathrm{P}$ Filipendula.

Filix mas.

" foem

"spinosa.

, palustris.

$(87.0$

Flammula Jovis subrecta

CP Flos Adonis flo. rubro. I36, 3I9 , Africanus.

", solis. $\quad \mathbf{1 6 6}$

", solis Peruvianus. $\quad 167$

Foeniculum vulgare. $\quad 296$

c " $\quad \begin{aligned} & \text { dulce. } \\ & \text { silvestre Lusitani- }\end{aligned}$ cum.

318

CP Foenugraecum.

Fontilapathum pusillum.

Fragaria.

" maior subalba.

CP Fraxinella. sterilis.

Fraxinus.

I I 4

Frumentum Turcicum. We call it Virginian wheate.

Fumaria. $\quad 263,359$

" claviculis donatis. $15 \mathrm{I}$

Fungi. I $\quad$ 96, 278, 283, 353

p Galega.

c flo. albo.

306,327

c Galeopsis Clus. legittimo.

317,359

C

Pannonica flo. rubro.

", flo. albo lusit.

", flo. rubro elegantissimo Boetico.

Galium luteum.

, album.

CP Genista Hispanica.

" Scoparia vulgi. Furze.

Genista spinosa minor. 189,282

" " major. I90

Genistae rapum.

Genistella infectoria.

Stichwort.

aculeata. We call this

CP Gentiana maior.

284

CP ", concava.

P $\quad$, minor sive Cruciata.

, minima.

Geranium flore coeruleo.

287

" malvoides.
Geranium Columbinum.

\begin{tabular}{|c|c|c|c|}
\hline & & I9I, 28I, 293, & \\
\hline & & Robertianum. & 281 \\
\hline & : & Haematodes. & 319 \\
\hline & ", & moschatum. & 147 \\
\hline & ", & $\begin{array}{l}\text { moschatum inodor } \\
\text { sanguinar. }\end{array}$ & \\
\hline $\mathrm{C}$ & $"$ & Creticum. & 147 \\
\hline c & $"$ & Boeticum species. & 146 \\
\hline & ", & saxatile. & 18 \\
\hline & 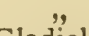 & Romanum. & \\
\hline & $\begin{array}{l}\text { Gladio } \\
\text { Glastu }\end{array}$ & $\begin{array}{l}\text { palustris. } \\
\text { sativum. }\end{array}$ & \\
\hline & & aris. & \\
\hline
\end{tabular}

, ixigua marittima. A trewe figure in Delesc. p. 487.352

Glycirrhiza.

275,283

Gnaphalium Americanum. 148 , Anglicum.

, vulgare.

, marinum. 148

Gramen iunceum. 282

, fluviatile.

" exile hirsutum. We call

this Hares bere.

Gramen marinum spicatum.

, aquaticum Cyperoides.

194

" caninum. 257

" caninum nodosum.

tomentarium.

leucanthemum.

cristatum.

bufonizum.

, tremulum. I58, 285,289

, paniceum.

195

Gramen sp.

$249,257,282,285-6,289$

C " lupuli glumis. 158, 347

C,$\quad$ striatum.

CP " plumosum. 289, 3 I 8

, Alopecuroides. 282

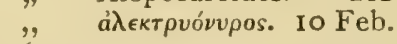
1622.

Gramen parnassi.

CP Gratiola.

I 71

305, 317

latifolia.

Halicacabus.

275,359

P Halymus vulgaris. G. 420. No good figure.

C Halymus surrectus Clusii. 320 Hedera corymbosa communis. "terrestris.

CP Hedysarum clypeatum. I47, 318

P $\quad$ sine securidaca. 305 C Ims"Clusii.

See also Index II and p. 334 . 
C Heliotropium Indicum vel Virginianum. Yow had lately planted it when I was at your howse 25 Martii 1617. I09, 166,317

CP Helleborastrum.

P Helleborine.

r Helleborus albus. ," albus flo. atrorubente.

326

Cl Helleborus niger verus. 327,347

Helxine.

237

C Hepatica trifolia coeruleo pleno flore.

p Hepatica exalbido flore. Heptaphyllon.

C Herba' aquatica rubescens. 187

CP Herba Doria. 119,319

CP , , altera serratofolio.

110

P Herba Paris. 110, 275, 307

P Herniaria. 327

Hieratium alterum grandius. 284 ,$\quad$ longius radicatum. , aphacoides. Succorie hawkweed. I have seen another Hieratium of 4 or 5 foot high having a round smoothe stalk.

283

C Hieracium falcatum maius. 149

C , falcatum minus.

C, medio nigrum flore majore.

149

C Hieracium medio nigrum flore minore.

I 49

Hieracium stellatum. $\quad 149$

, intybaceum. $\quad 149$ , lanosum. 150

C1 Hippoglossum bonifacia.

p Hippolapathum rotundifolium. lium. sativum latifo.

Hipposelinum.

C Quicki.

Holosteum.

Honewort.

Hop.

Hordeum spurium.

distichon. Lo. 29.

Ger. calls this Polystichum, p. 64 , which is false or els his fig. is misplaced.

c Hordeum nudum.

Hordei distichi ustilago.

Horminum sylvestre sive oculus Christi.

289

p Horminum sylvestre Pannonicun?.
C Horminum flore coeruleo. Hydrolapathum magnum.

CP Hyosciamus albus.

c. $"$ miger.

C, albus lutescens medio purpureus.

C Hypecoum Clusii. 129, 306, 309

l. Hypericum.

302

$\begin{array}{ll}, & \text { Syriacum. } \\ , & \text { exiguum Tragi. } \\ , & \text { tomentosum. }\end{array}$

Hyssopus offic. flo. coeruleo. II 5

C

, flo. albo.

319

Jacea maior.

165

C " palustris lusitanica non script. $\quad 164,317$

C Jacea repens luteo flore. 317

C " albo flore. 110, 317

C $\quad$ capitulis hirsutis. 164,317

P , marina. 317

p " marina Baetica.

C , Baetica aestiva.

Jacobaea marina.

Jasminum. Pannonica. 194,289

Americanum.

C Ignotum ex Virginea flo. Chrysanthemi parvo radice repenti, like to Lysimachia lutea.

P Ilex glandifera.

Illecebra.

P Imperatoria.

284

Iris alba.

. palustris Jutea.

., vulgaris.

c Isatis silvestris vaccaria. 26I

Juncus laevis.

$\because$ aquaticus maximus.

Juniperus.

123, 195

Kali geniculatum. Salicornia. , minus.

CI' Laburnum.

Lactuca sativa.

P , agnina.

P , agrestis.

, capitata.

c " Virginiana. 319

C, crispa.

"sylvestris. 111,158

Lagopus. $\quad 144$

Cl " flore ruberrimo. 284

Lamium album.

$\begin{array}{lrr}, & \text { rubrum. } & 281 \\ " & \text { luteum. } & 2 S 1,317 \\ \text { " false figure. } & \text { G. } 568, \\ \text { at } & 156\end{array}$


C Lamium Pannonicum. 2 Clusii. Lampsana. Hastie Roger, for cutts.

Lapathum sanguineum. I 49 , acutum.

", folio minus acuto.

Lappa maior. Bardana maior.

Lathyrus sylvestris floribus luteis.

Lathyrus latiore folio $\quad$ I 37

c $\quad$, palustris Lusit. $\quad 137$

c " Creticus belli.

, perenni radice.

C,$\quad$ Orobeus Boeticus.

c ., Dumetorum Baetic. 138 , aestivus Baeticus. 137

Laureola. major ang

FP Laurocerasus.

Laurus mas.

, foem.

Legumen pallidum.

c Lens minor.

" palustris.

Lens minor.

Lepidium Aeginetae.

Leucojum luteum duplici fore.

luteum simplici flore.

Wall-flower \& Hartesease.

Ione Grant: Turner calls it so.

Leucojum album.

,$\quad$ purpureum.

p $\quad$ " Patavinum marinum. " melancholicum. 327

P Levisticum. Lo. 703. G. 855 hath ye fig. of Siler montanum for it; and hath put the figure of Levisticum mathi. p. 853 for Laserpitium.

C Levisticum verum Gerardi. 319

Lichen.

230

, marinus.

Ligustrum.

1) Lilium Convallium. " Convallium rubro flore.

Limonium.

285

Linaria. I I 8, 324

C ,, aestiva minor. I43

Linum sativum.

Linum catharticum. 109,112

P Lithospermum maius.

Lolium" album.

F Lotus arbor. $\quad 326,339,346$

CP " siliquosus. Pisum quadratum.

139

Lunaria minor. I 10, 263, 264

Lupinus sativus flo. luteo.

fo. coeruleo.

C Lupinus coeruleo maior.

C, ex coeruleo albo.

C , Indicus flo. coeruleo medio purpureo.

Lupulus salictainus. " sylvestris.

Luteola.

Lychnis sylvestris albus multiplex.

Lychnis sylvestris cauliculis striatis albo flore.

Lychnis sylvestris rubello flore.

, Chalcedonica.

195

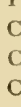

$"$ fl. carneo.

, " flo. albo.

," flo. mi-

niato et carneo.

Lychnis coronaria alba.

" coronaria subra.

C

, coronaria flo. suaverubente.

C Lychnismarina Anglica. 2S2, 3 I 8

P

Lysimachia lutea.

275

P

C

CP " campestris.

, galericulata.

, flore Delphinii.

,$\quad$ coerulea. $\quad 320$

, purpurea spicata.

, siliquosa.

357

" siliquosa ex Boria-

libus Virginiae.

Lysimachia forte. Wiltshere.

I I I

Majorana nostras.

120

Malus.

, silvestris. Crabbe tree, wildinge tree.

Malva rosea fruticosa.

C , , rosea multiplex

$$
\left\{\begin{array}{l}
\text { albo } \\
\text { rubro } \\
\text { purpureo }
\end{array}\right\} \text { flore. }
$$

Malva silvestris repens pumila. , silvestris precocior vulgaris. , crispa.

" vesicaria. Vide Alcea peregrina.

Malva aestiva flo. amplo Baet.

CP Mandragoras mas. $\quad 339$

P Maracoc Virginiana. 165,320

Marrubium album.

, aquaticum vulgi.

, nigrum.

Marum, herbe Mastick.

Matricaria nostras.

See also Index II and t. 334. 
C Matricaria grato odore.

Medica spinosa.

$$
\text { ,, anglica. }
$$

142

"pericarpio plano. 143

c " minor elegans.

(. " marina spinosa.

". vulgaris.

Melampirum.

(. Mílilotus Italica.

126,317

(')

$$
\text { , Germanica flo. albo. }
$$

$$
\text { " coronata. }
$$

$$
\text { " Indiae. }
$$

c Melissa Turcica.

$$
\text { Melo. Muske Melon. } 165
$$

p Mentha Cattaria.

c " Cattaria media.

c " Cattaria minima.

C " Cattaria tuberosa.

c " Romana offic.

, sativa rubra.

, Sisymbria aquatica.

Menthastrum.

$$
\begin{array}{ccc}
\text { c. } & \text { montanum. } \\
\text { CP Mercurialis mas. } \\
\text { CP } & \text { " } & \text { foemina. } \\
\text { C } & \text { ginea. } \\
& \text { Mespilus. }
\end{array}
$$

cP Meum.

P Mezereon Germanorum.

CP Millefolium odoratum sive nobile.

P Millefolium luteum.

, terrestre purpureis floribus.

Millefolium terrestre vulgare. nunculi.

flore \& semine Ra-

Millegrana minima.

275

Mill mountaine.

109,112

CP Mirabilia Peruviana.

Moly serpentinum.

, Homericum.

Morsus Diaboli.

, Ranae.

Morus candida. ", celsa offic.

Muscatella Cordi. I26, 29 I

CP Muscipula.

Muscus terrestris vulgaris.

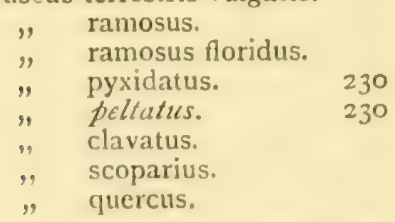

Muscus marinus sive corallina.

C Myagrum monospermon.

C1" " thlaspi facie. 319

CP Myrrhis. 290

Myrtus Brabantica.

Napellus verus coeruleus. 348

c. " minor serotinus.

Napus sive Bunias.

" silvestris.

p Nasturtium Indicum.

C , hortorum crispum.

, hortense.

" aquaticum. The

fig. is misplaced in Ger. p. 200. Sion cratervae Erucae folium Lo. 209.

Nepeta media.

162

p Nerium. Oleander.

Nidus avis. 126, I95, 290

C Nigella Delphinium elatius var. color.

C Nigella trigonum Lusitanicum.

CI " Romana flo. albo.

$$
\begin{array}{lr} 
& \text { I 52, } 348 \\
, \quad \text { multiplex. } & 152 \\
\text { elegans. } & 153
\end{array}
$$

Nummularia. $26 \mathrm{I}$

Nux Juglans. I12, 174

Nymphaea alba.

$$
\text { " lutea. } \quad 262,2 \delta 1
$$

Ocymoides semper virens, Clus.

Ocymum.

C Oenanthe cicute facic. 3 I9

C $"$ filipendula aquatica. " angustifolia. I I 5, 143, 195, 327

Olea silvestris. stellata.

Ophioglossum.

Ornithopodium perpusillum.

Orobanche.

C Orobus ex Venetiis.

l' , recept herbariorum.

Osmunda.

CP Oxalis franca. , tenuifolia sinuata ververina.

Oxis, vide Alleluia.

Oxyacantha. Hawthorne.

286, 292

Cl. Paeonia mas. 1 heard of one with doble flowers.

(1) Paeonia foemina. , foemina multiplex rubro flore.

Palma.

184 
C

Panax coloni

CP " heracleum alterum recentiorum.

C Panicum vulgare. „ sylvestre.

$P$ Papaver spumen

c " $\quad$ album multiflorum.

, corniculatum flore luteo.

Papaver cornutum flo. rubro.

" rhaeas. 155

CP " spinosum, Clus. 320

Parietaria. $\quad$ I 18

Paronychia alsine folia. $\quad 290$

" rutaceo folio.

Pastinaca domestica vulgi.

" sativa atro rubens.

", latifolia sylvestris.

" sativa Diosc.

", silvestris tenuifolia.

" aquatica minor. 116

$" \quad$ " latifolia.176

" maxima. 176

Pedicularis. " 263,290

$P$ Pentaphyllon maius. Quinquefolium.

P Pentaphyllon minimum alpinum petrosum.

Pentaphyllon supinum Tor. mentiliae facie. $\quad 273$

Pentaphyllon vulgare.

Pepo oblongus.

"rotundus.

CP Perfoliatum vulgatius. 26I, 28 I

$\mathrm{CP}$ Periclymenum rectum.

$$
\begin{array}{ll} 
& 2 S \text { I, } 301,320,346 \\
, & \text { perfoliatum. } \\
\text { non perfoliatum. }
\end{array}
$$

P Periploca repens folio angustiore. 346 , recta latifolia Virginiana.

Persica malus. I3 I, 32 I , malacatone.

Persicaria Hydropiper. mitis maculosa.

Pes anserinus.

Petasites.

Petroselinum, vide Apium.

Petum indicum. 318,327

Peucedanum. 160 348

C Phalaris bulbosa. 133, 317 , pratensis. 282

c " minor Boet. albo. 133

c " minor nigro. 133
C Phaseolus vulgaris albus.

, vulgaris niger.

". vulgaris ruber.

Phyllitis.

P " multifidofolio. 185,279

P Phyteuma monspel. 134, 327

p Pilosella maior.

C , maiore Syriaca. 317

, repens.

" flo. coeruleo.

flo. carneo.

P Pimpinella maior Fuchsii. L.720. Ger. fig. 887 agrees not with this herbe.

P Pimpinella saxifraga minor.

P , hortensis

282,286

Pinus.

agrimoniae folio. 318

CP Pishimon prunus Virginiana. 320

Pisum.

C , falcatum Boet. sine membrano.

C Pisum Indicum Gerardo. Vicia fructu albo. $\quad 139$

Pisum maculatum Boelii. I6, I 4 I , vulgatius maius.

, minus.

C " silvestre Boeticum.

" umbellatum. G. 1045. French pease.

Plantago incana.

CP :, rosea spicata.

, quinque nervia.186,301

, aquatica. 293, 353

" aquatica stellata.

I IO, I 80

" marina.

P Plumbago Plinii. Dentaria Rondeletii.

Pneumonanthe. $\quad 170$

Podagria germanica. I 10

Polemonium monspel.

r Polium montanum. $28 \mathrm{I}$

Polygala fiore coeruleo.

" flore purpureo.

, flore albo.

, Hore rubro.

, obsoleto flore.

C Polygonatum.

P " " Virginianum.

Polygonum Germanicum. 110 foemina.

" mas vulgare.

", marimum sp. 148

$\begin{array}{lr}\text { alterwm. } & 151 \\ \text { Polypodium. } & 184,230\end{array}$

C Pomum amoris parvum.

See also Inder II and p. 334. 
c Pomum spinosum.

327

c "spinosum flo. coeruleo.

Populus alba.

", nigra.

" Lybica.

Porrum vulgare.

" tonsile. French leeks.

Portulaca domestica.

Potamogeton.

Potentilla. Argentina. 262

Primula hortensis maxima Anglica floribus plenis. $\quad 280$

Primula veris, flore gemino. Cowslipps 2 in a hose.

Primrose 2 in a hose. 109, 316

Primula veris rubro flore. 283 " pratensis. Cowslips. ," pratensis inodora. Oxlips.

Primula silvarum.

" silvarum obscura virentibus.

Prunella.

, flore albo.

Prunus sylvestris.

, domestica.

Pseudo-melanthium.

c Psillium.

Ptarmica folio Taraconis.

I1 2

I 57,348

(1) ," Imperati. II9, 319

Pulegium regium vulgatum. 28 I

(I) Pervinum.

c Pulmonaria maculosa. G. 662. inc. flo. Io Marcii. 320

C Pulmonaria non maculosa. 320 , officinar. " folizs Echii.115,195 " gallica aurea. 180

Punicum malum.

Pyra.

P Pyracantha.

C Pyrethrum offic.

Pyrus silvestris.

Quadrifolium Phaeum fuscum hortorum.

Quercus marina. Sea oare.

,, vulgaris. $173,195,283$

Quinquefolium.

CP Radix cava flore albo. $34^{8}$

Ranunculus albus multiflorus. angustifolius. aquaticus. " aquatilis flammeus

Ranunculus aquatilis angustifolius serratus.

p Ranunculus arvorum.
Ranunculus bulbosus.

$\begin{array}{ll}\text { " } & \text { Creticus flo. albo. } \\ \text { gramineus. } \\ \text { Illyricus minor. } \\ \text { ", } & \text { Illyricus maior. } \\ \text { omnium maximus. } & \text { magnus Anglicus }\end{array}$

polyanthos flo. luteo. $\quad 284$

Ranunculus maximus multiplex. folio" palustris rotundiore

Ranunculus pratensis.

plantaginis

Pyrenaeus folio

c Ranunculus globosus.

Clus. p. 233

Raphanus silvestris aquaticus.

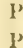

, rusticanus.

" niger.

, sativus.

Rapistrum arvorum.

,$\quad$ flo. albo.

Rapum maius orbiculatum.

" silvestris non bulbosum.

C Rapunculum silvestre Tragi. 191

,

cormiculatus.

III, II6

185,230

Rapuntium parvum. 320

Cl Rha capitatum folio Enulae. 318

(1) "Ponticum verum. 318

1' Rhamnus primus Clusii. 263,275

(:) $\quad$ Clusii. 3 I9

Rheseda. ", solutivas,

Rhodia radix.

134

Rhus Plinii myrtifolia.

P " coriaria Virginiana. Sumach.

321,346

Ribes Arabum.

c Ricinus.

Ros solis.

Rosa moscata simplici flore.

, cinamomea flore pleno. Rose de Canelle.

Rosa cinamomea simplici fiore.

$\begin{array}{ll}\text { (: sine spinis. } & 319\end{array}$

" illba,

" silvestris pomifera.

" canina odorata.

., canina inodora.

"Hollaudicat. P'rovince Rose.

Rosa holoserica. $\quad 110$

"lutea.

c. ", semper virens. 
Rosa rubra.

, Damascena.

Rosmarinum Coronarium.

", silvestris. I9I, 29I

C " spicata Clusii. 132

Rubus.

I 32
I 14

Ruscus.

C Ruta hortensis.

, muraria.

c Sabina baccifera.

, vulgatior, sive sterilis.

Sagittaria aquatica. 283,291

Salix aquatica. I have seene 8 kinds of osyars thus called by the baskett-makers. $\quad 77$

Salix caprea latifolia.

, humilis repens.

C Salvia Indica.

", maior.

, maior rubra.

" minor.

, agrestis.

Sambucus.

$$
\text { " aquatica }
$$$$
\text { , rosea. }
$$

C Sana sancta Indorum: a trewe

Tabaco. Petum latifolium.

P Sanicula.

CP ,, guttata.

Saponaria.

Satureia hortensis, WinterSavorie.

Satureia hortensis aestiva.

Saxifraga alba. , aurea lichenis facie.

Anclica facie prat. monsp.

Scabiosa maior vulgatior. , maior vulgatior flo. albo.

Scabiosa minor. $\quad 164$

.. minima hirsuta. I10

CP " montana flo. luteo.

$\because$ flore nubro. $\begin{array}{r}285, \\ 320 \\ 164\end{array}$

Scarlea.

Schoenoprassum. Cives. 260

Scolymus Theophrasti. 3 I 8

",, alterum.

Scordium.

C Scorpioides repens Bupleuri folio.

I 5 I

c Scorpioides Mathioli. Telephium Scorpioides. 131, 305
C Scorpioides siliqua crassa. I5I

momltiflorus. If

C,$\quad$ angustifolia. 317

C Scrophularia Lusitanica non script. $\quad 317$

p Scrophularia lutea Bauhini. Math. p. 792. ? whether all are not Lamium 2 exotic. Clusii.

Scrophularia maior. I56

Secale". secunda Cretica.

Secalina ustilago.

Securidaca minor. 130, 140

C Sedum maius Lusitanicum. 279 , minus offic. Prickmadam. 284

Sedum Divi Vincentii. $\quad 195$ Sedum minus haematodes. Stonecroppe.

Sempervivum maius.

Serpillum vulgare.

Serratula. $\quad 143,195,281,283$

Sesamoides argentea. $\quad 317$

CP Seseli. $\quad 346$

P $\quad$ species a D. Franquville.

326

C,$\quad$ species monspel. $\quad 319$

P ", Aethiopicum. 346

CP "Aethiopicum Mathioli.

CP " Creticum.

C Sideritis species. 230, 28 I

Silibum.

Sinapi sativum. , alterum sativum. White pepper.

Sisarum.

C Siser erraticum Plinii. Droxford.

Sison Math. 552.

Sium maius = Pastinaca aquatica. I 6,28 I

Sium Olusatri folio. $\quad 179,292$ "odoratum. 121

", repens. $1 \mathrm{I.t}$

"siifoliis. 121

" pusillum. 192

" agrorum. 327

C Smilax coeruleus minor Boetic. , laevis.

," laevis minor.

C Smyrnium Creticum.

P Solanum helicacabum. ., hortense.

P . " somniferum \& lethale. Bella dona.

275

CP Solanum Virginianum. 321

C ," Boeticum flo. rubro. 
p Soldanella marina. 185

(1) Solidago Sarracenica germanica. Sonchus aspera vulgi.

foliis profundis laciniis sinuata hederacea. 284

c Sonchus Africanus Boelio: like a Dandelion.

Sophia Chirurgorum.

latifolia.

Sorbus tormentalis Plinii.

" sylvestr. Alpina.

Sparganium.

Spartum Anglicanum. I7I, 282

Spergula saginae.

275

." marina.

Spica lavendula flo. coeruleo. 157

Spinacia.

Spondilium.

CP Stachys.

c Staphilodendron Plinii.

Stoebe Salmantica.

Stoechas. Salmantica altera. $\quad 317$

Superba maior vulgaris flo. Armeriae.

Symphytum alum.

" tuberosum.

Synanchica Deles. II $3,2 S_{4}$

p Syringa Italica alba. $\quad 346$ $"$ coerulea.

Tabaco.

I61, 327

Tamariscus.

Tanacetum millefolii foliis. I54 Anglicum. non odorum.

Tapsus barbatus.

$2 S I$

Taxus. $123,168,195,292$

c Telephium legittinum Imperati.

318

Terrae glandes. Chamabalani.

Tetrahit. $\quad$ I94

Teucrium arborescens. $\quad 317$

Thalictrum pratensis.

$$
\text { tenuifolium. }
$$

linace folio

Hispanicum aqui-

Thapsia.

Thlaspi Diosc.

,vulgatissimum: mytri. date mustard.

(. Thlaspi candice fio. albo. "umbellosum.

: Thymbra Boclii.

'Thymum durius.

rilia" foemina.
179)

346
Tithymalus Cupressinus sive humipinus. Welcome to our howse, or Cypres Spurge.

(c) Tithymalus montanus Boet.

$$
\begin{aligned}
& \text {, helioscopius. } \\
& \text { paralius. }
\end{aligned}
$$$$
\text { C } \quad \text {, serratus monspel. }
$$
Tracheliun maius Urticae foliis.

$\begin{array}{llll}\text { I' } & & \text { flo. albo. } & 292 \\ \text { (') } & ", & \text { gyganteum. } & 319 \\ & \quad \text { minus. } & 302\end{array}$

1) Tragacantha.

Tragon Mathioli.

Tragopogon luteum.

CP ", purpureum.

c , flo. cinereo.

Tribulus. $\quad$ 123-6

Trichomanes Diosc. I79, 275

CP Trifolium burgundiarum.

, pratense flo. albo. 144

", pratense flo. purpureo.

c, odoratum. 306

" corniculatum.

" cordatum.

, luteum.

, vesicaria.

" paludosum

c " falcatum Clusii.

" fruticans. $326-7$

Tripolium vulgare.

Triticum spica multiplici.

Tubera terrae. $2 S i$

Turritis. 292

Tussilago. 262

Typha. 2SI, 252, 296

Ulmaria.

Ulmus latifolia. Wich hasell. I 44 Wich elme in Essex. 43

Umbilicus Veneris.

292

Urtica minor acrior.

, Romana.

", silvestris aspcrior.

Uva crispa.

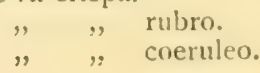

\section{Vaccinia nigra. \\ l' , rubra. \\ Valeriana Ciraca.}

c: , Graeca, flore albo.31\% ,, maior. Longe sore leafe for cuts.

(1) Valeriana rubra.

,$\quad$ silvestris.

,$\quad$ silvestris minor. 
CP Valeriana petraca.

C , Mexicana. I33

Veneris pecten.

318

C Verbascun 4 Mathioli.

c,$\quad$ blattariae folio.

Verbena communis.

Veronica vera et maior.

, minor serpilli folia.

"mas recta. 196

Viburnum. $\quad 275,346$

Vicia silvestris.

" maxima sylvatica.
190, 292, 308

p Viola Matronalis.

I 93

„, tricolor.

„ tricolor silvestris. I94

" Martia precox purpurea et alba.

Viola Martia purpurea multiplex.

, Martia alba multiplex.

109

CP " Mariana. 318
C Viola Mariana flo. albo.

" aquatilis.

" lunaris G. 377. Bolbonac.

, canina coerulea inodora.

Viorna.

P Virga aurea serrato folio.

Virga pastoris.

283,320

Viscum quercum.

C Visnaga.

Vitis uvifera.

CP " Virginiana. 32I, 346

Wheat.

180

P Wosaran Virginianum.

Xanthium. Bardana minor. I28

Xiphinem.

Xyris.

177

275

[Zea] Erased.

See also Index II and p. 334. 
PLANT-NAMES USED BY OTHER BOTANISTS, SUPPLEMENTARY TO THOSE LISTED IN INDEX I.

Abrotanum 355.

Absynthium 353-5.

Abutilon 358.

Acacalis 358 .

Acacia 365.

Acanthus 318.

Acer 346, 356.

Achillea 155, 3 I9.

Acinos 355 .

Aconitum 318.

Acorus 177, 234, 258, 287, 326, 365.

Actaea 329.

Adders tongue 3 II .

Adonis 319,358 .

Adoxa 69, 126.

Aegopodium IIO.

A esculus 346.

Agnus castus 240.

Agrifolium 28I.

Agrimony 311 .

Agropyrum 257.

Ajuga 244, 255, 264.

Alchemilla 155, 319-20.

Alexanders 3 I 2 .

Alisma 242, 358 .

Allium 259.

Alnus 175,358 .

Aloe 26I, 360.

Alopecuros 237.

Alsine 287, 292.

Althaea 242.

Amaranthus 320.

Ameos 365 .

Amivil 270.

Ammi 319-20, 365.

Amomum 365.

Amygdalus 358 .

Anacyclus 320 .

Anagallis 252 .

Anagyris 326.

Anchusa 131, 283, 336.

Andropogon 365 .

Androsace 150.

Andryale 320.

Anemone 311, 319-20, 328, 331.

Angelica 240, 312 .

Anonis 355-6.

Anotto 369 .

Anthemis 135, 154, 242, 301, 318-19. Anthericum 326.
Anthriscus 263.

Anthyllis 283 .

Antirrhinum 359.

Apium 114, 172, 192, 195, 302, 356.

Apocynum 329, 356, 359.

Apples 342, 386 .

, of Love 345 .

Apricots 58, 24I, 328, 344 .

Aquilaria 366.

Arach 31 .

Arbor tinctoria 356.

" vitae 328 .

Arbutus 287, 331, 346 .

Arctium 194.

Argemone 320.

Arisarum 319.

Aristolochia 335, 359.

Arkangel 240.

Artemisia 318-10, 356.

Artichoke 23-5, 241, 312 .

Asarina 287.

Asclepias 131, 312.

Ash 5 .

Asparagus 312.

Aspen 264.

Asperula 33, 113.

Asphodelus 359.

Aspidium 181-3.

Asplenium 108, 242, 263.

Assarabacca 312.

Aster 50, 320, 331, 356.

Astragalus I $30,140$.

Astrocarpus 317.

Athamanta 318.

Atriplex 236, 282, 320, 356 .

Aucklandia 364 .

Ballote $280,287$.

Balme 3II.

Balsamodendron 365 .

Banana 250.

Barba Jovis 331, 357.

Bardana 356.

Bartsia I 17, 150.

Basil 240.

Battato 238.

Bead tree 352 .

Beans, Kidney 312.

Bears Ears 311 .

Becabunga 293, 300. 
Bellflower $31 \mathrm{I}$.

Bellis 28I, 288, 352 .

Berberis 365 .

Beta 355-6.

Betonica 288.

Betony 3 II.

Betula 175 .

Bindweed 325 .

Bistorta 31 I, 356.

Bixa 369.

Blitum 356.

Bluebott!e 3 I .

Borage $31 \mathrm{I}$.

Botrychium I IO, 245, 263.

Brambles 34.

Brassica IOI, 3 I9.

Briza 158.

Brookweed 29.

Bryonia 82, 262.

Bugle 264.

Bugula 356.

Bunias 101 .

Bupleurum 261, 346.

Burri grass 352 .

Butomus 177 .

Cabbage tree 269 .

Cachrys 355 .

Calamintha $311,35 j$.

Calceolus $35^{6}$.

Camomile 310

Campanula 132, 195, 285, 288, 302, 318.

Campion $3 \mathbf{I}$.

Camphorata 359.

Candy Mustard 324 .

Cannabis $28 \mathrm{I}, 288$.

Capillus veneris 284 .

Capparis 357 .

Capsicum $357,368$.

Cardamine $284,288,356$.

Cardamons 365 .

Cardinal 331.

Carduncellus 317.

Carduus 2I, 112, $118,145,154,281$, $292,302,352,359$.

Carex 194-6, 257.

Carica 369.

Carlina $112,145$.

Carum 53, 121, 365.

Cassado 368.

Castanea 174 .

Cattaria $317,318$.

Caucalis 53, I1 4, I28, 195, 282, 356 .

Cedar 369.

Celtis 201, 326, 339, 346, 354 .

Centaurea I I0, I 54, I64, 317.

Centranthus 317 .

Cerasus $346,356$.

Cercis $317,346,370$.

Cerinthe $128,180,324$.
Ceterach 230, 263.

Chamaebuxus 292.

Chamaelaea 359.

Chamaerops 369 .

Chara 55.

Chelidonium 355 .

Chenopodium 260.

Cherry 55, 59, 328, 344 .

Chervil 3I2.

Chestnut 34, 312.

Chrysanthemum I 34, I 55, 318, 32 I.

Chrysosplenium I 85, 302.

Cichorium $150,260$.

Cicuta 179.

Cinara 352.

Cinnamomum 269, 364 .

Cistus 317,336 .

Citrullus 165 .

Clary 244,31 i.

Clathrus 196.

Clematis 236, 319, 326, 354, 359 .

Clinopodium 359

Cloudberry 222.

Cloves 269.

Clown's Allheal 312.

Cneorum 317.

Cnicus 21, 49, I09, I 44, I 46, I 54, 234 , 317-19.

Cochlearia 317,355 .

Coco 269.

Cogcigra 331.

Cola 269.

Colchicum IIO, 249, 258, 300, 316, 326, 359.

Columbine 25,312 .

Comfrey 3 II.

Conioselinum 318.

Convallaria 326.

Convolvulus $129,153,185$.

Coral root 26,74 .

Corallina 284 .

Corcorus 359.

Coriander 312.

Corn parsley 53.

Cornus 234, 346 .

Corona 326.

Coronilla 305 .

Corydalis 359 .

Costmary $31 \mathrm{I}$.

Costus 364 .

Cotinus 359.

Cotton 368.

Cotula 292.

Corvslip 27, 3 II. , of Jerusalem 3 II

Cracca 284.

Crambe 242.

Cranberry 330.

Cranes bill 312.

Crithmum I93.

See also Index 1 and p. 334.

I) $\mathrm{d} 2$ 
Crocus 249, 258, 316, 329, 326.

Crucianella 132.

Cucubalus 318.

Cucurbita 165, 321 .

Currant 328 .

Cuscuta II2.

Cyclamen 319, 331 .

Cynodon 257.

Cynoglossum 280, 302, 317 .

Cynosurus 157.

Cyperus 296, 359.

Cytisus 31 7, 331, 359 .

Daffodil 27, 240, 31 I, 326.

Dames Violets 311 .

Damasonium IIO, I80.

Datura 307, 320, 329.

Daucus I1 2, 243.

Delphinium 318.

Dentaria 186.

Dewberry 33 .

Digitalis $186,244,262,356$.

Digitaria I96, 257 .

Dill 312.

Diospyros 201, 320, 346 .

Diotis I 48 .

Dittander 3 II.

Dodder 3II.

Doronicum 237, 351 .

Draba 69.

Dracunculus 337.

Dragon 3 II.

Dryopteris 183 .

Durien 367.

Echatega 328.

Echinochloa 120, 195.

Echium 302, 317.

Elaphoboscus 359.

Eleocharis 257.

Elm 17, 30-1, 37-43, 52, 265, 308, 314.

Emblica 366.

Emex 107.

Endive 3 II.

Enula 3 II.

Epilobium III.

Epimedium 329.

Epipactis 47, 107, 126.

Equisetum 55.

Eragrostis 257.

Erigeron 162, 243.

Erodium 146.

Eryngium 110, 317.

Erynus 286.

Erysimum 319.

Erythraea 244.

Eupatorium 236.

Euphorbia $236,244,306,317,353$.

Everlasting $3 \mathbf{I}$.

Exotic fruit names 366 . liagus I SS.

Feather grass, 325.

Fennell 274, 312.

Ferns 67.90, 181 .

Ferula 366.

Ferulago 359.

Feverfew 3 II.

Ficus 242,328 .

Figwort 17 .

Filago 280.

Filipendula 312 .

Fir 369.

Flax 156 .

Flower Constantinople 31 I.

" de luce 310.

$"$ gentle, 325 .

Foeniculum 281, 318.

Foenum graecum 356.

Frangula 287.

Frankenia 148, 15 1, 318.

Fritillaria 249, 316, 321, 328 .

Fritillary 3 II.

Fruits $267,312,329,342-5$.

, exotic 365-71.

Fucus 287

Fumaria 263.

Fungus 245, 353.

Fustick 369 .

Galanga 367.

Galeopsis 194 .

Gallium I I3.

Genista 328.

Gentiana 20, 170, 292.

Gentianella 283, 286, $28 S$.

Geranium $185,191,234,284,286,301$, $319,329,33 \mathbf{I}$.

Germander 31 I.

Geum 234.

Gilliflower 6I, 240, 243, 308-I1, 328, 330.

Gladiolus 258, 310, 316, 321, 326, 338, 354.

Gladon 310.

Globe flower 312.

Gnaphalium I 48, 243 .

Goldenrod 3II.

Gonolobus 32I.

Goodyera 99,185 .

Gooseberry 312 .

Gratiola 317.

Gramen 352.

Grasses 71.

Grass of Parnassus 54.

Gromel 3II.

Guaicum 346, 37 I.

Hacchic 365.

Hazel 345 .

Heartsease 240. 
Hederula 289.

Hedysarum 147,318 .

Helianthemum 50.

Helianthus 23, 109, 166, 307, 317.

Heliotropium 24.

Hellebore 312.

Helleborus 285, 302, 327.

Henbane 3 II.

Hepatica 319.

Herb Gerard 312.

Hibiscus $306,346$.

Hieracium $149,180,28 \mathrm{I}, 2 \delta_{3}, 318$.

Hieracium 289, 317.

Higtaper 295.

Hippocrepis 77, 187 .

Hippomane 269 .

Hippophae $255,263$.

Hissopoides 359 .

Hollias, 33I.

Hollyhock 3 I 2.

Honewort 53, 67, I21.

Honeysuckle 240.

Honeywort 180 .

Hops 314 .

Hordeum 257, 282.

Humulus 107.

Hyacinths 311 .

Hyacinthus $240,249,31 \mathrm{I}, 316,321$, $325-6$.

Hymenaea 368 .

Hyoscyamus 122, 160, 320。

Hyoseris 289.

Hypecoum 129, 319.

Hypericum 77, 234.

Hyssopus 311 , 319.

Iberis $130,324$.

Ilex 352 .

Ingara 366.

Inula 320.

Ipomaea 262, 320 .

Iris $177,258,326,328,331,352$.

Isnardia, see Ludwigia.

Jaca 367.

Jacea 359 .

Jacobaea 357.

Jamboli 367.

Jasione I IO, I64.

Jasminum 326, 352 .

Jasonia 120.

Job's tears, 312.

Joseph and Mary 35.

Juglans I I 2, I74.

Juncaria 289.

Juncellus 282.

Juncus 257, 282, 284, 286, 296.

Juniperus $123,195,355,359$.
Kings spear 310.

Knot grass 241 .

Lactuca I I I, 158, 234, 319, 326.

Ladies bower 312 .

$"$ girdle 310.

", lacies 240.

" mantle $3 \mathrm{I}$.

", navel 240.

" seal 240 .

", smock 240.

" thistle 312 .

Lamium 156, 317, 353 .

Lapsana 151 .

Larks peel 308,312 .

Laserpitium 319.

Lathraea I23, 237.

Lathyrus I $36,195$.

Laurus 346.

Lavandula 106.

Lavatera 353.

Lavender 311 . cotton 312 .

Leneholans 312.

Lens 137.

Leontodon 3 I9.

Lepidium 329.

Leucoium 326, 352 .

Libanotis 359 .

Lignum aloes 366 .

Lilium $326,359$.

Lily 3 I I.

Lily of Valley 304.

Lime 17.

Linaria I7, I1 5, I43, I63.

Linariola 289.

Linum I09, 112.

Lithospermum 242.

Littorella 106.

Locust tree $346,368,370$.

London tuft 31 I.

Lonicera 30I, 320, 326, 346 .

Lovage 312.

Ludwigia 90, 187, 193, 195.

Lupinus 312,356 .

Lunaria $31 \mathrm{I}$.

Luzula 357.

Lychnis 283,285 .

Lycium 365 .

Lycopodium 108.

Lysimachia 187, 243, 261, 31 I, 355 .

Madder 312.

Maize 354 .

Makenbuy 355 .

Malacaton 58, 329.

Mallow 312.

Malva III, 134, 352-3.

Sec also Index $I$ and p. 334. 
Mancinel 369.

Mandragora 306.

Mango 367.

Manihot 368.

Maracoc 370.

Marigold 31 I.

Marigold, French 25, 3 II.

Marjoram 36, 62, 166, 240, 311 .

Marsdenia 329.

Martagon $326,328,343$.

Marum 356.

Marvel of Peru 25.

Matricaria 234, 355 .

Matthiola $242,330,339$.

Maudlain 311.

May apple 371 .

May Lily 326.

Mechoane 262 .

Medicago 141 .

Medlar 328, 352.

Melampyrum II 8 .

Melilotus 126, 306, 31\%.

Melon $274,369,37$.

Mentha 286, 326, 355- 6 .

Mercurialis 236 .

Militaris 290.

Mint $311,326$.

Mollugo 284.

Moly 325-6.

Monophyllon 264.

Monotropa 122.

Montia 195.

Moringa $36 \%$.

Motherwort 31x.

Mucca nut 369 .

Mulberry 312, 329.

Mullen 295.

Munk's Rhubarb 311 .

Muscus 282-4, 290, 352 .

Muttelina 359 .

Myosotis 302 .

Myrica 255, 305 .

Myrobalan 366.

Myrrhis 234, 312 .

Myrtil 329.

Narcissus 258, 311, 316, 321, 326, $331-3$.

Nardus I I .

Nasturtium 236.

Nectarine 345 .

Negundo 367.

Neottia 107.

Nepeta 111, 161, 317-18.

Nettle tree 326.

Nicotiana 160.

Nigella 25, 152.

Notobasis 145 .

Nux vesicaria 371 .

Nymphaea 293.
Oak 5, 34, 369.

Ocimum 166.

Oculus Christi 311.

Oenanthe 35, I15, 145, 319

Oenothera 159.

Olea 304.

Oleander 240, 329.

Olive 304 .

Olyas 33I.

Onobrychis 178.

Ononis 242.

Ophioglossum 245.

Ophrys 244.

Opuntium 292.

Orach 31 I.

Orange 329.

Orchis 286, 290, 301-2.

Organy 240.

Orice 240.

Origanum 166, 286

Ornithogalum 305,319 .

Ornithopus 131, 305.

Orobanche 47, 122.

Osiers 77.

Oxalis 290.

Oxys 355 .

Paeonia 359.

Paeony 312 .

Panax 359.

Pansy 325.

Papaver 155, 242, 366 .

Papyrifera 237.

Paralysis 283.

Paris $110,244,30 \%$.

Parnassia I80, 243.

Passiffora 320.

Peach 329, 345.

Pear 59, 343, 386.

Pellitory, bastard 312.

Pedicularis 106, 262.

Penny royal $31 \mathrm{I}$.

Pepper 236, 368 .

Perfoliata 359 .

Periclymenum 356 .

Periploca 346, 371 .

Periwinkle 312.

Persicaria 292, 356, 37 I.

Pescod tree 312 .

Petasites 234.

Phalangium 326.

Phalaris 133,317 .

Phaseolus 237 .

Phleum 257.

Phlomis 352-3.

Phragmites I08.

Phyteuma III, II6, 185, I96.

Picea 320.

Pilosella 282.

Pilularia 196. 
Pinus 346.

Piper 237.

Pistacia 201, 340.

Pisum I 39, I4I.

Planta 284.

Plantago 106, 244, 284, 286, 301-2, 356.

Plantain, Rose 311 .

Platycerium 249.

Plum 343.

Poa 256.

Poison weed 368 .

Polyacantha 360 .

Polyanthus 281, 352 .

Polygonatum 237.

Polygonum 290.

Polypodium 189.

Polypogon 237, 321.

Pompion 27.

Pomegranate 329.

Poppy 3 II.

Potamogeton 123.

Potato $75,216$. , sweet 28.

Potentilla $170,262$.

Poterium 318.

Primrose 27, 3I I.

Primula 109, 281, 316, 318, 352, 353 .

Privet 355

Prunella 244.

Prunus 321, 326, 346.

Pseudonarcissus 283, 326 .

Pseudodictamnus 327 .

Pulegium 285, 360 .

Pulicaria 236.

Pulmonaria $115,190,320$.

Pulsatilla 290.

Pyracantha 346.

Pyrethrum 318.

Pyrola 264.

Pyrus 195.

Quamoclet 360.

Quercus I 72, 195.

Quince 329, 343.

Ranunculus 29r, 301, 326.

Raphanus 242, 3 II.

Rapistrum 284.

Raspberry 310.

Reseda 134 .

Rhagadiolus 148 .

Rhamnus $255,263,31 \%, 319,341,346$.

Rheum 318.

Rhinanthus $26 \pi$.

Rhubarb 49, 260, 367.

Rhus 321, 341, 346, 368 .

Ribes 326.

Ribesium 284 .

Ribwort 24 I.
Ricinus $37 \mathrm{I}$.

Robinia 339, 346, 370.

Rose 110, 112, 243, 291, 301, 312, 319, 329-3I, 34I, 360.

Rosemary 8, 240, 312 .

Rubia I9I.

Rubus I I 4, 195, 243, 282 .

Rue 312.

Rumex I94, 319.

Saccharum 258.

Saffron 258, 3 II, 349 .

Sagapeni 360 .

Sage $31 \mathrm{I}$.

Sagina 77, 179, 186.

Salicornia 152.

Salix 77.

Salvia 156, 244, 305, 317, 356 .

Sambucus 87, III , 286, 29I.

Samolus III.

Sanicle 24I, 3II.

Santalum 366.

Saponaria $26 \mathrm{I}$.

Savey tree 312 .

Savory 311 .

Saxifraga 281, 301, 356, 360 .

Sawwort 3II.

Scabiosa 164, 243, 281, 320, 352 .

Scabious 25, $31 \mathrm{I}$.

Scammonea 360.

Scandix 306.

Scilla 259, 32 I.

Scirpus 175, 257.

Scleranthus IIo.

Scolopendrium 108.

Scolymus 318.

Scordium 360 .

Scorodoprassum 3 II.

Scorpioides 324.

Scorpiurus I 32, 15 I.

Scurvy grass 311 .

Scutellaria 301.

Sedum 77, 152, 195, 234, 243, 319-20, 324.

Selfheal 244 .

Selicio 319.

Sena 360.

Senecio 119, 193-4, 281, 319 .

Serpents Moly 3 II.

Serpillum 281.

Serratula 302 .

Sesamum 360.

Sesèli 292, 319, 360.

Sherardia 148.

Sideritis 317 .

Silaus 243 .

Siler 360 .

Silybum 320 .

Sinapis III.

Sison 121, 360. 
Sium 116, 176, 286, 302.

Smallage 312 .

Smilax 258

Smyrnium 318.

Snakeroot 371 .

Sneezewort 3II.

Snowdrop 3II.

Soapivort Gentian 3 II

Solanum 302, 320-1, 355, 360, 371 .

Solidago 319-20.

Solomon's Seal 312.

Sonchus 69.

Sowthistle 326.

Spartum 292.

Speculum veneris 280.

Spignel 312.

Spiraea 77.

Spongilla 290.

Squinant 365 .

Stachys $59,177,319$.

Staphylea $320,340,346,371$.

Star of Bethlehem 3 II.

Stellaria 261. Jerusalem $3 \mathrm{II}$.

Stickadove 240 .

Stipa 3 I 8.

Storksbill 319, 324.

Stramonium 320, 371。

Strychnos 352 .

Suaeda 179.

Succory 31 I.

Sumach 32 I.

Sugar cane 258.

Sweet William 308, 3I 1 .

Swertia 234 .

Sycamore 312, 357.

Symphitum 360 .

Syringa $339,346$.

Tamalapatra 368.

Tamarix $305,312,346$.

Tamus 127, I 53, 262.

Tansy 3 II.

Taraxacum II 5 .

Ta rragon $31 \mathrm{I}$.

Taxodium 337.

Taxus 168, 196.

Telephium 318,360 .

Terminalia 366.

Thalictrum 360 .

Thesium 117.

Thlaspi 236, 284.

Thora 360.

Thorowleaf 3 II.

Thrift 31 I.

Thymus $195,31 \%$

Tilia 346.

Tithymalus 306 .

Toadflax 17.

Tobacco $32,34,160,238,327,383$.
Tolpis I49.

Tomatoes 50.

Touchmenot 240 .

Tragacanth 33 I.

Trewlove 311 .

Trefoyle 25, 326.

Trifolium 292, 342, 356, 360 .

Trinciatella 360.

Trinia 77.

Triticum 257.

Trollius 319 .

Tropaeolum 329.

Tulips 3I I, 329, 331.

Turmerick $36 \%$

Tussilago 262 .

Tutsan 311 .

Twyblade 244 .

Ulex 189.

Ulmus $38-43,283$.

Urtica 156,280 .

Vaccinium 243, 292.

Valentina 357.

Valeriana $133,312,318,360$.

Veratrum 326, 337.

Verbascum 106, 284, 286, 360 .

Venus Looking glass 240 .

Veronica 76, 244, 300, 317, 320.

Viburnum 346.

Vicia 77, 139, 190, 193, I96, 281, 321.

Vicia 296.

Vina 356.

Vine $329,331,369$.

Viola 109, 194, 360 .

Violet 312.

Virgin's bower 240 .

Viscum 242 .

Vitex 326.

Vitis $32 \mathrm{I}, 346$.

Vulnearia 308.

Wheat $6 \hat{3}^{\circ}$

Winter cherry 311 .

Wolfsbane 312 .

Xanthium 128.

Xeranthemum 119, 319 .

Yeast 3 I 4 .

Yew 5,48 .

Yooke Elme 240

Youthwort 240.

Yucca 313, 321.

Zea $250 \%$.

Zephyranthus 320 .

Zizipha 352.

Sec also Initex I and fo 334 . 


\section{INDEX III \\ Persons, Places, and Things.}

Abbot 274 .

Abell, H. 378 .

Abergavenny, Lord, garden 261 .

Alberts, H. 200.

Ale 316.

Alexandria 364.

Aleyne 312.

Allestre 202.

Aloes 26r.

Alresford $5,12,373,383$.

Alton I, 8I.

America 369.

Amherst, Hon. A. 328.

Anagrams 273.

Anderson 279.

Andrewes, Bishop 59.

Annis seed 382.

Ansell 67.

Apothecaries 20, 21, 55, 57, 59, 76, 201, $270,275,304,353,384$.

Apuleius 70.

Arabia 364-8.

Argent 20, 250

Armada 12.

Ashmole 82, 330.

Assizes 73, 386 .

Astrology 82, 309 .

Athos Mt. 364 .

Atkins, Dr. H. 248.

Austen 83, I84.

$$
\text { , Jane } 4 .
$$

Backhouse 82.

Bacon, F. 62, 267.

Baetica 157.

Balden $47,127$.

Barber surgeon 274 .

Bargett 224.

Barlous 200.

Barlowe, T. 333.

Baronsdale, Dr. 249.

Barrowe 378 .

Bartar, T. 194.

Basing House 8I, 273 .

Basingstoke $21 \mathrm{I}$.

Baskett 91 .

Bath 9r.

Bauhin 46, 200

Bayley, W. 235, 304, 314.

Beacon-fire 5, 378 .

Beale, J. 83 .

Bedelcombe, R. 378 .
Bed-fleas $3 \mathrm{I}$.

Beeches Place I, 29.

Beer 314 .

Bell 374.

Belon 358.

Benwyn 374, 382 .

Berain 239.

Bere Forest 50.

Bermuda 368 .

Beryton, sce Buriton.

Betisworth, Edith 8.

Bettesworth, P. 96.

Billson, C. 96.

Bilson fam. 27, 95 .

" Bishop T. 7, 376.

, L. 7,95 .

" Mrs. 9.

" O. 96, 200, 297.

", Sir T. 6, 9, 46, 374-6, 379.

Binding, cost of 213 .

Bishops of Winchester 7 .

Andrewes 59.

Bilson q.v.

Cooper 10.

Curle 56.

Neile 56

Bishops Waltham 12.

Blackman 379.

Blois 279.

Blount 200.

Bobart 81, 276, 278, 293, 295.

Bodleian Library $27 \mathrm{I}$.

Boel I6, 313, 36I.

Bold 23I, 383 .

, A. 96.

J. 97.

Bonham $=$ Carter 6 .

Books I $3,197-232,380, \hat{3} 85$. , Italian 202

Boorde 314 .

Botanical excursions 75.

Boulger 295, 330, 346 .

Bowden 200.

Bower 208.

Bowles 274, 276-7.

Bowyier 67.

Boyle 304.

Bradley 65

Bramshott 5, 377.

Brazil 237, 268.

Brewing 16, 315.

Brewning II. 
British Museum 210.

Britten, J. 122, 295.

Broadgates Hall 225.

Browne, Lancelot 200, 238 .

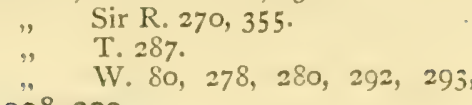
298-302.

Browne of Hoe 35, $115,297,378$.

Buckett 59.

Buckley, R. 272.

Buckner 55, 59, 276-8.

Bull 382 .

Bullein 216.

Burghley, Lord 254.

Buriton 5, 8, 11 , 94, 375 . , armour bearers 3 So. , pioneers $38 \mathrm{r}$.

Burley 97.

Burton, A. 264. , G. 194. , R. 264.

Bush 247.

Busher 237.

Bust 200.

Butser Hill 5.

Buttersworth Hill 74, 187.

Cachrys $172,363$.

Cadel 279.

Cairo 364.

Caltherste $3 I$.

Cambrai 325.

Camerarius 234,358 .

Canary Wine 9.

Canterbury 283.

Capel 30.

Carriers 202.

Casa bona, J. de 360 .

Cassel 360.

Cave, M. 274.

Cecil, Sir W. 254.

Cerevisia 315.

Chamber, M. 264.

Charles 154.

, II 355 .

Chescombe 5 .

Chester, R. $240,307$.

Chidden 375,379 .

Chioggia 274.

Chocolate 24.

Christchurch 51 .

Christ's Hospital 12.

Church, A. H. 187, 25 I.

Civil war 78 .

Clanfield 89,378 .

Clifton 76

Clinson, Capt. 273.

Clough 239.

Cludlie, 'T. 379 .
Clusius 14, 234, 237, 245, 364-5.

Cochineal 386.

Codemer 266.

Cole, J. 14, I 79, 200, 247.

, E. I2, 373.

, W. 81, 294.

Coleman 297.

Colfe 33 I.

Colson 21.

Compton 2.

Constantinople 324

Cooke, Canon 240.

Coppels 9.

Corbet 58.

Corn 382.

Courthope 222.

Cox 97.

Coys fam. 313 .

, G. 313 .

" Wm. 14, 16, 24, 36, 43, 50, 120, I $28-30, \quad 134,139-47$, I 50, I $56-8$, $160,210$.

Craig, Dr. J. 248.

Craster, H. 2.54, 308 .

Cratonis 210.

Crete 364.

Croft 280.

Crowcher 67.

Crumpe 64 .

Cusick 79.

Dale, Dr. J. 84, 92-4, 199-202, 206, 214 , $229-30,25 \mathrm{I}, 278,280,288,294-8$.

Dale, R. 297 .

" S. 295.

W. 295.

Dallman 238 .

Darlaston 297.

Davis 48,171 .

Davys, H. 378 .

Dawley 378 .

De Brina 200.

De la Broderie 328 .

De Lannoy 247.

De Laune 14, 19-20.

Descriptions of Plants 44, 100-96.

Digges, Sir D. 330.

Dioscorides 84-9.

Dixon 237.

Dodoens 14 .

Double flowers 62.

Downes 201, 220.

Downton 378 .

Drope, F. 80, 82 .

Droxford 3, 25, 28, 29, 33, 35, 74, 114 $116,118,122,126$.

Druce $47,52,231$.

Drugs 19, 383 .

Dunne, IV. 249 .

Durford Abbey 5, 373 . 
Elizabeth $211,240,246$.

Eryngo root 241 .

Essex 219.

Essex, Earl of 58, 241.

Eton Coll. 274.

Evelyn 60, 352 .

Everender 31 .

Evergreens 270, 355 .

Exotic plants $237,358-70$.

Fauntleroy 302.

Finchdean 6.

Florence 359 .

Flower lists 240, 308-12, 317-27, 331, 347.

Forster, R. 249.

Foulkes-Roberts 239.

Frankfort 359 .

Franqueville 22.

Freame 20I.

Frear, T. 249.

French plants 59 .

Froxfield $38 \mathrm{I}$.

Fruit lists $328,342-5,369,386$.

Fuchs 45.

Furner 221 .

Gallipoli 364.

Galls 35, 49.

Gambier-Parry $2 \delta 3$.

Gammon, W. 95.

GARDENS, PERSONS.

Abergavenny, Lord 261 .

Barnaby 306.

Basket 306.

Capel 30.

Coys 312-25.

Crosse 304.

Davies 309.

Delavale 307.

Edwards 110.

Forman 309.

Franqueville $303,325-6$.

Gerard 18, 247, 303 .

Gibbes I 8, 33, 303, 346-8.

Goodyer 67, 97, 325-7.

Helin 328.

Heneage $21 \mathrm{I}$.

Heyden 306.

James 305.

Johnson 273.

Jokkat 329 .

Lobel 247.

Millen 54, 59.

Monnel 252.

Morgan, E. 351-4.

" $"$ of Bodescien 308,353 .

, H. 354.

Morine 279, 331 .

Morison 354 .
Mount 256.

Nasmyth 249.

Norton 306.

Orleans, Duke of 279.

Parkinson 270, 327.

Pointer 58.

Reresby, Sir J. 350.

Robine 326, 328, 331, 354.

Salisbury, Lord 328 .

Salusbury 306.

Shanne 3 ro.

Stonehouse 292, 303, 348-51.

Thornes 308 .

Tradescant 303, 328-46.

Tuggy 331, 353 .

Uvedale 34 .

Wallop 306.

Walters 310.

Wootton, Lord 339-40.

Wotton 274.

Watson 305.

Yalden 28.

Zouch 247, 324 .

GARDENS, PLACES.

Blois 354.

Brussels 329.

Chioggia 274.

Constantinople 6, 324 .

Holland 320 .

Paris 329.

Tournai 252.

London.

Chelsea 353.

Coleman Sı. 354.

Hackney $247,324$.

Highgate 247.

Holborn 303.

Lambeth 303, 309, 330-46.

Long Acre 270.

Snow Hill 273.

Tuthill Fields 292.

Westminster 352-4.

Essex.

Stubbers 312-32.

Hants.

Droxford I6, 321, 327.

Dummer 306.

Sheet 28.

Southampton 306.

Winchester 305 .

Herts.

Hatfield 328 .

Kent.

Canterbury 339-40.

East Malling 256.

Middlesex.

Enfield 34.

Twickenhem 58 .

Northumberland.

Seaton 308.

Oxford 304 . 
GARDENS, PLACES (iont.). Somerset.

Bath 303, 347 .

Suffolk.

belnys nothers 304.

IVales.

Bodesclen 308.

Lleweni 306-9.

Yorks.

Darfield $272,292,303,34 \delta$.

Methley 310 .

Thrybergh 350 .

Garret 237.

Garth 201, 237, 290.

Gaudin 20I.

Geeres, Mrs. 266.

George 20I.

Gerard 16, 69, 139 .

Gerard's Herbal 45, 57, 275, 307.

Gesner 234.

Ghini 360 .

Gibbon 4.

Gilbourne 201.

Gill 8I.

Girdler 97.

Glasier 385.

Glyn, T. 287.

Glynn-lhivona 272.

Goade 279.

Gooch 20I.

Good, E. 385.

Goodyer fam. I.

, J. Botanical excursions 372 ; crest 63 ; descriptions of plants 10096; garden $67,97,325-7$; house 64 ; handwriting 55,169 ; indexing 203 ; letters 372 ; manor 377 ; manuscripts $229-3 I, 275,296,373-86$; marriage 64 ; plant records 293 ; protection order 78 ; recusancy 79 ; shopping $48,73,381-2$; will 94 .

Goodyer Plants, see Index I.

. Reginald 1 .

Grafting 267.

Gray 297.

Green 46, 70,

Grey 201 .

Guildford 56, 380.

Guinea 269.

Gunter, Dr. 98.

Gwinne, Dr. M. 249, 250.

Halilah $28 \mathrm{r}$.

Hamden Woods 352.

Hamelden 378 .

Hampshire lists of villagers 376,381 .

Hanbury, Th. 2.

Ilanson, Sir 'T.

Harrison 59.

Harvey 201.

Hasted $6 \%$
Hatch 378 .

Hatfield 289 .

Hatton, Ld. 279.

Heacham 57.

Heath, Eliz. 199, 202.

Heath, J. 84, 86, 89.

Heath House II, 373.

Heaton 276, 288.

Heneage $2 \mathrm{II}$.

Henly 64

Henrietta Maria 267.

Henry zor.

Herbal 45 .

Herbert, J. SI.

Herrick $22 \mathrm{I}$ of Cherbury $3 \delta_{3}$.

Herring, Dr. F. 249.

Herts I 79, 289.

Herytage 226 .

Hill, T. 61 .

Hill 172.

Hinton 56,58 .

Hoe 378 .

Holloway 277.

Holybourne 5.

Holybyn 277.

Hooper, IV. 79 .

Hopton, Lord $78,286$.

Horse medicine 224 .

Hort, Sir A. 5 I.

Horticulture 267 .

How, IV. 81, 188-95, 20I, 245-51, $276-94,298,300,354-6$.

How MS. $23 \mathrm{I}-2,245$.

Huchenson 201 .

Hugobert 59, 247.

Hull 373 .

Humplirey, L. 221.

Hunnibon 278, 283, 292.

Hyde, A. 9, 375.

, L. 291 .

IIsley 379.

India 366 .

Inkforbie 9, 374, 382 .

Inn-Names:

albus Leon 31, 372; Angell 58, 372 ;

Antilope 1So; King's Head, Guildford 56: Red Lion, Fleet St. 30, 372 ; Tabott 73; White Hart, Southwark 73.

inoculation $6 \mathrm{r}$.

Insects 174 .

Iron works 74 .

Ironsmith $20 \mathrm{I}$.

Jackison, B. D. $100,303,316$.

$$
, \quad \text { Sir J. } 271 .
$$

James 59

lames $13 \approx, 247,274$.

Jane, Lady, late Oneen 208 . 
Johnson, S. 49.

, Alice 274.

, Dr. S. 239.

, T. S, Iо, 30, 49, 56, 58, 69, $71,81,201,271,273-7,351,380$.

Johnson's handwriting 169 .

Jolyff $284,286$.

MSS. 232.

Jonson, Ben 58, 240.

Keipe 355.

Kempe 201.

Kingsley 377.

Lagouna 210.

Lake 2 I.

Langrish 60.

Langton $28 \mathrm{I}$.

Lau' 54 .

T. $248,27 \mathrm{I}$.

Laudanum 385.

Le Seigneur 316.

Leese, Sir H. 265.

Lefevre 201 .

Legge 6.

Leicester $22 \mathrm{I}$.

Leigh 122.

Leister 316.

Le Moyne 329.

Lete 316.

Library I3, 93, I97-232.

Lime 17.

Lincolnshire 265.

Liphook 5, 385 .

Liss (Leese) $3 \mathrm{~S} \mathrm{I}$.

Lister, Dr, E. 250 , 3 I 6. " M. 318 .

Lleweni $238-45,307$.

Lobel I4, 33, 52, 58, 201, 234, 237 , 245-53, 280, 282, 379 .

Lobel MSS. 231.

LOCALITIES OF PLANTS.

ENGLAND 91, 232, 298.

Berks.

Abingdon 146.

Cumnor 55 .

Reading 280-1, 30I-2.

Wallingford $30 \mathrm{I}$.

Windsor 288.

Cambridgeshire.

Cambridge 280.

Downham 193.

Ely, Isle of 290.

Over 290.

Saffron Walden 258.

Dorset.

Portland 379.

Derbyshire 288.

Essex.

Colchester 292.
Harwich 291.

Purfleet I I 3, I 18.

Rumford 67.

Hants.

Alton 47, 290.

Basingstoke $280,296$.

Bishops Waltham 122.

Buriton I 84 .

Bursledon 5, 47, I 52.

Chawton 4, 28 .

Chawlton 28.

Christ Church 52.

Drayton 33, 237, 290.

Droxford 30, 122.

Emsworth 28.

Habridge 127.

Haliborne $21,46,127,146$.

Hamble 5, 236.

Hayling 47, I 48 .

Hedley 302.

Holbury House 35, I I 5, 293.

Hurst Castle I93.

Idsworth 5, 50 .

Isle of Wight $33,90,285,290,353$.

Ladle Hill 194.

Liphook 196.

Lymington $5 \mathrm{I}$.

Marborne 46, 127.

New Forest 35, I $15,293$.

Petersfield 184, 188, 195-6, 280, $283,293$.

Poppie Hill 36.

Rake 52, 179.

Southsea 47.

Southwick 123.

Tichfield 28.

Vectis, see Isle of Wight.

Winchester 28.

Hereford 288.

Ledbury 284.

Yatton 284.

Herts.

Denham 179.

Moore Park 37, I79.

St. Albans 287.

Ireland.

Dublin 287.

Galloway 288 .

Kent 255-63, 275, 283-7.

Addington 257.

Ashford 283.

Black brooks 257.

Canterbury 283 .

Chiselhurst 286.

Dartford 292.

Deptford 292.

Dover 257, $263,283$.

East Malling 255, 257, 263.

East Peckham 263.

Folkestone 263.

Gravesend 287. 
LOCALITIES OF PLANTS (cont.).

Greenhythe 288, 292.

Greenwich 286, 28 .

Lewes 284 .

Leybourn 258.

Maidstone 263.

Rochester 263, 287.

Sandwich 257.

Snodland 257.

Thanet, I. $277,292$.

Woolwich 28I.

Wrotham 260.

Lancashire.

Blackburn 264.

Dingley Wood 264 .

London 352.

Aldgate 293.

Bermondsey 28 .

Bermonice 288.

Chelsea 289.

Fulham 283.

Hackney $247,283,289$.

Hamstead Heath 232, 280-I.

Highgate $284,286$.

London Fields 285, 289 .

Marylebone 296.

S. Georges Fields 280 .

S. Johns Wood 288 .

S. James 281, 352 .

Totnam 291.

Tuthill Fields $28 \mathrm{I}$.

Tyburn 296.

Westminster 296.

Whitechapel 191.

Middlesex.

Chapel on the Heath 293.

Hounslow Heath 28, 29.

Uxbridge 292.

Northants 53, 287.

Lichborough $287,302$.

Peterboro 289, 290, 292.

Wellingborough 53, 179, 180.

Northumberland.

Morpeth 284.

Norfolk.

Kings Lynn 193.

Witton Fen 287.

Oxfordshire.

Chilswell 301 .

Combe 300.

Cornbury 301 .

Dorchester 289 , 301 .

Headington 300 .

Honey Fixlong $30 \mathrm{r}$.

Oxford 49, 177, 196, 281, 291.

Sarsden 281.

Shotover 301.

Stokenchurch 122, 304 .

Witney 55.

Shropshire 284.

Kinlet 283.
Somerset $284,287$.

Bath 77, 190, 259, 284, 29I-3, 30I.

Bristol 75, 287, 291.

Clover 284, 287.

Hooms I. 291.

Mendip 287.

Nettleton 301 .

St. Vincents Rocks 76.

Smocombe Wood 77.

Surrey.

Kingston I 8 I.

Godalming 55, 180 .

Guildford 185, 286, 288, 302 .

Purbright 293.

Worplesdown 302.

Sussex.

Durford 46, 125, 178 .

Mayfield 186

Rye 296.

Shorham 300, 302.

Warwickshire 280-I, 288, 290.

Whichford Wood $28 \mathrm{r}$.

Wolver (Wulford) Wood 28 I 353 .

Wilts.

Devizes 77.

Langford $51,178$.

Stapleford 51, 178 .

Sutton-Veny 28,54 .

Warminster 28 .

Worcestershire 283,301 .

Alchurch 284 .

Kidderminster 284 .

Yorks.

Craven 264.

Darfield 348 .

Ingleborough $222,288,291$.

Methley 310.

Wales, North 292.

Bodfari 243.

Chirk 239, 244.

Clwyd 244, 309 .

Denbigh 238-45.

Glynn-lhivona 272.

Llandulas 242-4.

Llanrwst $239,242$.

Llansannen 239, 242.

Merioneth 243.

Snowdon 272.

Loggins 190, 276.

London 54,56 .

See under Gardens.

Addresses 48 .

Baynard's Castle 227.

Gray's Inn 289.

Great Fire 295.

Long Acre 270, 296.

Militia 227.

Milk St. 294.

St. Martin's 297.

Stepney 289. 
London Highway 146, ISI.

Lymphatics 286

Lyte Herbal 80.

Machetes 265 .

Maes, J. 249.

Maggotts 174 .

Majorca 234.

Malacca 367.

Mallinge 73 .

Mangersfield $28 \mathrm{I}$.

Maple Durham 6, 55, 69, $183,185$.

Mapletoft 222.

Marshall 215.

" A. 329 .

Martin 202.

Massa 201.

Materia Medica 19, 93, 241, 257, 316, 368.

Mayerne, T. de 234, 248.

Mayfield $34 n ., 73$.

Meader 193.

Medeley 201.

Medical books 93, 385 . , recipes $241,383-5$.

Melancholia 274.

Meon, East 5, 252 n., 297.

Merrett 35, 62, 81, 195-6, 294.

Mervyn I, I 78 .

Metheglin 237.

Methley 264.

Monnel 252 .

Mooring 67, 122 .

Morden 237.

Morgan 48. E. $92,277-8,292,351-4$.
$\quad$ H.237, 256, 258, 274, 354, 366.

Morison 92, 279, 293, 352 .

Morrice 74, 370 .

Mosco 63.

Mostart, D. 332.

Mouffet, J. 2 19, 234.

Moundeford 248, 250.

Mount 201, 216, 253-63.

Mundy, P. 333 .

Mussart 332.

Myddleton 239, 244 .

Myers 373.

Myres 247.

Nasmyth, J. 249.

Neale, J. 93, 385.

New Forest 51 .

Newarke 202

Nicholas, Sir E. 355.

Nid 222.

Nortons 236.

Nun, J. 264.

Ointment 384 .

Orleans 279.

Osler, Sir W. 254.
Oxford 48,81 .

, Colleges:

Christ Church 58, 89, 221, 238-45.

Gloucester Hall 49, 176.

Jesus 238.

Magdalen I, 49, 79, 249, 27 I, 297, 374.

New $8 \mathrm{I}-3,274$.

St. Johns 81, 251, 276.

Wadham 202, 272, 286.

Worcester 49 .

Paddy, Sir W. 248.

Padua 202, 299, 3 I 8.

Palestine 364 .

Palmer, R. 9.

, Ri. 250.

Palmer worm I 51 .

Papists 10.

Parey's Surgery 7o.

Parish relief for maimed soldiers 213 .

Parker 64.

$$
\text { , fam. } 274 .
$$

Parkinson $16,27,74,140-1,164,173$, 195, 250-2, 265-71, 293, 318, 330, 358-70.

Pashley 59.

Pawlett, Sir Richard I.

Pellisserius 252.

Penckhurst, S. 74, 186.

Penny 234, 256, 258.

Pernambuco 269.

Persia 367.

Petersfield 2, 64, 297, 373 .

Pharmaceutical Society 20, 272.

Physicians 20. , College of 298.

Phytologia 9I, 25 I, 276.

Pioneers 8.

Pitt, J. 375.

Plantin I 4.

Ploves 332.

Pocahontas 57.

Portesdowne 378 .

Potecary 54, 186.

Potosi 268.

Power, Sir D’A. 235, 295 7, 357.

Prain, Sir D. 351 .

Pratt 2.

Prelingworth 379.

Price 76.

Prices, Building 270 .

$$
\text { , Corn } 307 .
$$

Primrose, Dr. 249.

Priors Reade 1.

Proclamation 228 .

Provence 190.

Pulleyn 202, 294.

Pulteney 14.

Quicke, W. 3 I 8. 
Rabson, J. 378.

Raleigh 9, 32, 237, $24 \mathrm{I}$. last poem 32 .

Ramerus I 5, 201 .

Rauwolff 358.

Rawdon, Sir M. 273.

Ray 222, 298.

Read 215.

Recusants I1, 79.

Red bridge 376 .

Red Morley $2 S_{4}$.

Red Well 53.

Redgrave 218 .

Redmayne 57.

Relf 73 .

Rhé Island 330, 339.

Rhedus 252.

Ridley, M. 249.

Roberts 59.

$$
\text { , E. } 238 \text {. }
$$

Robin 249. Mirs. 309.

Robinson 202, 204, 296.

Rolfe 57.

Romney 73.

Rondelet 14, 201, 246.

Ropley 2, 12, 373 .

Rother 3 .

Rous 201 .

Rowland 12, 373 .

Ruff 265.

Russel, C. B. 16, 312.

Russia 63, 330, 362 .

St. Mary Hill Parish 215.

St. Vincents Rocks 75.

Salisbury 29, 378.

Salter, H. 236.

Salusbury, Sir J. $238-45$. , IVm. 238, 242.

Sambroke, Sir J. 377.

Sandy Chapel 181 .

Sandy, R. 316.

Sanfoin 51 .

Saracen 86, 36I.

Savile of Methley 264.

Sedlescombe 31 .

Selborne 5, 93.

Seward, 1'.7. maladies 385 .

Shakespeare 17, 61, $240,342$.

Shanne 264-5, 385 .

Sharrock 83 .

Sheete 2, 27, 28, 120, 379 .

Sihelden, 288.

shelley 12.

Shelley, Henry 7.

Shepey 59.

Shepherd 379.

Shipley 355.

Shrewsbury School 201.
Shute 3 .

Sinai 364.

Skilling, R. 383 .

Slaynie, H. 33 I.

Smith, J. 215.

Snave, J. 74.

Snow Hill 273.

Snuff 383 .

Soberton 5, 35, I I 5 . , inhabitants 379

Socii itinerantes 272,274 .

Southampton $159, \mathbf{I} 85$.

Southropp I.

Southwick 375 .

Spain 64, 361.

Species 6I.

Spigelius 363 .

Splith 359.

Sprague I89.

Stable, G. 378.

Stanford 287.

Stapf 47, 171, 189, 256-7.

Stealing children 228.

Steep 5, 379.

Stevens 81, 292, 299, 301.

Steventon 4.

Stirn 345.

Stockport 272.

Stockton 54.

Stonehouse I 5, 49, 79, 80, 82, 231, 264 , 27 I-3, 277-8, 290, 348-5I.

Stourbridge 297.

Stroud Common 5.

Strowde 236.

Stubbers 16, 17.

Surrey Assizes 73.

Sussex 73.

Sivalms 20r.

Swaneling 185.

Swanmore 379.

Sydney, Sir H. 24 I.

Sylvester 67, 379 .

Symings, Dr. 259 .

Taplow 280 .

Terrier 373.

Tewe 63, 362 .

Theophrastus 50.

Thornton 222

Thyn 287.

'Tichborne, Sir R. 378 .

Tithing 373 .

Townsend 34,35 .

Tradescant 55, 83,272 .

Tribe 379, 380.

'Trinity College, Cambridge 222.

Tunstal, Sir J. 274.

'Turkey 366.

Iurn[er] 229, 235.

Turner, R. 234.

, $\quad 1 \mathrm{Wm} .45,76,90,234$. 
Twickenham 58.

Uvedale $8, \mathrm{II}, 34,16 \mathrm{I}$.

Vachell 11,375 .

Vaughan, Canon 26, 35, 96, 197, 299.

Venice 274 .

Vesalius 258.

Vidian fam. 297.

Virgil 63.

Virginian plants 18, 74, 321, 340, 347, $351,369$.

Voake, Vok 97, 380, 382.

Wales 76, 91, 238-45, 272.

Wall, A. 377 .

Waller, F. 9, 375 .

Walnut 34 .

Walter, Sir W. $28 \mathrm{I}$.

Walton, I. 3, 26.

Ward, J. 92, 278, 293-5, 304, 352, 357.

Warminster 378 .

Warwickshire 280-I, 288.

Watson, Sir W. 335 .

Weather 307,386 .

Wells 202.

West, T. 218.

Westbrook 96, 379 .

Weston 6, 9, 94, 281, 288, 375-6.

Wharton 82 . Inhabitants of 376 .

Wheatham Green 5.

White 73.

, Gilbert 3 .
Whitrow Moore 184.

Wickham 8.

Willisel 298.

Willoughby, F. 222.

Willowby, E. 378 .

Wilmot 339.

Wilts $28,29,178,378$.

Win, W. 331 .

Winchester 21, 56, 163, 235, 286.

Winter, J. 96.

Winwood, Sir R. 274.

Witham 264.

Withowbie 59 .

Woodcot II.

Woolmer Forest 5, 179, 52.

Woolwich $28 \mathrm{I}$.

Worlidge, A. 95 .

Wotton, E. 234.

" H. 65, 96, 201, 271, 274.

Wray 60.

Wyche, Sir P. 33I.

Wye 288.

Wynn 239.

Yalden, Crusophilus 2.

" Dorothie 2

" Edmund 2, 55, 79, 95-7.

Yates 201

Yorkshire 264.

Zouch, Lord 247, 274. 


QK21.G7 G8 8 Nork Botanical Garden Library gen

Gunther, Robert Wil/Early British botani

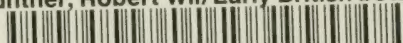

|

35185000964591 


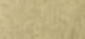

